


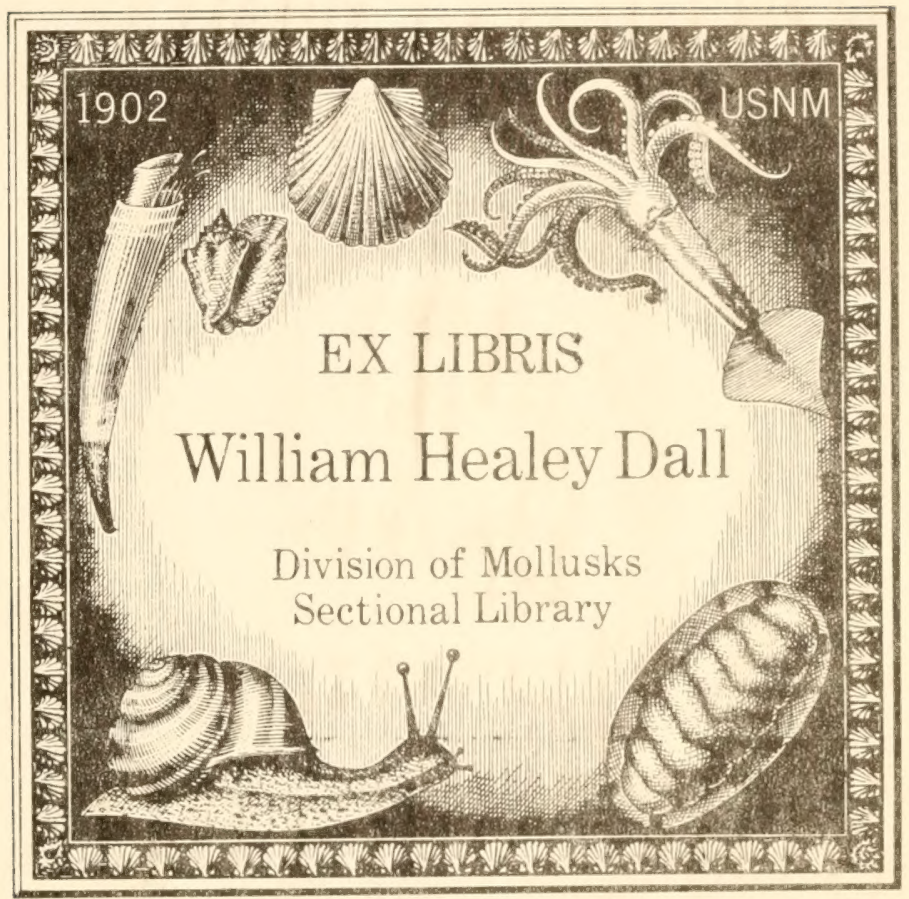


EvavgaAn

Divicion of Moln rols

Sectional Libromy 




Military Governor of Santo Domingo

R. M. Warfield, Lieutenant Commander, C. E. C., U. S. Navy

In Charge of the Secretaryship of State of Fomento and Communications

GEOLOGICAL SURVEY OF THE DOMINICAN REPUBLIC

Thomas Wayland Vadghan, Geologist in Charge

MEMOIRS, VOL. I

\section{A GEOLOGICAL RECONNAISSANCE OF THE DOMINICAN REPUBLIC}

BY

T. W. Vaughan, Wythe Cooke, D. D. Condit,

C. P. Ross, W. P. Woodring, and F. C. Calkins

Prepared by the United States Geological Survey

Official publication of the Secretaryship of State of Fomento and

Communications, Dominican Republic
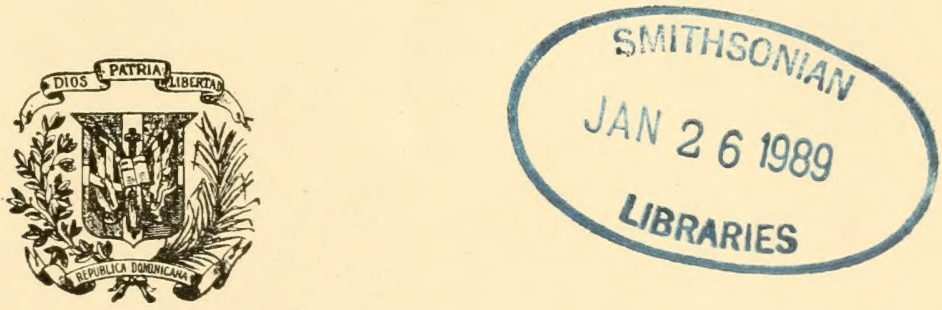

WASHINGTON 
PRESS OF

GIBSON BROTHERS, INC.

WASHINGTON, D. C. 


\section{CONTENTS.}

Chapter I. Introduction, by Thomas Wayland Vaughan

PAGE.

Preliminary arrangements for the geologic survey.

Field work

Office work

Outline of results

Physiography

Stratigraphy and geologic correlation.

Igneous activity and geologic structure

Economic geology

Acknowledgments

Chapter II. Bibliography, by Wendell Phillips Woodring 18

Chapter III. Geography, by Wythe Cooke............................................................

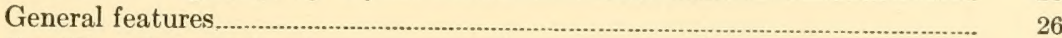

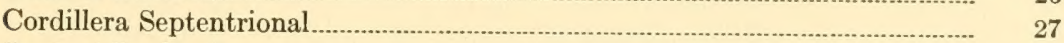

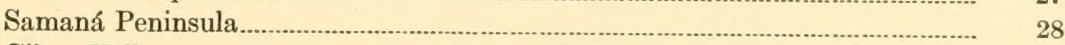

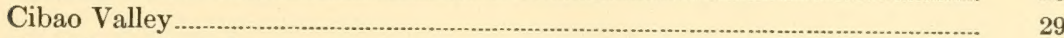

Cordillera Central .............................................................................................

General features....................................................................................... 30

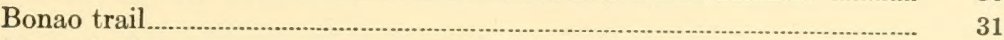

Sierra de Ocoa

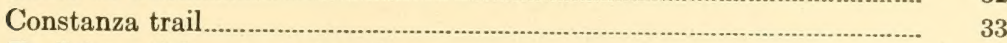

Trail from Sabaneta to San Juan …..............................................................

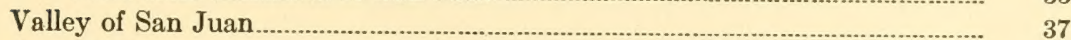

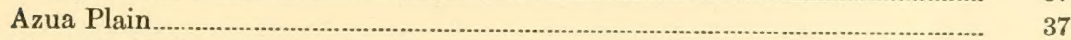

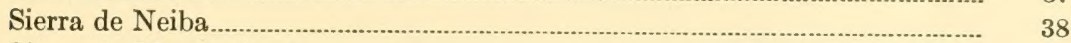

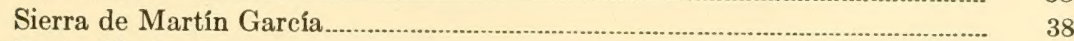

Enriquillo Basin.......................................................................................... 39

Sierra de Bahcruco........................................................................................... 39

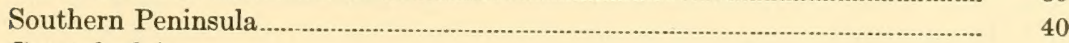

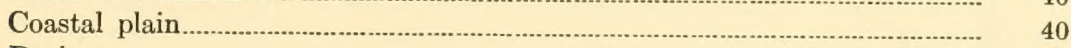

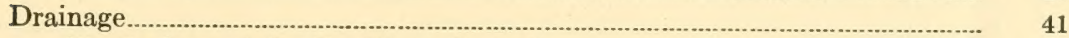

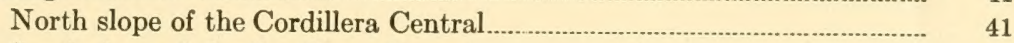

South slope of the Cordillera Central ........................................................... 42

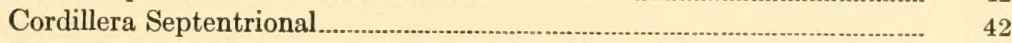

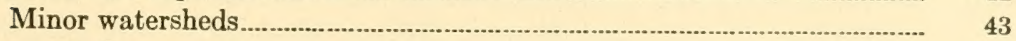

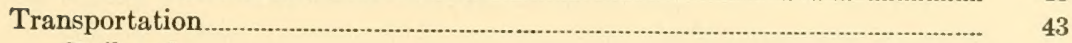

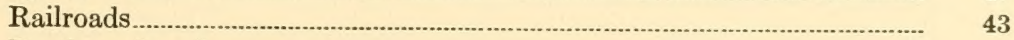

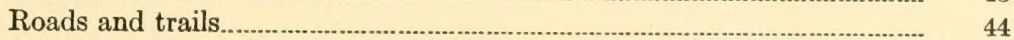

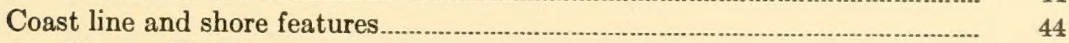

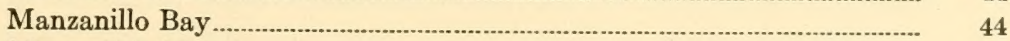

Monte Cristi Bank......................................................................................... 45

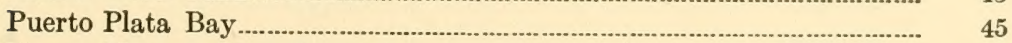

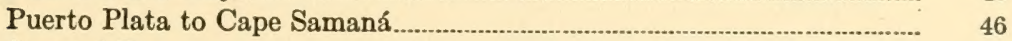

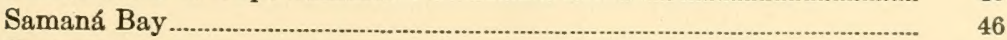

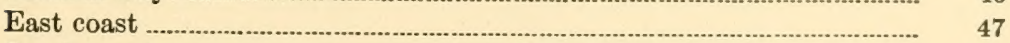

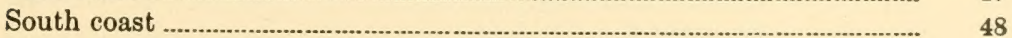


Chapter IV. Stratigraphic and structural geology and geologic history, by Wythe Cooke.

PAGE.

Stratigraphy.

Basal complex

Character and extent

Cordillera Central

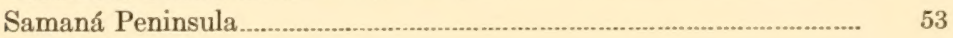

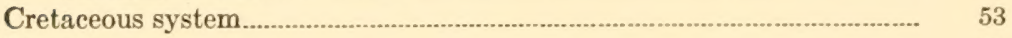

Tertiary system

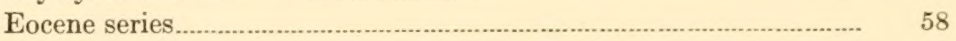

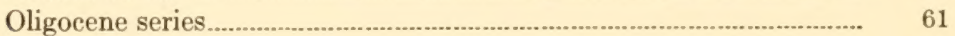

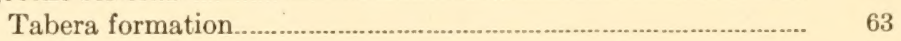

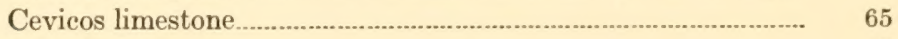

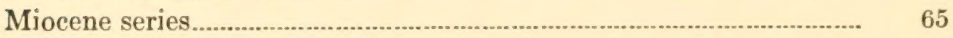

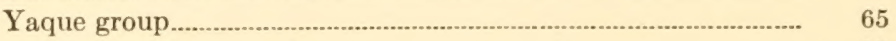

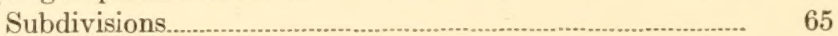

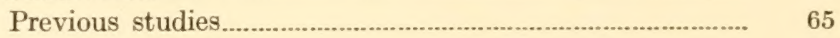

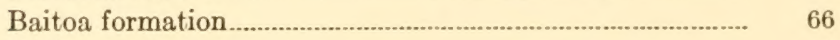

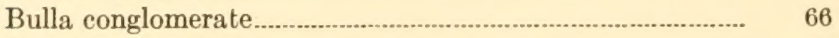

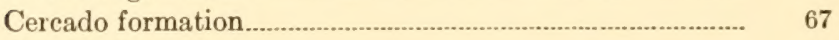

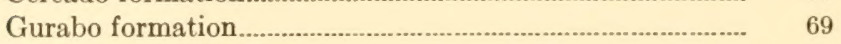

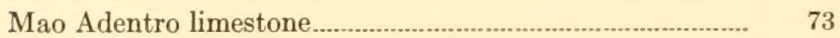

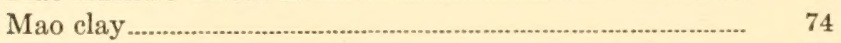

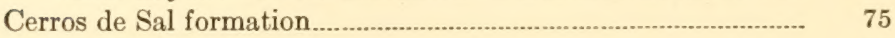

Miocene or Pliocene series............................................................... 76

Plant-bearing beds at Sánchez

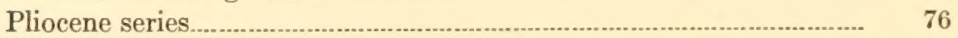

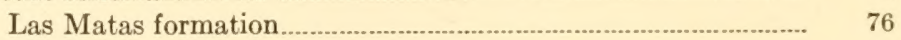

Quaternary system

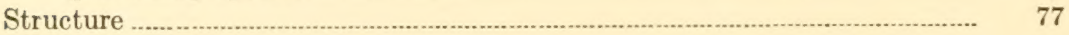

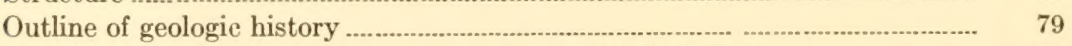

Chapter V. Metamorphic and igneous rocks, by F. C. Calkins............................ 83

Metamorphic sedimentary rocks........................................................................ 83

Granular intrusive rocks............................................................................. 84

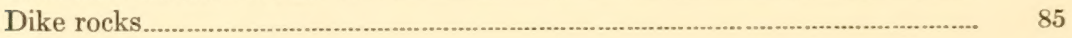

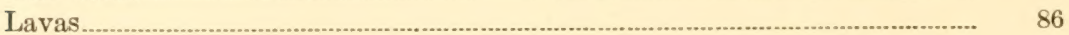

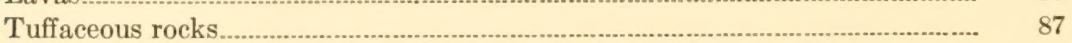

Chapter VI. Tertiary and Quaternary stratigraphic paleontology, by Thomas

Wayland Vaughan and Wendell Phillips Woodring .............................. 89

Objects of the paleontologic work

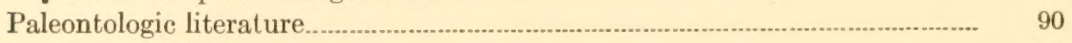

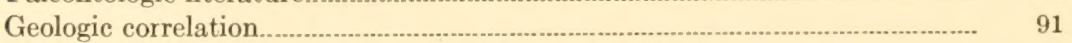

Relations of Dominican Tertiary and Quaternary biota_................................. 94

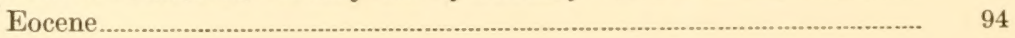

Oligocene

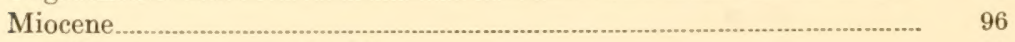

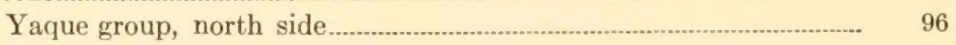

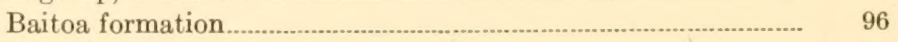

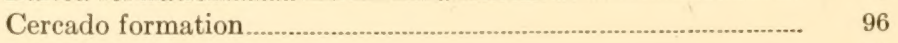

Modified Cercado fauna

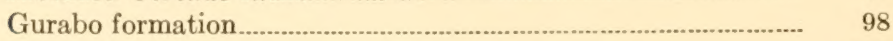

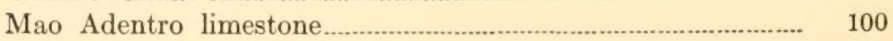


Chapter VI. Tertiary and Quaternary stratigraphic paleontology, by Thomas

Wayland Vaughan and Wendell Phillips Woodring-Continued.

Relations of Dominican Tertiary and Quaternary biota-Continued.

Miocene-Continued.

Yaque group, north side-Continued.

Mao clay.

101

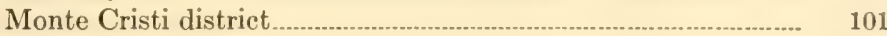

Yaque group, south side................................................................ 102

Cerros de Sal formation

Miocene or Pliocene district of Samaná 103

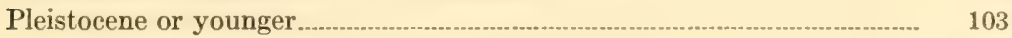

Extinct mammals of the Dominican Republic

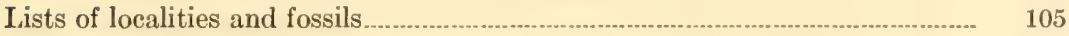

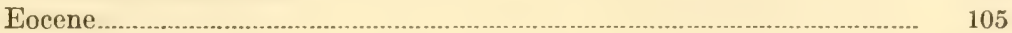

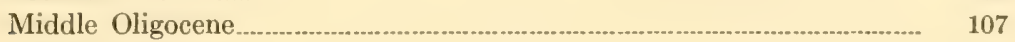

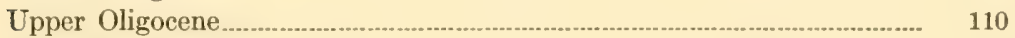

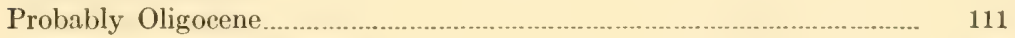

Apparently upper Oligocene ............................................................... 112

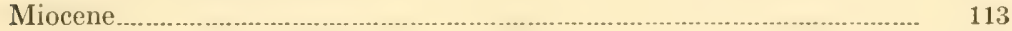

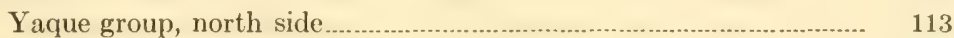

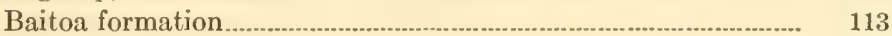

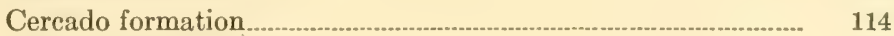

Modified Cercado fauna

Gurabo formation............................................................... 130

Deeper water facies of Gurabo formation

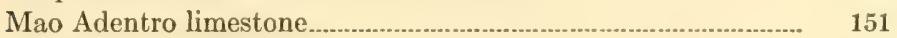

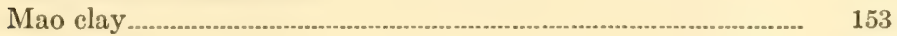

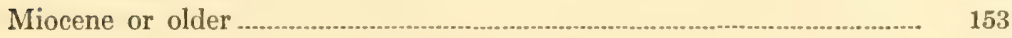

Yaque group, province of Monte Cristi............................................ 154

Yaque group, south side........................................................................ 155

Cerros de Sal formation....................................................................... 163

Miocene or Pliocene, Province of Samaná.............................................. 165

Pliocence or Pleistocene, Province of Monte Cristi $\ldots \ldots \ldots$

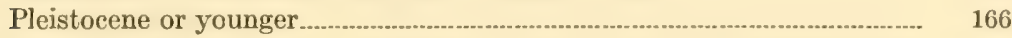

Chapter VII. Geology and water resources of the vicinity of Monte Cristi,

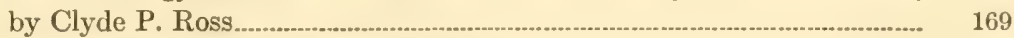

Character and purpose of the work done......................................................... 169

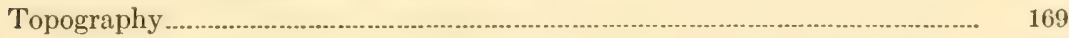

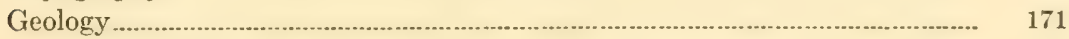

Quartz diorite....................................................................................... 171

Oligocene (?) limestone and sandstone

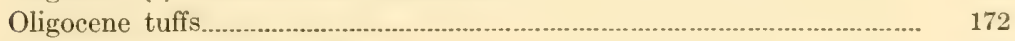

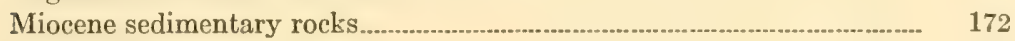

Pliocene (?) gravel .............................................................................. 175

Pleistocene (?) beach deposits _............................................................. 175

Recent alluvium ......................................................................................... 175

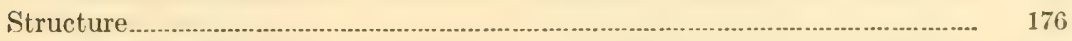

Water resources.......................................................................................... 177

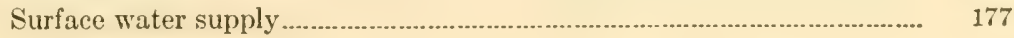


Chapter VII. Geology and water resources of the vicinity of Monte Cristi, by Clyde P. Ross-Continued.

Water resources-Continued.

Underground water supply.

Possibility of obtaining ground water.

Possibility of obtaining artesian water.

Conclusions and recommendations

Chapter VIII. Geology of the Province of Samaná, by Clyde P. Ross.................. 181

Topography

Samaná Peninsula.

Geology

Basal complex 182

Early Tertiary limestone conglomerate..................................................... 183

Oligocene or Miocene limestone....................................................................... 183

Miocene or Pliocene clay, sand, and conglomerate................................... 184

Pleistocene or Recent terraces and coral reefs................................................ 184

Recent deposits................................................................................................. 185

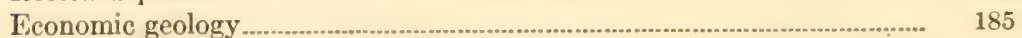

Chapter IX. Geology of the provinces of Barahona and Azua, by D. Dale Condit and Clyde P. Ross.

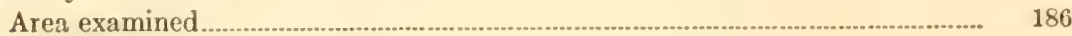

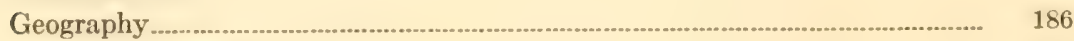

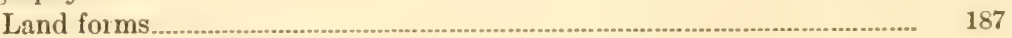

Province of Barahona

Province of Azua........................................................................... 188

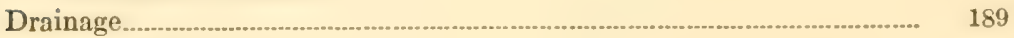

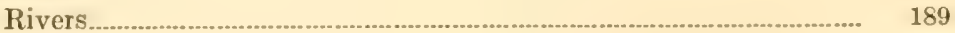

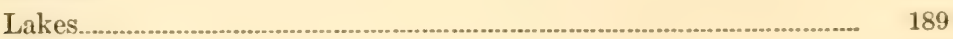

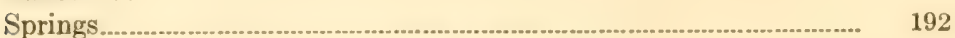

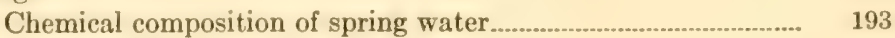

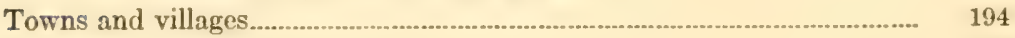

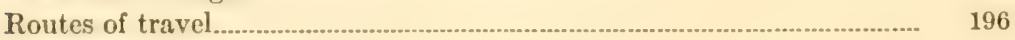

Climate and vegetation

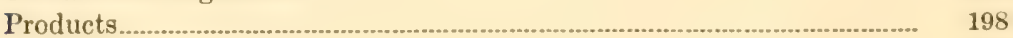

Geology

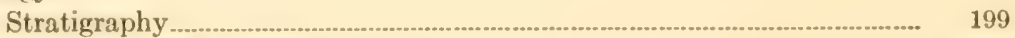

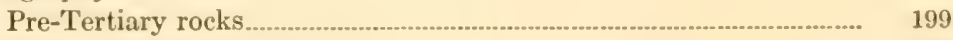

Tertiary sedimentary rocks............................................................. 199

Eocene ......................................................................................... 199

Oligocene.................................................................................. 200

Miocene ......................................................................................... 201

Yaque group

Cerros de Sal formation......................................................... 201

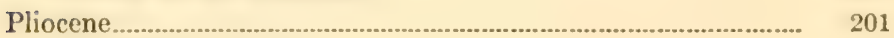

Las Matas formation ......................................................... 201

Quaternary sediments........................................................................ 202

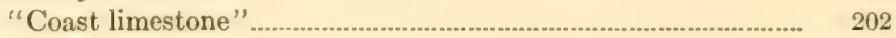

Alluvial deposits.................................................................. 202 
Chapter IX. Geology of the provinces of Barahona and Azua, by D. Dale Condit

PAGE. and Clyde P. Ross-Continued.

Geology-Continued.

Igneous rocks.

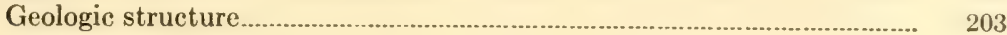

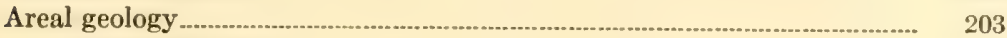

General features.................................................................................... 203

The Cordillera Central ........................................................................ 204

Rio Yaque Valley ............................................................................ 206

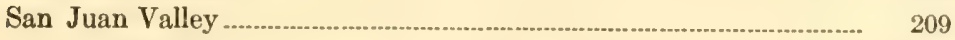

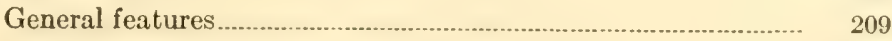

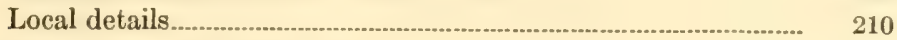

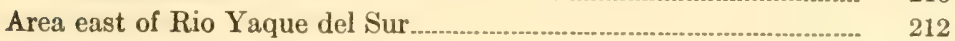

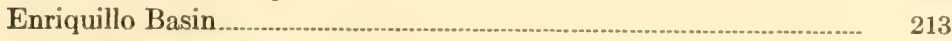

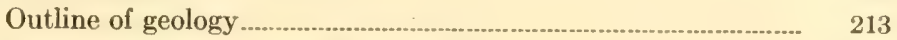

Vicinity of Barbacoa and eastward........................................ 214

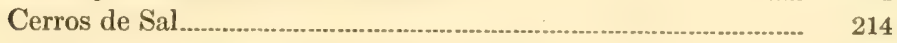

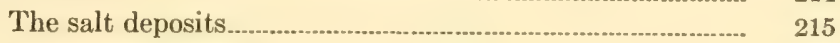

Petroleum possibilities in Enriquillo Basin........................... 219

Sierra Bahoruco south of Duvergé....................................... 219

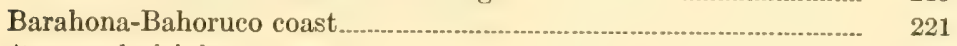

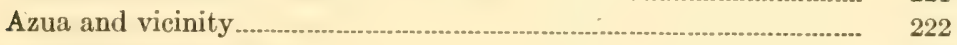

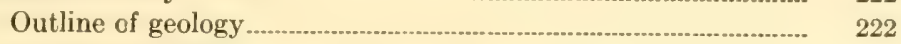

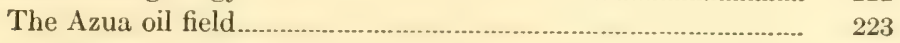

General features..................................................................... 223

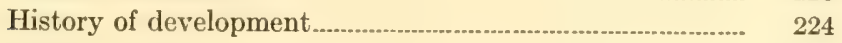

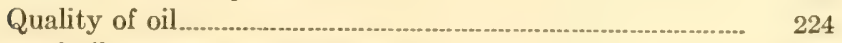

Reported oil seepages east of Azua...................................... 225

Summary of economic geology .......................................................... 226

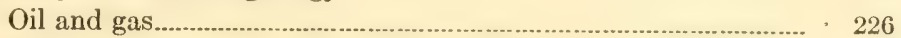

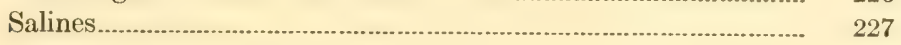

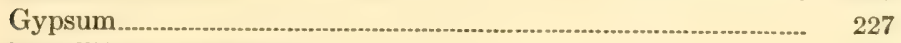

Metalliferous deposits............................................................... 227

Chapter X. Economic geology, by D. Dale Condit and Clyde P. Ross................ 228

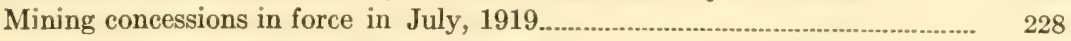

Mineral deposits near Hatillo and Maimon, province of La Vega.................. 228

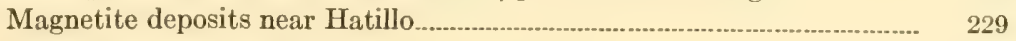

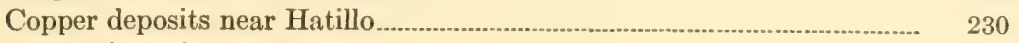

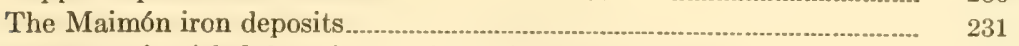

La Perseverancia nickel deposit, province of Santo Domingo........................ 231

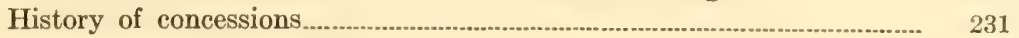

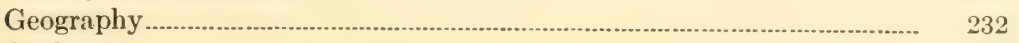

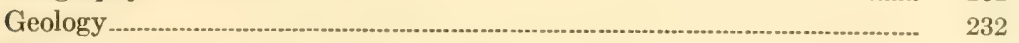

Mining operations

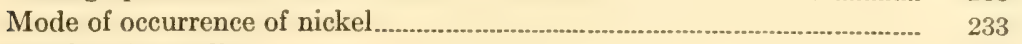

Results of sampling

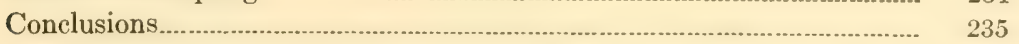

The San Cristóbal mining district, province of Santo Domingo........................ 236

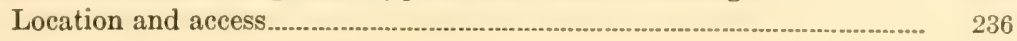


Chapter X. Economic geology, by D. Dale Condit and Clyde P. Ross-Continued.

PAGE.

The San Cristobal mining district, province of Santo Domingo-Continued.

History.

Development

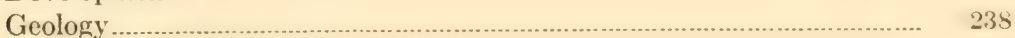

Búcaro Hill ore deposits _................................................................................ 239

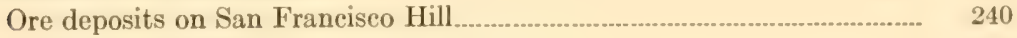

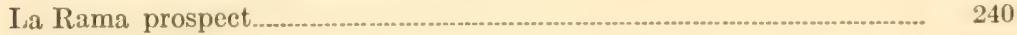

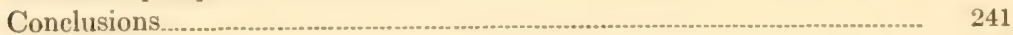

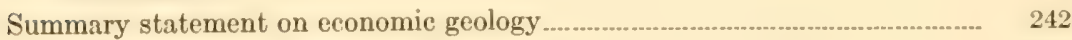

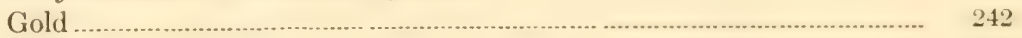

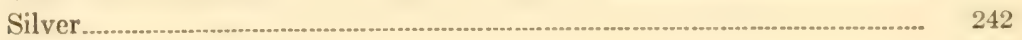

Platinum .

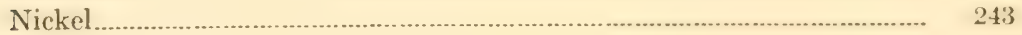

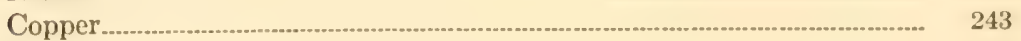

Iron

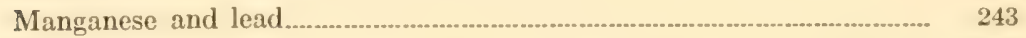

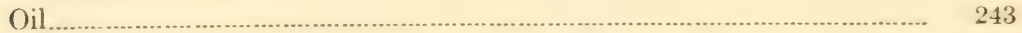

Coal

Amber ....................................................................................................... 244

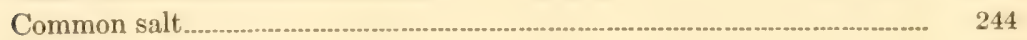

Gypsum

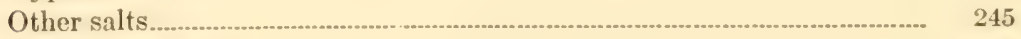

Building stone ............................................................................ 245

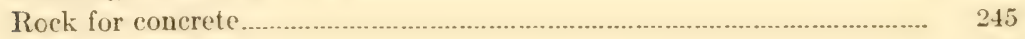

Road metal ...................................................................................................... 246

Lime

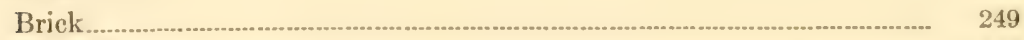

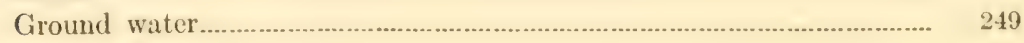




\section{ILLUSTRATIONS.}

PAGE.

Plate I. Physiographic provinces of the Dominican Republic

II. $A$, South front of the Cordillera Septentrional as seen looking north, from a point east of Santiago; $B$, El Morro de Monte Cristi as seen from the south side; $C$, Loma la Cumbre, the summit of the Cordillera Septentrional between Altamira and El Aguacate, as seen looking northward

III. $A$, Monte Isabel de Torres; $B$, Santa Barbara de Samaná; $C$, Sánchez, showing terraces between the hills and the shore.

IV. A, Vega Real, Sabana Llana near El Higo Gordo, province of La Vega, with the foothills of the Cordillera Central in the distance; $B$, Valley of Rio Yaque del Norte north of Esperanza

V. $A$, View northward from Hatillo, 28.5 kilometers northwest of the eity of Santo Domingo; $B$, View southward from Loma Coco between Hatillo and El Madrigal; $C$, Terrace flat at El Madrigal, on Rio Jaina

VI. A, Loma Peñita as seen from the trail from Sabaneta to Restauración; $B$, Siete Picos, looking northeastward from La Mata, between El Madrigal and Sabana Grande

VII. $A$, Terraces on Rio Maguá above San Pedro de Macorís; $B$, Sierra Prieta; cliff of white limestone; $C$, Gorge of Rio Mao above Bulla....

VIII. Geologic sketch map of the Dominican Republic

IX. Sketch map of part of Rio Mao showing position of stations at which collections of fossils were made

$\mathrm{X}$. Bulla conglomerate interbedded with fossiliferous sand northeast of Bulla, at east edge of flat on Rio Mao.

XI. Sketch map of part of Rio Gurabo showing positions of stations at which collections of fossils were made.

XII. $A$, Cercado formation on Rio Mao opposite Hato Viejo; $B$, Gurabo formation on Rio Mao just above El Paso Bajito

XIII. $A$, Gurabo formation on Rio Mao below Cercado de Mao; $B$, Rio Mao seen from top of bluff above El Paso Bajito

XIV. Sketch map of Monte Cristi and vicinity.

XV. Geologic map of parts of the provinces of Azua and Barahona.

XVI. A, Las Matas de Farfan and Sierra de Neiba as seen from the east; $B$, View in the Cordillera Central southwestward from a point on the Bánica-Restauración trail near La Cruz.

XVII. A, Young lignum-vitae tree (guayacan) along road near Rio Ocoa; $B$, Typical exposure of reef corals forming a bench on the south side of Lake Enriquillo.

XVIII. A, Sandy shale and sandstone of the Yaque group on Rio Yaque del Sur at crossing of Azua-San Juan road; $B$, View northward, up the valley of Rio Yaque del Sur from the vicinity of Boca Mula........

XIX. $A$, Part of Duvergé; Sierra de Bahoruco in background; $B$, Sierra de Bahoruco, looking south from San José.. 
PAGE.

Plate XX. A, Plication in shaly purplish red limestone of early Tertiary (?) age along Rio Ocoa; $B$, Tilted beds of purplish red limestone near suppased oil seep on Arroyo Salado.

XXI. Index map of Dominican Republic showing mining concessions in force in July, 1919

XXII. Map of Sierra Prieta at "Perseverancia mine".

XXIII. Map of part of the San Francisco concession, San Cristóbal mining district. 


\title{
A GEOLOGICAL RECONNAISSANCE OF THE DOMINICAN REPUBLIC.
}

\author{
CHAPTER I. \\ INTRODUCTION.
}

\author{
By Thomas Wayland Vaughan.
}

\section{PRELIMINARY ARRANGEMENTS FOR THE GEOLOGIC SURVEY.}

On April 1, 1917, Rear Admiral H. S. Knapp, Military Governor of the Dominican Republic, addressed to the Director of the United States Geological Survey a request for an estimate of the cost of a complete mensuration survey of the Republic and of supplemental mineralogical and botanical investigations. The estimates requested were furnished to Admiral Knapp, and after further correspondence it was agreed that the direction of a topographic and geologic survey of the Republic should be undertaken by the United States Geological Survey, the expense of the work, except that of certain office and laboratory investigations, to be borne by the Dominican Government.

There is no adequate base map of the Dominican Republic, and as a detailed geologic survey must be based upon detailed topographic maps more thorough geologic studies must await the completion of the topographic mapping; but as so little reliable information concerning the geology was available it appeared necessary to make preliminary geologic examinations before beginning more detailed work. Accordingly, on December 4, 1918, the Director of the United States Geological Survey wrote to Admiral Knapp a letter which contained the following paragraph:

At present the geologic formations in Santo Domingo are not sufficiently well known for purposes of geologic mapping, and not enough information is available on the mineral resources of the island to make practicable the formulation of plans for careful study. It therefore seems to me advisable to make a preliminary inspection of the Republic, and to collect fossils, rocks, minerals, etc., for shipment to Washington, where the material can be studied in connection with other investigations that are in progress. The proper study of such collections and the comparison of them with material from other parts of the West Indies, Central America, and the United States, would probably consume more than a year. The office work on these collections could be prosecuted in Washington without any expense to the Santo Domingo Government, if you are willing to have the material become a part of the United States National Museum collections. However, should a nuseum ever be established in Santo Domingo, the first set of duplicate specimens could be sent as a beginning toward a local museum. The office studies above outlined could be profitably done while the topographic survey is in progress 
and then, by the time the topographic maps are available, more reliable geologic mapping will be possible than would be the case without a preliminary examination of the area and office study of collections made during such an examination.

About the time the letter containing this paragraph was dispatched Rear Admiral Knapp was succeeded as Military Governor by Rear Admiral Thomas Snowden, who acted favorably upon the recommendation of the Director of the United States Geological Survey.

The preliminary arrangements having been made, the Geological Survey party-Messrs. D. D. Condit, Wythe Cooke, C. P. Ross, and I-left New York for Santo Domingo City on March 24, 1919, and arrived there on the morning of April 5, after making reconnaissance examinations around Puerto Plata, Sánchez, and San Pedro de Macorís. On reaching the city I reported to Admiral Snowden and he referred me to Lieutenant Commander Baughman, who helped to complete the preparations for the geologic field work.

\section{FIELD WORK.}

The original plan comprised reconnaissance examinations of the Province of Seibo, the Samaná Peninsula, the Cordillera Septentrional, the Cibao Valley, the main Cordillera Central along at least three different routes, and the provinces of Azua and Barahona, including the Enriquillo basin. This plan was carried out, except that the Province of Seibo was not visited at all and that the Samana Peninsula was examined only along its south shore and at its west end.

The itinerary of the party was as follows: On April 11, Messrs. Condit, Cooke, Ross, and I, in company with Lieutenant Colonel Glenn S. Smith, who has charge of the topographic surveys of the Republic, left Santo Domingo City by automobile for Hatillo, which is about 28.5 kilometers from the city, on the Carretera Durate. At Hatillo we took a pack train by way of El Madrigal, Sabana Grande, and Bonao to El Pino, at the northern foot of Loma Miranda, whence we went to La Vega, arriving there on April 15. At La Vega the party divided, Messrs. Cooke and Ross going to Cotui, Hatillo, Maimón, Cevicos, and Villa Rivas, whence Doctor Cooke went to Sánchez by train to do several days' work at the west end of Samank Peninsula, while Mr. Ross worked westward along the southern foot of the Cordillera Septentrional toward Santiago de los Caballeros. Colonel Smith, Mr. Condit, and I went to Santiago, and the next day Colonel Smith and I started by automobile for Port-au-Prince, Haiti, while Mr. Condit made geologic studies from Tabera, at the northern foot of the Cordillera Central, across the Cibao Valley and as far north in the Cordillera Septentrional as Bajabónico, where his work connected with that carried southward from Puerto Plata.

Colonel Smith and I separated in Port-au-Prince, and I returned to Sant iago by automobile, arriving there April 26. Messrs. Condit, Cooke, and Ross soon joined me at Santiago, and on May 1, after some examinations 
had been made near Santiago, Mr. Ross went by stage to Monte Cristi to study the western part of the valley of Ris Yaque del Norte, and Messrs. Condit and Cooke and I moved by pack train westward along the south side of the valley of Rio Yaque del Norte. Studies were made from the foothills of the Cordillera Central along Rio Amina as far downstream as Potrero, along Rio Mao as far downstream as Valverde (Mao), along Rio Gurabo as far downstream as a few kilometers below Gurabo Adentro, and Rio Cana was examined at Caimito. On May 10 Mr. Ross joined Messrs. Condit and Cooke and me at Gurabo Adentro and the next day the party again divided.

Doctor Cooke and I started for Santiago with our collections and reached there on May 12. On May 13 I left Santiago for Santo Domingo City by way of Moca and Sánchez and arrived there on May 17. On May 19 I left Santo Domingo City for Porto Rico and the Virgin Islands.

On May 11 Messrs. Condit and Ross started from Gurabo Adentro by way of Sabaneta for Restauración, whence they went across the Cordillera Central to Joca, and thence by Las Matas, to San Juan, reaching there on May 18. The remainder of May and a part of June were devoted to studies in the provinces of Azua and Barahona.

Doctor Cooke was detained several days in Santiago attending to the shipment of collections and did not leave there until May 18, when he started southward across the Cordillera Central. He went by Jarabacoa and Constanza, thence down Rio del Medio to Cañitas, and from there to Túbano and Azua, where he arrived on May 27. He spent the last days of May and part of June in work around Azua, San José de Ocoa, and Baní.

After concluding their work in Azua and Barahona provinces Messrs. Condit, Cooke, and Ross returned to Santo Domingo City. From Santo Domingo City as a base Mr. Condit examined the Perseverancia nickel prospect, Mr. Ross examined the San Cristóbal mining district, and Doctor Cooke made a trip to San Pedro de Macorís. Messrs. Condit and Cooke returned to Washington at the end of June, but Mr. Ross remained several weeks longer to make additional studies around Samaná Bay.

\section{OFFICE WORK.}

The original plan for the preliminary reconnaissance included office study of the field observations and the collections, with the intention of utilizing the information thus obtained in planning more careful investigations, but the preparation of a formal volume setting forth the results of the work was not contemplated. Two conditions of later development, however, seem to make it highly desirable that the information obtained be published as soon as practicable. The first of these conditions is the demand for a reliable account of the general geologic features of the Republic by those who are interested in the development of its natural resources. Although our work was only a preliminary inspection, we obtained far more information 
than has hitherto been available, and we may reasonably hope that its publication will be of some service. The other condition is the uncertainty regarding the continuity of personnel in the investigations. Mr. Condit resigned from the United States Geological Survey in October, 1919, to enter upon private commercial work, and later Messrs. Cooke and Ross both applied for furloughs for similar work. Under such conditions it is obvious that the information obtained through the preliminary studies should be put into such form as to make it available for geologists, whether working for the Government or privately, and as a consequence of these conditions this volume is issued.

Several members of the Geological Survey and others have assisted in the office study of the field data and collections. The chemical analyses of samples of water were made in the water-resources laboratory of the United States Geological Survey under the direction of Mr. C. H. Kidwell, formerly chief of the division of quality of water, and analyses of samples of other kinds were made in the chemical laboratory of the Geological Survey under the direction of Mr. George Steiger, chief chemist. The specimens of igneous and metamorphic rocks were determined by Mr. F. C. Calkins, geologist of the Geological Survey, and the chapter on economic geology was reviewed by Mr. H. G. Ferguson, also geologist of the Geological Survey. Specimens of rock and clay-sand were tested by the Bureau of Public Roads, United States Department of Agriculture. The very large paleontologic collections were sorted into groups and distributed to specialists for study and report. A list of the names of those who cooperated in the study of this material is given on page 89 .

Although the chapters of this volume bear authors' names, it is not possible, in a product which is the result of the cooperative efforts of a group of workers, to designate exactly the share done by any one, and such a designation is probably of no great importance. The authors' names indicate those who devoted most attention to the preparation of the several chapters, but Dr. W. P. Woodring and I have reviewed the entire volume and have endeavored to see that the different parts of the report are accordant with one another. This has been a considerable task, as it had to be done in the absence of Messrs. Condit, Cooke, and Ross.

The preparation of the Spanish text has been a task of no small difficulty, because of the great number of technical terms employed. The book was rendered into Spanish by Señor E. M. Amores, chief translator of the Pan American Union, and the translation was carefully compared with the English original by Doctor Cooke. The quality of the result can best be judged by the reader. In justice to both these gentlemen it should be stated that the legends for the maps were written and draughted during Doctor Cooke's absence from the United States and before Señor Amores' services were engaged. The numerous errors in the Spanish legends were not detected until it was too late to correct them. 


\section{OUTLINE OF RESULTS.}

PHYSIOGRAPHY.

The major physiographic subdivisions of the Republic were ascertained, and they are systematically described in Chapter III and are mapped on Plate I (opposite p. 26). This work has never been done before. Gabb's description of the topography of Santo Domingo ${ }^{1}$ contains much information, but it is not presented in a way to bring out clearly the relations between the different features.

\section{STRATIGRAPHY AND GEOLOGIC CORRELATION.}

Prior to the reconnaissance of 1919 the only geologic formations in the Dominican Republic that had been recorded consisted of beds of Cretaceous, Miocene, and post-Pliocene age. Doctor Carlotta J. Maury, as a result of her investigations in the valley of Rio Yaque del Norte, discriminated there two Miocene formations, the Cercado and Guarabo formations, and proposed for them the only two definite names that had been applied to Dominican geologic formations. Our examinations have probably yielded knowledge of at least most of the major stratigraphic units, but the basal complex must be more closely studied before it can be clearly understood. It certainly includes rocks of Cretaceous age and probably rocks of preCretaceous age. We obtained additional data on the Cretaceous system and are able to correlate the formation exposed near Sabaneta with the Upper Cretaceous of Cuba, Jamaica, and other islands of the West Indies.

Among the important additions to knowledge made through the reconnaissance are the recognition of a great thickness of upper Eocene deposits, mostly limestones, the discovery of deposits of both middle and later Oligocene age, and the discovery of an unconformity between the Miocene Baitoa formation and the underlying middle Oligocene Tabera formation. Four additional Miocene formations were recognized in the Cibao Valley, and a late Miocene formation, the Cerros de Sal formation, was discriminated on the north side of Sierra de Bahoruco. Some other additions were also made to the knowledge of the stratigraphy.

The geologic correlation of the formations in one part of the Republic with those in other parts and with those in other regions must depend principally upon a knowledge of the remains of the organisms they contain. The preliminary lists of fossils given in Chapter VI show what was accomplished in acquiring knowledge of this kind, which is not only needed for geologic correlation, but is of great value in solving some problems of economic geology. More detailed investigations of the fossils than has yet been practicable will undoubtedly yield a larger amount of valuable information than that contained in this volume.

\footnotetext{
I See Bibliography, p. 18.
} 


\section{IGNEOUS ACTIVITY AND GEOLOGIC STRUCTURE.}

Although the igneous rocks and their relations to the sedimentary deposits were only superficially investigated some information was obtained concerning the different kinds of rocks they include, their modes of occurrence, their areal distribution, and their geologic ages. There was igneous activity in the Republic prior to Upper Cretaceous time, and it was recurrent, if not persistent, in parts of the territory until almost Recent time. The igneous rocks of the Republic offer a promising field for investigation and enough was discovered concerning them to guide future work.

The most important result of the study of the geologic structure was the recognition of the highly significant part-in places the dominant partplayed by faulting in the deformation of the rocks, and we who were engaged in the field felt keen regret that the lack of good maps and the shortness of the time at our disposal prevented us from studying the faults in detail. In future investigations of the mineral resources of the Republic the contacts of the igneous rocks and the fault systems will be among the phenomena that most need attention. The faults are worthy of study also because of the causal relation they may bear to the severe earthquakes that afflict the Republic from time to time, as it is highly probable that recurrent movement takes place along certain definite zones of fracture.

\section{ECONOMIC GEOLOGY.}

The object of the preliminary examination was to procure reliable information on which to base plans for a careful study of the economic geology of the Republic rather than to prepare a special report for publication, but the need of such reliable information as can be given is so obvious that it is now published. Chapter IX gives the results of a reconnaissance of the provinces of Azua and Barahona with particular reference to oil and salt and discusses the probabilities of obtaining supplies of ground water in the western part of the valley of Rio Yaque del Norte. The results of several special examinations of mineral properties are given in Chapter $\mathrm{X}$, on the economic geology, and other information on the mineral resources is there summarized. There is in the Dominican Republic no established mining industry of more than local importance, and none may be developed, but the evidence now at hand appears to indicate that certain tracts are worthy of careful prospecting, and it is reasonable to suppose that still other tracts that may deserve attention will be discovered. One of the great handicaps of the Republic is its inadequate means of transportation, both within its own confines and with the outside world. The means of internal communication are steadily being improved, however, and as the resources of the Republic gain economic importance communication with the outside world may be bettered. Without cheap transportation, it scarcely need be said, low-grade mineral properties cannot be operated profitably. 
Two resources that particularly deserve geologic study are the rock available for constructing roads and buildings and the ground water. Although some attention is devoted to these resources in this report, they have received by no means the consideration they deserve. Precise information concerning them will be gained and will become available as rapidly as progress can be made in the detailed geologic studies.

\section{ACKNOWLEDGMENTS.}

It is a pleasure to record the efforts made by Rear Admiral Snowden and the members of his staff, particularly Lieut. Commander Baughman, to have all arrangements for the geologic work as nearly perfect as was practicable and to acknowledge the value of a note of general introduction given to me by Monsignor Noel, Archbishop of Santo Domingo. So many courtesies were shown us outside of Santo Domingo City that it is impracticable to mention all who assisted us, in one way or another, in the prosecution of our examinations. It therefore seems better to mention no names and thereby to avoid making invidious distinctions. It can be said, however, that wherever we went the officers of the United States Marine Corps, the officers of the Guardia Nacional Dominicana, and the engineers of the Departamento de Obras Publicas did all they could for us, and the same is true of the local alcaldes. The people in the country were everywhere kind, helpful, and hospitable, often refusing to accept remuneration for our entertainment. Those of us who took part in the reconnaissance look back with pleasant memories of the beautiful country we saw, the interesting scientific experiences we had, and the agreeable human relations that were ours while we were in the Dominican Republic.

As the names of those who have contributed information for use in this report are given elsewhere, it is here only necessary to say that this report has been prepared in the offices of the United States Geological Survey and in the United States National Museum without any expense to the Dominican Government. This work, however, was done in accordance with the proposal made by the Director of the United States Geological Survey in the letter already quoted. 


\section{CHAPTER II. BIBLIOGRAPHY.}

\section{By Wendell P. Woodring.}

The following list contains the titles of the principal publications on the geology and geography of the Dominican Republic, and the titles of some of the principal publications on the geology and geography of the Republic of Haiti, which are included in the list because of the close relations of the two Republics. The writer has examined all the publications listed. Publications that merely describe itineraries in either Republic are omitted, although some of them contain valuable geographic information. Notices of the occurrence of minerals, such as have appeared in consular reports, are likewise omitted, for they are usually based on unconfirmed rumors. Much of the reliable information contained in these papers is incorporated in the present report with proper acknowledgment, except that West Indies Pilot, vol. 1, and the charts of the Dominican shore issued by the Hydrographic Office of the United States Navy have been freely used in the description of the shore line without special credit other than that expressed here.

Abad, José Ramón, La República Dominicana; 400 pp., Santo Domingo, 1888. (Chapters 1-3, geography and topography; chapter 4, geology.)

Agamennone, G., Il terremoto di Haiti (Antille) nella mattina dal 29 diciembre, 1597: Soc. seismol. ital. Bull., vol. 4, pp. 177-191, 1898.

Alberti y Boscr, N., Apuntes para la prehistoria de Quisqueya, tomo 1, geológica y partes descriptivas; 148 pp., 14 pls., 67 figs., 4 maps, La Vega, 1912

ARNOLD, RALPH, Conservation of the oil and gas resources of the Americas (Haiti and Santo Domingo): Second Pan Am. Sci. Congr. Proc., Sec. III, Conservation of Natural Resources, vol. 3, p. 224, 1917.)

Bergt, W., Zur Geologie von San Domingo: Naturwiss. Gesell. Isis in Dresden, Sitzungs. und Abhand., Jahrgang 1897, pp. 61-64, 1897.

Berry, E. W., Tertiary fossil plants from the Dominican Republic: U. S. Nat. Mus. Proc., vol. 59, No. 2363, pp. 117-127, pl. 21, 1921.

Brinsmade, R. B., Iron in Santo Domingo: Min. and Sci. Press, vol. 117, pp. 356-358, sketch map, 1918.

Brown, A. P. and Pilsbry, H. A., Fauna of the Gatun formation, Isthmus of Panama: Acad. Nat. Sci. Philadelphia Proc., vol. 63, pp. 336-373, 3 pls., 3 figs., 1911; vol. 64, pp. 500-519, 5 pls., 5 figs., 1912. (Includes deseriptions of a few species of Mollusea from the Miocene of the Dominican Republic.)

Cabon, A., Contribution à l'étude de la géographie d'Haïti; notes historique sur la détermination de la position géographique d'Haiti: Bull. semest. de l'observ. météorol. du Séminaire-Collège St. Martial, Jan.-June, 1916, pp. 51-67, 1916.

Contribution à 1 'étude de la géographie d'Haiti; notes bibliographiques sur la géographie d'Haïti: Bull. semest. de l'observ. météorol. du Séminaire-Collège St. Martial, July-Dec., 1916, pp. 149-174, 1917; idem, Bull. ann. 1917, pp. 93-128, 1918. 
Cand, Ferdinand, and Bassler, R. S., Fossil Bryozoa from the West Indies: Carnegie Inst. Washington Pub. 291, pp. 75-102, 7 pls., 1919. (Describes and lists, on pages 75-76, the Maury collection of Bryozoa from the Miocene of the Dominican Republic.)

Conrad, T. A., Remarks on the Tertiary strata of St. Domingo and Vicksburg (Miss.): Acad. Nat. Sci. Philadelphia Proc., pp. 198-199, 1852.

Cooke, C. W., A geologic reconnaisance in Santo Domingo (abstract): Geol. Soc. America Bull., vol. 31, pp. 217-219, 1920.

The stratigraphic significance of Orthaulax (abstract): Geol. Soc. America Bull., vol. 31, p. 206, 1920. (Contains discussion of species of Orthaulax from the Oligocene and Miocene of the Dominican Republic.)

Cossuann, M., Etude comparative de fossiles miocéniques recueillis à la Martinique et à l'isthme de Panama: Jour. Conch., vol. 61, pp. 1-64, 5 pls., 1913. (Describes and figures several species of Mollusca from the Miocene of the Dominican Republic.)

Courtney, W. S., The gold fields of St. Domingo; 144 pp., New York, 1860.

Cushman, J. A., Fossil Foraminifera from the West Indies: Carnegie Inst. Washington Pub. 291, pp. 23-71, 15 pls., 1919. (Describes and lists the Foraminifera collected by Miss Maury and her associates in 1917 and gives notes on the correlation and the physical conditions indicated by the fauna. Pages 25-27 refer particularly to the Dominican Republic.

DaLL, W. H., Diagnoses of new Tertiary fossils from the southern United States: U. S. Nat. Mus. Proc., vol. 18, pp. 21-46, 1895. (Includes descriptions of mollusks from the Miocene of the Dominican Republic.)

- Tertiary fauna of Florida: Wagner Free Inst. Sci. Philadelphia, vol. 3, pts. 1-6, pp. 1-1654, 60 pls., 1890-1903. (Contains figures of the species of mollusks described in the preceding paper and discussions of other species from the Miocene of the Dominican Republic.)

De Garston, E. M., Mineral resources of the Dominican Republic: The Mining Journal, vol. 83, p. 682, 1908. [Iron ore in the Dominican Republic (abstract): Iron and Steel Inst. Jour., No. 3, 1908, pp. 495-496; Petroleum in the Dominican Republic (abstract): idem, p. 542; Coal in Dominican Republic (abstract) : idem, p. 527.] - Mineral resources of the Dominican Republic: Board of Trade Journal, vol. 61, no. 600, pp. 450-452, 1908. [Manganese in Dominican Republic (abstract), Iron and Steel Inst. Jour., no. 3, p. 497, 1908.]

De Moya, C. N., Mapa de la Isla de Santo Domingo y Haîti: Published by Rand, MeNally \& Co., 1906. (Scale 1:400,000.)

Donnelly, T. F., The copper deposits of San Cristobal, Santo Domingo: Am. Inst. Min. Eng. Bull. No. 104, pp. 1759-1768, 7 figs., 1915; Am. Inst. Min. Eng, Trans., vol. 52, pp. 645-656, 7 figs., 1916; Abstract: Mexican Min. Jour., vol. 21, pp. 8-10, 1916.

Duncan, P. M., On the fossil corals of the West Indian Islands: Part I, Geol. Soc. London Quart. Jour., vol. 19, pp. 406-458, 4 pls., 1863; Part II, vol. 20, 20-44 4 pls., 1864; Part III, vol. 20, pp. 358-374, 1864; Part IV, vol. 24, pp. 9-33, 2 pls. 1867.

On the correlation of the Miocene beds of the West Indian Islands: Geol. Mag., decade 1, vol. 3, pp. 97-102, 1864.

On the genera Heterophyllia, Battersbya, Palaeocyclus, and Asterosmilia: The anatomy of their species, and their position in the classification of the Sclerodermic Zoantharia: Roy. Soc. Phil. Trans., vol. 157, pp. 643-656, 2 pls., 1867. (Genus Asterosmilia, pp. 652-654, pl. 32, figs. 3a-3d, 4 and 5.)

A revision of the families and genera of the Sclerodermic Zoantharia, Ed. and H., or Madreporaria (M. rugosa excepted): Linn. Soc. Jour. (Zool.), vol. 18, pp. 1-204, 1884. (Contains notes on Dominican fossil corals.) 
Eggers, Baron H., Reise in das Innere von Santo Domingo: Petermanns Mitt., Band 34, II, pp. 35-41, map, 1888. (Account of a journey from Jarabacoa to Constanza and Pico del Valle.)

FABENS, J. W., Facts about Santo Domingo, 32 pp., map, New York, 1862. (Condensed and published under the title "Resources of Santo Domingo," $22 \mathrm{pp}$., map, Washington, 1869. The first publication was slightly revised and republished as "Resources of Santo Domingo," 30 pp., map, New York, 1871.

FALCoNer, J. D., The evolution of the Antilles: Scottish Geog. Mag., vol. 18, pp. 369376, 1902. (Discusses the tectonic features and geologic history of the West Indies and Central America.)

Fengoson, E. G. W., The mineral resources of Haiti, West Indies: Mining World, vol. 31, pp. 133-135, 1909.

Fortunat, Dantes, Île d'Haïti [map]; Paris, 1888. (Scale, 1:400,000).

Frazer, P., Archean characters of the nucleal ranges of the Antilles: British Assoc. Adv. Sci. Rept. 58th meeting, 1888, pp. 654-655, 1889.

GABB, W. M., Informes presentados al gobierno Dominicano por el professor William M. Gabb acerca del examen jeolojico del territorio de la República Dominicana en los años 1869-1871: Revista de Agricultura, Año V, Num. 11 (following p. 314) pp. 1-64; Año V, Num. 12 (following p. 330); pp. 65-92, Santo Domingo, 1910. (In Spanish and English.)

- Notes on the geology of Santo Domingo: Am. Jour. Sci., 3d series, vol. 1, pp. 252-255, 1871.

- On the occurrence of petroleum in the island of Santo Domingo: Am. Jour. Sci., 3d series, vol. 3, p. 481, 1872.

Description of some new genera of Mollusca: Acad. Nat. Sci. Philadelphia Proc., pp. 270-274, 2 pls. 1872. (Describes new genera from the Tertiary system of the Dominican Republic.)

- On the Santo Domingo Miocene and its fossils: Am. Philos. Soc. Proc., vol. 12 , pp. 371-373, 1873.

On the topography and geology of Santo Domingo: Am. Philos. Soc. Trans. new series, vol. 15, pp. 49-260, 2 maps, 1873.

- Notes on West Indian fossils: Geol. Mag., decade 2, vol. 2, p. 544, 1875.

Garrison, F. L., Gold in Santo Domingo: Eng. and Min. Jour., vol. 79, pp. 1128-1130 5 figs., 1905.

- The Island of Santo Domingo; its natural resources and their prospective development: Cassier's Magazine, vol: 30, no. 5, pp. 395-412, 14 figs., map, 1906.

Gold mining in Santo Domingo: Eng. and Min. Jour., vol. 84, pp. 490-492, 5 figs., 1907.

- Metallic sulphides in the tuffs of Santo Domingo: Mining and Sci. Press, vol. 95, pp. 305-310, 6 figs., 1907.

The minerals of Santo Domingo: Eng. and Min. Jour., vol. 99, pp. 641-644, 3 figs., 1915.

- The copper deposits of San Cristobal, Santo Domingo: Am. Inst. Min. Eng. Bull. 108, pp. 2473-2474, 1915.

Garrison, F. L., and Chalas, A., Mining laws and legislation in Santo Domingo: Eng. and Min. Jour., vol. 84, pp. 588, 589, 1907.

Gentil, R., and Chauvet, H., Grande géographie de l'île d'Haïti, 384 pp., Paris, 1896.

Gregory, J. W., Contributions to the palaeontology and geology of the West Indies: Geol. Soc. London Quart. Jour., vol. 51, pp. 255-310, 1 pl., 1895. (Contains notes on a number of species of fossil corals from the Dominican Republic.)

Guppy, R. J. L., On the relations of the Tertiary formations of the West Indies: Geol. Soc. London Quart. Jour., vol. 22, pp. 570-593, 1 pl., 1866. (Contains a short account of the fauna of the Miocene of the Dominican Republic on pp. 574, 575.) 
GסPpy, R. J. L., On the West Indian Tertiary fossils: Geol. Mag., decade 2, vol. 1, pp. 404-411, 433-446, 3 pls., 1874. (Contains a check-list of Tertiary fossils from the Island of Haiti.)

On the Miocene fossils of Haiti: Geol. Soc. London Quart. Jour., vol. 32, pp. 516-532, 2 pls., 1876.

The geological connexions of the Carribean region: Canadian Inst. Trans., vol. 8, pp. 373-391, map, 1909.

Guppy, R. J. L., and Dall, W. H., Descriptions of Tertiary fossils from the Antillean region: U. S. Nat. Mus. Proc., vol. 19, pp. 303-331, 4 pls., 1896. (Includes descriptions of Mollusca from the Miocene of the Dominican Republic.)

Hatch, D., On a saliferous deposit in St. Domingo: Geol. Soc. London Quart. Jour., vol. 24, p. 335, 1868.

Heneken, T. S., On some Tertiary deposits in Santo Domingo, with notes on the fossil shells by J. C. Moore and on the fossil corals by W. Lonsdale: Geol. Soc. London Quart. Jour., vol. 9, pp. 115-134, 7 figs., 1853.

HiLl, R. T., Fundamental geographic relation of the three Americas: Nat. Geog. Mag., vol. 7 , pp. 175-181, map, 1896.

- Cuba and Porto Rico, with other islands of the West Indies: 408 pp, 79 pls., 2 maps, New York, 1898. (Contains discussion of Haiti on pp. 236-295.)

- The geology and physical geography of Jamaica: Mus. Comp. Zool. Harvard Coll. Bull., vol. 34, pp. 256, 41 pls., 40 figs., 1899. (Contains discussion of Dominican Republic on pp. 168-198.)

Jones, William F., A geological reconnaissance in Haiti: Jour. Geology, vol. 26, No. 8, pp. 728-752, 1 pl., 10 figs., 1918.

Kempton, C. W., Some investigations of Santo Domingo minerals: Mining World, vol. 30, pp. 637-639, 8 figs., 1909 .

Knapp, I. N., Santo Domingo petroleum resources: Oil and Gas Jour., vol. 17, no. 5, p. 50, 1918.

Koffmahn, O. See Petermann, A.

LEDoox, J. W., Placer salting in Santo Domingo: Eng. and Min. Jour., vol. 97, pp. 384386, 1914.

I.ewis, Henry P., Mining laws of Santo Domingo: Mining World, vol. 33, p. 804, 1910.

New mining law of the Dominican Republic: Mining Science, vol. 62, p. $473,1910$.

LÜtgens, Rudolf, Geographische und geologische Beobachtungen in NordwestHaïti: Geog. Gesell. in Hamburg Mitt., Band 32, pp. 41-90, 1 map, 3 pls., 10 figs., 1919.

Machado, Mandel A., Datos sobre la estratificacion geológica de la República Dominicana: Gaceta Oficial, 2-5, Santo Domingo, July 10, 1912.

Magnin, J., Les gisements petrolifères de la République dominicaine: Jour. de Pétrole, vol. 7, pp. 99-101, 1907.

Matry, Carlotta J., Santo Domingo type sections and fossils: Bull. Am. Paleont., pp. 165-459, pls. 27-68, 1917.

Santo Domingo paleontological explorations: Jour. Geology, vol. 26, no. 3, pp. 224-228, 1918.

A proposal of two new Miocene formational names: Science, new series, vol. 50, p. 591, 1919. (Proposes names Gurabo formation and Cercado formation for certain Miocene deposits in the valley of Rio Yaque del Norte.)

On the correlation of Porto Rican Tertiary formations with other Antillean and mainland horizons: Am. Jour. Sci., vol. 48, pp. 209-215, 1919. (Includes a correlation table showing the position of some of the Tertiary formations of the Dominican Republic.) 
Maury, Carlotta J., Tertiary Mollusca from Porto Rico: New York Acad. Sci., Scientific Survey of Porto Rico and the Virgin Islands, vol. 3, pt. 1, 77 pp., 9 pls. 1920. (Correlation table opposite p. 4 includes some of the Miocene deposits of the Dominican Republic.)

Miller, Gerrit S., Jr., Bones of mammals from Indian sites in Cuba and Santo Domingo: Smithsonian Mise. Coll., vol. 66, no. 12, 10 pp., 1 pl., 1916.

Moreau de Saint-Merry, M. L. E., A topographical and political description of the Spanish part of Saint Domingo, translated from the French by William Cobbett: 2 vols.; vol. 1, 314 pp., vol. 2, 318 pp., Philadelphia, 1796. (Original French edition not available.)

- Description topographique, physique, civile, politique et historique de la partie française de l'isle Saint-Domingue: 2 vols., vol. 1, 788 pp., 2 maps, 1797; vol. 2, 856 pp., Philadelphia, 1798.

Moone, J. C., On some Tertiary beds in the Island of Santo Domingo, from notes by J. S. Heniker [sic], with remarks on the fossils: Geol. Soc. London Quart. Jour., vol. 6, pp. 39-44, 1850.

Petermann, A., Karte der Insel Haiti: Petermanns Mitt., Band 20, pl. 17, 1874. (Scale 1:1,100,000.) Koffmahn, O., Begleitworte zur Karte der Insel Haiti: Idem, pp. 321-323.

Prlsbry, H. A., A new Haitian Oligocene horizon: Acad. Nat. Sci. Philadelphia, Proc. vol. 62, pt. 2, pp. 487-489, 2 figs., 1910. (Describes a few species of mollusks from the Miocene of the Republic of Haiti.)

Pilsbry, H. A., and Brown, A. P., Oligocene fossils from the neighborhood of Cartagena, Colombia, with notes on Haitian species: Acad. Nat. Sci. Philadelphia Proc., vol. 69, pp. 32-41, 2 pls., 1917. (Includes descriptions of a few species of mollusks from the Miocene of the Dominican Republic and the Republic of Haiti.)

Pilsbry, H. A., and Johnson, C. W., New Mollusea of the Santo Domingan Oligocene: Acad. Nat. Sci. Philadelphia Proc., vol. 69, pp. 150-202, 1917.

Pilsbry, H. A. and Sharp, Benjamrn, Scaphopoda of the San Domingo Tertiary: Acad. Nat. Sci. Philadelphia Proc. pp. 465-475, 2 pls., 1897.

Poey y Aguirre, Andrés, Catalogue chronologique des tremblements de terre ressentis dans les Indes Occidentals de 1530 a 1858 ; suivi d'une bibliographie séismique concernant les travaux relatifs au tremblements de terre des Antilles: (Extrait de l'annuaire de la Société météorologique de France, tome 5, p. 75, séance du 12 mai, 1857) 76 pp., Versailles, 1858.

Potrtalès, L. F., List of fossil corals collected by W. M. Gabb, Esq., in Santo Domingo: Geol. Mag., dec. 2, vol. 2, pp. 544-545, 1875.

Rathbun, M. J., West Indian Tertiary decapod crustaceans: Carnegie Inst. Washington Pub. 291, pp. 159-184, 9 pls. 1919. (Includes descriptions of fossil Crustacea in the Gabb and Maury collections from the Dominican Republic.)

- Additions to West Indian Tertiary decapod crustaceans: U. S. Nat. Mus. Proc., vol. 58, pp. 381-384, pl. 25, 1920. (Describes additional crustaceans collected by the expedition of 1919.)

REclus, ELIsEe, The earth and its inhabitants: edited by A. H. Keane, 19 vols., New York, 1886-1895. (Describes the Island of Haiti in vol. 2, pp. 396-422, 1891.)

Ritter, Kart, Naturhistorische Reise nach der westindlichen Insel Hayti: 206 pp, 6 maps, 3 pls., Stuttgart, 1836.

Rотн, H. L., Bibliography and cartography of Hispaniola: Royal Geog. Soc. Supp. Papers, vol. 2, pp. 43-97, 1889.

Rotнwell, R. P., The gold fields of the southern portion of the Island of Santo Domingo: Am. Inst. Min. Eng. Trans., vol. 10, pp. 345-354, 1882; Eng. and Min. Jour., vol. 34, pp. 31-32, 1882. 
Rovzier, S., Dictionnaire géographique et administratif universal d'Haït: tome 1, 393 pp., 12 maps, 1 pl., 1892; tome 2, 402 pp., 3 maps, 6 pls., 16 figs., Paris, 1893. (Third volume not published.)

Ruschiaupt, F., On the salt mines of St. Domingo: Geol. Soc. London Quart. Jour., vol. 25, pp. 256-257, 1869. (Discussion pp. 257-258).

Sample, C. C., Amber in Santo Domingo: Eng. and Min. Jour., vol. 80, pp. 250-251, 1905).

Scherer, J., Earthquakes in Haiti, April 12-October 10, 1911: Seism. Soc. America Bull., vol. 1, no. 4, p. 171, 1911.

Great earthquakes in the Island of Haiti: Seism. Soc. America Bull., vol, 2 , no. 3 , pp. 161-180, map, 1912 .

Notes on remarkable earthquake sounds in Haiti: Seism. Soc. America Bull., vol. 2, no. 4, pp. 230-232, 1912.

Les grands tremblements de terre dans l'île d'Haïti: Bull. semest. de l'observ. météorol. du Séminaire-Collège St. Martial, July-Dec., 1911, pp. 153-162, 1912.

Les tremblements de terre de l'île d'Haïti dans leur rapports avec le relief du sol et les fosses maritimes que l'entourent: Bull. semest. de l'observ. météorol. du Séminaire-Collège St. Martial, July-Dec., 1912, pp. 132-139, 1913.

[SChERER, J.] Catalogue chronologique des tremblements de terre ressentis dans l'île d'Haïti de 1551 a 1900: Bull. semest. de l'observ. météorol. du Séminaire-Collège St. Martial, July-Dec., 1913, pp. 147-151, 1914.

L'île d'Ha îti et le tremblement de terre de Porto-Rico (du 11 octobre 1918): Bull. ann. de l'observ. météorol. du Seminaire-Collège St. Martial, 1918, p. 93, 1919.

Schoenrich, Otтo, Santo Domingo, a country with a future: 418 pp., 30 pls., 1 map, New York, 1918. (Contains short discussion of geology and minerals on pp. 132-143.)

Schombergk, Sir R. H., Visit to the valley of Constanza: The Athenaeum, No. 1291, pp. 797-799, 1852.

The peninsula and bay of Samaná in the Dominican Republic: Royal Geog. Soc. Jour., vol. 23, pp. 264-284, 1853.

Mapa de la Isla de Santo Domingo: Paris, 1858. (Scale 1: 400,000.)

Sievers, Wilhelm, Richard Ludwig's Reisen auf Santo Domingo 1888-1889: Gesell. für Erdkunde zu Berlin Zeitschr., Band 33, pp. 302-354, map, 1898.

Sowerby, G. B., Descriptions of new species of fossil shells found by J. S. Heniker [sic], Esq.: Geol. Soc. London Quart. Jour., vol. 6, pp. 44-53, 2 pls., 1849.

Stuart, R., Haïti, or Hispaniola: Royal Geog. Soc. Jour., vol. 48, pp. 234-274, 1878.

Suess, E., Das Antilitz der Erde (French translation by E. de Margerie, entitled La face de la terre); 3 vols. and index, 3695 pp., 5 pl., 10 maps, 551 figs., 19051918. (Discusses tectonic features of the West Indies in vol. 1, pp. 113-124; 362-369; 724-737; vol. 3, pp. 1285-1292; 1628.)

Tномasset, H., Carte physique et politique de l'ile d'Haïti: 1908, Port-au-Prince. (Scale 1:400,000.)

Tippenhader, L. G., Die Insel Haïti, 693 pp., 21 pls., 23 figs., Leipzig, 1892.

Geologische Studien in Haïti; I, Aus der sudwestlichen Halbinsel: Petermanns Mitt., Band 45, II, pp. 25-29, map, 1899.

Beiträge zur Geologie Haïtis; II, Aus der nordwestlichen Halbinsel: Petermann's Mitt., Band 45, VII, pp. 153-155, map, 1899.

Beiträge zur Geologie Haittis; III, Geologische studien zwischen Port-auPrince, Jacmel, Bainet, und Grand-Goave: Petermann's Mitt., Band 45, IX, pp. 201-204, map, 1899. 
Tippenhader, L. G., Beiträge zur Geologie Haïtis; IV, Die Erzfundstätten von TerreNeuve und Gonaives: Petermann's Mitt., Band 47, VI, pp. 121-127, map, 2 figs., 1901.

- Beiträge zur Geologie Haïtis; V, Das La Selle-Gebirge, die Cul-de-SacEbene, und das Salzseengebiet: Petermanns Mitt., Band 47, VIII, pp. 169-178, map, 1901.

Beiträge zur Geologie Haïtis; VI, Das Lingnitlager von Ma ̈ssade, und der Aufstieg zum Zentralplateau von Gonaĩves und von Norden aus: Petermanns Mitt., Band 47, IX, pp. 193-199, 3 maps, profiles, 3 figs., 1901.

- Neuer Beiträge zur Topographie, Bevolkerungskunde, und Geologie Haïtis: Petermanns Mitt., Band 55, III, pp. 49-57, map, 1909.

Toula, Franz, Eine jungtertiäre Fauna von Gatun am Panama Kanal: K. K. geolog. Reichsanst. Wien, Teil I, Band 58, pp. 673-760, 4 pls., 15 figs., 1908. Teil II, Band 61, pp. 487-530, 2 pls., 1911. (Refers to fossil Mcllusca from Dominican Republic.)

VAUGHAN, T. W., Some fossil corals from the elevated reefs of Curaçao, Arube, and Bonaire: Geolog. Reichs. Mus. Leiden, ser. 2, Band. 2, pp. 1-91, 1901. (Discusses species of West Indian fossil corals and contains "A list of papers on the Recent and fossil stony corals and coral reefs of the West Indies, Florida, the Bermudas, the western shores of the Gulf of Mexico, and northeastern South America," pp. 78-91.)

- [Correlation of the Cretaceous and Tertiary formations of the Antilles]: Washington Acad. Sci. Jour., vol. 5, no. 13, pp. 489-490, 1915.

- Correlation of the Tertiary geologic formations of the southeastern United States, Central America, and the West Indies: Washington Acad. Sci. Jour., vol. 8, no. 9, pp. 268-276, 1918.

- Geologic history of Central America and the West Indies during Cenozoic time: Geol. Soc. America Bull., vol. 29, pp. 615-630, 1918.

Fossil corals from Central America, Cuba, and Porto Rico, with an account of the American Tertiary, Pleistocene, and Recent coral reefs: U. S. Nat. Mus. Bull. 103, pp. 189-524, 1919. (Pages 213-218 deal particularly with the Dominican Republic.)

- The biologic character and geologic correlation of the sedimentary formations of Panama in their relation to the geologic history of Central America and the West Indies: U. S. Nat. Mus. Bull. 103, pp. 547-612, 1919. (Contains, opposite p. 585, a correlation table showing the position of the known Tertiary formations of the Dominican Republic; discusses tectonic relations on pp. 601-603.

Stratigraphy of the Virgin Islands of the United States and of Culebra and Vieques Island (Abstract): Geol. Soc. America Bull., vol. 31, pp. 216-217, 1920. (Contains discussion of the correlation of the rocks of the Virgin Islands with those of the Dominican Republic.)

Wade, B. F., White, A. D., and Howe, S. G., Report of the commission of inquiry to Santo Domingo: Senate Document No. 9, 42d Cong., 1st sess., 297 pp, map, 1871. (Includes brief reports by W. P. Blake, J. S. Adams, and A. R. Marvine on the geolcgy of parts of the Dominican Republic.)

Wells, James W., A survey journey in Santo Domingo, West Indies: Royal Geog. Soc. Supp. Papers, vol. 3, pp. 589-604, map, 1893. (An account of a trip through Enriquillo Basin.)

Anonymous, Tremblement de terre à Saint-Domingue (Antilles): Cosmos, 47e année, nouvelle série no. 688 , pp. 420, 421, 1898.

- The Dominican Republic; published by direction of the Department of Promotion and Public Works for the Jamestown Ter-Centennial Exposition, 98 pp., 1907. (Chapter 1, geography and topography; Chapter 5, economic geology.)

- Bermuda Islands, the Bahama Islands and the Greater Antilles: West Indies Pilot, vol. 1, 577 pp. Hydrographic Office, Washington, D. C., 1913. 
The following papers, which are cited in Tippenhauer's or in Roth's bibliography, have not been examined:

Castro, M. F. de, Nota sobre la geología de Santo Domingo: Revista Minera, vol. 13, pp. 633-642, 692-699, 729-738, 1862; vol. 14, pp. 42-51, 65-73, Madıid, 1863.

Noticias geográficas de la isla de Santo Domingo: Soc. Geog. Madrid Bol., vol. 6, pp. 317-339, map, 1879.

Schomburge, Sir R. H., The Loadstone Mountain at Santo Domingo: The Athenaeum, 1853, pp. 739-740.

Ausflug nach dem Henriquillo-See, Bestimmung von Santo-Domingo: Gesell. für Erdkunde zu Berlin, Monatsh., Neue Folge, Band 8, pp. 13-(?), 1850 (?).

Walton, William, Report on the mines known in the Eastern Division of Haiti and the facilities of working them: $47 \mathrm{pp} .$, London, 1825. 


\section{CHAPTER III.}

\section{GEOGRAPHY.}

\section{By Wythe Cooke.}

\section{GENERAL FEATURES.}

Haiti, which next to Cuba is the largest West Indian island, lies nearly midway between Cuba and Porto Rico. It is separated from Porto Rico, on the east, by the Mona Passage, and from Cuba, on the west, by the Windward Passage. As the maximum depth of water between Haiti and Porto Rico is about 318 fathoms (580 meters) these islands rise from a common, not greatly submerged bank, but the depth between Haiti and Cuba exceeds 1,000 fathoms (1,830 meters). The northern shore of Haiti is washed by the waters of the Atlantic Ocean; the southern shore forms part of the perimeter of the Caribbean Sea. The island lies wholly within the Torrid Zone, between parallels $17^{\circ} 36^{\prime} 40^{\prime \prime}$ and $19^{\circ} 58^{\prime} 20^{\prime \prime}$ north latitude. Its longitude ranges from about $68^{\circ} 20^{\prime}$ to nearly $74^{\circ} 30^{\prime}$ west of Greenwich. The area of the island is said to be 73,150 square kilometers, of which the Dominican Republic occupies the eastern two-thirds and the Republic of Haiti the western third, but until detailed accurate surveys are made and the boundary disputes between the republics are settled the true area of the island and that of its two political divisions will not be known.

Lying as it does at the intersection of , two of the major tectonic trends of the Caribbean area, ${ }^{1}$ the island of Haiti may be divided into two principal parts, a northern, including the greater part of the island, and a southern, including the southwestern peninsula and the area south of the Enriquillo Basin. The axes of the mountain ranges and principal valleys in the northern part trend about $\mathrm{N} .60^{\circ} \mathrm{W}$, , are parallel, and are evidently genetically related to the physical features of central and eastern Cuba. The southern part extends nearly east and west, and its major tectonic axis is in line with the major axis of Jamaica. These two parts can be subdivided into several topographically distinct areas, which will be described separately. A third part, which is structurally distinct from the others, is the broad coastal plain - the plains of Seibo and Bani-in the southeastern part of the island.

The topographic divisions in the part of the island that is included in the Dominican Republic are the Cordillera Septentrional, Samaná Peninsula, Cibao Valley, Cordillera Central, Valley of San Juan, Azua Plain, Sierra de Neiba, Sierra de Martín García, Enriquillo Basin, Sierra de Bahoruco, southern peninsula, and the coastal plain. The boundaries between these topographic areas are shown approximately on Plate I. 




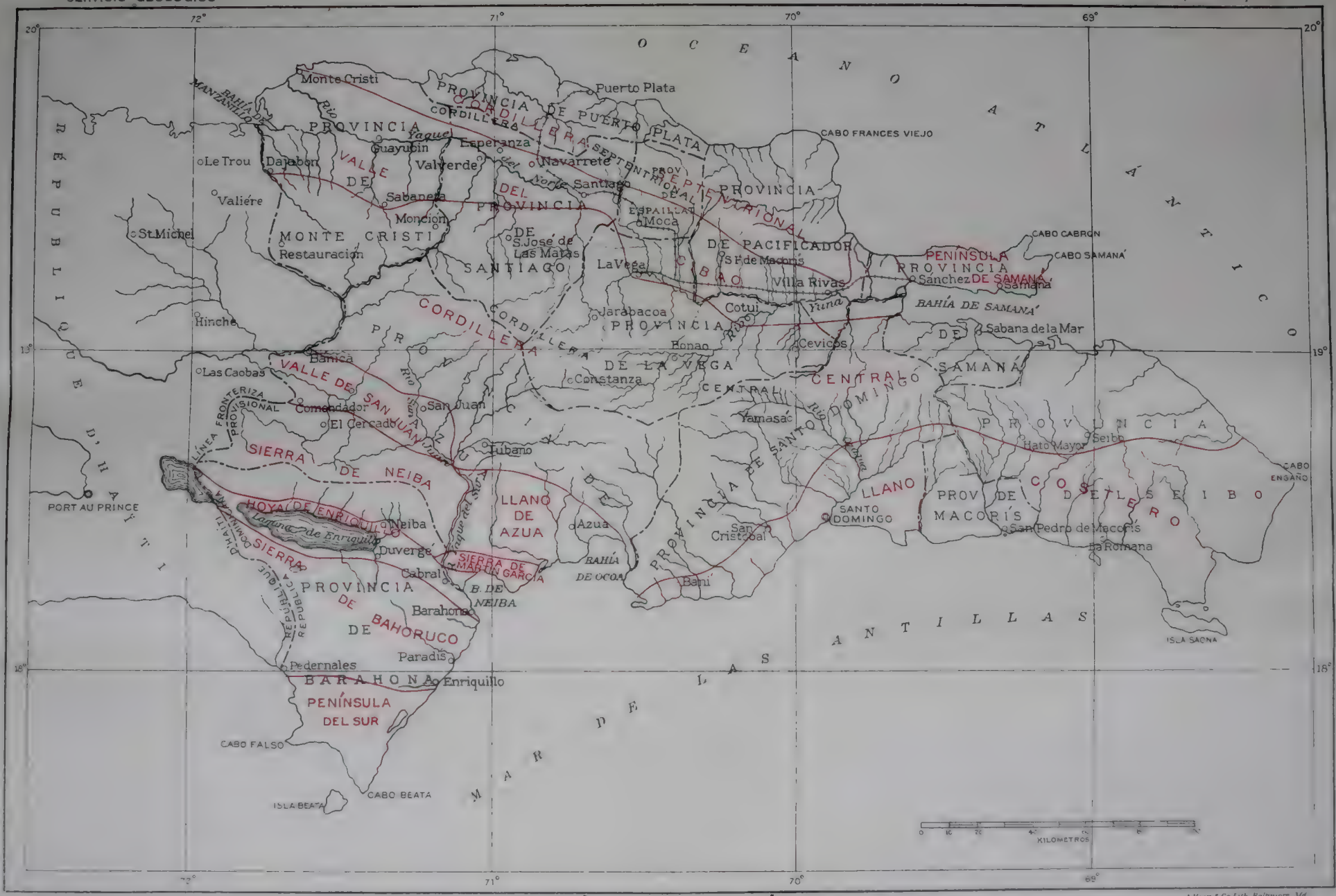

PROVINCIAS FISOGRÁFICAS DE LA REPÚBLICA DOMINICANA 



\section{CORDILLERA SEPTENTRIONAL.}

The Cordillera Septentrional (Northern mountain system), sometimes called the Monte Cristi Range, starts as low, rounded rocky hills near Monte Cristi, extends southeastward for about 200 kilometers parallel to the northern coast, and terminates near the shore of Bahía Escocesa. It is made up of several more or less parallel ranges and a few isolated mountain masses.

The highest mountains in the Cordillera Septentrional are in its westcentral part, north of Santiago, where some of the peaks are said to attain altitudes of 1,000 to 1,400 meters above sea level. The range near Santiago as seen from the south presents a fairly even sky line, broken by few serrated peaks such as characterize the Cordillera Central. (See Pl. II, A.) The parts of the range that project above the generally even profile have flat or rounded tops. The south front of this range is a fault scarp, which has been considerably modified by erosion.

The western part of the Cordillera Septentrional, to which the name "Monte Cristi Range" might appropriately be restricted, is very irregular. The hills and low mountains composing it are steep and in some places rough, but they do not rise to great heights. The part adjacent to Monte Cristi consists of isolated, rounded rocky hills, 60 meters or more high, rising abruptly from a rolling but, on the whole, level plain, which averages little more than 10 meters in height above sea level. El Morro de Monte Cristi, also called La Granja, shown in Plate II, $B$, is a narrow, wedge-shaped outlier about 225 meters high, composed of nearly horizontal sediments of Miocene age. It is separated from the mainland by salt marshes. ${ }^{1}$

At the arid west end of the Cordillera Septentrional there are few continuous water channels. A little farther to the southeast, where the hills are somewhat higher, the waterways are more continuous and better defined.

At the east end of the Cordillera Septentrional there is no steep southward-facing escarpment like the mountain front near Santiago. The ascent to the mountains proper from the Vega Real is over low foothills or spurs, which rise gradually to altitudes of 100 meters or more above the valley. The hills are composed of buff impure limestones which soften on exposure and afford few bare outcrops. The flat-topped mountains that form the summit of the Cordillera Septentrional between Altamira and El Aguacate suggest a peneplained surface at an altitude of about 650 meters. (See Pl. II, C.)

Monte Isabel de Torres (see Pl. III, $A$ ) rises steeply almost from the water's edge at Puerto Plata to an altitude of 815 meters above sea level and is a conspicuous landmark. As seen from the harbor it is wedge-shaped, and it culminates in a flat-topped peak, which is usually swathed in clouds. In

\footnotetext{
${ }^{1}$ For further description of the Monte Cristi region see Chapter VII of this volume.
} 
the areas east and west of Puerto Plata the mountains lie back from the shore, and the area between them and the sea is hilly or rolling.

The upland west of Puerto Plata and north of Bajabónico consists of rather evenly sloping ridges whose summits reach altitudes of about 250 meters. Above these summits rise sharp little peaks composed of steeply dipping bedded rock. The surface represented by the summits of these ridges appears to extend around the south, the east, and the west sides of Monte Isabel de Torres, but the details of its features and their significance cannot be ascertained without careful study aided by adequate topographic maps. A low coastal apron extends around Puerto Plata and an alluvial flat along Rio San Marcos. Alluvial or detrital benches appear to reach as high as about 60 meters above sea level, but during the very hasty examination of Rio San Marcos valley no definite system of terraces could be recognized.

\section{SAMANÁ PENINSULA.}

Samaná Peninsula consists of a mass of fairly rugged but not very high mountains and at some places of a fringe of flat to rolling lowlands. It projects about 50 kilometers eastward from the northeast corner of the main island mass. Its average width from north to south is 11 or 12 kilometers. The west end of the peninsula is separated from the Cordillera Septentrional on the mainland by a flat, swampy area, the Gran Estero, which in the not very remote past was an open strait, but which has now become nearly closed, partly by uplift of the land and partly by filling in by silt brought down by the Rio Yuna. Water connection between Samaná Bay and the Atlantic Ocean through the Gran Estero is said to be still maintained by several distributaries of the Yuna.

The main mountain mass is divided into three parallel ridges. On the north coast, the mountains come down close to the sea but are interrupted by several stretches of broad, sandy beach. The southern ridge rises steeply from the water between Punta Balandra, at the southeastern extremity of the peninsula, and Los Cocos (see Pl. III, B), but west of Los Cocos it is bordered by a narrow fringe of rolling land, probably the dissected remnants of a series of terraces, which range in altitude from sea level to about 30 meters above it. (See Pl. III, C.) The mountains in the central part of the peninsula rise to about 500 meters above sea level, and a few are probably somewhat higher. Among the more prominent peaks whose altitudes are shown on the charts of the Hydrographic Office of the United States Navy are El Pilón de Azúcar (Sugar-loaf), 491 meters, 6 or 8 kilometers inland from Santa Barbara de Samaná; a neighboring peak, perhaps Monte la Mesa (Table Mountain), 558 meters; Monte Diablo, rising from the water at Punta Balandra to a height of 400 meters; and Loma Las Cañitas, at Sánchez, the highest point of which is said to be 514 meters above sea level. 


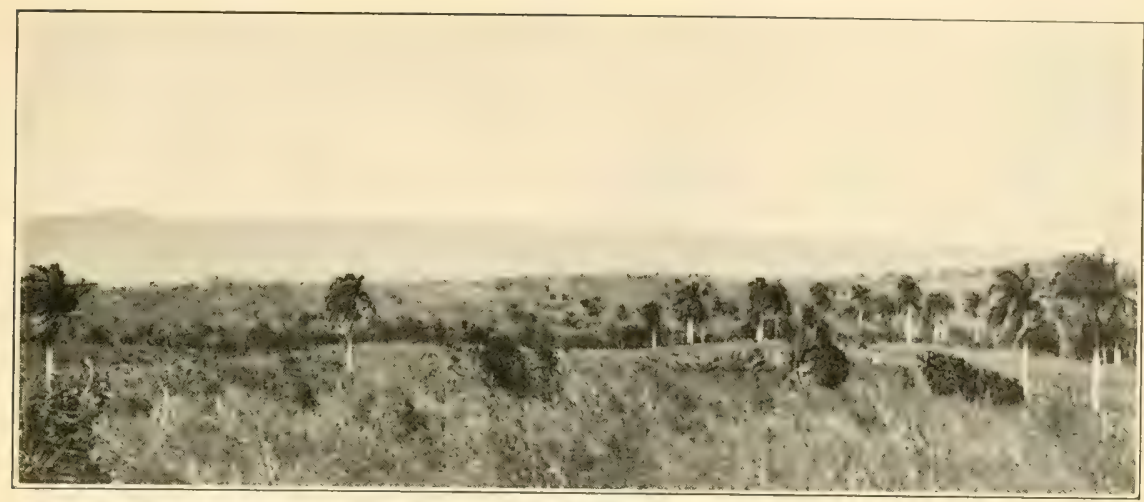

A. SOUTH FRONT OF THE CORDILLERA SEPTENTRIONAL AS SEEN LOOKING NORTH WARD FROM A POINT EAST OF SANTIAGO

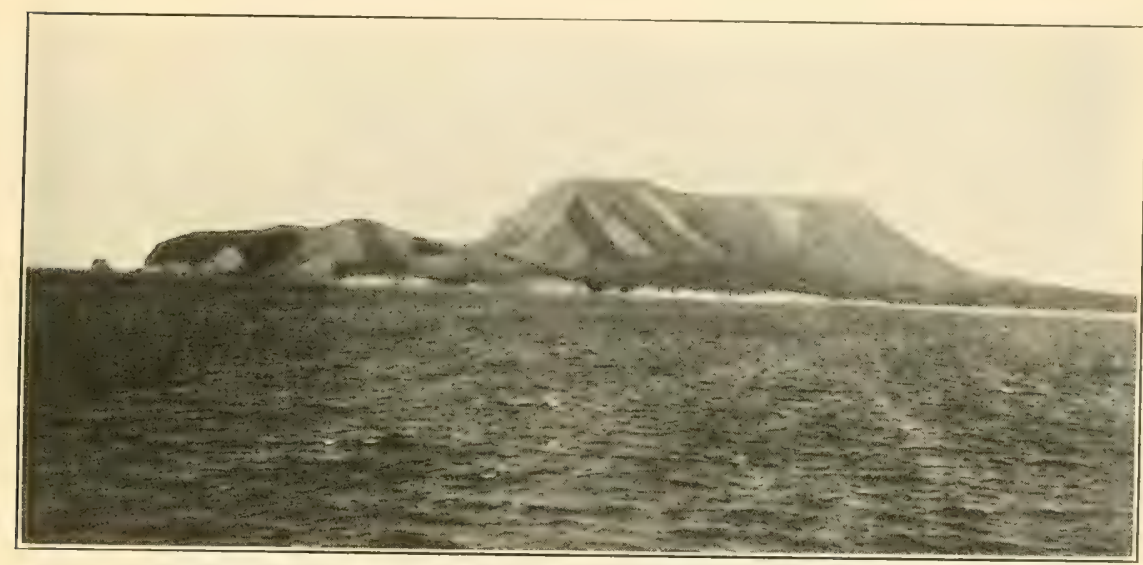

B. EL MORRO DE MONTE CRISTI AS SEEN FROM THE SOUTH SIDE.

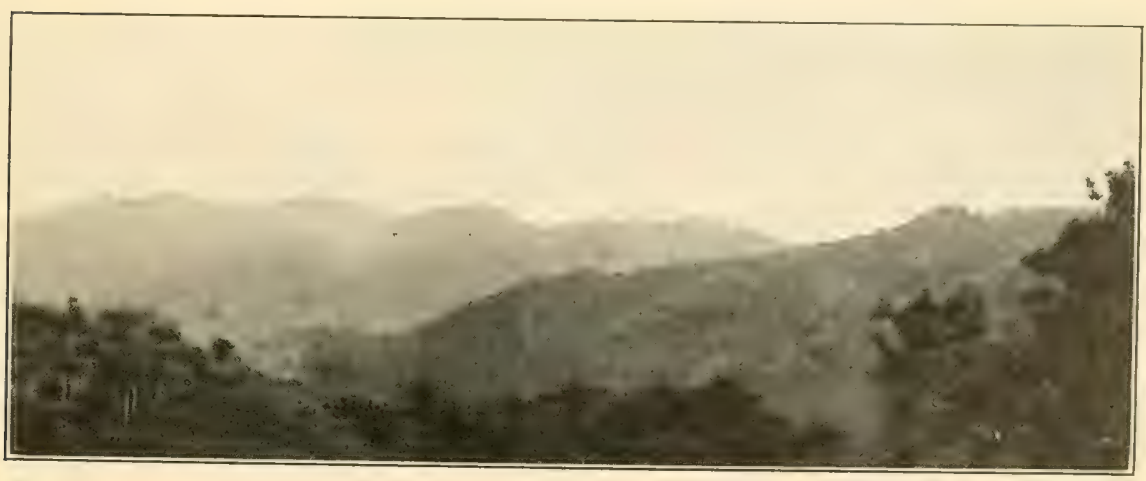

C. LOMA LA CUMBRE, THE SUMMIT OF THE CORDILLERA SEPTENTRIONAL BETWEEN ALTAMIRA AND EL AGUACATE, AS SEEN LOOFING NORTHWARD. 

At the east end of the peninsula, between Punta Balandra and the head of Rincón Bay, at an altitude of perhaps a hundred meters above sea level, there is a limestone plateau, which merges into the hills on the west side. This area is drained through sinks by subterranean streams, some of which are said to emerge on the beach as springs. Between Punta Balandra and Cabo Samaná several terraced flats, probably of marine origin, are plainly visible from the decks of passing steamers.

The rainfall is very heavy in Samana Peninsula and it is more evenly distributed throughout the year than in some other parts of the island. As the climate is moist and the soil is fertile, the peninsula is clothed with a dense cover of vegetation which, except on the beaten trails, is in many places impassable. ${ }^{1}$

\section{CIBAO VALLEY.}

The Cibao Valley extends from Monte Cristi and Manzanillo Bay eastward to Samaná Bay, a distance of about 225 kilometers, and it ranges in width from about 15 to about 45 kilometers. It is bordered on the north by the Cordillera Septentrional, which is nearly straight, and on the south by the Cordillera Central, which has an irregular front and many reentrant valleys. In the vicinity of Santiago it is divided by a low, hilly watershed into two nearly equal parts.

The western half of the Cibao Valley is drained by Rio Yaque del Norte, which flows northwestward into Manzanillo Bay. Most of the country here is rolling and open, and the streams in it are deeply entrenched below the general level. The gently tilted limestone ledges of the Yaque group (Miocene) form ridges or hogbacks, some of which are 100 or 200 meters high. Among the more prominent hills on the south side of the Yaque are the Loma de Caracol and the Sierra Zamba.

The greater part of the west end of the Cibao Valley is occupied by the broad delta and flood plain of Rio Yaque, but between this low country and the foothills of the mountains lies a strip of higher land dotted with gravelly knolls, which appear to be remnants of a formerly continuous sheet of gravel. Farther upstream the flood plain narrows and finally disappears

The eastern half of the Cibao Valley is drained by Rio Yuna, which flows eastward into Samaná Bay, and its principal tributary, Rio Camú. These streams, as well as the smaller ones, are sharply incised. Between San Francisco de Macorís and Santiago the valleys are 15 to 25 meters deep and little more than 100 meters wide at the surface. The eastern part of the Cibao Valley includes the fertile Vega Real (Royal Meadow), which extends from the swamp lands at the head of Samaná Bay nearly to Santiago. The Vega Real is among the most impressively fertile districts in the world. Its nearly level plains yield large crops of cacao, tobacco, and bananas, and its grassy savannas afford excellent pasturage. It is traversed by the Ferrocarril de Santiago y Samaná.

\footnotetext{
'For a more detailed description of Samana Peninsula see pp. 181-185 of this volume.
} 
South of the Vega Real, extending from Loma de los Palos eastward nearly to Sabana de la Mar, there is a plateau that stands 100 meters or more above the surrounding land. From a distance this plateau appears to be nearly flat, but closer inspection shows that it is deeply pitted with large cavities. It rises somewhat toward the east, and near Sabana de la Mar it attains an altitude of about 200 meters above sea level. This plateau is underlain by massive coralliferous limestone, probably of Miocene age, and is drained through underground passages. A trail from Cevicos to Villa Rivas, by far the most difficult trail travelled by any member of the expedition, crosses this plateau. From a point several kilometers south of Cevicos, where it first climbs to the plateau, the trail follows the course of an underground stream, which is marked by a chain of deep sinkholes connected by low passes. The surprised traveller scrambles down one side of a sink and up the other, over jagged masses of sharp limestone, only to find another sink, equally difficult and dangerous, just before him. There are said to be 24 of these holes to be crossed, but the weary traveller loses count long before he emerges upon the level plain of the Vega Real.

The part of the Cibao Valley that lies east of Santiago is abundantly watered $(\mathrm{Pl} . \mathrm{IV}, A)$, but the partwest of Santiago becomes progressively more arid westward, and open grassy meadows give way to cactus and mesquite clad plains (Pl. IV,$B$ ). Most of the water used for domestic purposes in this western area is carried on the backs of burros from Rio Yaque or its tributaries, in some places for as much as 20 kilometers.

The Cibao Valley is thickly settled, progressive, and prosperous. Santiago de los Caballeros, the second largest city in the country, is the metropolis of the region. It has direct rail connection with Puerto Plata by the Ferrocarril Central Dominicana, a government-owned railroad. which connects at Moca with the Ferrocarril de Santiago y Samaná, giving access to the port of Samaná. Other towns worthy of mention are Moca, La Vega, San Francisco de Macorís, and Villa Rivas on the east, and Navarrete, Valverde or Mao, Guayubin, and Monte Cristi on the west.

\section{CORDILLERA CENTRAL.}

\section{GENERAL FEATURES.}

The great mountainous backbone of the Dominican Republic, the Cordillera Central, starts from low hills at the extreme east end of the island, rises gradually towards the west and attains its greatest height in the westcentral part of the island. Its westward extension forms the north range of the Republic of Haiti and is connected by the Montagne Noir with the Sierra de Neiba. The range is widest in the middle, where it attains a width of 130 kilometers, extending from a point near Santiago to the latitude of Azua and sending a spur to the shore of the Caribbean Sea at Sabanabuey. 

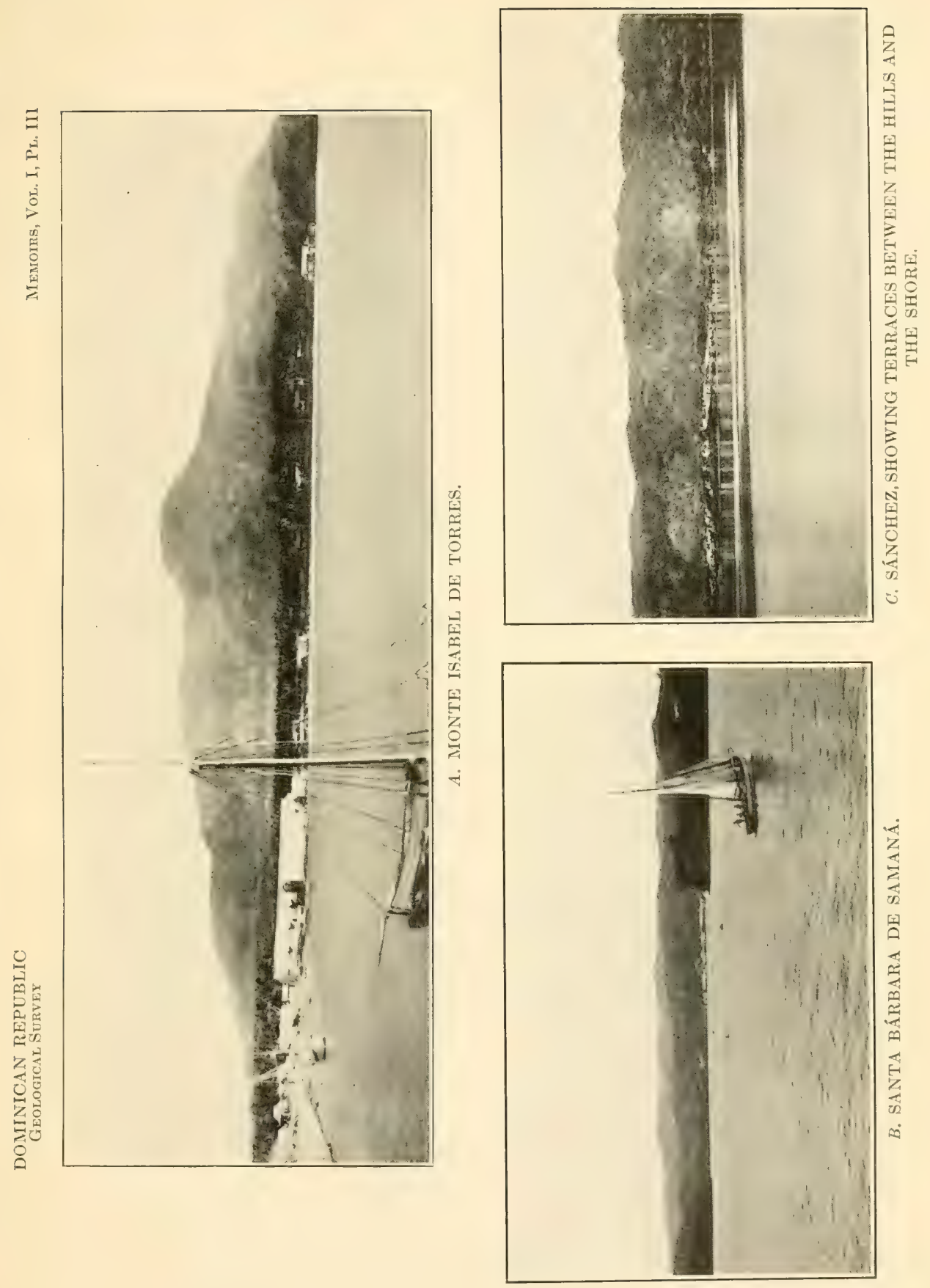

To the traveller on the few trails across the mountains no systematic arrangement of the elements composing the Cordillera is perceptible. The range appears to be a jumble of ridges and peaks, with occasional unexpected beautiful little flat-bottomed valleys nestling at their feet. The causes of this irregularity are to be sought in the complex geologic composition and structure of the Cordillera. Not only does the central mountain mass include many different kinds of rocks-effusive and intrusive igneous rocks, schists and other metamorphics, and a great variety of sedimentary rockseach of which has its own characteristic topographic development, but much of it has been faulted along several different axes and otherwise disturbed. Examples of discordant ridges due to faulting are Loma El Numero, east of Ocoa Bay, and the mountain front north of Azua. Both of these ridges, which run nearly at right angles to one another, are outlined by faults.

\section{BONAO TRAIL.}

The route across the Cordillera Central most frequently used by travelers between the capital and towns in the Cibao Valley is the Bonao trail. This route leads from Santo Domingo City through Los Alcarrizos and Bonao to La Vega. The Duarte Highway (Carretera Duarte), now under construction, follows this old trail for a considerable distance but departs from it at places in order to take advantage of easier grades.

Hatillo, 28.5 kilometers from the capital, is in the low hills at the southern border of the Cordillera Central. The approach to Hatillo is over a gradually rising, rolling country, much of which is cultivated. The camp at this place marked the end of the part of the Carretera Duarte leading from Santo Domingo City which had been completed by April 1, 1919.

Between Hatillo and El Madrigal, a settlement of a few scattered houses, the country is rather open. Many of the valleys are steep-sided and the ridges are rather sharp, but the soil is deep and not much rock is exposed. (See Pl. V, $A$ and B.) The higher mountains to the west are more rugged. Rio Jaina, where crossed, is clear and rapid, about one meter deep, 90 meters wide, and strewn with boulders. Near El Madrigal (see Pl. V, C) two terraces at heights of 26 and 49 meters respectively above the river were noted.

Between El Madrigal and Sabana Grande, which is marked by a single house, the route lies along the valleys of Rio Jaina and Arroyo Guananitos. The valley of Rio Jaina at El Madrigal is nearly 5 kilometers wide and has steep wooded hills on both sides. It is floored with clay, loam, and gravel, and is covered with a fairly dense growth of bushes, interspersed with somewhat swampy savannas. Arroyo Guananitos, above La Mata, is a small meandering stream having a fall of 4 or 5 meters per kilometer. Its channel is choked with logs and trees, and terraces of gravel and sand were noted at several places in its valley. The upper part of the valley of Arroyo 
Guananitos is broad and nearly flat. At Sabana Grande, which is about 250 meters above sea level, it is more than 6 kilometers wide. The floors of the stream valleys, although wide and flat, are bordered by mountains. (See Pl. VI, B.) The scenery along the route is attractive in many ways and very picturesque.

The main divide of the Cordillera Central between Sabana Grande and Bonao is crossed by the Bonao trail at an altitude of about 430 meters above sea level. The trail is somewhat steep but not difficult in dry weather, but here, as in many other parts of it, mud is very troublesome at all times except near the end of the dry season. Small pines grow at altitudes above 340 meters. Mahogany was noted between Piedra Blanca and Hato del Bonao. The growth of bushes and small trees of many kinds is in most places very thick, and some tree ferns were seen.

Rio Juan Manuel, Arroyo Maimón, and several other clear, swift streams are passed between the summit of the divide and Bonao. No falls were seen, but there are numerous small rapids. None of the streams are large, but several are large enough to supply a small town with water, and perhaps also with some power.

Bonao, a town of about 1,000 inhabitants and by far the largest settlement between the capital and La Vega, stands on the fertile alluvial flat that borders Rio Yuna. It is the center of an agricultural community, which produces considerable quantities of cacao, tobacco, coffee, beans, and many kinds of fruits.

Rio Yuna, a broad stream about a meter and a half deep, is forded about 1 kilometer north of Bonao. The trail thence leads across a low divide into the valley of Rio Jima, a much smaller stream, crosses a low pine-clad ridge, and comes to Loma Miranda.

Loma Miranda is crossed at an altitude of about 290 meters above sea level. Its grades are among the steepest on the Bonao trail, the descent on the northwestern side to the Vega Real being especially abrupt. The Carretera Duarte avoids this mountain by making a detour down the valley of Rio Jima. At El Pino, near the foot of Loma Miranda, the trail joins the Carretera Duarte and follows the nearly level floor of the Vega Real to Concepción de La Vega.

\section{SIERRA DE OCOA.}

The name Sierra de Ocoa is applied to the part of the Cordillera Central that lies south of Rio de las Cuevas and west of Rio Nizao. This region is well watered, presenting a striking contrast to the thirsty plains of Azua that adjoin it on the south. In the midst of the mountains is the thickly settled, fertile, terraced valley of Rio Ocoa, which drains almost the entire region and passes southward out of it through a gorge extending from San José de Ocoa to Los Ranchitos, near which it emerges upon the plain. 


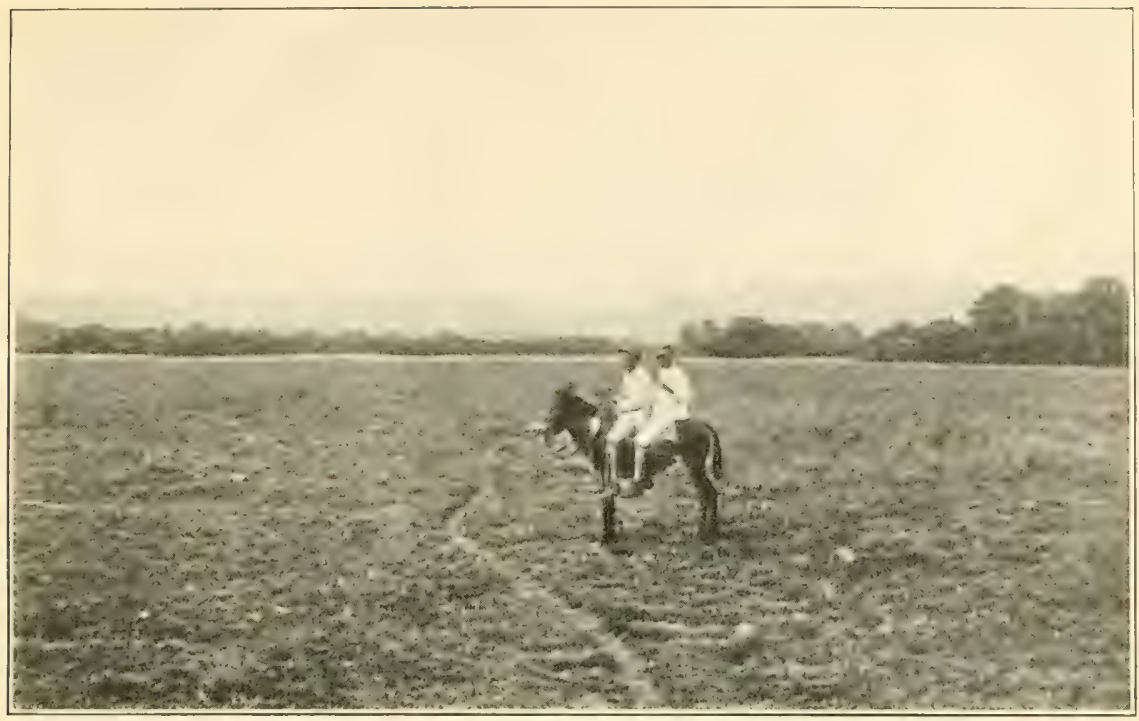

A, VEGA REAL, SABANA LLANA NEAR EL HIGO GORDO, PROVINCE OF LA VEGA, WITH THE FOOTHILLS OF THE CORDILLERA CENTRAL IN THE DISTANCE.

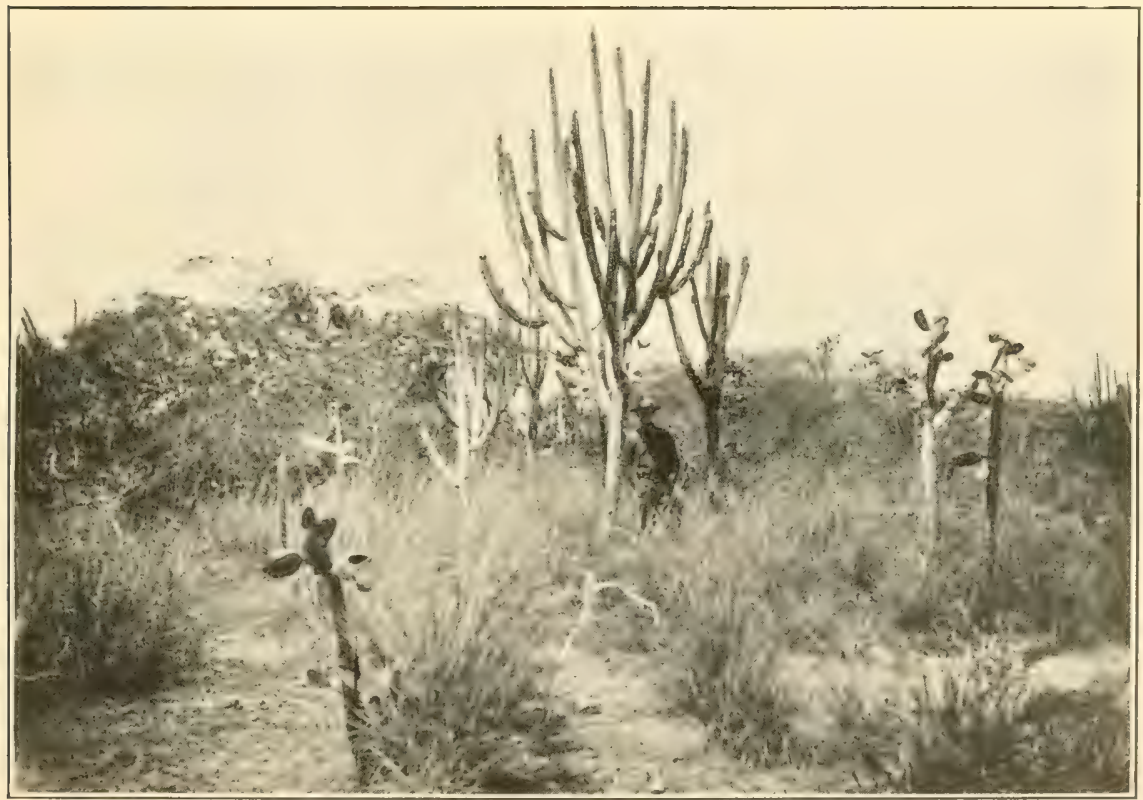

B. VALLEY OF RIO YAOUE DEL NORTE NORTH OF ESPERANZA. Large Cereus cacti in middle ground. 

San José de Ocoa, better known by its old name of Maniel, is charmingly situated on an outwash slope and well-developed terrace at an altitude of about 50 meters above Rio Ocoa and about 450 meters above sea level. The town is nearly surrounded by sharp ridges of limestone, but from it can be seen the high mountains at the headwaters of the Ocoa. It boasts a church and plaza and three coffee mills, in which the coffee berries are shelled through hoppers. Besides coffee, the neighborhood produces large quantities of red beans (habichuelas). A small detachment of the Guardia Nacional is stationed here.

Communication with the outside world is maintained over three difficult trails. One little used trail leads northeastward across Loma Nizao (altitude of pass about 875 meters above sea level) to Nizao Arriba and thence to Cotuí, meeting the Bonao trail from Santo Domingo to La Vega at Piedra Blanca. Another very hilly trail, which is slippery in rainy weather, after passing numerous ridges descends from Loma de Portezuelo, which is about 650 meters above sea level, and comes out upon the plain at the village of Estebanía, from which an easy trail leads to Azua. The third descends the gorge of Rio Ocoa, fording the river 15 times between San José de Oeoa and the little settlement of Los Ranchitos, where it turns southeastward to Baní. This trail, of course, is impassable when the river is in flood.

The highest mountains on the island rise from the area north of the Sierra de Ocoa. The top of Loma Tina, said to be the highest peak in the West Indies, is reputed to be 3,140 meters above sea level. Monte Culo de Maco, less famed but perhaps equally lofty, towers out of the cañon of Rio del Medio opposite the little settlement of Las Cañitas. As viewed from the west the mountain resembles a great wedge with a long, smooth, southward-sloping flank, strongly suggestive of a dip slope of sedimentary rocks and steeply truncated at the north end. The western face is very steep. El Rucillo, or Pico del Yaque, said to be 2,955 meters high, is nearly midway between San José de las Matas and Túbano and about 20 kilometers north of Monte Culo de Maco.

\section{CONSTANZA TRAIL.}

The part of the Cordillera Central that lies north of the Sierra de Ocoa is crossed by the Constanza trail, which leads from Santiago and La Vega through Jarabacoa and Constanza to San Juan and Túbano. From Santiago the trail leads up the east side of Rio Yaque del Norte and two or three kilometers below Angostura enters hills of coralliferous limestone and massive Miocene conglomerate. From Baitoa, a village of several hundred inhabitants, the trail passes southward or southeastward across steeply tilted conglomerate (Tabera formation) for about 2 kilometers, circles around a prominent double peak of hard limestone, and winds along a narrow, crooked ridge, which maintains a general southward trend and reaches a maximum altitude of about 415 meters above sea level. It then 
drops abruptly to Tabera, a little hamlet nestling in the Yaque Valley, surrounded by steep conical hills of conglomerate and brown shale just big enough to afford a perch for one or two houses. From Tabera the trail ascends gradually for 3 or 4 kilometers and then climbs a steep hill to an altitude of about 200 meters above sea level, where it is joined by a trail from La Vega.

From the summit of Loma Llanada or Loma de Joa (altitude about 630 meters), a great mass of serpentine, one can look southward across the wide valleys of Rio Yaque and Rio Jimenoa, and can get, far to the north, vistas of the Cibao Valley and the Monte Cristi Range, looming up beyond it. The south side of Loma Llanada is covered with an open pine forest, which gives way, near the base, to plant types more characteristic of the tropics, such as the royal palm, guava, and wild orange. In the lower, damp places the rose apple ("pomarrosa") flourishes in great luxuriance. Between Loma de Joa and Rio Jimenoa there are low hills and several small streams.

Jarabacoa, a compact little town of perhaps 1,000 inhabitants, is built on a terrace on the left bank of Rio Yaque del Norte at an altitude of about 480 meters above sea level. A well-defined higher terrace begins at the edge of the town, and corresponding terraces can be seen on the opposite side of the river. El Barrero (altitude about 1,000 meters) dominates the view on the south. From the top of hills near Jarabacoa can be seen the rounded peak of El Rucillo, and far away to the north the even profile of the Cordillera Septentrional.

A steady climb of an hour and a half brings one from Arroyo Baiguate to a grassy knoll at the top of El Barrero, from which the road circles westward down the southern side and climbs by easy stages to El Paso Bajito and past La Piedra del Toro to the ford of Rio Jimenoa at El Rio. All trails in this region follow the crests of ridges that extend like buttresses away from the main mountain mass.

From the top of Loma del Valle a beautiful view can be had of the flatfloored valley of Constanza and of the rugged, cloud-capped mountains that shut it away from the outside world. The valley occupies an area of perhaps 30 square kilometers at an altitude of about 1,100 meters above the sea. It is drained by Rio Limón, which has etched a narrow outlet through the mountains to the west. Because of the high altitude the climate of the valley of Constanza is delightfully invigorating. The nights are cool all the year round and frost is sometimes formed in winter. Mosquitoes, the bane of the tropies, appear to be unknown in this valley. About 1 kilometer from Constanza the Department of Agriculture maintains an experiment station for raising products of the temperate zone. Constanza is a forlorn village of several score of cabins, and except its beautiful location and healthful climate, has few attractions to the outsider. 


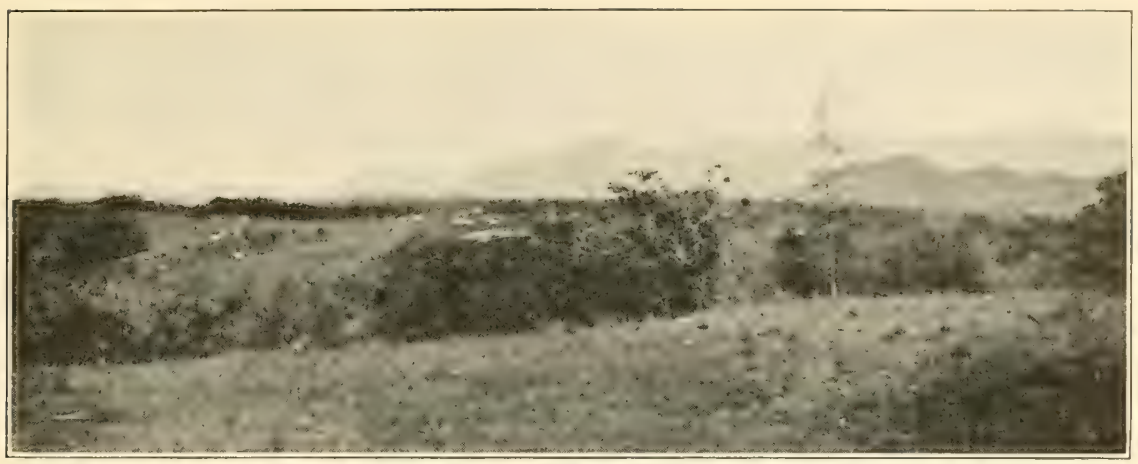

A. VIEW NORTHWARD FROM HATILIO, 28.5 KILOMETERS NORTHWEST OF THE CITY OF SANTO DOMINGO.

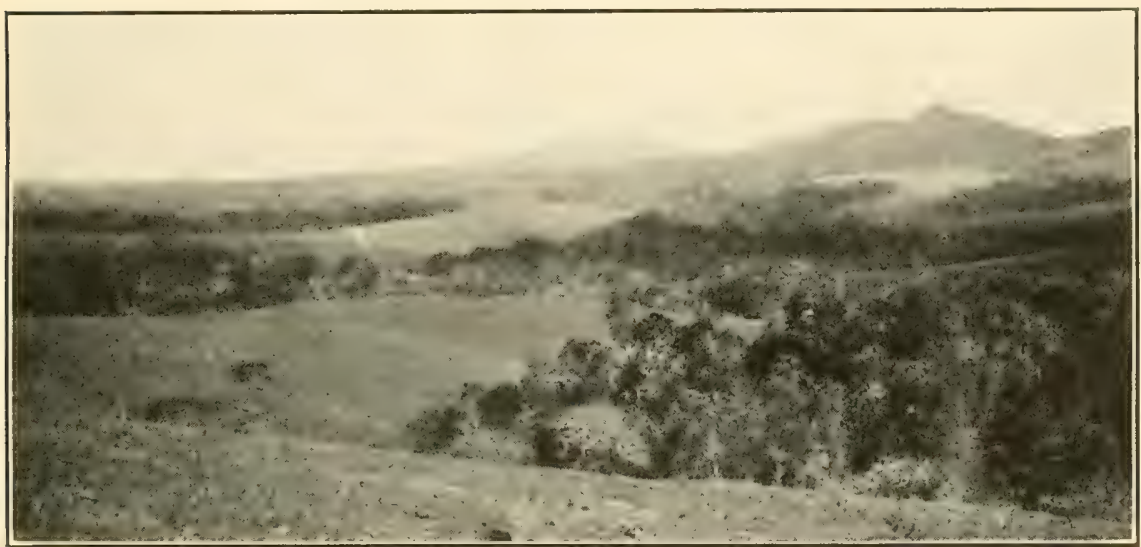

B. VIEW SOLTHWARD FROM I,OMA COCO, BETWEEN H.ATILLO AND EI, MIADIGAI.

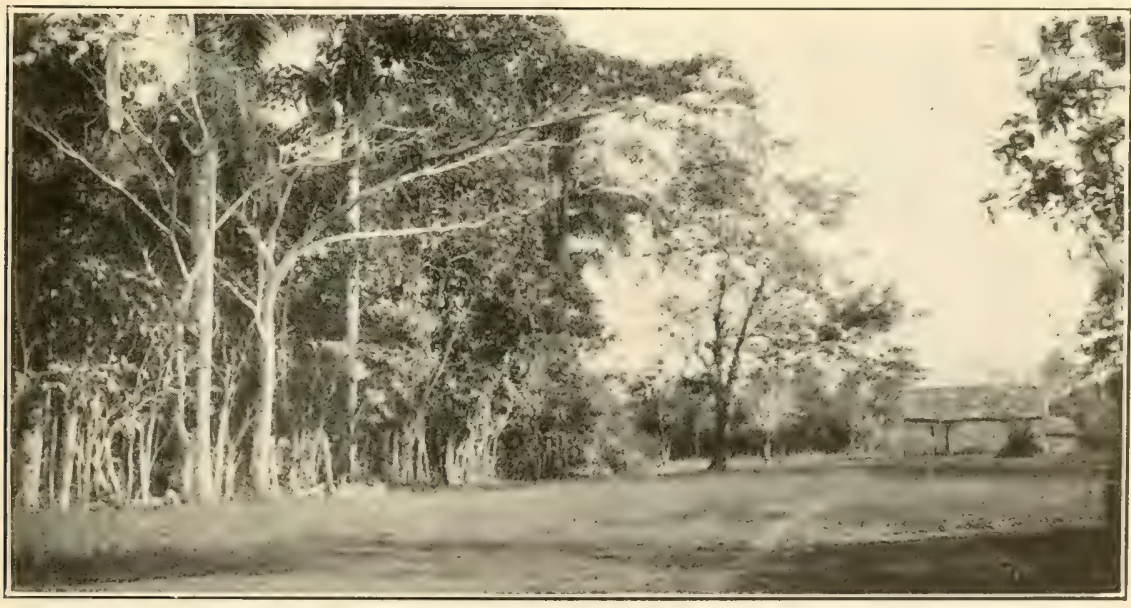

C. TERRACE FIAT AT EI, MADRIGAL, ON RIO JAINA. 

Beyond Constanza the trail runs westward, crossing Loma Chingüela at an altitude of about 1,150 meters, perhaps 350 meters below its summit. The descent to Rio del Medio, 300 meters below, is very steep.

On the west side of Loma Chingüela there is a sudden change in the character of the vegetation. The open pine woods stop abruptly, giving way to nearly bare slopes that bear only an occasional tree.

From the foot of Loma Chingüela the road descends the gorge of Rio del Medio, at some places clinging high up on the side of the gorge in a trail too narrow for two horses to pass, at others descending to the bank of the river, which it crosses twelve times. At Arroyo El Górbano it begins the ascent of Loma La Fortuna, scattered over whose side among the clouds, at an altitude of nearly 1,100 meters, is the settlement of Las Cañitas. The west flank of this mountain overlooks the Sierra del Agua into the Valley of San Juan.

After fording Rio del Medio for the thirteenth time the trail climbs the steep northern side of Loma la Laguna (altitude about 1,006 meters) and descends the longer, much gentler slope on the south to the boulderstrewn bed of Rio de las Cuevas, which it follows downstream for 9 or 10 kilometers to Túbano.

\section{TRAIL FROM SABANETA TO SAN JUAN.}

Near the Haitian border the Cordillera Central is crossed by several trails, none of which is an important thoroughfare. The trail followed by Messrs. Condit and Ross, upon whose notes this description is based, leads from Sabaneta, in the Province of Monte Cristi, southwestward to Restauración, near the Haitian border, thence through La Cruz, Guayajayuco, and Joca, to Las Matas, in the valley of San Juan. The usual route south from Restauración passes through an eastward projecting corner of Haiti to Bánica, but it was deemed advisable to follow the somewhat more difficult trail in order to remain in Dominican territory and thus to avoid conflicts with bandits and revolutionists.

For three kilometers southwest of Sabaneta the trail traverses grassy savannas, winds over hills of gradually increasing height and steepness, and crosses clear, gravelly brooks and small rivers to La Loma. Loma Peñita, locally famous for the wild hogs that roam over it, is the most impressive peak seen from the trail. (See Pl. VI, $A$ ). The highest point reached on this part of the trail is roughly 420 meters above sea level, at which altitude there is an extensive and well-marked dissected upland bench, apparently free from gravel. La Loma, a village of a few score houses in a valley about 160 meters below the level of the upland bench, is the center of an agricultural community.

From La Loma the trail rises to the level of the upland bench, and thence climbs to the crest of a ridge that stands at an altitude of about 550 meters 
above sea level, from which Manzanillo Bay and El Morro de Monte Cristi are visible in the distance. Just beyond this ridge the trail forks, one branch leading to Dajabon and the other southeastward along a steep ridge between deep valleys.

Near El Carrizal there is an even-topped pine-clad ridge about 713 meters above sea level. The pines are tall and spindling. One tree 63.5 centimeters in diameter was measured, but few are as much as 45 centimeters through. The ridge widens to a gently rolling upland at an altitude of about 715 meters, the highest point registered by the barometer east of Restauracion. The country is open, the soil is deep, and there are no rock outcrops. The trail here is broader and more work has apparently been done on it than in most other mountain districts in this country, possibly on account of the military importance of a road so near the Haitian boundary.

From El Carrizal the trail descends to Restauracion at an altitude of about 650 meters above sea level. Restauracion, although it is one of the larger towns in the region and contains a small detachment of the Guardia Nacional, presents a poverty-stricken appearance and shows few signs of activity.

The country between Restauracion and Joca is more mountainous than that to the north and east. After crossing Rio Neita, a small stream near Restauracion, the trail gradually rises toward the southeast to a ridge about 755 meters above sea level. The country here is rugged and is covered with the usual small pines and grass. Below the ridge, and perhaps 15 kilometers from Restauracion, is La Cruz, a solitary house among the pines. From the top of the next rise, which affords extensive vistas southwestward into Haiti (see Pl. XVI, $B$ ), the trail winds down into the valley of Rio Guayajayuco to a gravel-covered bench at an altitude of about 500 meters above sea level.

Rio Guayajayuco or Artibonito, here a swift stream about 18 meters wide flowing in a steep-walled sandstone gorge, is crossed near the small settlement of Guayajayuco. From Guayajayuco the trail leads over steep hills for 9 or 10 kilometers, follows the bed of Rio Guayajayuco for about one kilometer, and then ascends to the grassy bench upon which stands the little settlement of El Amacey.

At El Amacey begins the steep ascent of Loma Vieja. The trail climbs some 650 meters above the river to an altitude of approximately 1,035 meters above sea level, but Loma Vieja still towers above the trail, its summit lost in the mists. The vegetation is mostly shrubbery interspersed with a few small pines. An abundance of filmy, greenish-gray hanging moss gives it a ghostly appearance.

The trail follows narrow ridges on the flanks of Loma Vieja for two or three kilometers, then plunges down into the valley of Rio Joca, a swift 

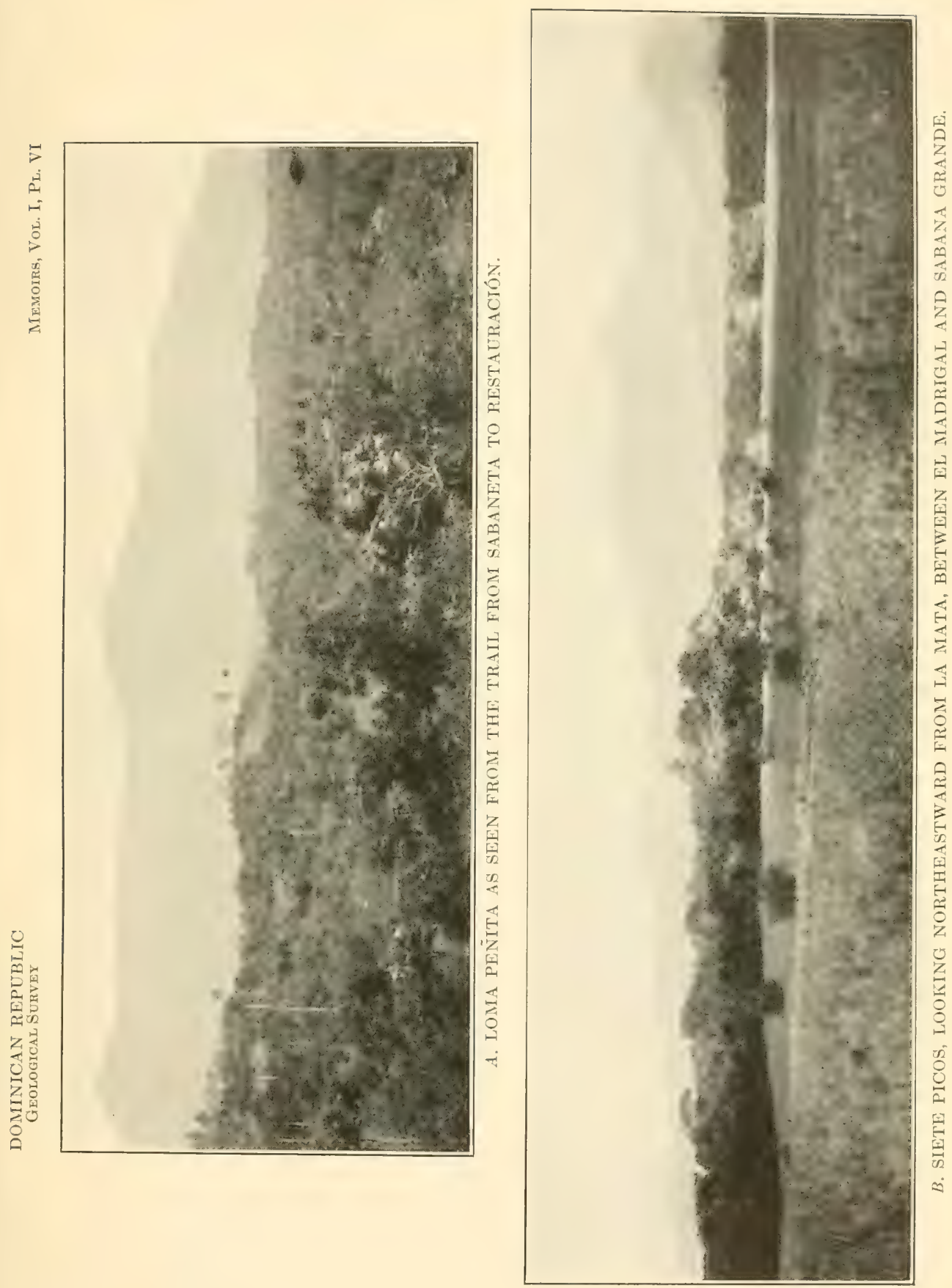

stream several meters wide flowing in a gorge about 40 meters deep. Joca, on the south side of the valley, is a station of the Guardia Nacional. From this lonely post patrols of two men are daily sent to meet the patrols from Restauración at Guayajayuco. Constant vigilance is needed to prevent the passage of bandits and smugglers across the Haitian boundary.

\section{VALLEY OF SAN JUAN.}

The great valley of San Juan occupies an area in the western part of Azua Province lying between the Cordillera Central on the north and the Sierra de Neiba on the south. On the west it merges into the central plain of Haiti; on the east it is separated from the Azua Plain by spurs from the Cordillera Central and the Sierra de Neiba. A low divide near Las Matas forms the watershed between Rio Macasía, which flows westward into Rivière Artibonite, and Rio San Juan, one of the larger tributaries of Rio Yaque del Sur. The part of the valley within the Dominican Republic extends northwestward for about 80 kilometers and ranges in width from 15 to 20 kilometers. It includes low hills, rolling plains, and large tracts of nearly level prairies or savannas.

Glowing accounts of the beauty and fertility of the valley of San Juan are brought out by travellers. The valley is favored with a larger and more evenly distributed rainfall than that of the adjoining Azua Plain, so that water for irrigation is more abundant.

San Juan de la Maguana is the center of the social and commercial life of the valley. It is connected with Azua by a wagon road, which is at most times passable by automobiles, and which, when the improvements now in progress shall have been completed, will afford easy access by motor car to Azua. Automobiles can also continue westward nearly or quite to Commendador. The valley is so nearly level that roads can easily be opened in most parts of it. The greatest obstacles to travel are the thick brush and the superabundant gravel in some areas.

\section{AZUA PLAIN.}

The Azua Plain extends from the foothills of the Sierra de Ocoa of the Cordillera Central on the north to the Sierra de Martín García on the south, and from Rio Yaque del Sur in the vicinity of Los Güiros to the foot of Loma El Número east of Bahía de Ocoa. The continuity of the plain along the shore is interrupted by Loma de la Vigía, a limestone ridge rising from the water's edge at the entrance to the Bahía de Ocoa to an altitude of about 425 meters above sea level. Inland the plain is broken by several hilly areas.

The Azua Plain is drained by Rio Tábara, Rio Jura, Rio Vía, and several smaller streams. All these streams are intermittent in their lower courses, but their perennial headwaters furnish water for domestic use and for irrigation. 
The Azua Plain is hot and semiarid. The rainfall is somewhat greater than the vegetation would indicate, but as much of it is torrential the runoff is excessive, so that much of the water is lost. A large part of the plain is overgrown with thickets of cacti and mesquite, which make travel across it tedious and painful except along beaten trails. A low, shrubby cactus, guazabara, is particularly annoying. 'The soil is fertile and responds readily to irrigation.

Azua, the only large town in the neighborhood, is 5 kilometers inland from its port on Bahía de Ocoa, with which it is connected by an improved highway and a narrow-gauge railroad. South of the town are several large sugar plantations. A wagon road passable by automobiles furnishes an outlet from the fertile Valley of San Juan to Azua, and another wagon road leads from Azua across El Número to Bani and thence to the capital. The trail to Barahona by way of Quita Coraza is usually traveled at night in order to avoid the heat and the glare of midday. A little-used trail across the Sierra de Martín García furnishes a difficult alternate route to Barahona.

\section{SIERRA DE NEIBA.}

The Sierra de Neiba is a range of high mountains lying south of the valley of San Juan and forming the boundary between the provinces of Azua and Barahona. The western extension of these mountains forms the central range of Haiti. The east end of the Sierra de Neiba is separated from the Sierra de Martín García by Rio Yaque del Sur. South of the mountains is the deep trough of Enriquillo Basin.

The Sierra de Neiba is composed chiefly of ridges of limestone ranging in altitude from 1,000 to 1,500 meters above sea level and having a fairly even profile, only a few peaks projecting above it, in this respect differing markedly from the rugged Cordillera Central. This uniformity gives a clue to the geological composition and structure of the range, which is formed of tilted blocks of hard limestone and other bedded rocks.

\section{SIERRA DE MARTÍN GARCÍA.}

East of the Sierra de Neiba and separated from it by Rio Yaque del Sur is the Sierra de Martín García, a short mountain range culminating in Monte Busú at an altitude of 1,340 meters above sea level. The range terminates in a row of hills, the Cerros de la Terraza, on the shore of the Caribbean Sea. The Sierra de Martín García overlooks the Azua Plain on the nort h and Neiba Bay on the south, and partly shuts off Enriquillo Basin on the west. From the vicinity of Azua or Barahona the Sierra de Martín García looms up as a lofty, rugged mountain. It is composed in part of limestones similar to those of the Sierra de Neiba. 


\section{ENRIQUILLO BASIN.}

The Enriquillo Basin is the eastward continuation of the Cul-de-sac region of Haiti. The two together form a valley about 15 kilometers wide, extending from the Bahía de Neiba, which itself is part of the same physiographic province, to Port-au-Prince, in Haiti. This valley, which in late geologic times was a strait, was uplifted so recently that it has been little modified by erosion. The visitor to the Enriquillo Basin has the unique experience of walking dry-shod on the bottom of the sea across shell-strewn sands and of wandering among forests of coral that appear so fresh that the water might have been withdrawn only yesterday. The Enriquillo Basin has been uplifted 35 meters or more, but some depressions in it stil remain considerably below sea level. Lake Enriquillo, a large remnant of the original strait, occupies one such depression. Its surface now stands 44 meters below sea level and is gradually being lowered by evaporation. In 1892, according to Wells, ${ }^{1}$ the surface of Lake Enriquillo stood practically level with the sea. In 1900, according to Tippenhauer, ${ }^{2}$ its surface stood 34 meters below sea level. The water in Lake Enriquillo is much saltier than sea water, owing mostly to its concentration by evaporation and partly to additions of saline matter carried by streams.

The waters of the Bahía de Neiba are kept out of the depression containing Lake Enriquillo by the delta deposits of Rio Yaque del Sur, which has built a dam across the head of the bay. During unusually high floods part of the water from Rio Yaque is diverted westward into Lake Enriquillo. Some of the flood water of Rio Yaque is stored in the Laguna del Rincón, a large fresh or slightly brackish lake connected with the Yaque by a channel near the village of Cabral.

The Etang Saumâtre, or Laguna del Fondo, occupies another depression west of Lake Enriquillo. When visited by Wells, ${ }^{3}$ in 1892, its water was slightly brackish, but potable, and its surface stood 58 meters above sea level. According to levels run in $1900^{4}$ the Etang Saumâtre stood 20 meters above sea level.

\section{SIERRA DE BAHORUCO.}

South of the Enriquillo Basin is a range of high mountains, the Sierra de Bahoruco, which forms the eastward prolongation of the south range of Haiti. These mountains come down to the sea near Barahona. The width of the range along the sea front is about 25 kilometers. Several peaks visible from the sea rise more than 1,400 meters above sea level, and one reaches 2,075 meters. The Montagne de la Selle, in the south range of Haiti, is said to be 2,700 meters high. The mountains are clothed with open pine forests and are carpeted with grass that affords pasturage for

\footnotetext{
${ }^{1}$ Wells, J. W., A survey journey in Santo Domingo, West Indies: Royal Geog. Soc. Sup. Pap., vol. 3, p. $595,1893$.

${ }^{2}$ Tippenhauer, L. G., Beiträge zur Geologie Haitis, V: Petermann's Mitt., Band 47, VII, p. 169, 1901.

3 Wells, J. W., op., cit., p. 595.

${ }^{4}$ Tippenhauer, L. G., op. cit., p. 170.
} 
many cattle. The north front of the range is composed chiefly of massive, steeply tilted, overturned and faulted limestone. The Cerros de Sal, foothills 150 to 200 meters high west of Laguna del Rincón, consist of nearly vertical beds of rock salt, gypsum, shale, and sandstone.

Tucked away in the mountains south of Duverge is Puerto Escondido, a settlement of prosperous, contented farmers. A trail leads through this village southward past Rancho Viejo, a cattleman's shelter, to Pedernales, on the Caribbean Sea at the Haitian border.

\section{SOUTHERN PENINSULA.}

The peninsula south of the Sierra de Bahoruco was not visited during this reconnaissance. The coast charts show a spur of the Sierra de Bahoruco reaching nearly to the shore at Cabo Falso and a range of hills parallel to the coast and not far inland, extending from Cabo Falso to the southern extremity of the peninsula. The triangular areas between these two ridges and the Sierra de Bahoruco are probably terraced plains. The region is said to be thickly wooded and to have a more abundant rainfall than the regions farther north.

\section{COASTAL PLAin.}

Fringing the Caribbean Sea from Calderas Bay to the eastern extremity of the island is a series of terraces, which rise gradually from the shore to an altitude of 100 meters or more at the edge of the foothills of the Cordillera Central. The coastal plain, as the entire area may be called, increases in width from a narrow fringe only a few kilometers wide at the west end to a maximum width of perhaps 65 kilometers (including Saona Island) in the vicinity of Higüey. Near Santo Domingo the coastal plain is about 16 kilometers wide. The part of the coastal plain east of Rio Jaina is sometimes called the Eastern Valley, or the Seibo Plain, and the narrower western part is called the Bani Plain. The Seibo Plain is more humid than the Baní Plain, which verges on aridity and is dependent partly upon irrigation. The Seibo Plain contains extensive forests and savannas. The soil is fertile and productive. Sugar cane is the most valuable crop. Several sugar mills have been established in the vicinity of San Pedro de Macorís and La Romana.

Three terraces are crossed on the road from San Pedro de Macorís to Consuelo. (See Pl. VII, A.) The lowest slopes gently from a little less than 6 meters at San Pedro de Macorís to 9 meters at kilometer 1.4 from that city. An intermediate terrace plain, 18 meters above sea level at kilometer 1.8 , rises gradually to 26.5 meters at kilometer 5 . The upper plain, which is very slightly dissected, ranges in altitude from 42 meters at its outer margin (kilometer 5.7) to about 51 meters above sea level. It extends to kilometer 25.5 on the road to Hato Mayor. 


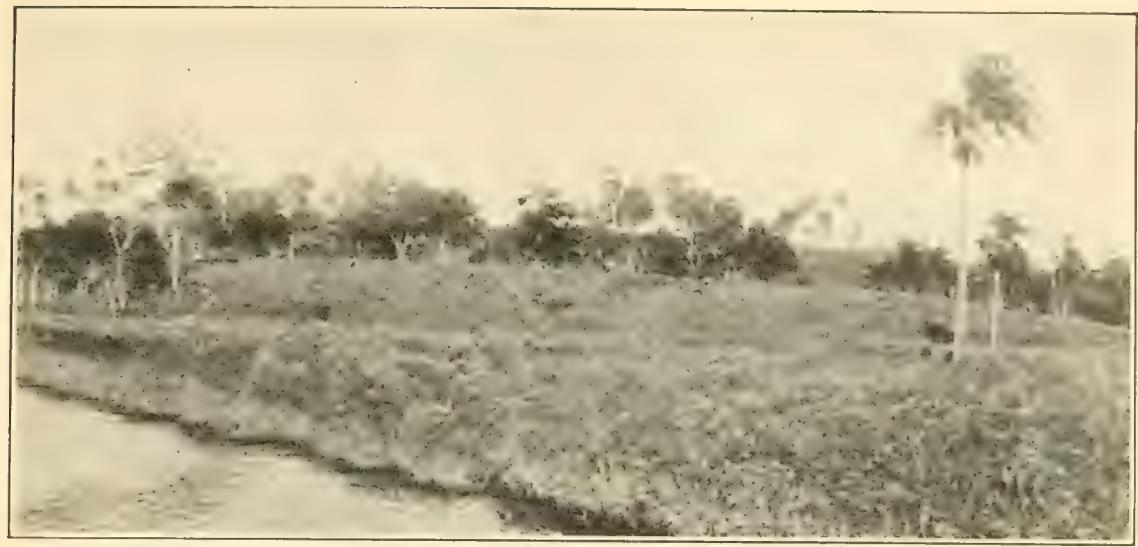

A. TERRACES ON RIO MAGUA ABOVE SAN PEDRO DE MACORÍS

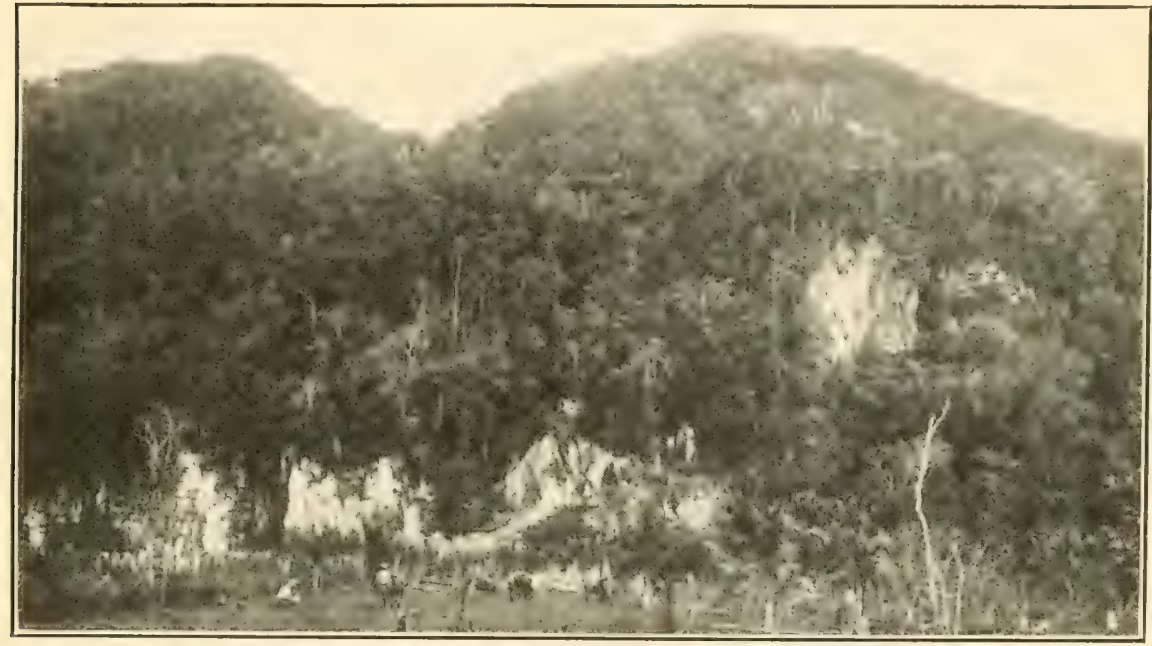

B. SIERRA PRIETA; CIIFF OF WHITE IIMESTONE.

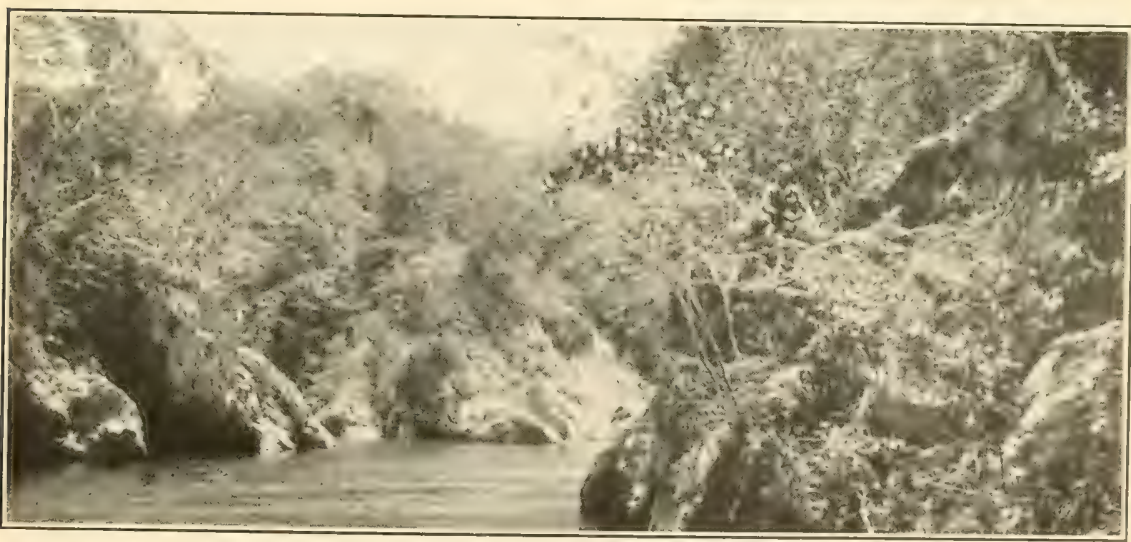

C. GORGE OF RIO MAO ABOVE BULIAA. 

The principal towns of the coastal plain are Santo Domingo, the capital of the Dominican Republic; San Pedro de Macorís, one of the most modern towns but cursed with mosquitoes; and Baní. San Cristóbal, Hato Mayor, Seibo, Higüey, and La Romana are small villages.

Saona Island, a flat-topped terraced island, is obviously an outlier of the limestone plain of the southeast peninsula, from which it is separated by a shallow, narrow channel. Catalina Island, off the port of La Romana, is also a remnant detached from the mainland.

Many good-sized streams, some of them navigable, cross the coastal plain. Ocean-going steamers enter the mouth of Rio Ozama at Santo Domingo, and the river is navigable by small boats for some distance above the city. Sugar from the large mills at Consuela and the neighboring estates is lightered down Rio Maguá and Rio Macorís to San Pedro de Macorís.

\section{DRAINAGE.}

\section{NORTH SLOPE OF THE CORDILLERA CENTRAL.}

The principal watershed of Santo Domingo is the Cordillera Central, in which all the larger streams have their source. The actual divide is very sinuous and lies somewhat south of the center of the mountain mass. From both sides of this divide good-sized streams find their way to the sea. Rio Yuna, one of the three largest rivers of the republic, heads in the mountains east of Constanza, flows in a tortuous course eastward and northeastward past Bonao, and emerges into the Vega Real near Cotuí. Its channel eastward through the Vega Real to the head of Samana Bay is sunk 15 meters, more or less, below the surface of the plain. The Yuna has built a wide delta which nearly blocks the passage between Samaná Peninsula and the mainland. About midway between Cotui and Villa Rivas the Yuna is joined by its principal tributary, Rio Camú, which, although it has its source in the Cordillera Central, receives many tributaries from the north. Although these two rivers are navigable by launches for many miles no boats larger than dug-out canoes were seen on either of them. These rivers drain nearly all the north slope of the Cordillera Central east of a line through Santiago and Constanza. Most of the limestone plateau between Cevicos and Sabana de la Mar is drained through underground channels. Rio Yaque del Norte rises on the slopes of El Rucillo in the center of the island, runs eastward through the mountains to Jarabacoa, swings nearly due north to Santiago, and thence flows northwestward to the sea at Monte Cristi. Like the Yuna, it has built a large delta, cut by several distributaries, some of which enter Manzanillo Bay and others extend to the ocean near Monte Cristi. Only the northern channel now contains water. Unlike the Yuna and the Camú, the Yaque receives few tributaries from the north. From the south, however, it receives practically all the drainage from the large area between Santiago and the 
Haitian border and north of the main watershed. The Amina, Mao, and Cana carry a considerable volume of clear, pure water. Rio Gurabo is a smaller, sluggish stream, but is the only source of drinking water for the villages along its banks. Rio Guayubin and the watercourses west of it are mere arroyos, dry most of the time but raging torrents in wet weather.

\section{SOUTH SLOPE OF THE CORDILLERA CENTRAL.}

The drainage from the south slope of the Cordillera Central falls into three principal groups-the through-flowing streams of the coastal plain, the basin of the Rio Yaque del Sur, and the headwaters of the Artibonite.

Many large rivers cross the coastal plain and enter the Caribbean Sea, most of them in directions normal to the coast. Though none of these are ong in comparison to the rivers in other parts of the island, yet because of the large rainfall in this region they carry a surprisingly large volume of water and are subject to sudden floods. The larger rivers of the coastal plain, named from east to west, are the Chavón, the Soco, the Macorís and its principal tributaries (the Maguá and the Iguamo), the Ozama, the Jaina, the Nigua, the Nizao, and the Ocoa. Many of the smaller streams, such as Rio Baní, have broad, boulder-strewn beds capable of carrying a large volume of flood water. The Ozama and the Macorís are navigable for some distance above their mouths.

Rio Yaque del Sur, one of the three largest rivers, rises on the south flank of El Rucillo not far from the source of Rio Yaque del Norte. Its principal tributaries are Rio del Medio, a brawling torrent that twists through a deep gorge between Monte La Fortuna and Monte Culo de Maco; Rio de las Cuevas, whose milky waters, anastomosing over a broad, boulderstrewn bed, come from the direction of Monte Tina; and Rio San Juan, which drains a large mountainous area and the east end of the valley of San Juan. The Yaque receives no large tributaries below the mouth of Rio San Juan. It cuts across the end of the Sierra de Neiba, runs back of the Sierra de Martín García, and builds its delta at the head of the Bahía de Neiba.

Rivière Artibonite, formed by the confluence near the Haitian border of Rio Macasía and Rio Guayajayuco, flows westward across Haiti and drains the western part of the valley of San Juan and its continuation, the central plain of Haiti, as well as part of the Cordillera Central. Along the Haitian boundary the Guayajayuco flows through a deep cañon cut in shales and slates. This river system shows anomalies that offer interesting problems to be solved when accurate maps and more detailed knowledge of the geology are available.

\section{CORDILLERA SEPTENTRIONAL.}

The divide between the drainage basins of the Cibao Valley and the Atlantic coast is the high ridge that forms the south front of the Cordillera Septentrional. From the south slope of this ridge small streams flow south- 
ward into Rio Camú and Rio Yaque del Norte. The principal drainage lines north of the divide follow the longitudinal valleys, some streams flowing eastward into Escocesa Bay, others flowing northwestward into the Atlantic, but some streams cut across the obstructing ridges and find their way to the sea by shorter courses. The principal streams are Rio Boba and Rio Isabel, flowing east and west, respectively, and Rio Yásica, which cuts across the "grain" of the country. Many other smaller streams flow northward into the ocean.

\section{MINOR WATERSHEDS.}

Samaná Peninsula is too small to support any large streams. A number of rivulets, most of them having their sources in springs at the foot of the front range, find their way into Samaná Bay. So far as known, no streams break through the front range from the higher land farther north. The limestone plateau at the east end of the peninsula is drained by subterranean channels, some of which terminate as springs along the shore. The streams on the north side are on the whole longer and larger than those on the south, for more than half the peninsula is drained to the north.

Because of the low rainfall in the southwestern part of the Republic no large streams have their source in the Sierra de Neiba. The headwaters of Rio Macasía, one of the tributaries of the Artibonite, come from the north slope of the Sierra de Neiba, and a few small tributaries of Rio San Juan head farther east in the same range. Some large springs that are tributary to Lake Enriquillo issue at the foot of the mountains south of the lake. A few ephemeral rivulets trickle down the southeast end of the range only to lose themselves in the thirsty soil of Enriquillo Basin.

The Sierra de Bahoruco probably receives more rain than the Sierra de Neiba, but no large streams have their source in it. Rio de las Damas flows northward into Lake Enriquillo, as do also several smaller brooks. Little is known of the drainage of the south side of the range and of the southern peninsula, but neither probably contains any large streams.

\section{TRANSPORTATION.}

RAILROADS.

There are two public railroads in the Dominican Republic, both narrowgauge, and both serving only part of the Cibao Valley-the area north of the Cordillera Central. The Ferrocarril Central Dominicano is a government-owned line extending from Puerto Plata across the Cordillera Septentrional to Santiago and thence by way of Peña to Moca, where it connects with the Ferrocarril de Santiago y Samaná. The Ferrocarril Central Dominicano crosses the mountains on grades so steep that it can only with great difficulty maintain traffic, which is at times wholly interrupted because of slippery rails. It crosses the divide in a tunnel near Altamira at an altitude of about 490 meters. The main line of the Ferrocarril de 
Santiago y Samaná, sometimes called the "Scotch Railroad" because of the nationality of its promoters, extends from La Tega to a terminal on Samaná Bay at Sánchez, and one branch runs northward to San Francisco de Macorís and another to Salcedo and Moca.

Several large sugar estates have constructed short railways for their own use. These roads are most numerous in the vicinity of San Pedro de Macorís, Azua, and other towns on the south coast.

\section{ROADS AND TRAILS.}

Highway construction in the Dominican Republic is now being vigorously prosecuted by the Departamento de Obras Públicas, but the mileage of roads passable for wheeled vehicles is still lamentably small. The most important road projected is the Carretera Duarte, which will run from Santo Domingo through La Vega and Santiago to Monte Cristi. Much of this road, which will connect the capital with the Cibao Valley, is already open to traffic, and the final and most difficult section, that across the Cordillera Central, is now under construction.

Nearly all overland traffic uses trails that are absolutely impassable for wheeled vehicles and that appear to have received few repairs since the time of Columbus. The sharp hoofs of innumerable mules and burros, heavily laden with the varied products of the country, have cut the softer stretches of road into remarkably even transverse furrows, some of them nearly belly deep, which fill with a sticky mixture of mud and water during rains and rarely become dry. The hard ridges between the furrows offer a precarious footing to pedestrians, but the canny donkey prefers to follow in the footsteps of his ancestors. As many of these mudholes occur on steep mountain sides very little labor in digging ditches would greatly reduce their number. Mud is more to be dreaded than mountains.

The most formidable obstacle to travel in the Dominican Republic is the Cordillera Central. This great mountain range is crossed by several trails, all of them rather difficult. The passes across the east end of the range are low and very muddy. The trails across the central and western parts of the range are not so muddy but are very rough and steep. In the course of this investigation the Cordillera was crossed by three trails-the Bonao trail, which leads from the capital through Los Alcarrizos, Piedra Blanca, and Bonao to La Vega; the Constanza trail; and a trail from Sabaneta to Restauración and thence along the cañon of the Guayajayuco to the vicinity of Bánica and on to San Juan.

\section{COAST LINE AND SHORE FEATURES.}

MANZANILLO BAY.

At the mouth of Rio Massacre, the boundary between the Dominican Republic and the Republic of Haiti, a V-shaped tongue of deep water, probably formed by a down-dropped fault block, pushes into the land. 
On the south side of this $V$ the 100 -fathom line hugs the north coast of Haiti, but on the north side it sweeps northwestward about 40 kilometers to the outer end of Monte Cristi Bank, a submerged platform that projects from the mainland of the province of Monte Cristi. Manzanillo Bay, at the head of this $V$-shaped deep, is one of the best harbors on the north coast of the island. It is large and well protected, and its deep water extends close up to the shore. The east and north shores of the bay, which are formed by the delta of Rio Yaque del Norte, are low and swampy, and are penetrated by several abandoned distributaries of the river. Manzanillo Bay is now very little used, but when a railroad from Santiago is extended to terminals on deep water, it should become the outlet for a large commerce.

\section{MONTE CRISTI BANK.}

Several islets on the submerged platform called the Monte Cristi Bank now rise a few feet above sea level or lie awash, and an uplift of 40 mets would convert the greater part of the bank into dry land. The sides of the bank slope steeply into water exceeding in depth 100 fathoms (183 meters). Off Monte Cristi the bank is about 22 kilometers wide, but it gradually narrows eastward to Punta Rucia, some 50 kilometers from Monte Cristi, where deep water extends close to shore. The delta of Rio Yaque del Norte is gradually pushing westward across the Monte Cristi Bank. Corals grow plentifully on much of the bank, and barrier reefs separated from the shore by lagoons extend along part of its eastern end.

Monte Cristi Bay is an open roadstead, sheltered from the trade winds by Cabra Island and the headland of El Morro, a prominent butte 275 meters high. As the water near the shore is too shallow for any but small boats, sea-going vessels are compelled to anchor 2 or 3 kilometers out and transfer their cargoes to lighters.

The shore near Monte Cristi is low and shelving and is bordered by salt marshes, which are protected from the sea by a low sand bar. South of the town is the broad delta of Rio Yaque del Norte. The main channel of the river is about 3 kilometers from the town, but old, abandoned distributaries ramify across the delta to the south. The land back of the town rises into a low, semicircular ridge, which leads northeastward to the foothills of the Cordillera Septentrional, or Monte Cristi Range. El Morro, nearly 5 kilometers north of Monte Cristi (Pl. II, B), is separated from it by salt marshes. Flat terraces, some of them strewn with conch shells, indicate relatively recent uplifts along this part of the coast.

\section{PUERTO PLATA BAY.}

The circular harbor of Puerto Plata indents the north shore of the Republic about 70 kilometers east of Monte Cristi. The harbor is entered through a narrow channel between coral reefs that extend in a line of foam from West Point, on the west, nearly across its entrance. The battered 
hulks of wrecks on the reefs bear silent testimony to the perils of navigation in this treacherous spot. On the east rise the time-stained walls of Fort San Felipe, at the top of a low cliff, and on a gentle rise behind the fort is the lighthouse.

Except along the promontories of East Point and West Point, the bay is bordered by a narrow strip of palm-fringed sandy beach, broken through on the southwest by Rio San Marcos, a sluggish stream that wanders in a swampy alluvial plain. On the south rise the steep sides of Monte Isabel de Torres, a conspicuous landmark from the sea (Pl. III, A), and on the outwash slopes at its feet is built the picturesque town of Puerto Plata. Along the western skyline rise the jagged profiles of several sharp conical hills.

Puerto Plata Bay appears to be the drowned mouth of the valley of Rio San Marcos, but a dead coral reef 10 feet above sea level adjoining the living reef at the mouth of the bay shows that there has been emergence as well as submergence in this region.

\section{PUERTO PLATA TO CAPE SAMANÁ.}

East of Puerto Plata gentle slopes that extend back several kilometers from the shore give room for farms and plantations between the mountains and the sea. Much of the coast between Puerto Plata and Cape Francés Viejo is bordered by coral reefs through which narrow openings lead to the indentations in the shore forming the ports of Sosúa and Cabarete.

Cape Francés Viejo is a bold, lofty headland that stands less than 6 kilometers from the shore and rises 346 meters above sea level. It is visible 50 kilometers from the shore. From far out at sea off this cape can be seen Loma Quita Espuela, a peak on the south front of the Cordillera Septentrional overlooking the Vega Real near San Francisco de Macorís.

From Cape Francés Viejo the coast runs southward past the village of Matanzas to the mouth of the Gran Estero, the swampy area that separates the peninsula of Samana from the mainland. The great bight in the angle between Samaná Peninsula and Cape Francés Viejo is known as Escocesa Bay. A submerged bank supporting reefs and a few small cays extends from Matanzas to Cape Cabrón and attains a maximum width of about 12 kilometers off Puerto Escondido.

The deep bight between Cape Cabrón and Cape Samaná, called Rincón Bay, contains several small cays skirted by a reef. The bottom of the bay is a submerged bank that is in most places less than 20 fathoms (37 meters) below sea level.

\section{SAMANÄ BAY.}

Samaná Bay is justly famous as one of the best and most beautiful harbors in the West Indies. Ships entering the bay pass first the bold, rocky, southwestward-trending shore between Cape Samaná and Ballandra Point, against which the waves spout high in air. Several step-like terraces 
lead down from the two headlands to the lower plateau between them. From Ballandra Point the bay extends westward about 45 kilometers to the flat delta of Rio Yuna, maintaining an average width of about 16 kilometers and a depth great enough to admit the largest ships nearly to the head of the bay. Shoal water at the mouth of the bay restricts entrance to an easily defended channel near the northern shore, but within the bay there is ample room for many ships to maneuver or to lie safely at anchor.

Along most of the eastern half of the north shore the mountains rise almost from the water's edge, but at Santa Barbara de Samaná they are lower and more broken and the shore is indented by a little bay, which is shut off from the greater bay by several pretty little wooded rocky islets. (See Pl. III, B.) The west half of the north shore is bordered by a narrow fringe of terraced lowlands, back of which the mountains rise steeply. Near the west end of this terraced area is the town of Sanchez, the terminus of the Ferrocarril de Santiago y Samaná and a port of entry. As the town is a considerable distance from deep water large vessels are unable to dock there and have to load and unload cargo from lighters.

From the head of the bay to San Lorenzo Bay the south shore is jagged with cliffed spurs that extend into the water from a lofty, even-profiled limestone plateau. East of San Lorenzo Bay is a stretch of low, thickly wooded country, back of which rise low, jagged mountains. Sabana de la Mar, the only village worthy of notice on the south shore, cannot be reached by ships because of very shallow water.

Samana Bay is the drowned extremity of the great Cibao Valley, but traces of rather recent slight emergence are seen in raised beaches, raised coral reefs, and sea caves that now stand above tide. Many such caves have been found west of San Lorenzo Bay.

\section{EAST COAST.}

From Cape Rafael, a low point at the entrance to Samaná Bay, the coast trends southeastward, in line with the end of Samaná Peninsula, to Cape Engaño. It is skirted by a broken reef. Cape Engaño is a low, reeflocked point that rises several kilometers inland into low hills. A bank, which at its outer margin is in places only 30 fathoms below the surface, extends eastward from Cape Engaño for 50 kilometers into the Mona Passage. This bank may be the cause of the heavy swells that prevail in this part of the Mona Passage. A lateral extension of this bank borders the coast at Point Espada, a prominent cliff over 90 meters high.

Between Point Espada and the east end of Saona Island is a semicircular indentation in which deep water reaches within a short distance of the shore. Most of the shore along this indentation is bold and rocky, and part of it is bordered by a raised coral reef. Yuma Bay, north of Cabo Falso, receives Rio Yuma, which drains a considerable area in the eastern peninsula. 


\section{SOUTH COAST.}

The peninsula extending southward from Yuma Bay to Catalinita Bay continues as a partly submerged boot-shaped bank for a considerable distance into the Caribbean Sea. Saona Island, on this bank, is about 22 kilometers long (from east to west) and about 3 to $5 \mathrm{I} / 2$ kilometers wide. The greater part of the island is low, but at its eastern end there is a rocky bluff 35 meters high. In Catalinita Bay, the shallow channel separating Saona Island from the mainland, there are several small islands and cays.

From Saona Island to Punta Salinas the south shore of Santo Domingo presents little diversity. Rocky cliffs 3 to $4 \frac{1}{2}$ meters high, against which the waves break and dash high in air, extend for leagues. Wooded plains reach inland to the foot of the hills, which can be dimly discerned far away to the north but which approach closer to the shore west of Santo Domingo City. Low Catalina Island, off the port of La Romana, marks the end of a bank that fringes the shore as far west as Andres Bay and attains a maximum width of 11 kilometers off San Pedro de Macorís. Another triangular bank between Punta Palenque, near the mouth of Rio Nizao, and Punta Salinas is 9 kilometers wide. At San Pedro de Macorís and Santo Domingo raised coral reefs and terrace plains show that this part of the coast stands higher with respect to the sea than formerly. The terraces near Macorís are described on page 40.

Between Punta Salinas and Punta Avarena, a distance of 55 kilometers, the south coast of Santo Domingo is deeply indented by three bays. Las Calderas Bay, cut off from the Caribbean Sea by the long sandy spit terminating in Punta Salinas and Punta Calderas, is the smallest and most sheltered of the three. Ocoa Bay is much larger and is wide open to the south. Its bottom is a submerged bank whose outer edge runs westward from the mouth of Rio Ocoa to Punta Martín García. Loma El Número rises steeply from its eastern edge, and Loma de la Vigía, on the opposite side, partly protects the port of Azua from south winds. Puerto Viejo, the old port of Azua, southwest of the Loma de la Vigia, has the appearance of the drowned mouth of a valley, but is partly enclosed by raised coral reefs 3 meters above sea level. Neiba Bay, on the south side of which is the village of Barahona, is the continuation of Enriquillo Basin, from which it has been separated by the delta of Rio Yaque del Sur. It lies between the lofty Sierra de Martín García on the north and the Sierra de Bahoruco on the south. A bight of very deep water extends from the southeast nearly to the mouth of Rio Yaque del Sur, at the head of the bay, but the shallower water along the sides is obstructed by reefs and shoals.

From the mouth of Neiba Bay the shore trends southwestward to Punta Beata, at the end of the southern peninsula, and the edges of the banks of Beata Island and Alta Vela maintain the same direction for 35 kilometers beyond the point. A channel exceeding 100 fathoms in depth separates the 
banks on which are Alta Vela and Beata islands, and a wide expanse of very deep water intervenes between these two islands and Los Frailes, a cluster of white-topped, rugged rocks rising from a bank 3 kilometers in diameter nearly midway between Alta Vela and Cabo Falso. The Beata Island bank is attached to the mainland and sweeps in a broad semicircle to Cabo Falso. The shore from Punta Beata as far north as Cabo Rojo is a succession of steep cliffs, which maintain their verticality even where they are faced by a beach of sand or pebbles.

Cabo Falso, 40 meters high, is the extremity of a long headland which is connected by a ridge with the Sierra de Bahoruco. The shore north of it is indented by several small bays. A bank of irregular outline hugs the shore north of Cabo Falso, widens off Cabo Rojo and Trou Jacob, and attains a width of 10 or 11 kilometers off Pedernales at the Haitian boundary. 
CHAPTER IV.

\title{
STRATIGRAPHIC AND STRUCTURAL GEOLOGY AND GEOLOGIC HISTORY.
}

\author{
By Wythe Cooke.
}

\section{STRATIGRAPHY.}

BASAL COMPLEX.

\author{
CHARACTER AND EXTENT.
}

The oldest rocks in the Dominican Republic form a complex group of schists, serpentines, intrusive and extrusive igneous rocks, tuffs, and more or less altered conglomerates, shales, and limestones. These ancient basal rocks resemble the basal rocks in Cuba, Porto Rico, and the Virgin Islands, are genetically related to them, and have suffered similar metamorphism. This basal complex forms the axis of the Cordillera Central and makes up a large part of Samaná Peninsula. (See Pl. VIII.)

The complex includes rocks of many kinds, and a part of it certainly dates from Cretaceous time, but part is probably older. Some of the igneous and pyroclastic rocks that are now included in it are of Tertiary age, for they are intruded into or interbedded with Tertiary sediments. To untangle the intricacies of the basal complex, to map its component parts, and to ascertain the relative ages of the various rocks will require long and intensive work in both field and laboratory - work which cannot be done until suitable base maps have been made.

\section{CORDILLERA CENTRAL.}

Along the Bonao trail from Santo Domingo to La Vega the first outcrop of rocks referable to the basal complex is about 5 kilometers north of Los Alcarrizos, where brecciated augite andesite that weathers into spheroidal masses, outlined by rhombohedral joints, is exposed. No other outerops were noted on this trail before Hatillo was reached.

Most of the rock exposed between Hatillo and El Madrigal is schistose serpentine. In the road cuts near Hatillo the serpentine is much sheared and folded, and is metamorphosed into a talcose slate. The rock was probably originally lava and pyroclastic material of intermediate composition. It is cut in places by dikes of fresher and less sheared black rock, which shows a tendency to ophitic texture.

Several of the hills between Hatillo and El Madrigal are capped with limonitic boulders and pebbles. Near Rio Jaina there are several exposures of creamy-yellow rock, probably weathered sandstone. In the bed of Rio Jaina at the first crossing there are many boulders of dioritic gneiss, but 
SERVICI 1, LAM. VIII

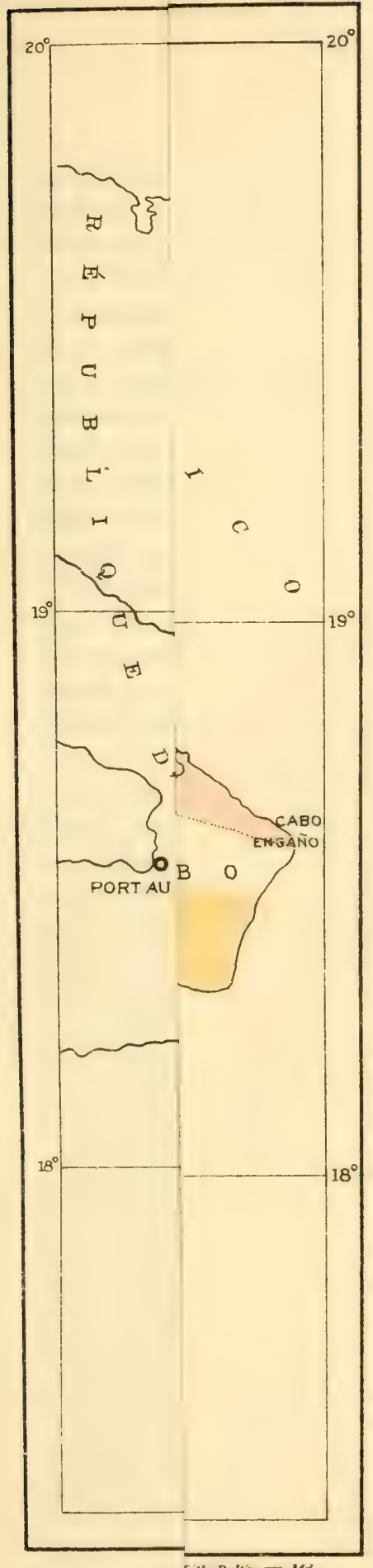

\section{EXPLICACION}

EXPLANATION

ROCAS SEDIMENTARIAS SEDIMENTARY ROCKS

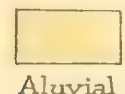

Alluvial deposits

"Coast limestone, calizas de coral en la Hoya de Enriquillo

"Coast limestone, conalliferous limestore in Enriquillo Basin.

Formación I as Matas, cascajos y marǵa Las Matas formation. Gravel and márl.

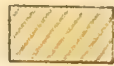

Conglomerado, arenisca,esquita, caliza de coral, sal y yeso.

Conglomerate, sandstone, shale, coralliferous limestone, salt and gypsum.

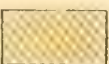

Caliza y conglomerado

Limestane and conglomerate.

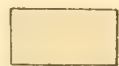

Principalmente caliza. Contiene algunas rocas Cretaceos.

Frincipally Jimestone. Inciudes some Cretaceous rocks.

ROCAS VULCÁNICAS VOLCANIC ROCHS

Lavas, basálticas

Basaltic lavas

ROCAS METAMÓRFICAS METAMORPHIC ROCKS

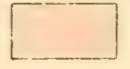

Rocas metamórficas de orígines ambos sedmentarias y ígneas. Contiene algunas rocas vuicánicas Tertiarias.

Basal complex. Metamorphosed rocks, both sedimentary and ifneous. Includes some Tertiary volcanic rocks. 


the bedrock is green chloritic schist. The profile of some of the mountains far west of this point suggests that they are composed of thick-bedded sediments that dip gently southward.

At the second crossing of Rio Jaina, about 12 kilometers upstream from El Madrigal, an outcrop of weathered tuff or similar rock was seen. The gravel in the river here consists of diorite, a crystalline dark igneous rock, and a smaller amount of more siliceous intrusive rock that contains dark inclusions. No pebbles of sedimentary rocks were seen. Arroyo Guananitos at its junction with Rio Jaina flows over hard, tough, and somewhat schistose greenish amphibolite, which weathers to a soft, rusty brown rock above river level. Near Sabana Grande the bedrock is gray dioritic gneiss containing much biotite.

Between Sabana Grande and Bonao all the rocks are metamorphic. They are mostly micaceous, chloritic, sericitic, and quartzose schists and various metamorphosed intrusives. Between Rio Juan Manuel and Rio Maimon a dark, schistose amphibolite is exposed. The cobbles in Rio Maimon are principally coarse and slightly gneissoid diorite, but the bedrock is a greenish slate or phyllite, in places cut and altered by dikes.

Between Bonao and Jayaco no outcrops of hard rock were noted. The alluvial plains in this region are composed of clay and loam interbedded with gravel, which should be a valuable source of well-water. The gravel in the bed of Rio Jima consists largely of porphyritic andesite but includes some banded slate and basalt. Near the last ford on Rio Jima pebbles of lignite were noted, which were probably derived from a low bluff near by.

Loma Miranda, the last mountain crossed on this trail, is composed of sericite schist and schistose serpentine cut by dikes of andesite or basalt, which show little or no schistosity. Outcrops of brilliant red gossan and quartz veins containing numerous leached cavities show the effect of mineralizing solutions, which probably were associated with the intrusion of the dikes mentioned above. Some prospecting for copper has been carried on in this vicinity, but so far without marked success. Cuts along the new Duarte Highway will afford good fresh exposures of rocks of the basal complex. In the bed of Rio Jima near kilometer 96 from Santo Domingo on this road there are boulders of conglomerate that contain pebbles distorted by squeezing.

Along the road from La Vega to Cevicos, on a low ridge 2 kilometers west of the crossing of Rio Yuna, fragments of white tuff were noted, and 2 kilometers east of the river there is a higher ridge composed of fine-grained granitic rock associated with tuffs. On the low round hills known as the Cerros de la Travesía, west of Rio Chacuey, there are exposures of light gray or yellowish tuff. The first ridge east of Rio Chacuey contains greenish-gray volcanic rocks. Loma de los Palos is composed of basalt. The tuffs and effusives along the northern foothills of the Cordillera 
Central are probably much younger than the schists and serpentines of the basal complex, which are exposed a few kilometers farther south, on the road from Cotuí to Maimón.

Most of the hills in the vicinity of Maimon are composed of serpentine that appears to be an alteration product of some basic igneous rock. On Loma Pegado, about 4 kilometers southwest of Maimón, the serpentine has weathered at the surface to a brick-red, highly ferruginous soil similar to the lateritic iron ores of Cuba but too thin, where seen, to be of commercial value. Near the top of Loma Pegado the serpentine is cut by a dike of hornblende diabase. Near the foot of a low mountain southeast of Hatillo there are exposures of granitic gneiss, but the mountain is composed chiefly of chloritic schist, which near the summit of the mountain is impregnated with copper ore. Near Hatillo the clay soil contains small boulders of magnetite. A more detailed description of the iron and copper prospects of this region is given on pages 228-231.

The Constanza trail crosses slates, schists, tuffs, diorites, and serpentines, which are cut by several kinds of dike rocks. The mountain at Las Minas, northwest of Jarabacoa, consists of schist. El Barrero, south of Jarabacoa, is composed of serpentine. At Constanza there is greenish basalt tuff cut by dikes of a fine-grained lamprophyre. Rio Limón and Rio del Medio, southwest of Constanza, cut through fine-grained red and green rocks and serpentine.

A fault block of muscovite-chloritic schist, chloritic schist, calcareous argillite, and diorite-gneiss north of San José de las Matas is separated from the main body of the basal complex, which is bounded south of the town by conglomerates and limestones, probably all of Oligocene age. At Bulla, Rio Mao emerges from a gorge cut in laminated chloritic schist, which is overlain unconformably by Miocene gravels. Outcrops of schist similar to that near San José de las Matas were seen also along the headwaters of Rio Gurabo near the point where it is crossed by the trail from Moncion to Sabaneta. Near the edge of the basal complex south of Sabaneta there are exposures of blue sericite schist or phyllite, more or less gneissoid quartz diorite, and hornblende schist. Associated with the schists, but probably much younger, are lavas, tuffs, and porphyritic intrusions. Most of the trail from Sabaneta to Restauración passes over quartz diorite, which is apparently intruded into schist and quartz diorite gneiss. Over the first 4 or 5 kilometers east of Restauración green voleanie agglomerate and tuff apparently rest with depositional contact upon the quartz diorite.

Between Restauracion and Joca the geology differs considerably from that farther east. Black basaltic rock, weathering to a serpentine-green in places, local beds of coarse agglomerate, and a few siliceous dikes are exposed over the first 8 or 10 kilometers from Restauracion. Beyond this is hard purplish limestone, much jointed and veined and dipping steeply 
northward. On the descent toward La Cruz bedded tuffs, somewhat copper-stained in places, strike N. $35^{\circ}$ E. Near La Cruz there is siliceous tuff, which dips steeply southwestward. A few kilometers beyond La Cruz there are tuff and impure limestone, which dip very steeply eastward. About 1 kilometer farther on shale and sandstone stand vertical or dip steeply westward. Similar rock occurs between this point and Joca. Near Guayajayuco there are many minor flexures, but the general strike of the beds is $\mathrm{N} .50^{\circ} \mathrm{W}$. The rock in the gorge of Rio Guayajayuco where first seen is flaggy blue sandstone. Farther downstream there is a slaty shale, which weathers to gray splintery rock of schistose appearance. The beds strike $\mathrm{N} .35^{\circ} \mathrm{W}$, and stand vertical or dip eastward at a high angle. The trail passes over greenish shale for several kilometers and then again descends into the river canyon. Here the rock resembles dark-blue veined and sheared slate, in which most of the veins run at right angles to the slaty cleavage. The rock is similar to the blue phyllite on Rio Yaguajal near Sabaneta. Loma Vieja is composed of the same kind of rock. The slaty cleavage on its north slope strikes $\mathrm{N} .40^{\circ} \mathrm{W}$., approximately at right angles to the bedding. Near the highest point reached on the trail the cleavage strikes N. $50^{\circ} \mathrm{W}$. and dips $60^{\circ}$ E., but the bedding strikes north and dips $30^{\circ} \mathrm{W}$. At a point on the southwest slope the bedding strikes N. $30^{\circ} \mathrm{W}$. and $\operatorname{dips} 70^{\circ} \mathrm{W}$. On the lower part of this slope and in the valley of Rio Joca the rock is a bluish quartzitic slate containing thin layers of limestone, which is in part recrystallized into rather coarse-grained marble.

\section{SAMANÁ PENINSULA.}

Rocks of the basal complex make up the greater part of Samaná Peninsula. The rocks seen in place in this area are micaceous schists and schistose limestones, but pebbles of pegmatites, felsites, and other igneous rocks included in younger conglomerates probably had their source somewhere on the peninsula. The predominant rock on the south slope of the mountains is hard, fairly pure, moderately schistose limestone. Some of the rock on the top of Loma las Cañitas at Sánchez is marble. The strike of the schistosity of all the formations in the basal complex is in general east, parallel to the trend of the peninsula.

\section{CRETACEOUS SYSTEM.}

Rocks of Cretaceous age are supposed to make up a large part of the basal complex, but they have not been discriminated from formations that may be older. Gabb ${ }^{1}$ collected a few poorly preserved fossils from earthy pebbly limestone at two localities on Rio Nigua, probably somewhere between San Cristóbal and Santa María, but he does not give the exact localities. As the species collected by Gabb include such characteristically

${ }^{1}$ Gabb, W. M., On the topography and geology of Santo Domingo; Am. Philos. Soc. Trans., vol. 15, n. s., pp. $86-87,1873$. 
Mesozoic molluses as a Trigonia, an ammonite, and a baculite (?), he undoubtedly was correct in referring the bed containing them to the Cretaceous, but it seems very unlikely that all of the great variety of rocks correlated by Gabb with this fossiliferous limestone are of the same age. Alberti $i^{1}$ found Cretaceous fossils near Guayubin.

East of the Azua-Baní road at Monte Mamón there are two hills, Cerros los Piñones, the backbone of which is a vertical ledge of limestone, 3 or 4 meters thick, striking $\mathrm{N} .10^{\circ} \mathrm{W}$. On the east side of the ledge is dark gray shale. Both hills are capped by a nearly horizontal deposit of loosely cemented conglomerate having a calcareous matrix ("caliche"). Foraminifera from one of these hills were examined by Doctor Cushman, who submits the following memorandum regarding them:

Station 8612. Very peculiar material. I have not yet been able to make out whether this is Cretaceous or Eocene. If Eocene, these species are different from those of any Eocene known previously in the West Indies. I have no good Cretaceous specimens with which to compare them.

If this rock is Cretaceous, as seems probable, much of the shale and limestone exposed along Rio Ocoa below San José de Ocoa and in Loma el Numero, which appear to be part of the same formation, is probably of Cretaceous age. Limestone containing indistinct mollusks, fragments of which are scattered along the ascent of Loma de Portezuela on the trail from Azua to San José de Ocoa about 200 meters above the foot of the mountain, may be part of the same formation.

Dense, hard, dark-blue banded, slightly magnesian calcareous argillite, which breaks into rectangular fragments, underlies the Eocene limestone in the front range of the Cordillera Septentrional near Damajagua, northwest of Navarrete. As fragments of this rock are included in the Eocene limestone they must at least be older than upper Eocene. This rock closely resembles certain parts of the Cretaceous formations in Porto Rico and the Virgin Islands and is regarded as of Cretaceous age.

Cretaceous rocks were noted at two localities near Gurabo, in the Province of Monte Cristi. The sedimentary rocks south of the village of Gurabo probably abut against the schists in fault contact. The schist is similar to that on Rio Mao above Bulla but is more metamorphosed and finely banded. The following descending sequence of beds, which strike N. $60^{\circ} \mathrm{W}$. and $\operatorname{dip} 75^{\circ} \mathrm{NE}$., was crossed in traveling southwest beyond the contact with the schist: (1) reddish-brown shales, sandstone, and dark gray limestone, which contain a network of white calcite seams and poorly preserved fossils (station 10274; for list of fossils see p. 55); (2) limestone conglomerate; (3) amygdaloidal basalt; (4) more limestone.

The level valley floor of Arroyo Clavijo, which is about 3 kilometers west of Gurabo and stands about 288 meters above sea level, is composed

${ }^{1}$ Alberti y Bosch, N., Apuntes para la prehistoria de Quisqueya, tom. 1, p. 27, Ia Vega, 1912. 
of coarse conglomerate. A short distance downstream from the trail an outcrop of this conglomerate forms a bluff 20 meters high along the stream. This rock is similar to the basal Miocene conglomerate exposed along Rio Mao at Bulla. At the last crossing of the trail over Arroyo Clavijo there is an outcrop of basalt that shows rude bedding and resembles the basalt interbedded with limestone of Cretaceous age in the hills south of Gurabo. West of this locality similar flows and pyroclastics crop out most of the way to Sabaneta. About 11 kilometers east of Sabaneta (station 10275; list of fossils given below) tuff is interbedded with a thin layer of bluish limestone conglomerate, the pebbles of which contain poorly preserved fossils similar to those found in the limestone south of Gurabo.

The fossils collected at stations 10274 and 10275 were submitted to Dr. T. W. Stanton, whose report is as follows:

Although most of the small fragments of limestone show sections of fragmentary fossils on weathered surfaces none of the fossils could be freed from the matrix by the ordinary methods of preparation. It was therefore necessary to depend on the study of sections as shown on weathered surfaces and on the polished surfaces of eleven selected specimens, which were ground down and polished.

Station 10274 (D. C. 68). Limestone about 1.5 kilometers south of Gurabo village near Monción:

Coral. Undetermined genus.

Radiolites sp. Fragment showing shell structure similar to R. nicholasi Whitfield.

Station 10275 (D. C. 69). About 11 kilometes east of Sabaneta, on telegraph line to Guaraguanca; limestone interbedded with tuff:

Coral. Undetermined genus.

Radiolites sp. Fragments with some shell structure as in specimen from station 10274.

Caprinula (?) sp. Three fragments of a rudistid with shell structure like that of Caprinula.

Gastropod. Section of small, slender shell of undetermined genus.

The fragments of Radiolites and Caprinula (?) give conclusive proof of the Cretaceous age of the rocks in which they are found, and they suggest correlation with the fossilif erous Cretaceous rocks of Jamaica, Cuba, and the Virgin Islands.

Near Sabaneta there are extensive level plains consisting of sand and gravel that are only slightly cemented. In some of the ravines there are outcrops of the volcanic tuff above described. A broad bench at an altitude of 225 meters is cut by deep ravines here and there. The rocks exposed in the ravines are coarse sand and conglomerate interbedded with clay shale locally containing lignitic bands.

Other outcrops of volcanic rocks similar to those associated with the Cretaceous limestone near Gurabo and probably of the same age were found south of Sabaneta. Similar rocks outcrop about 5 kilometers south of Sabaneta. A short distance to the south are foothills, which rise to an altitude of about 450 meters. The rocks composing them are of several igneous and metamorphic types, but have been so much weathered that 
they could not be classified in the time available. Perfect exposures were seen in the gorge of Rio Yaquejal, which was followed for a distance of several kilometers. Along the lower part of the gorge there are exposures of dark bluish to serpentine green volcanic rock, similar to the basalt east of Sabaneta, but more indurated and containing coarse veins and much epidote. The mass has been greatly broken by minor faulting. Intruded into the volcanic rock are irregular dikes of granitic or dioritic porphyry, at least 5 meters wide. Farther up the river this volcanic rock lies in contact with a blue sericite schist or phyllite, which also is cut by numerous large irregular dikes similar to those that cut the greenish volcanic rock down the river. It is significant that the volcanic rock of serpentine green color cut by the granitic dikes is similar in appearance to the basalt found east of Sabaneta interbedded with fossiliferous limestone conglomerate of Cretaceous age. Whether these two rocks are of the same age could probably be cletermined by carefully tracing the outerops between the two localities. It would be interesting to learn whether the granitic dikes were formed before or after the Cretaceous limestone conglomerate.

\section{TERTIARY SYSTEM.}

Rocks of Tertiary age occupy probably two-thirds of the area of the Dominican Republic. Lower and perhaps middle Eocene deposits were not seen, but upper Eocene, middle and upper Oligocene, Miocene, and Pliocene deposits have been recognized. The names of the Tertiary formations and those of some of their supposed equivalents are shown in the following correlation table: 
GEOLOGY AND GEOLOGIC HISTORY.

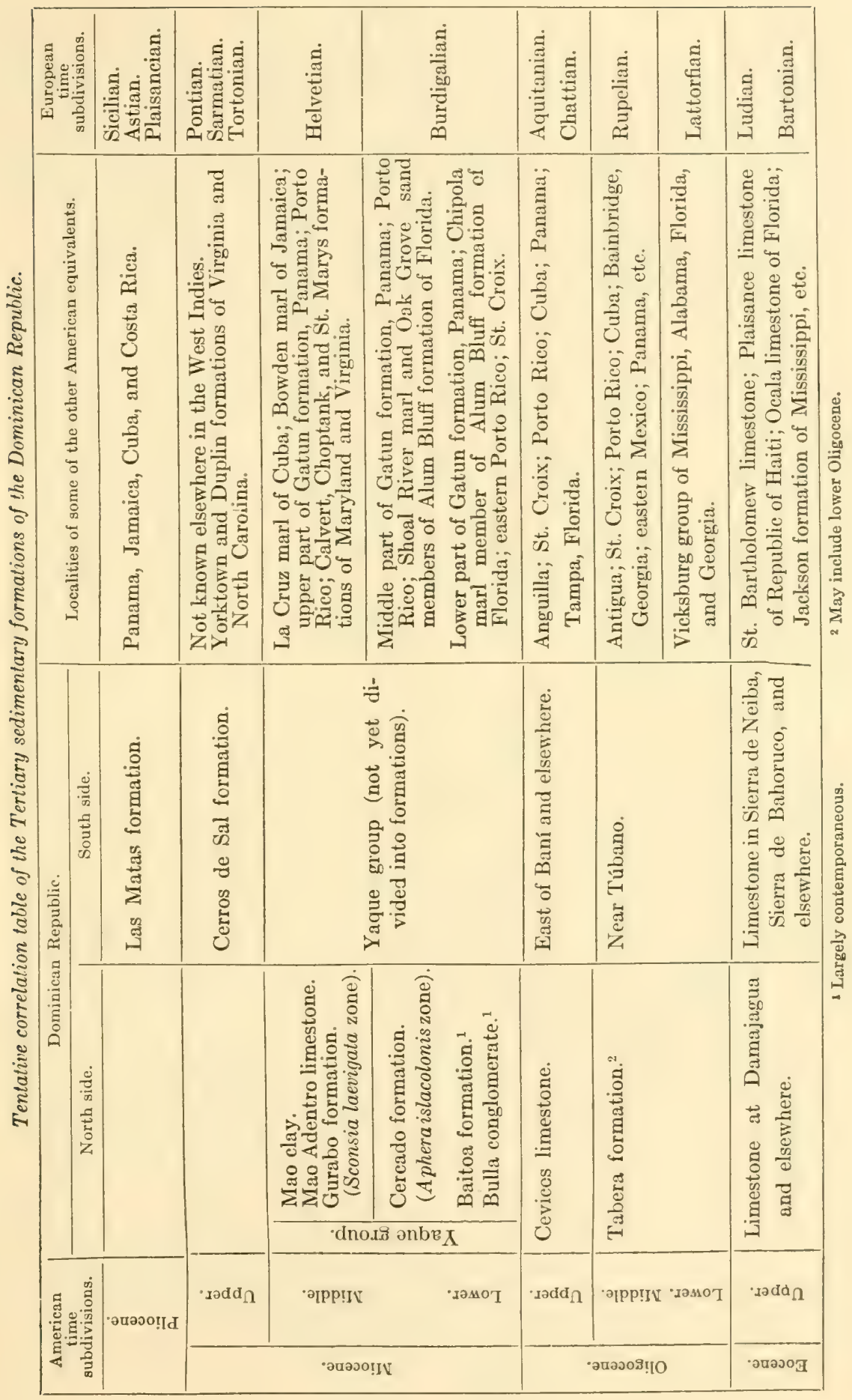


EOCENE SERIES.

The Eocene rocks in the Dominican Republic, though widely distributed, are almost exclusively limestones. Eocene limestone has been recognized on both the north and south slopes of the Cordillera Septentrional, on the south slope of the Sierra de Ocoa, and farther east, near Bani, in the Province of Santo Domingo. Similar Eocene limestone forms a large part of the Sierra de Bahoruco and the Sierra de Neiba, and probably also of the Sierra de Martín García. Patches of limestone along the northern slope of the Cordillera Central are supposed but not proved to be of Eocene age.

The relations of the Eocene limestone to the underlying deposits are not definitely known, but limestone of Eocene age overlies deposits apparently of Cretaceous age in the southern scarp of the Cordillera Septentrional near Damajagua, northwest of Navarrete. At Las Lajas, on the Ferrocarril Central Dominicano, between Bajabónico and Altamira, Eocene limestone and sandstone apparently lie directly on sheared greenish hornstone and banded slate of the basal complex. At this locality the rocks of the basal complex are vertical and strike $\mathrm{N} .40^{\circ} \mathrm{W}$.; the Eocene beds have the same strike, but dip southward about $60^{\circ}$. Other exposures in the vicinity of Las Lajas show that a conglomerate immediately overlies the rocks of the basal complex. Apparently the limestone and sandstone from which Eocene Foraminifera were collected (see list on p. 105, station 8708) are interbedded with the conglomerate.

The only identified fossils that have been obtained from the Eocene of the Dominican Republic are Foraminifera, which are listed on pages $105-106$. A sufficient number of recognizable species have been identified to establish close correlations with the Eocene deposits of the Republic of Haiti and of the other islands of the West Indies.

The thickness of the Eocene limestones in the Dominican Republic is unknown. In Haiti, according to T. W. Vaughan, a considerable thickness of Eocene limestone occurs at Cape Haitien and in the mountains between Plaisance and Ennery. Similar limestone composes the main mountain mass from Ennery to Gona ïves, thence to Artibonite Valley, and between St. Marc and the north side of the Cul-de-Sac. For this Eocene limestone, as exposed between Plaisance and Ennery, he proposes the name Plaisance limestone. The type exposure is at an altitude of 705 meters up the mountain from Plaisance toward Ennery. Typical fossils are Orthophragmina, Conulites, and other Foraminifera. Southeast of Port-auPrince, on the road to Furcy, W. F. Jones ${ }^{1}$ reports a thickness of at least 8,000 feet $(2,438$ meters $)$ of limestone which he refers to the Eocene and Oligocene. That any of this great thickness of limestone is younger than

1 Jones, W. F., Jour. Geol., vol. 26, p. 733, 1918. 
the Eocene has not been proved. The Eocene limestone of the Dominican Republic is probably not so thick.

On the lower slopes of the front range of the Cordillera Septentrional near Damajagua, in Santiago Province, there is hard light-gray limestone of Eocene age. Some of this rock contains inclusions of hard, brittle, banded calcareous argillite, which breaks with rectangular, smooth faces and was probably derived from the Cretaceous rocks that are believed to underlie the Eocene at this locality. In a fragment of the Eocene limestone picked up loose on the hillside, but evidently not far from place, Doctor Cushman identified the species of Foraminifera listed on page 105 as from station 8721. Rock in place near this locality contains identifiable Foraminifera, which are listed on page 105 (stations 8725 and $8725 \mathrm{a}$ ), but they are neither so well preserved nor so abundant as the species at station 8721 .

Limestone of Eocene age also outcrops at several places near Altamira, in the Province of Puerto Plata. The identifiable Eocene fossils collected in Santiago and Puerto Plata provinces are listed on page 105.

Besides the rocks in Puerto Plata Province that have been identified as of Eocene age, Eocene strata probably occur near the city of Puerto Plata. South of Rio San Marcos, along both the railroad and the trail to Bajabónico, the oldest rock examined in exposures was serpentine, above which is limestone that contains angular fragments of lava. The corals, probably Oligocene, from the north slope of Monte Isabel de Torres (station 8675), listed on page 111, came from a younger geologic formation. The limestone above mentioned would therefore be either of Upper Cretaceous or Eocene age, probably Eocene, but further study is needed before a positive opinion will be warranted.

The caves of Las Guácaras are in thick, massive, dark blue-gray siliceous limestone, so hard that it strikes fire with steel. This limestone forms many steep hills, some of them 100 meters high, in the Sierra Prieta west of Rio Yuna and south of the road from La Vega to Cotuí. (SeePl.VII, B.) The rock is so massive that it is difficult to ascertain its strike and dip. At El Comedero, one of the caves, the strike appears to be east, the dip $70^{\circ} \mathrm{S}$. Some of these scattered limestone hills appear to be fault blocks. No fossils were obtained from this limestone, but the stratigraphic and structural relations indicate that it is of Eocene age.

Blue limestone similar to that at the caves of Las Guacaras is exposed in a small arroyo crossed by the road from La Vega to Cotui several kilometers west of Rio Yuna.

In the vicinity of Hatillo, a village near Rio Yuna on the road from Cotú to Piedra Blanca, there are several hills composed of hard limestone, which is in part dark blue and somewhat bituminous and in part cream-white. The rock strikes $\mathrm{N}$. $10^{\circ} \mathrm{W}$. and dips $25^{\circ}$ to $30^{\circ} \mathrm{S}$. At one locality large 
lumps of limestone breceia were found. The limestone hills are probably fault blocks in which the tilting did not produce folds in the limestone. The dip of the limestone, were there no fault, would carry the rock beneath sericite schists of the basal complex. The limestone is more thinly bedded than at the caves in Sierra Prieta but in other respects elosely resembles it. Associated with the limestone on a hill west of Hatillo are many loose blocks of magnetite, the source of which has not been discovered. This is the celebrated "Iron Mountain," described in glowing terms by Gabb, ${ }^{1}$ but there is evidently no large deposit of magnetite at this locality. Further remarks on the iron deposits of this region will be found in a paper by R. B. Brinsmade ${ }^{2}$ and in the report on mineral deposits near Hatillo and Maimon on pages 228-231 of this volume.

Paleontologic evidence of the age of the limestone in Sierra Prieta and at Hatillo is lacking. The only organisms that were obtained from the rock are massive forms, which appear to be calcareous algae, and these have not yet been critically studied. This limestone is supposed to be of Eocene age because it resembles other Eocene rocks, but it may be older.

Specimens of limestone collected by Mr. Condit from the seashore about 8 kilometers south of Barahona (station 8576) contain Foraminifera that are regarded by Doctor Cushman as "very definitely upper Eocene." The same species are found in the upper Eocene of Cuba. Mr. Ross found limestone containing Foraminifera similar to those in the Plaisance limestone of Haiti on the southwest slope of Cañada de Rancho Viejo, in the Sierra de Bahoruco, south of Rancho Viejo (station 8627), and pebbles of similar limestone occur also in Oligocene or Miocene conglomerate in the vicinity of Rancho Viejo (station 8626 ).

Rubble containing the Foraminifera listed on page 106 (station 8595) was found by Mr. Condit in the Sierra de Neiba about 2.5 kilometers north of Barbacoa.

Rocks of Eocene age were identified at several localities in the Province of Azua. These are discussed on pages 199-200, and lists of the identifiable fossils found in them are given on page 106 .

Along Rio Vía above Azua there is massive limestone conglomerate, probably not over 50 feet thick, containing pebbles of greenish rock. Apparently above the conglomerate there is a thicker series of massive blue-gray limestone and alternating thin beds of limestone and shale, followed, near the top, by a few beds of limestone and shale. This entire formation except the limestone conglomerate is very much sheared and cut by small overthrust faults. A larger fault causes repetition of the greater part of the formation, including the conglomerate. The strike of the forma-

${ }^{1}$ Gabb, W. M., On the topography and geology of Santo Domingo: Am Philos. Soc. Trans., vol. 15, n. 8., pp. 141-142, 1873.

2 Brinsmade, R. B., Iron in Santo Domingo: Min. and Sci. Press, vol. 117, pp. 356-358, 1918. 
tion is variable but is prevailingly northwest. The dip is high, and in most places, except where the beds are overturned, it is toward the northeast. The age of this formation has not been ascertained, but it is manifestly older than the Miocene deposits that adjoin it in fault contact on the south and is probably either Eocene or Oligocene. No fossils were found in it.

\section{OLIGOCENE SERIES.}

Tabera Formation.

The name Tabera formation is here proposed for the strata exposed along Rio Yaque del Norte in the vicinity of Tabera, a village on the east bank of the Yaque about 20 kilometers south of Santiago. The formation consists of alternate beds of blue-gray shale, sandstone, massive conglomerate, and some beds of limestone. It rests with depositional contact upon diorite or epidiorite and is overlain with marked angular unconformity by yellow shell-bearing conglomerate and sand of the Baitoa formation (Miocene).

The thickness of the Tabera formation can not now be stated with precision. Probably not less than 300 meters of strata are exposed at Baitoa, and the lower beds, which outcrop farther upstream, are reported by Mr. Condit to be considerably thicker. In the vicinity of Tabera Mr. Condit noted more than 800 meters of shales and conglomerates referable to the Tabera formation, and all these beds lie stratigraphically below the part of the formation exposed at Baitoa. Unless some of the strata exposed are duplicated by faulting, the Tabera formation is probably not less than 1,500 meters thick.

The basal beds of the Tabera formation exposed along Rio Yaque near the mouth of Arroyo Milac about 3 kilometers above Tabera consist of about 10 meters of limestone, which grades downward from massive limestone into conglomerate containing a few small, well-rounded pebbles of igneous rock but consisting chiefly of angular or rudely rounded cobbles of the dioritic rock upon which it rests. Large specimens of Lepidocyclina are scattered through the calcareous part of the rock but the largest and the most abundant are in the massive beds of limestone. The basal limestone and conglomerate are overlain by a series of thick, dark-green sandstones and shales containing local beds of conglomerate. This series is considerably sheared and crumpled and is cut by minor faults. About 600 meters above Tabera, on the Yaque, a 6-meter bed of conglomerate apparently grades laterally (southeastward) into limestone containing the Foraminifera listed on page 107 (station 8671).

A double-peaked hogback about 1 kilometer southeast of Baitoa is composed of limestone containing Lepidocyclina and corals (station 8672), which appears to be of the same age as the conglomerate on Rio Yaque.

The fossils collected from the conglomerate and sandstones of the Tabera formation on Rio Yaque at and below Baitoa are listed on pages 107-108 (stations 8557 and 8673). 
At San José de las Matas, and extending southward from the town a distance of about 1.5 kilometers, $\mathrm{Mr}$. Condit found steeply inclined reddish conglomerate interbedded with shaly layers. The strike of the beds is $\mathrm{N} .60^{\circ} \mathrm{W}$. In the south bank of Arroyo Hondo at San José de las Matas there is an outcrop of gray semicrystalline limestone. Ferruginous conglomerate similar to that at San José de las Matas is exposed at a waterfall on Rio Inoa about 3 kilometers farther west and not far below the mouth of Arroyo Hondo. At the confluence of Rio Inoa and Rio Ámina, about 3 kilometers below the waterfall, conglomerate and dark shaly sandstone dip westward at an angle of $20^{\circ}$ to $40^{\circ}$. Mingled with igneous pebbles in the calcareous cement of the conglomerate are small lumps of limestone containing corals and orbitoidal Foraminifera. Some of the Foraminifera (Lepidocyclina sp.) are curved and are more than 25 millimeters in diameter. They lie between the pebbles of coarse conglomerate. On the basis of these Foraminifera the rock is correlated with the Tabera formation. The beds of the Tabera formation in the vicinity of San José de las Matas abut against gneissic igneous rocks to the south; to the north they are separated from the sediments of the Yaque group by a strip of sericite schist, perhaps 1.5 or 2 kilometers wide. The presence of these conglomerates and shales in the midst of the basal complex is doubtless due to faulting.

Nearly a kilometer down the valley of Rio Gurabo from the village of Gurabo are outcrops of sedimentary rocks that are believed to be, in part at least, of Oligocene age. The schist here is overlain by a basal conglomerate, or rather a ferruginous breccia, made up almost entirely of fragments derived from the adjacent schists. The fragments are angular and poorly assorted but show distinct stratification. This deposit grades upward into a fine-grained conglomerate that has a limestone matrix containing Foraminifera. A little higher stratigraphically there are beds of massive limestone rich in corals and Foraminifera. This series of conglomerates and limestones dips northeastward at an angle of about $15^{\circ}$. Unconformably beneath these gently dipping strata are nonfossiliferous, coarse-grained, bluish sandstone and dark conglomerate, which dip northwestward at a steep angle. The conglomerate of the lower series appears to contain no fragments from the adjacent schists. The deposits above the unconformity are not greatly indurated, and lithologically the finer-grained beds resemble some of those in the Tabera formation. Unfortunately the fossils collected in the upper limestone strata were lost in transit, so that the age can not be confirmed, but in the field the fossils were believed to be probably Oligocene. The bed's below the unconformity are probably Cretaceous or Eocene.

Besides the deposits above described and referred to the Tabera formation, limestone containing similar fossils was found at several places in the northern part of the Republic - at El Limón, on the trail from Santiago 
to Altamira (station 8713); at Yaroa village, about 17 kilometers north of Peña (station 8719); at Las Cacaos, north of Peña, near the head of Rio Licey (station 8740); on Las Lavas Creek, above Las Lagunas, on the Santiago-Altamira trail (station 8704); and probably at Las Lagunas (station 8703). Lists of the fossils from these localities are given on pages $107,108,111$.

In the Province of Puerto Plata deposits of probably Oligocene age were found on the north slope of Monte Isabel de Torres at an altitude of about 320 meters (station 8675 ). The fossils collected at this locality are listed on page 111. They resemble in their stratigraphic affinities the fauna of the Tabera formation.

Limestone containing fossils of middle Oligocene age was found on the south side, in the Province of Azua, at at least five localities. The lprecise localities for the fossils and their names are given on pages 108-109.

At the east end of the Sierra de Neiba limestone containing Foraminifera that are probably of Oligocene age was collected on the right bank of Rio Yaque del Sur opposite Bastia, about 1.6 kilometers northwest of La Trinchera. The Foraminifera are listed on page 112 (station 8569).

\section{Cevicos Limestone.}

The name Cevicos limestone is taken from the village of Cevicos, near the east end of the Province of La Vega. The formation has been explored only along the trails leading from Cotuí eastward to Cevicos and from Cevicos northward to Villa Rivas. On the trail from Cotui the formation was first seen in Arroyo Blanco, at the eastern foot of Loma de los Palos, from which it extends, most of the way under cover, to Cevicos. It was traced several kilometers north of Cevicos but disappears beneath a thick reef-coral limestone, supposed to be of Miocene age, which forms the rugged plateau bordering the Vega Real. (See page 30).

The Cevicos limestone is yellow or cream-colored, more or less argillaceous, and in places nodular. It contains many fossils, but few of them are sufficiently well preserved to be identified. A species of Orthaulax (O. aguadillensis) is abundant at Arroyo Blanco but was not seen elsewhere. This species, as well as two echinoids, Clypeaster concavus Cotteau and Brissopsis antillarum Cotteau, correlates the Cevicos limestone closely with the fauna of the Anguilla formation of Anguilla, which, according to current American usage, is considered uppermost Oligocene.

Although it is here classified as Oligocene, the Cevicos limestone as well as the Anguilla formation of Anguilla and the Emperador limestone of Panama, with which it is tentatively correlated, may ultimately be referred to the lower Miocene. The coral faunas of these formations, according to Vaughan, are in some respects similar to Miocene faunas and can be separated from them only with difficulty. In its lithology and structure also the Cevicos limestone resembles the formations of the Yaque group much 
more elosely than it resembles the Tabera formation. Its softness and lack of alteration and its comparatively slight deformation suggest an age considerably later than that of the Tabera formation.

The relations of the Cevicos limestone to the basalt that forms the Loma de los Palos have not been ascertained, but it seems probable that the limestone is younger and was deposited upon the basalt. Wherever beds of limestone have been observed they are very nearly horizontal, although they probably slope gently northward or northeastward. The massive reef-limestone that covers the Cevicos limestone to the north is evidently younger, but whether the reef was deposited conformably upon the Cevicos limestone or whether there is a stratigraphic break between was not determined.

In the bank of Arroyo Blanco outcrops of creamy yellow limestone, nodular on weathered surfaces, extend 12 to 15 meters above water level. The bedding is indistinct but appears to be nearly horizontal. Softer and more argillaceous nodular limestone is exposed at about the same altitude in the banks of Arroyo la Mora about 1.5 kilometers east of Arroyo Blaneo. This bed contains numerous casts of mollusks, including species of Arca, Cardium, and several venerids. The only fossils collected in which the shell substance is preserved are a species of Ostrea and a crushed specimen of Brissopsis antillarum Cotteau. Yellow nodular limestone containing mollusks, corals, and Foraminifera is exposed to a thickness of less than 2 meters on the east side of Arroyo Barranca, the first arroyo northeast of Cevicos on the road to Villa Rivas. It is overlain by 12 to 15 meters of yellow loam. Similar rock containing a Pecten, apparently a variety of Pecten vaun Cooke, and other fossils was found on both sides of a stream supposed to be Arroyo Jerguen. The fossils from all these localities are listed on page 110 .

Either the Cevicos limestone or formations similar to it extend eastward for a considerable distance. According to Mr. Ross the south shore of Samaná Bay as far east as San Lorenzo Bay is made up of massive pink to white cavernous limestone similar in general appearance to the coral-bearing limestone overlying the Cevicos limestone and perhaps identical with it. This rock forms a level plateau like that south of Villa Rivas and probably about as high. According to Gabb ${ }^{1}$ the summit of Loma de los Muertos, 10 kilometers south of Sabana de la Mar, is capped with thick horizontal beds of limestone similar to that near Cevicos.

In the southern part of the island limestone containing corals of upper Oligocene facies is exposed in the slopes and foothills of Monte Calabaza near San Cristóbal and at a place 24 kilometers from Santo Domingo City on the road to San Cristóbal. Precise data on the localities and lists of the fossils are given on page 112 .

${ }^{1}$ Gabb, W. M., On the topography and geology of Santo Domingo: Am. Philos. Soc. Trans., vol. 15 n. s., p. 148,1873 . 


\section{MIOCENE SERIES, \\ Yaque Group. \\ PREVIOUS STUDIES.}

The Miocene formations of the Cibao Valley have been studied in greater detail and by more investigators who have published the results of their work than any other strata in the Dominican Republic. T. S. Heneken ${ }^{1}$ described the geology of part of this region in 1853, but his conception of the geology contains many errors. The collections of fossils procured by him were studied by British paleontologists, ${ }^{2}$ whose descriptions give the first account of the Miocene fauna of the island. Gabb ${ }^{3}$ criticized scathingly the work of Heneken, but his own interpretation of the geology leaves much to be desired. Dr. Carlotta J. Maury ${ }^{4}$ and her associates in the expedition to the Yaque Valley in 1916 brought back large collections of fossils, by means of which she discriminated two faunal zones, the Sconsia laevigata zone and the Aphera islacolonis zone, to which she later ${ }^{5}$ applied the names Gurabo formation and Cercado formation, respectively.

SUBDIVISIONS.

The work of the expedition of 1919 increased the number of formations discriminated in the Miocene of the valley of Rio Yaque del Norte from two to six, of which the lower two are regarded as approximately contemporaneous. The names applied to these formations are the following:
Mao clay.
Mao Adentro limestone.
Gurabo formation.
Cercado formation.
Baitoa formation.
Bulla conglomerate.

For the six formations of Miocene age in the valley of Rio Yaque del Norte and its tributaries the name Yaque group is here proposed. This name is peculiarly appropriate, because the equivalent strata on the south side of the Cordillera Central are best exposed along Rio Yaque del Sur.

The formations of the Yaque group in the area south of the Cordillera Central have not been named, although five divisions that are probably worthy of formational rank have been discriminated by Condit and Ross. The generalized section of the Yaque group in the vicinity of Quita Coraza is described by Condit and Ross as follows:

\footnotetext{
1 Heneken, T. S. On some Tertiary deposits in Santo Domingo, with notes on the fossil shells by J. C. Moore and on the fossil corals by W. Lonsdale: Geol. Soc. London Quart. Jour., vol. 9, pp. 115-134, 1853.

2 Duncan, P. M., On the fossil corals (Madreporaria) of the West Indian Islands: Geol. Soc. London Quart. Jour., vol. 19, pp. 406-458, Pls. XIII-XVI, 1863; idem, vol. 20, pp. 20-24; 358-374, Pls. II-V, 1864; idem, vol. 24, pp. 9-33, Pls. I, II, 1867. Sowerby, G. B., Descriptions of new species of fossil shells found by T. S. Heneken: Geol Soc. London Quart. Jour., vol, 6, pp. 44-53, 1849.

${ }^{3}$ Gabb., W. M., On the topography and geology of Santo Domingo: Am. Philos. Soc. Trans., vol. 15 n. 8., p. 95, 1873.

- Maury, C. J., Santo Domingo type sections and fossils: Bull. Am. Paleont., vol. 5, Nos. 29, $30,1917$.

Maury, C. J., Science, new ser,, vol. 50, p. 591, 1919.
} 
Section of Yaque group (Miocene) near Quita Coraza.

5. Sandstone, coarse to conglomeratic, with shaly beds in the lower part; light olive to gray. Large Areas and other fossils plentiful in the lower beds

4. Clay-limestone member; calcareous, containing branching corals and layers of limestone filled with fossils (station 8590)

Thickness in meters.

600

2. Shale, bluish with thin sandstone laminae; no fossils seen

1. Sandstone and conglomerate, bluish sandy shale, and thin, 400 nonpersistent beds of limestone; some of the beds contain a few fossils, chiefly fragments of branching colals and oysters

Lists of fossils collected from the Yaque group on the south side of the Cordillera Central are given on pages 155-162.

BAITOA FORMATION.

The Baitoa formation is named from a village on Rio Yaque del Norte on the road from Santiago to Jarabacoa. The formation at the type locality is a conglomeratic sandy marl containing an abundance of fossil shells. It rests with marked angular unconformity upon the upturned and beveled edges of the Tabera formation. Its upper limit has not been ascertained, but it is probably conformable with the Cercado formation. At Baitoa it dips gently northward. It is exposed in the bluff at Baitoa for a thickness of probably about 30 meters, but it may be considerably thicker.

The formation is best exposed in the high, horseshoe-shaped bluff on the right bank of Rio Yaque just below Baitoa, where it forms a nearly vertical cliff at the top of a very steep slope composed of blue-gray shales, sandstones, and conglomerates of the Tabera formation. The older formation is steeply tilted $40^{\circ}$ toward the northeast and strikes N. $40^{\circ} \mathrm{W}$. Upon the truncated edges of the dark strata of the Tabera formation lie the gently sloping, rusty-yellow conglomeratic sand and marl of the Baitoa formation. Even from a distance the contact is clearly visible, for the contrast between the formations is striking. The vertical climb of nearly 50 meters from Rio Yaque to the base of the Baitoa formation is difficult, and in many places it is impossible. The formation is more conveniently examined along the trail leading from Baitoa to Santiago, which passes up the hill and along the edge of the cliff, but the exposures here are poor and the fossils are not so abundant.

The fossils named in the lists given on pages 113-114 were collected from the Baitoa formation.

HOLLA CONGLOMERATE.

The Bulla conglomerate, which is named from a village on the west side of Rio Mao near the crossing of the trail from San José de las Matas to Nonción, rests with depositional contact upon schistose sediments of the 
DOMINICAN REPUBLIC

Geological SURVey

Memoirs, VoL. I, PL. IX

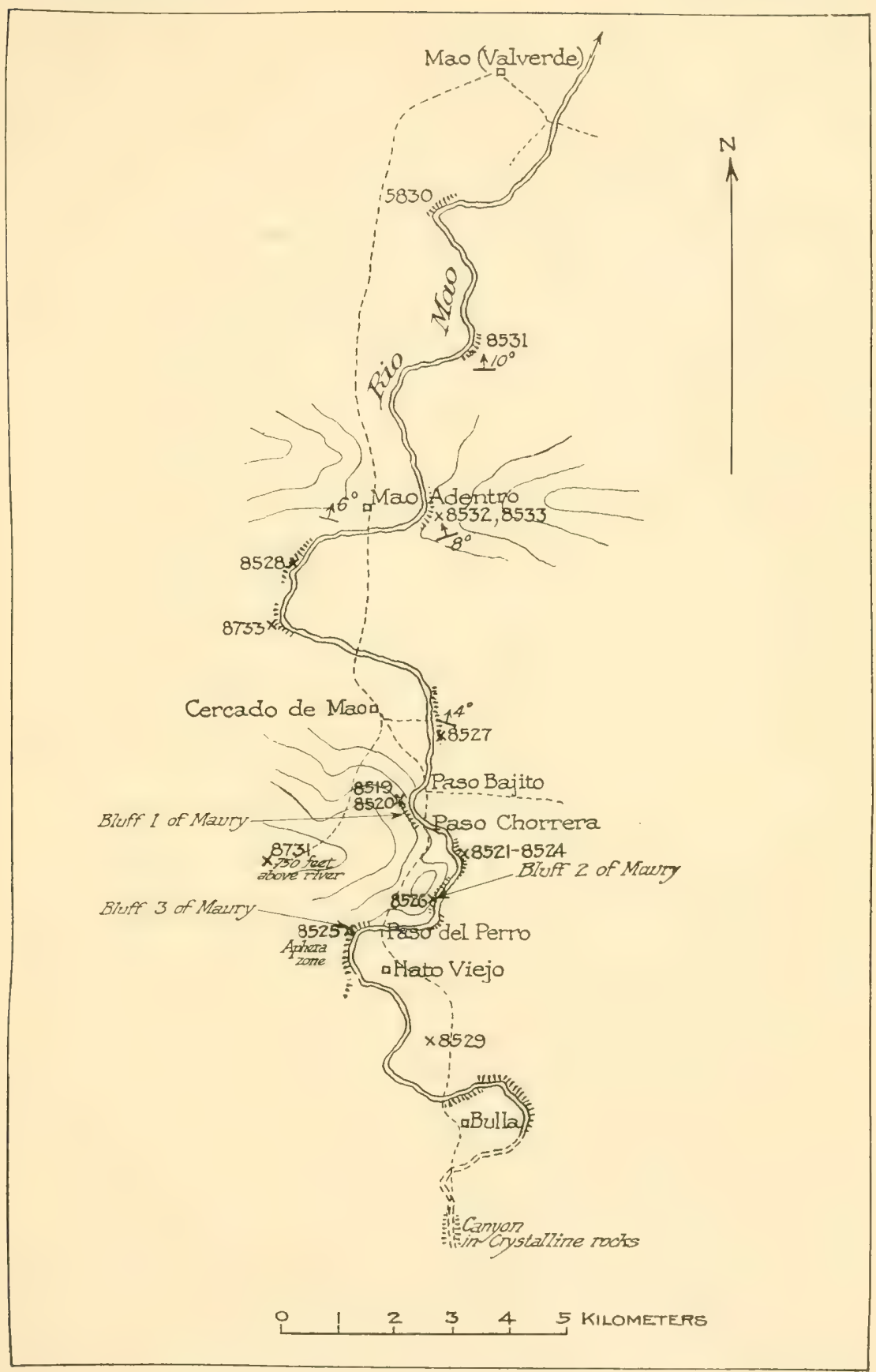

SKETCH MAP OF PART OF RIO MAO SHOWING POSITIONS OF STATIONS AT WHICH COLLECTIONS OF FOSSILS WERE MADE. 

basal complex and is apparently conformable with the overlying Cercado formation. It is probably of nearly the same age as the Baitoa formation.

The Bulla conglomerate is exposed from the entrance to the gorge of Rio Mao at Bulla downstream nearly to Hato Viejo, but its lateral extent has not been traced.

The gorge of Rio Mao at Bulla is cut in greatly folded and highly metamorphosed schistose shale (see Pl. VII, C), upon which rest coarse cobbles of the Bulla conglomerate. On the left bank of Rio Mao, at the lower ford at Bulla (see Pl. IX), the Bulla conglomerate forms a bluff that extends below water level. The conglomerate contains greatly decayed boulders of many kinds of igneous and metamorphic rocks, some of them more than 30 centimeters long, which are not definitely sorted.

The first bare bluff on the east side of Rio Mao below Bulla on the trail to Hato Viejo is about 50 meters high and is separated from the river by a broad flat. The bluff is composed of beds of coarse conglomerate ranging in thickness from 30 centimeters to 3 meters or more, interbedded with layers of sand from 30 centimeters to 2.5 meters thick. The conglomerate contains poorly sorted pebbles and subangular boulders of diorite, hornstone, schist, and other rocks of the basal complex, ranging from about 1 centimeter to 30 centimeters in diameter. The upper, more sandy part, which appears to mark the transition to the Cercado formation, contains a few poorly preserved mollusks (station 8529; for list see pp. 116-124). The inter-fingering of sandstone and conglomerate is shown in Plate $\mathrm{X}$. The strata in this bluff dip northward at an angle of $8^{\circ}$.

The thickness of the Bulla conglomerate is about 120 meters.

CERCADO FORMATION.

The name Cercado formation has been applied by Maury ${ }^{1}$ to the fine blue or gray silty sand exposed in a long double bluff (Bluff 3 of Maury; see $\mathrm{Pl}$. VIII and Pl. XII, $A$ ) on the west side of Rio Mao 5 to 7 kilometers south of the village of Cercado de Mao, just above Paso del Perro and opposite Hato Viejo. The strata which are exposed in bluffs at and near the village of Cercado and for which the name Cercado would be more appropriate are younger than the Cercado formation and are included in the Gurabo formation.

The height of the bluff at the type locality ranges from about 18 meters at its lower end to perhaps 75 meters. It is cut through about 1 kilometer above the ford by an arroyo. The cliff is nearly vertical, but at its base there are several massive rounded ledges. The lower 6 meters of the bluff consist of bluish sandy shell-marl that includes some layers composed principally of Foraminifera of the genus Amphistegina. These little shells are so abundant that the beds containing them resemble coarse sand.

\footnotetext{
1 Maury, C. J., Science, n. ser., vol. 50, p. 591, 1919.
} 
Pockets in the blue marl contain a great profusion of mollusks. Aphera islacolonis is regarded by Maury as characteristic of the Cercado formation.

The fossils that have been identified in the collections from the type locality of the Cercado formation (station 8525) are listed on pages 115-126.

According to information received from Maury, her Bluff No. 2 is the low bluff on the left side of the river between Paso del Perro and Paso Chorrera (station 8526; see sketch map, Pl. IX). The following is a section by T. W. Vaughan of the exposure there:

Section at station 8526 , on Rio Mao.

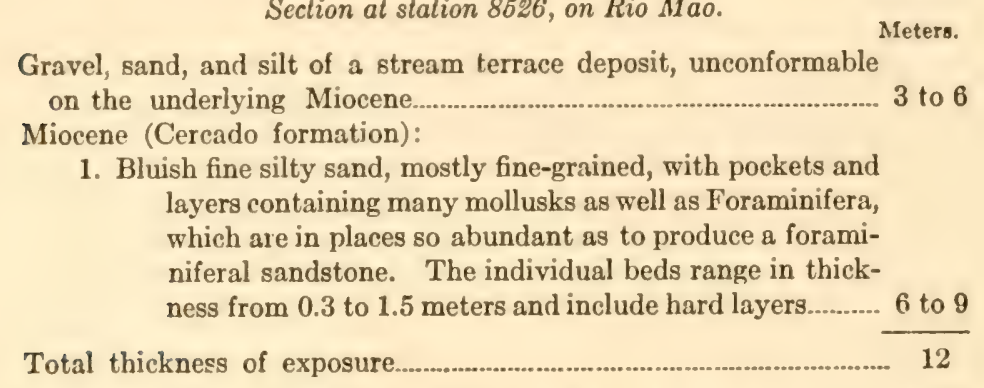

The beds dip northward at an angle of $4^{\circ}$. A list of the few fossils collected in the lower bed at this locality is given on pages 115-126.

The Cercado formation is exposed on Rio Cana at the ford of the trail from Las Caobas to Sabaneta, near the villages of Cana (east bank) and Caimito (west bank). The section below is given by T. W. Vaughan:

Section on Rio Cana at crossing of road from Las Caobas to Sabaneta.

Soil and river gravel at top.

Miocene (Cercado formation):

6. Sand, yellowish on weathered surface.

Meters.

5. Conglomerate and coarse sand 2.1

4. Greenish sandstone, some large grains as much as $6 \mathrm{~mm}$. in diameter; a seam of pebbles.................................. 4.9

3. Bed of small pebbles; pebbles mostly less than $25 \mathrm{~mm}$. long 0.3

2. Bluish sands; some pebbles. The sandstone weathers to yellowish sands. Contains many fossils in pockets.... 5.3

1. Dark-bluish sands, compact and somewhat indurated, interbedded with conglomerate. The lowest 1 meter is mostly sand with a little clay, and it contains a pebble seam a few centimeters thick. 'This is overlain by a pebble bed about $1.3 \mathrm{~m}$. thick. The pebbles range in length from 3 to 15 centimeters. The edges of most of them are rounded, but many are subangular. Composed of igneous rock, laminated hornstone, etc. 3.7

From bed 2 a considerable number of fossils were collected (station 8534; for list see pp. 115-124). 


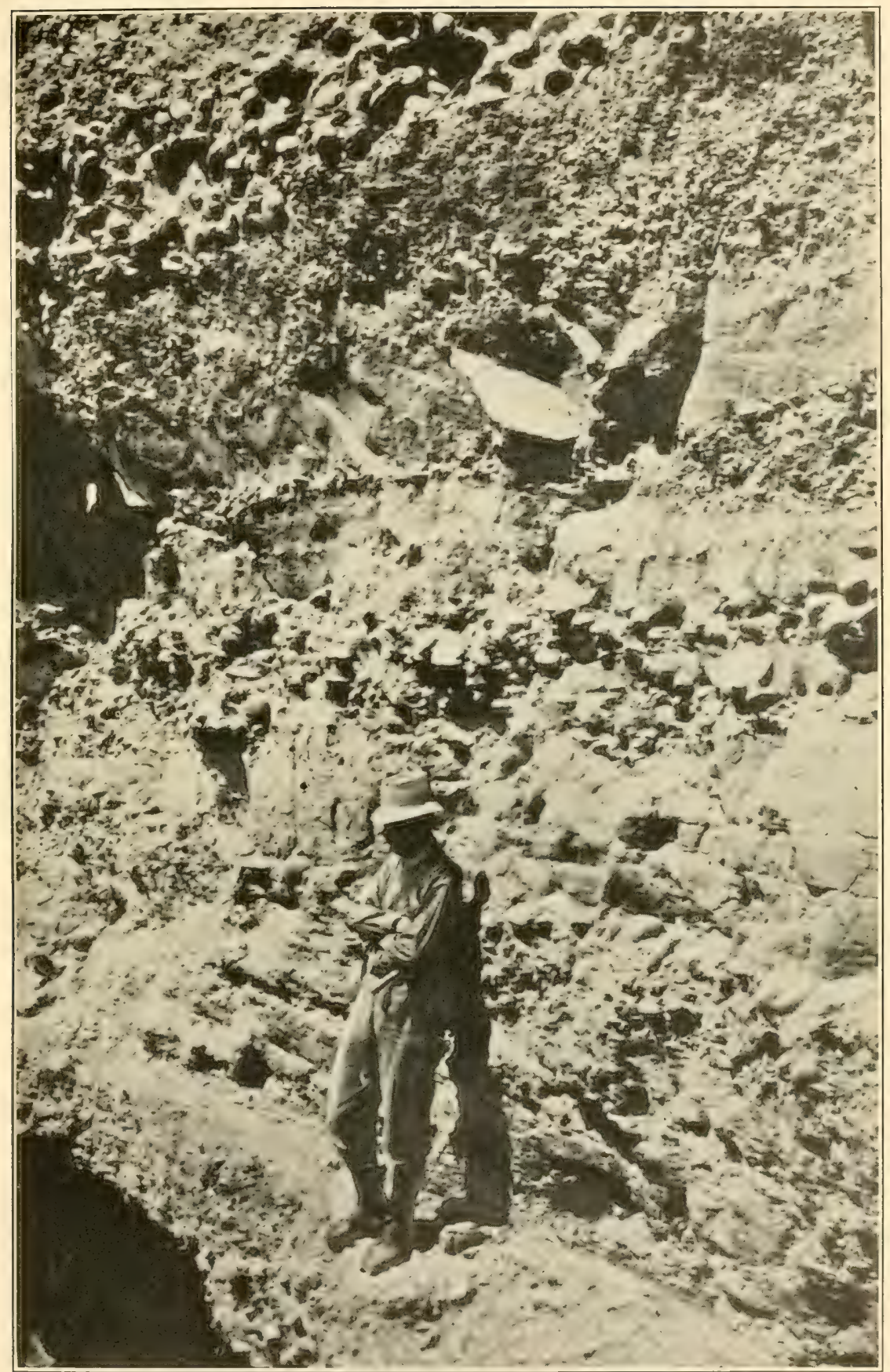

BULLA CONGLONERATE INTERBEDDED WITH FOSSILIFEROUS SAND NORTHEAST OF BULLA, AT EAST EDGE OF FLAT OF RIO MAO. 

At an altitude of 53 meters (by barometer) above the river a bed of large Teredo tubes similar to Teredo incrassatus (Gabb) was crossed on the east side of Rio Cana. This bed may correspond to that noted by Maury ${ }^{1}$ on the river 3 kilometers below Caimito.

The section above described corresponds to Maury's Zone H. ${ }^{2}$ Mollusks characteristic of the Cercado formation were also collected by the Maury expedition farther upstream, at a locality apparently about 3 kilometers above the crossing of the road from Las Caobas to Sabaneta. This locality is Maury's Zone $\mathrm{I}^{3}$

The Cercado formation is exposed on Rio Gurabo between Rio Mao and Rio Cana, about 8.5 kilometers above Gurabo Adentro (see Pl. XI, stations $8737,8738,8739)$. The fossils from these localities are listed on pages 115-124, 127-129.

The Cercado formation has been recognized as far eastward as Rio Albano (station 8729), near San José de las Matas, where a characteristic faunule, which is listed on pages 116-124, was collected.

\section{GURABO FORMATION.}

The type locality of the Gurabo formation is on Rio Gurabo from "Zone A" to "Zone F," inclusive, of Maury, ${ }^{4}$ near Los Quemados. As the descriptions of localities given by Doctor Maury are obscure it is rather difficult to identify some of the places she mentions. Apparently the locality to which she attached the name "Los Quemados" is the last crossing of Rio Gurabo on the trail from Gurabo Adentro to Los Quemados, about 3 kilometers west of Los Quemados. (See Pl. XI.) The exposures on Rio Gurabo are described by her in the section below. The lettered "zones" are the successive bluffs met on ascending the river.

\section{Section at Los Quemados.}

Concealed by vegetation and unexplored.

Feet.

Limestone with poorly preserved corals. Approximate thickness...... 50

Zone A. Hard light-blue clays forming vertical cliffs, slightly concave near the base. The clays weather yellowish white. Fossils rare or absent in the upper part of the bluffs; abundant below. Fauna chiefly Gastropods. A few pelecypods, such as Venericardia and Echinochama. Approximately

Zone B. Hard blue clays, blocky, not well stratified, weathering grayish. Fossils abundant. Thickness about

Zone C. Alternating clays and limestones, with a rather heavy bed of the latter above. Fossils very scarce; Cassis sulcifera. Thickness approximately.

Zone D. Hard blue calcareous clays. Corals. Cerithium abundant. About.

Zone E. Blue uniform clays with Cerithium, Phos, Cypraea. Approximately

\footnotetext{
${ }^{1}$ Maury, C. J., Am. Paleont. Bull., vol. 5, p. 441, 1917.

2 Maury, op. cit.

Maury, op. eit., p. 442.

- Maury, C. J., Science, new ser., vol. 50, p. 591, 1919; Am. Paleont. Bull., vol. 5, p. 434, 1917.
} 
Zone F. Hard greenish clays with concretions. Corals, Cassis, Zenophora. Approximately.

Zone G. Two miles above Los Quemados. Hard grayish-green clays with sandy layers and limonitic nodules. Strata in general unfossiliferous, but lenses very rich in fossils occur. Amauropsis. Few species in common with the preceding zones. Exposed thickness 10 feet; estimated total thickness at least

The Gurabo formation is exposed along Rio Gurabo from near the north end of the stretch of the river shown on Plate XI to a point several kilometers above the south end of the stretch shown on the map. For much of this distance the river winds through a narrow gorge cut in the siltstone of the Gurabo formation. The gorge is narrowest and virtually continuous along the upper reaches of the river. In many places great blocks of coralliferous Mao Adentro limestone have tumbled down from the top of the cliffs and cover the Gurabo formation.

On Rio Gurabo the top of the Gurabo formation is exposed at the bluff marked "U" (station 8556) on Plate XI, about 3 kilometers south of Gurabo Adentro. The following section at bluff " $U$ " was measured by Mr. Condit:

Section at bluff " $U$," Rio Gurabo, about 3 kilometers below Gurabo Adentro.

Top of Gurabo formation.

Meters.

4. Calcareous silt 0.9

3. Calcareous silt containing many branching corals 0.36

2. Fossiliferous calcareous silt 1.3

1. Conglomerate consisting chiefly of pebbles of igneous rock less than $75 \mathrm{~mm}$. in diameter. 0.46

The strike of the beds at bluff " $U$ " is N. $60^{\circ} \mathrm{W}$., and the dip is $15^{\circ} \mathrm{NE}$. The strata exposed along Rio Gurabo consist chiefly of beds of finegrained siltstone. They include a few beds of rather coarse sandstone and some conglomeratic layers, but conglomerate is rare. The prevailing color is light brownish-green, but weathered surfaces are light brown or yellow. The silt in most of the beds is so fine as scarcely to feel gritty when rubbed between the fingers. All the beds are calcareous and some contain calcareous concretions. Several beds of limestone are intercalated between the silts. Many of the beds of both siltstone and limestone are rich in fossils, but in some beds fossils are scarce or lacking. The pebbles of the conglomerates are of metamorphic rocks, principally igneous, and in part fine-grained and porphyritic. The siltstone contains many glistening particles of a micaceous mineral resembling chlorite.

Mollusks are less numerous in the Gurabo than in the underlying Cercado formation. Sconsialaevigata is common and appears to be restricted to the Gurabo formation. Corals, both in number of species and in abundance of individuals, are more numerous than in the Cercado formation but less numerous than in the Mao Adentro limestone. Some of the reef-forming corals in the upper ledges of the Gurabo formation are very large; specimens 


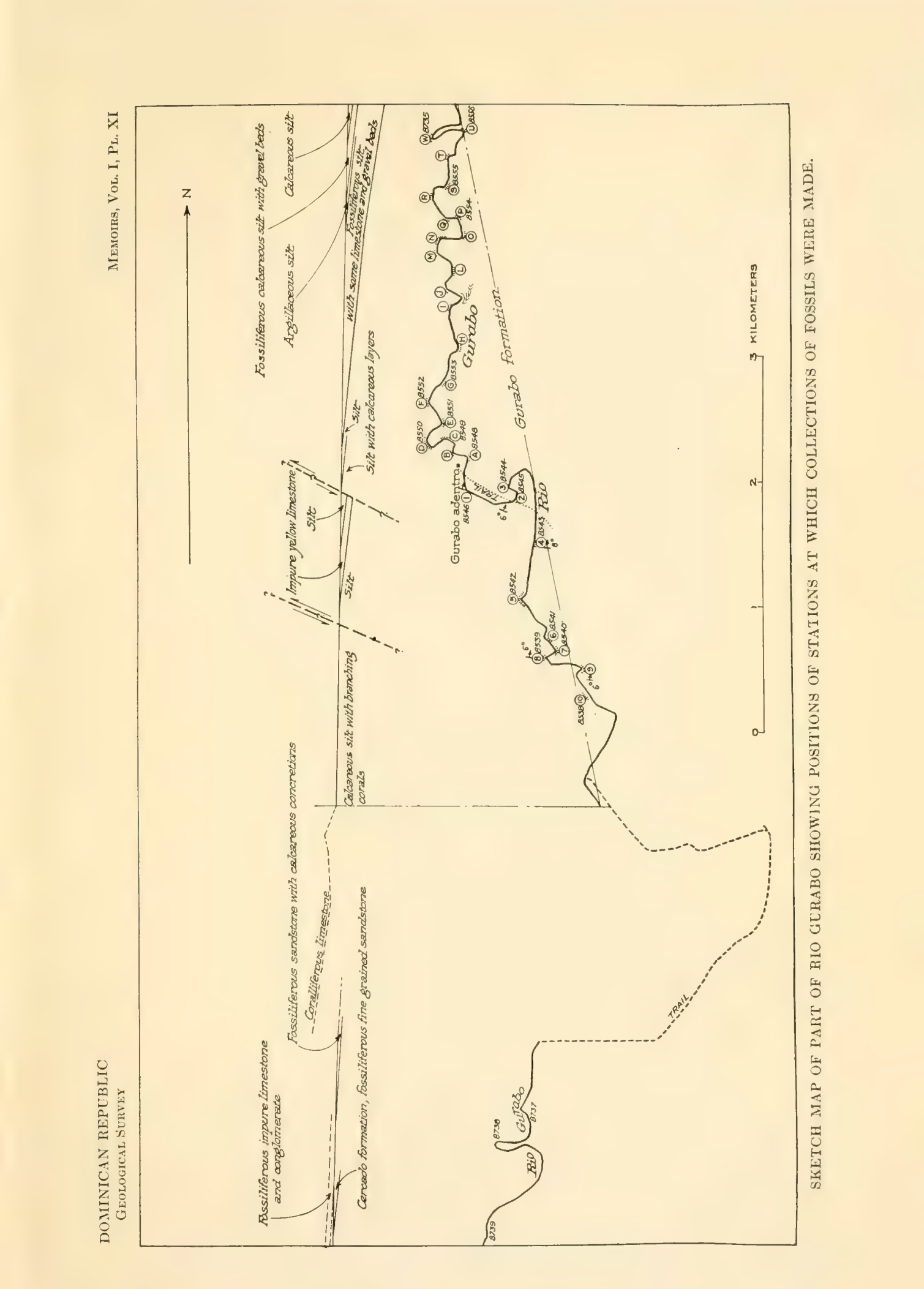



of Goniopora, Orbicella, and Siderastraea nearly 1 meter in diameter are not rare. The species of fossils that have been identified in collections from the Gurabo formation along Rio Gurabo are listed on pages 133-147. The locations of the stations at which they were taken are shown by numbers corresponding to those on Plate XI.

The Gurabo formation appears to be conformable with the underlying Cercado formation. As the lower part of the Mao Adentro limestone, which overlies the Gurabo formation, contains local deposits of conglomerate, it seems probable that crustal movements were going on at the close of Gurabo time, but deposition appears to have been continuous.

Along Rio Mao the Gurabo formation is exposed in every bluff from a point about 5 kilometers south of Cercado de Mao to the first bluff above Mao Adentro, about 3 kilometers north of Cercado de Mao. (See Pl. IX.) The beds are of the same lithologic character here as on Rio Gurabo, and they contain the same fauna. The formation dips generally northward at a low angle, probably in most places less than $5^{\circ}$.

The following section was measured in the first bluff on the east bank of Rio Mao above the ford known as Paso la Chorrera:

Section on right bank Rio Mao above Paso la Chorrera.

Miocene (Yaque group):

Meters.

Gurabo formation:

6. Inaccessible.

5. Yellowish calcareous sand and hard nodular limestone containing Placocyathus and casts of mollusks................................................................ 3

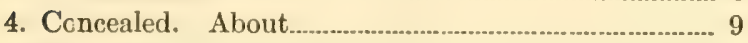

3. Fine, friable yellowish sand; when fresh probably like the underlying beds. About...................................32

Cercado formation:

2. Compact, fine-grained calcareous sand, with ledges of nodular limestone. Contains a bed rich in shells, overlain by a layer consisting chiefly of Foraminifera which, where locally indurated, resembles a coarse sandstone. Station 8522 ...... 4.5

1. Compact, fine-grained calcareous sand with ledges of nodular limestone. Contains mollusks, corals, and imperfect plant remains. Certain layers contain great numbers of small Foraminifera. Station 8521 .

2


Section on left bank of Rio Mao 1 kilometer above the ford at Cercado de Mao.

Pleistocene:

Meters.

4. Thin cover of river gravel, thickness varisble.

Miocene (Gurabo formation):

3. Soft yellowish fine silty marl containing Placocyathus, Amusium, and Amphistegina. Contains a few harder nodular ledges, especially in the lower part. Forms a vertical or overhanging bluff

2. Thin-bedded hard yellowish limestone. Some ledges are platy. Collection cf corals. Station 8520................... 9.1

1. Massive soft calcareous sand with a few locally indurated nodular ledges. Contains many mollusks and corals, especially in the lower part. "Sconsia laevigata zone." Station 8519.

The bluff on the right bank of Rio Mao opposite Cercado de Mao, about 1 kilometer below Paso Bajito, the ford of the road to Potrero, shows about 12 meters of blue clay, light gray when dry, stained yellow with iron in places. This bed (station 8527), which contains many fossil corals, is the stratigraphic equivalent of bed 3 of the preceding section. This bed dips a few degrees east of north at an angle of about $4^{\circ}$. The fossiliferous bed is overlain by about 3 meters of gravel.

Very nearly the same horizon is represented in the two bluffs on the left bank of Rio Mao between Cercado de Mao and Mao Adentro (stations 8528 and 8734). The lowermost of these, which is about 25 meters high and is capped with gravel, is composed of bluish silty clay, bluish silt, and sand. The dip averages $7^{\circ}$, nearly due north. Plate XIII, $A$, is a view of the bluff at station 8528 .

The entire thickness of the Gurabo formation is probably comprised within the interval between the top of the ridge south of Cereado de Mao, which is capped by the Mao Adentro limestone, and the river at its foot. According to a barometric reading the altitude of this ridge above the river is about 230 meters. The thickness of the Gurabo formation on Rio Mao is probably about 200 meters.

Excellent exposures of the Gurabo formation were noted on Rio Guanajuma at the crossing of the trail from Potrero to Cercado de Mao. The formation here has the same lithologic character and faunal content as on Rio Mao and Rio Ảmina.

Large collections of fossils were obtained from the Gurabo formation at Potrero, on Rio Ámina (station 8516). The principal collection was made from a 15-meter bed of bluish silt overlain by river terrace gravel deposits, which are exposed in the right bank of the river from a point just above the ford at Potrero for about 300 meters upstream. The dip of the Gurabo formation in this bluff is about $6^{\circ}$ toward the north. 


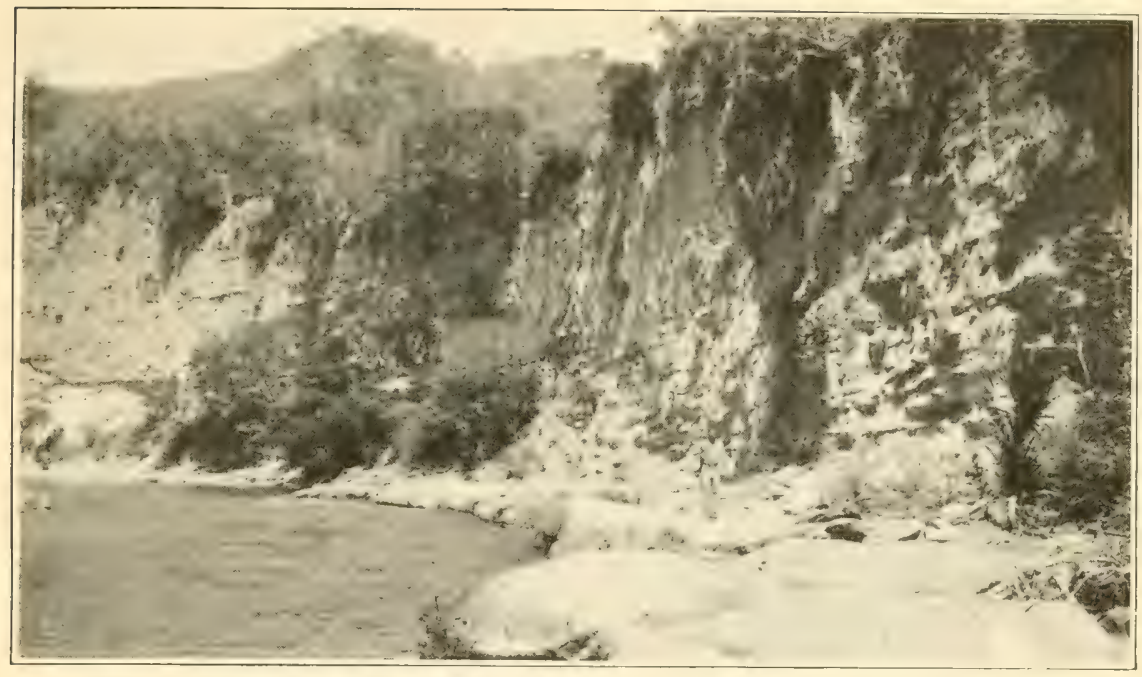

A. CERCADO FORMATION ON RIO MAO OPPOSITE HATO VIEJO; STATION 8625.

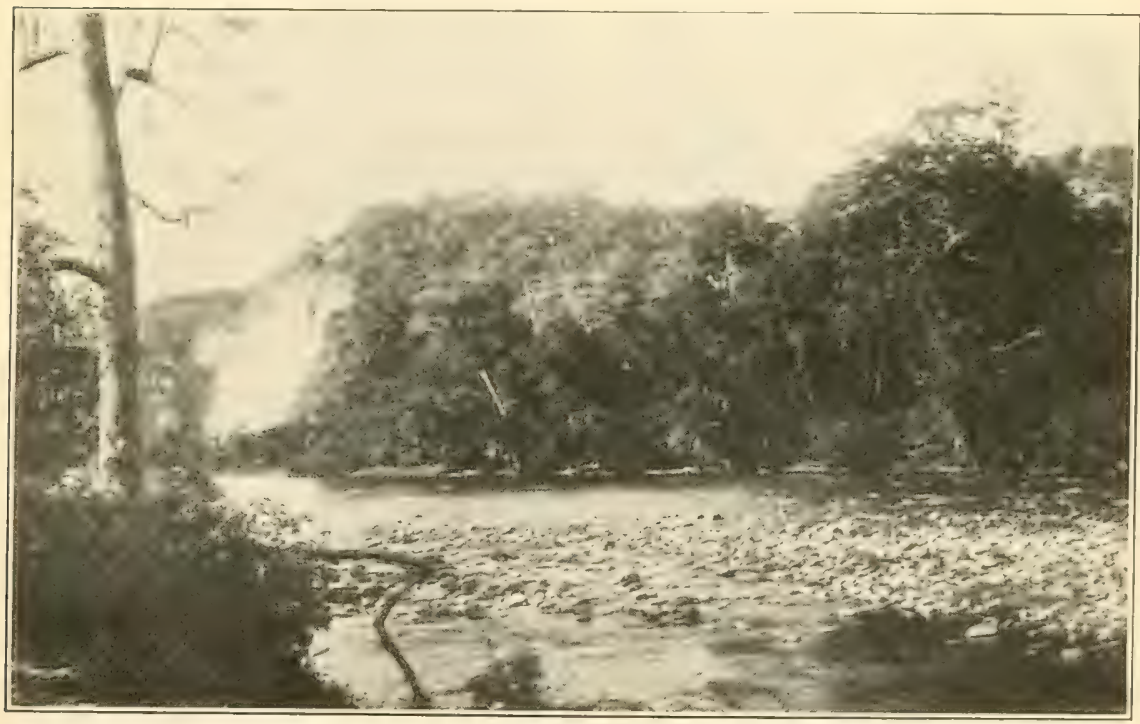

B. GURABO FORMATION ON RIO MAO JUST ABOVE EL PASO BAJITO; STATIONS 8519, 8520 

A cut near Canela, 15 kilometers from Santiago, on a road from Santiago to Sabaneta, exposes soft greenish-gray shale, sandstone, and a little nodular limestone containing many fossils (station 8726).

The Gurabo formation is exposed also at many other places in the valley of Rio Yaque del Norte, especially in the vicinity of Santiago. Lists of fossils obtained from the formation are given on pages 130-151.

MAO ADENTRO IIMESTONE.

The Mao Adentro limestone is typically exposed in the bluff on the right (east) bank of Rio Mao opposite the village of Mao Adentro. The following section is given by T. W. Vaughan:

\section{Section on Rio Mao opposite Mao Adentro.}

Miocene (Mao Adentro limestone): Meters.

2. Conglomeratic limestone interbedded with bluish shale; about five limestone ledges and five shale beds within 8 meters. The limestone is a mat of corals, among which branching folms are predominant. Station 8532. Total exposed thickness in cliff face about.

1. Laminated sand and silts, originally bluish, oxidized yellowish or brown. The sand is medium to coarse with a few small pebbles 1.5 to $3 \mathrm{~mm}$. long. There are interbedded thin laminated beds of more argillaceous material, which is well and rather evenly stratified in layers from $6 \mathrm{~mm}$. to 15 cm. thick. Station 8533. A few fossil corals.

The beds $\operatorname{dip} 8^{\circ} \mathrm{N} .60^{\circ} \mathrm{W}$. and strike N. $30^{\circ} \mathrm{E}$.

The Mao Adentro limestone forms the hogback ridge at Mao Adentro and caps the ridge south of Cercado de Mao. The top of the Samba Hills is probably formed of this rock. A view of the ridge on the east side of Rio Mao is shown in Plate XIII, $B$.

An exposure on Arroyo las Lavas at the crossing of the highway from Santiago to Monte Cristi, several kilometers southeast of Navarrete, seems to represent the Mao Adentro limestone. The strike of the beds in the arroyo agrees with the alignment of the mountain front of the Cordillera Septentrional (about N. $70^{\circ} \mathrm{W}$.), and the apparent dip is about $80^{\circ} \mathrm{N}$., toward the mountains, but the beds are really overturned. This deformation is doubtless the result of the fault that separates the Miocene deposits of the Yaque Valley from the Eocene and Cretaceous rocks adjacent to them in the front of the Cordillera Septentrional. The material in the exposure on Arroyo las Lavas is a mass of corals, chiefly of branching forms, in a matrix of soft yellowish argillaceous marl. Associated with the corals are a few mollusks. The species collected at this locality (station 8663) are listed on pages 152153.

The Mao Adentro limestone caps a hill about 3 kilometers northeast of Santiago, at the locality known as Gurabo Hills (stations 8723 and 8724). The harder parts of this limestone are quarried by the Department of 
Obras Públicas for road metal. The rock is yellowish, soft, somewhat argillaceous coralliferous limestone, in which are lumps of harder limestone composed largely of corals and other fossils. The harder lumps are used as road metal and the soft matrix is discarded. The rock is exposed in numerous test pits scattered over the hills. In a quarry where a face over 30 meters wide is exposed a good section of the formation was observed. Here the lumps suitable for road metal occur in a bed about 3 meters thick that strikes approximately N. $30^{\circ}$ E. and dips $15^{\circ} \mathrm{N}$. This bed of harder material is underlain by calcareous clay, which is about 6 meters thick and contains a few small, hard lumps. Below the calcareous clay is an equal thickness of bedded sand, which has been disturbed by a small fault. The sand contains a few small coral lumps in the upper part and a few thin beds, about 5 centimeters thick, of hard, impure limestone in the lower part.

The Mao Adentro limestone is an important formation in the valley of Rio Yaque del Norte, for it seems to form the summits of most of the prominent hogback ridges there. Besides the ridges already mentioned there is Sierra del Viento, which is north of Rio Yaque and east of Rio Ảmina. This ridge is capped by a hard coralliferous limestone, which is under lain by an argillaceous or arenaceous deposit containing great numbers of branching corals. The beds in which branching corals are so numerous are tentatively considered a part of the Gurabo formation.

As the Gurabo formation appears to grade into the Mao Adentro limestone, notwithstanding the presence of beds of gravel near their contact and evidence of crustal disturbance in the area whence the gravels were derived, it was not practicable to decide with certainty as to which of the two formations some exposures should be referred. The Mao Adentro limestone probably possesses a peculiarity that will need to be considered in future field work. It is composed largely of corals, and in places it seems to be true coral-reef rock. Living coral reefs form broken ridges or chains or discontinuous patches of limestone, between and on the sides of which are contemporaneous sediments of different character. It is highly probable that the Mao Adentro limestone never formed a continuous rock sheet throughout its extent, but that it was composed of broken ridges and patches similar to the coral reefs of modern times. The relations of this limestone to older, contemporaneous, and younger deposits offer puzzling problems that can be solved only by detailed field studies.

The fossils obtained in the Mao Adentro limestone are listed on pages 152-153.

MAO CLAY.

The Mao clay overlies the Mao Adentro limestone and forms the topmost division that has thus far been discriminated in the Yaque group. It is exposed in a bluff on the west side of Rio Mao 2 or 3 kilometers south of the town of Valverde (old name Mao). The sediment exposed in this bluff 


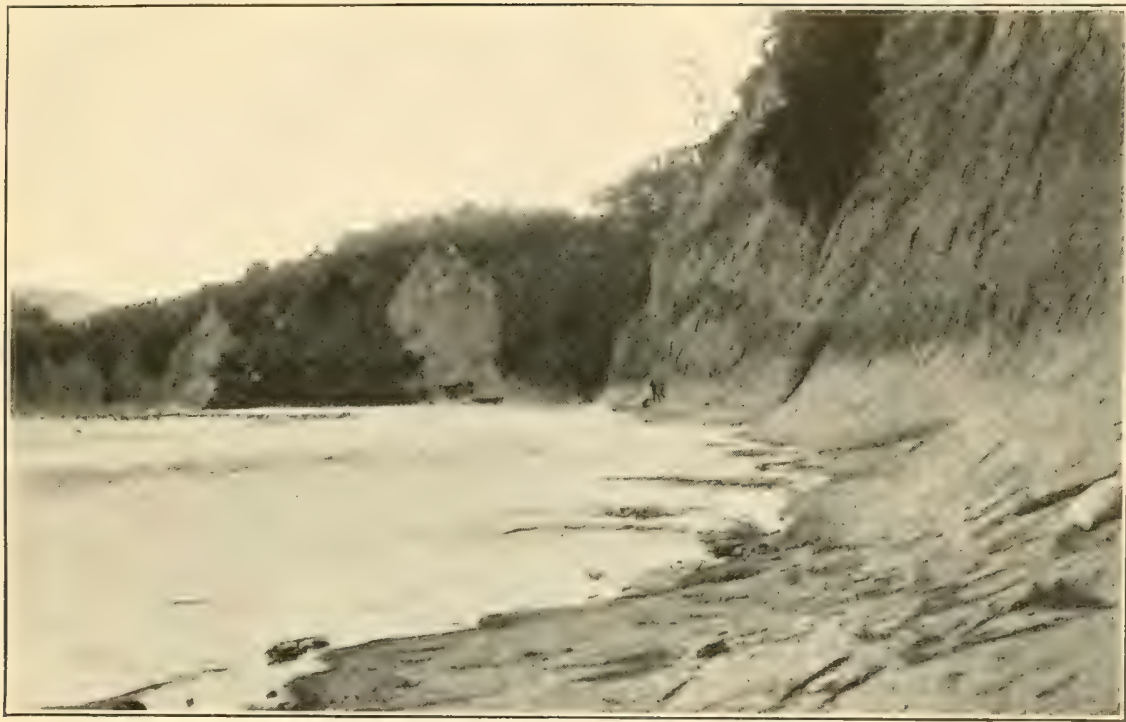

A. GURABO FORMATION ON RIO MAO BELOW CERCADO DE MAO; STATION 8528.

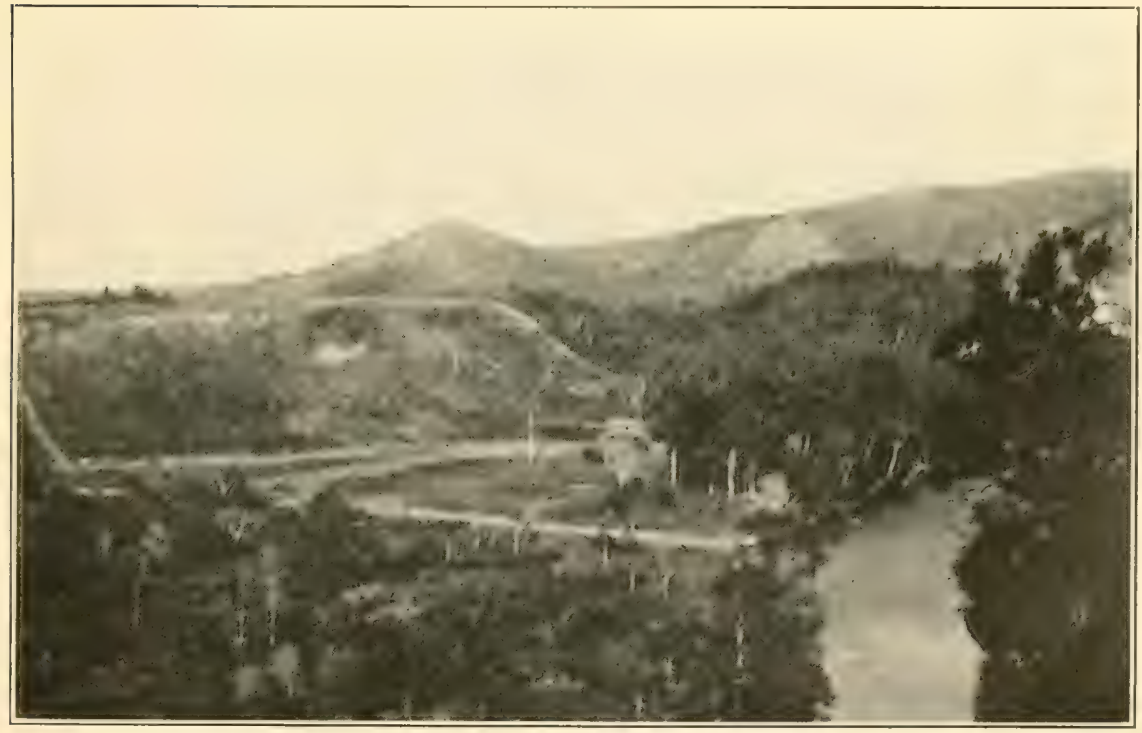

B. RIO MAO SEEN FROM TOP OF BLUFF ABOVE EL PASO BAJITO. 

is blue clay-shale or siltstone resembling that so common in the lower formations of the Yaque group, especially in the Cercado formation, but is finer-grained and contains only a few fossils. The thickness of the Mao clay is unknown but is probably not less than 150 meters and may be considerably more.

The type exposure is at station 8530 on Plate IX. The few fossils that have been collected from the Mao clay are listed on page 153 .

\section{Cerros de Sal Formation.}

Around the border of Enriquillo Basin there are strata containing Miocene fossils that are obviously younger than the beds of the Yaque group. For these strata the name Cerros de Sal formation is proposed by Condit and Ross. (See p. 201.) The name is taken from the Cerros de Sal, where salt is mined.

The stratigraphic relations of the Cerros de Sal formation to the formations of the Yaque group have not been determined, but the presence in the formation of beds of salt and gypsum, evidently formed in enclosed basins, suggests that the Cerros de Sal formation is not conformable with the Yaque group.

The lithology of the Cerros de Sal formation is shown in the following generalized section, which was measured by Condit and Ross in the Cerros de Sal. The thicknesses given are regarded as minima.

Generalized section in the Cerros de Sal.

Miocene (Cerros de Sal formation):

Meters.

7. Sandy shale, poorly exposed, alternating with calcareous fossiliferous sandstone that forms low ridges north of Cerros de Sal

6. Cross-bedded sandstone, unconsolidated, alternating with gypseous shale; strike N. $70^{\circ} \mathrm{E}$.

5. Sandy clay beds, light olive color, with embedded ccrals at two horizons (station 8574 ); strike about N. $70^{\circ}$ W., dip vertical.

4. Sandy clay beds of various colors with several shell beds (station 8742) and thin layers of impure earthy lignite...... 170

3. Sandstone, sandy shale, and thin layers of pinkish fossiliferous limestone, forming north face of high ridge.

2. Gypsum in thick, massive, white, finely crystalline layers, alternating with thinner layers of green, gypseous shales, and with beds of coarsely crystalline salt; gypseous shales in upper part

1. Sandy clay and sandstone, red and yellow. 100

The fossils collected from the Cerros de Sal formation are listed on pages 163-164. The fauna has no known counterpart on the north side of the island. The Cerros de Sal formation is younger than any other Miocene deposits hitherto discovered in the West Indies. It is provisionally correlated with the upper Miocene of Europe-that is, with the Tortonian, Sarmatian, or Pontian stages of the Mediterranean region. 


\section{MIOCENE OR PLIOCENE SERIES.}

Plant-Bearing Beds at Sánchez.

Beginning at an exposure about 180 meters east of the pier at Sánchez, unconsolidated plant-bearing clay and sand containing seams of limonite crop out for several kilometers eastward along the south shore of Samana Bay. In the exposure 180 meters east of the pier (station 8684) the strata dip castward at an angle of $24^{\circ} ; 270$ meters cast of the pier (station 8685) they dip westward at an angle of $45^{\circ}$. At other localities farther east they show diversity in both strike and dip. More detail on this formation is given on page 184, and fossils from it are listed on page 165 . The data at hand are inadequate for fixing the geologic age of the deposit, but as it is older than the terraces that bevel its surface around Sánchez it is tentatively referred to the Miocene or Pliocene.

PLIOCENE SERIES.

Las Matas Formation.

The name Las Matas formation is applied by Condit and Ross (p. 201 of this report) to loosely consolidated deposits of gravel, clay, and limestone in the valley of San Juan and adjacent areas. The name is taken from the village of Las Matas, in the province of Azua. The Las Matas formation lies unconformably upon the Yaque group. The contact is plainly shown at a place on Rio Yaque del Sur 3 kilometers upstream from Los Guiros, where the Yaque group is overlain with angular unconformity by the Las Matas formation. At this locality the strikes as well as the dips are discordant.

The formation consists chiefly of gravel but includes some marly limestone and clay. The gravel is yellowish-gray and is less firmly cemented than the conglomerate of the Yaque group. The clay is faint reddish to purplish, presenting a marked contrast to the bluish-gray to olive-green clay of the Yaque group. The formation looks like a subaerial deposit. The gravels resemble outwash material such as is now being laid down along the border of the mountains in this region.

No fossils have been found in the Las Matas formation, but it is evidently younger than the Miocene, and as it is certainly older than some deposits referred to the Pleistocene it is provisionally regarded as Pliocene, though it may be early Pleistocene.

\section{QUATERNARY SYSTEM.}

Raised coral reefs that are evidently not older than Pleistocene were seen at almost every place along the shore that was visited by members of the expedition, and the coast charts show raised recfs at many other places.

Adjoining the living reef that partly encloses the harbor of Puerto Plata is a dead reef, now standing 2.5 to 3 meters above sea level. At San Pedro de Macoris fossil reefs are even more conspicuous. The flat, rocky plain 
which there forms the point between the harbor and the ocean is a reef that stands about 2.5 meters above the sea. This plain is composed of hard, nodular, white or yellowish limestone containing many living species of corals. Doctor Vaughan recognized near or at the sea front the corals Orbicella annularis, Maeandra strigosa, Manicina gyrosa, Siderastrea siderea, Acropora muricata, and Acropora palmata. Back from the shore this hard rock merges laterally into soft, creamy-yellow nodular limestone. A cut near the steamer dock at Macorís exposes about 3 meters of this marl, in which there are many corals representing species characteristic of protected but clear water. The following species were identified by Doctor Vaughan:

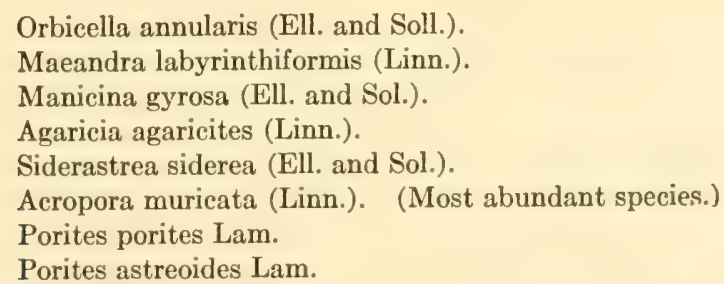

At Santo Domingo City the sea front in the vicinity of the wreck of the U. S. S. Memphis is bordered by a raised reef.

Lake Enriquillo is bordered by a terrace of coral limestone at an altitude of about 35 meters above sea level and about 79 meters above the present level of Lake Enriquillo. This coral reef is conspicuous at Neiba and Duvergé, but farther east it takes the form of a flat-lying bedded limestone. It is either of the same age as the conglomeratic "coast limestone," which extends from Cabral southeastward beyond Barahona, or it is a little younger. Plate XVII, $B$ (p. 198), is a view of a part of this reef.

The "coast limestone," which was referred to the Pleistocene by Gabb, is not a unit but includes sediments ranging in age from Miocene to Recent. Much of it, however, is of Pleistocene age. A large part of it is soft, pulverulent, marly limestone, which is locally called "caliche." Some of this rock is conglomeratic and contains large boulders of older rocks of many kinds.

Raised rocky beaches, which still carry clinging shells, such as Mytilus, were seen at several widely separated places, notably several kilometers inland from San Pedro de Macorís, at an altitude of more than 30 meters above sea level, and along the shore northeast of Monte Cristi.

The fossils collected from Pleistocene or younger deposits are listed on pages 166-168.

\section{STRUCTURE.}

The structure of the Dominican Republic as a whole is simple, but its details are very intricate. The oldest rocks form a broad strip through the center of the island, and the younger rocks flank them on each side. 
Except within the basal complex, where folding as well as faulting has been intense, faulting is the dominant element of the structure and folding is distinctly subordinate. Faults outline many of both the major and minor topographic features and determine the distribution of the geologic formations. The three longitudinal valleys that cross the island-the Cibao Valley, the San Juan-Azua area, and the Enriquillo Basin-are areas of Miocene and younger sediments that are partly outlined by faults. The mountain ridges that bound these valleys are composed of hard, older formations. Block faulting, both in the Cordillera Central and in the flanking areas, has caused frequent repetition of strata and greatly complicates the problem of interpreting the stratigraphy of the island.

The struct ure of the southwestern part of the Cibao Valley is monoclinal. The Miocene formations of the Yaque group dip gently northward and abut against the steep front of the Cordillera Septentrional, which, in the area between Santiago and Esperanza, is a fault scarp. At places, as in Arroyo las Lavas at the crossing of the Monte Cristi road, the edge of the Miocene formations has been dragged upward and the strata slightly overturned. At Damajagua, northwest of Navarrete, this great fault brings up Cretaceous "hornstone" and Eocene limestone high above the Miocene. The extension of this fault toward the northwest and southeast has not been traced. No faults of great magnitude were observed near Monte Cristi. Faulting has also taken place along the south side of the Cibao Valley, but the throw of the faults in that area is apparently not so great as that above described. The Oligocene Tabera formation, which dips steeply away from the Cordillera Central, is cut by many faults, but the throw of all that were examined is small. Block faulting of greater magnitude has taken place in the neighborhood of San José de las Matas and also near Dajabon.

The east end of the Cibao Valley is a gentle syncline. The Cevicos limestone in the neighborhood of Cevicos dips very gently northward, and the yellowish limestone that forms the foothills of the Cordillera Septentrional near Villa Rivas and Arenoso, which probably should be correlated with the Cevicos limestone, is inclined toward the south. No faulting was observed along the northern margin of the Cibao Valley east of San Francisco de Macorís. The large fault that forms the scarp near Navarrete either does not extend so far east or passes north of any route traversed by a member of the expedition.

Faults of undetermined magnitude involve schists and associated rocks of the basal complex and also hard limestones, probably of Eocene age, in the Lomas de Sierra Prieta near the margin of the Cibao Valley west of Rio Yuna and at Hatillo near Rio Yuna, southwest of Cotuí.

The mountain front north of Azua marks a fault which brings limestones and shales, probably Eocene or older, against beds of Miocene age. This 
fault appears to run nearly due east and west and intersects the northsouth fault which extends from San José de Ocoa southward along the edge of Loma el Número. Rio Ocoa from San José de Ocoa to Los Ranchitos follows this north-south fault line.

The diastrophic movements that have affected the Dominican Republic occurred during many geologic periods. The stresses that folded and sheared the rocks of the basal complex and converted so many of them into schists were probably active during Eocene time or earlier. Great diastrophic movement probably antedated later Eocene time, when limestones were formed over much of the present land surface of the island. The Tabera formation, of middle Oligocene age, was steeply tilted, faulted, and uplifted during late Oligocene time, while the upper Oligocene Cevicos limestone was being laid down in a sinking area farther east, which may have remained above water while the shales and conglomerates of the Tabera formation were deposited. The latest known Miocene deposit, the Cerros de Sal formation, has in places been faulted and tilted vertically since its deposition. The deposits of salt and gypsum in the Cerros de Sal formation show that changes in the level of land and sea were taking place while the beds were being deposited. Gentle flexures in the Las Matas formation, which is supposed to be of Pliocene age, and many raised beaches and uplifted coral reefs not older than Pleistocene record oscillations of comparatively recent date. Nor is there any sign of cessation of crustal movements in this region. On the contrary, evidence on every hand indicates that crustal movements are still in progress. The violent earthquakes which have repeatedly laid waste the ancient city of Santiago link the diastrophism of the past with that of the present and indicate that crustal movements are probably going on today with as great intensity as at any time in the past.

\section{OUTLINE OF GEOLOGIC HISTORY.}

The geologic history of the Dominican Republic is not yet fully understood and any outline of it must therefore be defective. The oldest rocks whose age has been definitely established are Upper Cretaceous deposits, but these deposits contain pieces of igneous rock, which indicate either Cretaceous or earlier igneous activity. Contemporaneous igneous activity is shown by the interbedding of extrusive igneous rocks with Cretaceous sediments. As the Cretaceous sediments are of a kind characteristic of shallow water, there was necessarily a shoal-water bank over at least a part of the area now occupied by the Dominican Republic. Some of the rocks may be much older than Upper Cretaceous. In Cuba Doctor Barnum Brown has recently traced an Upper Jurassic shore line, showing that there was land in Cuba prior to Upper Jurassic time. Farther west, in Guatemala and Nicaragua, certain prominent tectonic features that are 
in line with the main tectonic features of the Antilles existed at the close of Paleozoic time. In fact, a gradually increasing body of evidence points to the existence of the major tectonic lines of the Antilles in late Paleozoic time.

It is inferred that during early Eocene time the site of the Dominican Republic was mostly a land area, because the widespread deposits of Eocene age all seem to belong to the latest subdivision of Eocene time. Until the geologic map of the Republic has been completed it will not be practicable to ascertain whether any part of it remained above sea during all of Eocene time, but the Eocene sediments contain large Foraminifera, such as Lepidocyclina, Orthophragmina, and Nummulites, that inhabited shallow tropical waters. The limestones in the areas occupied by Sierra de Neiba, Sierra de Bahoruco, and other mountains in the southwestern part of the Republic attained considerable thickness, and Eocene limestone with conclomerate at its base overlies the Cretaceous deposits in the Cordillera Septentrional. The Eocene limestones, however, appear to be thicker in Haiti than in the Dominican Republic. The intrusion of the great masses of dioritic rocks probably occurred before the deposition of the Eocene sediments.

It seems that after the deposition of the Eocene sediments there was a period of diastrophism, because the Tabera formation, of middle Oligocene age, is composed largely of coarse conglomerate, which indicates erosion at its source, and the Oligocene deposits in the vicinity of Los Bancos appear to be separated from Eocene deposits by a marked erosion unconformity. (See p. 95, Chapter VI.) Before middle Oligocene time there must have been a great deal of igneous activity to supply the material for the conglomerates and there may have been volcanic extrusions. Igneous activity during Oligocene time is shown by the interbedding of tuffs with fossiliferous deposits. Although middle Oligocene deposits occupy considerable areas in the Republic the whole of its surface was not under sea at this time. The earth movements during this period were evidently complex, and at the close of Oligocene time there appears to have been further diastrophic movement.

At the beginning of Miocene sedimentation the central axis of the Island was a mountainous ridge bordered by a shallow sea in which the basal conglomerate and sandy sediments of the Cibao Valley and of Azua Province were deposited to a thickness ranging from a few hundred to at least 1,500 meters. Active erosion of the adjacent land was almost continuous, and sandy sediments were spread over the sea bottom with only a temporary pause now and then permitting the deposition of thin beds of limestone. Nearly all the calcareous beds are made up of reef corals intermixed with some sandy material. No evidence of igneous activity in Miocene time is now known. 
The events since Miocene time have included elevation and erosion, which were accompanied by pronounced faulting and folding and which lifted the Cordillera Central considerably higher than it stands now and brought into existence the Cordillera Septentrional, an uplifted block of Oligocene and older strata bounding the Miocene deposits of Cibao Valley on the north. Structural deformation of the Miocene strata, although not great in the Cibao Valley, proceeded apace in the southern region, where the beds were folded, faulted, and overturned. The great structural valleys, such as San Juan, Enriquillo, and Cibao, were probably produced during Pliocene time, and into them were carried the products of erosion of the central mountain chain, which were laid down at or near sea level. The work of block faulting in shaping the topography of Haiti and other islands of the West Indies group has been described by Vaughan. ${ }^{1}$

The events of late Pliocene time include mild folding and repeated elevation and depression, accompanied by more or less movement, which has continued down to the present and which produce the destructive earthquakes that occur from time to time. There is evidence of late vulcanism in the sheets of basaltic lava that cover the Las Matas formation along the upper valley of Rio Yaque del Sur.

During Pleistocene time there was a period of quiet, gradual submergence, which favored deposition of the "coast limestone," a marly porous rock of a type common throughout the West Indies, made up largely of reef corals of species still living in the Antillean seas. The "coast limestone" has been elevated so as to form an almost continuous line of cliffs along much of the coast and has undergone slight deformation. The paleontologic evidence indicates that its beds slope seaward, the youngest beds being exposed nearest the coast. These beds locally rest unconformably on Miocene strata, which appear a short distance inland in the province of Santo Domingo and in other areas to the east.

The extent to which the coast has undergone subsidence and emergence is indicated by sea-cut cliffs and terraces at different altitudes and by the presence of recent shell beds on these terraces. The amount of displacement differs at different places. Meinzer ${ }^{2}$ reports that beds in eastern Cuba containing Pleistocene or younger fossils have been found up to an altitude of 200 meters above sea level. Doctor Berkey ${ }^{3}$ has likewise found widespread evidence of depression and reelevation in Porto Rico. Similar evidence was found by our party, the best being seen near San Pedro de Macorís, where a shell bed some kilometers inland stands at an altitude of

\footnotetext{
1 Vaughan, T. W., Geologic history of Central America and the West Indies during Cenozoic time: Geol. Soc. America Bull., vol. 29, 1918, p. 618.

2 Meinzer, O. E., Geological reconnaissance of a region adjacent to Guantanamo, Cuba (unpublished report), quoted by Vaughan in Contributions to the geology and paleontology of the Canal Zone, Panama, and geologically related areas in Central America and the West Indies: U. S. Nat. Mus. Bull. 103 , p. 265.

${ }^{3}$ Berkey, C. P., Geological reconnaissance of Porto Rico: New York Acad. Sci. Annals, vol. 26, p. 60, 1915.
} 
40 meters. Along the Barahona coast shells of species that are still extant were found on a terrace at an altitude of 20 meters.

The course of events along the Dominican coast subsequent to the deposition of the "coast limestone" may have been as follows:

1. Elevation of at least 100 meters, with intermittent pauses during which wave-cut terraces were formed.

2. Active erosion during which deep valley notches were cut across the "coast limestone."

3. Depression that produced drowned valleys, which indent the coast and furnish the harbors, such as Puerto Plata and Samaná Bay. The depression occupied by Lake Enriquillo probably dates from this time. It may have been cut off from Neiba Bay by delta deposits of Rio Yaque.

4. Elevation as the latest event. The elevation appears to have been about 35 meters in Barahona Province but was very different in other parts of the island. The chief evidence of elevation in Barahona Province is the well-defined coquina and coral reef terrace around Enriquillo Basin, which is very conspicuous at Barbacoa, Neiba, and Duvergé. To the traveller passing over this forest of corals, some still bearing their original colors, its resemblance to a modern coral reef as seen at low tide is striking. There is also evidence that a slight elevation was the latest event in other parts of the Republic, especially in the vicinity of Monte Cristi and Samaná Bay.

The course of events has probably been much more complex than that outlined above. There may have been in addition minor oscillations. The "coast limestone" itself is made up of strata of ages ranging from Miocene to Recent, and it may have been elevated above the sea in late Pleistocene or Recent time, for the corals and other fossils found in it along the sea front are identical with forms now found in the adjacent sea.

Volcanism probably recurred in early Pleistocene time and has been practically continuous almost to the present. There is no historic record of late voleanic activity, but it is denoted by the recent aspect of some of the volcanic vents and lava fields in the province of Azua. Hot springs that may be regarded as phenomena associated with final stages of volcanism are reported to occur at a few localities in the Cordillera Central. 


\title{
CHAPTER V. METAMORPHIC AND IGNEOUS ROCKS.
}

\author{
By F. C. Calkins.
}

\section{METAMORPHIC SEDIMENTARY ROCKS.}

All the metamorphic sedimentary rocks represented in the collection made in the Dominican Republic belong to the basal complex in the provinces traversed by the Cordillera Central and in Samaná Peninsula. They do not include all the rocks that are here assigned to the basal complex, nor some of the distinctly tuffaceous sediments mentioned on page 55 , which may be Cretaceous. The term "sedimentary rocks" as here used includes tuffaceous material.

The most intensely metamorphosed specimen is D. C. $23 \mathrm{a}$, a silverylooking micaceous schist from the Province of La Vega. This rock has undergone "regional" metamorphism, and seems to be much older than Cretaceous. The same may be said of the marbles from Samana Peninsula and the Province of Santiago, which are gray to white and are markedly crystalline. These marbles contain mica and probably other metamorphic minerals, which cause certain layers to stand out in relief on weathered surfaces. A much lower degree of alteration is shown by a reddish limestone, supposedly Cretaceous, from the vicinity of Baní.

There are several specimens of pale-green chloritic schist that resemble altered tuff, especially R. 6, which exhibits vestiges of brecciated texture.

The absence of sediments resembling quartzite is rather noteworthy.

Specimens of metamorphic sedimentary rocks.

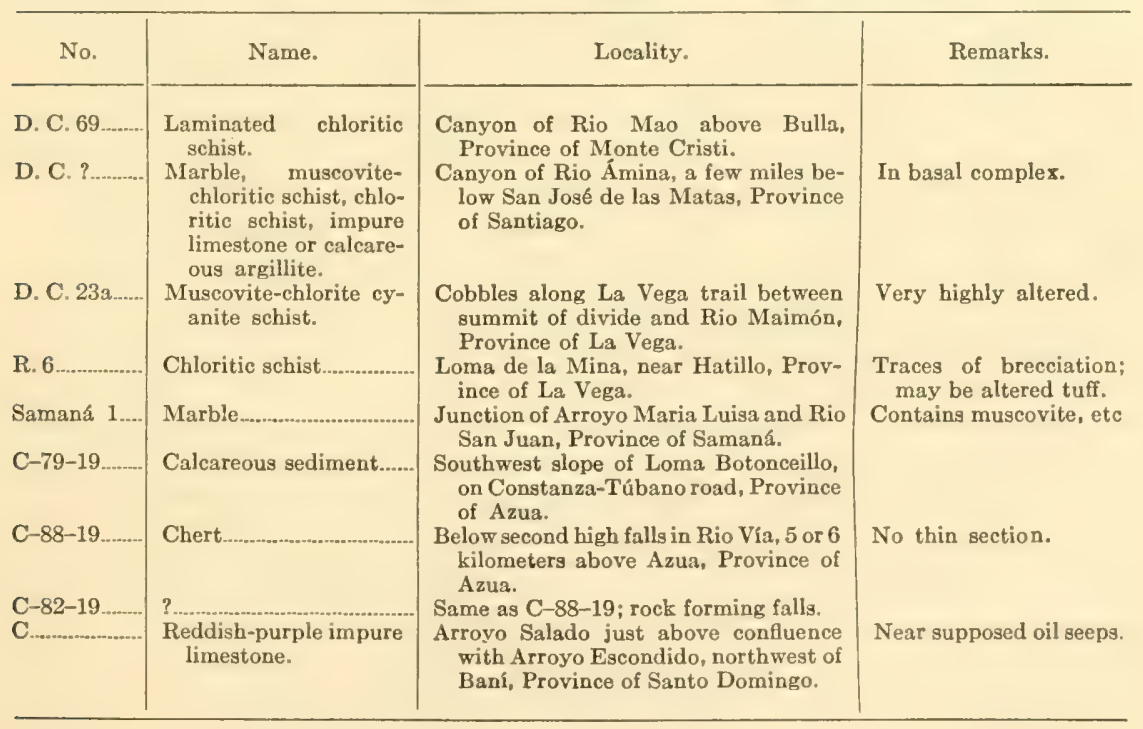




\section{GRANULAR INTRUSIVE ROCKS.}

Diorite.-The granular intrusive rocks include none more siliceous than quartz diorite or granodiorite. Most of the specimens are quartz diorites. Rocks of this class are found in the provinces of Monte Cristi, Santiago, and Pacificador. The commonest type is medium-grained, gray, graniticlooking rock, rather rich in quartz, containing variable amounts of hornblende. Biotite is subordinate to hornblende in all the specimens and is quite absent from some. Most specimens contain little or no potash feldspar. Only one (D. C. 56b) contains enough to suggest its affinity to granodiorite. In one specimen (R. 33) the usual interstitial position of orthoclase is occupied by albite, which may be secondary after orthoclase. The poverty of these rocks in potash, combined with their rather high silicity, is noteworthy.

One specimen has a gneissic texture induced by pressure (D. C. 72). Two (D. C. 23d, D. C. 25) are tentatively grouped with the diorites; they have suffered deep-seated alteration and are possibly epidiorites derived from gabbro. The feldspar is abnormally sodic for rocks so rich in dark minerals.

Gabbro.-A single specimen of gabbro (D. C. 23c) was collected in the Province of Santiago. It consists essentially of labradorite, augite, and hornblende. The hornblende, which is more abundant than the augite, is probably in part secondary. Some of the altered rocks just mentioned, however, may have been derived from gabbro.

Peridotite.-A specimen (D. C. 3) of altered peridotite, consisting mainly of dull serpentine derived from olivine but sprinkled with satiny erystals of bastite, was collected near the town of Puerto Plata, and a hornblendeolivine rock was collected in the Province of La Vega (D. C. 23e).

Specimens of granular intrusive rocks.

\begin{tabular}{|c|c|c|c|}
\hline No. & Name. & Locality. & Remarks. \\
\hline R. $33 \ldots \ldots$ & Quartz diorite...... & $\begin{array}{l}\text { Juan Calvo Hills, } 4 \mathrm{~km} \text {. south of } \\
\text { Dajabon, Province of Monte } \\
\text { Cristi. }\end{array}$ & $\begin{array}{l}\text { Cobble. Contains inter- } \\
\text { stitial albite (replacing } \\
\text { orthoclase?). }\end{array}$ \\
\hline D. C. $72 \ldots$ & Quartz diorite gneiss...... & $\begin{array}{l}\text { Arroyo Blanco, road from Sabaneta } \\
\text { to Restauración, Province of } \\
\text { Monte Cristi. }\end{array}$ & No alkali feldspar present. \\
\hline D. C. 3 & Serpentine ......... & $\begin{array}{l}\text { Along railroad } 5.8 \mathrm{~km} \text {. west of } \\
\text { Puerto Plata, Province of Puerto } \\
\text { Plata. }\end{array}$ & $\begin{array}{l}\text { An altered olivinc-enstatite } \\
\text { rock, also some limestone. }\end{array}$ \\
\hline R. $12 \ldots$ & Quartz diorite................... & $\begin{array}{l}\text { Arroyo Arenasito, Cordillera } \\
\text { Septentrional, near Villa Rivas, } \\
\text { Province of Pacificador. }\end{array}$ & Cobble; quartz abundant. \\
\hline R. 11 ......nenten & $\begin{array}{l}\text { Quartz diorite, aplitic } \\
\text { tacies. }\end{array}$ & $\begin{array}{l}\text { Arroyo Higuero, Cordillera Sep- } \\
\text { tentrional, near Villa Rivas, } \\
\text { Province of Pacificador. }\end{array}$ & $\begin{array}{l}\text { Cobble similar in com- } \\
\text { position to R. } 12 \text { but finer- } \\
\text { grained. }\end{array}$ \\
\hline D. C. $56 \mathrm{~b} \ldots . .$. & $\begin{array}{l}\text { Quartz diorite or grano- } \\
\text { diorite. }\end{array}$ & $\begin{array}{l}\text { Rio Jinoa, about } 5 \mathrm{~km} \text {. southwest } \\
\text { of San José de las Matas, Prov- } \\
\text { ince of Santiago. }\end{array}$ & \\
\hline D. C. $25 \ldots$ & Diorite or epidiorite....... & $\begin{array}{l}\text { Canyon of Rio Yaque del Norte } \\
\text { above Tabera, Province of } \\
\text { Santiago. }\end{array}$ & $\begin{array}{l}\text { Much altered; amphibole is } \\
\text { fibrous; might be altered } \\
\text { gabbro. }\end{array}$ \\
\hline
\end{tabular}


Specimens of granular intrusive rocks-Continued.

\begin{tabular}{|c|c|c|c|}
\hline No. & Name. & Locality & Remarks. \\
\hline D. C. $23 a_{-}$ & Quartz diorite & $\begin{array}{l}\text { La Vega trail between summit of } \\
\text { divide and Rio Maimon, Prov- } \\
\text { ince of Santiago. }\end{array}$ & $\begin{array}{l}\text { Hornblende abundant; feld- } \\
\text { spar bytownite; no potash } \\
\text { feldspar present. }\end{array}$ \\
\hline D. C. $23 \mathrm{~d}$ & $\begin{array}{l}\text { Quartz diorite or epi- } \\
\text { diorite. }\end{array}$ & Same as $23 a$, above & $\begin{array}{l}\text { Texture indicates deep- } \\
\text { seated alteration. Feld- } \\
\text { spar abnormally sodic. }\end{array}$ \\
\hline D. C. $23 \mathrm{f}$ & Amphibolite schist.......... & Same as $23 a$, above............ & $\begin{array}{l}\text { Essentially quartz, horn- } \\
\text { blende, and albite. May } \\
\text { be of same origin as } 23 \mathrm{~d} \text {, } \\
\text { but more thoroughly } \\
\text { altered. }\end{array}$ \\
\hline D. C. $23 \mathrm{c} \ldots$ & 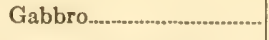 & 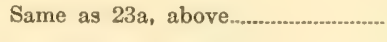 & Contains hornblende, prob- \\
\hline D. C. $23 \mathrm{e}$ & Hornblende peridotite.... & Same as $23 a$, above & $\begin{array}{l}\text { Much altered; olivine wholly } \\
\text { replaced. }\end{array}$ \\
\hline$C-76-19$ & Quartz diorite.................. & $\begin{array}{l}\text { Rio Medio, between } 10 \text { th and } 11 \text { th } \\
\text { crossings, road from Constanza } \\
\text { to Las Cañitas, Province of Azua. }\end{array}$ & $\begin{array}{l}\text { Also a dark porpbyritic rock, } \\
\text { not determined. }\end{array}$ \\
\hline
\end{tabular}

\section{DIKE ROCKS.}

Many of the specimens are either described as occurring in dikes or, as their texture indicates, are obviously dike rocks. Some others are only tentatively classified as dike rocks in the absence of adequate information regarding their mode of occurrence.

Silicic dike rocks.-The most common sort of silicic dike rock in the collection is a whitish granite porphyry containing phenocrysts of quartz and albite and sparse vestiges of some altered ferromagnesian mineral in a groundmass of albite, quartz, and orthoclase. Specimens of such rock were collected in the Provinces of Santiago and Pacificador. An aplitic rock (D. C. 27a) from the Province of Santiago consists essentially of feldspar, abundant quartz, and a moderate amount of hornblende. The feldspar is albite or sodic anorthoclase. Both this aplite and the granite porphyry may be genetically related to the quartz diorites.

Intermediate dike rocks.-A dark-green sheared and highly altered diorite porphyry (D. C. 23b) was found in the Province of Santiago, and a very fresh gray diorite porphyry (D. C. 83) from the Province of Azua contains phenocrysts of labradorite, augite, hornblende, and biotite.

Mafic dike rocks. - The collection contains several specimens of diabase, which may be dike rocks, though some of them may be lavas. They are from the provinces of Azua and Santiago. Two specimens (R. 7 and D. C. $56 a)$ have the texture of diabase but contain hornblende in place of augite; in D. C. 56a the feldspar is near albite and probably secondary.

Some other dark greenish dike rocks containing augite but not diabasic in texture are listed as lamprophyres. They were found in the provinces of Samaná, Monte Cristi, and Santo Domingo. They are considerably altered and in at least one (D. C. 68b) the feldspar is albite. 
Specimens of dike rocks.

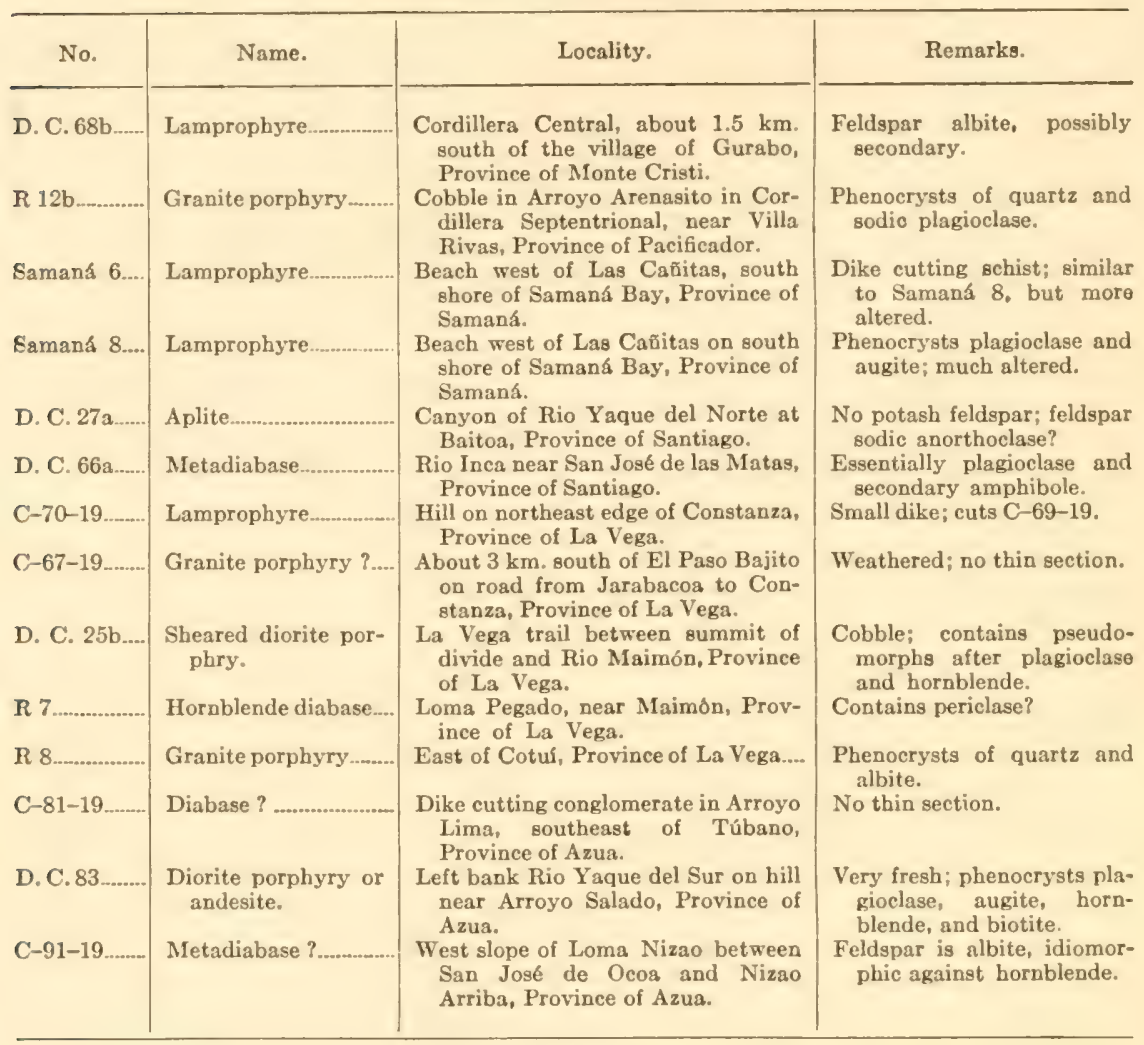

\section{LAVAS.}

Among the lavas, as among the granular intrusives, there are no decidedly silicic or alkalic types, but there are intermediate, basic, and ultrabasic types.

Andesites.-A gray poryphyritic typical hornblende-augite andesite was found in the Province of Azua (D. C. 74), and two other specimens, of which no thin sections are available, from the same province, apparently belong to hornblende andesite. A black augite andesite with phenocrysts of plagioclase and augite was collected in the Province of Santo Domingo.

Basalts.-The collection contains specimens of basalt from the provinces of Monte Cristi, La Vega, Azua, Barahona, and Santo Domingo, and also two specimens from the Département du Nord, Republic of Haiti. The rocks are variously altered, the olivine in many of them being replaced by chlorite or serpentine. Two extremely fresh specimens of very basic lava classifiable as limburgite rather than basalt are D. C. 76 and 79 . One of these contains no feldspar, though feldspar might be present if the glass of the groundmass were crystallized. 
Specimens of lavas.

\begin{tabular}{|c|c|c|c|}
\hline No. & Name. & Locality. & Remarks. \\
\hline D. C. $68 \mathrm{c} \ldots$ & Basalt & $\begin{array}{l}\text { Cordillera Central, about } 1.5 \mathrm{~km} \text {. } \\
\text { south of Gurabo, Province of } \\
\text { Monte Cristi. }\end{array}$ & Amygdaloidal. \\
\hline R $9 \ldots \ldots \ldots$ & Basalt & $\begin{array}{l}\text { Western foothills of Loma de los } \\
\text { Palos near Cotuí, Province of La } \\
\text { Vega. }\end{array}$ & $\begin{array}{l}\text { Texture intersertal. Con- } \\
\text { tains much chlorite and } \\
\text { epidote. }\end{array}$ \\
\hline$C-74-19 \ldots$ & Amygdaloidal basalt.. & $\begin{array}{l}\text { Loma Chingüela(?), } 31 \frac{1}{2} \text { hours west of } \\
\text { Constanza, road to Túbano, Prov- } \\
\text { ince of La Vega. }\end{array}$ & \\
\hline D. C. 74 & $\begin{array}{l}\text { Hornblende - augite } \\
\text { andesite. }\end{array}$ & $\begin{array}{l}\text { Ridge about } 8 \mathrm{~km} \text {. east of Bánica, } \\
\text { Province of Azua. }\end{array}$ & Hornblende resorbed? \\
\hline$C-?-19 \ldots$ & Hornblende andesite.. & $\begin{array}{l}\text { Boulder in Rio Medio at first crossing, } \\
\text { road from Constanza to Túbano, } \\
\text { Province of Azua. }\end{array}$ & No thin section. \\
\hline C-83-19...... & Hornblende andesite.- & $\begin{array}{l}\text { Near Tábano, on road to Constanza, } \\
\text { Province of Azua. }\end{array}$ & No thin section. \\
\hline C-80-19 & Altered basalt ?........... & $\begin{array}{l}\text { Rio Medio at Limón, Province of } \\
\text { Azua. }\end{array}$ & \\
\hline D. C. $79 \mathrm{a} \ldots$ & Hornblende basalt...... & $\begin{array}{l}\text { East side of Rio Yaque del Sur op- } \\
\text { posite mouth of Rio de las } \\
\text { Cuevas, Province of Azua. }\end{array}$ & $\begin{array}{l}\text { Phenocrysts of basaltic } \\
\text { hornblende, olivine, and a } \\
\text { few of augite. }\end{array}$ \\
\hline D. C. 76 & Limburgite or basalt.. & $\begin{array}{l}\text { Punta Caña, between Las Matas and } \\
\text { San Juan, Province of Azua. }\end{array}$ & $\begin{array}{l}\text { Contains olivine, augite, } \\
\text { magnetite and a rather } \\
\text { small amount of glass. }\end{array}$ \\
\hline D. C. 79 & Limburgite or basalt.. & $\begin{array}{l}\text { West side of Rio Yaque del Sur op- } \\
\text { posite mouth of Rio de las Cuevas, } \\
\text { Province of Azua. }\end{array}$ & $\begin{array}{l}\text { Similar in composition to } \\
\text { D. C. } 76 \text { but apparently } \\
\text { contains a little feldspar. }\end{array}$ \\
\hline R $80 \ldots$ & $\begin{array}{l}\text { Altered vesicular } \\
\text { basalt ?. }\end{array}$ & $\begin{array}{l}\text { Búcaro Hill, San Francisco Mining } \\
\text { Concession, Province of Santo } \\
\text { Domingo. }\end{array}$ & $\begin{array}{l}\text { Abundant chlorite and sec- } \\
\text { ondary quartz. }\end{array}$ \\
\hline $\begin{array}{l}\text { D. C. Alcar- } \\
\text { rizos. }\end{array}$ & $\begin{array}{l}\text { Brecciated augite an- } \\
\text { desite. }\end{array}$ & $\begin{array}{l}5 \mathrm{~km} \text {. north of Los Alcarrizos on the } \\
\text { Duarte Highway, Province of } \\
\text { Santo Domingo. }\end{array}$ & $\begin{array}{l}\text { Phenocrysts plagioclase and } \\
\text { augite. }\end{array}$ \\
\hline D. C. 98 & Basalt... & $\begin{array}{l}\text { Rio Bahoruco, on the coast south of } \\
\text { Barahona, Province of Barahona. }\end{array}$ & Amygdaloidal. \\
\hline D. C. $98 a \ldots$ & Basalt & $\begin{array}{l}\text { Rio Bahoruco, on the coast south of } \\
\text { Barahona, Province of Barahona. }\end{array}$ & \\
\hline$H-3-v_{\ldots}$ & $\begin{array}{l}\text { Hornblende - bearing } \\
\text { basalt. }\end{array}$ & $\begin{array}{l}\text { Kadiak, between Limbe and Camp } \\
\text { Le Coq, about one-third the dis- } \\
\text { tance from Limbé, Department du } \\
\text { Nord, Republic of Haiti. }\end{array}$ & Hornblende in groundmass. \\
\hline $\mathrm{H}-4-\mathrm{V}_{\ldots} \ldots . . .$. & Basalt ?.......................... & $\begin{array}{l}\text { Beudaret (altitude } 442 \text { meters), at top } \\
\text { of divide at head of Rivière Limbé, } \\
\text { between Limbe and Plaisance, Dé- } \\
\text { partment du Nord, Republic of } \\
\text { Haiti. }\end{array}$ & $\begin{array}{l}\text { Thoroughly altered; contains } \\
\text { much epidote, chlorite and } \\
\text { secondary amphibole. }\end{array}$ \\
\hline
\end{tabular}

\section{TUFFACEOUS ROCKS.}

The collection contains specimens of typical unsorted tuffs, of water-laid sandstone consisting largely of volcanic material, and of metamorphic rocks that may be altered tuffs. The last named are described under "Metamorphic sedimentary rocks," page 83.

Unsorted tuffs were found in the provinces of Puerto Plata, Azua, Barahona, Santo Domingo, and La Vega. In composition they are andesitic and basaltic. They vary widely in degree of alteration and range in color from whitish to dark green or red.

Tuff sandstones in which feldspar crystals are somewhat concentrated by current action were collected in the provinces of Santiago, Pacificador, and Puerto Plata. These are olive-green. 
A specimen (R 2,3) of pale drab limestone collected in the Province of Puerto Plata contains fragments of green decomposed lava whose sharp angularity indicates that they were not carried far by currents and that they were erupted while the limestone was being formed.

A dark-gray calcareous rock from the Constanza-Túbano road, in the Province of La Vega (C 73-19), contains much noncalcareous material that forms a pale rind on its weathered surface. This material may be volcanic, as Dr. Vaughan has suggested, but the suggestion can not be verified without microscopic study. This rock probably belongs to the basal complex.

Specimens of tuffaceous rocks.

\begin{tabular}{|c|c|c|c|}
\hline No. & Name. & Locality. & Remarks. \\
\hline D. C. $1 \ldots$ & Tuff (andesitic ?)....... & Southern edge of the city of Puerto Plata, & \\
\hline R $1 \ldots$ & Tuff-sandstone.............. & $\begin{array}{l}\text { Province of Puerto Plata. } \\
\text { Trail to Santiago, about } 300 \text { meters west of }\end{array}$ & \\
\hline$R_{2}^{2}, 3 \ldots$ & Limestone containing & $\begin{array}{l}\text { San Marcos, Province of Puerto Plata. } \\
\text { Trail between Puerto Plata and Santiago, }\end{array}$ & Fragments angular. \\
\hline & fragments of lava. & $\begin{array}{l}\text { southwest of San Marcos, on the north- } \\
\text { east slope of divide, Province of Puerto } \\
\text { Plata. }\end{array}$ & \\
\hline R $17 \ldots$ & $\begin{array}{l}\text { Andesitic? tuff-sand- } \\
\text { stone. }\end{array}$ & $\begin{array}{l}\text { Arroyo north of Los Ranchos, Cordillera } \\
\text { Septentrional, near lignite prospect, } \\
\text { Province of Pacificador. }\end{array}$ & $\begin{array}{l}\text { Lignite is interbedded } \\
\text { with similar ma- } \\
\text { terial. Contains } \\
\text { fluorite. }\end{array}$ \\
\hline D. C. $27 \mathrm{~b} \ldots$ & $\begin{array}{l}\text { Andesitic tuff-sand- } \\
\text { stone. }\end{array}$ & $\begin{array}{l}\text { Canyon of Rio Yaque del Norte at Baitoa, } \\
\text { Province of Santiago. }\end{array}$ & Cretaceous? \\
\hline C- $66-19 \ldots$ & Indurated tuff ?........ & $\begin{array}{l}\text { About } 1.5 \mathrm{~km} \text {. south of El Paso Bajito, road } \\
\text { from Jarabacoa to Constanza, Province } \\
\text { of La Vega. }\end{array}$ & \\
\hline $\mathrm{C}-69-19 \ldots$ & Basalt tuff & $\begin{array}{l}\text { Hill northeast of Constanza, Province of } \\
\text { La Vega. }\end{array}$ & \\
\hline C-73-19.... & $\begin{array}{l}\text { Andesitic or basaltic } \\
\text { tuff ?. }\end{array}$ & $\begin{array}{l}\text { First crossing of Arroyo Hondo, road from } \\
\text { Constanza to Túbano, Province of La } \\
\text { Vega. }\end{array}$ & Dark red. \\
\hline C-82-19.... & Andesite tuff.. & Cerro de las Chibras, Túbano, Province of & Very fresh. \\
\hline & Andesitic tuff.... & $\begin{array}{l}\text { Azua. } \\
\text { La Rama prospect, San Francisco Mining }\end{array}$ & \\
\hline R 86 & Tuff ?.... & $\begin{array}{l}\text { Concession, Province of Santo Domingo. } \\
\text { Chini prospect, near Arroyo Alga, San Fran- }\end{array}$ & Much altered. \\
\hline & & & \\
\hline R 55. & Decomposed tuff & $\begin{array}{l}\text { Sierra Bahoruco, north side of Cañada } \\
\text { Diablo, south of Duvergé, Province of } \\
\text { Barahona. }\end{array}$ & \\
\hline
\end{tabular}




\section{CHAPTER VI.}

\section{TERTIARY AND QUATERNARY STRATIGRAPHIC PALEON- TOLOGY.}

\section{By Thomas Wayland Vaughan and Wendell Phillips Woodring.}

\section{OBJECTS OF THE PALEONTOLOGIC WORK.}

As is stated in the introductory chapter of this volume, one of the objects of the preliminary geologic work done in the Dominican Republic included the collection of fossils that would establish a more accurate geologic correlation of the formations in the Republic and that would aid in correlating them with formations in other West Indian islands, southern North America, Central America, and northern South America and in establishing geologic correlations of formations on the two sides of the Atlantic. The large collections obtained during the reconnaissance have been studied in a preliminary way and the information they afford is here presented. The only other collections made in the Dominican Republic that can aid in determining geologic correlations are those obtained by Dr. Carlotta J. Maury and her party in May and June, 1916. ${ }^{1}$ The results of studies by specialists of the Foraminifera, Echinii, Bryozoa, and Crustacea collected by her party, as well as of some stratigraphic information contained in her report, have been used, for by thus combining the results of the studies of the two sets of collections we are able to give a summary of all that is now known of the Tertiary stratigraphic paleontology of the Dominican Republic. The small fauna of the known Cretaceous is discussed on pages 53-55.

The identification of the fossils has been a laborious undertaking, in which a number of investigators have collaborated. Credit for the determinations should be given as follows: Foraminifera, Dr. Joseph A. Cushman, of the United States Geological Survey; corals, Dr. T. Wayland Vaughan, of the United States Geological Survey; Echinii, Dr. Robert T. Jackson, of Peterborough, New Hampshire; Bryozoa, Dr. Ray S. Bassler, of the United States National Museum, and Monsieur F. Canu, of Versailles, France; Mollusca, Dr. W. P. Woodring and Mr. W. C. Mansfield, both of the United States Geological Survey; Crustacea, Dr. Mary J. Rathbun, of the United States National Museum. The few fossil phanerogamous plants were examined by Professor E. W. Berry, of Johns Hopkins University. It would possibly be no more than just to give the names of all these collaborators as joint authors of this chapter. In references to fossils given in the following lists the identifications should be credited to the

1 Santo Domingo type sections and fossils: Bull. Am. Paleontology, vol. 5, pp. 165-459, Pls. 27-68, 1917. 
specialists who made them. Dr. Marshall A. Howe, of the New York Botanical Garden, is preparing a report on the fossil calcareous algae, but the results of his study are not yet available.

The lists here given are only preliminary, because, although great care has been taken both in the identification of species and in the compilation of the lists, it has not yet been practicable to make monographic studies of the several groups of organisms represented. Many species have not yet been named and further field work will doubtless add greatly to the number already collected, but notwithstanding these limitations much valuable information was procured. The general biologic features of several of the formations have become fairly well known, and when the data are presented in detail they will help still further to solve problems of both local and regional geology.

\section{PALEONTOLOGIC LITERATURE.}

As it is not practicable to illustrate in this volume the fossils mentioned in the tables, it is desirable to give references to the more valuable illustrated reports on the West Indian and Central American representatives of the groups here considered. Three volumes of particular value have appeared during the last few years. They are as follows:

Carlotta J. Maury, Santo Domingo type sections and fossils: Bull. Am. Paleontology, vol. 5, pp. $165-459$, pls. 27-68, 1917.

T. W. Vaughan and others, Contributions to the geology and paleontology of the Canal Zone, Panama, and geologically related areas in Central America and the West Indies, prepared under the direction of T. W. Vaughan: U. S. Nat. Mus. Bull. 103, 612 pp., 154 pls., 25 text-figs., 1918-1919. This volume contains memoirs on fossils as follows: Calcareous algae, by M. A. Howe; Higher plants, by E. W. Berry; Foraminifera, by J. A. Cushman; Echinii, by R. T. Jackson; Bryozoa, by F. Canu and R. S. Bassler; Decapod Crustacea, by Mary J. Rathbun; Cirrepedia, by H. A. Pilsbry; Corals, by T. W. Vaughan. The last paper in the volume is one by T. W. Vaughan summarizing the paleontologic data and discussing problems of correlation and of geologic history.

T. W. Vaughan and others, Contributions to the geology and paleontology of the West Indies, prepared under the direction of T. W. Vaughan: Carnegie Inst. Washington Pub. 291, 184 pp., 53 pls., 7 text-figs., 1919. Besides a brief introduction by T. W. Vaughan this volume contains papers on West Indian fossils as follows: Calcareous algae, by M. A. Howe; Foraminifera, by J. A. Cushman; Bryozoa, by F. Canu and R. S. Bassler; Mollusks, by C. W. Cooke; Decapod Crustacea, by M. J. Rathbun.

These volumes contain references to older works. Several other valuable papers on Foraminifera by Doctor Cushman have recently been published. Among these papers are "The American species of Orthophragmina and Lepidocyclina” (U. S. Geol. Survey Prof. Paper 125-D, pp. 39-105, pls. 7-35, text-figs., 1920) and "Lower Miocene Foraminifera of Florida" (U. S. Geol. Survey Prof. Paper 120-B, pp.60-74, pl. 11, 1920).

The publications here cited, together with the references they contain and the bibliography given on pages $18-25$, include nearly all the important papers on West Indian stratigraphic paleontology. 
GEOLOGIC CORRELATION.

The expression "geologic correlation" means the determination or the attempt to determine the contemporaneity of geologic events in different regions-proximate or remote-the attempt to determine, for instance, what deposits were forming at the same time at the two ends of the present valley of Rio Yaque del Norte and what deposits were forming at that time on the south side of the Cordillera Central. As applied to the Dominican Republic it involves a comparison of the geologic history of the Dominican Republic with that of Cuba, Jamaica, and other West Indian islands, and of the geologic history of this general region with that of other parts of America or of more remote parts of the earth.

Geologic correlation may be made: (1) by actually tracing geologic formations from one area to another through adjacent exposures; (2) by comparing the record of the diastrophic events (earth movements) in the two areas; (3) by studying the remains of such organisms as may be entombed in the sediments in the two areas if they are sufficiently abundant. Each of these methods has its limitations and its liability to error, and in many regions a reliable conclusion can not be reached by means of any one of them, but satisfactory correlations in some regions may be reached by combining evidence afforded by two or all of them.

Correlation by tracing formations through lithologic continuity and similarity is not invariably trustworthy, because formations that are different in character may have been deposited contemporaneously and because similar formations may have been deposited at different times. Everyone who is familiar with the physical features of the Republic knows that the sediments now forming at the mouths of such streams as Rio Yuna and Rio Yaque del Norte are different from those forming on Monte Cristi Bank or in any other area around the shores of the Dominican Republic that is not reached by detritus washed from the land; yet these different kinds of sediments are forming at precisely the same time. One could not therefore correlate these contemporary river-borne formations by tracing them along the shore from the mouth of the Yuna to the mouth of the Yaque, for they are not continuous. The discontinuity between the formations of Haiti and of Cuba is still more striking. Rock of the same kind may be formed in widely separated geologic ages. In the West Indies there are shallowwater limestones of Jurassic, Upper Cretaceous, Eocene, middle Oligocene, late Oligocene, Miocene, and Pleistocene age, so that one who employed no other criteria than lithology for determining the geologic age of a deposit-which means also its stratigraphic position-might make very serious errors. Yet, although geologic correlations by lithology may sometimes fail, it is nevertheless valuable. 
Correlations by diastrophic events, a method which is based on similarity in deformation or in succession of deformation or on similarity in degree of metamorphism, is also defective, for the whole crust of the earth is not simultaneously subjected to earth movements of the same kind and intensity. Parts of the earth's crust have remained almost undisturbed while other parts have been folded into mountain chains, and igneous activity was violent in some regions while there was none at all in others. Notwithstanding the limitations of the method of correlation by diastrophism, however, it is of great value, because the strata in some large parts of the earth did undergo deformation at nearly the same time, and in a study of those parts the complicated events of the past may be traced by carefully studying the relations of the rocks one to another and thereby learning something of the history of their deformation.

Correlation by means of fossil organisms depends upon the premise that the organisms which inhabited the earth in past geologic time have changed in character and in grouping from age to age and that the organisms which lived in each geologic age were similar. The defects of this method of correlation are numerous: (1) Many deposits, particularly those formed on the land, contain no organic remains; (2) land, water, or climatic barriers may not permit organisms to move freely to any part of the earth-that is, the organisms of one time and place may be restricted in their geographic distribution, and the organisms that lived at a certain time may have been very different in different regions; (3) if organisms had suddenly changed at the beginning of each geologic epoch and if all the organisms that lived during that epoch were characteristic of it there would be no great difficulty in recognizing the age of a deposit that contains abundant organic remains, but abrupt breaks do not generally occur between faunas of successive epochs. For instance, it seems that nearly all the species of the living shallow-water coral fauna of the West Indies already existed in Miocene time-probably in older Miocene time. The Miocene coral fauna of the West Indies is characterized by some genera and groups of species some of which are now extinct while others persist in the Indo-Pacific region. Almost all the superspecific groups of the Recent West Indian shallow-water Mollusea were also living in Miocene time in the West Indian region, but the Miocene Mollusca include groups that are now restricted to the west coast of America or to the Indo-Pacific region.

Correlation by means of fossils involves still other difficulties and liabilities to error. The original subdivision of the Tertiary system into Eocene, Miocene, and Pliocene was made by Lyell according to the percentage of living species of mollusks found in the rocks, the Eocene containing 3.5 per cent, the Miocene 17 per cent, and the Pliocene 30 to 50 per cent of species still living. Two other subdivisions of the Tertiary were afterward made, the Oligocene by Beyrich and the Paleocene by 
Schimper, the Oligocene containing 10 to 15 per cent of living species of Mollusca and the Paleocene practically none. The comparison of faunas by means of such percentages is likely to lead to very serious errors and possesses significance only when all the species of a given ecologic complex are known and are compared with all the species of a similar ecologic complex. In the discussion of fossil faunas too little attention has been paid to differences in contemporaneous faunas due to differences in environment. The necessity of giving greater consideration to ecology in the study and geologic use of fossils has been recently emphasized by Vaughan. ${ }^{1}$ If the percentage method of comparing faunas were applied to the living lagoon fauna and the living exposed barrier reef fauna of Cocos-Keeling Islands, on the assumption that the lagoon fauna is geologically Recent, the barrier fauna would be Miocene, and the fauna of the pools and flats behind the barrier reef would be oldest Pliocene. By this method much of the West Indian Miocene might be made Pliocene or even Pleistocene. Errors may be introduced because a fossil fauna may not be homogeneous. Marine Mollusca, for example, may be collected from different ecologic stations at a single locality within a single formation. Mud-burrowing and boring bivalves have been washed upshore and mixed with gastropods that lived only on intertidal sand flats; offshore and estuarine forms have been washed in among indigenous shoal-water species. Yet percentage comparisons are valuable if they are applied to complete faunas of a similar ecologic complex, and though one may seldom be sure of having collerted all the members of any fauna, careful and thorough collecting may give a large proportion of it. The biologic method of correlation affords its best results only if it is applied after a study of the vertical distribution of species, particularly the minor variants of species, in accurately ascertained columnar sections. By studying in this way the faunas and the associated sediments over areas of moderate extent the stratigraphic range of many species and variants may be ascertained, and these species rather than percentages supply a basis for the correlation of similar deposits. Even this method of work involves liability to error, however, because the observed stratigraphic ranges of the organisms studied may not sufficiently represent the actual ranges.

In establishing the correlations of the formations of the Dominican Republic all three methods were used. It was not practicable in many places to trace the formations from one area to another even where it is possible to do so; the record of earth movements, although it has not been fully deciphered, was a valuable aid, but the most generally useful method, and that by which the ages of most of the formations were inferred, was

\footnotetext{
1 Vaughan, T. W., Fossil corals from Central America, Cuba, and Porto Rico, with an account of the American Tertiary, Pleistocene, and Recent coral reefs: U. S. Nat. Mus, Bull. 103, pp. 190-193, 1918, (Section entitled "Geologic correlation by means of fossil corals.") Corals and the formation of coral reefs: Smithsonian Rept. for 1917, pp. 186-276, pls. 37, text-figs. 16, 1919.
} 
the biologic. In some cases it was possible to apply both diastrophic and biologic criteria, as, for instance, in referring the Baitoa formation to the Miocene. The underlying Tabera formation, which, as is clearly shown by its fossils, is of the same or nearly the same age as the middle Oligocene Antigua formation, was folded and eroded before the Baitoa was deposited upon it. It may reasonably be inferred that this folding and erosion consumed a long time-probably all of upper Oligocene time-and that the Baitoa formation is of Miocene age. Moreover, the fauna of the Baitoa shows affinities with that of the other members of the Yaque group, not with the faunas of the older formations. The Baitoa is therefore referred to a stratigraphic position low in the Miocene. One result of this conclusion is to place in the Miocene the type species of the genus Orthaulax, O. inornatus Gabb, a species that had been supposed to be of Oligocene age.

\section{RELATIONS OF DOMINICAN TERTIARY AND QUATERNARY BIOTA.}

Within the last two years Vaughan has discussed in three papers the relations of the West Indian and Central American Tertiary marine invertebrate fauna, ${ }^{1}$ and Dr. C. J. Maury ${ }^{2}$ and Dr. Bela Hubbard ${ }^{3}$ have more recently published two papers that are devoted particularly to Porto Rico. As rather full references to other literature are given in the papers cited, particularly the longer one by Vaughan, the present discussion is much condensed.

\section{EOCENE.}

The Dominican Eocene seems to be of very nearly the same if not the same geologic horizon on both the north and the south side of the island. The tables on pages 105-106 show that the same species are found on both. The same or a very similar fauna is found in Saint Bartholomew, Jamaica, Cuba, Nicaragua, Costa Rica, and Panama, and probably in Colombia and Trinidad. Vaughan also obtained it in Haiti at Cape Haïtien and between Plaisance and Ennery, at an altitude of about 705 meters above sea level, on the north side of the summit of Mount Puilboreau. The genera of Foraminifera in the Haitian deposits were determined by Doctor Cushman as Globigerina, Calcarina, Orthophragmina, Conulites, Biloculina, and Quinqueloculina. To the Eocene limestone that is so well exposed in northwestern Haiti Vaughan has applied the name Plaisance limestone.

This fauna is late Eocene, the same age as that of the Jackson formation and Ocala limestone of the southern and southeastern United States and

\footnotetext{
${ }^{1}$ Vaughan, T. W.. Correlation of the Tertiary geologic formations of the southeastern United States, Central America, and the West Indies: Washington Acad. Sci. Jour., vol. 8, pp. 268-276, 1918. Geologic history of Central America and the West Indies during Cenozoic time: Geol. Soc. America Bull., vo!. 29. pp. 615-630, 1919. The biologic character and geologic correlation of the sedimentary formations of Panama in their relation to the geologic history of Central America and the West Indies: U. S. Nat. Mus. Bull. 103, pp. 547-612, 1919.

Maury, Carlotta J., On the correlation of Porto Rican Tertiary formations with other Antillean and mainland horizons: Am. Jour. Sci., vol. 48, pp. 209-215, 1919.

- Hubbard, Bela, The Tertiary formations of Porto Rico: Science, D. 8., vol. 51, pp. 395, $396,1920$.
} 
the Priabona formation of northern Italy. It appears that there are no Paleocene nor lower and middle Eocene sediments above sea level in the West Indies. Upper Cretaceous deposition was terminated by intense deformation and by the emergence of the sea bottom above sea level, where it stood for a long time. The unconformity between the Upper Cretaceous and the overlying Tertiary deposits is great wherever it has been actually studied-in fact, it is the greatest unconformity known in that part of the world.

\section{OLIGOCENE.}

Most of the Oligocene deposits of the Dominican Republic are of middle Oligocene age. They occur on both the north and the south side of the Cordillera Central and in the Sierra Septentrional. The deposits in the different districts that are sufficiently fossiliferous to warrant the expression of an opinion regarding their age seem to be stratigraphically equivalent and to be of about the same age as the Antigua formation of Antigua. Equivalent deposits also occur in Saint Croix, where Vaughan collected Lepidocyclina morgani Lem. and R. Douv., Carpenteria americana Cushman, Astrocoenia decaturensis Vaughan, Goniastrea reussi (Duncan), Cyathomorpha tenuis (Duncan), Diploastrea crassolamellata (Duncan), and Goniopora microscopica (Duncan). Deposits of middle Oligocene age are found also in Porto Rico, Cuba, southwestern Georgia, eastern Mexico, and Panama, and probably in Trinidad. The European equivalent of this horizon seems to be the Rupelian Oligocene.

The recognition of middle Oligocene in the Dominican Republic is based primarily upon Foraminifera and corals. The mollusean fauna can not be confused with the later faunas, and it indicates that the middle Oligocene Mollusca of the Dominican Republic form a local faunule that bears little relation to the known faunules of similar age in other West Indian islands. Two small faunules from Rio Yaque del Sur near Los Bancos (stations 8565 and 8619) are apparently of middle Oligocene age. The determination of these two faunules as middle Oligocene is based not so much on their similarity to known middle Oligocene faunules as on their dissimilarity to the Miocene faunules collected on the south side. The small collection of plants from station 8564 is of middle Oligocene age if the age of the Mollusca from station 8565 has been correctly determined. Until now no lower Oligocene marine sediments have been certainly recognized in the West Indies, perhaps because of emergence above sea level or because some of the sediments now classified as middle Oligocene should be referred to the lower Oligocene; or lower Oligocene deposits may be there but have not yet been found. The Tabera formation, according to Cooke (p. 61, this volume), is thick, and the middle Oligocene fossils were found in its upper part. Its lower part may be lower Oligocene. On the south side of the Republic a period of erosion appears to have intervened between Eocene and Oligocene deposition. 
The upper Oligocene deposits consist of the Cevicos limestone, which is found in the Cibao Valley, and limestone on Monte Calavosa and near San Cristobal, on the south side. The faunas are meager and the correlation is uncertain, but if it is correct deposits of the same age occur in the islands of Anguilla, Porto Rico (according to Maury), and Cuba, and in Florida, Panama, and Trinidad. These deposits are tentatively correlated with the Chattian-Aquitanian of southern Europe. Doctor Cooke (see p. 63) has noted the uncertainty as to whether these deposits should be classified as uppermost Oligocene or basal Miocene.

\section{MIOCENE.}

YAQUE GROUP, NORTH SIDE.

Baitoa Formation.

Only the corals and mollusks and one bryozoan of the Baitoa formation have been identified. One species of coral, Goniopora sp., appears to be the same as that found in the Chipola marl of Florida. The bryozoan Cupularia denticulata Defr. ranges stratigraphically from the Chipola marl to Recent in America. The most abundant fossils are Mollusca. The most conspicuous faunal break in the Tertiary system of the Dominican Republic indicated by the Mollusca is that between the upper Oligocene and the Baitoa formation. The fauna of the Baitoa formation closely resembles the succeeding Miocene faunas. Only two of the Baitoa superspecific groups, the genera Orthaulax and Cymia, are not known in the later Miocene faunas of the valley of Rio Yaque del Norte. The curious stromboid genus Orthaulax, which is represented by the genotype $O$. inornatus Gabb, has been considered a typical Oligocene genus; but the faunal assemblage of the Baitoa formation clearly indicates its Miocene (Burdigalian) age. Phos semicostatus Gabb is the most characteristic mollusk of the formation. The horizon of the Baitoa formation, which has not been found elsewhere in the West Indies, is correlated with that of the Chipola marl of Florida.

Cooke ${ }^{1}$ has recently discussed the stratigraphic significance of Orthaulax. In the D Jminican Republic this genus, according to present information, appears to range from upper Oligocene to middle Miocene. In contending that the Quebradillas limestone of Porto Rico is upper Oligocene because it contains Orthaulax in abundance, Hubbard ${ }^{2}$ is expressing an opinion once held, but unwarranted, that this genus is restrieted to the Oligocene. Doctor Maury ${ }^{3}$ has, however, referred the Quebradillas limestone to the lower Miocene.

\section{Cercado Formation.}

The faunal lists for the Cercado formation embrace all fossils collected in 1919 except the Foraminifera, which have not yet been studied, but lists of Foraminifera obtained by Doctor Maury are included. This formation

1 Cooke, C. W., Abstract, Geol. Soc. America Bull, vol. 31, p. 206, 1920.

2 Hubbard, Bela., Science, new ser., vol. 51, p. 396, 1920.

Maury, C. J., Am. Jour. Sci., vol. 48, p. 212, 1919. 
is of old Miocene age. The coral fauna comprises about 19 species, only about four of which, Placocyathus n. sp. b, Stylophora n. sp. with a commensal worm, Thysanus corbicula Duncan, and Porites n. sp. with a commensal worm, seem to be confined to the formation; most if not all the other species range upward into the Gurabo formation, and at least two species, Solenastrea bournoni M. Edw. and H. and Siderastrea siderea (Ell. and Sol.), have persisted until Recent time. The most abundant organisms are Mollusca, of which about 500 species have been recognized. The characteristic species are Conus cercadensis Maury, Cancellaria (Aphera) islacolonis Maury, Arca (Scapharca) corcupidonis Maury, Arca (Scapharca) arthurpennelli Maury, Pecten (Aequipecten) n. sp. a, Cardium (Trachycardium) dominicanum Dall, and Corbula (Bothrocorbula) viminea Guppy. The largest faunule, 260 species, was collected on Rio Mao at station 8525, which is Doctor Maury's "bluff 3."' The faunule on Rio Albano (station 8729) is remarkably like the faunule at station 8525, though the two localities are far apart geographically. The Cercado faunule on Rio Cana (station 8534) is characterized by the substitution of peculiar specific stocks for many species that are conspicuous at other localities of the Cercado formation.

Because of the apparent specific identity of several species of corals in this formation with species found in the Bowden marl of Jamaica Vaughan correlated it with the Bowden marl, but there is considerable similarity between the corals of the Gurabo formation and those of the Bowden, and this is true of other organisms, so that the Cercado formation is probably a little older than the Bowden. (For fuller discussion see pp. 98-99.)

\section{Modified Cercado Fauna.}

Cercado faunules that are modified by the first appearance of a number of species of mollusks that elsewhere are confined to the overlying Gurabo formation were collected on Rio Mao (station 8522) and on Rio Gurabo (station 8739). These species are Terebra sulcifera Sowerby, Conus haytensis Sowerby, Conus multiliratus Böse subsp. gaza Brown and Pilsbry, "Clavatula" labiata Gabb, Cancellaria guppyi Gabb, Lyria pulchella (Sowerby), ${ }^{2}$ Metulella venusta (Sowerby), Distortio simillima (Sowerby), Pecten (Aequipecten) eugrammatus Dall and Echinochama antiquata Maury not Dall. All these species are abundant at one or more localities of the Gurabo formation and, moreover, the above list includes six superspecific groups that are not known in the typical Cercado fauna.

According to Doctor Maury's faunal lists her expedition collected a similarly modified Cercado faunule from "Zone G," Rio Gurabo. ${ }^{3}$ The faunule of "Zone G" includes four species that are found in the Gurabo

\footnotetext{
${ }^{1}$ Maury, C. J., Bull. Am. Paleontology, vol. 5, p. 425, 1917.

2 This species is reported by Maury from the Cercado formation at "Bluff 3," Rio Mao (= station 8525 ).

3 Maury, C. J., Bull. Am. Paleontology, vol. 5, pp. 439-440, 1917.
} 
formation but not in the typical Cercado formation-Conus consobrinus Sowerby, Conus marginatus Sowerby, Fasciolaria semistriata Sowerby, and Metulella venusta (Sowerby).

Gurabo Formation.

The faunal lists for the Gurabo formation are incomplete, as the Foraminifera obtained in it have not been identified; the fauna here recorded consists mostly of corals and mollusks. One of the striking peculiarities of the formation is the relatively rich coral fauna, comprising between 70 and 80 species, a considerable number of which, particularly in its upper part, are of reef facies. Although several species also occur in the underlying Cercado formation and others range upward into the overlying Mao Adentro limestone, the assemblage differs from that of each of the adjacent formations and some species appear to be confined to it, for example, Asterosmilia abnormalis (Duncan), A. exarata Duncan, A. profunda (Duncan), A. hilli Vaughan, Teleiophyllia grandis Duncan, and Syzygophyllia dentata (Duncan). Several of the species occur in the Cercado formation and in the lower part of the Gurabo; others occur in the upper part of the Gurabo and in the Mao Adentro limestone. It is therefore possible to tell the part of the formation from which a fairly large collection of well-preserved corals came.

About 400 species of Mollusca have been recognized in the Gurabo formation, and almost half of these species are not known in the typical Cercado formation. The most abundant species that do not occur in the typical Cercado formation are Terebra sulcifera Sowerby, Conus haytensis Sowerby, Conus symmetricus Sowerby and subsp. domingensis Sowerby, "Clavatula" labiata Gabb, "Drillia" venusta (Sowerby), Lyria pulchella (Sowerby), Murex domingensis Sowerby, Metulella venusta (Sowerby), Distortio simillima (Sowerby), Sconsia laevigata (Sowerby), Morum domingense (Sowerby), Crepaticella capula Guppy, Pecten (Aequipecten) eugrammatus Dall, Echinochama antiquata Maury not Dall, and Cytherea (Tentricola) blandiana (Guppy). The largest shoal-water faunules were collected on Rio Mao at stations 8519 (Maury's Bluff 1) and 8734, and on Rio Ámina (station 8516). The large collection from Rio Yaque del Norte (station 8702) includes several groups, such as Leucosyrinx, Pleurotomella, Caricella, and Terticordia (Trigonulina), that indicate deeper water. Several species of Mollusea are confined to certain horizons within the Gurabo formation, so that subdivisions of the formation can be recognized.

The Bowden marl of Jamaica is apparently of about the same age as the Gurabo formation. Woodring has recently completed a monograph on the Mollusca of the Bowden marl, which has been submitted to the Carnegie Institution of Washington for publication. ${ }^{1}$ The Bowden molluscan

1 Vaughan, T. W., Carnegie Institution of Washington Year Book No. 18, p. 345, 1920. 
fauna, consisting of about 600 species from a single locality, is more diversified than the faunas of either the Cercado or Gurabo formations, but is more similar to the Gurabo fauna than to the Cercado. There is no faunal or stratigraphic evidence to sustain Doctor Maury's assumption that the Bowden fauna is stratigraphically a mixed fauna, though it is less homogeneous than either the typical shoal-water Cercado or Gurabo faunas.

The Gurabo corals that occur also in the Bowden marl and in the marls at Baracoa and Matanzas, Cuba, are listed in the following table:

\begin{tabular}{|c|c|c|c|}
\hline Gurabo corals. & Bowden. & Baracoa. & Matanzas. \\
\hline Stylophora granulata Duncan............. & \multirow{3}{*}{$\begin{array}{l}x \\
x\end{array}$} & $x$ & \multirow[t]{2}{*}{$x$} \\
\hline Madracis decactis (Lyman) & & & \\
\hline Madracis mirabilis (Duch. and Micht.)... & & & \multirow[t]{2}{*}{$x$} \\
\hline Asterosmilia profunda (Duncan) ................... & \multirow{5}{*}{$\begin{array}{l}x \\
x \\
x \\
x\end{array}$} & & \\
\hline 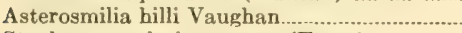 & & & \\
\hline Stephanocoenia intersepta (Esper) & & & \\
\hline Thysanus n. sp. a & & & \\
\hline Agaricia dominicensis Vaughan ........ & & & \multirow{2}{*}{$\stackrel{x}{x}$} \\
\hline Porites baracoaensis Vaughan .......... & $x$ & $x$ & \\
\hline
\end{tabular}

Siderastrea siderea (Ell. and Sol.), which occurs at Bowden, was not collected in the Gurabo, but as it was found in the underlying Cercado formation and in the overlying Mao Adentro limestone the failure to obtain it in the Gurabo was probably accidental. Another Bowden species, Placocyathus barretti Duncan, was collected by Doctor Maury's party in the Samba Hills at an altitude of about 540 feet (station 7787), and Mr. Condit collected on Rio Yaque del Norte at station 8702 a specimen that is referred to in the list (p. 147) as Placocyathus barretti Duncan var., but this may be a varietal form of $P$. variabilis Duncan. The number of species now known from the Bowden marl is $17,{ }^{2}$ and 9 of these occur in or range through the Gurabo formation. A species of Goniopora at Bowden is very close to G. jacobiana Vaughan, which occurs in the Gurabo and in the Mao Adentro. Another Bowden species, Antillia walli Duncan, was collected on the south side, a mile north of Azua (station 8609).

The correlation by Vaughan of the La Cruz marl of Cuba with the Gurabo formation appears to be correct, as every species identified in it except Thysanus excentricus Duncan, a Bowden species, is found also in the Gurabo formation, but the La Cruz marl may be the equivalent of the Mao Adentro limestone. It now seems that the faunal differences between the marls at Baracoa and Matanzas, Cuba, and the La Cruz marl at Santiago, Cuba, may be due to difference in ecologic conditions rather than to difference in age, the marl at Baracoa and Matanzas and that at Bowden having been deposited in somewhat deeper water than that in which the La Cruz marl and most of the Gurabo formation were deposited. 
Deposits of nearly the same age as the Gurabo formation are known in Costa Rica, Panama, Colombia, and other parts of northern South America, and probably in Trinidad and Martinique.

An attempt to correlate the Cercado and Gurabo formations with the Miocene deposits of the southeastern United States involves difficulties because of differences in faunal facies due to differences in climate. The Alum Bluff formation of Florida, comprising, in ascending order, the Chipola marl, Oak Grove sand, and Shoal River marl members, is considered Burdigalian in age. Of these three stratigraphic units the Chipola marl was deposited under climatic conditions that most closely appr ached the conditions in the West Indies, although the fauna of the Chipola marl is very warm temperate to subtropical and not tropical. The faunas of the Oak Grove sand and Shoal River marl have a cooler water facies. The Baitoa formation of the Dominican Republic appears to be the correlative of the Chipola marl. In Florida the only subtropical fauna that is younger than the Chipola is the Pliocene Caloosahatchee fauna. In many respects the molluscan faunas of the Cercado and Gurabo formations, as well as that of the Bowden marl, are more similar to the Caloosahatchee fauna than to the Chipola or other Alum Bluff faunas. In 1917 Woodring ${ }^{1}$ stated that the Bowden marl is distinctly younger than the Alum Bluff formation, and as the Alum Bluff formation was then considered upper Oligocene he suggested that the Bowden marl was Burdigalian, but the Gurabo formation, like the Bowden marl, is doubtless younger than the Alum Bluff formation, and is probably the equivalent of part of the Chesapeake group, so that in European terminology it is of Helvetian age.

The correlation suggested in the foregoing paragraph differs from that of Vaughan published in 1918 and $1919^{2}$ in that the Gurabo formation and its correlatives are now regarded as one stage younger and the lower three formations of the Chesapeake group as one stage older, or as the equivalent of the European Helvetian. This opinion is a return to that of Dall ${ }^{3}$ as against that of Berry "that the Calvert flora indicates a Tortonian age is as conclusive as intercontinental correlations ever can be." ${ }^{4}$ The table on page 57 is adjusted to these modifications in correlation, but as the correlations are still tentative readjustments may yet be made.

\section{Mao Adentro Limestone.}

Only the corals and mollusks of the Mao Adentro limestone have been identified, but the collections include a few calcareous algae and a considerable number of Foraminifera. The corals represent a reef-coral

\footnotetext{
1 Woodring, W. P., Johns Hopkins University Circular, March, 1917, p. 254, 1917.

2 U. S. Nat. Mus. Bull. 103, pp. 514-516, 586-593, tables opposite p. 569, 595, 1919.

- Dall, WV. H., The relations of the Miocene of Maryland to that of other regions and to the Recent fauna: Maryland Geol. Survey, Miocene, p. cxliii, 1904.

- Berry, E. W. The physical conditions indicated by the flora of the Calvert formation: U. S. Geol. Survey Prof. Paper 98, p. 66, 1916.
} 
fauna and in places constituted reefs. The type locality of the formation is at stations 8532 and 8533, opposite Mao Adentro, on Rio Mao, where 18 species of corals were collected. Station 8531 is on the same river farther downstream. The stratigraphic relations of these exposures to the Gurabo formation are entirely clear. The total number of species of corals collected at the two localities is 26. The exposure at station 8663, on Arroyo las Lavas, is correlated with the Mao Adentro limestone because of faunal similarity, as about 14 out of 18 species (about 80 per cent) of the corals collected at the type locality of the formation occur also at station 8663 . However, the total number of species obtained at station 8663 is about 34 . A comparison of the list of species of the Mao Adentro limestone with that of the Gurabo formation shows that the faunas of the two formations have many species in common; in fact there is very little difference between the fauna of the upper part of the Gurabo and that of the Mao Adentro. The strata exposed at stations 8556 and 8735 , bluffs $U$ and W on Rio Gurabo, might, according to the fossils, be referred with almost equal propriety to either of the formations.

The molluscan fauna of most coral reefs is meager, and it is therefore not surprising that only 19 species were collected from the Mao Adentro limestone. Most of these were collected at Arroyo las Lavas (station 8663). All the species determined except one, which is confined to this horizon, occur also in the Gurabo formation. Although most of these species have been found in the upper part of the Gurabo formation, Conocerithium gurabense (Maury), the most abundant species at station 8663, occurs in the lower part of the Gurabo formation at stations 8715 and 8519.

As the Mao Adentro limestone is faunally so similar to the Gurabo formation it should probably be considered middle Miocene, slightly younger than the Gurabo.

\section{Mao Clay.}

The fauna of the Mao clay is very meager. It includes one species of coral and nine species of Mollusca. Only one of the determinable species of Mollusca is confined to this horizon. All the other species occur in the Gurabo formation, and one of them, Cancellaria (Bivetia) epistomifera Guppy, is also found in the Cercado formation. There is no evident faunal basis for recognizing the Mao clay as a separate formation. The reason for assigning a distinctive name to it is given on page 75 .

\section{Monte Cristi District.}

As it is not practicable to apply with certainty the formation names used east of Rio Cana to the deposits examined by Mr. Ross in the vicinity of Monte Cristi the collections made near that town are listed separately from those made from the Miocene formations of the north side of the Republic. (See pp. 153-154.) The exposure at station 8780 represents a horizon 
either near the top of the Gurabo formation or the Mao Adentro limestone. The collection from station 8783 (El Morro de Monte Cristi, altitude 153 meters) represents the Gurabo formation, and that from station 8774 (altitude 155 meters) probably belongs to the same formation. These determinations essentially corroborate the opinion of Doctor Maury regarding the age of these beds. ${ }^{1} \quad$ The collections from stations 8777 and 8778 are apparently from a horizon high in the Yaque group, for they include Arca (Scapharca) patricia Sowerby, which was collected by the Maury expedition $^{2}$ on Rio Cana from beds in the upper part of the Gurabo formation or above the Gurabo formation. This species was not collected by the expedition of 1919 on the south side of the valley of Rio Yaque del Norte.

YAQUE GROUP, SOUTH SIDE.

Although the fossils collected from the Yaque group on the south side of the Republic are numerous and comprise more than 50 species of corals, about 120 species of mollusks, and many other organisms, including abundant unidentified Foraminifera, they afford no adequate basis for precise correlation of the formations of the south side with those of the valley of Rio Yaque del Norte. This is due to lack of precision in the data on the stratigraphic relations of the beds from which the collections were made and to apparent mixtures of faunas of different ages at some of the localities. One locality that appears to be the correlative of the upper part of the Gurabo formation is station 8622, where at least 9 out of 14 species of corals seem to be common to the Gurabo. At station 8621, however, which according to the field notes is stratigraphically higher than station 8622 , the Mollusca indicate that the horizon is that of the Cercado formation.

The collections from stations 8572,8590 , and 8760 include a species of Orthaulax that, according to Doctor Cooke, is Orthaulax aguadillensis Maury, which is found also in the upper Oligocene Cevicos limestone of the Cibao Valley and in the Aguadilla limestone of Porto Rico. The collections from stations 8572 and 8590 probably represent more than one horizon. The Mollusca collected at stations 8570 and 8760 , apparently from a single horizon, indicate that the south side Orthaulax horizon occupies a position between the Baitoa formation and the Cereado formation or even higher. Aside from Orthaulax this horizon is characterized by a new species of Scapharca that closely resembles Arca (Scapharca) patricia Sowerby. In the valley of Rio Yaque del Norte A. patricia is apparently confined to a horizon in the upper part of the Yaque group.

Perhaps some beds at other localities may be correlated with some on the north side after the collections have been more critically studicd, but as the collections can not be referred to their precise positions in the stratigraphic

1 Maury, C. J., Bull. Am. Paleontology, vol. 5, p. 450, 1917

${ }^{2} \mathrm{Idem}, \mathrm{p} .441$. 
sections and as some of them represent mixed faunas adequate stratigraphic knowledge of the Yaque group in the southwest part of the Republic can be obtained only through additional field work. It seems, however, that the principal formations of the Cibao Valley are represented by contemporaneous deposits on the south side.

\section{CERROS DE SAL FORMATION.}

Only corals and mollusks are listed from the Cerros de Sal formation. The corals do not indicate the precise position of the formation in the Miocene series, but the mollusks may afford ground for a more definite opinion. The molluscan faunules at the four localities at which collections were made have only a few species in common and most of these species are pelecypods. The collection from station 8591 is remarkable for the large proportion of pelecypods, which outnumber the gastropods by 100 per cent. The fauna is evidently younger than any of the faunas of the Yaque group on both the north and south sides of the island, for it includes a larger number of Recent species or Recent specific stocks, especially among the pelecypods.

The formation can not yet be definitely correlated with European divisions, but if the correlations suggested for the older subdivisions of the Dominican Miocene are correct it should be Tortonian or younger, perhaps Sarmatian or Pontian.

\section{MIOCENE OR PLIOCENE IN DISTRICT OF SAMANÁ.}

The plants and fresh or brackish water Mollusca collected at Sánchez (stations $8607,8764,8684$, and 8685) include the largest collection of fossil plants made during the reconnaissance. The stratigraphic significance of these plants is not yet known, but the beds in which they were found are greatly deformed, so that considerable earth movement has occurred since their deposition.

\section{PLEISTOCENE OR YOUNGER.}

Nearly all the Pleistocene or later corals and mollusks listed on pages 166-168 are now living in West Indian waters, and the few species that seem to be new may yet be found there. The close of Pleistocene time in North America, according to geologic opınion, was marked by the retreat of the last Wisconsin ice cap, between 10,000 and 30,000 years ago, but as the tropies were not directly affected by glaciation it is not always possible to distinguish between tropical Pleistocene and Recent deposits, for at least the marine faunas of the two epochs are almost identical. The reference of a marine deposit within the tropics to the Pleistocene must therefore depend upon indirect evidence derived from a study of geologic history, and as the geology of the Dominican Republic has been studied merely in a reconnaisance way only rather general statements as to the deposits of these ages are now warranted. Along much of the southern lowland of the Republic Miocene limestone is overlain by coralliferous limestone containing 
remains of species of corals that are still living. By referring to page 82 it will be seen that this coralliferous limestone is crossed by streams whose lower stretehes have been slightly submerged and that there may have been slight emergence after the submergence. These events indicate a considerable lapse of time after the limestone was formed and would appear to justify its reference to the Pleistocene series.

Other possible evidence of the age of this limestone may also be considered. Most geologists who have studied the subject hold that during the existence of the continental ice caps the sea level was lowered in the tropics because so much water was locked up in the glaciers. After the glaciers melted the sea level was raised by the return of the water to the ocean. It is therefore at least probable that the drowning of the mouths of the valleys that cross the limestone containing species still living was due to water returned to the ocean by the melting of the Wisconsin ice sheet. The limestone may therefore be of Pleistocene age. ${ }^{1}$

The considerations thus presented apply particularly to the elevated coral-reef limestone of the District of Macorís and the Province of Santo Domingo. Parts of the "coast limestone" may be later than Pleistocene. (For a discussion of the phenomena around Enriquillo Basin see page 77.)

\section{EXTINCT MAMMALS OF THE DOMINICAN REPUBLIC.}

No mammalian remains were collected during the geologic reconnaissance but as such remains have a bearing on the geologic history of the West Indies it may be noted that G. S. Miller, Jr., has recorded ${ }^{2}$ the rodents Isolobodon portoricensis Allen, Plagiodontia aedium F. Cuvier, and Brotomys voratus Miller, from collections made in kitchen middens at San Pedro de Macorís by Dr. Theodor de Booy and at San Lorenzo by Dr. W. L. Abbott. The geologic significance of these animals becomes obvious when they are considered in connection with the faunas of Cuba, Porto Rico, and other West Indian islands. Miller says, regarding the West Indian hystricine rodents:

They suggest direct descent from such a part of a general South American fauna, probably not less ancient than that of the Miocene, as might have been isolated by a splitting off of the Archipelago from the mainland. Of later influence from the continent there is no trace.

In subsequent field work in the Republic it is highly important that Indian dwelling sites and caves should be thoroughly explored for vertebrate remains in order to increase our knowledge of the extinct mammals.

\footnotetext{
1 For $a$ discussion of West Indian shore-line features, see Vaughan, T. W., Fossil corals from Central America, Cuba, and Porto Rico, with an account of the American Tertiary, Pleistocene, and Recent coral reefs: U. S. Nat. Mus. Bull. 103, pp. 189-524, pls. 68-152, 1919, especially pp. 263-306.

2 Bones of mammals from Indian sites in Cuba and Santo Domingo: Smithsonian Misc. Coll., vol. 66. No. 12 , pp. 10, 1 pl., 1916.
} 


\section{LISTS OF LOCALITIES AND FOSSILS. EOCENE.}

List of stations on north side.

8705 (D. C. 35). Province of Puerto Plata, along railroad above Altamira, north slope. Specimens from limestone in conglomerate boulders. D. D. Condit, collector. April $22,1919$.

8707 (D. C. 36). Province of Puerto Plata, 0.8 kilometer south of Sabana de Pérez, along the railroad from Puerto Plata to Altamira. D. D. Condit, collector. April 22, 1919.

8708 (D. C. 38). Province of Puerto Plata, Las Lajas, sandstone in contact with basal complex. D. D. Condit, collector. April 22, 1919.

8711 (D. C. 40). Province of Puerto Plata, 0.8 kilometer southeast of Altamira. D. D. Condit, collector. April 23, 1919.

8721. Province of Santiago, southern foot of Monte Cristi Range, north side of Damajagua. Limestone float. T. W. Vaughan, collector. April 29, 1919.

8722 (D. C. 48). Province of Santiago, head of Yaroa Creek. D. D. Condit, collector. April 26, 1919.

8725 (D. C. 51). Province of Santiago, between Damajagua, a camp at base of mountains nor th of Esperanza, and the southern foot of the Monte Cristi Range. T. W. Vaughan and D. D. Condit, collectors. April 29, 1919.

8725a. Same locality as 8725 .

Faunal list.

\begin{tabular}{l} 
Species. \\
\hline
\end{tabular}

${ }_{1}^{1}$ Throughout the faunal lists undetermined species of a genus are listed together on the same line in the ocality columns, although the species at those localities may not be identical. 


\section{List of stations on south side.}

8614. Province oí Santo Domingo, road from Bani to San Cristobal about 0.8 kilometer east of Cruz de los dos Caminos and about 5.2 kilometers east of Bani. C. WV. Cooke and D. D. Condit, ccllectors. June 10, 1919.

8562 (D. C. 75). Province of Azua, Folaminileral limestone flom gravels on the Bánica-Ias Matas road at half-way point. D. D. Condit, collector. May 17, 1919. 8608 (C. 84). Prcvince of Azua, rubble cn roadside north of Arrcyo Salado near Higuero Largo; road from Túbano to Las Yayas, altitude 495 meters above sea level. C. W. Cooke, collector. May 26, 1919 .

8644. Province of Azua. Lcose rubble from Higuerito, Azua oil fields. D. D. Condit, collector. 1919.

8595 (D. C. 94). Province of Barahona, Foraminiferal limestone from point on mountain slope 2.5 kilometers north of Barbacoa, altitude about 180 meters; none of the material was in place. D. D. Condit, collectcr. May 29, 1919.

8626 (R. 57). Province of Barahona. Limestone pebbles with Foraminifera from point near Rancho Viejo; traverse of June 3, 1919, Sierra de Bahoruco. C. P. Ross, collector.

8627 (R. 58). Province of Barahona, Foraminiferal limestone, traverse of June 3, 1919, Sierra de Bahoruco, west slope of Cañada de Rancho Viejo. C. P. Ross, collector.

8576 (D. C. 97). Province of Barahona, rubble from near sea beach south side of Rio Caña and about 8.5 kilometers south of Barahona. D. D. Condit, collector. June 4, 1919.

Faunal list.

\begin{tabular}{|c|c|c|c|c|c|c|c|c|}
\hline \multirow{3}{*}{ Species. } & \multicolumn{8}{|c|}{ Stations. } \\
\hline & $\begin{array}{c}\text { Prov. } \\
\text { Santo } \\
\text { Do- }\end{array}$ & \multicolumn{3}{|c|}{$\begin{array}{l}\text { Prov. } \\
\text { Azua. }\end{array}$} & \multicolumn{4}{|c|}{$\begin{array}{l}\text { Prov. } \\
\text { Barabona. }\end{array}$} \\
\hline & 8614 & 8562 & 8608 & 8614 & 8595 & 8626 & 8627 & 8576 \\
\hline \multicolumn{9}{|l|}{$\begin{array}{l}\text { Foraminifera: } \\
\text { Textularia sp. cf. T. agglutinans } \\
\text { d'Orbigny..................... }\end{array}$} \\
\hline \multicolumn{9}{|l|}{ Textularia sp. (coarse species) } \\
\hline \multicolumn{9}{|l|}{ 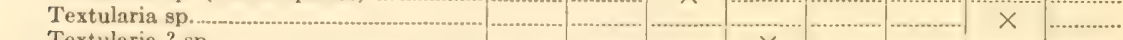 } \\
\hline \multirow{2}{*}{\multicolumn{9}{|c|}{$\begin{array}{l}\text { Textularia ? sp. } \\
\text { Globigerina sp. (large species) }\end{array}$}} \\
\hline & & & & & & & & $\times$ \\
\hline \multicolumn{9}{|l|}{ Conulites americana Cushman } \\
\hline \multirow{2}{*}{\multicolumn{9}{|c|}{ 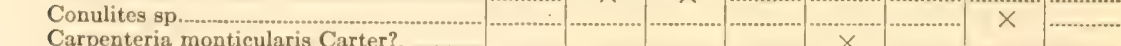 }} \\
\hline Carpenteria monticularis Carter? & & & & & $\times$ & & & \\
\hline \multicolumn{9}{|l|}{ Nummulites sp. (large species) } \\
\hline 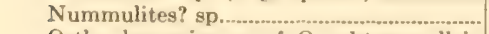 & & $x$ & & $x$ & $\times$ & $\times$ & & \\
\hline \multicolumn{9}{|l|}{$\begin{array}{l}\text { Orthophragmina sp. cf. O. subtaramellei } \\
\text { Cumbman. }\end{array}$} \\
\hline \multirow{2}{*}{\multicolumn{9}{|c|}{$\begin{array}{l}\text { Orthophragmina sp. (stellate species)........ } \\
\text { Lepidocyclina antillea Cushman }\end{array}$}} \\
\hline \multirow{2}{*}{\multicolumn{9}{|c|}{$\begin{array}{l}\text { Lepidocyclina sp. cf. L. antillea Cush- } \\
\text { man }\end{array}$}} \\
\hline & & & & & & & & \\
\hline Lepidocyclina subraulinii Cushman.............. & $x$ & 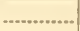 & & & $x$ & $x$ & $\ldots . .$. & .............. \\
\hline \multicolumn{9}{|l|}{$\begin{array}{l}\text { Lepidocyclina sp. ef. L. subraulinii } \\
\text { Cushman }\end{array}$} \\
\hline \multirow{2}{*}{\multicolumn{9}{|c|}{$\begin{array}{l}\text { Lepidocyclina perundosa Cushman } \\
\text { Lepidocyclina sp. cf. L. duplicata Cush- }\end{array}$}} \\
\hline & & & & & & & & \\
\hline \multicolumn{9}{|l|}{ Operculina? sp. } \\
\hline \multicolumn{9}{|l|}{ 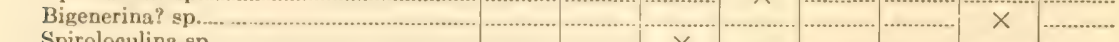 } \\
\hline \multicolumn{9}{|l|}{ 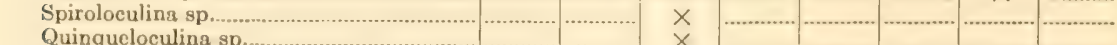 } \\
\hline Quinqueloculina sp......... & & & $x$ & & & & & \\
\hline \multicolumn{9}{|l|}{ 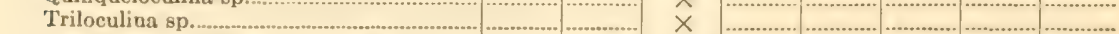 } \\
\hline $\begin{array}{l}\text { Gen.? and sp. ? (same as species from } \\
\text { upper Eocene of Cuba).......................... }\end{array}$ & & & & & & & & $\times$ \\
\hline & & & & & & & & \\
\hline
\end{tabular}


MIDDLE OLIGOCENE.

List of stations on north side.

8669 (D. C. 24). Province of La Vega, Tabera, on Rio Yaque del Norte, about 0.5 kilometer southwest of the village; fossils from conglomerate. D. D. Condit, collector. April 17, 1919.

8671 (D. C. 26). Province of La Vega; fossils in limestone on trail from Tabera to Cañon of Rio Yaque del Norte. D. D. Condit, collector. April 18, 1919.

8713 (D. C. 42). Province of Santiago, El Limon; trail from Altamira to Santiago; specimens from limestone ledge above valley to southwest. D. D. Condit, collector. April 23, 1919.

8672 (D. C. 27). Province of Santiago, Baitoa, on Rio Yaque del Norte; fossils from conglomerate. D. D. Condit, collector. April 18, 1919.

8557 (C. 63). Province of Santiago, bluff on right bank of Rio Yaque del Norte below Baitoa; fossils from gray conglomerate and sandstone, steeply tilted, in lower part of bluff. C. W. Cooke, collector. May 14, 1919.

8719 (D. C. 47 A). Province of Santiago, Yaroa village, about 17 kilometers north of

Peña. D. D. Condit, collector. April 26, 1919.

8673 (D. C. 30). Province of Santiago, on Rio Yaque del Norte from Baitoa down to mouth of Rio Bao; from blue shales. D. D. Condit, collector. April 19, 1919.

8740 (D. C. 49). Province of Santiago, Los Cacaos, north of Peña, near head Rio Licey. D. D. Condit, collector. April 26, 1919.

8741. Province of Santiago, near Tabera, exact locality unknown; probably from Oligocene limestone on Rio Yaque del Norte. D. D. Condit, collector. 1919.

8704 (D. C. 34). Province of Santiago, from shale below principal limestone series on Las Lavas Creek above Las Lagunas on Altamira trail. D. D. Condit, collector. April 21, 1919.

Faunal list.

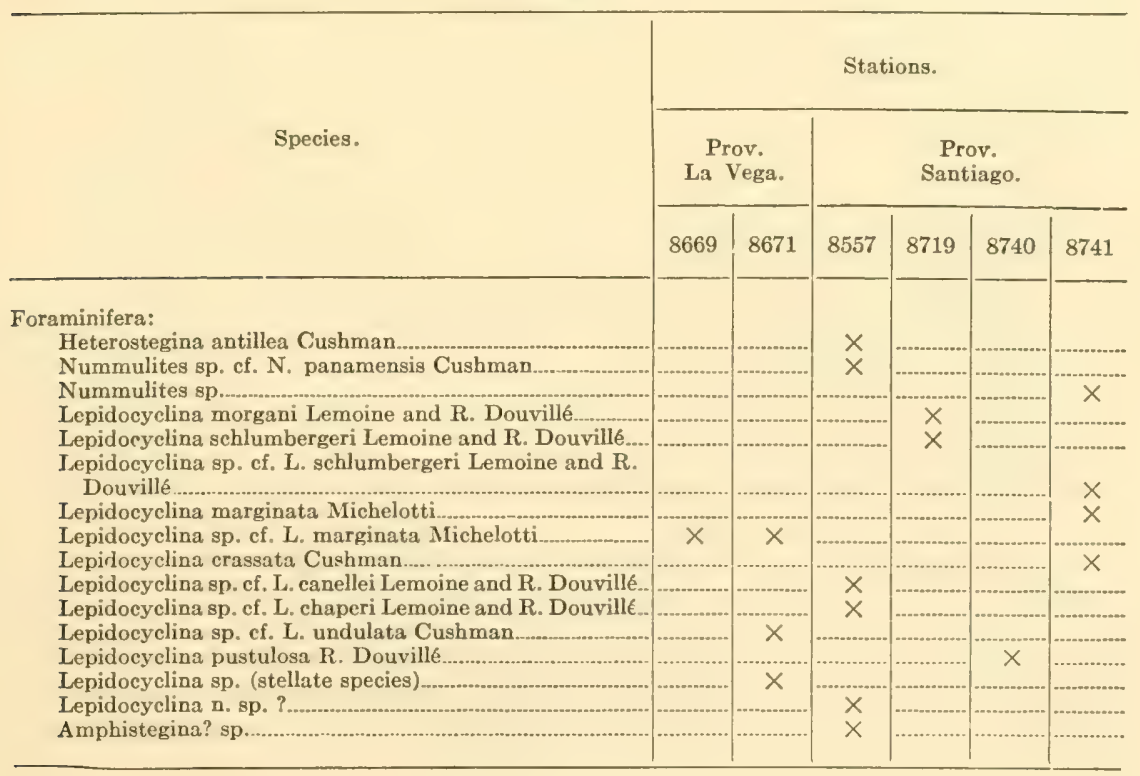


Faunal list-Continued.

\begin{tabular}{|c|c|c|c|c|c|c|c|}
\hline \multirow{3}{*}{ Species. } & \multicolumn{7}{|c|}{ Stations. } \\
\hline & \multicolumn{2}{|c|}{$\begin{array}{l}\text { Prov. } \\
\text { La Vega. }\end{array}$} & \multicolumn{5}{|c|}{$\begin{array}{l}\text { Prov, Santiago, } \\
\text { Rio Yaque del Norte. }\end{array}$} \\
\hline & 8669 & 8713 & 8672 & 8557 & 8673 & 8741 & 8704 \\
\hline \multicolumn{8}{|l|}{$\begin{array}{l}\text { Corals: } \\
\text { Pocillopora n. sp. } \\
\text { Stylophora n. sp. (cf. an unpublished species }\end{array}$} \\
\hline $\begin{array}{l}\text { Stylophora n. sp. (cf. an unpublished species } \\
\text { from Anguilla) }\end{array}$ & & & & \multirow{3}{*}{$\begin{array}{l}x \\
x\end{array}$} & & & \\
\hline Stylophora $\mathrm{n} . \mathrm{sp}$ & & & ......... & & ..... & & ........ \\
\hline Astrocoenia decaturensis Vaughan & & \multirow[t]{2}{*}{$x$} & & & & \multirow{4}{*}{$\begin{array}{l}x \\
x\end{array}$} & \\
\hline Astrocoenia sp. & ......... & & .......... & \multirow{4}{*}{$\stackrel{\times}{\times}$} & ............ & & ........... \\
\hline Antiguastrea cellulosa (Duncan) & & ............... & ........... & & ........... & & ............. \\
\hline Orbicella sp. aff. $O$. canalis Vaughan & & & & & & & \\
\hline Orbicella insignis (Duncan) & 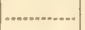 & \multirow[t]{2}{*}{$x$} & & & & & \\
\hline Orbicella sp., probably O. costata (Duncan)......... & .......... & & & \multirow{3}{*}{$x$} & $x$ & & ............ \\
\hline Orbicella sp. & & ................. & & & & & \\
\hline Orbicella? sp & \multirow[t]{2}{*}{$x$} & \multirow{4}{*}{$\begin{array}{l}x \\
\times\end{array}$} & & & & & \\
\hline Orbicellid coral? (perhaps Astreopora) & & & & \multirow{3}{*}{$x$} & \multirow{4}{*}{$\begin{array}{l}\times \\
\times\end{array}$} & \multirow{6}{*}{$\begin{array}{l}x \\
x\end{array}$} & \\
\hline Cyathomorpha tenuis (Duncan) & ............ & & $?$ & & & & \\
\hline Cyathomorpha antiguensis (Duncan) & ............ & & $?$ & & & & $\times$ \\
\hline Cyathomorpha ? sp. ef. C. hilli Vaughan............... & ............. & $\ldots+\cdots$ & 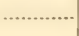 & ......... & & & ............ \\
\hline Psammocora sp & & & & \multirow{5}{*}{$\begin{array}{l}x \\
x \\
x\end{array}$} & ........ & & ........... \\
\hline $\begin{array}{l}\text { Astreopora sp. (near species in Antigua and the } \\
\text { Pepino formation of Porto Rico) }\end{array}$ & & & & & & & \\
\hline Acropora sp. (near an Antiguan species) & ......... & & & & & .... & \\
\hline Actinacis sp. (near an Antiguan species).. & & & & & & \multirow{3}{*}{$x$} & \\
\hline Actinacis? sp. & \multirow[t]{3}{*}{$x$} & …....... & & & & & \\
\hline Goniopora sp. aff. G. microscopica (Duncan) & & \multirow{4}{*}{$\begin{array}{l}\stackrel{x}{x} \\
\times\end{array}$} & & \multirow[t]{2}{*}{$\times$} & & & \\
\hline Goniopora sp. aff, G. regularis (Duncan) & & & & & & & \\
\hline \multirow{2}{*}{$\begin{array}{l}\text { Goniopora sp } \\
\text { Fungioid coral }\end{array}$} & \multirow{2}{*}{$(-\ldots \ldots . . . .}$. & & & & & & \\
\hline & & & & & & ............... & \\
\hline & & & & & & 8557 & 8672 \\
\hline Mollusca: & & & & & & & \\
\hline $\begin{array}{l}\text { Gastropoda: } \\
\text { Conus sp }\end{array}$ & & & & & & & \\
\hline 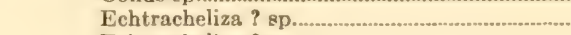 & & & & & & $\hat{x}$ & ........... \\
\hline Echtracheliza ? sp. & & 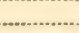 & ............. & 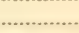 & & $\ddot{x}$ & ............ \\
\hline Strombus sp. & ............... & ................. & ................ & ................ & ........... & $x$ & ........... \\
\hline 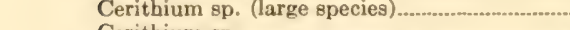 & ................... & ...................... & ............... & 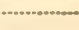 & & $\underset{x}{x}$ & ............ \\
\hline 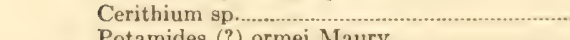 & ............ & .......... & ........... & ....... & & $x$ & …...... \\
\hline $\begin{array}{l}\text { Potamides (?) ormei Maury } \\
\text { Pelecy.......................... }\end{array}$ & & & & & & $\lambda$ & \\
\hline 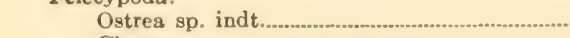 & 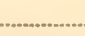 & & & & & $x$ & $x$ \\
\hline 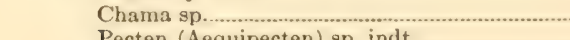 & .................... & ............. & 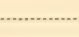 & 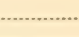 & 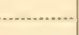 & $x$ & \\
\hline 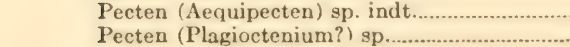 & ...1............. & 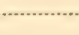 & ……..... & ............ & .......... & $x$ & \\
\hline 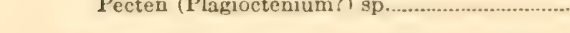 & ............. & & & & & & $x$ \\
\hline
\end{tabular}

List of stations on south side.

8565 (D. C. 77 B). Province of Azua, left bank of Rio San Juan, about 1.7 kilometers west of Los Bancos, fossils from a point about 100 meters higher stratigraphically than those at station 8564 (D. C. 77A). D. D. Condit, collector. May 21, 1919.

8564 (D.C. 77A). Same locality as 8565 , but about 100 meters lower stratigraphically. D. D. Condit, collector. May 22, 1919. 
8567 (D. C. 80). Province of Azua, from limestone along right bank of Rio de las Cuevas, about 2.5 kilometers west of 'Túbano. D. D. Condit, collector. May 22, 1919 . 8617 (R. 41). Province of Azua, Las Cuevas, on Rio San Juan, north of San Juan. C. P. Ross, collector. May 19, 1919.

8618 (R. 42). Province of Azua, from limestone hill at Majagual, on Rio San Juan north of San Juan. C. P. Ross, collector. May 19, 1919.

8619 (R. 43). Province of Azua, from station 5 of traverse of May 22, on Rio Yaque del Sur near Los Bancos. C. P. Ross, collector. May 22, 1919.

Faunal list.

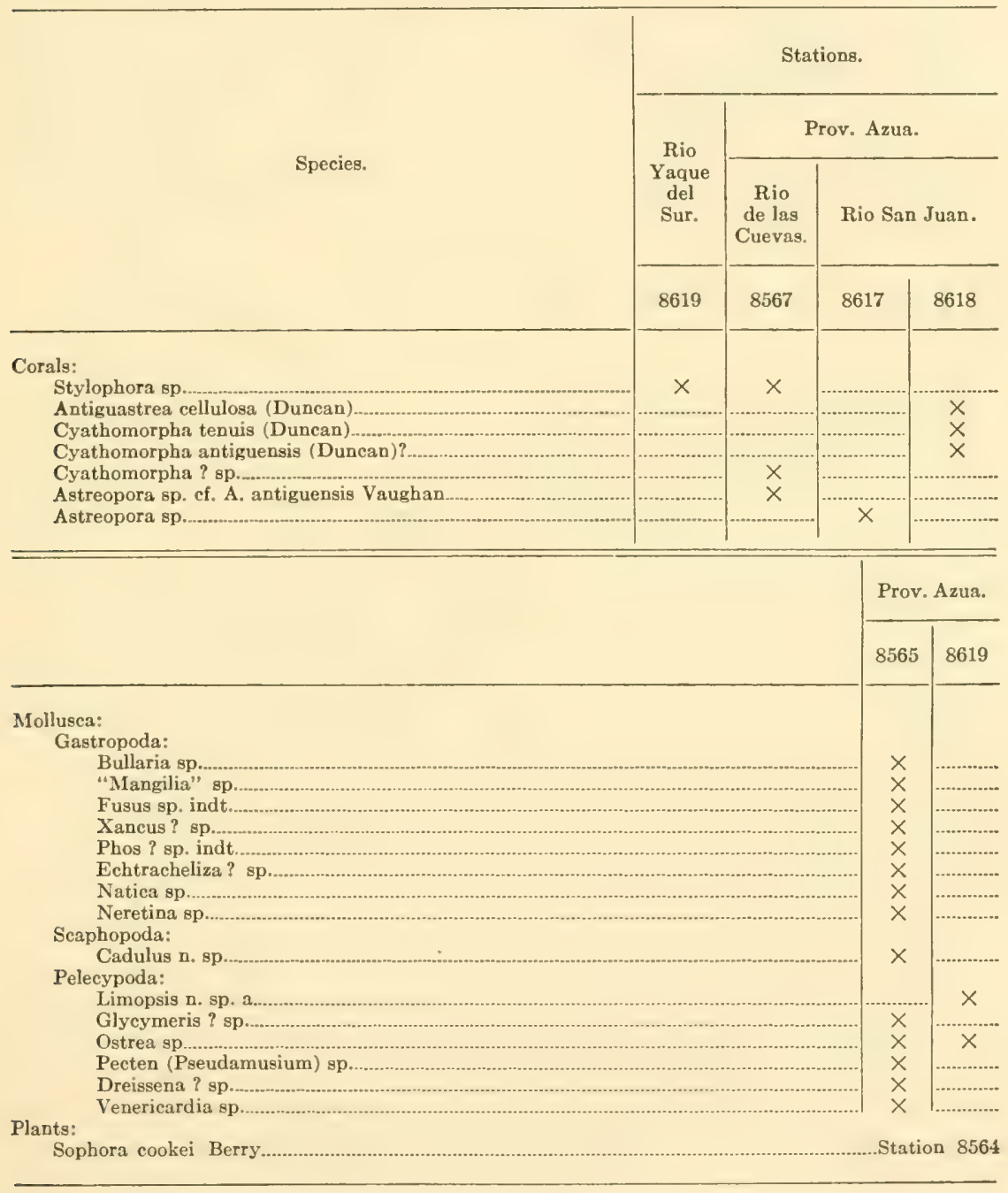


UPPER OLIGOCENE.

List of stations on north side.

8598 (C-8). Province of La Vega, east side of Arroyo Blanco (?), east ci Loma de los Palos, on road from Cotuí to Cevicos. C. W. Cooke and C. P. Ross, collectors. April 21, 1919.

8600 (C-10). Province of La Vega, east of Cevicos, on nor theast side of Arroyo Barranca, on road to Villa Rivas. C. W. Cocke and C. P. Ross, collectors. April 22, 1919.

8601 (C-11). Province of La Vega, Arroyo Jerguen; road from Cevicos to Villa Rivas. C. W. Cooke and C. P. Ross, ccllectors. Apil 22, 1919.

8602 (C-12). Province of La Vega, northeast side of Arroyo Jerguen, about 4.5 meters below top of hill. C. W. Cooke and C. P. Ross, collectors. April 22, 1919.

8603 (C-13). Province of La Vega, at second (?) crossing of Arroyo Barranca on trail from Cevicos to Villa Rivas. C. W. Cocke, collector. April 22, 1919.

8604 (C-14). Province of La Vega, at second (?) crossing of Arroyo Barranca on trail from Cevicos to Villa Rivas, 9-12 meters abcve 8603 (C-13). C. W. Cooke, collector. April 22, 1919.

Faunal list.

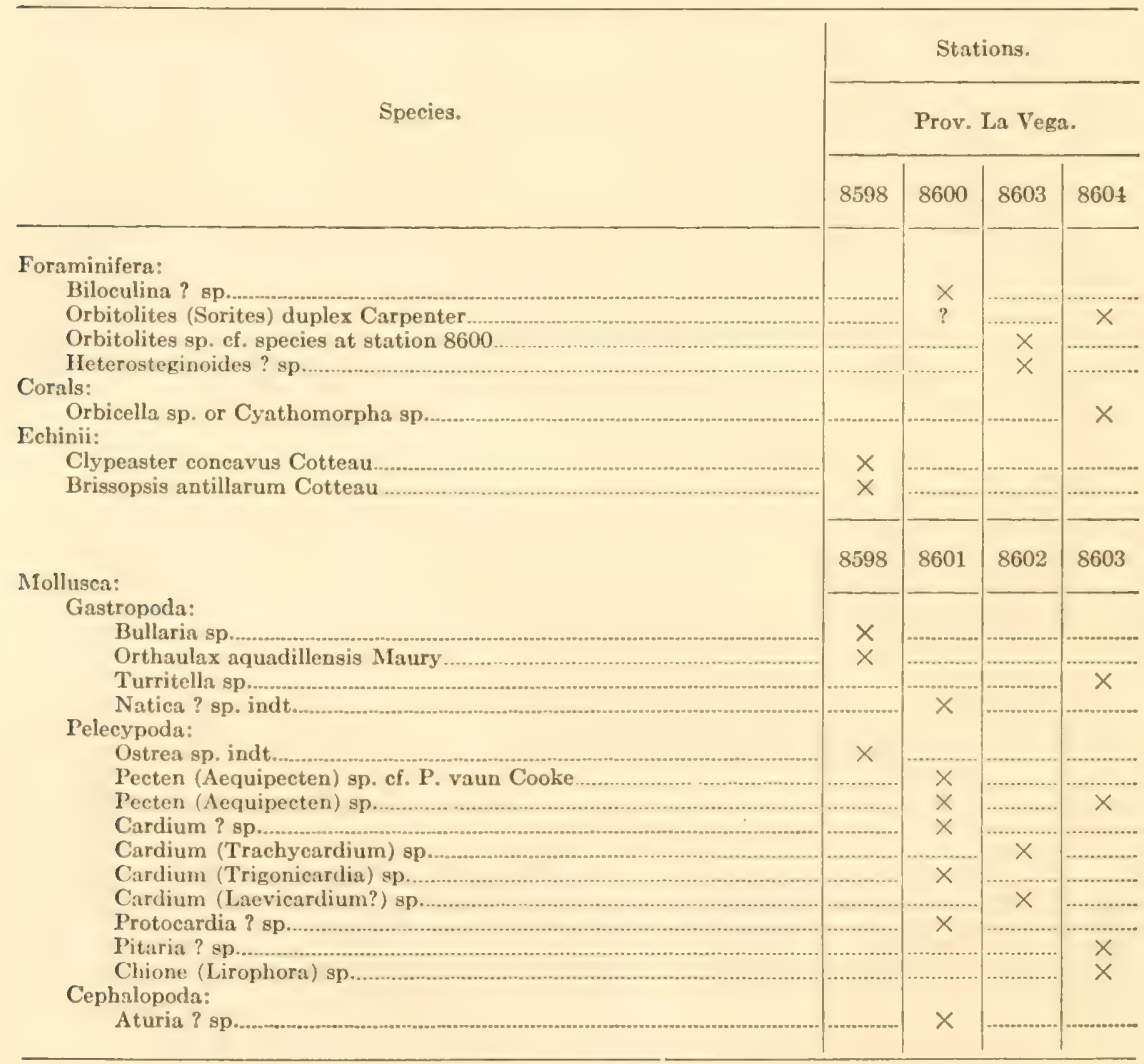




\section{PROBABLY OLIGOCENE.}

\section{List of stations on north side.}

8606 (C-16). Province of Samaná, near top of Sierra Prieta, a hill on road to Matanzas, about 17 kilometers nor thwest of Sánchez; coral limestone. C. W. Cooke, collector. April 25, 1919.

8675 (C-1). Province of Puerto Plata, north slope of Monte Isabel de Torres, above Puerto Plata; loose lumps of coral picked up on surface 300 meters abcve sea level. D. D. Condit and C. W. Cooke, collectors. March 30, 1919.

8605 (C-15). Province of La Vega, coral reef, first high hill on road from Cevicos to Villa Rivas. C. P. Ross, collector. April 22, 1919.

8703 (D. C. 33). Province of Santiago, Las Lavas Creek near first exposure above Las Lagunas on Altamira trail; fossils in conglomerate. D. D. Condit, collector. April 21, 1919.

8775 (R. 26). Province of Monte Cristi, on seashore 5 kilometers northeast of Rodriquez house, which is about 25 kilometers northeast of Monte Cristi. C. P. Ross, collector. May 4, 1919.

Faunal list.

\begin{tabular}{|c|c|c|c|c|c|}
\hline \multirow{3}{*}{ Species. } & \multicolumn{5}{|c|}{ Stations. } \\
\hline & $\begin{array}{l}\text { Prov. } \\
\text { Sa- } \\
\text { maná. }\end{array}$ & $\begin{array}{l}\text { Prov. } \\
\text { Puerto } \\
\text { Plata. }\end{array}$ & $\begin{array}{l}\text { Prov. } \\
\text { La } \\
\text { Vega. }\end{array}$ & $\begin{array}{l}\text { Prov. } \\
\text { San- } \\
\text { tiago. }\end{array}$ & $\begin{array}{l}\text { Prov. } \\
\text { Monte } \\
\text { Cristi. }\end{array}$ \\
\hline & 8606 & 8675 & 8605 & 8703 & 8775 \\
\hline \multicolumn{6}{|l|}{$\begin{array}{l}\text { Foraminifera: } \\
\quad \text { Carpenteria sp......... }\end{array}$} \\
\hline 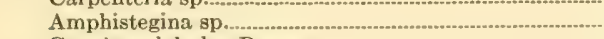 & & $\hat{x}$ & & & \\
\hline Gypsina globulus Reuss....... & & $x$ & & & \\
\hline \multirow{2}{*}{\multicolumn{6}{|c|}{$\begin{array}{l}\text { Corals: } \\
\text { Stylophora sp. } \\
\text { Stylophora sp. }\end{array}$}} \\
\hline & & & & & \\
\hline Orbicella sp. aff. $O$. canalis Vaughan............. & & $x$ & & & \\
\hline 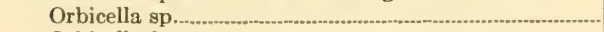 & 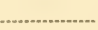 & $x$ & & $x$ & \\
\hline 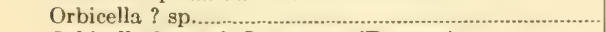 & & $x$ & & & \\
\hline Orbicella ? sp. cf. O. costata (Duncan) & & & $x$ & & ….... \\
\hline Maeandra sp. aff. M. labyrinthiformis (Linn.) ....... & $\times$ & & & & \\
\hline Siderastrea sp. aff. S. conferta (Duncan) & $x$ & & & & \\
\hline 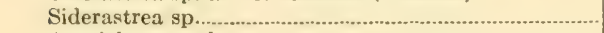 & & & & $x$ & \\
\hline 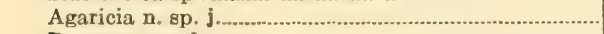 & & & & $x$ & \\
\hline 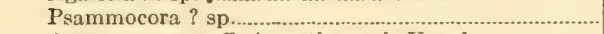 & & $x$ & & & \\
\hline Astreopora sp. aff. A. antiguensis Vaughan & & $x$ & & & \\
\hline Astreopora ? sp. & & & & $x$ & $x$ \\
\hline Porites sp & $x$ & 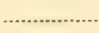 & & & ........... \\
\hline $\begin{array}{l}\text { Goniopora sp. aff. a massive large-caliced species } \\
\text { from Antigua. }\end{array}$ & & $x$ & & & \\
\hline Goniopora sp. aff. G. decaturensis Vaughan .............. & & $x$ & …...... & & .......... \\
\hline Goniopora sp. aff. G. microscopica (Duncan) ................. & & $x$ & & & \\
\hline Goniopora sp & & $x$ & & $x$ & \\
\hline
\end{tabular}

Station on south side.

8569 (D. C. 82). Province of Azua, station 12 of traverse on right bank of Rio Yaque del Sur, about 1.6 kilometers northwest or La Trinchera, opposite Bastia. D. D. Condit, collector. May 23, 1919. 
Faunal list.

\begin{tabular}{|c|c|}
\hline \multirow{2}{*}{ Species. } & Station. \\
\hline & 8569 \\
\hline $\begin{array}{l}\text { Foraminifera: } \\
\text { Globigerina sp...................................... }\end{array}$ & \\
\hline $\begin{array}{l}\text { Globigerina spp } \\
\text { Amphistegina ? sp...... Operculina ? sp............ } \\
\text { Heterostegina ? sp. or }\end{array}$ & $\begin{array}{l}x \\
x \\
x\end{array}$ \\
\hline Gypsina globulus Reuss, small form....-.....-... & $\hat{x}$ \\
\hline
\end{tabular}

\section{APPARENTLY UPPER OLIGOCENE.}

List of stations on south side.

8691 (D. C. 12). Province of Santo Domingo, foothills of Monte Calabaza, 3.5 kilometers north of San Cristóbal. C. W. Cuoke and D. D. Condit, collectors. April 7,1919 .

8692 (D. C. 13). Province of Santo Domingo, foot of Monte Calabaza, about 3.5 kilometers north of San Cristóbal. C. W. Cooke and D. D. Condit, collectors. April 7, 1919.

8693 (D. C. 14). Province of Santo Domingo, slope of Monte Calabaza. C. W. Cooke and D. D. Condit, ccllectors. April 7, 1919.

8674. Province of Santo Domingo, 24 kilometers from Santo Domingo City cn road to San Cristóbal; altitude about 60 meters above sea level. .T. W. Vaughan, collector. April 6, 1919.

Faunal list.

\begin{tabular}{|c|c|c|c|c|}
\hline \multirow{2}{*}{ Species. } & \multicolumn{4}{|c|}{ Prov. Santo Domingo. } \\
\hline & $8691^{a}$ & 8692 & 8693 & 8674 \\
\hline \multicolumn{5}{|l|}{ Corals: } \\
\hline 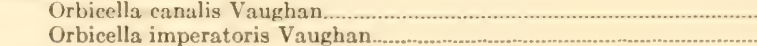 & $x$ & $x$ & & Y \\
\hline Agaricia, probably 2 species & $x$ & & & $x$ \\
\hline Cyathomorpha n. sp. & & $x$ & & \\
\hline Psammocora sp. (seems to be the same species as at station 8741 ). & & & $x$ & \\
\hline $\begin{array}{l}\text { Mollusea: } \\
\text { Gastropoda: }\end{array}$ & & & & \\
\hline $\begin{array}{l}\text { Turris ? sp. a } \\
\text { Turris? sp. b............ }\end{array}$ & $\begin{array}{l}x \\
x\end{array}$ & & & \\
\hline "Drillia"? sp & $\hat{x}$ & & & \\
\hline Strombus sp. indt & $x$ & & & \\
\hline Pelecypoda: & & & & \\
\hline $\begin{array}{l}\text { Leda sp. indt } \\
\text { Pecten sp. }\end{array}$ & $\begin{array}{l}x \\
x\end{array}$ & & & \\
\hline Spondylus sp. & & $x$ & & \\
\hline Venericardia sp & $x$ & & & \\
\hline
\end{tabular}

$a$ The limestone at this locality consists principally of calcareous algae. 
MIOCENE.

YAQUE GROUP, NORTH SIDE.

Baitoa Formation.

List of stations.

8668 (D. C. 29). Province of Santiago, Baitoa, bluff of yellow sandstone along Rio Yaque del Norte. D. D. Condit, collector. April 19, 1919.

8558 (C-64). Province of Santiago, fossils fallen from upper part of bluff on right bank of Rio Yaque del Norte below Baitoa. C. W. Cooke, collector. May 14, 1919.

8559 (C-65). Province of Santiago, roadside at top of hill leading down to Baitoa on road from Santiago. C. W. Cooke, collector. May 15, 1919.

Faunal list.

\begin{tabular}{|c|c|c|c|}
\hline \multirow{2}{*}{ Species. } & \multicolumn{3}{|c|}{$\begin{array}{l}\text { Rio Yaque } \\
\text { del Norte. }\end{array}$} \\
\hline & 8668 & 8558 & 8559 \\
\hline \multicolumn{4}{|l|}{ Corals: } \\
\hline \multicolumn{3}{|l|}{$\begin{array}{l}\text { Stylophora sp. } \\
\text { Madracis sp. (with only } 8 \text { principal septa) }\end{array}$} & $x$ \\
\hline \multicolumn{4}{|l|}{$\begin{array}{l}\text { Madracis sp. (with only } 8 \text { principal septa) } \\
\text { Antillia ? sp. }\end{array}$} \\
\hline \multicolumn{4}{|l|}{ Orbicella sp., cf. species from lower Miocene of Trinidad } \\
\hline \multicolumn{4}{|c|}{ 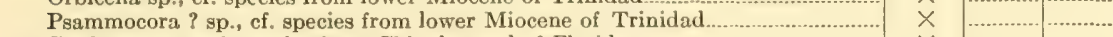 } \\
\hline \multirow{2}{*}{\multicolumn{4}{|c|}{$\begin{array}{l}\text { Goniopora sp., ef. species from Chipola marl of Florida } \\
\text { Bryozoa: }\end{array}$}} \\
\hline \multicolumn{2}{|l|}{ Cupularia denticulata Defrance ..... } & & \\
\hline \multicolumn{4}{|l|}{$\begin{array}{l}\text { Mollusca: } \\
\text { Gastropoda: } \\
\text { Ringicula n. sp. a, cf. R. dominicensis Maury }\end{array}$} \\
\hline \multicolumn{4}{|c|}{$\begin{array}{l}\text { Ringicula } \mathrm{n} \text {. sp. a, cf. R. dominicensis Maury } \\
\text { Terebra (Strioterebra) gatunensis Toula }\end{array}$} \\
\hline \multicolumn{4}{|c|}{ Terebra (Strioterebra) sp. indt } \\
\hline \multicolumn{4}{|c|}{ Conus williamgabbi Maury } \\
\hline \multirow{2}{*}{\multicolumn{4}{|c|}{$\begin{array}{l}\text { Conus n. sp. b } \\
\text { Conus n. sp. e }\end{array}$}} \\
\hline Conus n. sp. e................................... & & & \\
\hline \multirow{2}{*}{\multicolumn{4}{|c|}{$\begin{array}{l}\text { Conus n. sp. p } \\
\text { Surcula (Pleurofusia) n. sp. b, n. subsp. } a^{\prime}\end{array}$}} \\
\hline & & & \\
\hline \multicolumn{4}{|l|}{ Turris (Pleuroliria) haitensis (Sowerby)?.... } \\
\hline \multicolumn{4}{|c|}{ "Drillia" henekeni (Sowerby) n, subsp. a' } \\
\hline \multicolumn{4}{|c|}{ "Drillia" consors (Sowerby) n. subsp. a' "Drillia" } \\
\hline \multicolumn{4}{|c|}{$\begin{array}{l}\text { "Drillia" } \mathbf{n} \text { sp. } \mathbf{x} \\
\text { "Drillia" sp. indt. }\end{array}$} \\
\hline \multicolumn{4}{|l|}{ 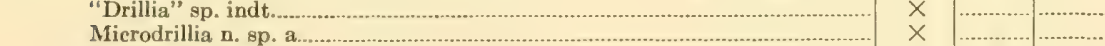 } \\
\hline \multicolumn{4}{|l|}{ 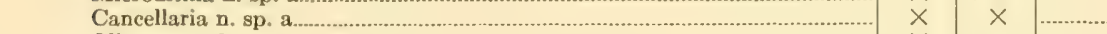 } \\
\hline \multicolumn{4}{|c|}{ Oliva n. sp. b } \\
\hline \multicolumn{4}{|c|}{ 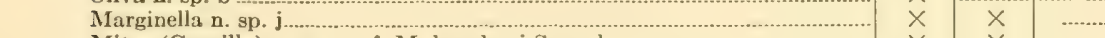 } \\
\hline \multirow{2}{*}{\multicolumn{4}{|c|}{$\begin{array}{l}\text { Mitra (Cancilla) n. sp. a, cf. M. henekeni Sowerby } \\
\text { Mitra (Cancilla) n. sp. b, ef. M. longa Gabb }\end{array}$}} \\
\hline & $x$ & & \\
\hline \multicolumn{4}{|c|}{ Mitra (Cancilla) sp. indt. } \\
\hline Vasum tuberculatum Gabb. & $x$ & & \\
\hline Melongena consors (Sowerby) ........ & $x$ & $x$ & \\
\hline Fasciolaria kempi Maury & $x$ & $x$ & \\
\hline 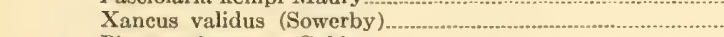 & $x$ & $x$ & \\
\hline Phos semicostatus Gabb. & $x$ & $x$ & $x$ \\
\hline Phos costatus Gabb & $x$ & $x$ & \\
\hline Alectrion sp. & & & $x$ \\
\hline Strombina sp. ef. S. cyphonotus Pilsbry and Johnson........... & $x$ & & \\
\hline 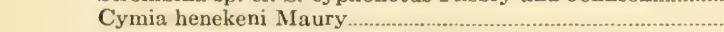 & $x$ & $x$ & \\
\hline Distortio simillima (Sowerby)? & $x$ & & \\
\hline 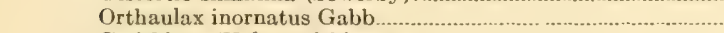 & $x$ & & \\
\hline Cerithium (Vulgocerithium) sp...... & & & $x$ \\
\hline Potamides sp....................................... & $x$ & & \\
\hline 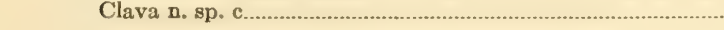 & & X & \\
\hline
\end{tabular}


Faunal list-Continued.

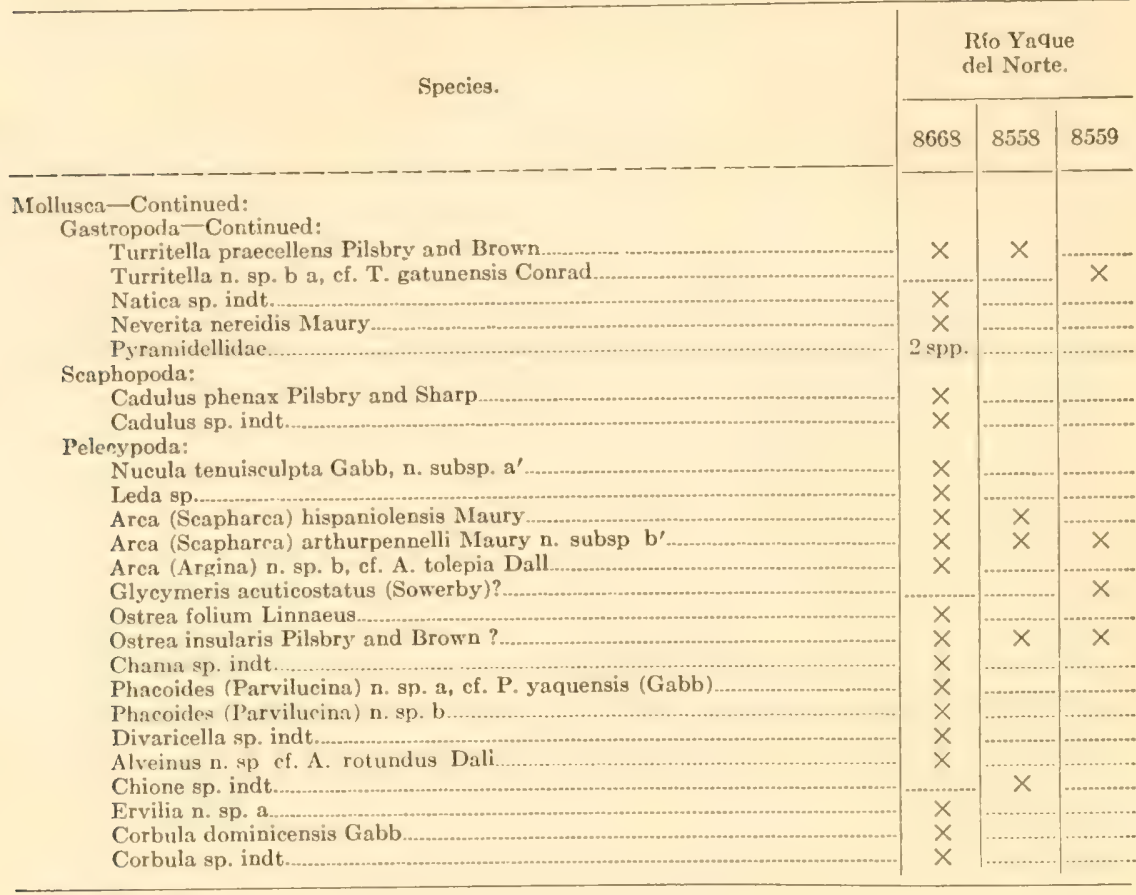

\section{Cercado Formation.}

List of stations.

(See Plates IX and XI for maps of Rio Mao and Rio Gurabo.)

7786. Province of Santiago, Rio Mao, "Bluff 3, 5 miles above Cercado de Mao." C. J. Maury, collector. May 1916. (Same as station 8525 of Vaughan and Cooke.)

Province of Santiago, Rio Mao, "Bluff 2, 4 miles above Cercado de Mao." C. J. Maury, collector. May 1916. (Same locality as station 8526 of Vaughan and Caoke.) 7781. Province of Monte Cristi, "Rio Cana, zone H, at Caimito." C. J. Maury, ccllector. May 1916. (This is the same locality as station 8534 of Vaughan and Cooke.)

Province of Monte Cristi, Rio Cana, above Caimito, zone I. C. J. Maury, collector. May 1916.

8729 (D. C. 55). Province of Santiago, Rio Albano near San José de las Matas.

D. D. Condit, collector. May 2, 1919.

8529 (C-35). Province of Santiago, fossils from near top of bluff on right side of Rio Mao about 1.0 kilometer by trail $N .40^{\circ} \mathrm{E}$. of Bulla and about 1.7 kilometers above the ford El Paso de los Perros. T. W. Vaughan, C. W. Cooke, and D. D. Condit, collectors. May 5, 1919.

8525 (C-31). Province of Santiago, long bluff on left bank of Rio Mao oppesite Hato Viejo, abcut 5 kilometers above the ford (Paso Bajito) at Cercado de Mao. T. W. Vaughan, C. W. Cooke, and D. D. Condit, collectors. May 5, 1919.

8526 (C-32). Province of Santiago, second bluff on left side of Rio Mao about 3.5 kilometers by trail above the ford (Paso Bajito) at Cercado de Mao. T. W. Vaughan and C. W. Cooke, collectors. May 6, 1919.

8521 (C-27). Province of Santiago, bluff on right bank of Rio Mao about 1.7 kilometers above Paso Bajito at Cereado de Mao, fossils fram basal 4.5 meters oi section. T. W. Vaughan and C. W. Cooke, collectors. May 4, 1919. 
8737 (D. C. 64). Province of Monte Cristi, Rio Gurabo, about 5 miles above Gurabo Adentro; base of coralliferous limestone and above conglomerate. D. D. Condit collector. May 9, 1919.

8738 (D. C. 64 A). Province of Monte Cristi, Rio Gurabo about 8.5 kilomeiers above Gurabo Adentro; beds near base of coralliferous limestone and above conglomerate. D. D. Condit, collector. May 9, 1919.

8534 (C-40). Province of Monte Cristi, bank of Rio Cana at Caimito, road from Las Caobas to Sabaneta. T. W. Vaughan and C. W. Cooke, collectors. May 10, 1919.

Faunal list.

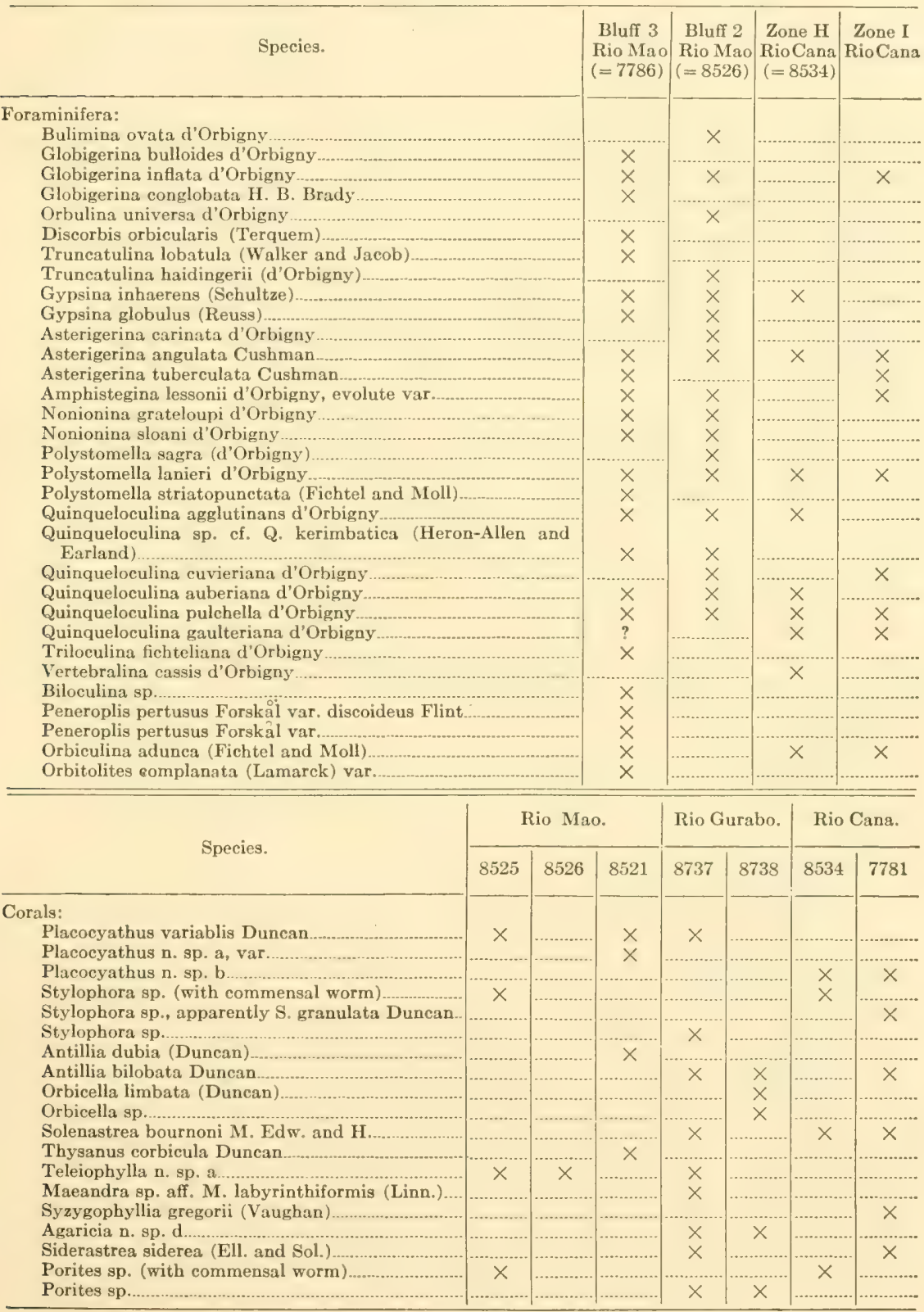


Faunal list-Continued.

Species.

Bryozoa:

Membranipora vaughani Canu and Bassler

Cupuladria canariensis Busk

Acanthodesia savarti (Savigny-Audouin) forma monilifera Canu and Bassler.

Nellia oculata Busk

Cupularia umbellata Defrance

Cupularia denticulata Defrance

Corynostylus labiatus Canu and Bassler

Corynostylus ellipticus Canu and Bassler

Thalamoporella biperforata Canu and Bassler

Steganoporella parvicella Canu and Bassler.

Schizopodrella ? mutabilis Canu and Bassler

Hippomenella infratelum Canu and Bassler.

Smittina? brevis Canu and Bassler.

Rhynchozoon vaughani Canu and Bassler.

Metrarabdotos colligatum Canu and Bassler.

Adsona porosa Canu and Bassler

Holoporella albirostris Smitt.

Stichoporina tuberosa Canu and Bassler

Idmonea milneana d'Orbigny

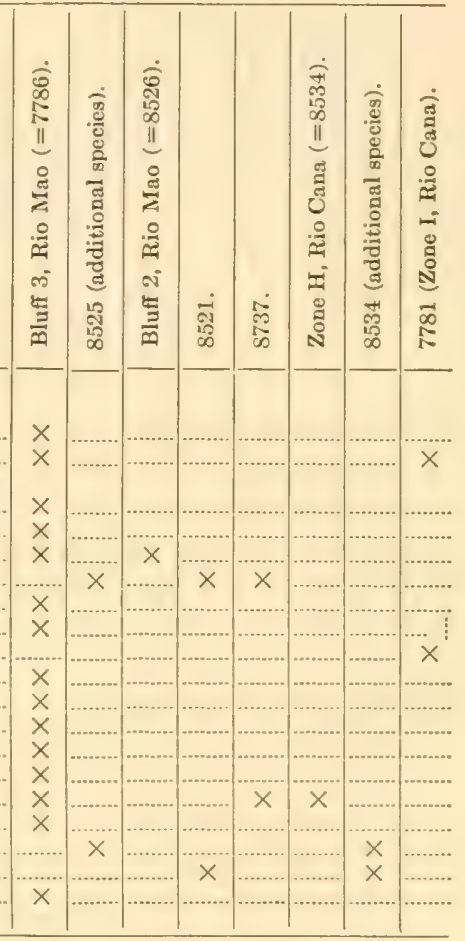

\begin{tabular}{|c|c|c|c|c|c|c|c|c|}
\hline \multirow{2}{*}{ Species. } & \multirow{2}{*}{$\begin{array}{c}\begin{array}{c}\text { Rio } \\
\text { Albano. }\end{array} \\
8729\end{array}$} & \multicolumn{4}{|c|}{$\begin{array}{l}\text { Rio } \\
\text { Mao. }\end{array}$} & \multicolumn{2}{|c|}{$\begin{array}{c}\text { Rio } \\
\text { Gurabo. }\end{array}$} & \multirow{2}{*}{$\begin{array}{c}\begin{array}{c}\text { Rio } \\
\text { Cana. }\end{array} \\
8534\end{array}$} \\
\hline & & 8529 & 8525 & 8526 & 8521 & 8737 & 8738 & \\
\hline \multicolumn{9}{|l|}{$\begin{array}{l}\text { Mollusca: } \\
\text { Gastropoda: }\end{array}$} \\
\hline Cavolina sp. & & & $x$ & & & & & 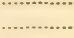 \\
\hline 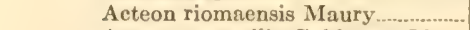 & .......... & .......... & $x$ & & & $x$ & & ............... \\
\hline $\begin{array}{l}\text { Acteon tornatilis Gabb not Lin- } \\
\text { nacus }\end{array}$ & $x$ & & & & & & & \\
\hline Ringicula dominicensis Maury...... & & & $x$ & & & & & $\ldots \ldots \ldots$ \\
\hline $\begin{array}{c}\text { Acteocina recta Maury not } \\
\text { d'Orbigny }\end{array}$ & $\times$ & & $x$ & & & $x$ & & $x$ \\
\hline $\begin{array}{l}\text { Acteocina canaliculata Maury } \\
\text { not Say. }\end{array}$ & & & $\times$ & & & & & \\
\hline Acteocina n. sp. a & $\ldots$ & & & & $x$ & ............ & …....... & …..... \\
\hline Acteocina n. sp. b & & & & & $x$ & & & \\
\hline $\begin{array}{l}\text { Retusa sulcata Gabb not d'Or- } \\
\text { bigny }\end{array}$ & & & $x$ & & & & & \\
\hline Cylichnella trictum-tritonis Maury & $x$ & & $x$ & & & ......... & ........ & ………..... \\
\hline Cylichnella n. sp. a & & & & & $x$ & & & \\
\hline Volvula cylindrica Gabb. & $x$ & & $x$ & & $x$ & $x$ & $x$ & $x$ \\
\hline $\begin{array}{l}\text { Bullaria paupercula (Sowerby) } \mathbf{n} \text {. } \\
\text { subsp. } a^{\prime}\end{array}$ & $x$ & & $x$ & & & & & \\
\hline Bullaria n. sp. a & ……….......... & ............. & $x$ & & & & & $\times$ \\
\hline Aty's n. sp. a & ....................... & ………... & $x$ & ................ & $x$ & & $?$ & \\
\hline
\end{tabular}


Faunal list-Continued.

\begin{tabular}{|c|c|c|c|c|c|c|c|c|}
\hline \multirow{2}{*}{ Species. } & \multirow{2}{*}{ 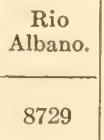 } & \multicolumn{4}{|c|}{$\begin{array}{l}\text { Rio } \\
\text { Mao. }\end{array}$} & \multicolumn{2}{|c|}{$\begin{array}{l}\text { Rio } \\
\text { Gurabo. }\end{array}$} & \multirow{2}{*}{$\begin{array}{c}\begin{array}{c}\text { Rio } \\
\text { Cana. }\end{array} \\
8534\end{array}$} \\
\hline & & 8529 & 8525 & 8526 & 8521 & 8737 & 8738 & \\
\hline \multicolumn{9}{|l|}{$\begin{array}{l}\text { Mollusca-Continued: } \\
\text { Gastropoda-Continued: } \\
\text { Atys n. sp. b................ }\end{array}$} \\
\hline 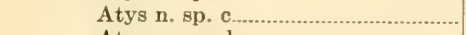 & & & $x$ & & & & & \\
\hline Atys n. sp. d & & & $\times$ & & & & & \\
\hline Atys (Alicula) yaquensis (Maury).. & & & $x$ & & $x$ & $x$ & & $x$ \\
\hline Atys (Alicula) n. sp. a & $x$ & & $\mathrm{X}$ & & & & & \\
\hline Atys (Alicula) n. sp. b & & & X & & & & & \\
\hline Atys (Roxania) doliola Maury ...... & & (n)............ & $x$ & & & & & \\
\hline $\begin{array}{l}\text { Terebra (Strioterebra) cambiarsoi } \\
\text { Maury }\end{array}$ & & & & & & & & \\
\hline $\begin{array}{l}\text { Terebra (Strioterebra) cambiarsoi } \\
\text { Maury n. subsp. a }\end{array}$ & & & & & $\times$ & & & \\
\hline $\begin{array}{l}\text { Terebra (Strioterebra) cambiarsoi } \\
\text { Maury n. subsp. b'............................ }\end{array}$ & & & & & . & & & $x$ \\
\hline $\begin{array}{l}\text { Terebra (Strioterebra) cambiarsoi } \\
\text { Maury n. subsp. c c'.................... }\end{array}$ & & & & & & & & 人 \\
\hline $\begin{array}{l}\text { Terebra (Strioterebra) cambiarsoi } \\
\text { n. subsp. } d^{\prime}\end{array}$ & & & & & & & & ᄉ \\
\hline $\begin{array}{l}\text { Terebra (Strioterebra) cirra Dall } \\
\text { subsp. a'........ }\end{array}$ & $x$ & & $x$ & & & & & $\lambda$ \\
\hline $\begin{array}{l}\text { Terebra (Strioterebra) oligomitra } \\
\text { Maury not Dall }\end{array}$ & & & $x$ & $x$ & & & $x$ & \\
\hline $\begin{array}{l}\text { Terebra (Strioterebra) spirifera } \\
\text { Maury not Dall }\end{array}$ & & & & & $x$ & & & \\
\hline $\begin{array}{l}\text { Terebra (Strioterebra) berlinerae } \\
\text { Maury }\end{array}$ & & & & & . & & & $x$ \\
\hline 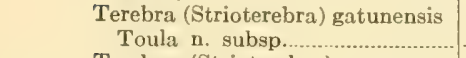 & & & $x$ & & $x$ & & & \\
\hline Terebra (Strioterebra) n. sp. a... & & & $x$ & & & & & \\
\hline $\begin{array}{l}\text { Terebra (Strioterebra) laevifas- } \\
\text { ciola Maury }\end{array}$ & $x$ & & $x$ & & $x$ & & & \\
\hline Terebra (Strioterebra) n. sp. b..... & 八 & & $x$ & & 人 & & & \\
\hline $\begin{array}{l}\text { Terebra (Strioterebra) n. sp. b, n. } \\
\text { subsp. } \mathrm{a}^{\prime}\end{array}$ & & & $x$ & & $x$ & & & \\
\hline $\begin{array}{l}\text { Terebra (Strioterebra) n. sp. b, n. } \\
\text { subsp. b' }\end{array}$ & & & $x$ & & & & & \\
\hline Terebra (Strioterebra) n. sp. c...... & & & $x$ & & & & & \\
\hline Terebra (Strioterebra) n. sp. d...... & & & $x$ & & & & & \\
\hline Terebra (Strioterebra) n. sp. e..... & & & $x$ & & & & & \\
\hline Terebra (Strioterebra) n. sp. f & & & & & $\times$ & & & $\ldots \ldots$ \\
\hline Terebra (Strioterebra) n. sp. g........ & & & & & $x$ & & & ........... \\
\hline Terebra (Strioterebra) n. sp. h.... & & & & & $x$ & & & \\
\hline Terebra (Strioterebra) n. sp. i...... & & & & & & & & $x$ \\
\hline Terebra (Strioterebra) n. sp. j...... & & & & & & & & $x$ \\
\hline Terebra (Strioterebra) sp. indt. & & & & & & $x$ & & \\
\hline Terebra (new section A) n. sp. a..... & $\ldots . . .$. & & $\times$ & & & & & \\
\hline $\begin{array}{l}\text { Terebra (new section A) n. sp. a, } \\
\text { n. subsp. a }\end{array}$ & & & & $x$ & & & & \\
\hline $\begin{array}{l}\text { Terebra (new section A) n. sp. a, } \\
\text { n. subsp. b }\end{array}$ & & & & & & & & $x$ \\
\hline Terebra (new section B) n. sp. a..... & & & & & & & & $x$ \\
\hline Hastula n. sp. a & & & $x$ & & & & & \\
\hline 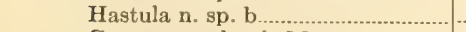 & & & & & & & & X \\
\hline Conus cercadensis Maury ................ & $x$ & $x$ & $x$ & $x$ & $x$ & & & \\
\hline Conus furvoides Gabb. & & & $\times$ & & & & & $x$ \\
\hline Conus kitteredgi Maury .................. & & & & & & & & $x$ \\
\hline $\begin{array}{l}\text { Conus recognitus Maury not } \\
\text { Guppy }\end{array}$ & & & & & & & & $x$ \\
\hline $\begin{array}{l}\text { Conus gracilissimus Guppy } \mathrm{n} . \\
\text { subsp. } \mathrm{a}^{\prime} \ldots \ldots \ldots \ldots \ldots \ldots \ldots \ldots\end{array}$ & & & & & & & & $x$ \\
\hline Conus n. sp. a & & & $x$ & & $x$ & & & \\
\hline Conus n. sp. b. & & & $x$ & & $x$ & & & \\
\hline 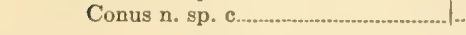 & & & $x$ & $x$ & & & & \\
\hline
\end{tabular}


Faunal list-Continued.

\begin{tabular}{|c|c|c|c|c|c|c|c|c|}
\hline \multirow{2}{*}{ Species. } & \multirow{2}{*}{$\begin{array}{c}\text { Rio } \\
\text { Albano. } \\
8729\end{array}$} & \multicolumn{4}{|c|}{$\begin{array}{l}\text { Rio } \\
\text { Mao. }\end{array}$} & \multicolumn{2}{|c|}{$\begin{array}{l}\text { Rio } \\
\text { Gurabo. }\end{array}$} & \multirow{2}{*}{$\begin{array}{c}\begin{array}{c}\text { Rio } \\
\text { Cana. }\end{array} \\
8534\end{array}$} \\
\hline & & 8529 & 8525 & 8526 & 8521 & 8737 & 8735 & \\
\hline \multicolumn{9}{|l|}{$\begin{array}{l}\text { Mollusca-Continued: } \\
\text { Gastropoda-Continued: } \\
\text { Conus n. sp. d............... }\end{array}$} \\
\hline 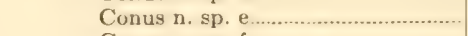 & & & & & & & & $x$ \\
\hline Conus n. sp. f & & & & & & & & \\
\hline Conus sp. indt. & & & & & & & $x$ & \\
\hline Surcula (Pleurofusia) n. sp. a............ & & ........ & & & $x$ & & & \\
\hline 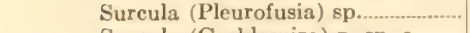 & & & & & $x$ & & & \\
\hline Surcula (Cochlespira) n. sp. a........ & & & & & $x$ & & & \\
\hline $\begin{array}{l}\text { Turris (Pleuroliria) haitensis } \\
\text { (Sowerby) }\end{array}$ & & & $x$ & & & & & \\
\hline Turris (Pleuroliria) n. sp. a & & & & & x & & & $x$ \\
\hline Turris (Pleuroliria) sp. indt & & & & $x$ & & & & 人 \\
\hline "Drillia" maoisriparum Maury..... & & & $x$ & & & & & \\
\hline "Drillia" henekeni Sowerby ........... & & & $?$ & $x$ & $x$ & ....... & & $x$ \\
\hline "Drillia" n. sp. a & & & $\dot{x}$ & $\lambda$ & $\lambda$ & & & $\lambda$ \\
\hline "Drillia" n. sp. b. & & & $\hat{x}$ & & $\ldots$ & & & \\
\hline 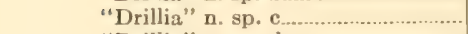 & & & & & $x$ & & & \\
\hline 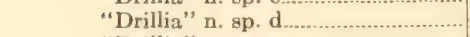 & & & & & $x$ & & & \\
\hline 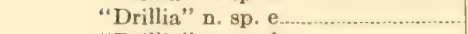 & & & & & $x$. & & & \\
\hline "Drillia" n. sp. f & & & & & $x$ & & $\ldots \ldots$ & \\
\hline "Drillia" n. sp. g & $\cdots . .$. & & & .......... & $x$ & $\ldots \ldots \ldots$ & ............... & $\cdots \cdots$ \\
\hline "Drillia" n. sp. h. & & (n............. & $\ldots$. & ............... & $x$ & .................. & …............. & $\cdots$ \\
\hline "Drillia" n. sp. i & & …............. & & $\cdots \cdots$ & $\widehat{x}$ & ……… & …….... & \\
\hline 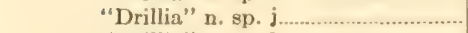 & & & & & $\widehat{x}$ & & & \\
\hline 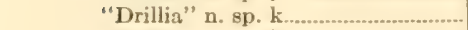 & & & & $\ldots \ldots$ & $\hat{x}$ & & & \\
\hline 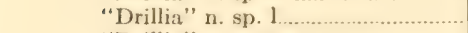 & & $\cdots$ & $\ldots$ & & $\hat{x}$ & & & \\
\hline 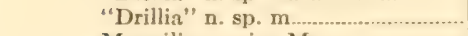 & & & & & $\hat{x}$ & & & \\
\hline Mangilia maoica Maury & & & $x$ & & & & & \\
\hline "Mangilia" Jaloni s Maury ............... & & $\ldots \ldots$ & $x$ & & $x$ & & & \\
\hline "Mangilia" n. sp. a & $\times$ & ............ & $x$ & & & & & $\ldots$ \\
\hline 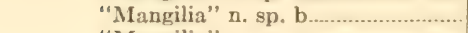 & & $\ldots \ldots$ & $x$ & & & & & \\
\hline "Mangilia" n. sp. c........................ & & …....... & $x$ & & & & & \\
\hline 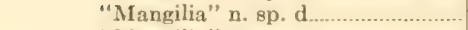 & $\ldots$ & ….......... & & ............ & $x$ & ........ & & \\
\hline 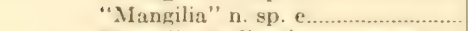 & & $\cdots \cdots$ & & $\ldots \ldots$ & $\hat{x}$ & & & \\
\hline Mangilia (Bellaspira) n. sp. a........ & & & & & $x$ & & & \\
\hline "Cythara" polygona (Gabb) .......... & $x$ & $\ldots . .$. & $x$ & & ........... & & & \\
\hline "Cythara" elongata (Gabb) ....... & & & $x$ & & & & & \\
\hline "Cythara" heptagona (Gabb)....... & & & & & $x$ & & & \\
\hline "Cythara" n. sp. a & & & & & $x$ & & & \\
\hline "Cythara" n. sp. b & & & & & $x$ & & & \\
\hline 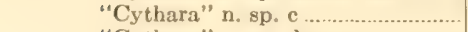 & & $\ldots \ldots$ & .............. & ........... & $x$ & 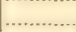 & .......... & …........ \\
\hline "Cythara" n. sp. d & ............. & $\ldots \ldots$ & $\ldots \ldots$ & $\ldots \ldots$ & $x$ & & ........ & \\
\hline "Cythara" n. sp. e & & $\ldots \ldots \ldots$ & & & x & & & \\
\hline "Clathurella" n. sp. a & . & …................ & x & & & & & \\
\hline 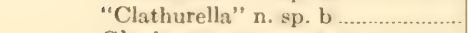 & . & (…….......... & & & $x$ & & & \\
\hline Glyphostoma n. sp. a & & & & & $x$ & & & \\
\hline 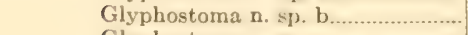 & & & & & $x$ & & & \\
\hline 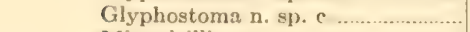 & & & ..... & & $x$ & & & ........ \\
\hline Microdrillia sp. & & & & & $x$ & & & \\
\hline $\begin{array}{l}\text { Cancellaria barretti Maury not } \\
\text { Guppy }\end{array}$ & & & $x$ & & & & & \\
\hline $\begin{array}{l}\text { Cancellaria (Bivetia) epistomifera } \\
\text { Guppy }\end{array}$ & & & $x$ & $x$ & & & & \\
\hline Cancellaria (Bivetia) harrisi & & & 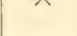 & $\lambda$ & & & & \\
\hline Maury & …............ & ......... & & & & & & $x$ \\
\hline $\begin{array}{c}\text { Cancellaria (Aphera) islacolonis } \\
\text { Maury }\end{array}$ & & & & & & & & \\
\hline Oliva cylindrica Sowerby & ........ & & $\begin{array}{l}x \\
x\end{array}$ & & $x$ & & & $\begin{array}{l}x \\
x\end{array}$ \\
\hline Oliva brevispira Gabb........................ & $x$ & .............. & $x$ & $\ldots \ldots \ldots$ & $x$ & $\ldots \ldots \ldots$ & $x$ & $\hat{x}$ \\
\hline 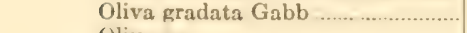 & & & & $x$ & & & & $x$ \\
\hline ()liva sp. & . …….......... & & & & & X & $x$ & \\
\hline Olivella n. sp. a & x & & $x$ & & & & & \\
\hline
\end{tabular}


Faunal list-Continued.

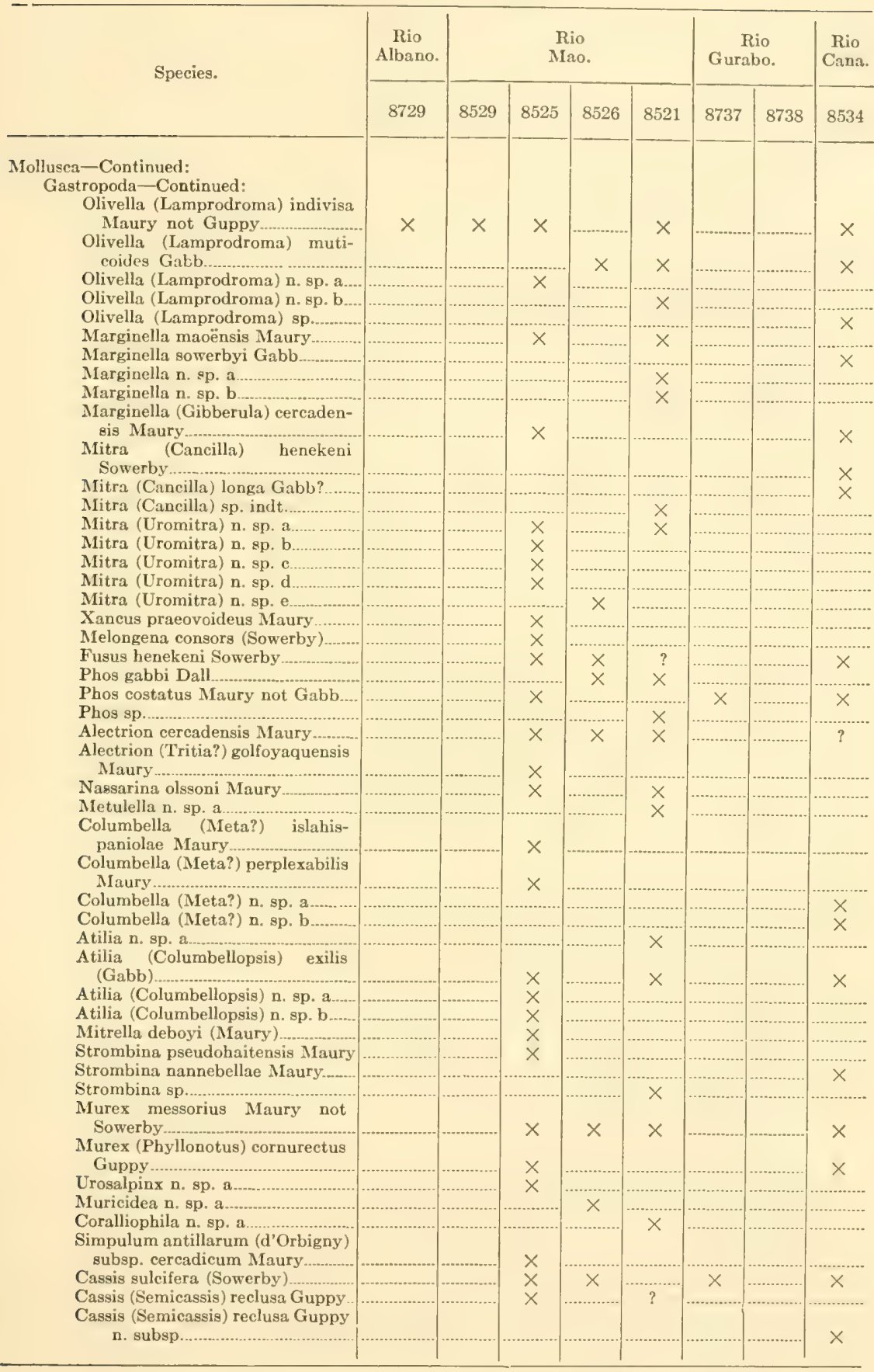


Faunal list-Continued.

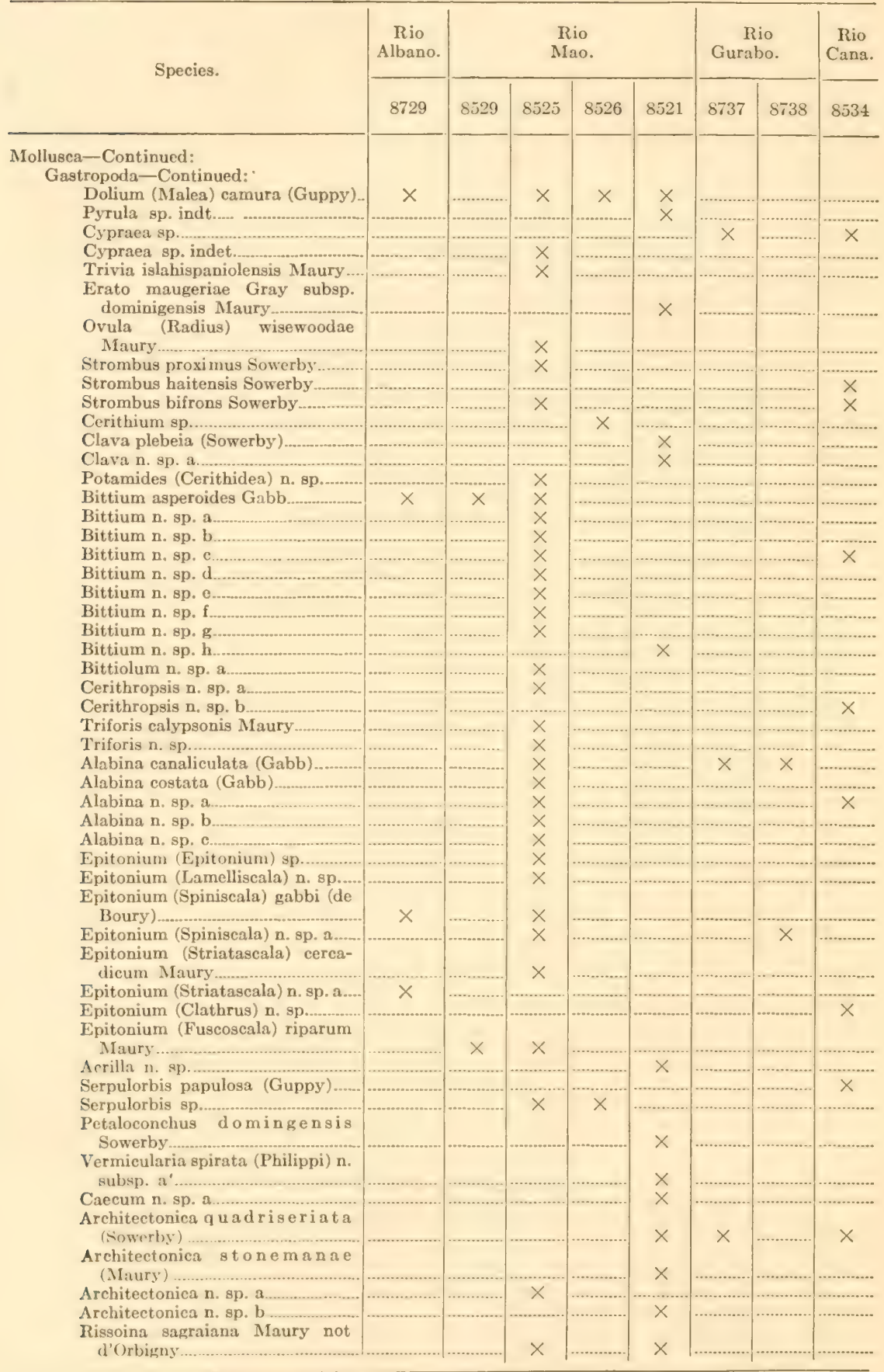


Faunal list-Continued.

\begin{tabular}{|c|c|c|c|c|c|c|c|c|}
\hline \multirow{2}{*}{ Species. } & \multirow{2}{*}{$\begin{array}{c}\begin{array}{c}\text { Rio } \\
\text { Albano. }\end{array} \\
8729\end{array}$} & \multicolumn{4}{|c|}{$\begin{array}{l}\text { Rio } \\
\text { Mao. }\end{array}$} & \multicolumn{2}{|c|}{$\begin{array}{l}\text { Rio } \\
\text { Gurabo. }\end{array}$} & \multirow{2}{*}{$\begin{array}{c}\text { Rio } \\
\text { Cana. } \\
8534\end{array}$} \\
\hline & & 8529 & 8525 & 8526 & 8521 & 8737 & 8738 & \\
\hline \multirow{2}{*}{\multicolumn{9}{|c|}{ 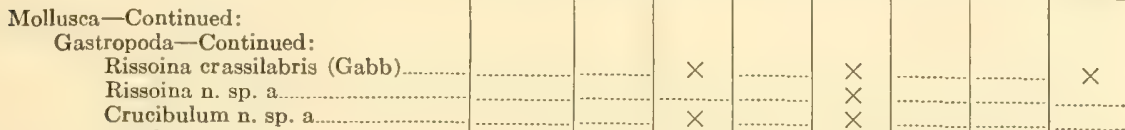 }} \\
\hline & & & & & & & & \\
\hline $\begin{array}{l}\text { Amalthea n, sp. a. } \\
\text { Capulus n. sp. a }\end{array}$ & & & & $x$ & $\begin{array}{l}x \\
x\end{array}$ & & & $x$ \\
\hline Xenophora delecta Guppy? & & & & & $x$ & $x$ & & \\
\hline Natica canrena Linnaeus n. subsp. & & & $x$ & $x$ & & & . & $x$ \\
\hline $\begin{array}{c}\text { Natica canrena Linnaeus n. subsp. } \\
\text { b' }\end{array}$ & $x$ & & & & $x$ & & & 人 \\
\hline Natica guppiana Toula & $x$ & & & & & & & \\
\hline Natica youngi Maury & & & & & $x$ & & & \\
\hline $\begin{array}{l}\text { Natica n. sp. a } \\
\text { Natica (Stigmaulax) sulcata Born.. }\end{array}$ & & & $x$ & & & & & \\
\hline & & & $x$ & $x$ & $x$ & $x$ & $x$ & $\times$ \\
\hline $\begin{array}{l}\text { Natica (Cryptonatica) n. sp. a } \\
\text { Polynices subclausa (Sowerby) }\end{array}$ & $\begin{array}{l}x \\
x\end{array}$ & X & & & $x$ & $x$ & & $x$ \\
\hline $\begin{array}{l}\text { Polynices subclausa (Sowerby) } \\
\text { Neverita nereidis Maury }\end{array}$ & $x$ & & $x$ & & X & & & $x$ \\
\hline & & & & & & & & $x$ \\
\hline 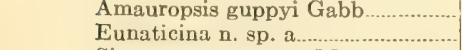 & & & X & $x$ & $x$ & $?$ & & $x$ \\
\hline $\begin{array}{l}\text { Eunaticina n. sp. a....................... } \\
\text { Sinum gatunense Maury not }\end{array}$ & & & X & & $x$ & $x$ & & \\
\hline $\begin{array}{l}\text { Sinum gatunense Maury not } \\
\text { Toula. }\end{array}$ & & & x & & & & & $x$ \\
\hline Collonia n. sp. a & & & x & & X & & & $x$ \\
\hline Collonia n. sp. b. & & & & & & & & $x$ \\
\hline Cyclostrema striata Gabb.............. & & & $x$ & & & & & $x$ \\
\hline Adeorbis pentagona (Gabb) & & & $x$ & & & & & \\
\hline Solariorbis n. sp. a & & & $x$ & & & & & \\
\hline Solariobis n. sp. b & & & $x$ & & & & & \\
\hline Teinostoma sandomingense Maury & & $x$ & & & & & & \\
\hline Teinostoma n. sp. a. & & & $x$ & & & & & \\
\hline 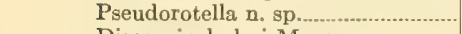 & & & & & & & & $x$ \\
\hline 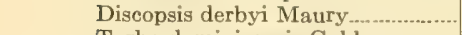 & & & $x$ & & & & & \\
\hline Turbo dominicensis Gabb & & & $x$ & & & & $x$ & \\
\hline $\begin{array}{l}\text { Turbo dominicensis Gabb subsp. } \\
\text { laloi Maury }\end{array}$ & & & $x$ & & & $x$ & & \\
\hline $\begin{array}{l}\text { Turbo dominicensis Gabb n. } \\
\text { subsp. } a^{\prime}\end{array}$ & & & & & & $x$ & & \\
\hline Turbo crenulatoides Maury & & & & & & & & $x$ \\
\hline $\begin{array}{l}\text { Astralium sublongispinum } \\
\text { Maury. }\end{array}$ & & & $x$ & & & & & \\
\hline Astralium karlschmidti Maury ...... & & & & & & $x$ & & $x$ \\
\hline $\begin{array}{l}\text { Phasianella (Eucosomia) punc- } \\
\text { tata (Gabb) }\end{array}$ & & & $x$ & & $x$ & $x$ & $x$ & \\
\hline Calliostoma n. sp. a & & & $x$ & & & & & $x$ \\
\hline Calliostoma n. sp. b............. & & & $x$ & & X & $x$ & $\ldots$. & \\
\hline Calliostoma n. sp. c........ & & & $x$ & & & & & \\
\hline Calliostoma n. sp. d... & & & & & & & & $x$ \\
\hline 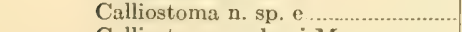 & & & & & & $x$ & $x$ & \\
\hline Calliostoma grabaui Maury.......... & & & & & $?$ & & & \\
\hline Euchelus n. sp. a ...................... & & & $x$ & & $x$ & & & \\
\hline $\begin{array}{l}\text { Neretina (Puperita) fulgopicta } \\
\text { Maury }\end{array}$ & & & & & & & & $x$ \\
\hline $\begin{array}{l}\text { Neretina (Smaragdia) viridi- } \\
\text { maris Maury }\end{array}$ & $x$ & & $x$ & & X & $x$ & & \\
\hline $\begin{array}{l}\text { Fissuridea alternata Maury not } \\
\text { Say }\end{array}$ & & & $x$ & & & & & \\
\hline Atlanta rotunda Gabb & & & $x$ & & & & & \\
\hline Atlanta cordiformis Gabb....... & & & $x$ & & & & & \\
\hline Melanella tethyos Maury......... & & & $x$ & .......... & ........ & & & (........... \\
\hline Melanella maoica Maury......... & & & $x$ & & & & & \\
\hline 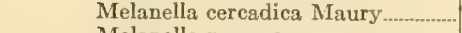 & & & $x$ & & .... & (........... & & (.............. \\
\hline Melanella n. sp. a & & & $\mathrm{X}$ & & & & & \\
\hline 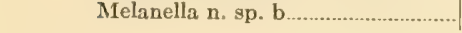 & & & & & $x$ & & & $x$ \\
\hline
\end{tabular}


Faunal list-Continued.

\begin{tabular}{|c|c|c|c|c|c|c|c|c|}
\hline \multirow{2}{*}{ Species. } & \multirow{2}{*}{$\begin{array}{c}\begin{array}{c}\text { Rio } \\
\text { Albano. }\end{array} \\
8729\end{array}$} & \multicolumn{4}{|c|}{$\begin{array}{l}\text { Rio } \\
\text { Mao. }\end{array}$} & \multicolumn{2}{|c|}{$\begin{array}{l}\text { Rio } \\
\text { Gurabo. }\end{array}$} & \multirow{2}{*}{$\begin{array}{c}\text { Rio } \\
\text { Cana. } \\
8534\end{array}$} \\
\hline & & 8529 & 8525 & 8526 & 8621 & 8737 & 8738 & \\
\hline \multirow{2}{*}{\multicolumn{9}{|c|}{$\begin{array}{l}\text { Mollusca-Continued: } \\
\text { Gastropoda-Continued: } \\
\text { Melanella n. sp. c....... } \\
\text { Melanella n. sp. d....... }\end{array}$}} \\
\hline & & & & & & & & \\
\hline 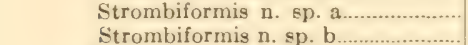 & X & & $\begin{array}{l}x \\
x\end{array}$ & …...... & $x$ & & & $x$ \\
\hline 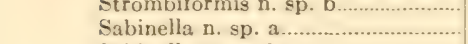 & & & $\hat{x}$ & & & & & \\
\hline Sabinella n. sp. b. & & & & & $x$ & & & \\
\hline Niso grandis Maury not Gabb...... & & & $x$ & & $x$ & & & \\
\hline 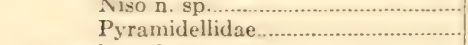 & \multirow{2}{*}{2 sp. } & \multirow{2}{*}{ 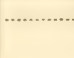 } & 45 sp. & 1 sp. & $7 \mathrm{sp}$. & $1 \mathrm{sp}$. & \multirow{2}{*}{$1 \mathrm{sp}$. } & \multirow{2}{*}{$5 \mathrm{sp}$} \\
\hline & & & & $\times$ & $\times$ & & & \\
\hline \multicolumn{9}{|l|}{$\begin{array}{l}\text { Dentalium dissimile Guppy........... } \\
\text { Dentalium dissimile Guppy } \\
\text { subsp. ponderosum Gabb.......... }\end{array}$} \\
\hline Dentalium haytense Gabb............... & \multirow[t]{2}{*}{$\times$} & & \multirow[t]{2}{*}{$x$} & & $x$ & \multirow[t]{2}{*}{$x$} & & \multirow[t]{2}{*}{$x$} \\
\hline Dentalium glaucoterrarum Maury & & & & & $x$ & & & \\
\hline $\begin{array}{l}\text { Dentalium pyrum Pilsbry and } \\
\text { Sharp............... }\end{array}$ & & & & & & $x$ & $x$ & $x$ \\
\hline $\begin{array}{l}\text { Dentalium praecursor Pilsbry and } \\
\text { Sharp }\end{array}$ & & & & & & $x$ & 人 & 乞 \\
\hline Dentalium n. sp. a............................ & & & $x$ & & & & & ....... \\
\hline Dentalium sp & & & & .... & $x$ & & $\cdots$ & ........ \\
\hline "Dentalium" rudis Gabb............... & & & & & $x$ & & & \\
\hline $\begin{array}{l}\text { Cadulus phenax Pilsbry and } \\
\text { Sharp }\end{array}$ & & X & $x$ & & & & & \\
\hline $\begin{array}{l}\text { Cadulus elegantissimus Pilsbry } \\
\text { and Sharp }\end{array}$ & & & $x$ & & & $x$ & & $x$ \\
\hline Cadulus colobus Pilsbry and & & & & & & & & 八 \\
\hline Pelecypoda: & $x$ & & $x$ & & & & & ........... \\
\hline Nucula tenuisculpta Gabb.............. & & & $x$ & & X & $x$ & $x$ & \\
\hline Leda peltella Maury not Dall....... & $x$ & & $x$ & $x$ & X & $x$ & X & ........ \\
\hline Leda n. sp. a & & & $x$ & & $\begin{array}{l}x \\
x\end{array}$ & & & \\
\hline Arca (Arca) yaquensis Maury ....... & $\cdots$ & 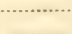 & $x$ & .... & $x$ & .......... & $x$ & $x$ \\
\hline $\begin{array}{l}\text { Area (Calloarea) n. sp. a........... } \\
\text { Area (Sheldonella) maoica Maury.. }\end{array}$ & & & $x$ & & 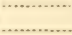 & & & \\
\hline $\begin{array}{l}\text { Arca (Sheldonella) maoica Maury.. } \\
\text { Arca (Scapharca) cibaoica Maury.- }\end{array}$ & $x$ & $x$ & $x$ & $x$ & $x$ & $x$ & & ....... \\
\hline Arca (Scapharca) henekeni Maury & & & & $?$ & $x$ & $?$ & & \\
\hline $\begin{array}{c}\text { Arca (Scapharca) corcupidonis } \\
\text { Maury }\end{array}$ & & & & & & & & \\
\hline Arca (Scapharca) arthurpennelli & $x$ & & $\lambda$ & & & $\lambda$ & & \\
\hline Maury & $x$ & X & $x$ & & $x$ & & & \\
\hline $\begin{array}{l}\text { Arca (Seapharea) arthurpennelli } \\
\text { Maury n. subsp. a }\end{array}$ & & & $x$ & & & & & \\
\hline $\begin{array}{l}\text { Arca (Scapharca) willardausteni } \\
\text { Maury }\end{array}$ & & & & & & & & \\
\hline Arca (Scapharea) caimicta Maury.- & & & & & & & & $\hat{x}$ \\
\hline $\begin{array}{l}\text { Arca (Scapharca) riocanensis } \\
\text { Maury }\end{array}$ & & & & & & & & \\
\hline $\begin{array}{l}\text { Glyeymeris acuticostata (Sower- } \\
\text { by) }\end{array}$ & & & & $x$ & $x$ & & & 人 \\
\hline $\begin{array}{l}\text { Glycymeris acuticostata (Sower- } \\
\text { by) n. subsp. a' }\end{array}$ & & & $x$ & & & & & \\
\hline Glycymeris jamaicensis Dall.......... & & & & & & & & $x$ \\
\hline Glycymeris n. sp. a & & & x & & & & & \\
\hline Glycymeris n. sp. b............... & & & & & & & & $x$ \\
\hline Pteria inornata Gabb........ & $x$ & & $x$ & & & & & \\
\hline Ostrea folium Linnaeus..... & & & $x$ & & & & & \\
\hline 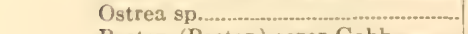 & & & & x & & & & \\
\hline Pecten (Pecten) soror Gabb. & ...... & $\ldots \ldots$ & & $x$ & $x$ & & & \\
\hline Pecten (Aequipecten) thetidis & & & & & & & & \\
\hline Maury not Sowerby.................... & & & & $x$ & X & & & $\mathrm{X}$ \\
\hline
\end{tabular}


Faunal list-Continued.

\begin{tabular}{|c|c|c|c|c|c|c|c|c|}
\hline \multirow{2}{*}{ Species. } & \multirow{2}{*}{$\begin{array}{c}\text { Rio } \\
\text { Albano. } \\
8729\end{array}$} & \multicolumn{4}{|c|}{$\begin{array}{l}\text { Rio } \\
\text { Mao. }\end{array}$} & \multicolumn{2}{|c|}{$\begin{array}{l}\text { Rio } \\
\text { Gurabo. }\end{array}$} & \multirow{2}{*}{$\begin{array}{c}\text { Rio } \\
\text { Cana. } \\
8534\end{array}$} \\
\hline & & 8529 & 8525 & 8526 & 8621 & 8737 & 8738 & \\
\hline \multicolumn{9}{|l|}{ 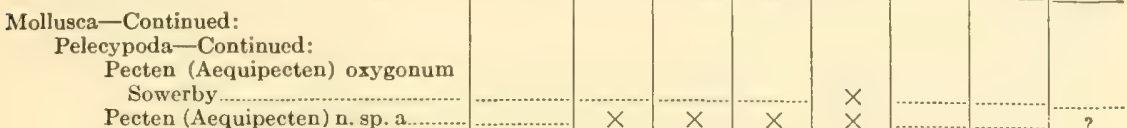 } \\
\hline $\begin{array}{l}\text { Pecten (Aequipecten) n. sp. a.......... } \\
\text { Pecten (Aequipecten) n. sp. b....... }\end{array}$ & & $x$ & $x$ & $x$ & $x$ & $x$ & & $?$ \\
\hline Pecten (Aequipecten) n. sp. c......... & & & & & & A & \multirow{2}{*}{$\times$} & \\
\hline $\begin{array}{l}\text { Pecten (Plagioctenium) excen- } \\
\text { tricus Gabb }\end{array}$ & \multirow[t]{3}{*}{ X } & \multirow[b]{2}{*}{$\times$} & \multirow{2}{*}{$\begin{array}{l}x \\
x\end{array}$} & \multirow{6}{*}{\begin{tabular}{c} 
\\
$\times$ \\
\hdashline
\end{tabular}} & \multirow{4}{*}{$\begin{array}{l}x \\
\times \\
x \\
x\end{array}$} & & & \\
\hline $\begin{array}{l}\text { Pecten (Plagioctenium) thomp- } \\
\text { soni Maury }\end{array}$ & & & & & & & & \\
\hline $\begin{array}{l}\text { Pecten (Plagioctenium) n. sp....... } \\
\text { Pecten (Plagioctenium) sp. }\end{array}$ & & & & & & & & \\
\hline Pecten (Plagioctenium) sp............. & & & & & & & & \\
\hline $\begin{array}{l}\text { Pecten (Amusium) papyraceus } \\
\text { Gabb }\end{array}$ & & & & & X & & & \\
\hline Pecten (Pseudamusium) n. sp....... & ...... & & $x$ & & $x$ & & & \\
\hline Spondylus sp. indt. & & & & & $\times$ & & & \\
\hline Anomia simplex d'Orbigny .............. & & & & $x$ & $?$ & & & \\
\hline 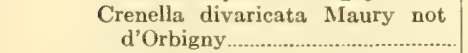 & \multirow[t]{2}{*}{$\times$} & & \multirow{6}{*}{$\begin{array}{l}x \\
x \\
x \\
x \\
x\end{array}$} & & $x$ & & & \\
\hline Julia n. sp. a & & & & & & & & \\
\hline Pandora inconspicua Gabb............ & \multirow[t]{2}{*}{$\times$} & & & & & & & \\
\hline $\begin{array}{l}\text { Cuspidaria (Cardiomya) isla- } \\
\text { hispaniolae Maury................ }\end{array}$ & & & & & & & & \\
\hline $\begin{array}{c}\text { Crassinella guppyi Maury not } \\
\text { Dall }\end{array}$ & & & & & & & & \\
\hline Crassinella n, sp. a & & & & & & & & \multirow{5}{*}{$\begin{array}{l}x \\
\times \\
x \\
x\end{array}$} \\
\hline $\begin{array}{l}\text { Venericardia scabricostata Maury } \\
\text { not Guppy }\end{array}$ & & & \multirow{2}{*}{$x$} & \multirow{2}{*}{$\times$} & \multirow{2}{*}{$\times$} & & & \\
\hline Venericardia n. sp. a & & & & & & & & \\
\hline Chama innoluta Guppy & & & & & $\times$ & & & \\
\hline 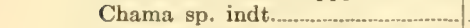 & & & \multirow{2}{*}{$x$} & & & & & \\
\hline Myrtaea lomasdesamba Maury.... & & & & & $\mathrm{x}$ & & & \\
\hline Lucina chrysostoma Philippi....... & & & x & & & & & \\
\hline Lucina n. sp. a & & & $x$ & & & & & \\
\hline Lucina n. sp. b. & & & & & & $x$ & $x$ & \\
\hline Phacoides (Here) n. sp. a................... & & & $x$ & & & $\lambda$ & $\lambda$ & \\
\hline Phacoides (Here) sp............................. & & & & $x$ & & & & \\
\hline Phacoides (Cavilucina) n. sp. a..... & & & $x$ & & & & & \\
\hline Phacoides (Lucinisea) hispani- & & & & & & & & \\
\hline $\begin{array}{l}\text { olensis Maury .............................. } \\
\text { Phacoides (Parvilucina) yaquensis }\end{array}$ & & & $x$ & & & & & \\
\hline$(\mathrm{Gabb})$ & $x$ & & $x$ & & $\times$ & $x$ & $x$ & $\times$ \\
\hline $\begin{array}{l}\text { Phacoides (Miltha) smithwood- } \\
\text { wardi Maury }\end{array}$ & & & $x$ & & & & & \\
\hline Phacoides (Miltha) sp. & & & & & & & $x$ & \\
\hline Divaricella prevaricata Maury & & & & & & & & \\
\hline $\begin{array}{l}\text { not Guppy } \\
\text { Diplodonta capuloides (Gabb) }\end{array}$ & $\begin{array}{l}x \\
x\end{array}$ & & $\begin{array}{l}x \\
x\end{array}$ & & $x$ & $x$ & $x$ & \\
\hline $\begin{array}{l}\text { Diplodonta capuloides (Gabb) } \\
\text { Diplodonta subquadrata (Gabb)?.- }\end{array}$ & $x$ & & & & & & & \\
\hline $\begin{array}{l}\text { Diplodonta (Phlyetiderma) punc- } \\
\text { turella Maury not Dall }\end{array}$ & & & $x$ & & & & & \\
\hline Montacuta maoica Maury & & & $\hat{x}$ & & & & & \\
\hline Montacuta hispaniolae Maury ...... & & & $x$ & & & & & \\
\hline Montacuta ? n. sp. a & & & $x$ & & & $x$ & & \\
\hline Sportella n. sp. & & & $x$ & & & & & \\
\hline $\begin{array}{l}\text { Cardium (Trachycardium) tin- } \\
\text { tinnabularum Maury }\end{array}$ & & & $x$ & & & & & \\
\hline $\begin{array}{l}\text { Cardium (Trachycardium) do- } \\
\text { minicanum Dall }\end{array}$ & $x$ & & $x$ & $x$ & & & & \\
\hline Cardium (Trachycardium) sp.indt. & & & & & $x$ & $x$ & & $x$ \\
\hline 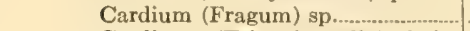 & $\ldots$ & & & & & & & $\hat{x}$ \\
\hline $\begin{array}{l}\text { Cardium (Trigoniocardia) hai- } \\
\text { tense Sowerby }\end{array}$ & & & & & & & & \\
\hline & & & & & & & & \\
\hline
\end{tabular}


Faunal list-Continued.

\begin{tabular}{|c|c|c|c|c|c|c|c|c|}
\hline \multirow{2}{*}{ Species. } & \multirow{2}{*}{$\begin{array}{c}\begin{array}{c}\text { Rio } \\
\text { Albano. }\end{array} \\
8729\end{array}$} & \multicolumn{4}{|c|}{$\begin{array}{c}\text { Rio } \\
\text { Mao. }\end{array}$} & \multicolumn{2}{|c|}{$\begin{array}{l}\text { Rio } \\
\text { Gurabo. }\end{array}$} & \multirow{2}{*}{$\begin{array}{c}\text { Rio } \\
\text { Cana. }\end{array}$} \\
\hline & & 8529 & 8525 & 8526 & 8621 & 8737 & 8738 & \\
\hline \multirow{2}{*}{\multicolumn{9}{|c|}{ 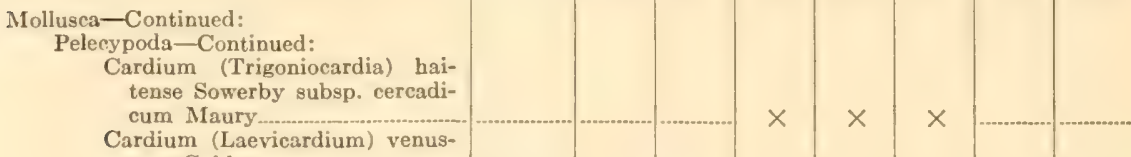 }} \\
\hline & & & & & & & & \\
\hline 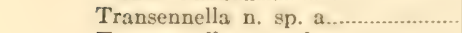 & & & $x$ & & & & & \\
\hline Transennella n. sp. b. & & & 人 & & $x$ & X & $x$ & $\times$ \\
\hline 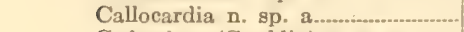 & & & & & $x$ & & & $x$ \\
\hline Gafrarium (Gouldia) n. sp. a ....... & & & $x$ & & & & & \\
\hline $\begin{array}{l}\text { Pitaria (Lamelliconcha) plani- } \\
\text { vieta (Guppy) }\end{array}$ & & & $?$ & $x$ & $x$ & $x$ & & \\
\hline $\begin{array}{l}\text { Pitaria (Lamelliconcha) cercadica } \\
\text { Maury }\end{array}$ & & & $\times$ & & & & & \\
\hline $\begin{array}{l}\text { Pitaria (Lamelliconcha) circinata } \\
\text { (Born) }\end{array}$ & & & & & & & & $x$ \\
\hline $\begin{array}{l}\text { Pitaria (Lamelliconcha) acutico- } \\
\text { stata (Gabb) }\end{array}$ & $x$ & & & & & & & \\
\hline Chione woodwardi (Guppy) ............. & & & & & $\times$ & X & $x$ & \\
\hline Chione n. sp. a & .................. & ............ & $x$ & $x$ & & & & ................ \\
\hline Chione n. sp. b. & ................ & & $\times$ & $\times$ & & & & \\
\hline 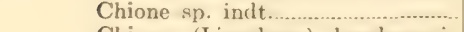 & & & & & & & & $x$ \\
\hline $\begin{array}{l}\text { Chione (Lirophora) hendersoni } \\
\text { Dall }\end{array}$ & & & & & & & & \\
\hline Cytherea sp. indt & & & & $\times$ & & & & \\
\hline Tellina (Eurytellina) maoica & & & X & & & & & \\
\hline Tellina (Eurytellina) riocanensis & & & A & & & & & \\
\hline Maury & & & & & & $?$ & & $x$ \\
\hline $\begin{array}{l}\text { Tellina (Eurytellina) cibaoica } \\
\text { Maury }\end{array}$ & & & & & & & & \\
\hline Tellina (Eurytellina) n. sp. a & & & ....... & & & & & $\hat{x}$ \\
\hline Tellina (Moerella) n. sp. a.............. & & & $x$ & & & & & \\
\hline $\begin{array}{l}\text { Tellina (Merisca?) islahispaniolae } \\
\text { Maury }\end{array}$ & & & & & & & & \\
\hline $\begin{array}{l}\text { Tellina (Merisca) crystallina } \\
\text { Maury not Chemnitz }\end{array}$ & & & & & & & & \\
\hline Tellina (Scissula) cercadica & & & X & & & & & \\
\hline Maury & & & X & & & & & \\
\hline Tellina (Scissula) seitula Dall........ & $x$ & & $x$ & & & $x$ & $x$ & $x$ \\
\hline Tellina (Scissula) n. sp. a & & & $x$ & & & & & \\
\hline Tellina sp. indt. & & & & ....... & $x$ & & $x$ & $x$ \\
\hline Strigilla pisiformis (Linnaeus) & X & & $x$ & & $x$ & X & & ............ \\
\hline Macoma n. sp. a & & & $x$ & & & & & \\
\hline Macoma n. sp. b & & ...... & ........... & & & & N. & $\times$ \\
\hline $\begin{array}{l}\text { Macoma (Psammacoma) yaquen- } \\
\text { sis Maury }\end{array}$ & & & $x$ & & & & & \\
\hline Semele claytoni Maury................. & & & $x$ & & & & & $x$ \\
\hline 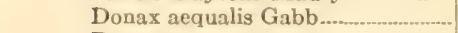 & $\ldots \ldots$ & ....-_-.... & $x$ & & & $x$ & $x$ & $\ddot{x}$ \\
\hline Donax n. sp. a. & & & $x$ & & & & & \\
\hline Psammosolen sanctidominici & & & & & & & & \\
\hline 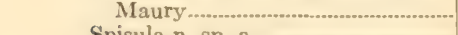 & $x$ & & 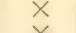 & $\stackrel{?}{\vee}$ & $?$ & & & \\
\hline Spisula n. sp. a. & & . & $x$ & $x$ & & & & $x$ \\
\hline Ervilia n. sp. b ..... & $\stackrel{x}{x}$ & & & $x$ & & & & \\
\hline $\begin{array}{l}\text { Corbula cereadica Maury } \\
\text { Corbula (Aloidis) vieta Guppy......... }\end{array}$ & x & x & $x$ & $x$ & $\begin{array}{l}x \\
x\end{array}$ & $x$ & & $x$ \\
\hline Corbula (Brothrocorbula) vi- & & & & & & & & \\
\hline minea Guppy & & & $x$ & $x$ & X & $x$ & $x$ & $x$ \\
\hline $\begin{array}{l}\text { Teredo incrassata (Gabb) } \\
\text { Clavigella sp.......... }\end{array}$ & & & $x$ & & & $x$ & $x$ & $\underset{y}{X}$ \\
\hline 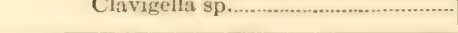 & & & & & & & & \\
\hline
\end{tabular}


According to Dr. Maury's faunal lists the following additional species of Mollusca were collected by the Maury expedition from the Cercado formation.

Faunal list.

\begin{tabular}{|c|c|c|c|c|}
\hline & \multicolumn{2}{|c|}{ Rio Mao. } & \multicolumn{2}{|c|}{ Rio Cana. } \\
\hline & Bluff 3. & Bluff 2. & Zone $\mathbf{H}$. & Zone $\mathbf{I}$ \\
\hline \multicolumn{5}{|l|}{$\begin{array}{l}\text { Mollusea: } \\
\text { Gastropoda: }\end{array}$} \\
\hline \multirow{3}{*}{\multicolumn{5}{|c|}{$\begin{array}{l}\text { Bullaria granosa (Sowerby) } \\
\text { Bullaria......... } \\
\text { Conus baytensis Sowerby }\end{array}$}} \\
\hline & & & & \\
\hline & & & & \\
\hline \multicolumn{5}{|l|}{ Conus molis Brown and Pilsbry } \\
\hline \multicolumn{5}{|l|}{ Conus proteus Hwass. } \\
\hline \multirow{2}{*}{\multicolumn{5}{|c|}{ 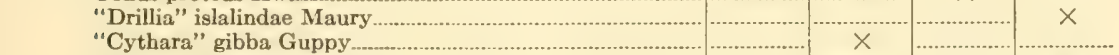 }} \\
\hline & & & & \\
\hline \multicolumn{5}{|l|}{ 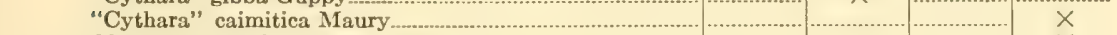 } \\
\hline \multicolumn{5}{|l|}{ 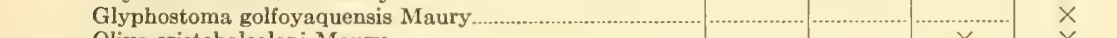 } \\
\hline \multirow{2}{*}{\multicolumn{5}{|c|}{$\begin{array}{l}\text { Oliva cristobalcoloni Maury } \\
\text { Lyria pulchella (Sowerby) }\end{array}$}} \\
\hline & & & & \\
\hline \multicolumn{5}{|l|}{ Latirus fusiformis Gabb } \\
\hline \multirow{2}{*}{\multicolumn{5}{|c|}{$\begin{array}{l}\text { Fusus henekeni Sowerby subsp. haitensis Sowerby } \\
\text { Fusus heneknei Sowerby subsp. veatchi Maury }\end{array}$}} \\
\hline & & & $x$ & \\
\hline \multicolumn{5}{|l|}{ Phos fasciolatus Dall } \\
\hline \multirow{2}{*}{\multicolumn{5}{|c|}{$\begin{array}{l}\text { Bursa amphitrites Maury } \\
\text { Pyrula pilsbryi Smith }\end{array}$}} \\
\hline \multirow{2}{*}{\multicolumn{5}{|c|}{$\begin{array}{l}\text { Pyrula pilsbryi Smith } \\
\text { Cypraea henekeni Sowerby }\end{array}$}} \\
\hline & & & & \\
\hline \multirow{2}{*}{\multicolumn{5}{|c|}{$\begin{array}{l}\text { Cypraea spurca Linnaeus. } \\
\text { Trivia suffusa Gray subsp. sanctidominici Maury }\end{array}$}} \\
\hline Trivia suffusa Gray subsp. sanctidominici Maury & & & & \\
\hline \multicolumn{5}{|l|}{ Trivia globosa Gray } \\
\hline Cerithium uniseriale Sowerby & ...... & $x$ & ..... & (...................... \\
\hline Turritella planigyrata Guppy & . & $x$ & & \\
\hline Fissuridea henekeni Maury & & & $\times$ & \\
\hline Aclis acuminatoides Maury....... & + & & & \\
\hline Melanella jaculum Maury & + & & & \\
\hline $\begin{array}{l}\text { Arca occidentalis Philippi............ } \\
\text { Arca umbonata Lamarck }\end{array}$ & & & $\hat{x}$ & \\
\hline Arca (Acar) reticulata Gmelin & $x$ & & & \\
\hline Arca (Calloarca) submarylandica Maury.... & & & $x$ & \\
\hline Arca (Scapharca) golfoyaquensis Maury.... & & & $x$ & \\
\hline Arca (Scapharca) inaequilateralis Guppy ..... & & & & $x$ \\
\hline 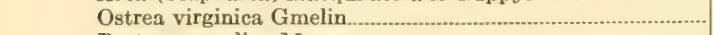 & $x$ & & & \\
\hline 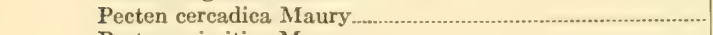 & & $x$ & & \\
\hline Pecten caimitica Maury & & & & $x$ \\
\hline Pecten nodosus Linnaeus......... & & & $x$ & (n................... \\
\hline Modiolus cercadicus Maury.... & $x$ & $-\ldots$ & & \\
\hline Modiolus maonis Maury.............. & $x$ & & & \\
\hline Botula hispaniolae Maury ................ & & $\ldots . .$. & $x$ & ........................... \\
\hline Lithophaga antillarum d'Orbigny.... & & & $x$ & (n.................... \\
\hline Lithophaga nigra d'Orbigny & & & $x$ & ...................... \\
\hline Mytilopsis domingensis Recluz & & & $x$ & \\
\hline Coralliophila coralliophila (Gmelin) & & & $x$ & \\
\hline Chama caimitica Maury & & & $x$ & 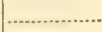 \\
\hline Chama congregatoides Maury & & & $x$ & $\ldots \ldots$ \\
\hline 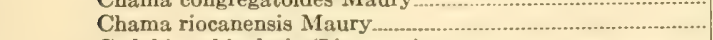 & & & $x$ & ............ \\
\hline Codakia orbicularis (Linnaeus) & & & $x$ & \\
\hline Phacoides domingensis Dall & & $x$ & & \\
\hline Phacoides (Lucinisca) cereadica Maury.... & $x$ & & & \\
\hline Phacoides (Miltha) riocanensis Maury...... & & & $x$ & (n)....... \\
\hline Phacoides (Bellucina) actinus Dall............. & & & $x$ & (................ \\
\hline Montacuta cercadica Maury & $x$ & & & ................... \\
\hline Cardium (Trachycardium) linguatigris Maury..... & & & $x$ & . \\
\hline Antigona tarquinina Dall. & & & $x$ & ........... \\
\hline Petricola caimitica Maury & & & $x$ & . \\
\hline Petricola (Rupellaria) riocanensis Maury... & & & $x$ & \\
\hline
\end{tabular}


Faunal list-Continued.

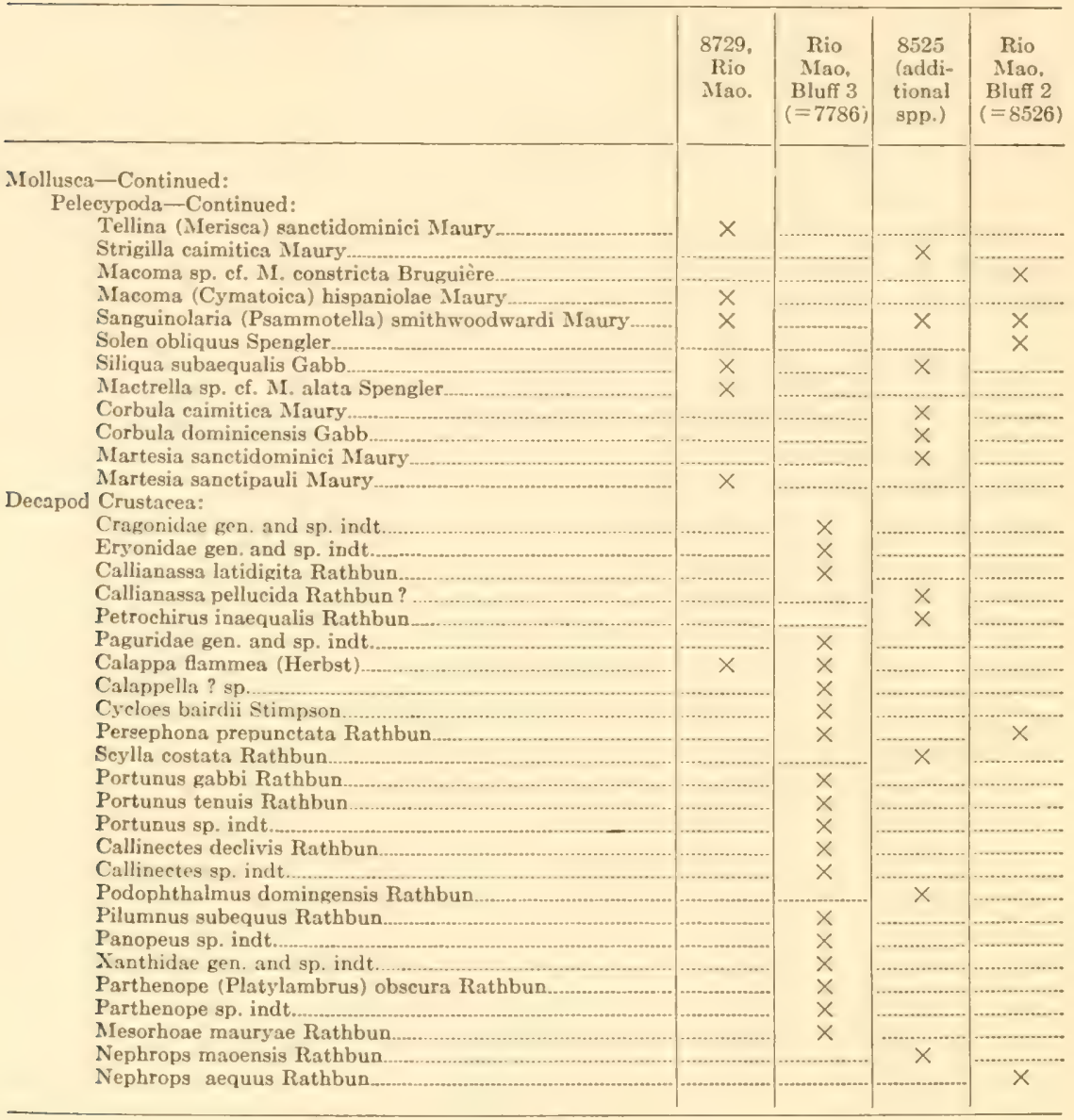

\section{Modified Cercado Fauna.}

List of stations.

Province of Monte Cristi, Rio Gurabo, Zone G, 2 miles above Los Quemados. C. J. Maury, collector. May, 1916.

8522 (C-28). Province of Santiago, bluff on right bank of Rio Mao, about 3 to 3.5 kilometers above Cercado de Mao; fossils from 4.5 to 9 meters above water. T. W. Vaughan and C. W. Cooke, collectors. May 4, 1919.

8739 (D. C. 65). Province of Monte Cristi, about 9.5 kilometers up Rio Gurabo from Gurabo Adentro; fossils from below conglomerate. D. D. Condit, collector. May 9, 1919.

F raminifera:

\section{Faunal list.}

Asterigerina rotundata Cushman. Zone G, Rio Gurabo.

Orbiculina adunca (Fichtel \& Moll). 
Faunal list.

\begin{tabular}{|c|c|c|}
\hline Spscies. & $\begin{array}{l}\text { Rio } \\
\text { Mao } \\
8522\end{array}$ & $\begin{array}{c}\text { Rio } \\
\text { Gurabo } \\
8739\end{array}$ \\
\hline \multicolumn{3}{|l|}{ Corals: } \\
\hline Placocyathus variabilis Dunean. & \multicolumn{2}{|c|}{ Placocyathas n. sp. a } \\
\hline \multicolumn{3}{|l|}{ Antillia bilobata Duncan } \\
\hline \multicolumn{3}{|l|}{ Thysanus corbicula Duncan } \\
\hline \multicolumn{3}{|l|}{ Teleiophylla n. sp. a a } \\
\hline \multicolumn{3}{|l|}{ 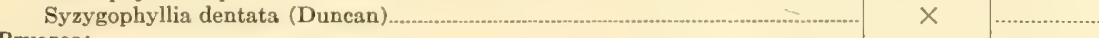 } \\
\hline \multicolumn{3}{|l|}{ Bryozoa: } \\
\hline \multicolumn{3}{|l|}{$\begin{array}{l}\text { Cupularia denticulata Defrance.............................. } \\
\text { Metrarabdotos colligatum Canu \& Bassler }\end{array}$} \\
\hline \multirow{2}{*}{\multicolumn{3}{|c|}{$\begin{array}{l}\text { Mollusca: } \\
\text { Gastropoda: }\end{array}$}} \\
\hline & & \\
\hline \multicolumn{3}{|l|}{$\begin{array}{l}\text { Gastropoda: } \\
\text { Acteon riomaensis Maury.... }\end{array}$} \\
\hline \multicolumn{3}{|l|}{ Ringicula dominicensis Maury } \\
\hline \multirow{2}{*}{\multicolumn{3}{|c|}{$\begin{array}{l}\text { Acteocina recta Maury not d'Orbigny.... } \\
\text { Acteocina n. sp. a }\end{array}$}} \\
\hline & & \\
\hline \multicolumn{3}{|l|}{ Acteocina n. sp. b.... } \\
\hline \multicolumn{3}{|l|}{ Retusa sp. indt...................... } \\
\hline \multicolumn{3}{|l|}{$\begin{array}{l}\text { Volvula cylindrica Gabb................... } \\
\text { Bullaria paupercula (Sowerby) }\end{array}$} \\
\hline \multirow{2}{*}{\multicolumn{3}{|c|}{$\begin{array}{l}\text { Bullaria paupercula (Sowerby) } \\
\text { Atys n. sp. c }\end{array}$}} \\
\hline & & $x$ \\
\hline Atys (Alicula) yaquensis Maury & & $x$ \\
\hline Atys (Alicula) n. sp. a & $x$ & \\
\hline Terebra (Strioterebra) cambiarsoi Maury n. subsp. a'........... & & $x$ \\
\hline 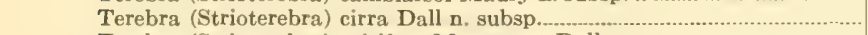 & & $x$ \\
\hline Terebra (Strioterebra) spirifera Maury not Dall & & $x$ \\
\hline Terebra (Strioterebra) n. sp. g & $x$ & \\
\hline 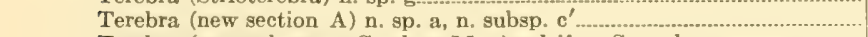 & 入 & $x$ \\
\hline Terebra (new subgenus, Gardner Mss.) sulcifera Sowerby................ & $x$ & \\
\hline Conus haytensis Sowerby & $x$ & \\
\hline 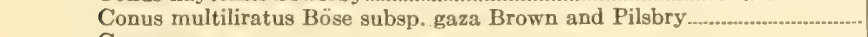 & & $x$ \\
\hline Conus n. sp. a & $x$ & X \\
\hline 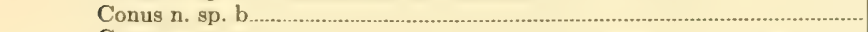 & $x$ & \\
\hline 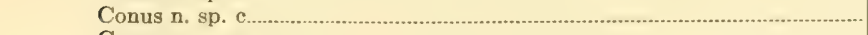 & ……........ & $x$ \\
\hline Conus n. sp. g & .......... & $x$ \\
\hline Conus n. sp. h & & $x$ \\
\hline "Clavatula" labiata Gabb & $x$ & \\
\hline Surcula (Pleurofusia) n. sp. a & $x$ & \\
\hline Turris (Pleuroliria) haitensis (Sowerby) ........................... & $x$ & \\
\hline 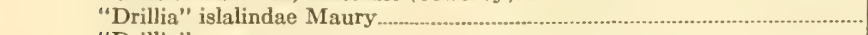 & & $?$ \\
\hline 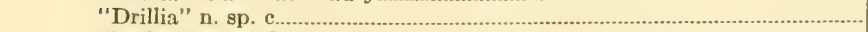 & $x$ & \\
\hline 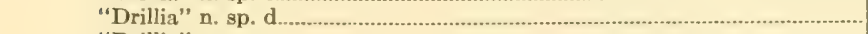 & $x$ & \\
\hline "Drillia" sp................................ & $x$ & \\
\hline "Mangilia" n. sp. f & & $x$ \\
\hline "Mangilia" n. sp. g. & & $x$ \\
\hline 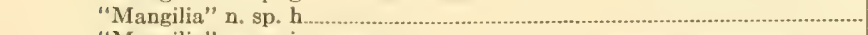 & $x$ & \\
\hline "Mangilia" n. sp. i........................... & $x$ & \\
\hline "Cythara" polygona (Gabb)....... & & $x$ \\
\hline "Cythara" heptagona (Gabb) & $x$ & \\
\hline "Cythara" n. sp. a & & $x$ \\
\hline 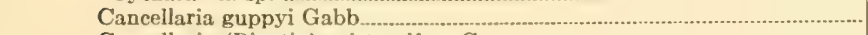 & $x$ & $x$ \\
\hline Cancellaria (Bivetia) epistomifera Guppy & & $x$ \\
\hline 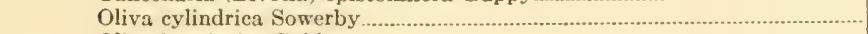 & $x$ & \\
\hline 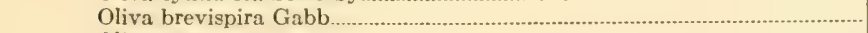 & & $x$ \\
\hline 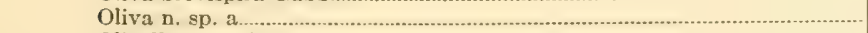 & & $x$ \\
\hline 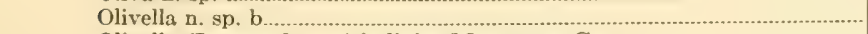 & $x$ & \\
\hline Olivella (Lamprodroma) indivisa Maury not Guppy & $x$ & $x$ \\
\hline Olivella (Lamprodroma) muticoides Gabb & $x$ & \\
\hline Olivella (Lamprodroma) n. sp. c & & $x$ \\
\hline Marginella hispaniolensis Maury & $x$ & $x$ \\
\hline Marginella n. sp. a & $x$ & \\
\hline Marginella n. sp. c & $x$ & \\
\hline Marginella $\mathrm{n} . \mathrm{sp} . \mathrm{d}$ & $x$ & \\
\hline
\end{tabular}


Faunal list-Continued.

\begin{tabular}{|c|c|c|}
\hline Species. & $\begin{array}{c}\text { Rio } \\
\text { Mao } \\
8522\end{array}$ & $\begin{array}{c}\text { Rio } \\
\text { Gurabo } \\
8739\end{array}$ \\
\hline \multicolumn{3}{|l|}{$\begin{array}{l}\text { Mollusca-Continued: } \\
\text { Gastropoda-Continued: }\end{array}$} \\
\hline 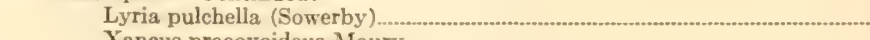 & X & $x$ \\
\hline Xancus praeovoideus Maury .......... & & $\mathrm{x}$ \\
\hline $\begin{array}{l}\text { Melongena consors (Sowerby).......... } \\
\text { Fusus henekeni Sowerby }\end{array}$ & $x$ & $x$ \\
\hline $\begin{array}{l}\text { Fusus henekeni Sowerby } \\
\text { Phos gabbi Dall }\end{array}$ & $x$ & \\
\hline $\begin{array}{l}\text { Phos gabbi Dall } \\
\text { Alectrion cercadensis Maury }\end{array}$ & $x$ & $x$ \\
\hline $\begin{array}{l}\text { Alectrion cercadensis Maury } \\
\text { Alectrion losquemadica Maury }\end{array}$ & & $x$ \\
\hline Alectrion losquemadica Maury & $x$ & \\
\hline 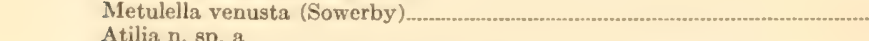 & $\times$ & $x$ \\
\hline Atilia n. sp. a & $\times$ & \\
\hline Atilia (Columbellopsis) exilis (Gabb) & & $x$ \\
\hline Strombina pseudohaitensis Maury subsp. gurabensis Maury & & $x$ \\
\hline Murex messorius Maury not Sowerby & & $\hat{x}$ \\
\hline 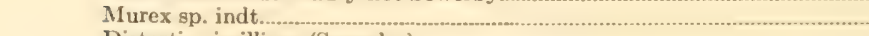 & $x$ & \\
\hline 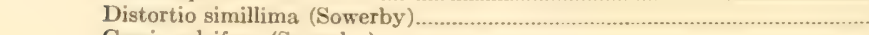 & $x$ & \\
\hline Cassis sulcifera (Sowerby) & $x$ & \\
\hline Cassis (Semicassis) reclusa Guppy & & ? \\
\hline 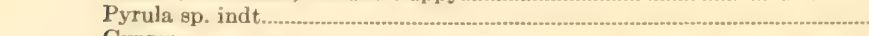 & $x$ & \\
\hline Cypraea n. sp. a & & $x$ \\
\hline Strombus proximus Sowerby..... & & $x$ \\
\hline Clava plebeia (Sowerby) .............. & X & $x$ \\
\hline Clava n. sp. a & $x$ & \\
\hline 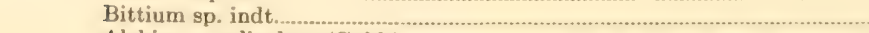 & & $x$ \\
\hline 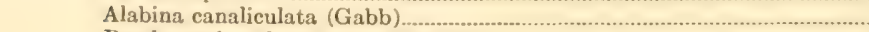 & & $x$ \\
\hline Petaloconchus domingensis Sowerby .................. & $x$ & $x$ \\
\hline 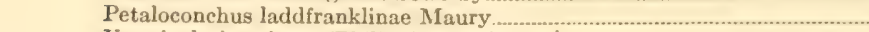 & $x$ & \\
\hline Vermicularia spirata (Philippi) n. subsp. $a^{\prime} \ldots \ldots \ldots \ldots$ & $\hat{x}$ & \\
\hline Architectonica quadriseriata (Sowerby) & $\times$ & \\
\hline 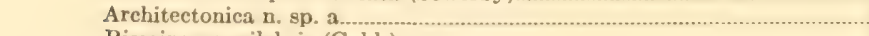 & $x$ & \\
\hline Rissoina crassilabris (Gabb) & $x$ & $x$ \\
\hline 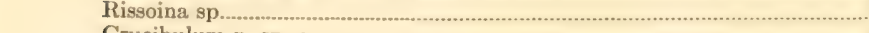 & $\times$ & \\
\hline Crucibulum n. sp, a. & & $x$ \\
\hline Natica canrena Linnaeus $\mathbf{n}$. subsp. a' & & $x$ \\
\hline 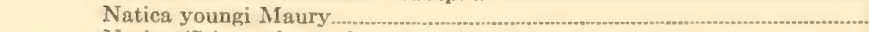 & $x$ & \\
\hline 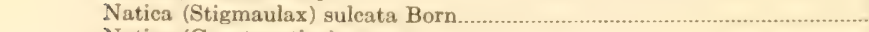 & & $x$ \\
\hline Natica (Cryptonatica) n. sp. a & $x$ & $x$ \\
\hline 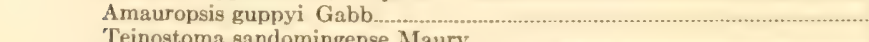 & $x$ & Y \\
\hline $\begin{array}{l}\text { Teinostoma sandomingense Maury } \\
\text { Phasianella (Eucosomia) punctata (Gabb) }\end{array}$ & $x$ & $\begin{array}{l}x \\
x\end{array}$ \\
\hline Calliostoma sp. indt. & $\ddot{x}$ & \\
\hline 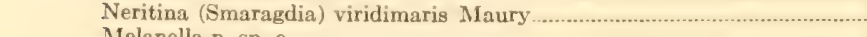 & $x$ & Y \\
\hline $\begin{array}{l}\text { Melanella n. sp. e } \\
\text { Pyramidellidae }\end{array}$ & & 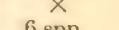 \\
\hline $\begin{array}{l}\text { Pyramidellidae } \\
\text { Scaphopoda: }\end{array}$ & & 6 spp. \\
\hline $\begin{array}{l}\text { Scaphopoda: } \\
\text { Dentalium dissimile Guppy }\end{array}$ & $x$ & \\
\hline 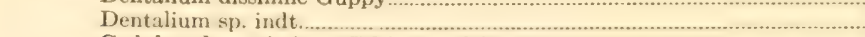 & $\hat{x}$ & \\
\hline Cadulus elegantissimus Pilsbry and Sharp & & $x$ \\
\hline Pelecypoda: & & \\
\hline Leda peltella Maury not Dall $\ldots . .$. & & $x$ \\
\hline Leda n. sp. a & $x$ & $\ldots \ldots$ \\
\hline Arca (Arca) yaquensis Maury & $x$ & $x$ \\
\hline Area (Calloarea) n. sp. a & $x$ & $x$ \\
\hline Area (Seapharca) cibaoica Maury & $x$ & $x$ \\
\hline Arca (Scapharca) golfoyaquensis Maury & $x$ & $x$ \\
\hline Arca (Scapharca) riocanensis Maury & & $x$ \\
\hline 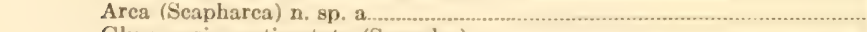 & & $x$ \\
\hline Glycymeris acuticostata (Sowerby) & $x$ & \\
\hline Glycymeris acuticostata (Sowerby) n. sub. sp. a' & .1.... & $x$ \\
\hline 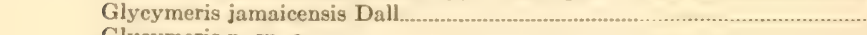 & & $x$ \\
\hline Glycymeris n. sp. a & $x$ & \\
\hline 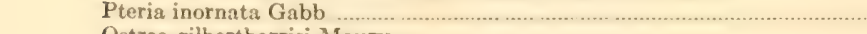 & & $?$ \\
\hline Ostrea gilbertharrisi Maury & $x$ & \\
\hline 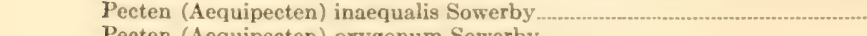 & $x$ & $x$ \\
\hline Pecten (Aequipecten) oxygonum Sowerby.................... & $x$ & \\
\hline
\end{tabular}


Faunal list-Continued.

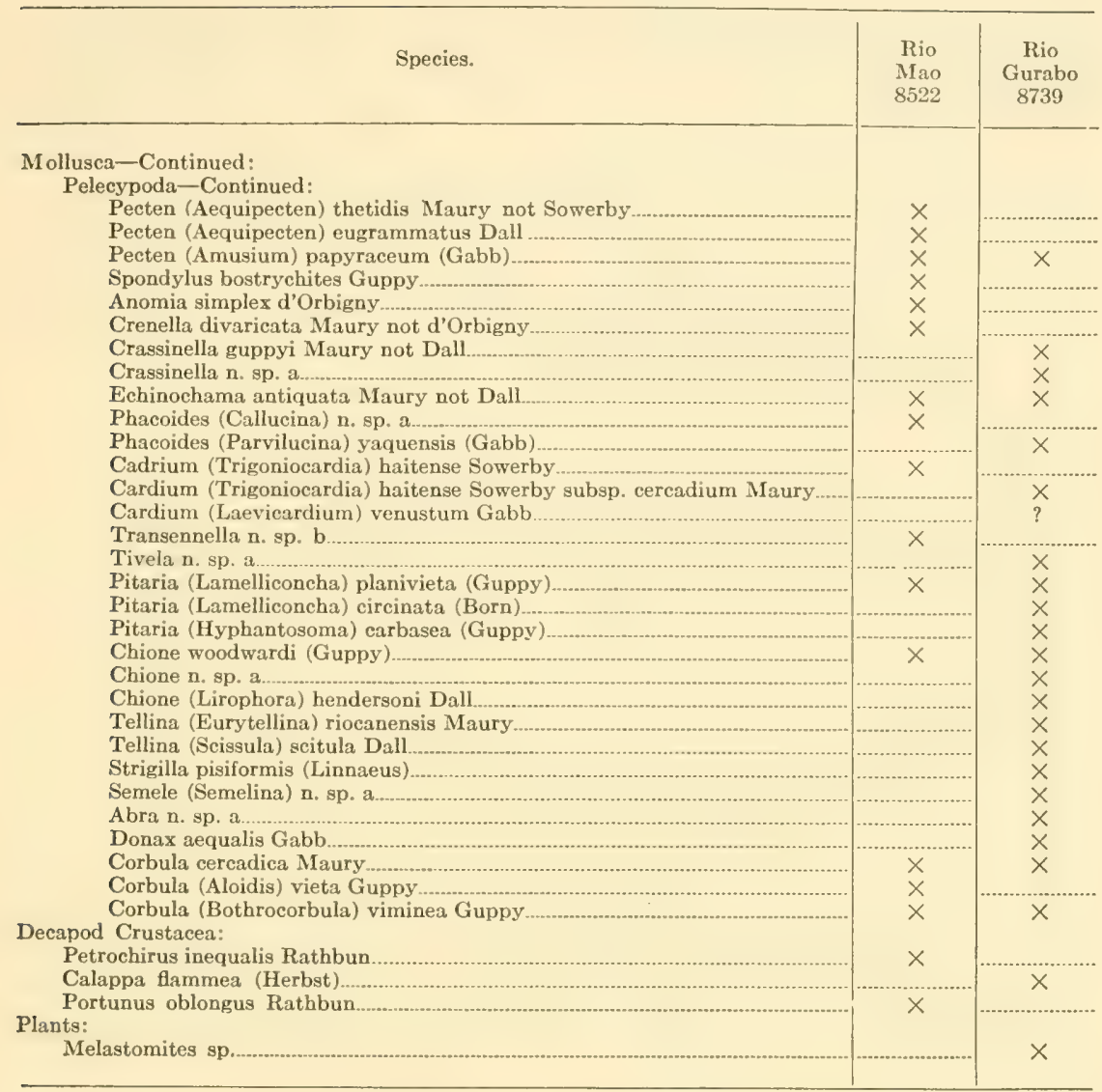

According to Dr. Maury's faunal list the following additional species of mollusks were collected from "Zone G," Rio Gurabo:

Gastropoda:

Conus consobrinus Sowerby.

Conus tortuostriatus Toula.

Conus marginatus Scwerby.

Conus bonaczyi Gabb.

Cancellaria (Aphera) islacolonis Maury.

Fasciolaria semistriata Sowerby.

Strombina nuestrasenovae Maury.

Cassis (Phalium) monilifera Guppy.

Dolium (Malea) camura (Guppy).

Cypraea henekeni Sowerby.

Strombus haitensis Sowerby.

Amauropsis guppi Gabb subsp. gurabensis Maury. 
Sinum gatunense (Toula).

Turbo dominicensis Gabb subsp. laloi Maury.

Calliostoma grabaui Maury.

Scaphopoda:

Dentalium dissimile Guppy subsp. ponderosum Gabb.

Cadulus denticulus-tigris Maury.

Pelecypoda:

Arca (Scapharea) inaequilateralis Guppy.

Venericardia scabricostata Guppy.

Protocardia gurabica Maury.

Pitaria (Lamelliconcha) acuticostata Gabb.

Tellina waylandvaughani Maury.

\section{Gurabo Formation.}

List of stations.

(For maps of Rio Mao and Rio Gurabo see Plates IX and XI.)

Province of Santiago, Potrero, Rio Ảmina. C. J. Maury, collector. May 22, 1916. Province of Santiago, Ric Mao, Bluff 1, a mile above Cercado. C. J. Maury, collector. May 1919.

Province of Monte Cristi, Rio Gurabo, zone A at Los Quemados. C. J. Maury, collector. May 1916.

Province of Monte Cristi, Rio Gurabo, zones B, D, E, and F, above Los Quemados. C. J. Maury, collector. May 1916.

7791. Province of Monte Cristi, Los Quemados, limestone. C. J. Maury, collector. May 1916.

8714 (D. C. 44). Province of Santiago, Rio Yaque del Norte, about 3.5 kilometers S. $25^{\circ} \mathrm{W}$. of wireless tower at Santiago. D. D. Condit, collector. April 24, 1919.

8715 (D. C. 45). Province of Santiago, Rio Yaque del Norte, station 5 cf traverse above Santiago, above Las Charcas. D. D. Condit, collector. April 24, 1919.

8726 (D. C. 52). Province of Santiago, La Canela, south side of Rio Yaque del Norte, 15 kilometers west of Santiago. T. W. Vaughan and C. W. Cooke, collectors. May 1, 1919.

8727 (D. C. 53). Province of Santiago, 13 kilometers from Potrero on trail to San José de Las Matas. D. D. Condit, collector. May 2, 1919.

8728 (D. C. 54). Province of Santiago, about 14 kilometers from Potrero on trail to San José de los Matas. D. D. Condit, collector. May 2, 1919.

8516 (C-22). Province of Santiago, bluff on right bank Rio Ámina at ford near

Potrero. T. W. Vaughan and C. W. Cooke, collectors. May 2, 1919.

8517 (C 8517 (C-23). Province of Santiago, left bank of Rio Ảmina about 0.5 kilometer upstream from crossing at Potrero. T. W. Vaughan and C. W. Cooke, collectors. May 2, 1919.

8518 (C-24). Province of Santiago, left bank Rio Ámina about 0.8 kilometer above crossing at Potrero; next horizon below 8516 (C-22). T. W. Vaughan and C. W. Cooke, collectors. May 2, 1919.

8523 (C-29). Province of Santiago, bluff on right bank of Rio Mao about 1.7 kilometers above Cercado de Mao, 33 meters above water level. C. W. Cooke, collector. May 4, 1919.

8519 (C-25). Province of Santiago, left bank of Rio Mao about 0.8 kilometer above the ford at Cercado de Mao; specimens mostly from lower part of bluff. T. W. Vaughan and C. W. Cooke, collectors. May 3, 1919. 
8520 (C-26). Province of Santiago, bluff on left bank Rio Mao about 0.8 kilometer above ford at Cercado de Mao; specimens from upper part of bluff. C. W. Cooke, collector. May 4, 1919.

8527 (C-33). Province of Santiago, along the bluff on right bank Rio Mao, opposite Cercado de Mao, first bluff below Paso Bajito. T. W. Vaughan and C. W. Cooke, collectors. May 6, 1919.

8733 (D. C. 62). Province of Santiago, bluff along west side of Rio Mao, 1.7 kilometers northwest of Paso Bajito, near Cercado de Mao. D. D. Condit, collector. May 6, 1919.

8734 (D. C. 62a). Province of Santiago, bluff along west side of Rio Mao, 1.7 kilometers northwest of Paso Bajito near Cercado de Mao; corals from loose boulders slipped from upper part of bluff. D. D. Condit, collector. May 6, 1919.

8528 (C-34). Province of Santiago, long bluff on left side Rio Mao at head of a long eastward reach about 3.5 kilometers below Cercado de Mao, the second bluff on the left side below Paso Bajito. T. W. Vaughan and D. D. Condit, collectors. May 6, 1919.

8538 (C-44). Province of Monte Cristi, left bank Rio Gurabo about 1.6 kilometers southeast of the upper ford at Gurabo Adentro, road from Las Caobas to Los Quemados, bluff 10 of traverse. T. W. Vaughan and C. W. Cooke, collectors. May 9, 1919.

8539 (C-46). Province of Monte Cristi, left bank Rio Gurabo about 1.3 kilometers above upper ford at Gurabo Adentro, bluff 8 of traverse. T. W. Vaughan and C. W. Cooke, collectors. May 8, 1919.

8540 (C-47). Province of Monte Cristi, right bank Rio Gurabo about 0.4 kilometer above upper ford at Gurabo Adentro, about 180 meters downstream from station 8539 (C-46), bluff 7 of traverse. T. W. Vaughan and C. W. Cooke, collectors. May 9, 1919.

8541 (C-48). Province of Monte Cristi, right bank Rio Gurabo, about 0.8 kilometer above upper ford at Gurabo Adentro, bluff 6 of traverse. 'T. W. Vaughan and C. W. Cooke, collectors. May 9, 1919.

8542 (C-49). Province of Monte Cristi, left bank Rio Gurabo about 660 meters above upper ford at Gurabo Adentro, bluff 5 of traverse. T. W. Vaughan and C. W. Cooke, collectors. May 9, 1919.

8543 (C-50). Province of Monte Cristi, right bank Rio Gurabo about 240 meters above upper ford at Gurabo Adentro, bluff 4 of traverse. T. W. Vaughan and C. W. Cooke, collectors. May 9, 1919.

8544 (C-51). Province of Monte Cristi, right bank of Rio Gurabo, about 150 meters above middle ford at Gurabo Adentro, bluff 3 of traverse. T. W. Vaughan and C. W. Cooke, collectors. May 9, 1919.

8545 (C-52). Province of Monte Cristi, left bank of Rio Gurabo, about 60 meters downstream from middle ford at Gurabo Adentro, bluff 2 of traverse. T. W. Vaughan and C. W. Cooke, collectors. May 8, 1919.

8546 (C-53). Province of Monte Cristi, left bank of Rio Gurabo just above lower ford at Gurabo Adentro, bluff 1 of traverse. T. W. Vaughan and C. W. Cooke, collectors. May 9, 1919.

8548 (C-54). Province of Monte Cristi, right bank of Rio Gurabo, 150 meters below lower fold at Gurabo Adentro, bluff A of traverse. T. W. Vaughan and C. W Cooke, collectors. May 8, 1919.

8549 (C-55). Province of Monte Cristi, right bank of Rio Gurabo about 0.4 kilometer below the lower ford at Gurabo Adentro, bluff $\mathrm{C}$ of traverse. T. W. Vaughan and C. IV. Cooke, collectors. May 8, 1919.

8550 (C-56). Province of Monte Cristi, left bank of Rio Gurabo, second bluff on left side below lower ford at Gurabo Adentro, bluff D of traverse. T. W. Vaughan and C. W. Cooke, collectors. May \&, 1919. 
8551 (C-57). Province of Monte Cristi, light bank of Rio Gurabo; thind bluff on right bank below lower ford at Gurabo Adentrc, bluff $\mathrm{E}$ of traverse. T. W. Vaughan and C. W. Cooke, collectors. May 8, 1919.

8552 (C-58). Province of Monte Cristi, left bank of Rio Gurabo, about 0.8 kilometer below lower ford at Gurabe Adeniro, bluff $\mathrm{F}$ cf traverse. T. W. Vaughan and C. W. Cooke, collectors. May 8, 1919.

8553 (C-59). Province of Monte Cristi, right bank of Rio Gurabo, 180 meters downstream from collection $8552(\mathrm{C}-58)$, bluff G of traverse. T. W. Vaughan and C. W. Cooke, collectors. May 8, 1919.

8554 (C-60). Province of Monte Cristi, right bank of Rio Gurabo, about 2 kilometers due north of lower ford at Gurabo Adentro, bluff $\mathbf{P}$ of traverse. T. W. Vaughan and C. W. Cooke, collectors. May 8, 1919.

8555 (C-61). Province of Monte Cristi, right bank of Rio Gurabo, about 0.4 kilometer northwest of bluff G, station $8553(\mathrm{C}-59)$, bluff S of traverse. T. W. Vaughan and C. W. Cooke, collectors. May 8, 1919.

8556 (C-62). Province of Monte Cristi, right bank of Rio Gurabo, about 3 kilometers north of the lower ford at Gurabo Adentro, bluff $U$ of traverse. T. W. Vaughan and C. W. Cooke, collectors. May 8, 1919.

8735 (D. C. 63). Province of Monte Cristi, left bank of Rio Gurabo, about 3.4 kilometers below Gurabo Adentro, bluff W of traverse, near base of cliff. D. D. Condit, collector. May 8, 1919.

8536 (C-42). Province of Mente Cristi, road from Gurabo Adentro to Las Caobas, up slope trom Rio Gurabo, between 70 to 85 meters above the river bed. T. W. Vaughan, collector. May 10, 1919.

8537 (C-43). Province of Monte Cristi, road from Gurabo Adentro to Las Caobas on slope from Rio Gurabo, 12 to 18 meters above river bed. T. W. Vaughan, collector. May 10, 1919.

8535 (C-41). Province of Monte Cristi, road from Caimito to Gurabo Adentro, about 0.8 kilometer west of Las Caobas. T. W. Vaughan and C. W. Cooke, collectors. May $10,1919$.

Foraminifera: Faunal list.

Orbulina universa D'Orbigny Station,

Amphistegina lessonii D'Orbigny, flat var. Zone A, Rio Gurabo Zone A, Rio Gurabo 


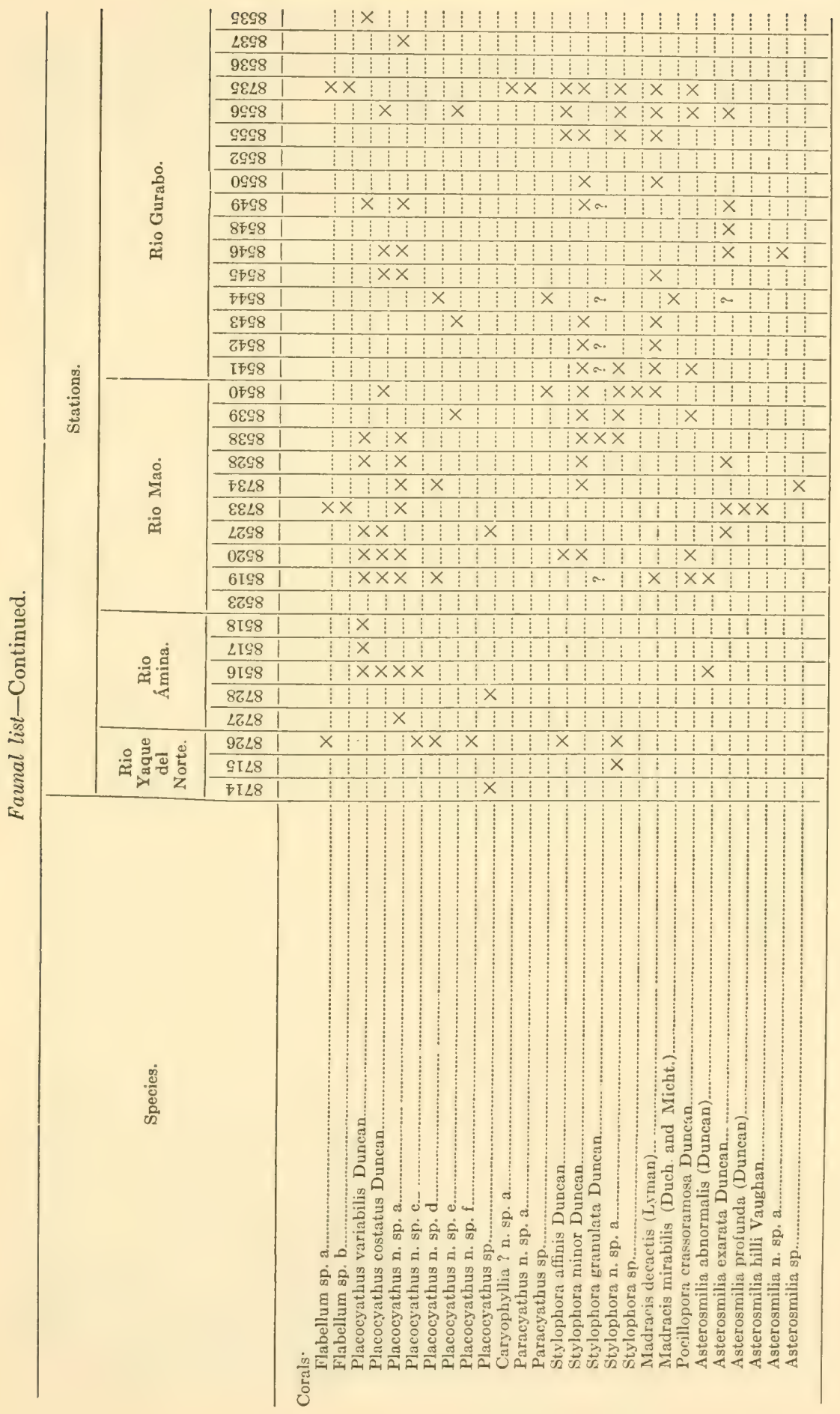




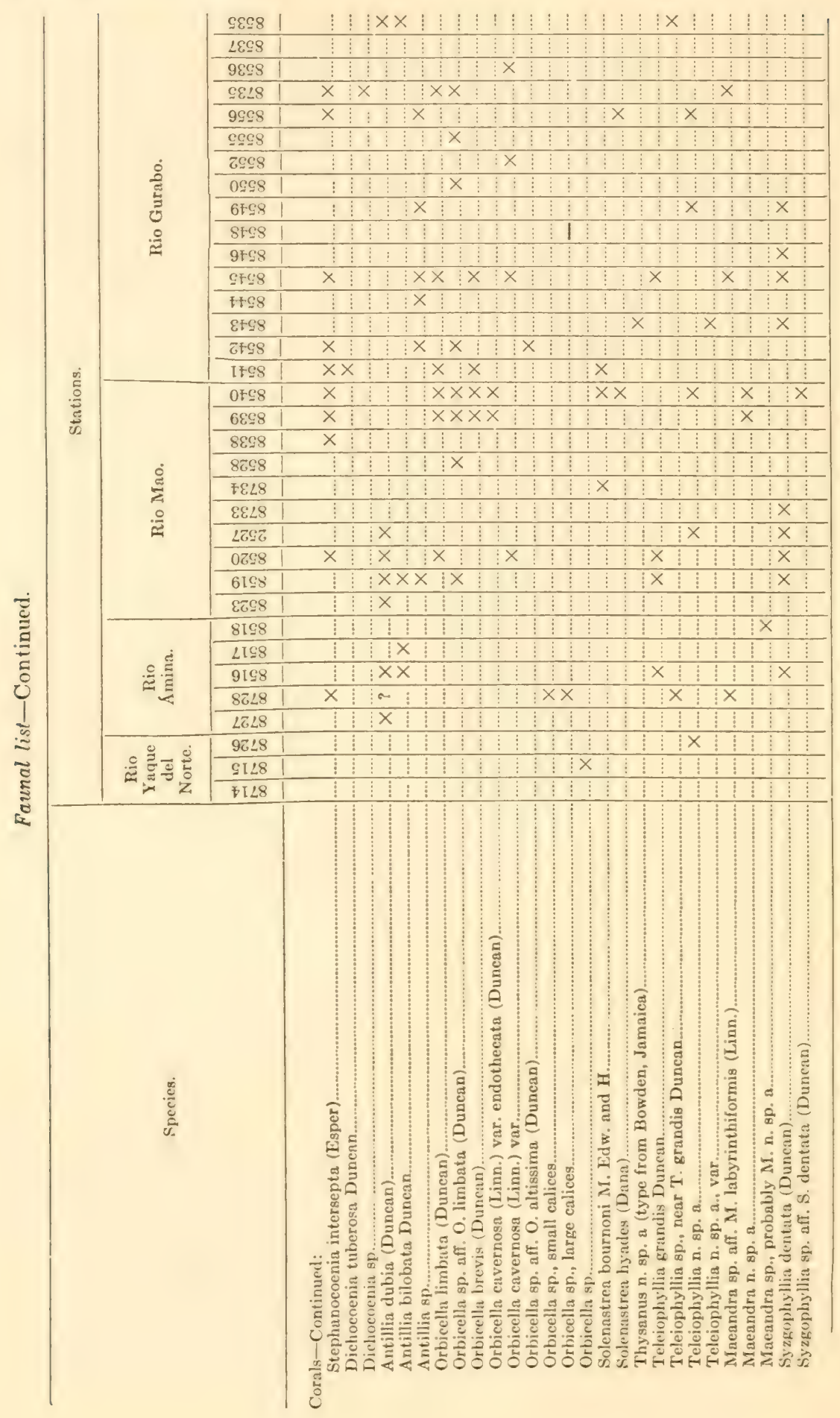




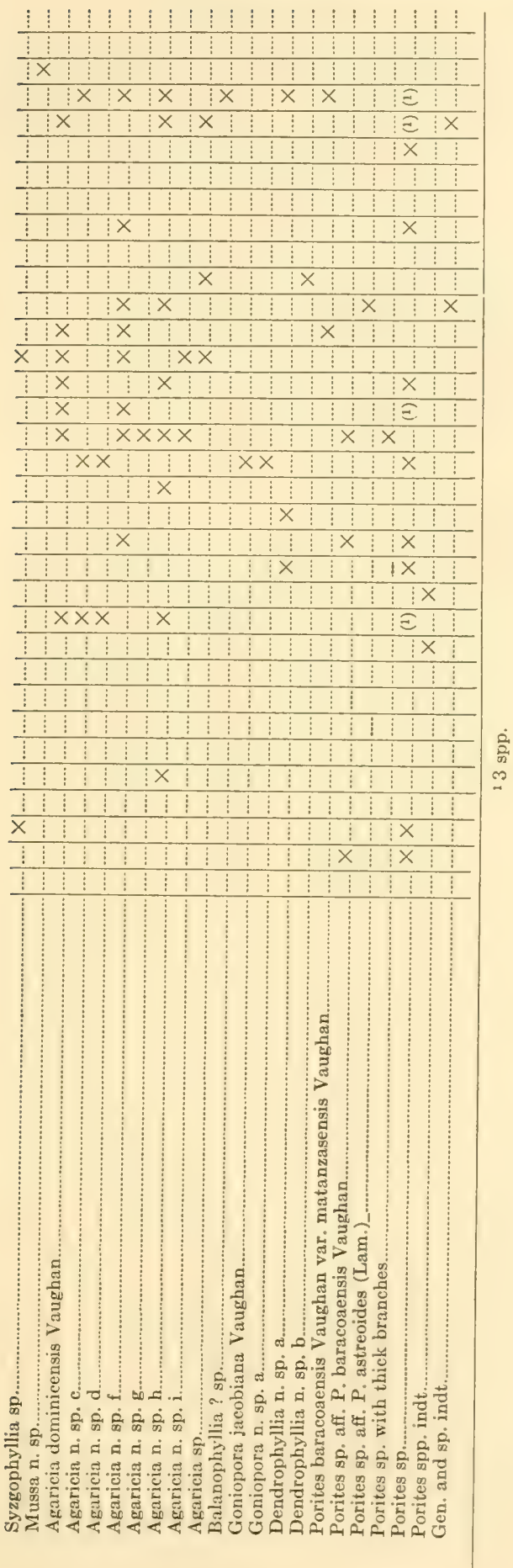


Faunal list-Continued.

\begin{tabular}{|c|c|c|c|c|c|c|}
\hline \multirow{2}{*}{ Species. } & \multirow{2}{*}{$\frac{\begin{array}{c}\text { Rio } \\
\text { Amina. }\end{array}}{8516}$} & \multicolumn{4}{|c|}{ Rio Mao. } & \multirow{2}{*}{$\begin{array}{c}\begin{array}{c}\text { Rio } \\
\text { Gurabo. }\end{array} \\
\text { Zone D. }\end{array}$} \\
\hline & & 8519 & 8527 & 8733 & 8734 & \\
\hline \multirow{7}{*}{ 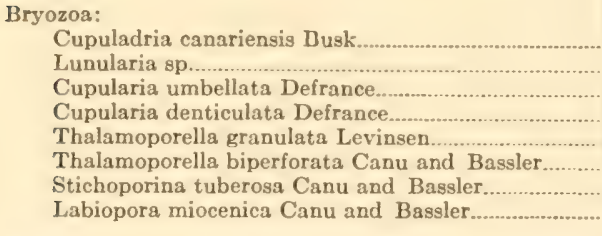 } & \multirow{4}{*}{$x$} & \multirow{4}{*}{$\times$} & \multirow{4}{*}{$\times$} & \multirow{4}{*}{$x$} & \multirow[b]{3}{*}{$x$} & \multirow{3}{*}{$\begin{array}{l}x \\
x \\
x\end{array}$} \\
\hline & & & & & & \\
\hline & & & & & & \\
\hline & & & & & \multirow{4}{*}{$\begin{array}{l}x \\
x \\
x \\
x\end{array}$} & \multirow{2}{*}{ 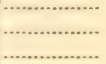 } \\
\hline & & & & & & \\
\hline & & .............. & .......... & …........ & & 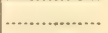 \\
\hline & & & & & & ............... \\
\hline \multirow{2}{*}{ Species. } & & & & & $\begin{array}{l}\text { Rio } \\
\text { Mao. }\end{array}$ & $\begin{array}{c}\text { Rio } \\
\text { Gurabo. }\end{array}$ \\
\hline & & & & & 8519 & 7791 \\
\hline \multirow{2}{*}{$\begin{array}{l}\text { Echinii: } \\
\text { Cidaris melitensis Forbes,.................... } \\
\text { Clypeaster caudatus Jackson n. sp.... }\end{array}$} & & & & & \multirow{2}{*}{$\times$} & \\
\hline & & & & & & $1 \times$ \\
\hline
\end{tabular}

1 Collected loose at foot of bluff; probably from "Zone C." 
STRATIGRAPHIC PALEONTOLOGY.

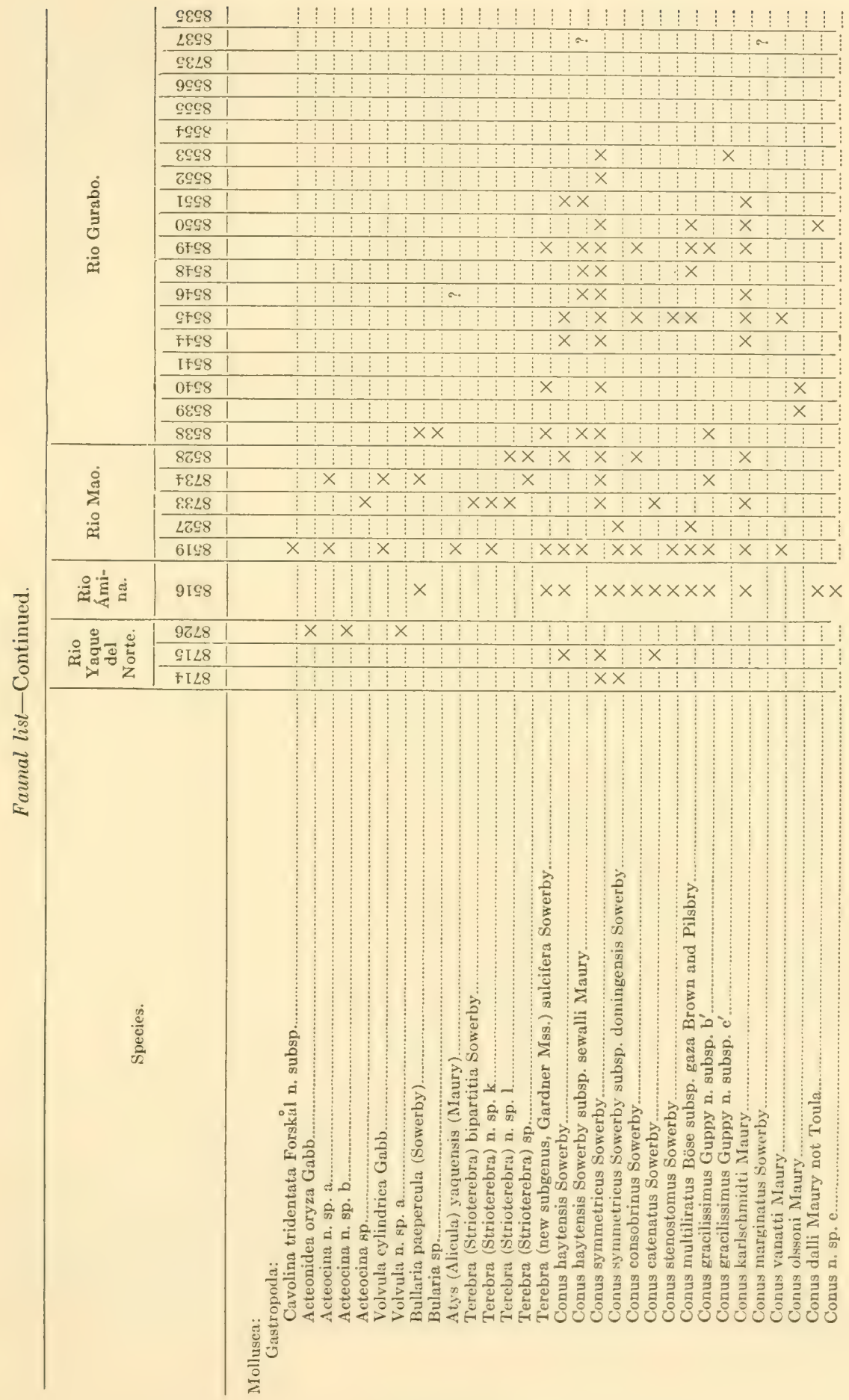




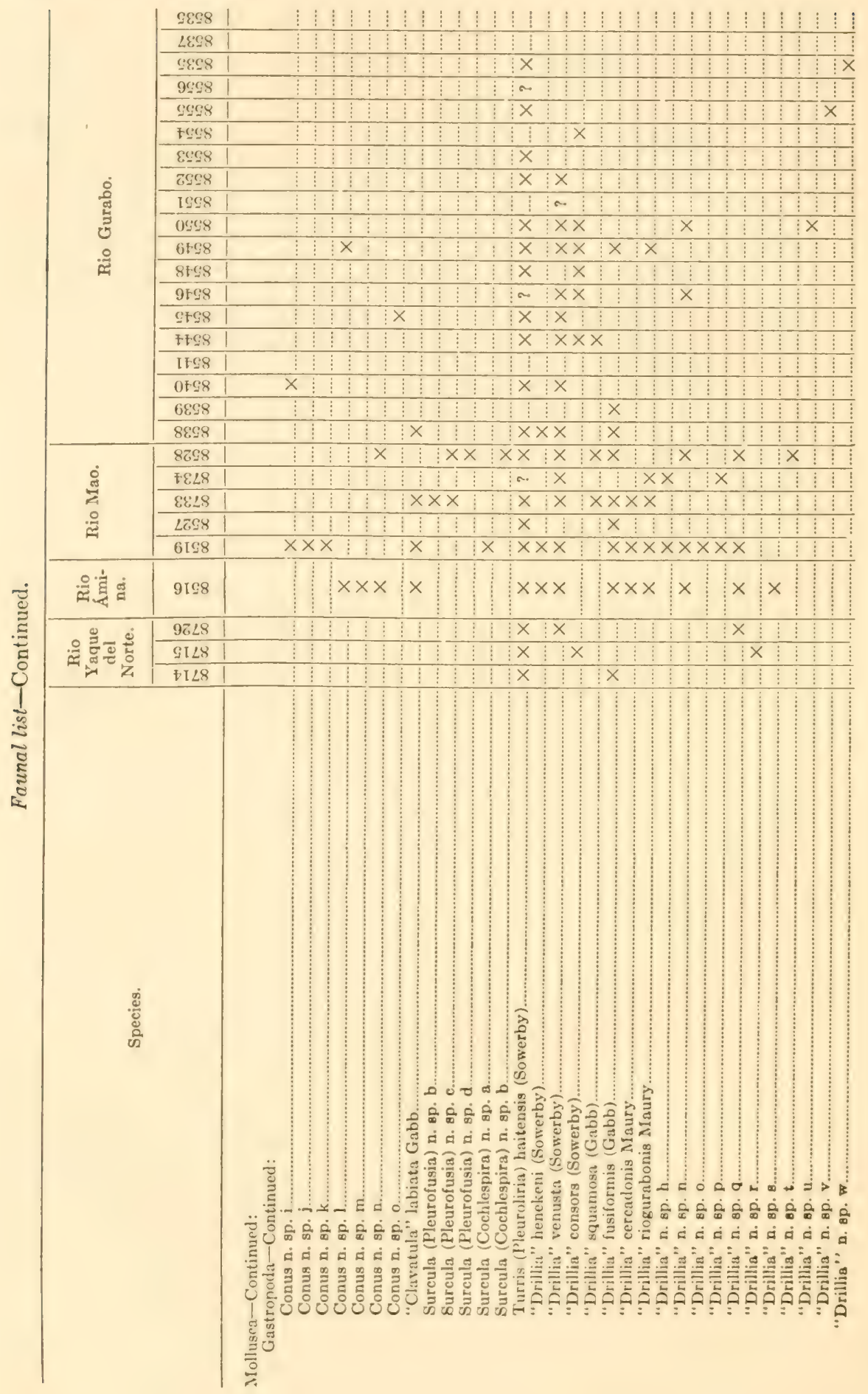




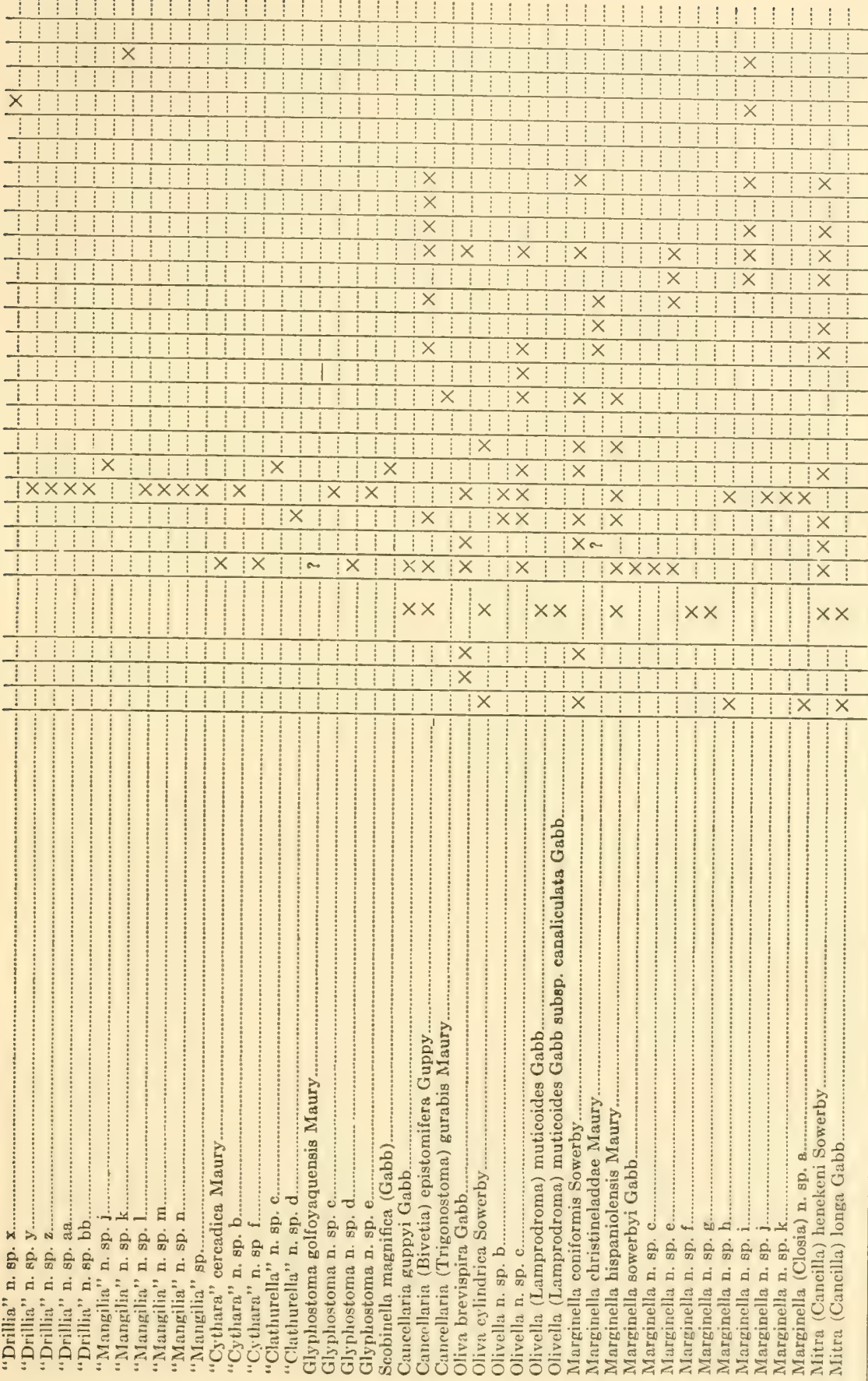




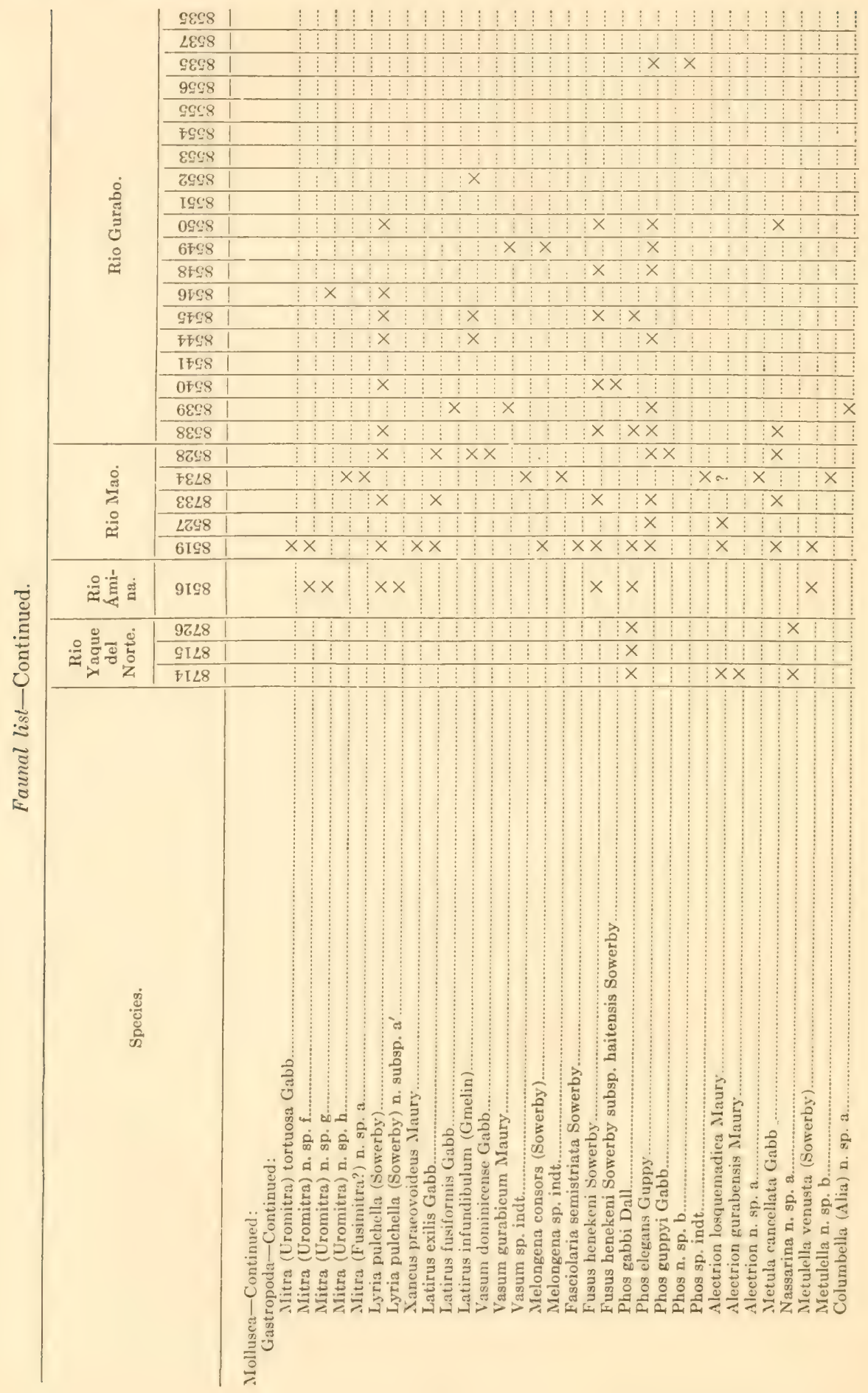




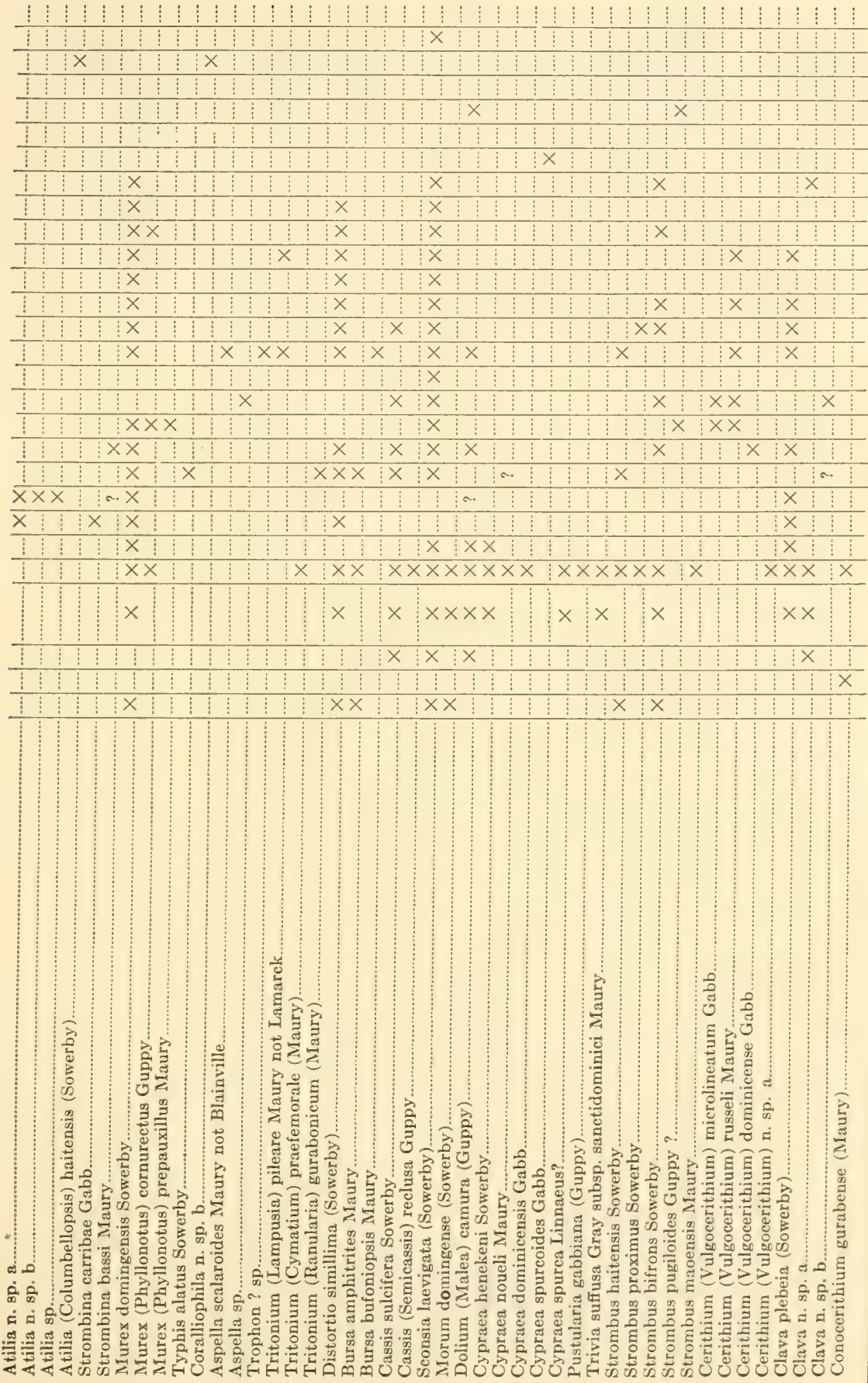


GEOLOGICAL RECONNAISSANCE OF THE DOMINICAN REPUBLIC.

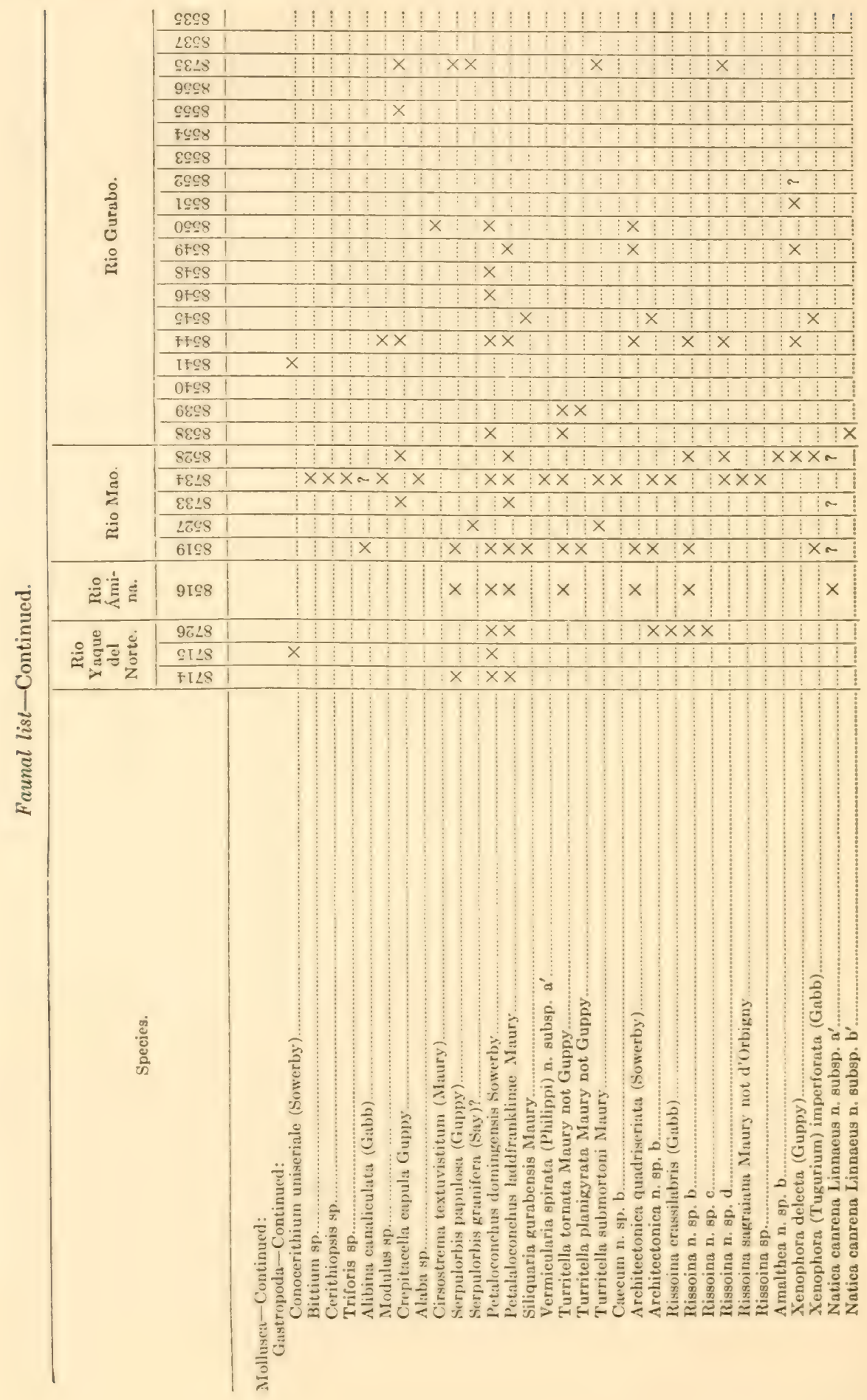




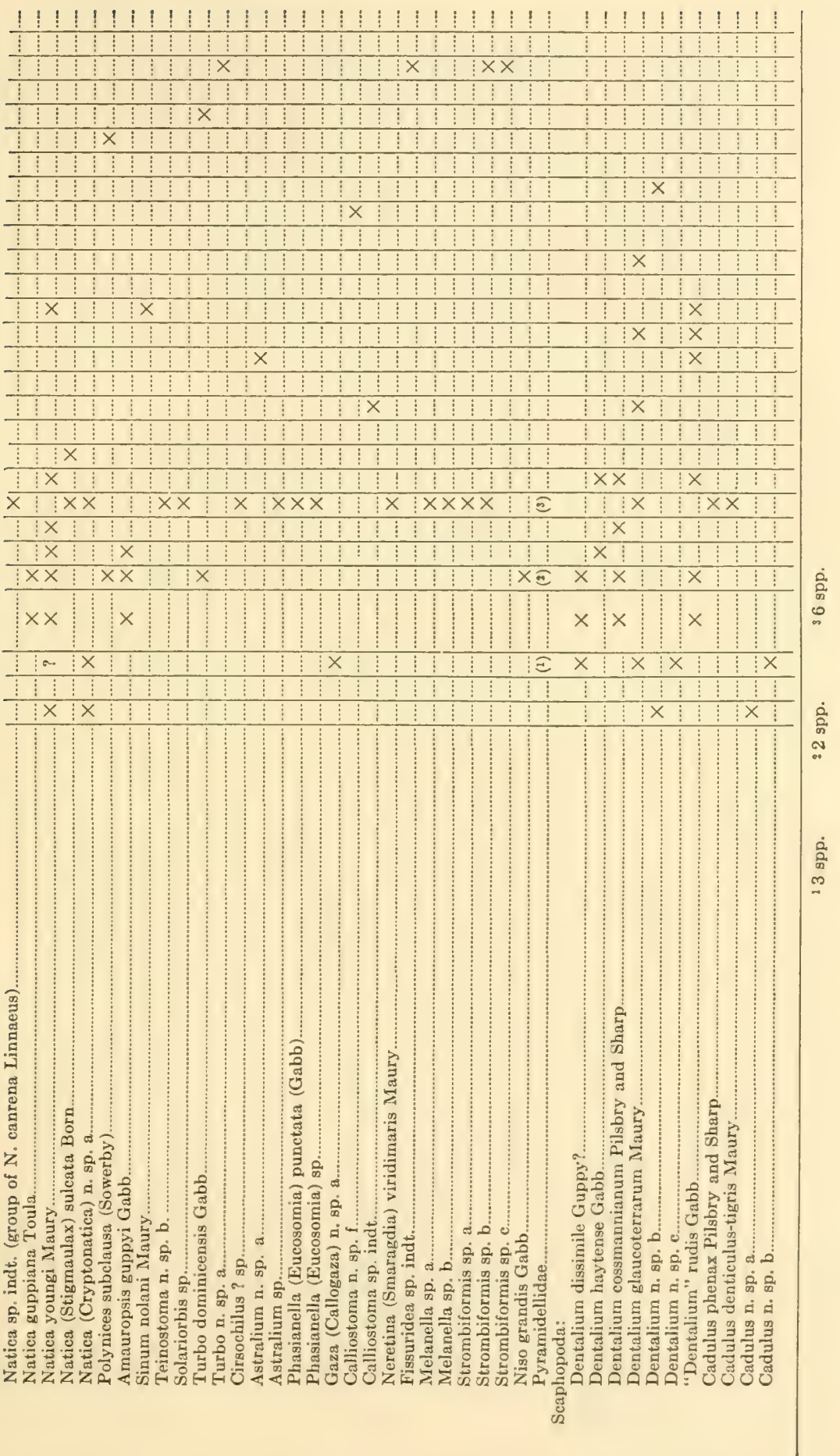


144 GEOLOGICAL RECONNAISSANCE OF THE DOMINICAN REPUBLIC.

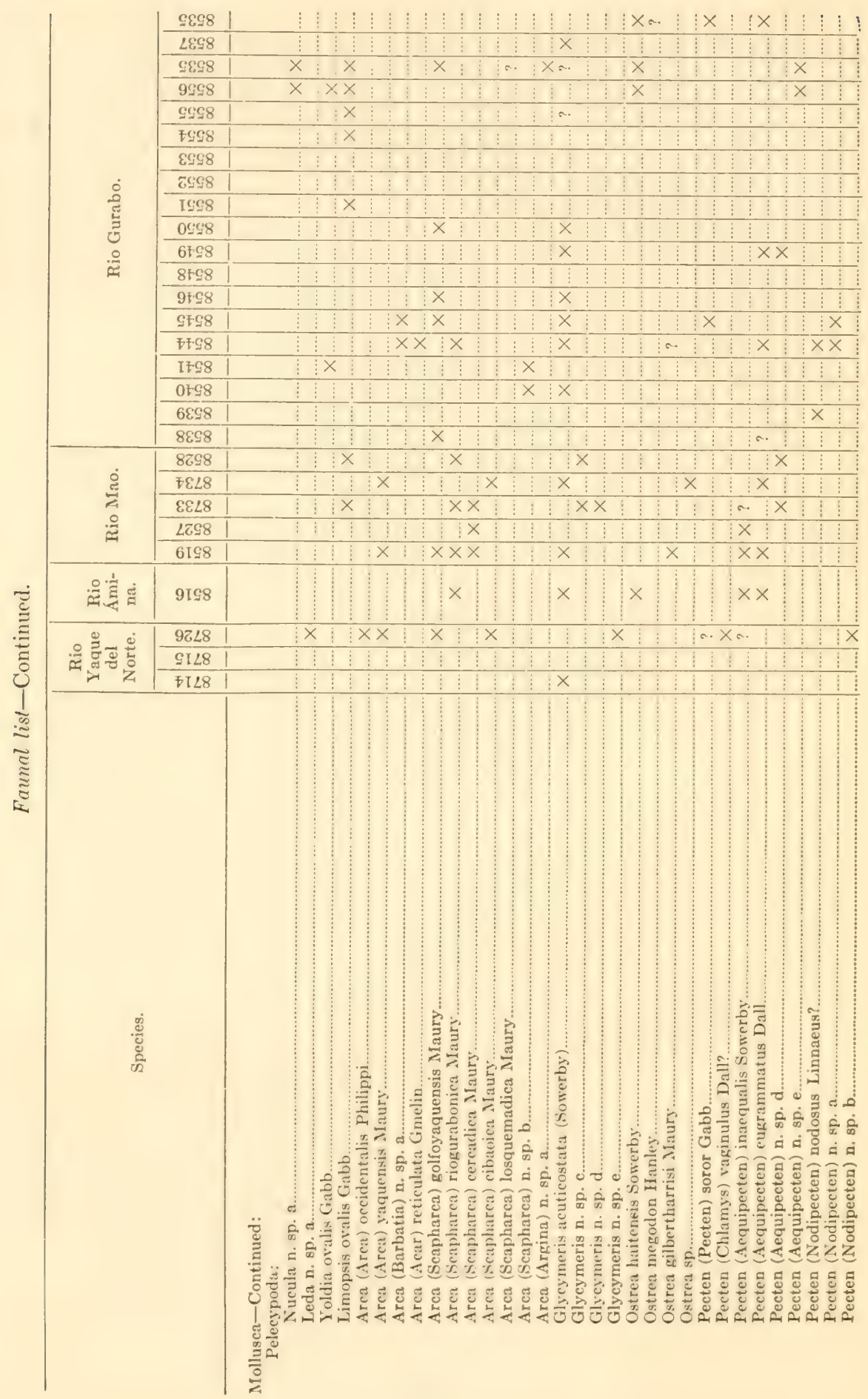




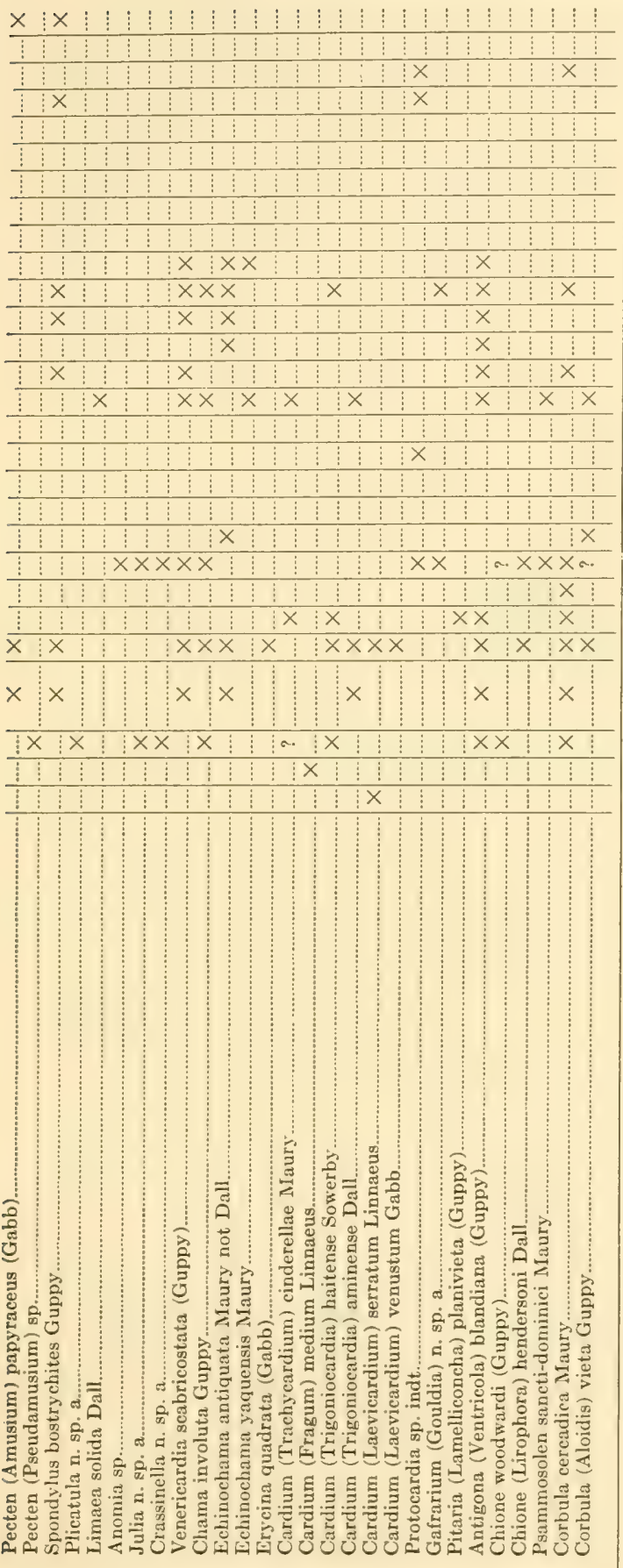


According to Doctor Maury's faunal lists the following additional species of Mollusca were collected from the Gurabo formation by the Maury expedition.

\begin{tabular}{|c|c|c|c|c|c|c|c|}
\hline \multirow{2}{*}{ Species. } & \multirow{2}{*}{$\begin{array}{c}\begin{array}{c}\text { Rio } \\
\text { Ámina. }\end{array} \\
\text { Potrero. }\end{array}$} & \multirow{2}{*}{$\begin{array}{c}\begin{array}{c}\text { Rio } \\
\text { Mao. }\end{array} \\
\text { Bluff 1. }\end{array}$} & \multicolumn{5}{|c|}{ Rio Gurabo. } \\
\hline & & & $\begin{array}{l}\text { Zone } \\
\text { A. }\end{array}$ & $\begin{array}{l}\text { Zone } \\
\text { B. }\end{array}$ & $\begin{array}{l}\text { Zone } \\
\text { D. }\end{array}$ & $\begin{array}{l}\text { Zone } \\
\text { E. }\end{array}$ & $\underset{\mathrm{F}}{\text { Zone }}$ \\
\hline \multicolumn{8}{|l|}{$\begin{array}{l}\text { Mollusca: } \\
\text { Gastropoda: } \\
\text { Terebra inaequalis Sowerby }\end{array}$} \\
\hline Terebra petiti Maury & & & $x$ & & & & \\
\hline $\begin{array}{l}\text { Conus haytensis Sowerby subsp. gura- } \\
\text { bensis Maury }\end{array}$ & & $=3$ & & \multirow{2}{*}{$\times$} & & & \\
\hline Conus tortuostriatus Toula & & & & & \multirow{3}{*}{$x$} & \multirow[t]{2}{*}{$x$} & ........... \\
\hline Conus proteus Hwass ............. & & & & & & & \\
\hline Surcula riomaonis Maury & & \multirow[t]{2}{*}{$x$} & & & & & ............ \\
\hline "Drillia" losquemadica Maury...... & & & & & \multirow{5}{*}{$\begin{array}{l}x \\
x \\
x \\
x\end{array}$} & & \\
\hline "Drillia" donalbertonis Maury & & & & & & & ........... \\
\hline "Drillia" hispaniolae Maury......... & & & & & & & ................ \\
\hline "Clathurella" vendryesiana Dall... & & & & & & & \\
\hline Cancellaria barretti Guppy & & \multirow{2}{*}{$\times$} & & ......... & & & \\
\hline $\begin{array}{l}\text { Cancellaria (Narona) losquemadica } \\
\text { Maury }\end{array}$ & & & & & & \multirow[t]{2}{*}{$x$} & \\
\hline Olivella sanctidominici Maury & & & & & \multirow{3}{*}{$\begin{array}{l}x \\
\times\end{array}$} & & ․․… \\
\hline Mitra quemadica Maury & & \multirow{3}{*}{$x$} & & & & …...... & ................... \\
\hline Mitra berlinerae Maury & & & & & & \multirow{2}{*}{$x$} & \\
\hline Mitra (Strigatella?) pertubatrix Maury.. & & & & & $x$ & & .............. \\
\hline $\begin{array}{l}\text { Turricula (Costellaria) bullen-newtoni } \\
\text { Maury }\end{array}$ & & $=$ & & & \multirow{2}{*}{$x$} & \multirow{2}{*}{$x$} & \\
\hline Fasciolaria carminimaris Maury .............. & & \multirow[t]{2}{*}{$\times$} & & & & & 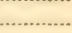 \\
\hline Vasum haitense (Sowerby) & & & $x$ & $x$ & & \multirow{2}{*}{$\begin{array}{l}x \\
x\end{array}$} & \\
\hline Phos moorei Guppy & & \multirow[t]{2}{*}{$x$} & & & \multirow[b]{2}{*}{$x$} & & $\times$ \\
\hline Nitidella cibaoica Maury.... & & & & & & & \\
\hline $\begin{array}{l}\text { Typhis cereadicus Maury } \\
\text { Coralliophila miocenica (Guppy) }\end{array}$ & & $\times$ & & & \multirow{2}{*}{$x$} & & ............... \\
\hline $\begin{array}{l}\text { Coralliophila miocenica (Guppy)......... } \\
\text { Cypraea patrespatriae Maury }\end{array}$ & & \multirow{2}{*}{$\times$} & & & & & \\
\hline Triforis calypsonis Maury & & & & & \multirow{2}{*}{$x$} & & ................ \\
\hline Xenophora conchyliophora Born & ......... & & & & & $x$ & $x$ \\
\hline Turbo crenulatoides Maury & & & & $x$ & & & \\
\hline \multirow{2}{*}{\multicolumn{8}{|c|}{$\begin{array}{l}\text { Pelecypoda: } \\
\text { Limopsis hatoviejonis Maury }\end{array}$}} \\
\hline & & & & & & & \\
\hline $\begin{array}{l}\text { Area (Barbatia) sp. ef. A. bonacyzi } \\
\text { Gabb. }\end{array}$ & & & & & $x$ & & \\
\hline Arca (Scapharca) henekeni Maury ....... & & & & $x$ & & & \\
\hline Ostrea virginica Gmelin & & & & ........ & $\times$ & & ............. \\
\hline Peeten excentricus Gabb & & $\times$ & & & & & …-1..... \\
\hline Pecten hatoviejonis Maury ................. & $\times$ & & & & & & ............... \\
\hline Venericardia islahispaniolae Maury........ & & & $x$ & & & & ……........ \\
\hline Protocardia islahispaniolae Maury ......... & & & & $x$ & & & .......... \\
\hline
\end{tabular}

According to Dr. Maury's faunal lists the following additional species of Mollusea were collected by the Maury expedition from yellow clays presumably belonging to the Gurabo formation at an altitude of 540 feet near the foot of the Samba Hills between Las Caobas and Rompino:

Arca lomasdesamba Maury.

Cardium (Trigoniocardia) sambaicum Maury. 
The following additional species of Mollusca in the collections of the U. S. National Museum were collected at Potrero, on Rio Ámina, by Bland and Rowell. Some of the the species were described by Dall in $1895 .{ }^{1}$

Acteon riomaensis Maury.

Ringicula n. sp. cf. R. tridentata Guppy.

Retusa sulcata Gabb not d'Orbigny.

Cyclichnella trictumtritonis (Maury) n. subsp.

Terebra gabbi Dall.

Terebra (Strioterebra) cirra Dall.

Terebra (new subgenus Gardner MS.) sulcifer Sowerby subsp. haitensis Dall.

Terebra (Fusoterebra ?) emitra Dall.

"Mangilia" dominicensis (Gabb).

"Cythara" polygona (Gabb).

Cancellaria rowelli Dall.

Marginella amina Dall.

Marginella dominguensis Dall.

Marginella latissima Dall.

Phos guppyi Gabb.

Phos semicostatus Gabb. (Probably not from same horizon.)

Phos ccstatus Gabb. (Probably not from same horizon.)

Phos fasciolatus Dall.

Cymia n. sp. cf. C. henekeni Maury.

Strombina cyphonotus Pilsbry and Johnson.

Strombinella acuformis Dall.

Murex (Phyllonotus) compactus Gabb.

Trophon dominicensis Gabb.

Cadulus phenax Pilsbry and Sharp.

Faunal list-Continued.

\begin{tabular}{c|c|c}
\hline Species. & 8727 & Rio Ámina. \\
\hline $\begin{array}{c}\text { Decapod Crustacea: } \\
\text { Petrochirus inequalis Rathbun } \\
\text { Podophthalmus domingensis Rathbun }\end{array}$ & & $\times$ \\
\hline
\end{tabular}

Deeper-Water Facies of Gurabo Formation.

Station.

8702 (D. C. 32). Province of Santiago, bluff on south bank of Rio Yaque del Norte, 8.6 kilometers west of Santiago, D. D. Condit, collector. April 20, 1919.

Corals:

\section{Faunal list.}

Placocyathus variabills Duncan.

Placocyathus barretti Duncan, var.

Placocyathus n. sp. a.

Placceyathus n. sp. d.

Deltocyathus italicus (Mich't).

Stylophora granulata Duncan? var.

Asterosmilia sp.

Teleiophyllia n. sp. a.

Syzygophyllia dentata (Duncan).

Agaricia dominicensis Vaughan?

Agaricia n. sp. f.

Porites sp. 
Mollusca:

Gastropcda:

Ringicula tridentata Guppy ?

Acteocina recta Maury not d'Orbigny.

Acteocina sp.

Cylichna n. sp. a.

Cylichnella trictum-tritonis (Maury).

Volvula cylindrica Gabb.

Bullaria paupercula (Sowerby).

Terebra (Strioterebra) eirra Maury not Dall ?

Terebia (Strioterebra) n. sp. f.

Terebra (Strioterebra) n. sp. n.

Terebra (Strioterebra) n. sp. o.

Terebra (Strioterebra) sp.

Terebra (new subgenus Gardner MS.) sulcifera Sowerby.

Terebra (Fusoterehra) n. sp. a.

Conus furvoides Gabb.

Conus gracilissimus Guppy n. subsp. d'.

Conus n. sp. q.

Conus n. sp. r.

Conus sp.

Surcula humerosa (Gabb).

Surcula longicaudata (Gabb).

Surcula n. sp. a.

Surcula n. sp. b.

Surcula (Pleurofusia) parkeri (Gabb).

Surcula (Leucosyrinx) n. sp. a.

Turris n. sp. a.

Turris (Pleuroliria) n. sp.a.

"Drillia" venusta (Sowerby).

"Drillia" riogurabonica Maury.

"Drillia" n. sp. n.

"Drillia" n. sp. cc.

"Drillia" n. sp. dd.

"Drillia" n. sp. ee.

"Drillia" n. sp. ff.

"Drillia" n. sp. gg.

"Drillia" n. sp. hh.

"Drillia" n. sp. ii.

"Drillia" sp.

"Mangilia" n. sp. c.

"Mangilia" n. sp. o.

“Mangilia" n. sp. p.

"Mangilia" sp.

"Cythara" elongata (Gabb).

"Cythara" n. sp. g.

"Cythara" n. sp. h.

"Cythara" n. sp. i.

Pleurotomella sp.

Glyphostoma n. sp. f.

Oliva brevispira Gabb.

Oliva cylindrica Sowerby ?

Olivella n. sp. b.

Olivella (Lamprodroma) muticoides (Gabb).

Olivella (Lamprodroma) indivisa Maury not Guppy. 
Mollusca-Continued:

Gastropoda-Continued:

Olivella (Lamprodroma) sp.

Marginella coniformis Sowerby.

Marginella hispaniolensis Maury.

Marginella n. sp. c.

Marginella n. sp. i ?

Marginella n. sp. j.

Marginella n. sp. k.

Marginella n. sp. 1.

Marginella (Closia) n. sp. a

Mitra (Uromitra) n. sp. g ?

Mitra (Uromitra) n. sp. i.

Mitra (Fusimitra) n. sp. b.

Mitra (Fusimitra) n. sp. c.

Lyria pulchella (Sowerby).

Caricella striata (Gabb).

Fusus henekeni Sowerby.

Phos gabbi Dall.

Phos elegans Guppy.

Phos sp.

Alectrion losquemadica Maury.

Alectrion n. sp. a.

Nassarina n. sp. c.

Metulella venusta (Sowerby).

Metulella williamgabbi Maury.

Metulella sp.

Atilia n. sp. a.

Atilia (Columbellopsis) exilis (Gabb).

Atilia (Columbellopsis) n. sp. c.

Mitrella n. sp. a.

Strombina nuestrasenorae Maury.

Strombina bassi Maury.

Murex domingensis Sowerby.

Cassis sulcifera Sowerby.

Sconsia laevigata (Sowerby).

Sconsia n. sp. a.

Morum domingense (Sowerby).

Dolium (Malea) camura Guppy?

Strombus haitensis Sowerby?

Clava plebeia (Sowerby).

Bittium n. sp. i.

Bittium sp.

Cerithiopsis sp.

Triforis sp.

Alabina canaliculata (Gabb).

Modulus n. sp. a.

Modulus n. sp. b.

Alaba n. sp. a.

Alaba sp.

Serpulorbis papulosa (Guppy)

Serpulorbis sp.

Petaloconchus domingensis Sowerby.

Petaloconchus laddfranklinae Maury.

Turritella tornata Maury nct Guppy.

Turritella planigyrata Maury not Guppy.

Fossarus ? (Gottoina?) n. sp. a. 
Mollusca-Continued:

Gastropoda-Continued:

Architectonica n. sp. b.

Rissoina crassilabris (Gabb).

Risscina sagraiana Maury not d'Orbigny.

Rissoina n. sp. b ?

Rissoina n. sp. c.

Amalthea n. sp. a.

Natica canrena Linnaeus n. subsp. b'.

Natica (Stigmaulax) sulcata Born.

Natica (Cryptonatica', n. sp. a.

Polynices subclausa (Sowerby).

Amauropsis guppyi Gabb?

Cyclostrema striata Gabb.

Cyclostıema? n. sp. a.

Adeorbis pentagona (Gabb).

Teinostoma n. sp. a.

Turbo dominicensis Gabb ?

Astralium sublongispinum Maury.

Phasianella (Eucosomia) punctata (Gabb).

Calliostoma sp. indt.

Neretina (Smaragdia) viridimaris Maury.

Fissuridea sp. indt.

Melanella n. sp. f.

Melanella sp.

Strombiformis sp.

Niso sp.

Pyramidellidae $3 \mathrm{spp}$.

Scaphopoda:

Dentalium dissimile Guppy.

Dentalium praecursor Pilsbry \& Sharp.

Dentalium glaucoterrarum Maury.

Dentalium n. sp. d.

Dentalium sp.

Cadulus n. sp. b.

Pelecypoda:

Nucula tenuiseulpta Gabb.

Leda n. sp. c.

Area (Fossularea) adamsi Dall.

Area (Scapharca) cibaoica Maury.

Area (Scapharea) golfoyaquensis Maury.

Area (Scapharea) losquemadica Maury.

Arca (Scapharca) sp.

Glycymeris acuticostata (Sowerby).

Pteria inornata Gabb.

Ostrea sp. indt.

Pecten (Pecten) soror Gabb.

Pecten (Aequipecten) thetidis Sowerby.

Pecten (Amusium) sp. indt.

Spondylus bostrychites Guppy ?

Julia n. sp. a.

Verticordia (Trigonulina) n. sp. a.

Venericardia scabricostata Guppy ? 
Mollusca-Continued:

Pelecypoda-Continued:

Chama sp.

Myrtaea lomasdesamba Maury.

Phacoides (Parvilucina) yaquensis Gabb.

Cardium (Trachycardium) linguatigris Maury.

Cardium (Trigoniocardia) haitense Sowerby

Cardium (Laevicardium) sp. indt.

Antigona (Ventricola) blandiana (Guppy).

Chione sp. indt.

Chione (Lirophora) sp. indt.

Corbula cercadica Maury.

Corbula (Aloidis) vieta Guppy.

Gastrochaena sp.

According to Dr. Maury's faunal lists the following species of Mollusca which were not collected by the 1919 expedition, were collected by the Maury expedition on the Rio Cana below Caimito, from a horizon in or above the Gurabo formation.

Gastropoda:

Bursa crassa Dillwyn.

Polynices stanislas-meunieri Maury.

Pelecypoda:

Arca (Scapharca) margaratae Maury.

Area (Scapharca) guayubinica Maury.

Area (Scapharca), patricia Sowerby.

Arca (Scapharca) chiriquensis Gabb.

Placunanomia lithobleta Dall.

Mao Adentro Limestone. List of stations.

8716 (D. C. 46). Province of Santiago, 6 kilometers southeast of Santiago fort, on road to Baitoa. D. D. Condit, collector. April 24, 1919.

8717 (D. C. 46 A). Province of Santiago, hills on Baitoa road, 4.3 kilometers southeast of Santiago fort. D. D. Condit, collector. April 24, 1919.

8723 (D. C. 50 A). Province of Santiago, Gurabo Hills, about 3.4 kilometers northeast of Santiago, 0.4 kilometer northeast of station 8722 (D. C. 50). T. W. Vaughan and D. D. Condit, collectors. April 28, 1919.

S724 (D. C. 50). Province of Santiago, Gurabo Hills, about 3.4 kilometers northeast of Santiago, near rock-crushing site for road metal. T. W. Vaughan and D. D. Condit, collectors. April 28, 1919.

8663 (D. C. 43, 49). Province of Santiago, Arroyo las Lavas, crossing of road from Santiago to Monte Cristi. 'T. W. Vaughan and C. W. Cooke, collectors. April 23, 29, 1919.

8531 (C-37). Province of Santiago, right bank of Rio Mao, about 4.3 kilometers above mouth of irrigation ditch at Valverde (Mao), first bluff on right bank above Valverde. C. W. Cooke and D. D. Condit, collectors, May 7, 1919.

8532 (C-38). Province of Santiago, bluff on right bank of Rio Mao, opposite Mao Adentro, from the coralliferous beds 4 to 24 meters above the bottom of the exposure. T. W. Vaughan, collector. May 7, 1919.

8533 (C-39). Province of Santiago, bluff on right side of Rio Mao, opposite Mao Adentro, from lower part of the exposure. T. W. Vaughan, collector. May 7, 1919.

8731 (D. C. 61). Province of Santiago, Cercado de Mao, top of hogback, 2.5 kilometers southwest of village, altitude 330 meters above sea level. D. D. Condit, collector. May 6, 1919. 
8736 (D. C. 63 A). Province of Monte Cristi, left bank of Rio Gurabo about 3.4 kilometers below Gurabo Adentro, loose material from limestone up the hill. D. D. Condit, collector. May 8, 1919.

Faunal list.

\begin{tabular}{|c|c|c|c|c|c|c|c|c|c|c|}
\hline \multirow[b]{2}{*}{ Species. } & \multicolumn{10}{|c|}{ Stations. } \\
\hline & $8716 \mid$ & 8717 & 87238 & 8724 & $\begin{array}{c}\text { Arroyo } \\
\text { Las } \\
\text { Lavas. } \\
8663\end{array}$ & 8531 & $\begin{array}{l}\text { Rio } \\
\text { Mao. } \\
\text { Si:32: }\end{array}$ & 8533 & 8731 & $\begin{array}{l}\text { Rio } \\
\text { Gurabo. } \\
\text { \$736 }\end{array}$ \\
\hline \multicolumn{11}{|l|}{$\begin{array}{l}\text { Corals: } \\
\text { Placocyathus sp. aff. P. variabilin Dun- } \\
\text { can }\end{array}$} \\
\hline Placocyathus costatus Duncan & & & & & $x$ & $?$ & & & & \\
\hline 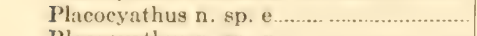 & & & & & X & & & & & \\
\hline Placoesathus n. ap. g & & & & & $x$ & & & & & \\
\hline Paracyathus henekeni (Duncan) & & .......... & …. & & $x$ & & & & & (................. \\
\hline Stylophora affinis Duncan & & ....... & & & X & $x$ & $x$ & & & (.................. \\
\hline Stylophora minor Duncan & & & ....... & & $x$ & $x$ & $x$ & & & \\
\hline Stylophora n. sp. a & & & & & X & & $\times$ & & & \\
\hline Stylophora sp. & & & $x$ & X & & & & & & $x$ \\
\hline Madracis decactis (Iyman) & $\ldots \ldots \ldots$ & & ........ & . & $x$ & ..... & $x$ & & & .. \\
\hline Pocillopora crassoramosa Duncan & & & & & $x$ & & $x$ & x & & \\
\hline Stephanocoenia intersepta (Esper)......... & & & & $x$ & $\begin{array}{l}x \\
x\end{array}$ & x & & & $x$ & \\
\hline Dichocoenia tuberosa Duncan & & & & & & & & & & -....... \\
\hline $\begin{array}{c}\text { Meandrina sp. ef. M. maeandrites } \\
\text { (Iimn.) }\end{array}$ & & & & & & & & & & \\
\hline $\begin{array}{l}\text { Antillia dominicensis Vaughan, ms....... } \\
\text { Antillia sp. }\end{array}$ & & & & & $x$ & $x$ & & & & \\
\hline $\begin{array}{l}\text { Antillia sp. } \\
\text { Orbicella limbata (Duncan) }\end{array}$ & & & & & 3.pp. & & X & & & X \\
\hline & & & $x$ & $x$ & $x$ & $x$ & X & & & \\
\hline & $\cdots \cdot$ & & & $x$ & $x$ & $x$ & $x$ & $x$ & $\times$ & $x$ \\
\hline 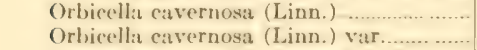 & . & & & & $x$ & & & & & \\
\hline & ... & & & & & $x$ & & & & \\
\hline & & & & & & & & & X & $\times$ \\
\hline 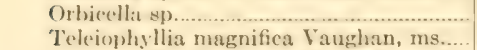 & $\times$ & $\times$ & & & & & & & $x$ & ….............. \\
\hline $\begin{array}{l}\text { Teleiophyllia nagnifica Vaughan, ms.... } \\
\text { Toleiophyllia ? sp., resembles T. n. sp. a. }\end{array}$ & & & & & X & & & & & $\cdots \cdot$ \\
\hline $\begin{array}{l}\text { Toleiophyllia ? sp., resembles T, n. sp. a. } \\
\text { Teleiophyllia sp. . }\end{array}$ & $x$ & & $\cdots \cdots$ & & & & & & $x$ & $\cdots$ \\
\hline $\begin{array}{l}\text { Maeandra sp. aff. M. labyrinthiformis } \\
\text { (Linn.) }\end{array}$ & $x$ & $x$ & & & & $x$ & $x$ & & & \\
\hline Maeandra sp. afT. M. pliocenica (Gane). & & & & & & & $\times$ & & & \\
\hline Mlacandra sp. aff. M. areolata (I.imn.).... & & & & & & & $x$ & & & \\
\hline Maeandra sp). aff. M. strigosa (Dana).... & & & & $\cdots \cdot$ & $x$ & & & & & \\
\hline Maeandra sp & $x$ & & & & & & & & & \\
\hline $\begin{array}{l}\text { Manicina sp. aff. M. gyrosa (Ell. and } \\
\text { Sol.) }\end{array}$ & & & & $x$ & & & & & & \\
\hline 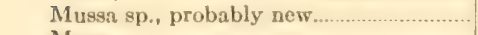 & & ........ & & & & $x$ & & & & \\
\hline Mussa sp. & & & $\ldots \ldots$ & & 3 sтp. & & $x$ & & & \\
\hline $\begin{array}{l}\text { Mussoid coral, probably Mycetophyllia } \\
\text { sp.... }\end{array}$ & $x$ & & & & & & & & & \\
\hline 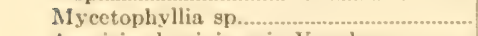 & & & & & & & & & & $x$ \\
\hline Agaricia dominicensis Vaughan........ & & & & & $x$ & & & & & ............. \\
\hline Agaricia n. sp. c & & & & & $x$ & $x$ & $x$ & & & (2)................. \\
\hline Agaricia n. sp. d .................................... & .. & . & ....... & -...... & $x$ & ....... & & & & .................... \\
\hline Agaricia n. sp. f & ......... & & $\ldots \ldots$ & & $x$ & & X & ....... & …..... & …................ \\
\hline Agaricia n. sp. h & ..... & ....... & $\mid \ldots \ldots$ & ....... & $x$ & $x$ & $x$ & ....... & ........ & .................... \\
\hline Agaricia n. sp. i. & & & & & & $x$ & & & $\times$ & .................... \\
\hline Siderastrea siderea (Ell. and Sol.)........... & ....... & & .......... & $x$ & x & $x$ & $x$ & ....... & $\times$ & 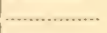 \\
\hline Siderastrea sp. aff. S, radians (Pallas)... & $x$ & & ...... & & ............ & & & & ....... & $\mid \ldots \ldots \ldots \ldots \ldots$ \\
\hline Goniopora jacobiana Vaughan................... & & & & & & & $x$ & & $\ldots . . .$. & - \\
\hline Porites sp. aff. P. furcata Linn.............. & & & & & $x$ & & & & & - \\
\hline Porites sp. aff. P. astreoides Linn. & & & & & $x$ & & & & & \\
\hline Porites sp. aff. P. baracoaensis Vaughan.. & & & . . . . & & & & & & & $x$ \\
\hline Porites spl ... & & ........ & $x$ & & $2 \times p \mathrm{P}$. & & $x$ & & & …................... \\
\hline & & & & & & & & & & \\
\hline
\end{tabular}


Faunal list-Continued.

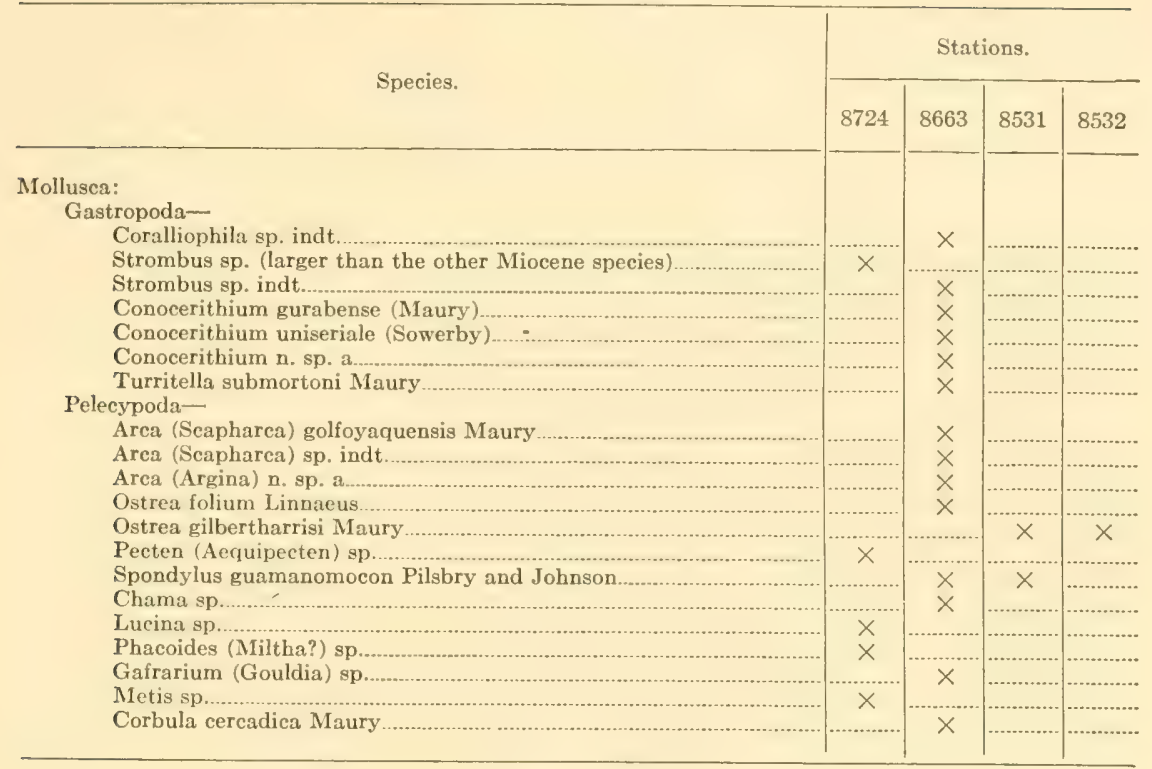

Mao Clay.

A collection of fossils was made from this formation at only one locality, as follows:

8530 (C-36). Province of Santiago, bluff on left side of Rio Mao, about 3.4 kilometers above intake of irrigation ditch at Valverde (Mao), first bluff above the town. C. W. Cooke, D. D. Condit, collectors. May 7, 1919.

Corals:

Faunal list.

Stylophora sp.

Mollusca:

Gastropoda:

Conus haytensis Sowerby.

Conus sp.

Turris (Pleuroliria) haitensis (Sowerby)?.

Cancellaria (Bivetia) epistomifera Guppy.

Murex domingensis Sotverby.

Cassis (Semicassis) sp. indt.

Crepitacella capula Guppy.

Pelecypoda.

Leda n. sp. b.

Pecten (Aequipecten ?) sp. indt.

\section{MIOCENE OR OLDER.}

List of stations.

8772 (R. 20). Province of Monte Cristi, El Morro, southern side, altitude 45 meters above sea level. C. P. Ross, collector. May 2, 1919.

8773 (R. 21). Province of Monte Cristi, El Morro, southern side, altitude 63 meters above sea level. C. P. Ross, collector. May 2, 1919. 
Corals:

Faunal list.

Placocyathus ? sp.

Station.

Leptoria sp.

8772

8773

\section{Yaque Group, Province of Monte Cristi.}

List of slations.

8782 (R 22). Province of Monte Cristi, El Morro, southern side, altitude 105 meters above sea level. C. P. Ross, collector. May 2, 1919.

8783 (R 23). Province of Monte Cristi, El Morro, southern side, altitude 153 meters above sea level. C. P. Ross, collector. May 2, 1919.

8774 (R 24). Province of Monte Cristi, El Mcrro, southern side, altitude 155 meters above sea level. C. P. Ross, collector. May 2, 1919.

8777 (R 30). Province of Monte Cristi, La Subida de la Salina, a hill about 12 kilometers southeast of house of Señor Rodríguez, which is about 25 kilometers nor theast of Monte Cristi, altitude 165 meters above sea level. C. P. Ross, collector. May 4, 1919.

8778 (R. 31?). Province of Monte Cristi, on trail between Sabana Cruz and Santana, at La Plata, 27 kilometers from Monte Cristi on Santiago road. C. P. Ross, collector. May 6, 1919.

8780 (R. 39). Province of Monte Cristi, on road from Dajabón to Monte Cristi, 2.5 kilometers from La Barca. C. P. Ross, collector. May 7, 1919.

8779 (R. 37). Province of Monte Cristi, hill 10 kilometers north of Dajabon, near Copey on road between Dajabón and Copey, altitude 12 meters above sea level. C. P. Ross, ccllectcr. May 7, 1919.

Faunal list.

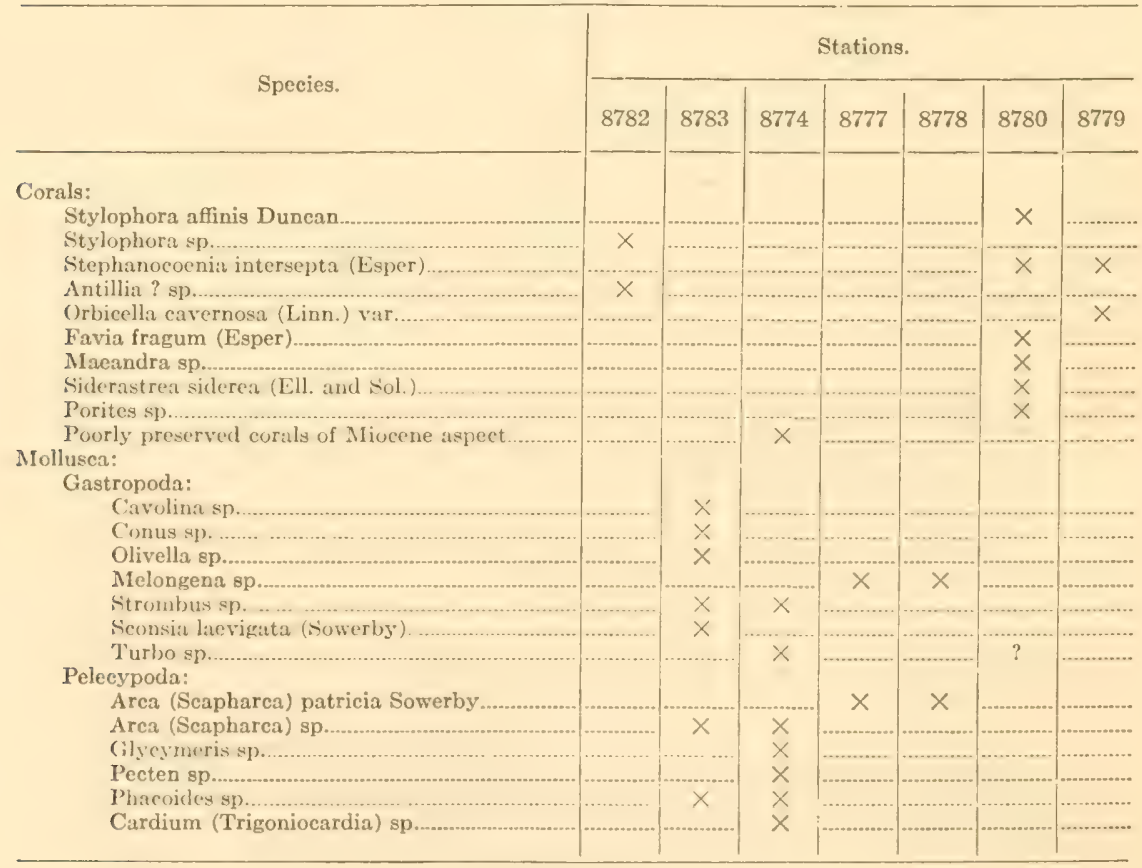


Yaque Group, South Side.

List of stations.

8687. Province of Maccris, "Balketa," about 600 meters below mouth of Rio Magua, branch of Rio Macorís, altitude as follows:

$8687 a$ (D. C. 6a). 6-9 meters.

$8687 b$ (D. C. $6 \mathrm{~b}) . \quad 15-18$ meters.

$8687 c$ (D. C. $6 \mathrm{c}$ ). 21-27 meters.

C. W. Cooke, D. D. Condit, and C. P. Ross, collectors. April 3, 1919.

8689 (D. C. 8). Province of Macorís, 12 kilometers from San Pedro de Macoris, Camino Real to Platanitos, altitude 45.5 meters. T. W. Vaughan, collector. April 3, 1919.

8580. Province of Santo Domingo, Arroyo Santa Cruz, road from Yaguate to San Cristobal. D. D. Condit, collector. June 10, 1919.

8696 (D. C. 17). Province of Santo Domingo, near Los Alcarrizos on the Duarte Highway, about 10.75 kilometers from Santo Domingo. T. W. Vaughan and others, collectors. April 6, 1919.

8699 (D. C. 20). Province of Santo Domingo, Duarte Highway near Los Alcarrizos, 15+ kilometers from Santo Domingo. T. W. Vaughan, collector. April 6, 1919.

8700 (D. C. 21). Province of Santo Domingo, quarry north of Duarte Highway, 14 kilometers from Santo Domingo. T. W. Vaughan, collector. April 6, 1919.

8609 (C-86). Province of Azua, ledge of coralliferous limestone on Rio Vía, abeut 1.7 kilometers above Azua. C. W. Cooke, collector. May 27, 1919.

8664. Province of Azua, pebble in Rio Vía about 1.7 kilometers above Azua. C. W. Cocke, collector. May 29, 1919.

8645. Province of Azua, loose rubble from Higuerito, Azua oil field. D. D. Condit, collector, May, 1919.

8608 (C-84). Province of Azua, rubble on road side, north of Arrcyo Salado near Higuero Largo on road from Túbano to Las Yayas, altitude 495 meters above sea level. C. W. Cooke, collector. May 26, 1919.

8610 (C-89). Province of Azua, coralliferous limestone interbedded with shale in arroyo on road betreen Higuero Largo and Las Yayas. C. W. Cooke, collector. May 26, 1919.

8579 (D. C. 83-A). Province of Azua, from limestone bluff near Trinchera on east side of Azua-San Juan road at station 27 of traverse. D. D. Condit, collector. May $25,1919$.

8760. Province of Azua, on Azua-Cabral trail, about 10 kilometers west of crossing of Rio Tábara. N. H. Darton, collector. January, 1920.

8568 (D. C. 81). Province of Azua, from limestone on right bank of Rio de las Cuevas, about 4.2 kilometers west of Túbano. D. D. Condit, collector. May 22, 1919.

8566 (D. C. 78). Province of Azua, left bank of Rio Yaque del Sur about 0.8 kilometer below mouth of Rio de las Cuevas. D. D. Condit, collector. May 22, 1919.

8563 (D. C. 77). Province of Azua, along left bank of Rio Yaque del Sur 0.4 kilometer east of crossing of Azua-San Juan road. D. D. Condit, collector. May 22, 1919.

8571 (D. C. 86). Province of Azua, sandy beds on a nameless arroyo emptying into Rio Yaque del Sur from west side a little below Boca Mula. D. D. Condit, collector. May 25, 1919.

8621 (R. 45). Province of Azua, Rio Yaque del Sur opposite Boca Mula, station "A" of traverse of Rio Yaque del Sur. C. P. Ross, collector. May 25, 1919.

8622 (R. 46). Province of Azua, Rio Yaque del Sur opposite Boca Mula, between 
staticns "B" and "C" of traverse of Rio Yaque del Sur. C. P. Ross, collector. May $25,1919$.

8570 (D. C. 84). Province of Azua, channel of Rio Yaque del Sur about 5 kilcmeters down stream from Boca Mula, beds in contact with Quarternary series. D. D. Condit, C. P. Ross, collectors. May 24, 1919.

8572 (D. C. 87). Province of Azua, left bank of Rio Yaque del Sur at upper edge of village of Los Güiros. D. D. Condit, collector. May 26, 1919.

8590 (D. C. 88). Province of Azua, west bank of Rio Yaque del Sur cpposite Palo Copado, D. D. Condit, collector. May 27, 1919.

Foraminifera:

Faunal list.

Amphistegina ? sp

Station.

Alveolina? sp

8568

8568 
STRATIGRAPHIC PALEONTOLOGY.

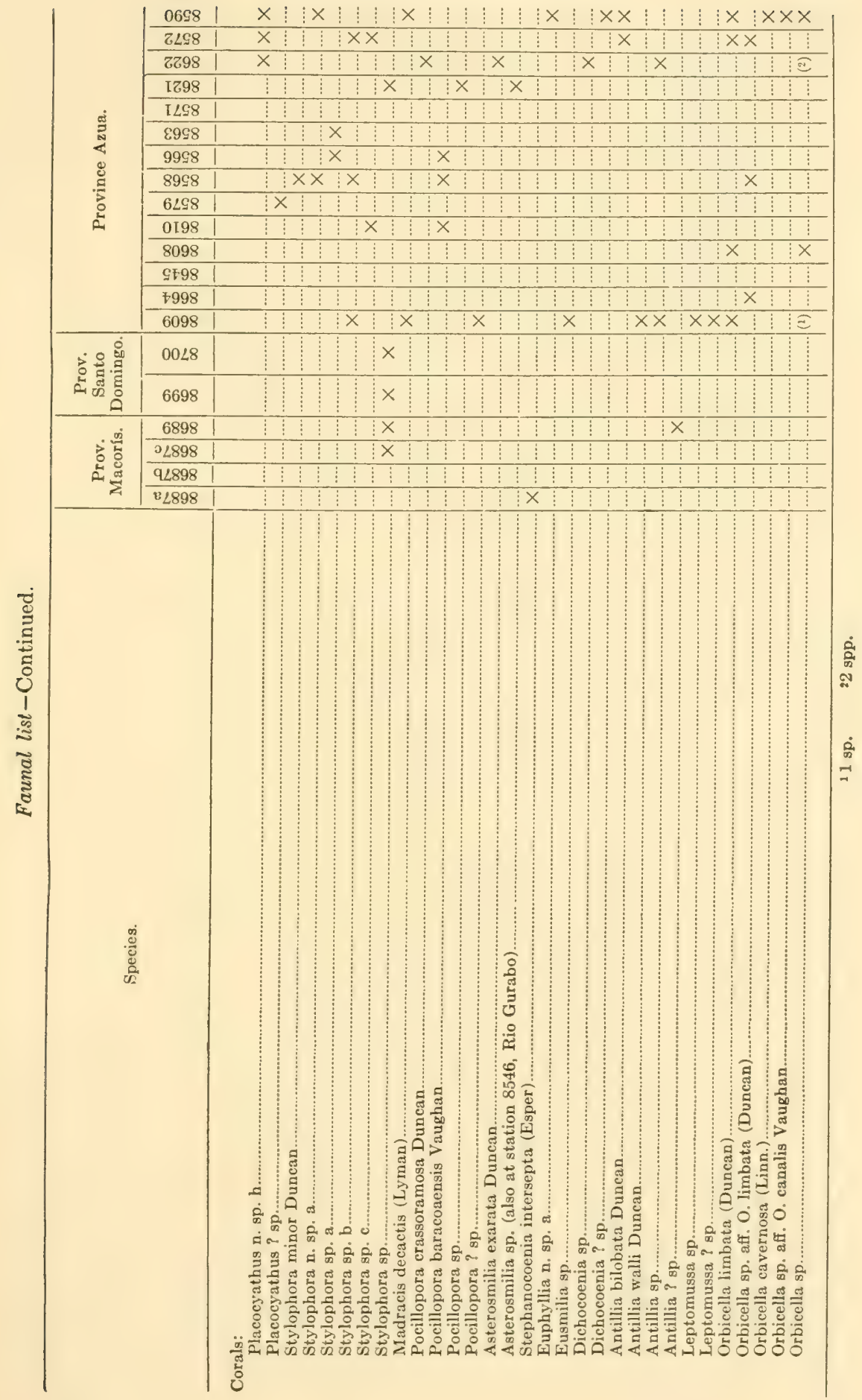




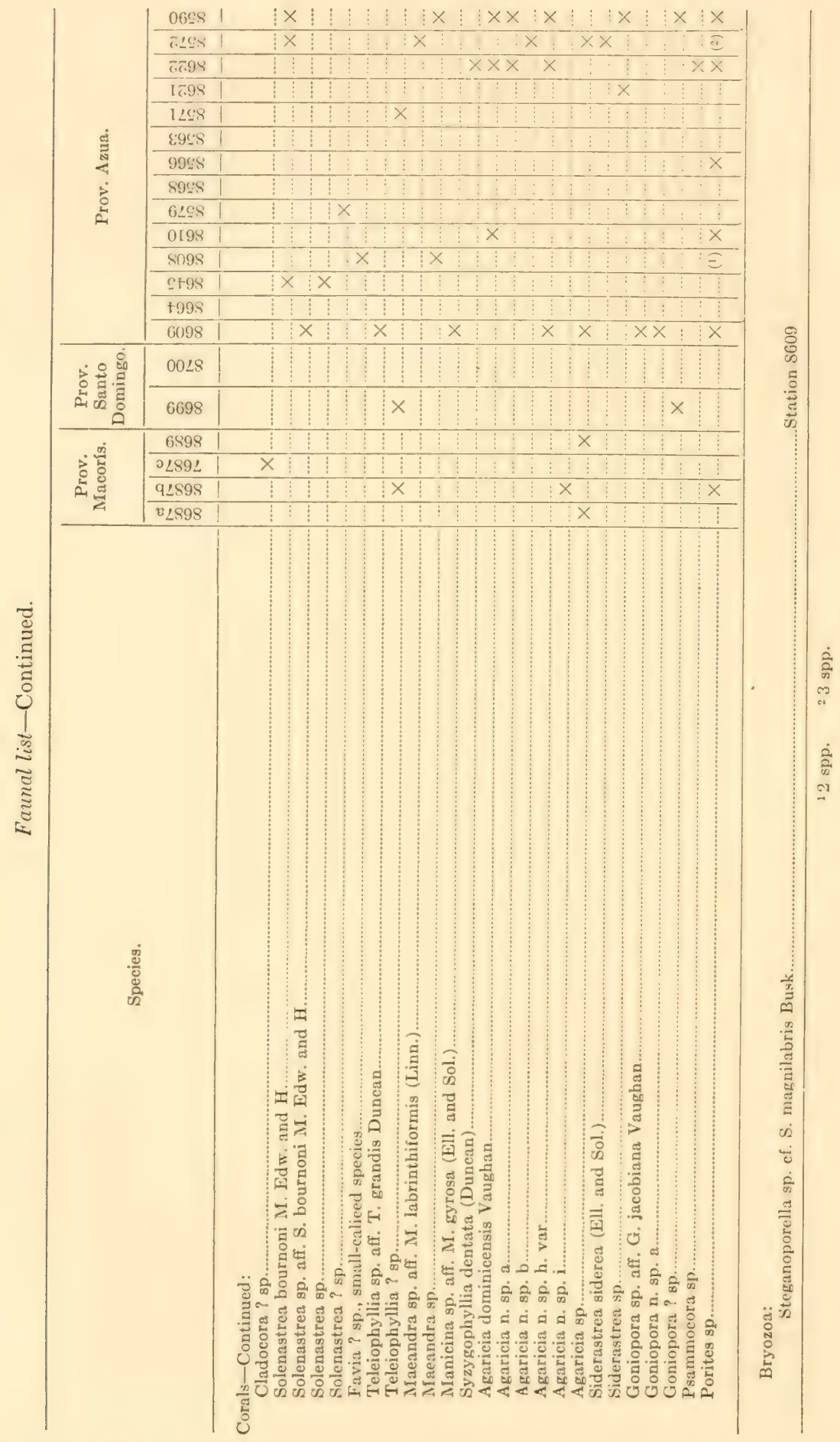


STRATIGRAPHIC PALEONTOLOGY.

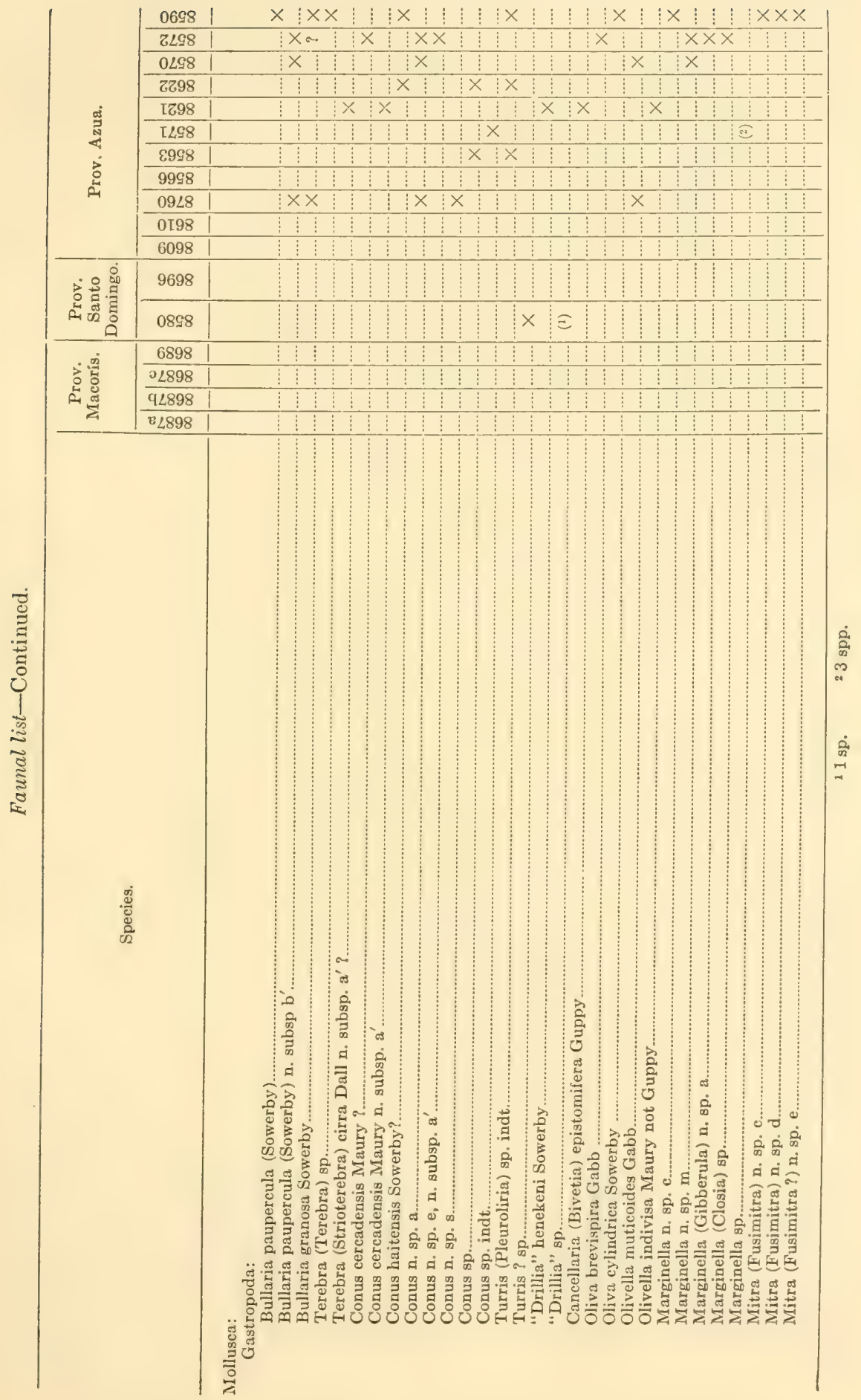




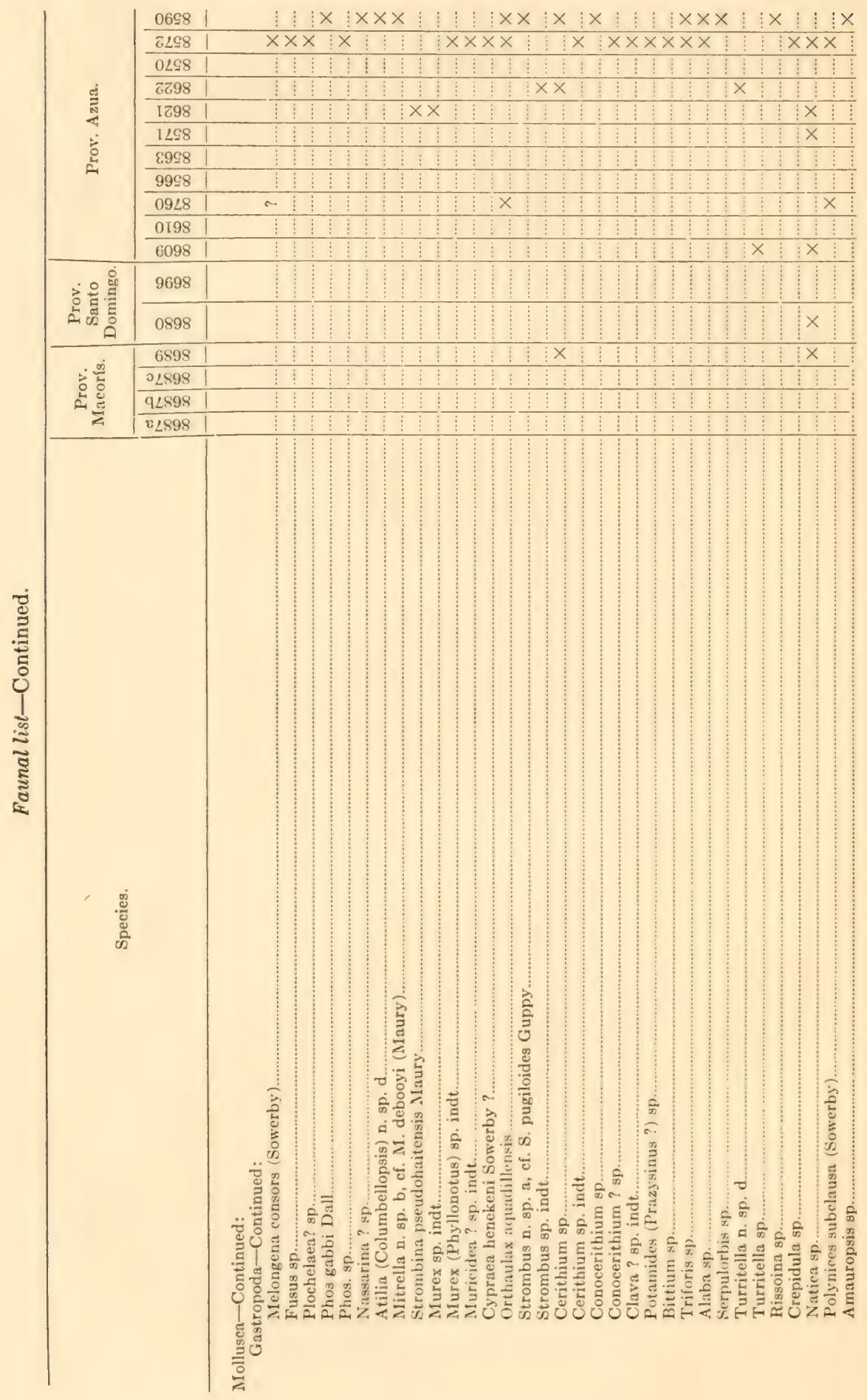




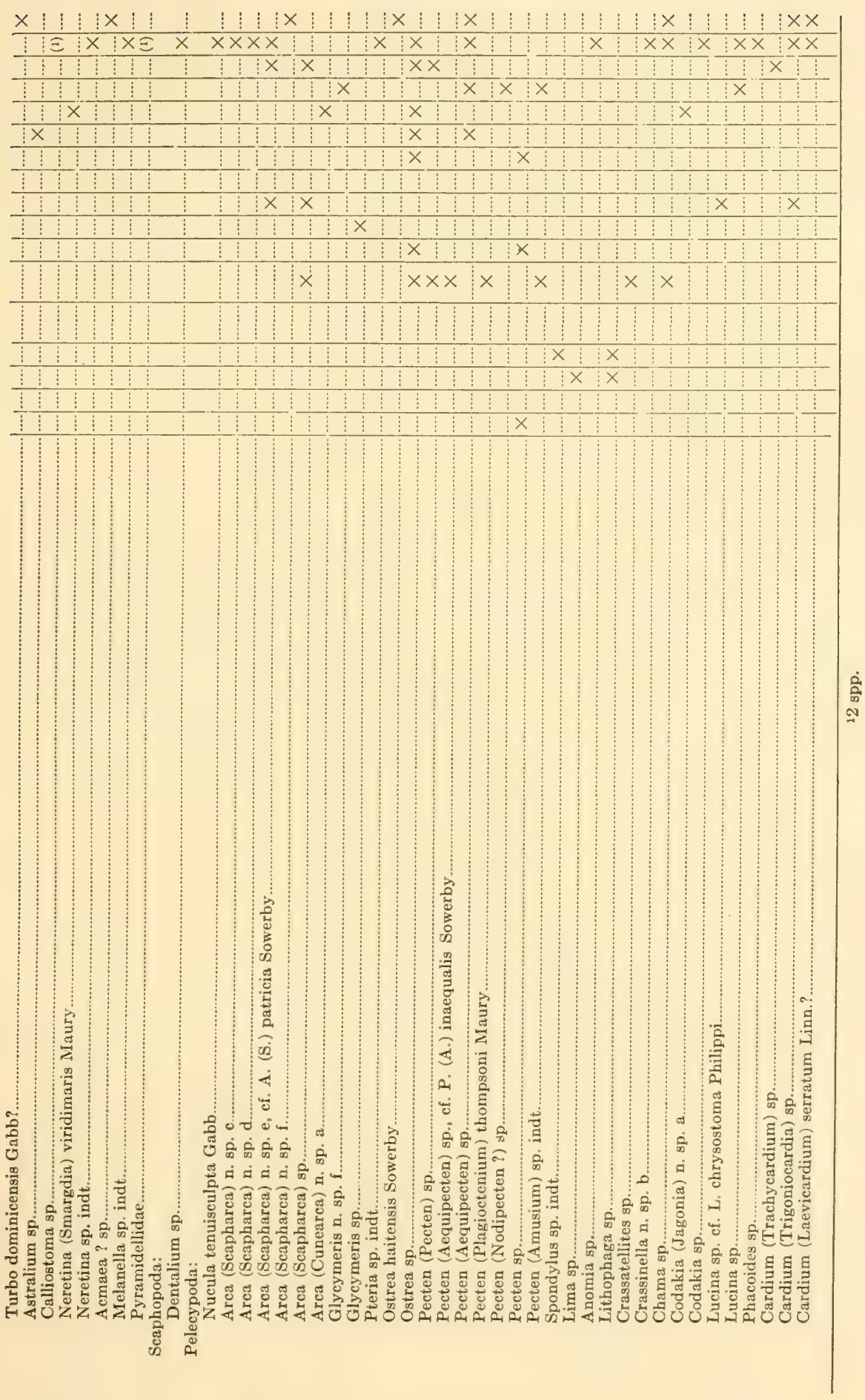




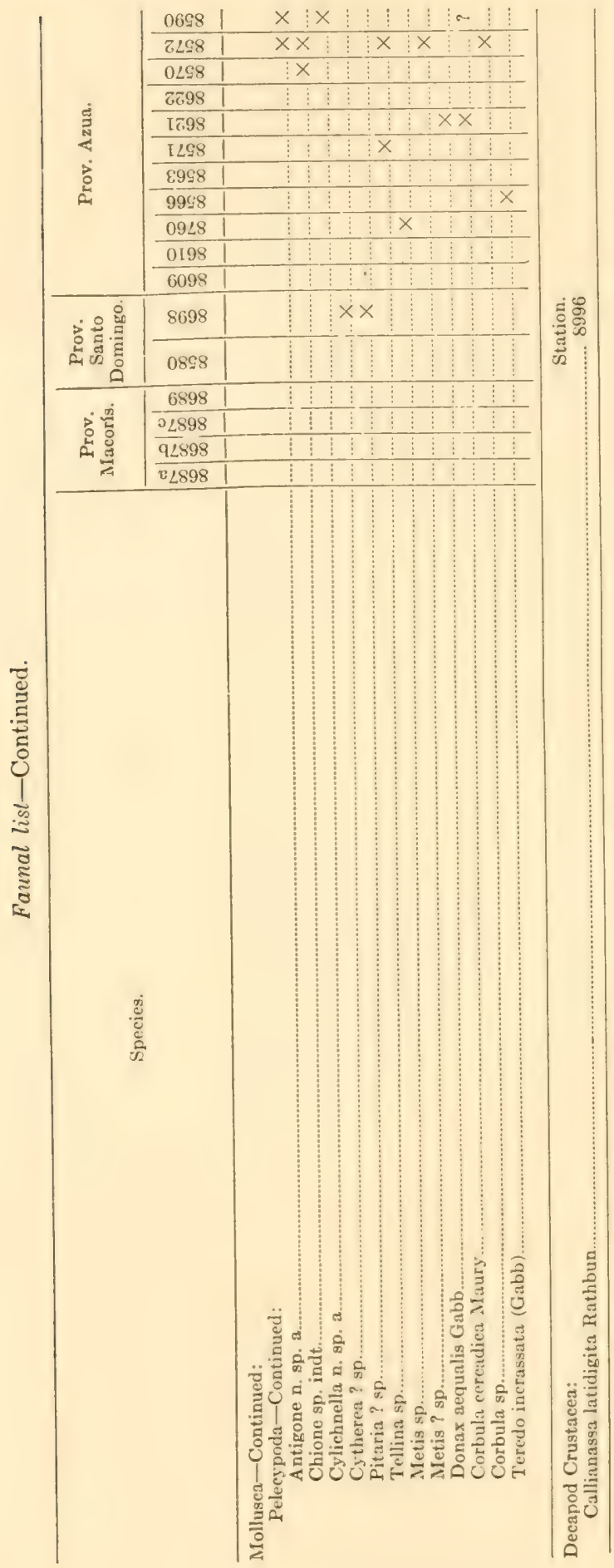




\section{Cerros de Sal Formation.}

List of stations.

8574 (D. C. 95). Province of Barahona, ravine on north side of Cerros de Sal about 4.2 kilometers west of Las Salinas; stations $0-8$ of traverse; foothills on north side of mountain. D. D. Condit, collector. May 30, 1919.

8742 (D. C. 95 A). Province of Barahona; ravine on north side of Cerros de Sal about 4.2. kilometers west of Las Salinas; stations 8-11 of traverse. D. D. Condit, collector. May 30, 1919.

8591 (D. C. 90). Province of Barahona, sandy beds along road from Cabral to Neiba, about 3.5 kilometers northwest of Las Salinas; altitude about 24 meters. D. D. Condit, collector. May 27, 1919.

8761. Province of Barahona, Angostura, west of Isas Salinas. N. H. Darton, collector. January, 1920.

\section{Faunal list.}

\begin{tabular}{|c|c|c|c|}
\hline & \multicolumn{3}{|c|}{ Prov. Barahona. } \\
\hline & 8574 & 8742 & 8591 \\
\hline \multicolumn{4}{|l|}{ Corals: } \\
\hline \multicolumn{4}{|l|}{ 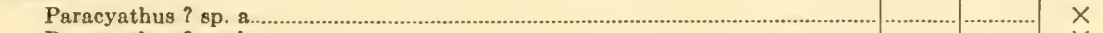 } \\
\hline \multicolumn{4}{|c|}{ Paracyathus ? sp. b. } \\
\hline \multicolumn{4}{|c|}{ Stylophora sp. a } \\
\hline \multicolumn{4}{|c|}{ 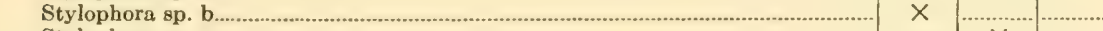 } \\
\hline Dichocoenia sp., aff. D. stokesi M. Edw. and H. & \multicolumn{3}{|c|}{ Stylophora sp } \\
\hline \multicolumn{4}{|c|}{ 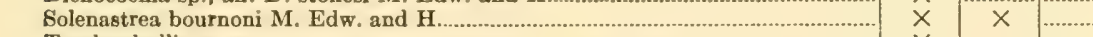 } \\
\hline \multicolumn{4}{|c|}{ 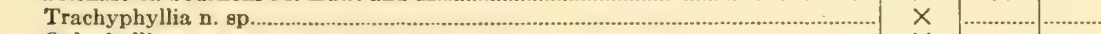 } \\
\hline \multicolumn{4}{|c|}{ Oulophyllia n. sp. } \\
\hline \multicolumn{4}{|c|}{ Agaricia n. sp. e } \\
\hline \multicolumn{4}{|l|}{ Siderastrea sp................... } \\
\hline Porites sp................................ & $x$ & & \\
\hline
\end{tabular}

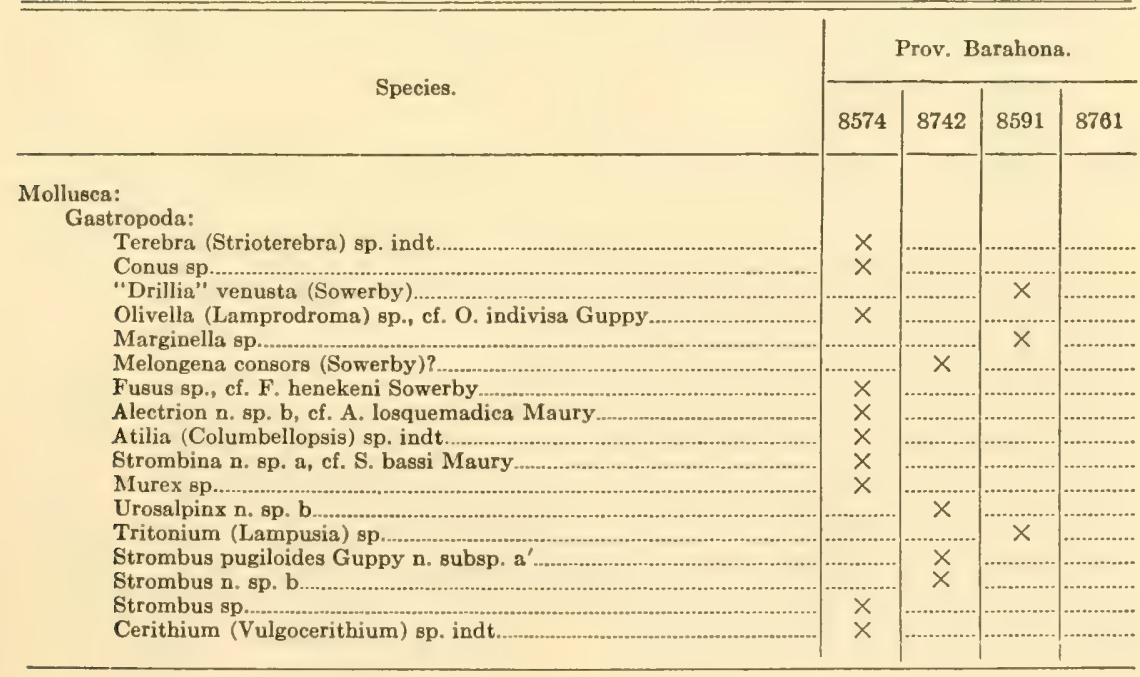


Faunal list-Continued.

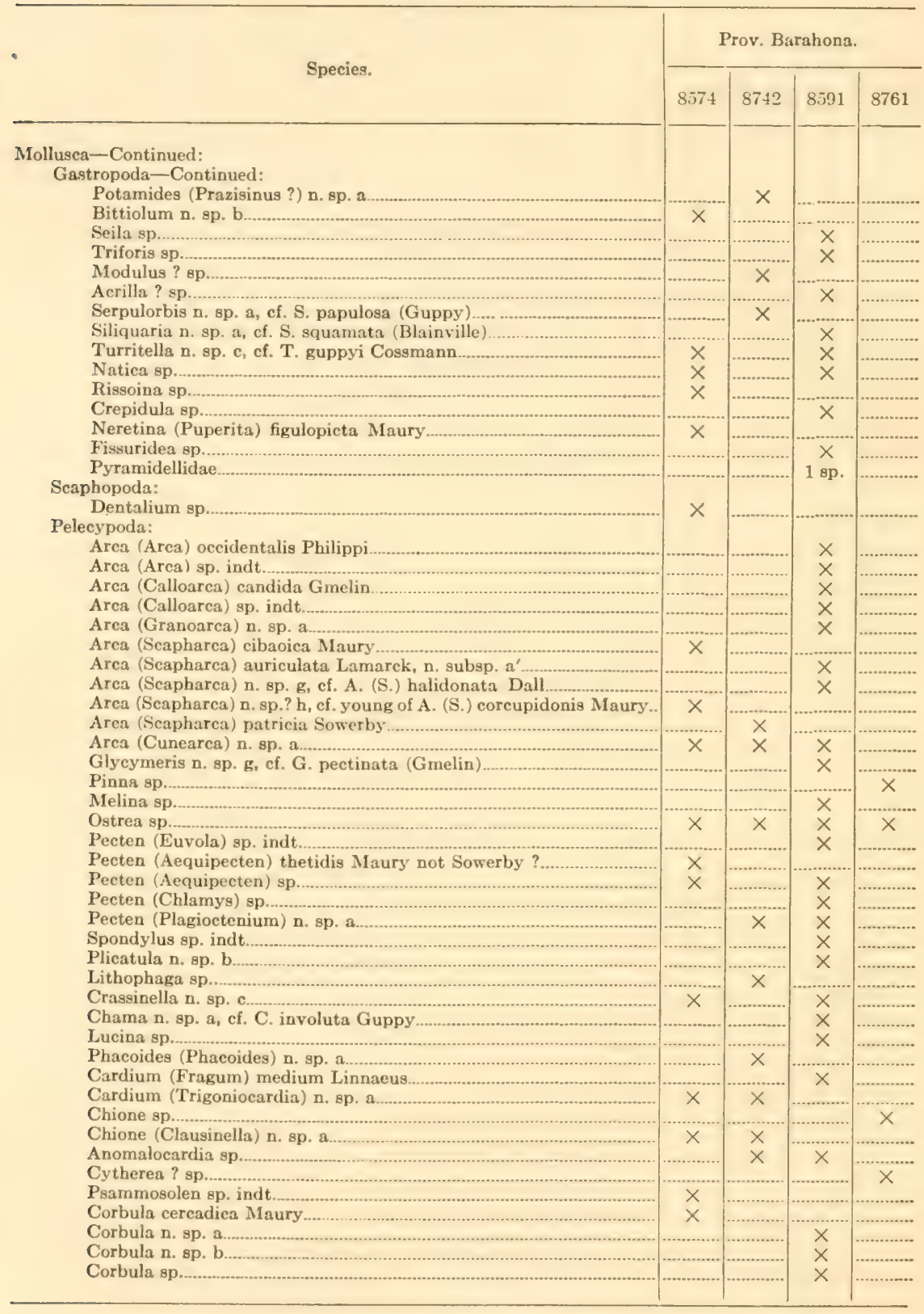


MIOCENE OR PLIOCENE, PROVINCE OF SAMANÁ.

\section{List of stations.}

8607 (C-21). Province of Sanamá, bluff on north coast of Samaná Bay, about 2.5 kilometers east of Sánchez. C. W. Cooke, collector, April 26, 1919.

8764. (R. 3). Province of Samaná, north shore of Samaná Bay, 1.7 kilometers east of pier at Sánchez. C. P. Ross, collector. June 27, 1919.

8684 (D. C. 4). Province of Samaná, eastward-dipping clay beds in cut near pier at Sánchez. C. W. Cooke and D. D. Condit, collectors. April 1, 1919.

8685 (D. C. 5). Province of Samaná, beach on Samaná Bay, 90 meters east of station 8684, near pier at Sánchez. C. W. Cooke and D. D. Condit, collectors. April $1,1919$.

\section{Faunal list.}

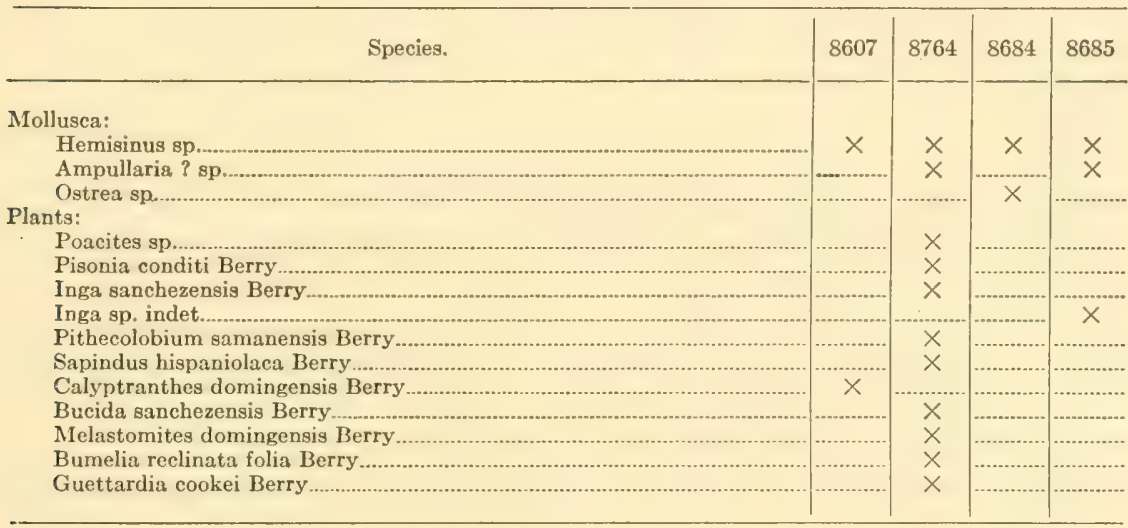

\section{PLIOCENE OR PLEISTOCENE, PROVINCE OF MONTE CRISTI.}

List of stations.

8560. Province of Monte Cristi, between Copey and Dajabon, at north edge of flat, on north side of Dajabon. T. W. Vaughan, collector. April 26, 1919.

8633 (R. 38). Province of Monte Cristi, on main road from Monte Cristi to Dajabon, at north edge of town of Copey. C. P. Ross, collector. May 7, 1919.

Faunal list.

\begin{tabular}{|c|c|c|}
\hline Species. & 8560 & 8633 \\
\hline \multicolumn{3}{|l|}{ Corals: } \\
\hline 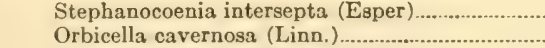 & $\begin{array}{l}x \\
x\end{array}$ & \\
\hline 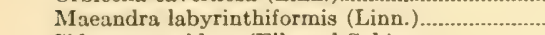 & $\hat{x}$ & \\
\hline 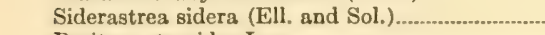 & $x$ & $x$ \\
\hline 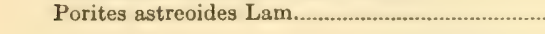 & $x$ & \\
\hline
\end{tabular}




\title{
PLEISTOCENE OR YOUNGER.
}

\author{
Station on north side.
}

8776 (R. 27). Province of Monte Cristi, from sea-beach at Rodriguez house, about 25 kilometers northeast of Monte Cristi; altitude, 7.5 meters above sea-level. C. P. Ross, collector. May 4, 1919.

Mollusca Station.

Strombus gigas Linnaeus? 8776

Codakia orbicularis (Linnaeus) 8776

List of stations on south side.

8688 (D. C. 7). Province of Macoris, 1.4 kilometers from San Pedio de Macoris, on Camino Real to Platanitos; altitude, 9 meters above sea-level. T. W. Vaughan, collector. April 3, 1919.

8690 (D. C. 11). Province of Macoris, from limestone underlying San Pedro de Macorís. D. D. Condit, collector. April 3, 1919.

8695 (D. C. 16). Province of Santo Domingo, road from Santo Domingo to San Crist6bal, 24.5 + kilometers from Santo Domingo; altitude, 80 meters above sea-level. T. W. Vaughan and others, collectors. April 6, 1919.

8674. Province of Santo Domingo, road from Santo Domingo to San Cristóbal, about 24 kilometers from Santo Domingo; altitude, 57 meters above sea-level. T. W. Vaughan and others, collectors. April 6, 1919.

8697 (D. C. 18). Province of Santo Domingo, road from Santo Domingo to San Cristóbal, 23+'kilometers west of Santo Domingo; altitude, 36 meters above sea-level. T. W. Vaughan and other, collectors. April 6, 1919.

8698 (D. C. 19). Province of Santo Domingo, west side of Rio Jaina, north of west end of bridge on road from Santo Domingo to San Cristobal. T. W. Vaughan and others, collectors. April 6, 1919.

8573 (D. C. 89). Province of Barahona, from "coast limestone" at Cabral. D. D. Condit, collector. May 28, 1919

8593 (D. C. 92). Province of Barahona, "coast limestone" fossiss from village of Barbacoa, altitude ranging from 33 meters below sea-level to about sea-level along the shore cf Iake Enriquillo. D. D. Condit, collector. May 27, 1919.

8629 (R. 63). Province of Barahona, from coral limestone along the road from San José to Lake Enriquillo. C. P. Ross, collector. June 4, 1919.

8625 (R. 52). Province of Barahona on road from Duvergé to Palma Dulce. C. P. Ross, collector. June 1, 1919.

8630 (R. 64). Province of Barahona, from sand in road west of Duvergé, a short distance beyond the place where the road reaches the shore of Lake Enriquillo, in entrance of pass into hills. C. P. Ross, collector. June 4, 1919. 
Faunal list.

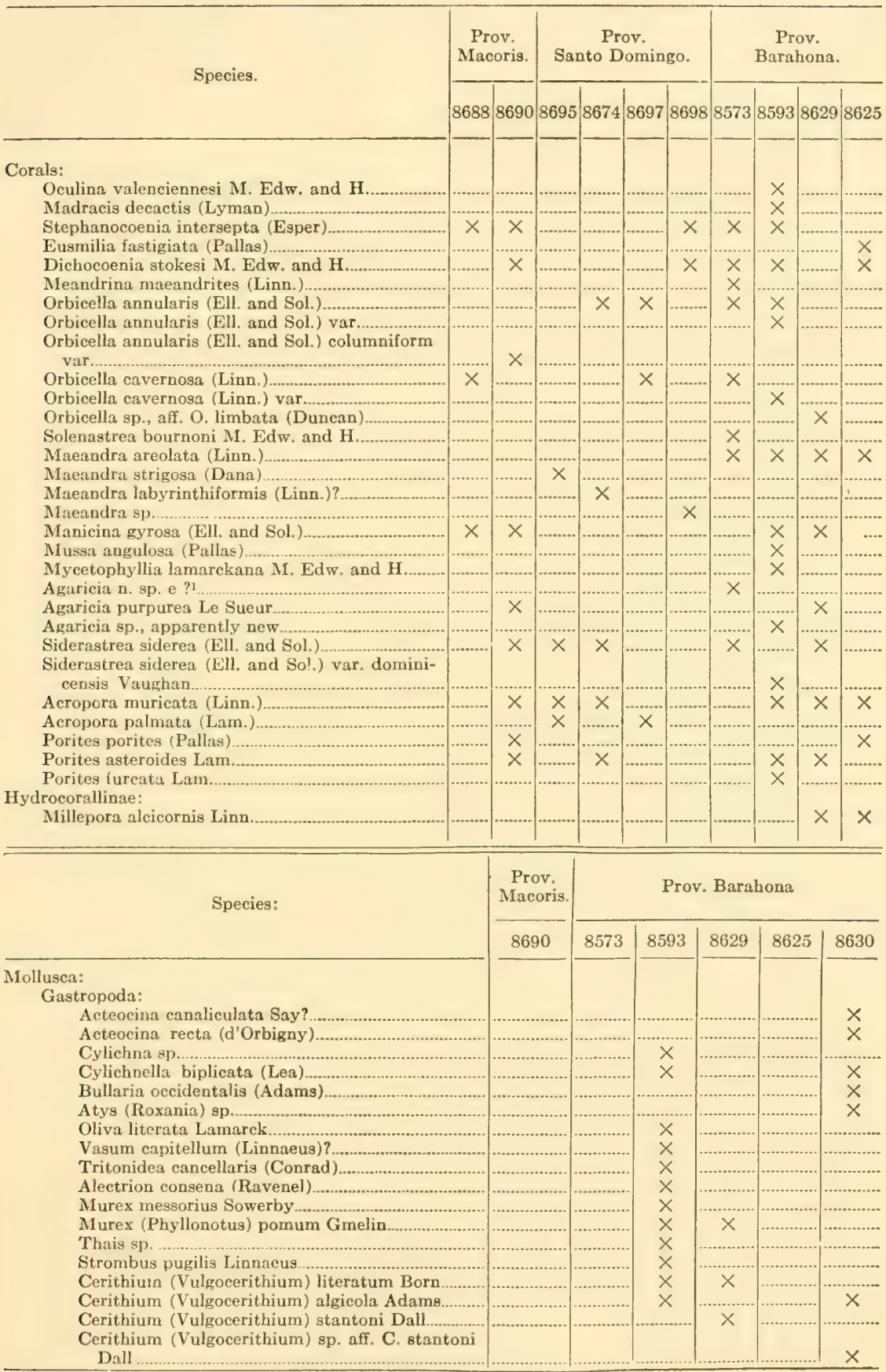

1 This species probably does not occur with the otherg listed from Station 8573 . 
Faunal list-Continued.

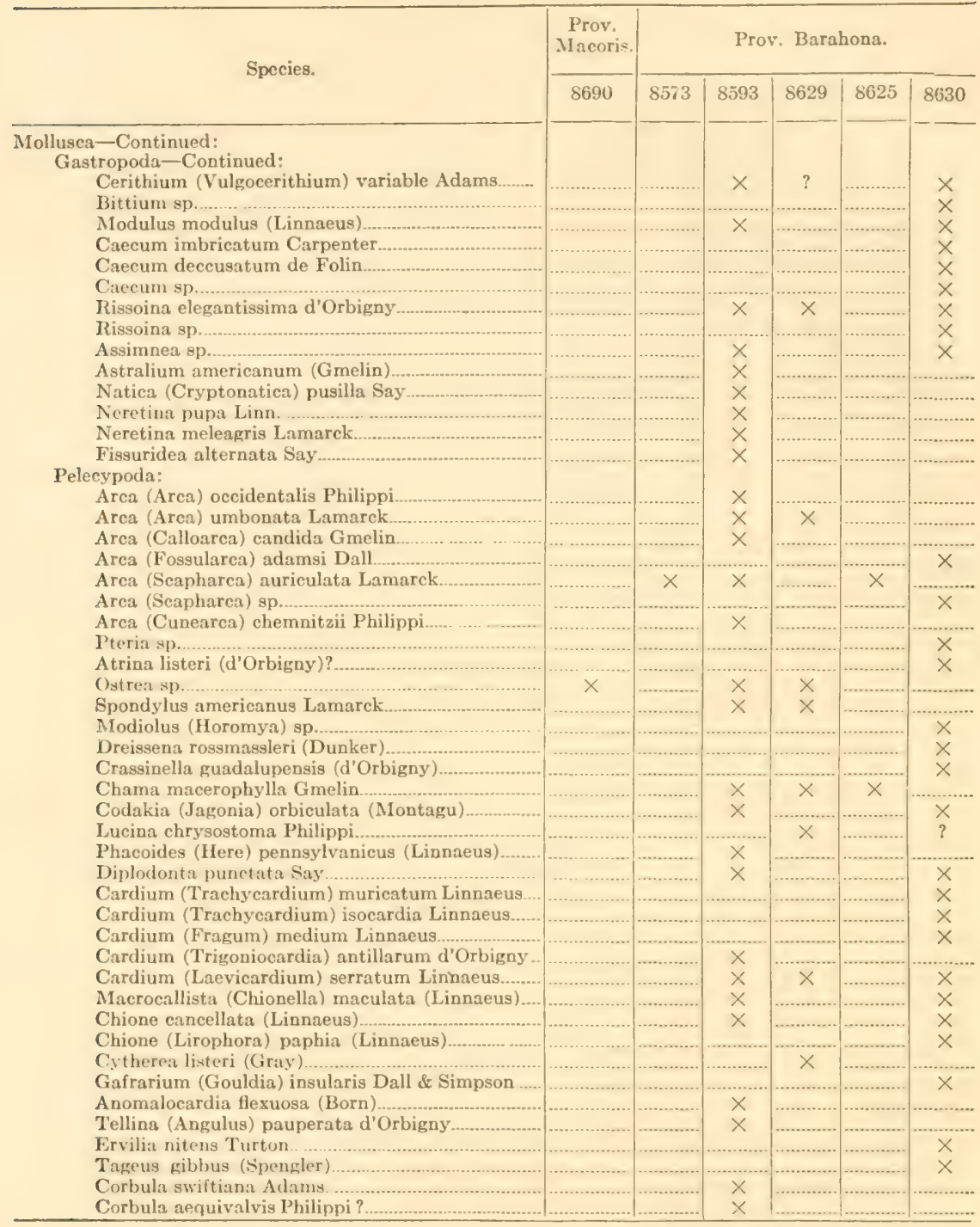




\section{CHAPTER VII. \\ GEOLOGY AND WATER RESOURCES OF THE VICINITY OF MONTE CRISTI.}

By Clyde P. Ross.

\section{CHARACTER AND PURPOSE OF THE WORK DONE.}

The town of Monte Cristi, the metropolis of the western part of the Cibao Valley, is on the north side of the mouth of Rio Yaque del Norte, near the seacoast, in the northwestern part of the Province of Monte Cristi. The area here considered, which includes most of the irrigated country under cultivation around Monte Cristi, extends about 30 kilometers east of the town and is bounded on the north by the Monte Cristi Range and on the south by the Cordillera Central. (See map, Pl. XIV.) Reconnaissance trips were made not only in the valley but through neighboring parts of the Monte Cristi Range and in the foothills of the Cordillera Central near Dajabon.

The object of this investigation was to gain a general knowledge of the geology of the region and to ascertain the probability of obtaining supplies of groundwater, particularly artesian flows. Supplies of stored water are greatly needed in this region for, according to the most reliable information obtainable, the rainfall here amounts to only about 31 centimeters a year. ${ }^{1}$ The success of the principal local industries, farming by irrigation and stock raising, is therefore dependent upon water derived from sources other than direct rainfall. The present principal source of water is Rio Yaque. The few wells in the region are shallow, and the water in many of them is salty. The water obtained from these wells is used for cattle and, if not too salty, for domestic purposes.

The examinations on which this report is based were necessarily hurried. More detailed investigations, aided by the drilling of test wells, would be necessary to warrant any but the most general conclusions as to the possibility of obtaining a sufficient supply of groundwater.

\section{TOPOGRAPHY.}

The dominant topographic features of this region are the broad valley of Rio Yaque and the two mountain ranges that bound it-on the north the Monte Cristi Range; on the south the Cordillera Central and its outliers, the Cerros de Jácuba.

Rio Yaque del Norte, the largest stream in the Republic, is nearly 240 kilometers long and is about 100 meters wide near its mouth. In the lower part of its valley the river has built an extensive delta, across which run 
a number of ramifying channels. The river formerly emptied into Manzanillo Bay, but it now enters the ocean at the southwest end of Monte Cristi Bay, about 3 kilometers from the town of Monte Cristi and 15 kilometers north of its former mouth. Its course is said to have been diverted several years ago by the construction of a dam near Las Cañas, about 13 kilometers upstream from the present mouth of the river. The dam has apparently concentrated all the water in the present channel, which probably was formerly one of many channels that extended across the delta.

The gradient of the river is about one meter to the kilometer, but the valley is in general a nearly level seaward-sloping plain. In the main valley the eminences that project above the plain are few and inconspicuous. The surface of the plain rises gradually to the foothills of the Monte Cristi Range on the north and to the Cerros de Jácuba and other outliers of the Cordillera Central on the south. The site of the town of Monte Cristi is bordered on its landward side by a low semicircular ridge and on its seaward side by salt marshes, which are protected from the sea by a low sand bar. The custom house and wharf are at one end of this sand bar. Almost 5 kilometers north of the town is a wedge-shaped butte about 225 meters high, called El Morro. (See Pl. II, B.) The butte is accessible by land only from the sand bar, for the sea washes its north and west sides and salt marshes stand on its other sides.

The Monte Cristi Range is composed of irregularly arranged hills and small mountains. Although some of the hills are steep, and even rough, none of them rise to a great altitude. The range was crossed on the trail from Monte Cristi through Isabel de los Torres to the sea at the finca of Señor Rodríguez, about 25 kilometers northeast of Monte Cristi town, where there is an old rope-fiber factory. Along this trail the range consists of isolated hills, 100 meters or more high, which rise abruptly from a rolling terrane that stands probably not much more than 10 meters above sea level. These hills, though rocky, are rounded rather than serrate. The hills southeast of the house of Señor Rodríguez are higher and the country there is not so open. The trail from this house to Sabana Cruz, after passing Arroyo Guanito, climbs nearly 70 meters up a steep slope called La Subida de la Salina. At the top of this slope is a plain, which stands about 170 meters above sea level, and scattered hills rise abruptly 70 to 100 meters higher. This plain extends eastward, though it becomes rolling and more dissected in that direction until it merges into the open valley of Rio Yaque near La Plata.

The rugged mountains of the Cordillera Central, which bound the valley of Rio Yaque on the south, rise abruptly from the savannas that occupy the area between the main mountain mass and its outliers. Hummocks of gravel are scattered over the savannas. The Cerros de Jácuba, one of the 




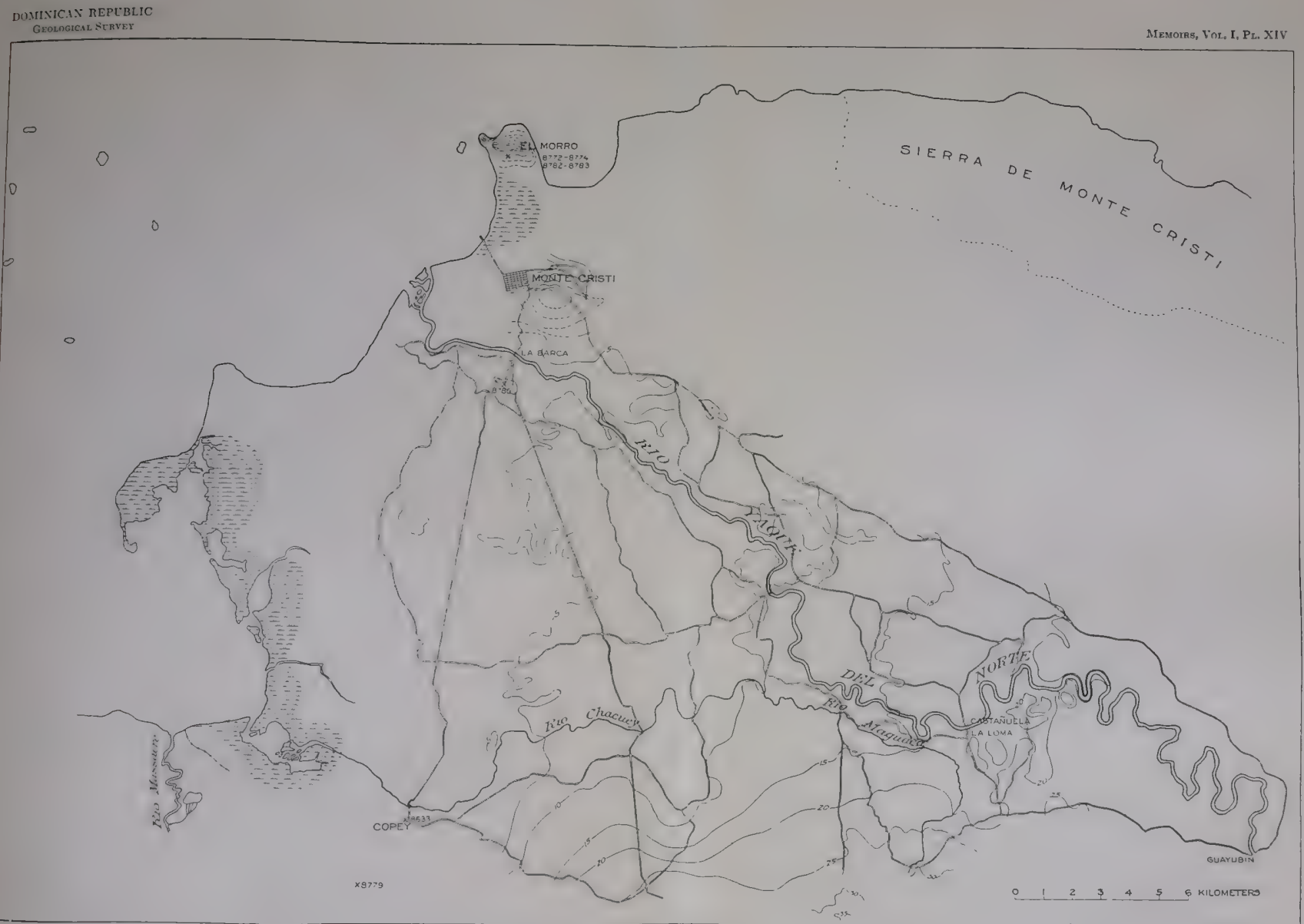

SKETCI MAP OF MONTE CRISTI AND VICINITY. 

outliers about 6 kilometers distant from the main mountains, are a series of rather low hills that trend parallel to the main mountains. The hills south of Copey, which are the northwestern extension of the Cerros de Jácuba, are rounded and less elongate.

\section{GEOLOGY.}

The following geologic subdivisions have been recognized in the area:

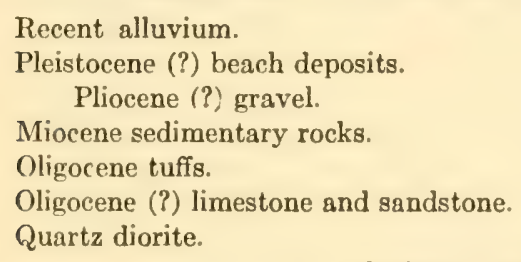

QUARTZ DIORITE.

During a trip from Sabaneta to Restauración ${ }^{1}$ by D. D. Condit and the writer quartz diorite was observed at one locality in the foothills of the Cordillera Central. A hill about 60 meters high, called Juan Calvo, which stands about 5 kilometers south of Dajabón, is composed of gray, rather coarsely crystalline biotite-hornblende-quartz diorite, which is cut by small dikes of an aplitic rock and numerous small quartz veins. On the north side of the hill the quartz diorite is sheared along a narrow zone 3 to 6 meters wide. This shear zone strikes N. $40^{\circ} \mathrm{E}$. and dips $45^{\circ} \mathrm{SE}$. Along the shear zone micaceous minerals are more abundant than in the unsheared parts of the rock. Similar rock probably forms the main mass of the northern part of the Cordillera Central in this area. The age of the rock is not known.

\section{OLIGOCENE (?) LIMESTONE AND SANDSTONE.}

Hard, compact limestone, probably of upper Oligocene age, was seen in the Monte Cristi Range and in the region immediately north of Dajabon. A low hill about 25 kilometers northeast of Monte Cristi and immediately east of the rope-fiber factory, on the seacoast, is composed of hard, massive cream-colored limestone. The Foraminifera Amphistegina sp., Globigerina sp., and Heterosteginoides? sp., probably of upper Oligocene age, were collected at this locality (station 8853). Less than 3.5 kilometers east of this hill similar limestone shows distinct bedding planes that strike east and $\operatorname{dip} 60^{\circ} \mathrm{N}$. Similar limestone was observed at another locality in the Monte Cristi Range on the trail 5.5 to 7 kilometers northeast of the settlement called Isabel de los Torres. The limestone at this place is hard, fine-grained, gray to cream-colored and distinctly bedded. The strike is east and the dip is $60^{\circ} \mathrm{N}$. Apparently the limestone has been metamorphosed by the intrusion of small dikes of a hard black aphanitio rock.

1 See p. 52 of this report. 
Several hills north of Dajabón show exposures of hard, gray massive limestone similar in lithology to the rock in the Monte Cristi Range. which contains Foraminifera, probably of upper Oligocene age.

Immediately north of these hills, on Sabana Cañongo along the trail from La Loma to Dajabón, is an outcrop of hard sandstone, which grades into conglomerate. This sandstone contains numerous fragments of the shells of marine mollusks. Although the bedding is indistinct the strike is apparently east and the dip is rather gentle to the north. This sandstone is considered older than the Miocene sediments because of its greater induration.

Hard, calcareous sandstone, overlain by conglomerate interbedded with sun-cracked sandstone, was also observed in the Monte Cristi Range east of the rope-fiber factory on the seacoast about 25 kilometers northeast of Monte Cristi. The beds strike N. $65^{\circ} \mathrm{W}$. and dip $55^{\circ} \mathrm{NE}$.

\section{OLIGOCENE TUFFS.}

Tuffs were observed at two localities in the Monte Cristi Range. Green weathered tuff outcrops along the coast at an altitude of about 45 meters above sea-level in an arroyo approximately 5 kilometers southeast of the rope-fiber factory. The tuff is not bedded, but a short distance upstream it is interbedded with coarse-grained sandstone, which strikes north and dips eastward. Corals that are apparently of Oligocene age and that are listed on page 111 (station 8775) were collected from thin calcareous beds intercalated in the sandstone.

Green jointed rock, which is apparently a fine-grained tuff, is exposed at an altitude of about 75 meters above sea level in Arroyo Guanito on the trail to Barranca Blanca, 9 or 10 kilometers from the rope-fiber factory. At this locality the tuff grades upward into a conglomerate composed of pebbles that have a maximum diameter of 15 centimeters. The conglomerate is overlain by hard, buff-colored, indistinctly bedded limestone. The beds strike N. $60^{\circ} \mathrm{W}$. and dip about $70^{\circ} \mathrm{SW}$.

Pebbles of green chloritized tuff and lava are of widespread occurrence in this region and similar tuff and lava were found in place in the Cordillera Central south of Sabaneta. ${ }^{1}$

\section{MIOCENE SEDIMENTARY ROCKS.}

Limestone, sandstone, and shale and less consolidated sand and clay of Miocene age are widely spread in the vicinity of Monte Cristi. Obviously the Miocene series includes several formations, but their relations were not definitely ascertained. The exposures on the slopes of El Morro, near Monte Cristi, indicate that Miocene sedimentary rocks form a large part of the western Monte Cristi Range. Rocks of the same age or slightly younger underlie the entire lower part of the Yaque Valley. 
The following section was measured on the steep, bare slopes of El Morro. A barometer was used to determine altitudes. The fossils are listed on page 154 .

Section at El Morro.

Meters.

8. Sandy porous limestone containing a few fossils (station 8774 , at an altitude of $155 \mathrm{~m}$.)

7. Thin beds of limestone alternating with fossiliferous clay (station 8783)

Unexposed

6. Soft sandy clay.

5. Soft clay and impure limestene

4. Thin-bedded layers of sandstone, clay, and impure limestone, containing a few fossils (station 8782 , at an altitude of $105 \mathrm{~m}$.).. $\quad 40$

$\begin{array}{lll}3 . & \text { Buff to reddish fossiliferous calcareous sandstone (station 8773).. } & 12\end{array}$

2. Hard, porous, buff-colored fossiliferous limestone, weathering gray (station 8772 )

Unexposed 18

Unexposed

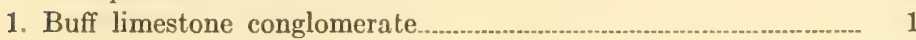

The beds that form El Morro strike N. $80^{\circ}$ E. and dip $5^{\circ} \mathrm{NW}$. The basal member of the above section is exposed at sea level about 600 meters south of El Morro. Members 4 and 5 are not actually exposed, but the lithology was determined from an examination of the surface débris. Although the collection of corals from member 3 (station 8773) is too small to warrant a definite determination of age, the other collections indicate that the beds exposed on El Morro are of the same age as the Yaque group of the middle part of the Yaque Valley. Sconsia laevigata (Sowerby), which is confined to the Gurabo formation in the middle Yaque Valley, was collected from member 7 (station 8783). Dr. Maury ${ }^{1}$ collected the same species at this locality.

Cross-bedded argillaceous sandstone and sandy clay are exposed on a hill immediately west of Isabel de los Torres, in the Monte Cristi Range, about 9 kilometers northeast of Monte Cristi. The beds strike N. $60^{\circ} \mathrm{E}$. and dip gently northward. No fossils were observed, but the beds resemble those exposed on El Morro, both in lithology and in structural relations.

Similar sedimentary rocks were observed at two localities on Rio Yaque. Thin-bedded sandstone and limestone, which strike N. $45^{\circ}$ E. and dip $20^{\circ} \mathrm{SE}$., crop out a short distance downstream from the manager's house on Manzanillo Plantation. Thin-bedded sandy limestone, which strikes N. $60^{\circ}$ E. and dips $20^{\circ} \mathrm{SE}$., is exposed on the south bank of Rio Yaqueat La Barca immediately upstream from the ferry landing.

Thin beds of clay, sandstone, and impure limestone are exposed in many cuts along the automobile road from Monte Cristi to Santiago. The gen-

\footnotetext{
'Maury, C. J., Bull. Am. Paleontology, vol. 5, p. 450, 1917.
} 
eral strike of the beds is northeast and the dip is southeast at an angle less than $25^{\circ}$. These rocks are exposed from Monte Cristi to a place 23.75 kilometers east of Monte Cristi, where younger unconsolidated sand and gravel are encountered.

In the vicinity of Barranca Blanca, in the Monte Cristi Range, sandstone, sandy caleareous clays and soft white limestone are exposed in the arroyos. The beds are more disturbed here than in other areas of Miocene rocks, although the sediments are less consolidated. The strike shifts from north to east and the dip ranges from $15^{\circ}$ to $60^{\circ}$.

In addition to the beds described in the above paragraph the Miocene series includes a younger group of less consolidated sand and gravel. Such beds are exposed along the road from Monte Cristi to Santiago east of a place 23.75 kilometers from Monte Cristi. Although local dips as high as $10^{\circ}$ were observed the beds are almost horizontal. The road to Guayubin and Sabaneta branches off the main road 24 kilometers from Monte Cristi. At La Plata, 27 kilometers from Monte Cristi, the fossil marine mollusks listed on page 154 (station 8778 ) were found partly embedded in the yellow soil that covers the plain. As the shells are numerous and widely spread they seem to be in place. They indicate a horizon high in the Miocene, probably higher than any of the horizons in the Yaque group of the middle Yaque Valley.

Fossils of the same species were collected at La Subida de la Salina, on the trail through the Monte Cristi Range (station 8777,p. 154). Soft, friable reddish-brown sandstone, which contains the fossils, is exposed along a steep slope almost 60 meters high. The beds strike N. $35^{\circ} \mathrm{W}$. and dip $30^{\circ} \mathrm{SE}$. At the top of the slope is a level plain, above which rise a few rounded hills. On the flank of one of the hills, west of the trail, there is a shallow syncline in reddish-brown sandstone.

Several low hills near La Barca, on the south side of Rio Yaque, are composed of undisturbed coralliferous limestone and sand. The corals (see list on p. 154, station 8780) represent a horizon high in the Miocene, perhaps equivalent to the horizon of the Mao Adentro limestone of the upper Yaque Valley.

The town of Copey, which stands between Monte Cristi and Dajabón, is built on rather soft, indistinctly bedded coralliferous light-gray sand and clay, which are well exposed immediately south of the town along the road to Dajabón (station 8779 , p. 154). These deposits are apparently of Miocene age but may be younger.

Farther north, on the south side of Rio Yaque between La Barca and Caño de Botijuela, several hummocks that rise above the plain are composed of horizontal beds of coralliferous limestone and subordinate amounts of detritus from the limestone. The patches of limestone clearly are coral reefs, which are probably of the same age as the coralliferous deposits at 
Copey, but the geologic age of the coralliferous rock at several localities has not yet been definitely determined. The rock at some places-for instance, just south of Ia Barca-is definitely Miocene, but at others it may be Pleistocene or even younger.

Poorly consolidater reddish-brown argillaceous sandstone unconfer mably overlies the Miocene sediments in the lower Yaque Valley. The unconformity is visible on the south bank of Rio Yaque at La Barca, immediately upstream from the ferry landing. The consolidated Miocene beds strike N. $60^{\circ}$ E. and $\operatorname{dip} 20^{\circ} \mathrm{SE}$., but the overlying soft sandstone strikes N.25 W. and dips $3^{\circ} \mathrm{NE}$. The soft sandstone is probably of Miocene age.

\section{PLIOCENE (?) GRAVEL.}

The gravels that form the hummocks on the savannas along the foot of the Cordillera Central near Dajabon may be of Pliocene age. Apparently the gravel was originally spread over the entire plain and the hummocks are mere remnants. The most common rocks in the gravel are quartz diorite, finely crystalline black igneous rock, and quartz. At one locality the gravels lie on the truncated surface of northward dippingthin-bedded sandstone and clay, probably of Miocene age.

\section{PLEISTOCENE (?) BEACH DEPOSITS.}

Horizontal beds of beach sand and gravel form a cliff 7 meters high on the coast just east of the rope-fiber factory, about 25 kilometers northeast of Monte Cristi. The recent species of mollusks listed on page 166 (station 8776) were collected from beds in the upper part of the cliff. These beds are not older than Pleistocene but may be younger.

\section{RECENT ALLUVIUM.}

The lower Yaque Valley is covered with a thin sheet of alluvium that forms a yellow to brown clayey soil. The alluvium is similar to the silt that is building the delta at the present time. Although the soil is fine-grained it absorbs water rather readily.

The thickness of this deposit is highly important to any one attempting to obtain a supply of ground water. The deposit forms the banks of Rio Yaque in its lower course, but at no place are the banks more than 3 to 6 meters high. Not far above the mouth of the river Miocene bedrock crops out in the channel of the river at places where the alluvium is not more than 6 meters thick. The wells, all of which are shallow, show that the alluvium is at least 6 meters thick. River deposits more than 15 meters thick will probably not be found in the part of the valley that includes the largest farms, but the thickness of the deposits can be definitely determined only by sinking test wells. 


\section{STRUCTURE.}

The structure of the rocks under the lower part of the Yaque Valley has an important bearing on possible supplies of underground water. The structure of the beds in this region is not a result of deformation during a single period but was developed progressively; each one of the sedimentary formations described above was deformed before the next younger formation was deposited. There has been both folding and faulting, but the deformation was not so intense as to produce great dynamic metamorphism. The older formations are somewhat metamorphosed, but the younger ones have been very slightly affected.

On the south side of the valley are the foothills of the Cordillera Central, which are evidently fault blocks. The quartz diorite appears abruptly in one of the foothills in Juan Calvo Hills near Dajabón, and there is a distinct shear zone. The topography of other outlying hills, Cerros de Jácuba, suggests faulting, and the correctness of this view is supported by the presence in them of limestone apparently of Oligocene age.

On the north side of the valley, along the southern foot of the Monte Cristi Range, no indications of faults of great magnitude were observed, but in some places there has been folding sufficient to produce dips as high as $70^{\circ}$. The rocks that underlie the valley were seen also in the Monte Cristi Range, where they are more disturbed than in the valley, and at Barranca Blanca Miocene strata have been faulted. The strike of the structural lines is prevailingly east and west. A study of El Morro de Monte Cristi (see section on p. 173) shows the presence there of strata equivalent to the Gurabo formation between altitudes of 153 and 155 meters above sea level, and the hill is 57 meters higher. Near La Barca, on the south side of Rio Yaque opposite the town of Monte Cristi (station 8780, p. 154), fossils representing either the upper part of the Gurabo formation or the Mao Adentro limestone were collected about 5 meters above sea level. The bed at this station represents a horizon stratigraphically as high as or higher than the horizon of the bed exposed in EI Morro de Monte Cristi at an altitude 150 meters or more higher topographically. The dip on the Morro is $5^{\circ} \mathrm{N}$., but the beds at station 8780 are almost undisturbed. These relations imply considerable deformation and perhaps a fault along or near the south side of the Morro, with downthrow to the south and upthrow to the north. The observations here recorded invalidate the opinion of Gabb and Heneken, quoted by Maury, that the limestone capping the Morro is "a continuation of that capping the Samba Hills, the intervening part having been removed by denudation." 1

The floor of the lower part of the Yaque Valley is formed of strata of Miocene age, which are either exposed or lie under a thin cover of younger deposits. These strata are slightly inclined, crossed by gently undulatory

1. Maury, Carlotta J., Bull. Am. Paleontology, vol. 5, p. 450, 1917. 
folds, and in places dislocated by small faults. The prevalent strike is transverse to the axis of the valley and the dips are more commonly westward than eastward. In places the same bed can be traced for considerable distances by continuous outcrop, although the valley floor slopes westward. If therefore seems probable that the strata have a general westward dip, which is varied by small transverse folds. One fold noted was a dome between La Barca and the town of Monte Cristi, and probably there are others. Although the dips are usually low and westward, they are in some places fairly high and southeastward. Along the road from Monte Cristi to Santiago, for instance, there are southeastward dips at angles as steep as $20^{\circ}$.

The general structural features of the part of the Yaque Valley near Monte Cristi appear to be favorable to the occurrence of artesian water, but this opinion is only preliminary and should be verified by more detailed examination.

\section{WATER RESOURCES.}

\section{SURFACE WATER SUPPLY.}

There is no permanent stream in the part of the Monte Cristi Range considered in this report, and the water in the streams that emerge from the Cordillera Central is available only in their immediate vicinity. Rio Yaque is the sole present source of water for irrigating the farms in the lower valley and is the principal source of water for domestic use, for which it is packed on burros for distances of 30 kilometers or more from the river. Unfortunately neither discharge records nor analyses of the water of this river are available. No springs are known in the area. After rains water is retained for long periods in pools in the channels of intermittent streams in the Monte Cristi Range, but most of these pools become dry during long droughts.

\section{UNDERGROUND WATER SUPPLY.}

POSSIBILITY OF OBTAINING GROUND WATER.

Only a few shallow wells, none of which have been carried more than a meter below the water table, have been dug in the area under consideration. All have been dug by hand and none are more than 10 meters deep. Some of these wells are merely holes in the channels of intermittent streams, have not penetrated the permanent zone of saturation, and are dependent on precipitation for their supply of water. Many of the wells are not reliable at all seasons and would have to be sunk deeper in order to obtain a permanent supply of ground water. The fact that water is found in wells 6 to 10 meters deep shows that the water table stands relatively close to the surface.

The presence of salt water in all the wells has discouraged further development of the underground supply, but the amount of salt in several of the older wells is said to have decreased so much that their water is potable. 
The salt in the ground immediately adjoining these wells appears to have been washed out, and if the wells had been energetically pumped the salt might have been removed much more quickly.

Though the wells are shallow and inadequate, enough of them have been sunk to show that ground water can be obtained in the lower part of the valley of Rio Yaque. The porous beds in the underlying rocks form a large reservoir for the storage of ground water. The drainage from the wellwatered region about Santiago and from the Cordillera Central furnishes an ample supply of water to fill this reservoir. Wells sunk almost anywhere in the lower part of the Yaque Valley would probably strike water, and a permanent supply might be obtained by pumping wells that penetrate the permanent water table. The quantity of water obtainable would be ample for domestic use and it might be sufficient for irrigation.

Definite statements concerning the mineral content of the water from such wells are unwarranted. The water obtained in shallow wells that have been dug is at first invariably salty, but several of the older wells now yield potable water. Most of these wells have been sunk in the alluvium, but several were dug in Miocene rocks. Evidently salt is present a short distance below the surface in both the alluvium and in the older rocks. In some places the salt appears in salt flats on the surface. The presence of potable water in some of the old wells shows that the salt in the soil or in the rocks near these walls is rapidly removed. If modern pumping methods were applied the salt might be removed even more rapidly and effectively. As many of the Miocene rocks are calcareous the water in some of the deep wells may be too hard for use in the laundry. Water obtained from the crystalline rocks near Dajabon would have a much lower mineral content.

POSSIBILITY OF OBTAINING ARTESIAN WATER.

The well-watered region of the middle part of the Yaque Valley and the part of the Cordillera Central that bounds the area on the south would evidently furnish an adequate supply of ground water, and as these areas are considerably higher than the lower Yaque Valley the water would be under adequate pressure, yet the information obtained does not warrant definite conclusions as to the possibility of obtaining artesian water in the valley. As older Miocene rocks dip from the south northward under younger rocks in the upper and middle parts of the Yaque Valley and pass below the rocks exposed around Monte Cristi, and as the valley floor slopes toward the mouth of the river, underground water from the middle parts of the valley might drain into the Miocene beds that underlie its lower parts. However, as the Miocene strata of the lower valley are faulted against the foothills of the Cordillera Central, the quantity of water that enters the Miocene strata may not be so great as might enter if the strata were upturned along the mountain front. 
Although the beds are thin and many of them discontinuous, some of the Miocene rocks are sufficiently porous to contain considerable quantities of water; and although no continuous thick beds of shale or other impervious rocks are known in the Miocene series, shaly beds are known that would be adequate retaining agents if advantageously placed with respect to a waterbearing stratum. In the area under consideration the water table lies close to the surface, so that the downward pressure of the water itself might take the place of a retaining agent and produce weak artesian conditions, but the flow under such conditions would not be very strong. It seems probable that artesian conditions may exist at some places near Monte Cristi, but whether adequate flows of suitable water could be obtained at moderate depths at such places can not be predicted from the data available. Artesian wells would have to be drilled to a greater depth than wells from which the water is obtained by pumping.

\section{CONCLUSIONS AND RECOMMENDATIONS.}

Ground water can be obtained at no great depth in the lower part of the valley of Rio Yaque, and pumped wells may yield it in considerable quantity. Although the upper ground water is more or less salty, water of good quality for both domestic use and irrigation can probably be obtained, and as such water is far less contaminated than the river water it will be preferable to the river water for domestic use. A much larger area might be irrigated by water from wells than by water drawn from Rio Yaque by present methods if the water should be suitable for irrigation, and as the water table is at many places only a little farther below the surface of the ground than the water in Rio Yaque is below the tops of the river banks, the cost of pumping from wells would be hardly greater than the cost of pumping from the river. If only water for domestic use is desired, wells equipped with windmills would furnish an adequate supply at a very low cost. Adequate supplies for watering stock could probably also be obtained in this manner, but sufficient water for irrigation on only a very small scale could be obtained with windmills.

Definite information concerning the amount and quality of water and the depth at which it would be encountered can be obtained only by drilling test wells. Water will be encountered at a shallow depth, but the drill must be sunk considerably deeper to obtain it in large quantity. As the rocks that underlie the valley are thin bedded and are of various types their water-bearing capacity will vary considerably both laterally and in depth. The quality of the water will also vary, and the first water encountered will probably be more saline than the deeper water.

Test wells might be sunk on government property-for instance, at the agricultural experiment farm-but the well should be drilled to a depth of 100 meters unless an adequate supply of water of satisfactory quality is 
obtained at less depth. For such a test a pipe 15-centimeters in diameter will be sufficient, and a strainer will be necessary if the water-bearing beds are composed of fine sand. An accurate record of the strata penetrated and of the quantity and quality of water encountered at each water-bearing stratum should be kept in order to obtain data for drilling other wells. Samples of the water from each water-bearing stratum should be collected in clean bottles that are stoppered with unused corks. Samples of the rocks that are penetrated should also be collected. A well of this size, though large enough to furnish a test, will not be large enough to supply water for irrigation. If the results of the test well are satisfactory a well with a 30 -centimeter casing should be drilled on high ground in the vicinity of the test well.

Although it is possible that a well 100 meters deep may obtain an artesian flow, an adequate test for artesian water will require a much deeper well, for failure to get water under pressure in a well at such a depth will not prove that artesian flows can not be found in this region. To make an adequate test for artesian water a well should be drilled to a depth of 500 to 700 meters unless a satisfactory supply is found at less depth or unless the stratified rocks are passed through and hard crystalline or metamorphic rocks are penetrated. A site farther upstream than the experimental farm-one near Guayubin, for example-would be more favorable for an artesian test well. Favorable artesian structure in this neighborhood is suggested by the fact that the Miocene sedimentary strata in the hills south of Guayubin dip gently northward, toward the valley. The ground water near Guayubin is nearer its source and is therefore probably less mineralized than that farther downstream. If favorable results are obtained from a test well sunk at this locality other deep test wells, both up and downstream, would be warranted. No single well will furnish conclusive proof as to the ground water conditions throughout the region around Monte Cristi, but one well properly drilled and tested will add to the knowledge of the ground water conditions and will furnish data that will afford more intelligent direction to further prospecting. 


\title{
CHAPTER VIII.
}

\section{GEOLOGY OF THE PROVINCE OF SAMANÁ.}

\author{
By Clyde P. Ross.
}

The conclusions here recorded concerning the geology of the Province of Samaná are based on observations made by the writer during a two weeks' reconnaissance between Sánchez and Santa Bárbara de Samaná, on the north shore, and during a trip by motor boat along the south coast of Samaná Bay, as well as on observations made by Wythe Cooke at the west end of Samaná Peninsula and on observations made by T. W. Vaughan, D. D. Condit, Wythe Cooke, and the writer during a day spent at Sánchez while en route to Santo Domingo City.

\section{TOPOGRAPHY.}

\section{SAMANÁ PENINSULA.}

Relatively low, rugged mountains cover almost the entire area of Samaná Peninsula. The mountains at the west end of the peninsula are seperated from the Cordillera Septentrional by a flat, swampy area called El Gran Estero, which was in relatively recent time beneath the sea, when Samaná Peninsula was an island. Recent species of corals and oysters were found in the soil along the road between Sánchez and Matanzas, at the west end of the mountains, at an altitude of less than 15 meters above sea level. As the peninsula is shown as an island on some of the earlier maps the sea probably continued to occupy this area even within early historic time.

The mountains of the peninsula consist of three parallel ranges. The southernmost range has a maximum altitude of about 300 meters above sea level, but the central range rises to at least 480 meters. The central range is drained northward. All the streams that enter Samaná Bay drain only the southernmost range and the narrow coastal plain. In the area between Sánchez and Los Cocos the streams originate in springs at the base of the southernmost range.

The east end of the peninsula is a more or less flat limestone plateau, which rises to an altitude of probably 100 meters above the sea and merges westward into the mountains. The streams on this plateau disappear in sink holes and flow underground to the sea, where some of them are said to emerge as springs along the beach.

A narrow strip of low, rolling country, which probably includes the dissected remnants of a series of sea terraces, fringes the mountains along the south coast of the peninsula between Sánchez and Los Cocos. (See Pl. III, C.) The highest parts of this rolling terrane stand about 30 meters 
above sea level. The altitude at Sánchez is 15 to 20 meters; immediately east of Sánchez it is 10 to 15 meters. The change from the subdued topography of the rolling terrane to the rugged topography of the mountains is extremely abrupt. The mouths of all the smaller streams in this area are blocked by sand bars.

Between Los Cocos and Samaná the mountains descend directly to the sea. (See Pl. III, B.) Hills 150 and 180 meters in altitude rise almost sheer from the water. At Samaná a narrow valley interrupts the mountains and off the coast there are several small rocky islands. East of Samaná the hills again reach the coast.

\section{SOUTH SHORE OF SAMANÁ BAY.}

During a trip by motor boat along the south shore of Samaná Bay landings were made at a cove a short distance west of Punta de Boca del Infierno, at Sabana de la Mar, and at Las Cañitas. The outline of the shore is shown on the United States Hydrographic Office chart No. 917.

West of Sabana de la Mar the hills rise abruptly from the water and a number of small islands lie off the coast. On both the mainland and the islands sea cliffs that rise 3 to 12 meters above the water have been cut in the limestone. Sea caves and horizontal channels, some of which are 3 meters above high tide, lead back from the cliffs. The skyline along this part of the coast is remarkably even. As viewed from the bay the hills seem to form a plateau which has an altitude of about 180 meters above sea level. Near Sabana de la Mar the hills probably reach an altitude of 200 meters above sea level.

East of Sabana de la Mar the topography is decidedly different. The hills are higher, are distinctly serrate, and apparently form several ranges. Except at a few places, the hills descend directly to the shore, but much less steeply than those to the west.

\section{GEOLOGY.}

The following geologic subdivisions were recognized along the north shore of Samaná Bay.

Recent deposits.

Pleistocene or Recent terraces and coral reefs.

Miocene or Pliocene clay, sand and conglomerate.

Oligocene or Miocene limestone.

Early 'Tertiary limestone conglomerate.

Basal complex.

\section{BASAL COMPLEX.}

The rocks of the basal complex form the mountains of Samana Peninsula and are therefore widely distributed. Metamorphic rocks were found in place and pebbles of pegmatites, felsites, and other igneous rocks in younger conglomerates indicate that such rocks are probably intruded into the metamorphic rocks. Nicaceous schist and schist ose limestone are exposed 
in the mountains. On the south slope of the mountains hard, moderately schistose gray limestone is the most common rock of the basal complex. The strike of the schistosity is in general parallel to the direction of the trend of the peninsula, but no bedding planes or fossils were observed in any of the metamorphic rocks. The age of these rocks is not known, but they probably are of the same age (Upper Cretaceous or older) as some of the rocks of the basal complex in the Cordillera Central. Evidences of normal faulting were observed along the southern base of the mountains.

On the south shore of the bay the mountains east of Sabana de la Mar appear to be composed largely of sedimentary schists cut by basic dikes. At Las Cañitas the schists are highly metamorphosed sandstone, sandy shale, and conglomerate. The bedding strikes N. $60^{\circ}-80^{\circ}$ E. and dips $15^{\circ}-40^{\circ} \mathrm{SE}$., but the schistosity strikes $\mathrm{N} .40^{\circ} \mathrm{W}$. and dips $70^{\circ} \mathrm{SW}$. The schists are cut by dikes of finely crystalline greenish lamprophyre that contains bunches of epidote. The dikes are vertical, are 30 to 60 centimeters wide, and strike northeast. Banding that strikes N. $10^{\circ} \mathrm{W}$. and dips $60^{\circ} \mathrm{NE}$. was observed in one of the dikes.

\section{EARLY TERTIARY LIMESTONE CONGLOMERATE.}

A heavy, rudely bedded conglomerate is exposed in stream valleys and on some of the mountain spurs on the south slope of the peninsula west of Samaná. The pebbles, which are oval and usually flat, consist almost exclusively of the schistose limestone of the basal complex. They average 15 to 18 centimeters long, 8 centimeters wide, and 4 centimeters thick. The matrix is a yellowish calcareous cement.

The conglomerate has been folded, but, though thoroughly consolidated, it has not been greatly metamorphosed. Its age is probably early Tertiary, for it rests unconformably on the basal complex and is overlain unconformably by deposits of supposedly late Tertiary age.

\section{OLIGOCENE OR MIOCENE LIMESTONE.}

Hard yellow limestone crops out in the upper part of Sierra Prieta, a small hill 45 to 60 meters above sea level at the foot of Loma Jackson, about 18 kilometers northwest of Sánchez. At the base of the hills lie loose blocks of hard conglomerate composed of limestone pebbles like those that form the conglomerate already described. The corals collected from the limestone (station 8606, p. 111) are of late Oligocene or early Miocene age.

Yellow foraminiferal limestone was found in talus at the foot of Loma Jackson. Similar rock, which has been brought from Arenosa, a station on the Ferrocarril de Santiago y Samaná, in the Province of Pacificador, about 30 kilometers west of Sanchez, is used in a retaining wall near the railroad station at Sánchez. This rock is probably of Miocene age.

Limestone also occurs in the plateau at the east end of the peninsula. The interior of the peninsula was not examined, but the flat and even sky 
line of some parts of the mountains suggests the presence of undisturbed sedimentary rocks that are younger than the rocks of the basal complex.

The flat-topped hills west of Sabana de la Mar, south of the western part of the bay, are principally or entirely underlain by massive pink to white limestone, which is apparently almost horizontal. Although the limestone is fossiliferous no determinable fossils were found in it during the reconnaissance. As has already been suggested (p. 64), this limestone may be an eastward extension of the limestone that overlies the Cevicos limestone, but additional studies are needed to determine the geologic age and relations of these limestones.

\section{MIOCENE OR PLIOCENE CLAY, SAND, AND CONGLOMERATE.}

Barely consolidated sands and clays underlie the low, rolling country that borders the mountains between Sánchez and Rancho Español. Some of the clays contain so much organic matter that they resemble lignite. A bed of lignitic clay 2.5 meters thick was examined near Punta de Santa Paula. A bed 35 centimeters thick, which contains a higher percentage of organic matter, is exposed near the warehouse at Sanchez. None of the beds of lignitic clay examined, however, have any value as fuel. The sands, which are interbedded with the clays, are for the most part finegrained but locally contain pebbles.

Although these beds are only slightly disturbed they are folded and faulted at some places, where the dips may be as steep as $45^{\circ}$. Many small folds and a few normal faults of slight displacement are exposed along the shore between Sánchez and Punta de Santa Paula. The beds strike generally N. $50^{\circ}-60^{\circ} \mathrm{W}$. and except in the disturbed areas dip gently toward the southwest. The terrace flats described on page 181 bevel the deformed strata of this formation.

The fossil coastal plants and brackish water mollusks that were collected from clays of this deposit near Sánchez (see lists on p. 165, stations $8607,8764,8684$, and 8685 ) are probably of Miocene or Pliocene age.

The heavy coarse conglomerate that forms the islands and much of the steep parts of the shore near Samana is probably of the same age. The pebbles composing this conglomerate comprise metamorphosed limestone, limestone conglomerate, and different kinds of igneous rocks, embedded in a soft calcareous matrix.

The marly coralliferous limestone in the vicinity of Los Rosales and Rancho Español and the oyster-bearing limestone bed near Punta Gorda may also be of the same age.

\section{PLEISTOCENE OR RECENT TERRACES AND CORAL REEFS.}

The presence of terrace flats whose surfaces bevel the plant-bearing clays and sands at and near Sánchez has already been mentioned (p. 1S4). The terraces are probably of Pleistocene age. 
Impure coral limestone, which lies nearly or quite horizontal, is exposed along the entire north shore of Samaná Bay at altitudes of less than 3 to 6 meters above sea level. The limestone closely resembles modern coral reef limestone and probably represents reefs that have recently emerged from the sea. Punta de los Corozos, Cabeza de Toros, Punta de Santa Paula, Punta Gorda, and almost all the other points along the coast between Punta de los Corozos and Sánchez are composed largely of this limestone.

\section{RECENT DEPOSITS.}

Rio Yuna is bringing a large volume of sediment to the head of Samana Bay and depositing it there while coral débris and beach sands are being deposited along the coast. The deposits in the streams are boulders, cobbles, and gravel, which the water has not sufficient power to carry beyond the steeper slopes.

The deposits of finer sediments are mostly in the western part of Samaná Bay, so that the water of the bay elsewhere is mostly clean and affords conditions suitable for the growth of corals, especially those that thrive best in rather quiet but pure water. Off the mouth of the harbor at Santa Bárbara de Samaná fine colonies of the staghorn coral and the closely related palmate coral (Acropora muricata and A. palmata) were seen. The general conditions under which the coral patches and the coral reefs in Samaná Bay are living accord with what is known regarding similar coral formations in other parts of the West Indies, indicating that the bay is due to submergence in geologically very late if not Recent time.

\section{ECONOMIC GEOLOGY.}

The country bordering Samaná Bay was examined with special reference to water supply and material for highway construction or other engineering enterprises. Analyses of waters are given on pages 249-254, and the results of tests of rock and clay-sand are given on pages 247-248. 


\author{
By D. Dale Condit and Clyde P. Ross.
}

\title{
AREA EXAMINED.
}

A brief reconnaissance was made late in May and early in June, 1919, in the Provinces of Barahona and Azua (see Pl. XV), which were then geologically unknown, for the purpose of outlining the geology and of determining whether the mineral resources offer sufficient promise to warrant a more detailed investigation. Seepages of oil, beds of rock salt, and indications of metalliferous deposits of various kinds have been known in these provinces for many years, but aside from drilling for oil near Azua and the quarrying of rock salt in Enriquillo Basin practically no systematic search has been made in them for mineral deposits. Both provinces are remote from the ordinary lines of travel and are so inaccessible that most of their natural resources have been unexplored.

The reconnaissance included a journey from Bánica, near the Haitian border, eastward through Las Matas and San Juan to Rio Yaque del Sur. A rough traverse of this river was made from the vicinity of Túbano to Cabral and side trips were made to points of interest along the route. One day was spent in the vicinity of Neiba, on the north shore of Lake Enriquillo, and about a week was spent on the south side of the Enriquillo Basin, between Cabral and Duvergé. A short trip was made southward from Barahona and several trips were made in different directions from Azua. Most of the work in the vicinity of Azua was done by Wythe Cooke, who also furnished notes on the region from Constanza southward through Túbano to Azua, and on the country east of Azua. All other parts of the area were covered by the authors.

We are indebted to officials of the Barahona Company for an excellent map of the lower part of Rio Yaque del Sur and the neighboring country to the west and for material assistance in other ways during the course of the work. Our thanks are due also to Captain Hoenes of the Guardia Nacional, who assisted us in many ways, and to Mr. Richard D. Upham of the. Interocean Oil Co., who placed at our disposal maps and geologic reports on the Azua district.

\section{GEOGRAPHY.}

The Provinces of Barahona and Azua are in the southwestern part of the Dominican Republic, along the Haitian frontier. (See Pl. I.) 'The position of the international boundary line is so uncertain that the exact areas of the provinces are unknown, but they comprise about one-third of the entire Republic, the total area of which is roughly 28,872 square kilometers. In longitude they range from about $70^{\circ} 30^{\prime}$ to $71^{\circ} 50^{\prime} \mathrm{W}$., and in latitude from $17^{\circ} 30^{\prime}$ to $19^{\circ} 15^{\prime} \mathrm{N}$. 




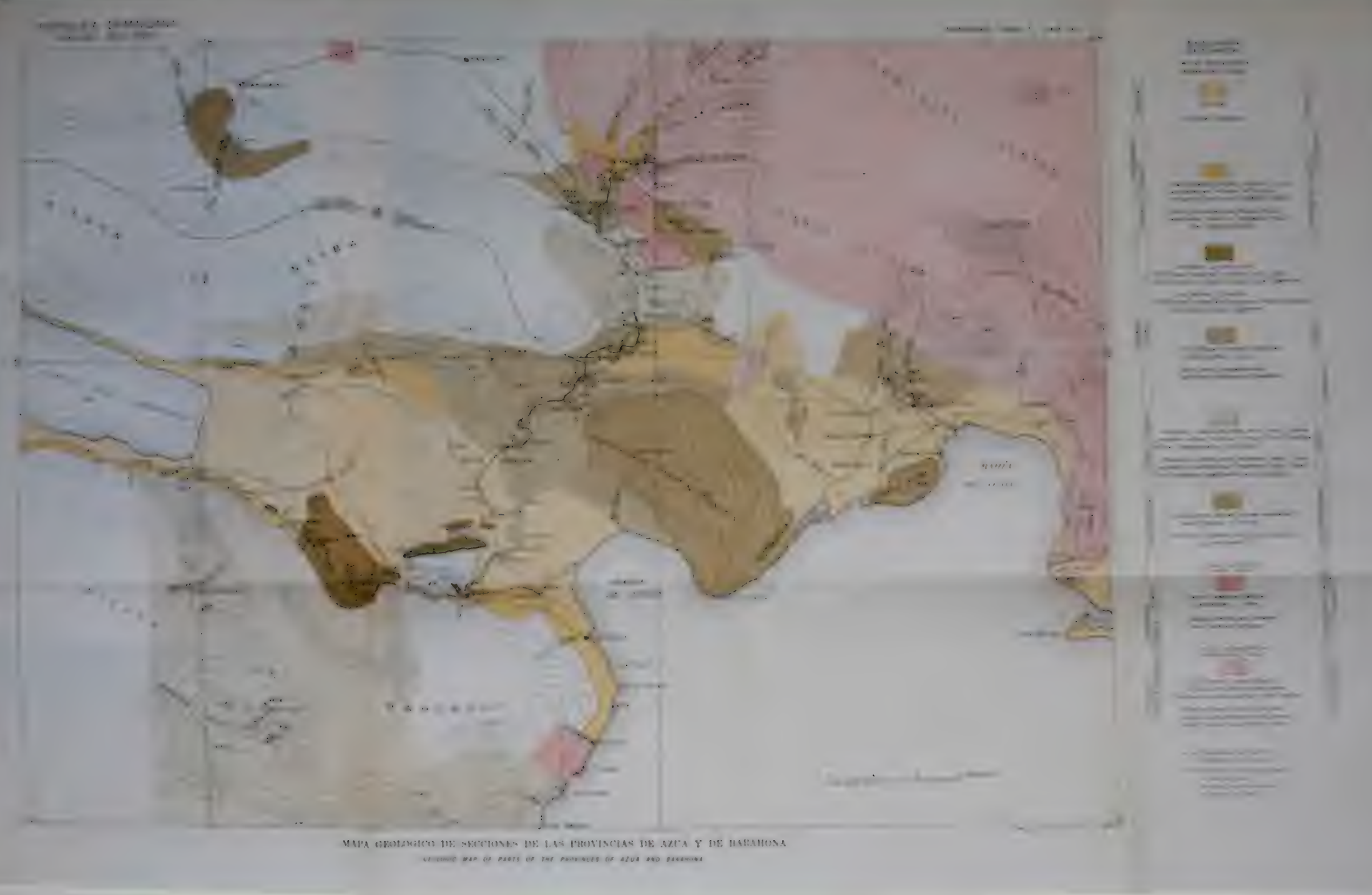





\section{LAND FORMS.}

PROVINCE OF BARAHONA.

The surface of the Province of Barahona consists mostly of numerous hogback ridges whose trend ranges from east to southeast. Most of the rock of these ridges is hard white limestone, in beds that are generally inclined northward more or less steeply. The parallel ridges are probably in large part the result of step faulting, a type of structure known to prevail in this part of the island. The mountain tops as seen from a distance are generally of even profile, but here and there isolated peaks extend above the general summit. Some of the peaks visited consist of volcanic rock. The highest mountain ridges are generally 1,000 to 1,500 meters above sea level, and probably no peaks are as high as 2,000 meters. Between the mountains are more or less extensive valleys that include local savannas. Most of those in the interior have less rainfall than the coastal region and some are said to be poorly watered and either treeless or covered with low shrubbery of the mesquite and cactus type.

The most striking topographic feature in the Province is Enriquillo Basin, a valley 12 kilometers broad, extending from the Bay of Neiba northwestward across the Haitian border to the sea at Port-au-Prince. A part of the interior is depressed and is occupied by Lake Enriquillo, a body of salt water whose surface lies (in June, 1919) about 44 meters below sea level. To the west, in the Republic of Haiti, is the smaller Etang Saumâtre, a lake said to be less salty than Enriquillo. Extending around Lake Enriquillo is a terrace of limestone having an altitude of about 35 meters above sea level and 79 meters above the lake. The upper part of this terrace is a mass of corals underlain by marly limestone consisting largely of shells. The Quaternary age of the fossils denotes an uplift of the valley from beneath the sea in comparatively recent time. The barrier to the east against the slowly flowing waters of Rio Yaque del Sur is so slight that they are used by the inhabitants for irrigating parts of the intervening area. In times of flood the river actually overflows the country and temporarily drains into Lake Enriquillo, and the Barahona Company proposes to irrigate some 160 square kilometers of this land by water diverted from the river through a tunnel to be cut through a low hill near the village of Alpargatal.

The general aspect of the lower valley of the Yaque suggests that its delta deposits may have separated Lake Enriquillo from the Bay of Neiba, the lake having been in comparatively recent geologic time an arm of the sea. The actual separation probably took place during the regional elevation that formed one of the latest diastrophic movements.

The east end of Lake Enriquillo is bordered by a broad mud flat that rises very gently eastward to a barren waste of sandy "saladas," which 
are too salty to support plant growth for a distance of several kilometers from the lake but which gradually merge into dense thickets of mesquite and cacti.

As the rainfall in all parts of the basin is more than 50 centimeters a year the somewhat desolate aspect of the region is due not to deficient rainfall alone but rather to the fact that most of the rain falls in torrents in one short rainy season and is thus of minimum benefit. Most of the bare lowlands are "saladas" caused by conditions other than scant rainfall.

It is said that the ground-water level throughout the lowlands is within a meter or two of the surface and that the water is in most places more or less saline. The irrigation of such land will certainly raise the water table and where the ground water is saline it will render the land unfit for cultivation, but such loss may be temporary, for prolonged flooding may flush the salt water out of the ground. The success of this process will be aided by digging deep drainage ditches at rather short distances apart to carry the salt water toward Lake Enriquillo. By such means an area much larger than that included in the present project of the Barahona Company might ultimately be reclaimed. The great fertility of the soil and its prospective value for raising sugar-cane and long staple cotton seem to warrant the expenditure of a large sum of money on the project. The methods used should be similar to those employed by the United States Reclamation Service in certain parts of Arizona.

PROVINCE OF AZUA.

The Province of Azua is somewhat more mountainous than the Province of Barahona, especially in its northern part, which includes many high peaks of the Cordillera Central. The most prominent peaks are Lomas Tina, Rucillo, and Gallo, probably the highest in the islands. It is said that Loma Tina stands 3,100 meters above sea level, but it is doubtful whether the peak has ever been accurately measured or even ascended.

Spurs extend southward from the principal mountains to the great central valley of San Juan, which, like Enriquillo Valley, to the south, trends a little north of west, reaching westward into the Republic of Haiti. The Neiba Mountains, which lie south of the San Juan Valley, are 1,000 to 1,500 meters high and differ from the jagged Cordillera Central in that they consist largely of limestone and other sedimentary rocks that form hogback ridges of fairly even profile. (See Pl. XVI.)

The central valley of San Juan ranges in width from 15 to 20 kilometers and the part of it that lies within the Dominican Republic extends from east to west for about 80 kilometers. Within the valley are low hills and rolling country as well as large tracts of nearly level savannas. The most extensive savannas are near the town of San Juan and consist of flat, treeless stretches that lie only a few meters above the level of the river and slope gently southward. 

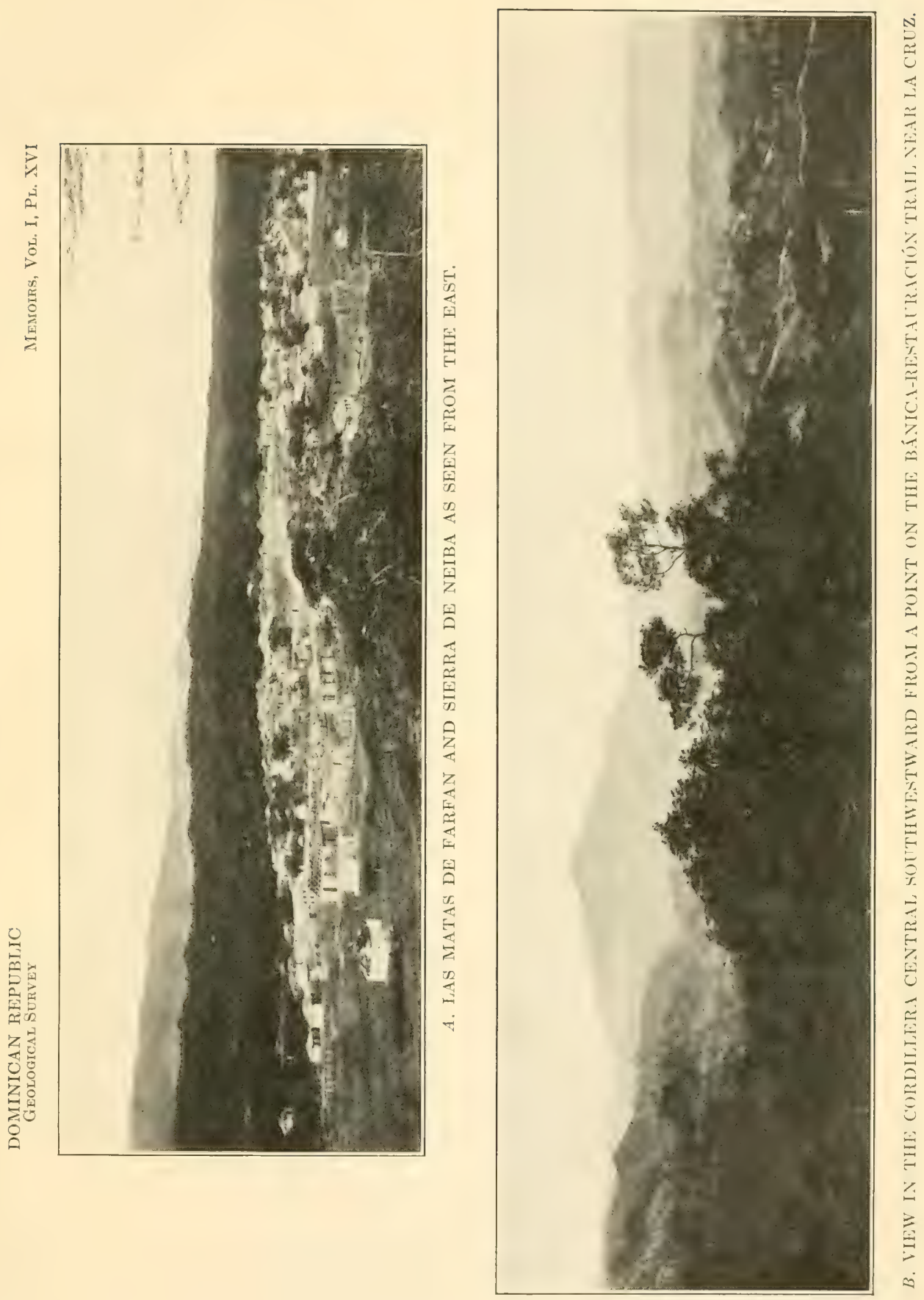



\section{DRAINAGE.}

RIVERS.

The Provinces of Barahona and Azua are rather plentifully supplied with streams, several of which are large. Many of the smaller ones, especially the "arroyos," are not through-flowing streams at all seasons. Some flow only after rainfall; others are perennial in their upper courses only.

Rio Yaque del Sur is the largest river in the region and, with the exception of Rio Guayajayuco, much the longest, its length being roughly 120 kilometers. Near its mouth it is about 50 meters wide and 3 or 4 meters deep and flows between banks of soft alluvium at a velocity of approximately 4 kilometers an hour. It maintains the same general character throughout the area covered by its delta deposits, which extend from the vicinity of Alpargatal to the Bay of Neiba.

At Palo Alto, in the delta area, the Barahona Company has maintained a self-recording stream gage for over a year. The gaging indicates that the low-water period in the river is from January to April. The minimum recorded flow is 18 cubic meters per second.

Above the delta the river flows in several braided channels, 35 to 75 meters wide, over a gravel-strewn bed that ranges in width from several hundred meters to a kilometer or more. The current here is much swifter than it is farther downstream, but the channel is at many points not too deep to be easily fordable except in times of flood.

Above Los Bancos the bed of the stream is more gorge-like. The water flows swiftly through channels strewn with coarse boulders or over bedrock. Occasional floods are reported to raise the stream level 6 meters in the gorges.

The Yaque has numerous tributaries, most of which are small streams that are dry during the greater part of the year. The longest tributaries are Rio San Juan ( 80 kilometers), Rio de las Cuevas (55 kilometers), and Rio del Medio (55 kilometers). Rio San Juan is itself a stream about 35 meters wide at its mouth. Its longer tributaries are Rio Vallejuelo (30 kilometers), Rio Maguana (25 kilometers) and Rio Mijo (55 kilometers).

Rio Guayajayuco, which drains the region adjacent to the Haitian frontier, is a large stream 230 kilometers long. About 180 kilometers of its course lie wholly in the Republic of Haiti and most of the remainder forms a natural boundary between the Republic of Haiti and the Dominican Republic. The headwaters of the stream are in Monte Cristi Province, Dominican Republic.

The Great Valley of San Juan is drained principally by the westward flowing Rio Macasía, 80 kilometers in length, a branch of Rio Guayajayuco. The longest tributaries of Rio Macasía are Rin Cana (80 kilometers), and Rio Ceiba (40 kilometers). The east end of this large structural valley is drained by Rio San Juan and its tributaries. 
Much of the gently rolling plain that stretches eastward from Rio Yaque to Azua is a waterless wilderness. Rio Tábara drains the country that extends southward from Las Yayas almost to Puerto Viejo. It is nearly 50 kilometers long, but as a large part of the country it crosses has a somewhat scanty rainfall the stream is ephemeral except in its upper part, where there is probably some flow at all seasons.

Rio Jura is a similar stream somewhat shorter than the Tábara. It drains the country just east of that served by Rio Tábara. When seen in June, 1919, near \&zua it contained a small quantity of water and may not completely dry up at any season.

The eastern part of the Province of Azua is drained by Rio Ocoa and its tributaries and by the headwaters of Rio Nizao. Rio Ocoa is about 65 kilometers long. It flows in a rock gorge above Arenoso, but below Arenoso it widens and flows in braided channels in a gravel bed. Rio Nizao is 80 kilometers long, about 35 kilometers of which are in the Province of Azua. Throughout its course it is a swift stream and flows over many rapids.

A number of short streams flow into Lake Enriquillo from both the north and the south. Rio de las Damas, which passes through Duvergé, was the only one examined during this investigation except the very short streams fed by springs near the lake. Rio de las Damas is about 15 kilometers long. It is about 8 to 10 meters wide and nearly 2 meters deep at Puerto Escondido, and only about 3 meters wide and 1 meter deep above Duvergé. Part of the loss between these places is caused by irrigation in Escondido Valley, but part is probably due to seepage into the cavernous limestone which here forms the country rock. On this stream between Puerto Escondido and Duvergé there are said to be two waterfalls that may furnish water power.

Several fair-sized streams about 30 kilometers in length flow into the sea along the coast south of Barahona, among them Rio Bahoruco, Rio de los Patos, and Rio Cito.

LAKES.

Lake Enriquillo is by far the largest inland body of water in the island. As already stated, it occupies a depression which in Pleistocene time was probably an arm of the sea and which was probably separated from it by delta deposits of Rio Yaque together with a regional elevation of about 35 meters. Although the lake receives more or less water from Rio Yaque in times of flood and a considerable volume from springs and streams, it appears to be progressively shrinking through evaporation. Its surface now stands about 44 meters below sea level. The map of Enriquillo Basin made by James W. Wells ${ }^{1}$ in 1893 gives the altitude of Lake Enriquillo

\footnotetext{
1 Wells, J. W., A survey journey in Santo Domingo; West Indies: Roy. Geographic Soc. Supplementary Papers, vol. 3, 1893.
} 
at that time as 2 feet ( 61 centimeters) above sea level. Although his estimates of altitude were made with a barometer and are therefore only approximately accurate it would seem that there has been very considerable evaporation since his map was prepared. According to Tippenhauer ${ }^{1}$ the surface of the water was 34 meters below sea level in 1900 .

The water is nearly 50 per cent more saline than sea water. The accompanying analyses show that its composition is in general similar but that the ratio between calcium and magnesium is reversed. Although Lake Enriquillo was undoubtedly at one time an arm of the sea its water has since then been considerably concentrated by evaporation, which is high in this region, for it has no outlet. The drainage from the surrounding limestone mountains has caused an increase in the percentage of calcium.

Mineral analysis and classification of water from Lake Enriquillo near Barbacoa, Province of Barahona.

[Sample collected by C. P. Ross, May 29, 1919. Analyst, Addie T. Geiger.]

Milligrams
per liter.
1,649
378
15,973
$a$
503
.0
512
3,833
25,547
44,000
.1
270
48,902

Calcium (Ca)

Magnesium $(\mathrm{Mg})$

Sodium ( $\mathrm{Na}$ ).

Potassium (K)

Carbonate radicle $\left(\mathrm{CO}_{3}\right)$

Bicarbonate radicle $\left(\mathrm{HCO}_{3}\right)$

Sulphate radicle $\left(\mathrm{SO}_{4}\right)$

Chloride radicle $(\mathrm{Cl})$

Alkali coefficient (inches) (computed)

Organic matter.

a Equivalent to 0.0006 per cent potash $\left(\mathrm{K}_{2} \mathrm{O}\right)$ in liquid brine or 1.23 per cent $\mathrm{K}_{2} \mathrm{O}$ in total solids.

Comparison of the composition of ocean water with that of Lake Enriquillo.

[Percentage of dissolved solids.]

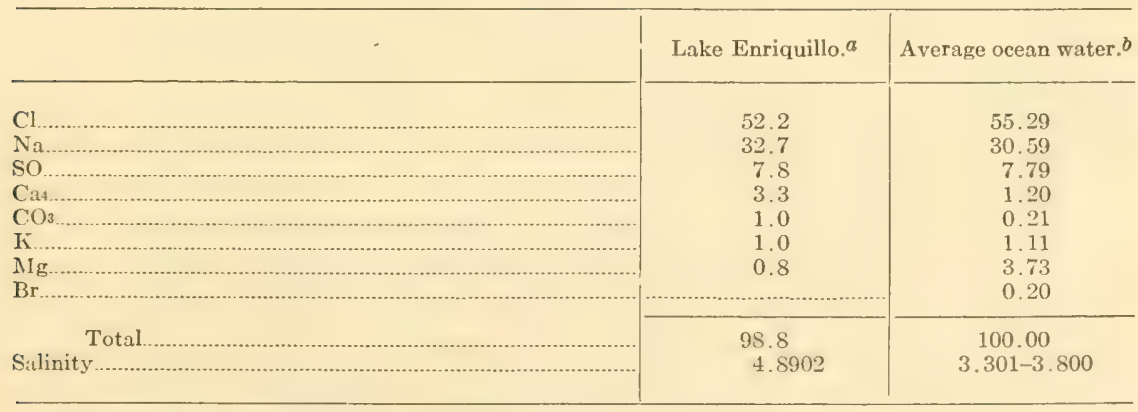

a Analysis made in water resources laboratory of U. S. Geol. Survey.

$b$ Clarke, F. W., Data of geochemistry: U. S. Geol. Survey Bull. 616, p. 123, 1916.

1 Tippenhauer, L. G., Beiträge zur Geologie Haitis, V: Petermann's Mitteilungen, Band 47, VII, p. 169, 1901. 
Lake Rincón is a much smaller lake near the east end of Enriquillo Basin. It differs from Lake Enriquillo in being only slightly brackish and in lying nearly 5 meters above sea level. A channel at Cabral connects it with Rio Yaque, through which the river water flows in times of flood. The lake abounds in fish, affording a means of livelihood for the people of neighboring villages. Lake Enriquillo, on the other hand, is reported to contain no fish at all. Alligators are reported to live in both lakes, and flamingoes and cranes of several species may be seen in large flocks along the low, muddy shores.

Lake Limón, which lies south of and only a few kilometers away from Lake Enriquillo, is reported to contain fresh water. It is separated from Enriquillo Basin by hills and occupies an independent depression that has no outlet.

Laguna de las Marias, shown on the map by Wells mentioned above and on the de Moya map, is reported to be no longer in existence. Wells ${ }^{1}$ describes it as a lagoon thickly studded with palm groves near a short range of bare hills called Sierra de los Remedios. The altitude of the lake shown on his map is 160 feet ( 49 meters) above sea level. This may be too high, as the altitudes given on this part of his map do not appear quite consistent. The map shows the area of overflow of Lake Enriquillo during the rainy season. An altitude of 32 feet ( 9.7 meters) is given at a point in this area near its eastern edge. If this is correct there was a rise of over 9 meters in the level of the lake during the rainy season, which is considerably more than seems probable.

\section{SPRINGS.}

In the area covered by this report springs are rather numerous and many of them are large. In some areas, notably in Enriquillo Basin, they are used for irrigation. A few, such as those at El Puerto, near Las Matas de Farfan, are reputed to have medicinal value, principally for the cure of skin diseases and rheumatism.

Sulphur springs are known at El Puerto, which is on Rio Macasía near Las Matas, as well as at several places along Rio Yaque between Villarpando and Boca Mula and near the head of Arroyo Quita Coraza, where there is a spring known as Agua Montilla. There are springs at many places on both sides of Enriquillo Basin. Many of them emit a strong odor of hydrogen sulphide, which is probably a constituent of the water in all these springs. Other sulphur springs are reported in many parts of the area.

There are springs that discharge strongly saline water in Arroyo Quita Coraza near the settlement of that name and there are others on the sea coast about 4 kilometers south of Barahona. Salt springs are also reported at Guanarate, at Fondo Negro, near Azua, between Barahona and Cabral, and at other localities.

1 Wells, J. W., op. cit., p. 603. 
Springs of pure water appear to be exceptional in this region. Most of those near Lake Enriquillo are sufficiently free from sulphur to be potable. Curiously enough there is a fresh-water spring less than 20 meters from the strong salt spring on the beach a short distance south of Barahona. Springs of pure water are reported near Rio del Medio on the trail between Constanza and Túbano, at Las Yayas, and there are doubtless others.

The springs near Lake Enriquillo are unusual in several respects and deserve study. They border the basin on both the north and south sides, emerging from the lower edge of the bench of coral limestone which fringes the mountains. This uniformity in position is probably not due to any fundamental structure and has no bearing on the origin of the springs. The springs have their origin in the older limestone that forms the mountains against which the coral limestone has been deposited. The coral rock is of recent age and is very porous. It probably merely conceals the source of the water, which doubtless flows out of the rork on which it lies, percolates through it, and emerges at its outer edge. The springs probably antedate the coral rock and may be of diverse origin, an assumption borne out by the marked differences in the sulphur content of springs that are close together. Hydrogen sulphide is so generally a constituent of the spring waters in this region that its presence in most of the springs does not imply a common origin. Although the coral limestone conceals the source of these springs, many of them are probably tubular solution cavities in the limestone of the mountain, like those at El Puerto near Las Matas and at other places in the region where the source of the water is more evident. A number of these springs are large, forming brooks of considerable size. The sulphide in the water does not appear to be harmful in irrigation, for which the water is extensively used.

\section{Chemical Composition of Spring Water.}

Mineral analysis and classification of spring water (dug dilch) from Campo el Puerto, Province of Azua.

[Samples collected by C. P. Ross, May 18, 1919; analyzed by Addie T. Geiger.]

\begin{tabular}{|c|c|}
\hline Silica $(\mathrm{SiO})_{2} \ldots$ & $\begin{array}{c}\text { Parts per million. } \\
18\end{array}$ \\
\hline Iron $(\mathrm{Fe}) \ldots \ldots . . .$. & .29 \\
\hline Calcium $(\mathrm{Ca})$ & 92 \\
\hline Magnesium (Mg) & 18 \\
\hline Sodium and potassium ( $\mathrm{Na} \mathrm{K}$ ) (calculated) & 12 \\
\hline 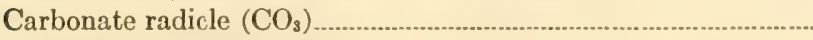 & .0 \\
\hline 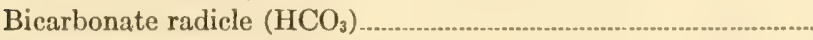 & 282 \\
\hline Sulphate radicle $\left(\mathrm{SO}_{4}\right) \ldots \ldots \ldots \ldots \ldots$ & 27 \\
\hline Chloride radicle $(\mathrm{Cl})$ & 49 \\
\hline Nitrate radicle $\left(\mathrm{NO}_{3}\right) \ldots \ldots \ldots$ & Tr. \\
\hline 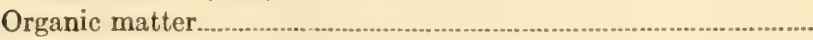 & 5.2 \\
\hline Total dissolved solids $\left(180^{\circ} \mathrm{C}.\right) \ldots$ & 350 \\
\hline
\end{tabular}




\begin{tabular}{|c|c|c|}
\hline Character... & Classification. & $\begin{array}{l}\text { Parts per million. } \\
\mathrm{CaCO}_{3}\end{array}$ \\
\hline Quality for $c$ & ...... & Fair ${ }^{a}$ \\
\hline Quality for & & Poor. \\
\hline Quality for i & & Good. \\
\hline Iineral con & & Moderate. \\
\hline
\end{tabular}

a Satisfactory for drinking.

Partial mineral analysis and classification of spring water from Arroyo Quita Corazo, Province of Azua.

[Samples collected by C. P. Ross, Miay 27, 1919; analyzed by Addie T. Geiger.]

Calcium $(\mathrm{Ca})$

Constituents.

Parts per million.

Sodium ( $\mathrm{Na}$ )

Potassium (I)

2149

Chloride radicle $(\mathrm{Cl})$

4786

Organic matter

Total dissolved solids at $180^{\circ} \mathrm{C}$.

8234

Chemical character

\section{Classification, $a$}

Quality for domestic use

$\mathrm{NaCl}$

Quality for boiler use.

Unfit.

Mineral content

Unfit.

Very high.

a Based upon relatively few determinations but sufficient to establish the elassification.

$b$ Unfit for drinking except possibly in small quantities by the passing traveller.

Mineral analysis and classification of spring water from 5 kilometers south of Barahona, Province of Barahona.

[Samples collected by C. P. Ross, June 5, 1919; analyzed by Addie T. Geiger.]

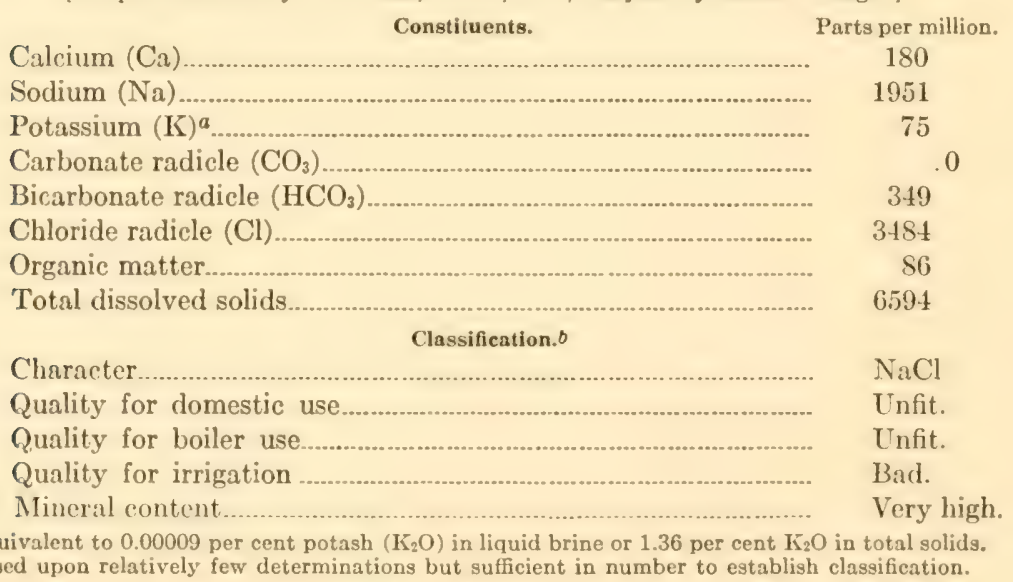

\section{TOWNS AND VILLAGES.}

No reliable figures to show the population of the Provinces of Barahona and Azua are available. Most of the people live in towns and villages along the principal rivers or near springs, much of the interior being without a water supply and therefore uninhabited. Many of the place names on the map are applied to agricultural communities spread over several square 
kilometers of fertile land in river bottoms or near springs that are used for irrigation. Some contain no more than two or three huts; others are villages of several hundred households. Some of the best farming land is on mountain slopes where the rainfall is generally sufficient for cultivation without irrigation.

Azua, the center of a large sugar industry, is the principal town in the region and by far the most progressive. It has a population of about 3,000 people and is surrounded by thickly settled country. The town is built on a broad plain that extends from Loma El Número on the east to the Yaque watershed on the west. Azua itself stands about 80 meters above sea level and a little more than 5 kilometers from the coast. About 15 kilometers southwest of Azua is Puerto Viejo, near which are the ruins of the old town of Azua, which is said to have been destroyed by an earthquake about 200 years ago. South of Azua are the Azuano and Ansonia sugar estates, which are connected with the port, to the east, by narrowgage railroads.

San Juan, a town of about 2,000 inhabitants, is in the central part of the fertile San Juan Valley, about 75 kilometers northwest of Azua. Beans, rice, tobacco, and other products of the country are marketed here in exchange for goods from the outside world. Las Matas and Comendador, smaller towns that stand farther west, are also in the great San Juan Valley, which will be highly productive when communication with the coast is facilitated by good roads.

Barahona, the capital of the Province of that name, is little more than a village. It is on the west side of Neiba Bay. A wharf is accessible to small ocean-going steamships, but the only boats that call regularly are sailing craft, which carry away large quantities of coffee as well as lignum vitae, mahogany, and other hard woods. Extensive improvements will be necessary to make the port fit for use by large steamships.

Along Rio Yaque north of Barahona there is a large agricultural population. Cabral, Peñon, Hatico, and Alpargatal are the principal villages. The people, by irrigation in a primitive manner, have brought under cultivation much of the valley bottom. In this same region is the site of the large irrigation project of the Barahona Company, which plans to establish one of the largest sugar plantations in the world.

The basin that includes Lake Enriquillo, although semi-arid and of saline soil, is bordered by mountains along whose bases emerge large springs that are used for irrigation and that form the centers of a number of agricultural communities. The principal villages are Neiba, which has 600 or 700 inhabitants, and Duvergé, which has nearly 1,500. There are also other villages that contain several hundred people. Several villages are scattered through the valleys of Sierra Bahoruco. Puerto Escondido, for example, is a prosperous farming community of over 500 people. 
Practically all the people lead an exceedingly primitive life. Their labor is almost entirely agricultural and is carried on intermittently in a haphazard manner. They have little idea of modern implements or their use, but they are intelligent and readily learn where attempts are made to teach them. The assurance of a stable government has been a great stimulus to increased effort, as is shown in the enlargement of areas under cultivation and the increase in cattle raising. Under the old state of affairs there was little encouragement to industry, for the farmer was at the mercy of roving bandits and revolutionists.

Although showing the effects of intermingling with the black people across the Haitian border, the features of a large percentage of the population of the Provinces of Azua and Barahona suggest Indian ancestry with a mixture of Spanish. Some of the influential people of the larger towns are of direct Spanish origin.

These border provinces have borne a reputation of lawlessness and unfriendliness to strangers that made travel difficult if not dangerous, yet our party had no experience whatever that would indicate unfriendliness and was invariably treated courteously and nearly everywhere hospitably.

\section{ROUTES OF TRAVEL.}

The total length of regularly constructed highways in the two districts is about 30 kilometers, all of which are near Azua. An excellent gravel road leads northwestward from Azua for 22 kilometers. At a distance of 15 kilometers the road to San Juan branches to the left from this road. In dry weather, when Rio Yaque is low, light automobiles are used for travel from Azua to San Juan, a distance of about 75 kilometers, and also to Las Matas, about 12 kilometers farther. They also traverse the road from Azua eastward to the capital city when conditions are favorable, but during the rainy months this road can be traveled only with difficulty even by saddle horses.

Wheeled vehicles can go from Barahona north to Cabral, thence west through Las Salinas to Neiba and Barbacoa, on the north shore of Lake Enriquillo, and to Duverge, on the south shore. The distance from Barahona to Neiba is about 55 kilometers and that to Duvergé a little less. From Cabral a cart route has also been cleared northward to the vicinity of Jobo and thence westward. In Barahona cars can be hired to travel all these roads in dry weather. Although the natural conditions favor the easy construction of excellent highways, few of those now existing are worthy of the name, being merely trails littered with rocks and bristling with stumps.

Travelers go by land from Barahona to Azua by saddle, generally up Rio Yaque to Quita Coraza, thence northeastward up an arroyo and across a low divide to the Azua-San Juan road at a point about 10 kilometers 
from Azua. A trail leads southward from Barahona along the rocky, precipitous coast to Paradise and Enriquillo. Another leads from Duverge southward through Puerto Escondido to Pedernales, and another from Neiba northward to San Juan. Both the north and south shores of Lake Enriquillo are followed by trails that lead to the Haitian border, the one on the south shore being most frequently used. From Azua Province northward across the Cordilleras there are only two practicable routes-one through Túbano and Constanza, the other from Las Matas to Bánica and thence over a rugged country on the east side of Rio Guayajayuco to Restauración. A much easier route from Bánica north can, however, be taken by crossing the river and passing across the eastern tip of the Republic of Haiti.

\section{CLIMATE AND VEGETATION.}

The general impression gained from the accounts of travelers is that much of the Provinces of Barahona and Azua consists of desert wastes that are almost devoid of rainfall. This is far from true, for no part of this region deserves that rating. The rainfall is so great in all parts of the provinces that the ground is covered with a dense growth of mesquite, guayacan, and other small trees. Tree cacti are only locally abundant. In areas where the surface bears little vegetation-as for instance, in the vicinity of Lake Enriquillo-its barrenness is caused by salinity of the soil rather than by scant rainfall. Within 3 kilometers to the north of Azua excellent gardens are grown without the aid of irrigation.

Figures showing the rainfall for a long period are not available, but reliable observations made for several years at a number of places along and near the lower Yaque Valley by the Barahona Company show at each point a rainfall of more than 50 centimeters a year. The least rainfall recorded was at Las Salinas, where the average during the past two years was 53 centimeters. At Palo Alto the average for four years was 94 centimeters, and at Barahona it was about 106 centimeters. Most of the precipitation at Barahona comes within two rainy seasons, one from April to the middle of June and the other from late in September nearly through Octoher. The precipitation near Azua is variable, but is about 76 centimeters at the base of the mountains and is a little less in the adjacent plain. The somewhat arid appearance of much of the country seems to be due to the fact that most of the rain falls in torrents during a short rainy season, so rapidly that it does not soak into the ground. A fall of as much as 20 centimeters within a few hours has been recorded at Palo Alto.

The mountain slopes nearly everywhere appear to receive considerably more rainfall than the adjacent plains and are accordingly clothed with a 
ranker growth of forest. The change is noticeable in an ascent of only a few hundred meters. Different exposures of the same mountain may not be similarly favored, however, for the clouds generally come from the northeast and lose much of their moisture on the northeastern slopes.

The vegetation of the coastal plain and low hills of the interior in the more arid part of the two provinces consists largely of a variety of mesquite (cambrón) and of logwood, together with lignum vitae (guayacán). (See Pl. XVII, A.) The cacti include large, branching trees of the Cereus type (cayuca) and the prickly pear type (taina); and a low, branching exceedingly troublesome cactus (guazabara) covers most of the ground and protects the scattered clumps of grass from hungry cattle. In the moist river bottoms there are many other trees, some of which grow very large, especially the ceiba. There are also the amacigo, mora, and other trees that are more or less valuable for export. Mahogany (caoba) is one of the most common woods and is used for lumber and fire wood. It generally grows in limy soil in the hills. Many of the higher mountains are timbered with pine, generally of telegraph pole size but here and there 60 to 80 centimeters in diameter. It makes an inferior lumber, rich in in resin and so heavy that it hardly floats. When placed in the river for rafting, the logs are said to absorb water and to sink after a short time.

\section{PRODUCTS.}

Coffee of excellent grade is grown in considerable quantity in the uplands near Barahona. The rice grown on the mountain slopes is nearly sufficient to supply the needs of the two provinces. Tobacco is a standard crop and is shipped in large quantities. Beans are grown in the mountain valleys north of Lake Enriquillo and as much as 1,000,000 pounds is said to have been marketed from that district alone in one year. Bananas, plantains, yams, and yuca, the food of the poor people, are plentiful in every community. The settled political conditions of the last few years have encouraged cattle raising. The Province of Azua is famous throughout the Republic for its excellent mules, and though these are small as compared with those raised in the United States, few of them being much over 14 hands high, they are as hardy and on the whole better tempered. There is no wild game, the largest animal native to the island being no larger than the woodchuck of the United States. Pigs and goats abound in every settlement, and wild pigs that have escaped from domestic stock roam in the mountains.

Many of the people are engaged in getting out mahogany, lignum-vitae, mora, dye woods, and other valuable timber for exportation, but their efforts are confined largely to small timber of inferior grade, for there are almost no roads over which the lumber can be carried to the sea for shipment. 

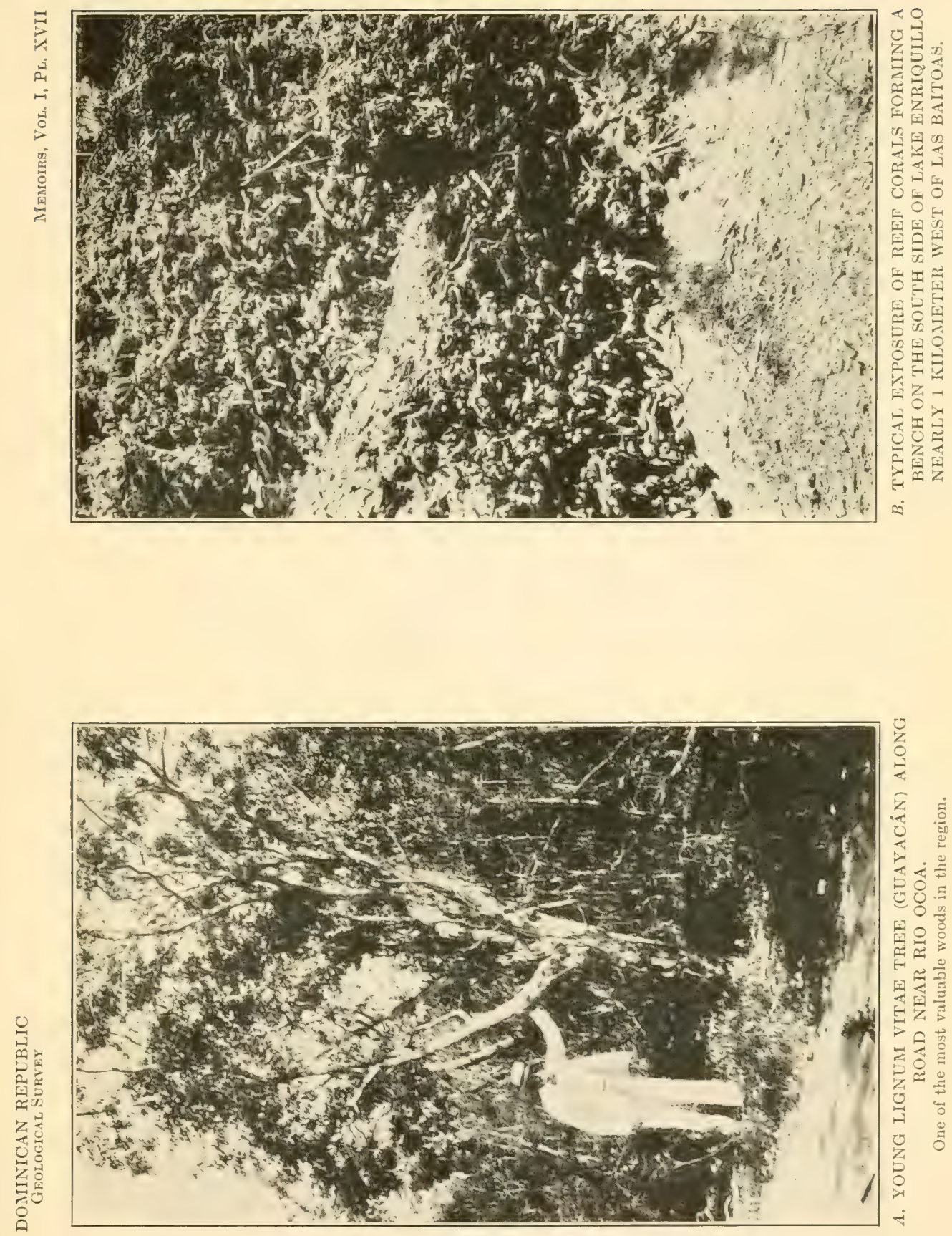



\section{GEOLOGY.}

STRATIGRAPHY.

The following table shows in a general way the character and sequence of the sedimentary rocks in the Provinces of Barahona and Azua.

Generalized stratigraphic table.

\begin{tabular}{|c|c|c|}
\hline Age. & Formations. & Character. \\
\hline Pleistocene........ & $\begin{array}{l}\text { "Coast limestone".............. } \\
\text { Unconformity. }\end{array}$ & $\begin{array}{l}\text { Limestone made up largely of reef-coral material together } \\
\text { with conglomerate from nearby mountains. Beds lio } \\
\text { practically flat and contain modern fossils. Reef coral } \\
\text { terraces of Enriquillo Basin may be later than the "Coast } \\
\text { limestone." }\end{array}$ \\
\hline Pliocene ?....... & $\begin{array}{l}\text { Las Matas formation......... } \\
\text { Unconformity. }\end{array}$ & $\begin{array}{l}\text { Gravels and marly non-fossiliferous clay, slightly folded and } \\
\text { resting unconformably on Miocene strata in San Juan } \\
\text { Valley. }\end{array}$ \\
\hline \multirow{2}{*}{ Miocene............... } & Cerros de Sal formation...- & $\begin{array}{l}\text { Variegated clays, shale, sandstone, and limestone, all more } \\
\text { or less fossiliferous, underlain by a thick sequence of crys- } \\
\text { talline gypsum and some rock salt. }\end{array}$ \\
\hline & $\begin{array}{l}\text { Yaque group......... } \\
\text { Unconformity. }\end{array}$ & $\begin{array}{l}\text { Sandstone, coarse to conglomeratic; fossiliferous. } \\
\text { Clay-shale and impure limestone rich in fossils. } \\
\text { Sandstone, shale, and conglomerate. }\end{array}$ \\
\hline Oligocene....... & & $\begin{array}{l}\text { Conglomerate, shale, sandstone, and limestone in area west } \\
\text { of Azua; bluish sandy shales and sandstone farther east. }\end{array}$ \\
\hline Eocene...... & & $\begin{array}{l}\text { Greenish to bluish sandy, fossiliferous, calcareous shale. } \\
\text { Impure shaly limestone, purplish to reddish. } \\
\text { Gray crystalline limestone. } \\
\text { Conglomerate and sandstone. }\end{array}$ \\
\hline Pre-Tertiary & & $\begin{array}{l}\text { Slates, schists, and gneisses, with a great variety of igneous } \\
\text { rocks, possibly in part Tertiary. }\end{array}$ \\
\hline
\end{tabular}

PRE-TERTIARY ROCKS.

Rocks of pre-Tertiary age are known only in the northern and eastern parts of the provinces. They consist of metamorphosed sandstone, shale, limestone and both effusive and intrusive igneous rocks. The ages and interrelations of these rocks have not been accurately determined. Some are probably Cretaceous, but others may be even older. Like most of the rocks of the basal complex they have been folded and faulted and have undergone so much contact and dynamic metamorphism that their complexity can not be unravelled without long and careful work in the field and laboratory.

TERTIARY SEDIMENTARY ROCKS.

\section{Eocene.}

Rock of Eocene age was identified at three localities in Azua Province, as follows: Station 8562, foraminiferal limestone in gravel on the road at a place halfway between Bánica and Las Matas; station 8608, rubble on the side of the road from Túbano to Las Yayas, north of Arroyo Salado, near Higuero Largo, altitude about 500 meters; station 8644, rubble from Higuerito. Rock of the same age was identified at several places in the 
Province of Barahona, as follows: Station 8626, limestone pebbles near Rancho Viejo; station 8627, foraminiferal limestone, Sierra de Bahoruco, west slope of Cañada de Rancho Viejo; station 8576, foraminiferal limestone from near sea beach, south side of Rio Cana, about 9 kilometers south of Barahona; station 8595 , rubble on mountain slope 2.5 kilometers north of Barbacoa. The fossils obtained at these localities are listed on page 106. Sediments of probably Eocene age were seen at other places.

The mountain ridges of dense gray limestone in the southwestern part of the Dominican Republic are at least in large part coinposed of rocks of Eocene age. In the Republic of Haiti similar rock containing Eocene fossils forms the limestone mountains. Vaughan collected specimens of limestone containing Eocene Foraminifera at Cape Haitien and around Plaisance. The mountains around Ennery, between Ennery and Gonaives and between Gonaives and the Cul-de-Sac are composed largely of Eocene limestone, according to Vaughan. ${ }^{2}$ W. F. Jones estimates that the limestones near Port-au-Prince attain a thickness of at least 8,000 feet, but he did not distinguish between Eocene and Oligocene deposits. ${ }^{3}$

Oligocene.

Oligocene fossils were found at five localities in the Province of Azua, as follows: Station 8617, Las Cuevas, Rio San Juan, north of San Juan; station 8618, limestone hill at Majagual, Rio San Juan, north of San Juan; station 8565, Rio San Juan, about 1.8 kilometers west of Los Bancos, upper part of exposure; station 8619, Rio Yaque del Sur, near Los Bancos; station 8567 , limestone, right bank of Rio de las Cuevas, about 1.9 kilometers west of Túbano. For lists of fossils from these localities see page 109.

The stratigraphic relations of the Oligocene to the Eocene deposits were not definitely ascertained, but the exposures along Rio San Juan about 1.8 kilometers west of Los Bancos strongly suggest that the rocks belonging to the two series are separated by an unconformity. The strata at station 8565 are exposed in a bluff about 900 meters long on the south side of Rio San Juan; the dip is northeastward at an angle of $10^{\circ}$ to $13^{\circ}$. The material consists of fossiliferous conglomeratic shale and argillaceous sandistone. The fossils comprise coral fragments, oysters, and gastropods. At a horizon about 100 meters stratigraphically lower poorly preserved plant remains were found in evenly bedded sandstone. Among these plants Prof. E. W. Berry has recognized a species of Sophora, a coastal member of the Leguminosae. The suggestion is that this area was land prior to the deposition of the marine Oligocene and that the Oligocene is separated by an erosion unconformity from the Eocene. Besides including conglomerate, shale, and sandstone, the Oligocene deposits are in large part composed of limestone.

\footnotetext{
1 Unpublished information.

- Jonea, William F., A geological reconnaissance in Haiti: Jour. Geology, vol. 26, p. 733, 1918.
} 
For lack of time it was not practicable to map separately the Eocene and Oligocene deposits and they were therefore considered together, but in subsequent work the rocks belonging to the two series should be discriminated. The fossils most useful in the determination of the age of the early Tertiary beds are the Foraminifera, which appear to be equally abundant in the limestones, the sandy beds, and even the coarse conglomerates, but they are so inconspicuous that they may readily be overlooked.

\section{Miocene.}

YAQUE GROUP.

The rocks of Miocene age, besides occupying the greater part of the Cibao Valley, also occupy the principal structural basins in the Provinces of Azua and Barahona. The strata exposed along Rio Yaque del Sur are at least 1,500 meters thick. Sandy conglomeratic strata predominate, but there are also shales and limestones. The deposits are almost entirely marine but include local beds of lignite and fossil plants, which denote temporary emergence. These beds belong to the Yaque group as defined by Cooke. (See pp. 65-66, and for lists of fossils see pp. 156-162.)

CERROS DE SAL FORMATION.

Around the border of Enriquillo Basin there are Miocene strata which are obviously much younger than those found along the upper course of Rio Yaque. They comprise the gypsum and salt-bearing beds, the fossils of which indicate late Miocene age. To these strata the name Cerros de Sal is applied, from the locality of that name, near which rock salt is obtained. Until a more detailed study is made it will not be possible to define sharply the boundary between these beds and the underlying Miocene strata. As stated above, the lowest strata of the Miocene found along the upper course of Rio Yaque are largely sandstone. It is not known whether the Yaque group occurs in the Bahoruco Mountains. A great thickness of impure limestone, probably of Miocene age, underlies the Cerros de Sal formation, but its lithologic character is so different from that of the Yaque formation that there is considerable uncertainty as to their relations. (For lists of fossils, see pp. 163-164.)

\section{Pliocene.}

LAS MATAS FORMATION.

There is no positive evidence of the presence of Pliocene deposits in the Dominican Republic. In San Juan Valley and to the southeast, along and near Rio Yaque, the plicated Miocene and older strata are overlapped by thick deposits of loosely cemented gravels and clays which generally dip gently basinward or are folded to a much less extent than underlying strata. These beds are called the Las Matas formation, for they are typically exposed near the town of Las Matas. No fossils have been observed in these gravels, but it is surmised that they are of Pliocene age. 


\section{QUATERNARY SEDIMENTS.}

"COAST LIMESTONE."

Along and near the coast in the Provinces of Barahona and Azua are locally flat-lying limestone and calcareous conglomerate called by Gabb the "Coast limestone." In the vicinity of Barahona village the rocks form terraced sea cliffs, and to the south, where the mountains lie near the sea, they consist largely of firmly cemented limestone conglomerate and reef-coral material. Somewhat similar deposits extend inland along the south border of Enriquillo Basin (Pl. XVII, B). (For lists of fossils see pp. 167-168.)

ALLUVIAL DEPOSITS.

South of Azua the material penetrated in drilling water nells appears to be in large part unconsolidated sand and gravel. Many deposits of such material are later than the "Coast limestone," including outwash gravels along the base of the mountains and sand and gravel along modern river channels and on terraces bordering the valleys. Part of the delta deposits of Rio Yaque and other streams and of the alluvium that forms the floor of Enriquillo Basin may be of Pleistocene age, but most of it is probably Recent.

\section{IGNEOUS ROCKS.}

As already stated, large parts of the Cordillera Central consist of crystalline igneous rocks ranging in composition from quartz diorite to granodiorite. Others consist of serpentine, probably altered basic igneous rock. The diversity of igneous rocks found in the gravel of almost any large river flowing from the Cordillera Central shows that the basal complex includes a wide variety of types. No adequate petrographic study of these rocks was made. Quartz diorite and granodiorite appear to compose the bulk of the larger batholithic masses. Nearly all the crystalline igneous rocks show evidence of dynamic metamorphism, and many have been changed to gneisses, but in few places has the metamorphism gone far enough to obscure the original character of the rock.

Besides the coarsely crystalline igneous rocks there is a thick series of volcanic rocks in the Cordillera Central, which are in part lavas and in part fragmental rocks, including tuffs and breccias. These are characteristically dark purple to green in color and vary in texture from fine-grained to coarse. They are metamorphosed, chloritized, and in part altered to serpentine. The more basic types of lavas are more common than the silicic types.

In San Juan Valley and here and there in the mountains of the two provinces there are small areas of volcanic rocks of Pliocene or more recent age. Some of these are fine-grained porphyritic lavas of andesitic composition but there are also basalts. In Sierra Bahoruco near the seacoast there are amygdaloidal basalts. 
At a locality called Punta Caña, between Las Matas and San Juan, there is a hill composed of lava that appears to be younger than those above mentioned and that may be of Pleistocene age. It is a fine-grained, freshappearing limburgite or basalt with phenocrysts of augite. It varies from dense and massive to amygdaloidal texture. Limburgite or basalt that is regarded as of similar age occurs in nearly flat beds capping mesas and upland areas of gravel elsewhere in San Juan Valley.

\section{GEOLOGIC STRUCTURE.}

The rugged central axis of Santo Domingo consists largely of igneous and metamorphic rocks, probably the oldest in the island. These are overlapped on the north and south sides by sediments of Tertiary age. Considered as a whole the island is therefore structurally a great anticline in which there are many flexures and faults. The principal mountain ranges and intermontane valleys that parallel the axis of the island are either up-faulted or down-faulted blocks or are the results of folding, or they have been formed by a combination of faulting and folding.

Block faulting is the principal factor in the development of broad valleys such as Enriquillo and Cibao. The Cibao, which is flanked on the north by the Cordillera Septentrional, serves as the best known illustration, the broad plain being made up of Miocene strata having a general northward dip, which abut against the upfaulted Eocene and older strata that form the mountain mass to the north. The same type of faulting has produced Enriquillo Basin and probably also San Juan Valley. Similar faulting on a minor scale is evident throughout the Provinces of Barahona and Azua and may be seen along almost any north-south valley, where repetition of beds through faulting forms successive hogback ridges.

No attempt is made to show these faults on the geologic map, for though many are known, none of them was traced throughout its extent. The principal faults are mentioned in the following description of the areal geology.

\section{AREAL GEOLOGY.}

GENERAL FEATURES.

The surface of the Provinces of Azua and Barahona, as already explained, falls naturally into four principal areas: (1) The Cordillera Central, consisting largely of metamorphic and igneous rocks; (2) the extensive inland valleys, made up of weak, easily eroded rocks but chiefly of structural rather than erosional origin; (3) the low mountain ranges, mostly of semicrystalline limestone, alternating with the valleys; (4) the coastal plain, made up of flat-lying, comparatively young beds of limestone and other rock that overlap the older or folded strata in the coastal region and are represented by gravel, sand, or limestone in the topographic depressions of the interior. The geology of parts of the Provinces of Azua and Barahona is shown on Plate XV (p. 186.) 


\section{THE CORDILLERA CENTRAL.}

The Cordillera Central was examined along the cross mountain trails through Restauración and Constanza, those being the only feasible routes of travel northward to the Cibao Valley. Only the parts south of Restauración and Constanza are described here. Plate XVI, $B$, shows a view in the Cordillera Central looking southwestward across the frontier of Haiti from a place on the Bínica-Restauración trail near La Cruz, in the Province of Monte Cristi.

The high mountains north of San Juan Valley are made up of a largo variety of rocks, both igneous and sedimentary, consisting in part of quartz diorite and related crystalline rocks, which have intruded and more of less extensively metamorphosed older crystalline and sedimentary rocks. The foothills are faced with white, finely crystalline limestone, which appears in bold exposures that stand out conspicuously as seen from far out in the valley. Resting on and cutting the metamorphosed sedimentary beds and diorite are volcanic rocks of several kinds that for convenience are designated the "early volcanics." They include dikes, lavas, and volcanoclastics, generally of basic variety, well advanced in alteration to serpentine. There are in addition the "late volcanics," of andesitic to basaltic composition, probably of Pleistocene age. These occur here and there in the valley and also cover small areas in the mountians. They are easily distinguished from the "early volcanics" by their slight decomposition and their lack of deformation.

The great San Juan Valley is bordered on the north by a conspicuous ridge of gray crystalline fossiliferous limestone, which forms a facing for bigher mountains opposite the town of San Juan, and thence extends westward to Bánica as a spur from the main mountain mass, 300 to 500 meters above the surrounding plain. The limestone is fincly crystalline, is greatly seamed by veinlets of calcite, and contains indeterminable Foraminifera.

Back of the limestone ridge and possibly conformably underlying it is a thick series of beds of hard shaly sandstone and sandy shale, which extend northward for many kilometers and form high mountains near the border of the Republic of Haiti. The hardness of these beds is the result of regional metamorphism that appears to become increasingly pronounced toward the north. The bedding lines in the shale are in large part obscured by a slaty cleavage having a general northwest strike. In the exposures farthest north the beds of shale have been changed to phyllite and the few beds of limestone have been changed to marble. From the vicinity of Guayajayuco southward to the mouth of Rio Joca, Rio Guayajayuco flows through a sharp canyon cut in this rock, which is a dark phyllite intricately seamed with white veinlets that run at right angles to the schistosity. In passing this canyon the trail along the Dominican 
side of the river leads over a steeply sloping mountain side at an altitude of about 1,100 meters.

The age of this series of sedimentary rocks is not known, as no fossils were found in it. The rocks are similar in lithology to sandy beds seen near Bani, which are probably of Eocene age. The regional alteration may have been caused by the intrusion of the large masses of quartz diorite that cover much of the region east of Restauracion.

The trail from Constanza southward descends the steep side of Loma Higüela or Chingüela, the top of which probably reaches an altitude of 1,500 meters above sea level, and follows the narrow gorge of Rio del Medio down to Arroyo el Gorbano, where it begins to ascend Loma la Fortuna, making a steady, steep climb to an altitude of about 1,000 meters above sea level, beyond which it follows the undulating crest of the mountain to Las Cañitas, a settlement scattered over the side of the mountain at an altitude of some 1,100 meters above sea level.

At Las Cañitas a splendid view can be had of the great bulk of Monte Culo de Maco, towering above the canyon of Rio del Medio. This mountain, which is said to be as high as the more famous Monte Tina, is probably one of the highest in the island. The mountain falls off steeply at its north end, but its southern or southwestern slope is even and gentle, appearing, as seen from a distance, like a dip slope. From the southwest side of Loma la Fortuna one can look out across the valleys of Rio Yaque del Sur and Rio de las Cuevas.

Beyond the ford of Rio del Medio at Limon the trail leads across Loma la Laguna (altitude about 950 meters above sea level) and descends gradually to Rio de las Cuevas, down the boulder-strewn bed of which it extends to Túbano.

The mountains between Constanza and Las Cañitas are carved out of a great massif of serpentine. Their slopes are steep but usually not precipitous, and they are easy to climb. They are clothed for the most part with an open pine forest and a thin carpet of grass. Near the foot of Loma las Cañitas, at an altitude of about 925 meters and about 8 kilometers from the village of Las Cañitas, a quartz vein that contains copper ore cuts the serpentine. The width of the vein is variable but where seen does not exceed 2 meters. Several of the common copper minerals, including chalcocite, chalcopyrite, and bornite and their oxidized products, were recognized.

About 1 kilometer beyond the outcrop of this vein and about 75 meters lower a bed of hard blue limestone abuts against the mountains of serpentine, from which it is evidently separated by a fault. This bed is probably a mass that has been separated from the main body of limestones of the older series, chiefly of Eocene age, by block faulting, but as no fossils 
were found in it, its age remains in doubt. Fragments of limestone breccia were found beside the trail a little farther down, and at La Madre Vieja, a spring about 1 kilometer beyond the outcrop of limestone, there were rolled boulders of conglomerate.

Massive red rock, weathering shaly and inclosing pebble-like lumps, forms the base of Loma la Laguna on its northern side, but higher there are large blocks of massive conglomerate, composed of many varieties of igneous rocks, and less abundant fragments of limestone. At the top of the mountain is massive blue limestone conglomerate containing large boulders of gray cherty limestone.

The bluff of Rio de las Cuevas where the Constanza trail meets it is composed of very coarse conglomerate with calcareous cement. It consists chiefly of boulders of igneous rocks, especially gray andesite, but it contains also travel-rounded boulders of limestone conglomerate similar to that at the top of Loma la Laguna. There are evidently conglomerates of two ages in this region and the limestone is older than either. The conglomerate at the river appears to dip $18^{\circ} \mathrm{N}$, , but its bedding is obscure.

\section{RIO YAQUE VALLEY.}

In its course from the high mountains to the sea Rio Yaque del Sur crosses weak Oligocene and Miocene sandstones and shales, which are exposed along the valley in cliffs on alternate sides almost continuously as far down as Alpargatal, where the river emerges from the hills and flows slowly through alluvial lands for the rest of its course. The opportunity for stratigraphic study is so excellent that a week was spent in examining the exposures from the vicinity of Túbano on Rio de las Cuevas down to Alpargatal. A rough compass traverse was carried the entire distance, and supplemental traverses were run to nearby points of interest along the route. An attempt was made to ascertain the stratigraphic sequence of the beds and to determine the possibility of their being oil-bearing under cover. As a result it is possible to give a section that is believed to be representative of at least the south-central part of the Province of Azua. At several places the river has cut close to the base of mountainous ridges of early Tertiary limestone. It crosses a spur of the Neiba Range just below the mouth of Rio San Juan, and farther down it runs just west of Sierra Martín García.

A good opportunity to study the character and thickness of the strata where they are but little affected by faulting was found in the vicinity of Quita Coraza, where beds of the Yaque group dip northward from the flank of Sierra Martín García into a synclinal trough. The following section is a compilation of measurements made in that vicinity: 
Geologic section in vicinity of Quita Coraza.

Las Matas formation. Loosely cemented conglomerate, sandstone, and variegated clays, with a little marly limestone; color of clays varies from faint maroon to olive green; no fossils seen. These beds rest unconformably on the marine Miocene beds of the Yaque group.

Yaque group: Sandstone, coarse to conglomeratic, with light olive to gray shaly beds in lower part. Large Arcas and other fossils plentiful in the lower beds.

Clay-limestone member, with branching corals and layers of limestone filled with fossils (station 8590).

Thickness in meters.

Shale, bluish with thin laminae of sandstone; no fossils seen.........

Sandstone and conglomerate, bluish sandy shale, and thin, nonpersistent beds of limestone; some of the beds containing a few fossils, chiefly fragments of branching corals and oysters.

Oligocene and Eocene?. Shales, bluish gray, with thin beds of calcareous sandstone.

Limestone, gray, sparingly fossiliferous; unmeasured; forming the slopes of Martín García.

The lowest beds recorded in the above section appear along an arroyo that emerges from the hills at the north edge of Quita Coraza. The highest beds of conglomeratic sandstone of the basal member of the Yaque group form a dip slope of $43^{\circ}$, against which the river waters wash, leaving a precarious footing for travelers along the trail. Perfect exposures of successively lower beds are washed bare in the arroyo, which is dry except during infrequent rainstorms. The rocks consist of an unvarying alternation of even-bedded sandstone and sandy shale with some conglomerate and a few thin, nonpersistent beds of gray limestone. In the conglomerate are embedded a few oysters and broken corals, together with fragments of other shells. Some of the shaly beds contain impressions of leaves and stems of plants. This thick sandy member rests on shale underlain by limestone, which appears far up the arroyo in the steep slopes of Martín García.

The above described beds of the lower part of the Yaque group resemble sandy strata that appear along Rio Yaque from the crossing of the AzuaSan Juan road northward, and it is surmised that the two are equivalent. They are believed to be the basal Miocene beds, and most if not all of the underlying shale and limestone probably is of Oligocene age.

The next higher member in the section is non-fossiliferous dark-gray shale containing thin laminae of sandstone one-fourth to one-half centimeter thick, spaced at nearly equal intervals of 3 to 4 centimeters in the shale. The thickness of this shale is $\mathbf{1 4 0}$ meters.

Overlying the dark gray shale are strata that may be designated the clay-limestone member. This member is about 60 meters thick and consists of gray, impure limestone and a little sandstone interbedded with 
the bluish-gray to olive-green clay that constitutes the greater part of the section. Both the clay and limestone contain a large number of fossils, including corals of several species (stations 8590; for lists of fossils see pp. 157-162). The clay-limestone beds form a prominent hogback bluff along the right bank of the river opposite Quita Coraza and extend southwestward for many kilometers to the lowlands near Hatico.

This part of the section is of chief interest as a possible container of oil. The thin beds of coarse sandstone in the midst of the clay-limestone member might serve as the reservoir rock and the richly fossiliferous beds might have furnished petroliferous material. The overlying clays would serve as a cap rock, preventing the escape of the oil into the higher sandy beds.

Above the calcareous beds is coarse sandstone that includes some conglomerate and some shaly and calcareous beds in its lower part. The sandy beds contain large Arcas, and some of the calcareous beds contain many corals. These strata appear on both sides of the east-west synclinal axis that lies between Los Güiros and Quita Coraza and are exposed on the south to a thickness of about 175 meters. Higher strata in this sequence are concealed by a covering of gravels of the Las Matas formation, which occupy the axis of the syncline.

The unconformable relations of the gravels of the Las Matas formation with the underlying strata is not pronounced here, the gravels agreeing rather closely in attitude with the substrata. In fact they would be taken for the same formation by one who had not become familiar with the lithologic character of the two and had not seen the decidedly unconformable relations at places up the river. The gravels of the Las Matas formation here, as usual, are less firmly consolidated than the deposits composing the Yaque group, and they contain no marine fossils. Interbedded with the gravel, which is yellowish gray, are layers of soft, marly limestone and layers of faint reddish to purplish clay, which differs strikingly in color from the bluish-gray to olive-green clays of the Yaque group. The unconformity between the two formations is plainly shown at a locality 3 kilometers upstream from Los Güiros. Here the gravel of the Las Matas formation forms a cliff on the left bank of the river, whereas a short distance farther upstream the water flows in a cataract over fossiliferous sandstone of the Yaque group. The unconformity between the two formations is very marked, for there is discordance in the strikes as well as the dips.

The general character of the strata along the upper course of Rio Yaque in the vicinity of the crossing of the Azua-San Juan road is described below. (See Pl. XVIII, A.) From the mouth of Rio de Las Cuevas down to the mouth of Rio San Juan there are thick deposits of sandstone and conglomerate, which are considered the basal part of the Yaque group. The same strata appear for a distance of several kilometers up Rio San Juan and com- 


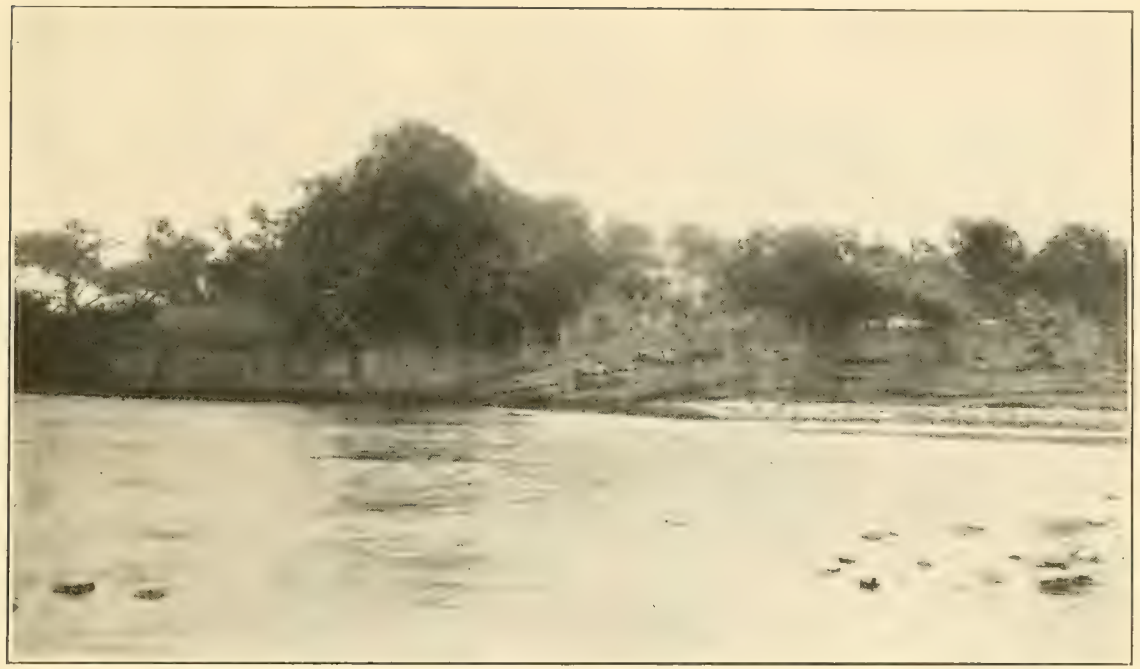

A. SANDY SHALE AND SANDSTONE OF THE YAQUF GROUP ON RIO YAQUE DEL SUR AT CROSSING OF AZUA-SAN JUAN ROAD.

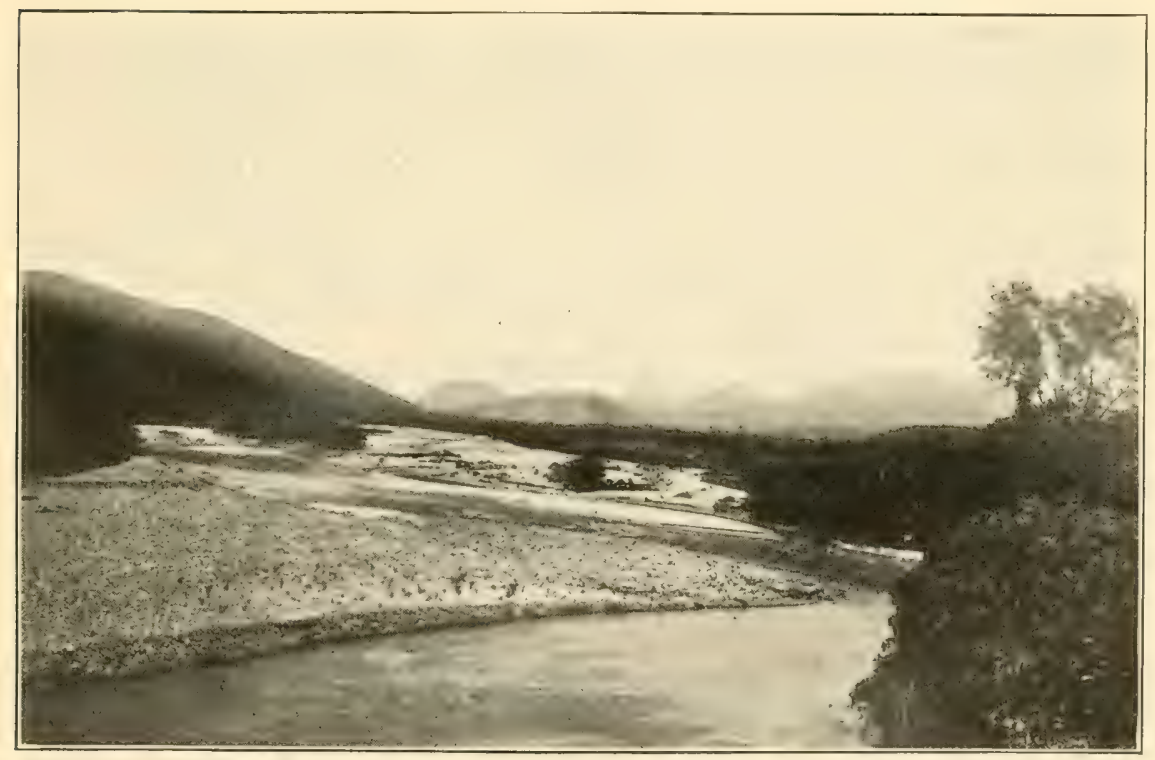

B. VIEW NORTHWARD UP THE VALLEY OF RIO YAQUE DEL SUR FROM THE VICINITY OF BOCA MULA.

The distant hills are capped with basaltic lava. 

pose the hills to the north. Near the mouth of Rio San Juan the beds are inclined northward at an angle of $50^{\circ}$ and overlie the shale and limestone of Eocene and Oligocene age that form the massif of the Neiba Range. (For lists of fossils see p. 109, stations 8564, 8565, 8619; pp. 157-162, stations 8563 and 8566.) From this point northward along the Yaque the dip at first is northward at a low angle, but it gradually steepens to more than $60^{\circ}$ near the mouth of Rio de las Cuevas. Some of the beds contain plentiful plant fossils, and others contain fragments of shells and branching corals, which are most abundant in the conglomeratic sandstone layers. The younger deposits are of Oligocene and Miocene age.

The Miocene strata near the mouth of Rio San Juan appear to rest on a hard, coral-bearing limestone, about 30 meters thick, which contains poorly preserved Foraminifera that are questionably referred to the Eocene. This limestone forms the summit of a high hill on the east side of the road about 1 kilometer south of La Trinchera. Beneath it are at least 1,000 meters of more or less sandy bluish shale containing calcareous layers that abound with a species of Nummulites of Eocene age. The bluff on the left bank of the river below La Trinchera consists of this shale, which is characterized by many thin sandy laminae, each less than 1 centimeter thick, spaced at intervals of 3 to 4 centimeters through the shale. At the first bluff on the right bank a few kilometers below La Trinchera this shale lies against Eocene limestone in possible fault contact.

The hills on the east side of Rio Yaque opposite the mouth of Rio San Juan (see Pl. XVIII, $B$ ) are capped with basaltic lava that may have come from a volcanic fissure in the high hills a short distance to the south, opposite La Trinchera, where basalt cuts the Eocene and Miocene country rock.

The gravel of the Las Matas formation, which occupies so large a part of the great San Juan Valley west of Sierra del Agua, may extend in a continuous belt around the north end of those hills to Rio Yaque, where the gravels form an extensive lowland at the confluence of the Yaque with its tributaries Rio del Medio and Rio de las Cuevas.

About 6 kilometers farther east up Rio de las Cuevas there are jagged hills of sandstone and conglomerate of the Yaque group. The rocks at this place dip steeply southwestward and apparently rest unconformably on a conglomerate composed largely of fine-textured gray limestone, which resembles a platy, thin-bedded, nonfossiliferous limestone that outcrops along the valley a little farther upstream, near Túbano.

SAN JUAN VALLEY.

General Features.

The Gran Valle de San Juan, with its extensive savannas and low hills, is made up largely of loosely consolidated gravel of the Las Matas formation. Interbedded with the gravel are a little sandstone, a little marly limestone, 
apparently without fossils, and shale that weathers to a faint reddishbrown color. These beds slope valleyward at a low angle. They dif southward in the northern part of the valley at an angle of $10^{\circ}$ to $15^{\circ}$, and dip northward at the few places where seen in the southern part. The gravel consists of pebbles of limestone, diorite, and volcanic rock in variable proportions, their character depending on the rocks in the mountains that border the basin.

The age of the gravel is not known, as no fossils were found within beds recognized with certainty as a part of the formation, but data obtained along Rio Yaque and farther south indicate that the formation is composed of terrestrial or near-shore deposits of early Pliocene age, postdating the late Miocene marine Cerros de Sal formation, which contains the beds of gypsum and rock salt found along the south side of Enriquillo Basin.

The gravel of the Las Matas formation of San Juan Valley, as has already been stated, apparently rests unconformably upon folded and faulted fossiliferous strata of Miocene age, which consist of dark-gray to bluish friable sandstone and conglomerate, shale, and a little limestone. As the Miocene rocks are largely concealed by the gravels in the valley they are exposed only in isolated hills that rise above the valley floor, for the Miocene rocks are slightly more resistant than the gravels. Sierra del Agua, a low range of hills that forms the eastern limit of the basin, is made up largely of these strata, typical exposures of which may be seen along the San Juan-Azua road near Rio Yaque.

The only other rock in San Juan Basin that is noteworthy in this connection is basaltic lava of recent age, which lies in nearly flat sheets, capping mesas and upland areas of the gravels. No attempt was made to find the vents from which the lava issued. Jones, in his report on Haiti, ${ }^{1}$ mentions having found in the Cul de Sac district, adjacent to Azua Province, a well-defined crater from which extend basalt flows that occupy depressions in the present surface and are evidently very recent.

\section{Local Details.}

San Juan Valley was entered from the northwest by the trail leading from Bánica to Las Matas. Short trips were made southward from Las Matas and in several directions from San Juan. The mountain slopes on the south side of the valley were not visited. As viewed from Las Matas the lower slopes are seen to be white limestone resembling the limestone on the north side of the basin, which is probably of early Tertiary age. The higher mountain slopes are covered with timber that conceals the rocks.

In the vicinity of Las Matas there are low hills of the Las Matas formation, made up of clay, shale, and gravel with interbedded marly limestone.

'Jones, William F., A geological reconnaisance in Haiti: Jour. Geology, vol. 26, pp. 728-752, 1918. 
The topography suggests a general northward dip of about $15^{\circ}$. About 6 kilometers southwest of Las Matas, near several large springs of sulphur water, at a locality known as El Puerto, Rio Macasía emerges from a gorge through limestone which strikes N. $75^{\circ} \mathrm{E}$. and dips $10^{\circ}$ to $30^{\circ}$ northward. The rock is regarded as probably older than Miocene.

Extending eastward from Bánica is a mountainous limestone ridge known as Sierra de los Altos. Where crossed at a point about 6 kilometers east of Banica the south side of this ridge consists of andesitic agglomerate and tuff resting on the limestone and possibly constituting the basal member of the Las Matas formation, which extends from here southward. Exposures in arroyos show loosely cemented, coarse conglomerate interbedded with sand and hematite-red clay beds. The dip is generally about $15^{\circ}$ southward. About 5 kilometers south from Sierra de los Altos is a small westward-flowing stream known as Rio Caña or Tocino. Eastward along this valley outcrops of the fossiliferous Yaque group were found underlying the Las Matas formation. These strata consist of sandstone, limestone, and conglomerate striking about east-west and dipping steeply southward. In these strata certain species of characteristic Miocene fossils, belonging to the genera Conus, Turritella, and Arca, are plentiful. Probably the presence of these deposits in the midst of the valley is due to comparatively recent faulting. This view is supported by the fact that in the same vicinity the beds of the Las Matas formation are steeply inclined.

The road from Las Matas to San Juan passes over a nearly level gravelly country with numerous dry, shallow arroyos and no rock outcrops for the first 10 kilometers east of Las Matas. At a distance of about 12 kilometers, at a locality known as Punta Caña, the road ascends to a bench about 10 meters high, which is capped by a basalt flow resting on gravel of the Las Matas formation. From this bench, which forms the divide between the westward-flowing waters tributary to Rio Artibonito and the Rio Yaque drainage, the road leads over low gravel hills and thence across the extensive Sabana de San Tomé to the town of San Juan.

For a long distance up Rio San Juan the country is a gravelly plain, across which the river flows swiftly in a shallow, bouldery channel bordered by low gravel embankments. A short distance above Carpintero massive buff to white limestone appears in the river channel, and a little farther upstream it forms hills. The rock is more or less brecciated, is finely crystalline, and dips steeply northward. This limestone is in fault contact with quartzitic sandstone and hard bluish shale that dip steeply northeastward. The recent gravels along the river consist largely of huge boulders of andesite but include some boulders of diorite and limestone. The mountain slopes to the west in the same vicinity consist of limestone. No identifiable fossils were found, but it is believed that all the hard rocks seen along this part of Rio San Juan are of pre-Miocene age. 
From the town of San Juan eastward beyond Rio Mijo gravels of the Las Matas formation are the only rocks encountered. At the crossing of the river is a gravel cliff with a bed of yellowish-gray marl, the strata dipping gently southward. A few kilometers east of Rio Mijo the road enters the hills known as Sierra del Agua, which form the east limit of the Gran Valle de San Juan. The rocks of the Yaque group in the Sierra del Agua are largely bluish-gray sandstone (weathering to olive green), interbedded with conglomerate. They contain many fragments of corals, plants, and other fossils. The beds dip steeply in various directions. Similar deposits may be seen in continuous exposures along Rio Yaque del Sur.

AREA EAST OF RIO YAQUE DEL SUR.

No attempt was made to cover systematically the region from Rio Yaque del Sur eastward to Azua. It was crossed by three different routes-one from Túbano southward through Las Yayas, another along the San Juan road, and another along the trail from Quita Coraza to Azua.

Most of the area east of Rio Tabara is a gravelly plain covered with a dense growth of mesquite, and bed rock is exposed only in the few hills that project above the plain. West of the Tábara there are fairly plentiful outcrops of gravel of the Las Matas formation, which unconformably overlies the folded beds of the Yaque group. Farther north, where the surface is more hilly, there are extensive areas of the Yaque group and voleanic rock and a small area of early Tertiary limestone.

The trail from Túbano southward through Las Yayas leads first over a series of steeply tilted and probably faulted calcareous shales interbedded with limestone (strike N. $80^{\circ} \mathrm{E}$.) and next over hard, brittle yellowish limestone of upper Eocene age. Rock of Oligocene age is exposed on Rio de las Cuevas below Túbano. In the vicinity of Higuero Largo fragments of white coraliferous limestone (station 8608, mixed Eocene and Miocene; for lists see pp. 106, 157-162), probably much younger than the distorted limestone that crops out in Arroyo Salado nearby, were found. The trail then crosses a series of massive, steeply tilted conglomerate.

About 3 miles south of Higuero Largo, in a branch of Arroyo Salado, a collection of corals (station 8610; for list see pp. 157-158), including Stylophora sp. and other branching forms, was made from a vertical bed of conglomerate striking north and south and interbedded with shale. This formation is of Miocene age. Non-fossiliferous conglomerate with the same strike but dipping eastward is exposed at Las Charcas.

Several dikes of hard, dark trap that cut Eocene rocks were seen in the vicinity of Túbano. The contact of the trap with limestone is well exposed in a small hillock known as La Cerrita, on the northern edge of Túbano. Other exposures of the intrusive rock were noted in the Cerro de las Chivas, northeast of the village, and in the upper course of Arroyo Lima. 
Loma la Guia, at Las Yayas, is composed of gray andesite containing black acicular crystals of hornblende. A steep hill less than a mile beyond La Guía, showing steeply tilted shale and limestone at the base, appears to be capped by lava, but the summit of the hill was not examined. Along the Azua-San Juan road at several places south of Las Yayas there are strata of the Yaque group, which dip steeply northward and are overlain by the flat-lying coarse gravel of the Las Matas formation, which lies in a porous gray matrix ("caliche").

\section{ENRIQUILLO BASIN.}

\section{Outline of Geology.}

Between Rio Yaque and Lake Enriquillo there is a westward-sloping plain that is interrupted by the low hogback hills on the north side of Laguna Rincon. The strata exposed in the north side of the basin along Rio Yaque represent the lower division of the sandstones and shales of the Yaque group. The beds dip northward into a syncline, along the axis of which there are strata that are probably equivalent to those in the Cerros de Sal, on the south side of the basin (Cerros de Sal formation). The limestone mountains of the Neiba Range are visible in the distance to the north, and about 30 kilometers to the west the same mountain front lies close to the shore of Lake Enriquillo. The south side of the basin is bounded by the Cerros de Sal, which contain thick beds of gypsum and rock salt. These hills are locally separated from the Bahoruco Mountains, to the south, by a lowland. Similar gypseous strata appear in the ridges on the north side of Lake Rincon. Lake Enriquillo is bordered by a terrace of coralliferous limestone having an altitude of about 35 meters above sea level. This is prominently developed at Neiba and Duvergé and was recognized as a flat-lying bedded limestone at several places to the east. It is either equivalent to or somewhat younger than the conglomeratic "coast limestone" that extends from Cabral southeastward beyond Barahona.

The higher mountains south of Cerros de Sal consist largely of limestone but include some sandy and shaly strata. The evidence of the fossils collected in the front range is not conclusive but indicates that these beds are probably Miocene. In the vicinity of Rancho Viejo, south of Duvergé, these beds rest on limestone containing many Foraminifera of Eocene age (station 8626, 8627, list on p. 106 ). In the same region there are areas of volcanic rock, which probably cuts the Eocene limestone. No Oligocene strata were recognized in this vicinity.

Enriquillo Basin, like other longitudinal valleys that traverse the island, is probably the result of downfolding and blockfaulting, the north side of each valley being downfaulted and in contact with a raised block of harder, older rocks that give a mountainous topography. In general the valley strata dip northward and are more or less repeated by step faulting. 
Such faulting appears to have occurred near Lake Rincón, where the gypsum and salt-bearing beds crop out as ridges in the midst of the valley.

Vicinity of Barbacoa and Eastward.

Both Barbacoa and Neiba stand on a terrace of coralliferous limestone that is about 80 meters above the level of Lake Enriquillo. At Barbacoa this terrace, which is only a few hundred meters wide, has a back slope of limestone rubble, which we ascended for more than 2 kilometers without reaching any outcrops. In a deep ravine well up the slope, where cliffs 50 meters high are exposed, the rubble is stratified as though waterlain and dips southward at an angle of $15^{\circ}$. The rubble consists entirely of gray semicrystalline limestone containing many orbitoid Foraminifera of Eocene age (station 8595, list of fossils on p. 106). The mountain top in the rear as seen from the valley is made up of limestone. The altitude is estimated at 1,300 meters. Several kilometers west of Barbacoa outerops of limestone appear to extend down to the shore. The mountain front is probably a fault escarpment and may extend eastward to the vicinity of Boca Mula, on Rio Yaque.

The rocks exposed in the few outcrops northward from Neiba for a distance of several kilometers show great variation in strike and are steeply inclined. The strata exposed nearer Neiba are probably of the same age as the Cerros de Sal formation on the south side of the basin and are doubtless in fault contact with the pre-Miocene limestone on the north. The results of observations by A. F. Dixon, who made a geological investigation in this area, ${ }^{1}$ indicate that from Neiba eastward to Rio Yaque the structure is synclinal and that the rocks consist in large part of beds of late Miocene age, which are in places covered by nearly flat strata supposed by Mr. Dixon to be the "coast limestone." Elsewhere the "coast limestone" extends up to an altitude of little more than 70 meters above sea level. In this region there are probably also areas of gravels of the Las Matas formation, which elsewhere unconformably overlie the Miocene strata.

\section{Cerros De Sal.}

The Cerros de Sal were named from beds of rock salt, which are there exploited on a small seale to supply local demand. The rock salt occurs also in the ridge near Las Salinas and for several kilometers westward. The associated gypsum beds extend eastward along the south side of Lake Rincón and upfaulted blocks of these beds also appear on the north side of that lake as far east as Rio Yaque. The beds can be traced westward nearly to Duvergé. Throughout their extent they generally dip steeply northward but in places they stand vertical or are even slightly overturned.

The stratigraphic sequence as studied about 3 kilometers west of Las Salinas, in the vicinity of the Manuel Pérez excavations, is shown in the

\footnotetext{
${ }_{1}^{1}$ Report furnished by Mr. R. D. Upham, of the Interocean Oil Co.
} 
accompanying section. Higher beds of the same formation outcrop in the lowlands and hills north of Cerros de Sal. Thick beds of clay and sandstone were also noted, but they are not listed in the section. Beds of bituminous limestone occur in the series near Angostura.

Condensed stratigraphic section of Cerros de Sal formation.

7. Sandy shale, poorly exposed, alternating with calcareous, fossiliferous sandstone that forms low ridges north of Cerros de Sal.

Thiokness in meters.

300

6. Cross-bedded sandstone, unconsolidated, alternating with gypseous shale; strike N. $70^{\circ} \mathrm{NE}$.

5. Sandy clay beds, light-olive color, with embedded corals at two horizons (station 8574, list of fossils on pp. 163-164); strike about N. $70^{\circ} \mathrm{W}$., dip vertical

4. Sandy clay beds of various colors, with several shell beds, composed of oysters, arcas, and other fossils (station 8572, list of fossils on pp. 163-164); also with thin layers of impure earthy lignite

3. Sandstone, sandy shale, and thin layers of pinkish fossiliferous limestone, which form the north face of the high ridge.

2. Gypsum in thick, massive, white, finely crystalline layers, alternating with thinner layers of green gypseous shales and with beds of coarsely crystalline salt; gypseous shales in upper part.

1. Red and yellow sandy clay and sandstone

Gypsum interstratified with beds of salt and shale forms the upper part of the high ridge of the Cerros de Sal (altitude about 200 meters). These beds are underlain on the southwest side of the ridge by shaly reddish-brown clays. In the valley on the northeast side of the ridge the gypseous strata are overlain by a few thin beds of pink limestone, above which lie shale and sandstone alternating with variegated clays, the whole loosely cemented or with only a few beds of calcareous sandstone, which is sufficiently indurated to form low hogback ridges. The mollusks and corals, which are abundant in the strata, indicate that the formation is late Miocene.

THE SALT DEPOSITS.

The salt deposits occur on the north side of Cerros de Sal near the top. They are the property of the communes of Las Salinas and Angostura. The people of Las Salinas work in the excavations known as the Carrera del Potro, Manuel Perez, and La Partilla and several smaller excavations. Work is usually done at only one locality at a time. The workings of the inhabitants of Angostura near the western end of Cerros de Sal were not examined.

The salt deposits are in the upper part of the gypseous beds of the Cerros de Sal formation. The thickness assigned to this member - 700 meters - is a minimum one, and more detailed work may show that it is much greater. The upper part of the member contains a larger proportion of shale than the 
lower part. The thickness of the part of the gypseous strata that contains the salt is about 50 meters, but further development would perhaps show a greater thickness and the presence of other salt-bearing strata.

The salt is found in lenticular masses. The pits have been dug to shallow depths in an unsystematic way and no lenses have been completely exposed. The thickness of the lenses ranges from a few centimeters to 6 meters and perhaps more, but in none of the excavations has any attempt been made to discover their length. Probably few of the lenses are much over 20 to 30 meters long and most of them are shorter. The three principal sets of workings of the Commune of La Salina are rather far apart but were probably located in a haphazard way, for salt is found at several places between these workings. Although individual lenses are short, the deposits probably are fairly continuous throughout the length of the Cerros de Sal. The salt in the lenses is massive, and nearly all of it is white. Layers of red and of black or nearly black salt are reported but are not common. Large, white, semitransparent crystals of halite, some of which are nearly a meter long, are found rather frequently. The green, soft shale associated with the lenses is distinctly saline in taste for considerable distances from the masses of salt.

The easternmost of the principal workings is Carrera del Potro, where only one opening has been made. The salt exposed is a lens nearly 6 meters thick, banded with ribbons of green shale, most of which are only one or two centimeters thick. These ribbons are somewhat wavy but are in general vertical, thus agreeing in dip with the lens. The strike is N. $85^{\circ} \mathrm{W}$. East of this opening, on the line of strike, is an outcrop of gypsum and west of it is shale.

The Manuel Pérez excavations are more than a kilometer west of Carrera del Potro. Here a number of pits are scattered over an area roughly 50 meters wide by 300 to 400 meters long. There are nearly a score of excavations in this area, all of which are small and shallow. The lenses of salt range in thickness from a few centimeters to more than a meter. Some are close together and even merge into one another. They lie in the usual green to yellow shale. At this locality work was in progress at the time of the visit.

The Partilla workings, which are about as far west of the Manuel Pérez locality as Carrera del Potro is east of it, are similar to those at the Manuel Pérez. The excavations are perhaps fewer, but are deeper, and the average thickness of the salt lens exposed is a little greater. The salt here has a more greenish cast than elsewhere, probably due to admixed clay.

The rock salt in Cerros de Sal is so good that it is used for some purposes without refining. Salt picked clean of shale will probably average about $90 \mathrm{per}$ cent of sodium chloride. The results of analyses of 12 samples from Cerros de Sal are given in the accompanying table. The impuri- 
ties are calcium, magnesium, and potassium chlorides and sodium and calcium sulphates. Such salt can be used without purification for some purposes, such as refrigeration, but it could not be exported for use as table salt without refining. Much of the salt now sold for this purpose contains more than 99 per cent of sodium chloride. It contains only very small amounts of potassium. A salt less pure is hygroscopic and is therefore not so desirable, for a very small amount of calcium or magnesium chloride in salt causes it to absorb moisture readily. The analyses indicate that the deposits have no commercial value except as common salt-sodium chloride. The water-soluble constituent is principally sodium chloride. The remaining constituents were determined qualitatively, except the potassium, which was determined quantitatively.

Qualitative and quantitative analyses of water-soluble constituents of samples of salt from Cerros de Sal.

[Analyses by E. T. Erickson.]

\begin{tabular}{|c|c|c|c|c|c|}
\hline \multirow[b]{2}{*}{$\begin{array}{l}\text { Sample } \\
\text { No. }\end{array}$} & \multicolumn{2}{|c|}{ Quantitative determinations. } & \multicolumn{3}{|c|}{ Qualitative determinations. } \\
\hline & $\begin{array}{l}\text { Potassium } \\
\text { (IK). }\end{array}$ & $\begin{array}{l}\text { Equivalent of } \\
\text { potash }\left(\mathrm{K}_{2} \mathrm{O}\right) \text {. }\end{array}$ & $\begin{array}{l}\text { Calcium } \\
\text { (Ca). }\end{array}$ & $\begin{array}{l}\text { Magnesium } \\
\text { (Mg.) }\end{array}$ & $\begin{array}{l}\text { Sulphates } \\
\text { (SOs). }\end{array}$ \\
\hline $1 \ldots$ & Trace...... & Trace..... & Small amount.......... & 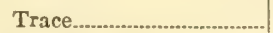 & Fair amount \\
\hline $2 \ldots \ldots$ & 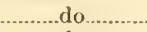 & 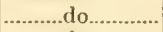 & 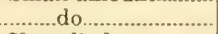 & Very small amount. & Do. \\
\hline $3 \ldots$. & 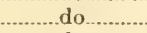 & ............................ & Very little.................. & 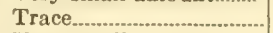 & Do. \\
\hline $4 \ldots$. & 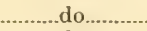 & 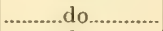 & do & Very small amount........ & Do. \\
\hline $5 \ldots$ & ..................... & ...........do.... & Small amount...... & 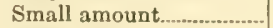 & Do. \\
\hline $6 \ldots$ & ................... & ................. & Very little............. & Trace......... & Do. \\
\hline 7. & $0.24 \ldots \ldots$ & $0.29 \ldots \ldots \ldots$ & do & Very small amount....... & Do. \\
\hline 8. & Trace....... & Trace....... & Small amount...... & Trace & Do. \\
\hline $9 \ldots \ldots$ & $0.24 \ldots \ldots \ldots \ldots$ & $0.29 \ldots \ldots \ldots \ldots \ldots$ & Fair amount......... & Small amount & Do. \\
\hline $10 \ldots \ldots$ & Trace........... & Trace................. & Small amount & .......................................... & Do. \\
\hline $11 \ldots$ & $0.16 \ldots \ldots \ldots$ & 0.19 & do & 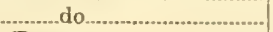 & Do. \\
\hline $12^{a}$ & Trace............ & Trace........ & 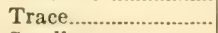 & Trace. & Small amount. \\
\hline $13^{b}$ & ...................... & .................. & Small amount....... & Small amount & Fair amount. \\
\hline
\end{tabular}

a Salt incrustation on rock of arroyo below La Partilla. Stained green with oxidized copper.

$b$ Soil from shore of Laguna Rincón, near Cristóbal, Barahona Province.

The terms used in the above table signify approximately as follows:

Trace $=$ less than .05 per cent.

Very small amount $=$ less than 1 per cent.

Small amount $=$ over 1 per cent and less than 5 per cent.

Fair amount $=$ over 5 per cent and less than 15 per cent.

Qualitative tests of the samples for bromine, iodine, boron, and lithium showed inappreciable quantities.

The amounts of potash in these samples are insignificant when compared with the amounts in the salt mined at deposits in Europe. The potash deposits of Upper Alsace average 18 per cent of $\mathrm{K}_{2} \mathrm{O}$; the part mined contains 20 to 22 per cent, and the principal bed is about 5 meters thick. This bed is overlain and underlain by a great thickness of rock salt. The 
general average of $\mathrm{K}_{2} \mathrm{O}$ in the deposits mined at Stassfurt, Germany, is 10 per cent.

The present methods of mining in the Cerros de Sal are very crude. No explosives are used. The tools used are axes, crowbars, and wedges. There is almost no timbering, although mesquite bushes of ample size grow on the hills close at hand. The soft shale that surrounds the salt lenses slacks and does not stand well, so that all the pits are shallow. Hillside locations that can be worked tunnel-fashion are sought, but, as the roofs will not stand without timbering the tunnels are very short. It is the present practice to work in one locality for a few months and then shift to another. Probably the pits at one place are pushed as far as is deemed safe and then temporarily abandoned. When erosion and weathering have removed the dangerous overhanging rock the miners return, clear out the debris, and resume work.

It is said that about 15 or 20 miners are usually employed in the workings of the Commune of Las Salinas. When we visited the mines work was in progress at only the Manuel Pérez excavations. Wages were $\$ 1$ a day when powder was used, but now that it is not used the average is reported to be $\$ 1.20$ a day. It is said that under favorable conditions one man can mine as much as 10 mule loads of salt in a day (say 750 kilograms), but the average daily production per man is probably not half that amount. The salt is sold for $\$ 1.25$ a mule load (70 to 80 kilograms) at the mine and for $\$ 1.50$ a mule load at the town of Las Salinas. Probably more salt is sold at the mine than in town. People come for long distances to get this salt, as it has a reputation for being superior to that obtained by the evaporation of sea water at the coast. The quantity sold daily is reported to range from 20 mule loads to 100 mule loads, but 20 mule loads is probably above the average.

Crude as the methods of operation are they may be the best that is possible under the present conditions. The rock is too firm for steam shoveling without blasting and the salt lenses are probably too small and too discontinuous to be worked by steam shovel or large-scale quarrying, yet more intelligent and systematic work, with the use of explosives and timbering, would no doubt materially lower the cost of mining. Transportation is not very difficult. There is already an automobile road between Barahona and Las Salinas, a distance of about 26 kilometers, and though it is poor it could be greatly improved at slight expense. There is now only a winding pack-mule trail from Las Salinas to the mines, and the slopes are so steep that the construction of a road which could be used for motor trucks would be somewhat expensive, but there would be no great difficulty in building a tramway. Whether the financial returns to be expected would warrant the outlay necessary to equip these mines with modern appliances could 
be determined only by field examination and careful calculation by a competent engineer. The output under present management is sufficient to supply the local demand, and the profit appears to satisfy the owners.

Petroleum Possibilities in Enriquillo Basin.

There are rumors that indications of petroleum have been seen at many places in and near Enriquillo Basin. Some of the places mentioned are east of Neiba, others are north and west of the Cerros de Sal, and still others are near Tierra Nueva and Jimaní. The indications reported are asphalt seeps, salt springs, limestone having the odor of "burned gasoline," and lignite.

E. I. Kilborne, an engineer in the employ of the Barahona Company, reports that he found asphaltic material which had the odor of petroleum on a branch of Arroyo Palma Dulce, about 6 kilometers east of Duvergé. Salt springs, which are regarded by the natives as indicating the presence of oil, are reported to exist at several places east of Neiba. Bituminous limestone that gives off a fetid odor when struck occurs near Angostura, at the west end of Cerros de Sal. There are small fragments of woody material at the same locality and elsewhere in the rocks of the Cerros de Sal formation.

The strata that overlie the gypsum beds in the Cerros de Sal appear to have been a possible source of petroliferous material, as they are rich in marine fossils and contain layers of lignite. The same beds under suitable cover might contain pools of oil. Any search for favorable structure in Enriquillo Basin should be preceded by a thorough study of the stratigraphic sequence along the Cerros de Sal, where the steep tilting of the beds furnish excellent exposures. The area from Neiba eastward to Rio Yaque is regarded as sufficiently promising to warrant a careful study of the structure and detailed investigation.

\section{Sierra Bahoruco South of Duvergé.}

Sierra Bahoruco is a rugged range that rises to an altitude of 1,700 meters on the south side of Enriquillo Basin, in the south-central part of the Province of Barahona. (See Pl. XIX.) Trips were made along the foothills of this range and southward from Duvergé through Puerto Escondido to Rancho Viejo, on the trail to Pedernales.

A bench of coralliferous limestone, which is mentioned elsewhere in this report (p. 213), is especially well developed between Duvergé and a point a few kilometers west of Las Baitoas. (See Pl. XVII, B.) Close to the road that skirts the base of the mountains there are cliffs, 3 to 12 meters high, composed almost entirely of branching corals, some of which are so fresh as to retain their original colors. Somewhat farther north in the basin there are more massive corals, which commonly occur as detached heads lying on or partly buried in the silty soil. Many of the mountain spurs 
are terminated by small cliffs, probably due to wave action in the sea that once filled Enriquillo Basin.

Along the border of the mountains, yet semi-detached from them, there are foothills, 40 to 100 meters high, composed of clayey sandstone, clays, and conglomerate, and probably some limestone. No fossils were collected from these beds, but it is believed that they form a part of the Cerros de Sal formation, because they are lithologically similar to some of the lower beds of that formation and lie stratigraphically above beds that make up the mass of the higher mountains in the northern part of Sierra Bahoruco. Near Duvergé the strike of these beds ranges from east-west to N. $50^{\circ} \mathrm{W}$. and the dip ranges from $20^{\circ}$ to $50^{\circ} \mathrm{NE}$.

From Duvergé southward through Sierra Bahoruco past Puerto Escondido to Cañada Diablo there is a single series of sedimentary beds. As indicated in the stratigraphic section given on page 215 , this series consists of several distinct parts, but there appear to be no great stratigraphic breaks between them. Nearly all the beds are calcareous and most of them are impure limestones. Many are fossiliferous, but the fossils are poorly preserved. There are corals, casts of pelecypods, and some Foraminifera. The beds are probably early Miocene or late Oligocene. At their base is a well-defined conglomerate with oval pebbles of hard limestone 5 to 6 centimeters and more in diameter. Many of the pebbles contain abundant orbitoidal Foraminifera.

A striking feature of this region of calcareous rocks is the intensely red color of a very large part of the clayey soil, which is apparently a product of the weathering of the limestone. A thickness of some 130 meters of the rock series is made up of red and yellow highly ferruginous clay-stones, but these are subordinate in amount to the limestone. The red color of the soil is most noticeable where limestone strata form the bed rock.

The average strike of the beds is $\mathrm{N} .70^{\circ} \mathrm{W}$., although variations of $10^{\circ}$ or more from this were noted. The rocks are folded into open anticlines and synclines, but no considerable faults were observed. Over most of the area between Duvergé and Cañada Diablo the dips are as high as $60^{\circ}$, but dips of $15^{\circ}$ to $25^{\circ}$ are more common. Near Cañada Diablo and Rancho Viejo, however, there is a change. Here the beds are bent sharply upward. Dips of $70^{\circ} \mathrm{N}$. to vertical are common, and at some places, as in the basal beds near Rancho Viejo, steep southerly dips were observed, indicating that the beds here are actually overturned.

The basal conglomerate containing foraminiferal limestone pebbles is found in the vicinity of Rancho Viejo on both sides of Cañada Rancho Viejo, a few kilometers above the point where it joins Cañada Diablo. This conglomerate rests directly upon the limestone from which its pebbles are derived. There is clearly an unconformity here, and probably a large one. The limestone is hard, fine-grained, semicrystalline, and massive. No 


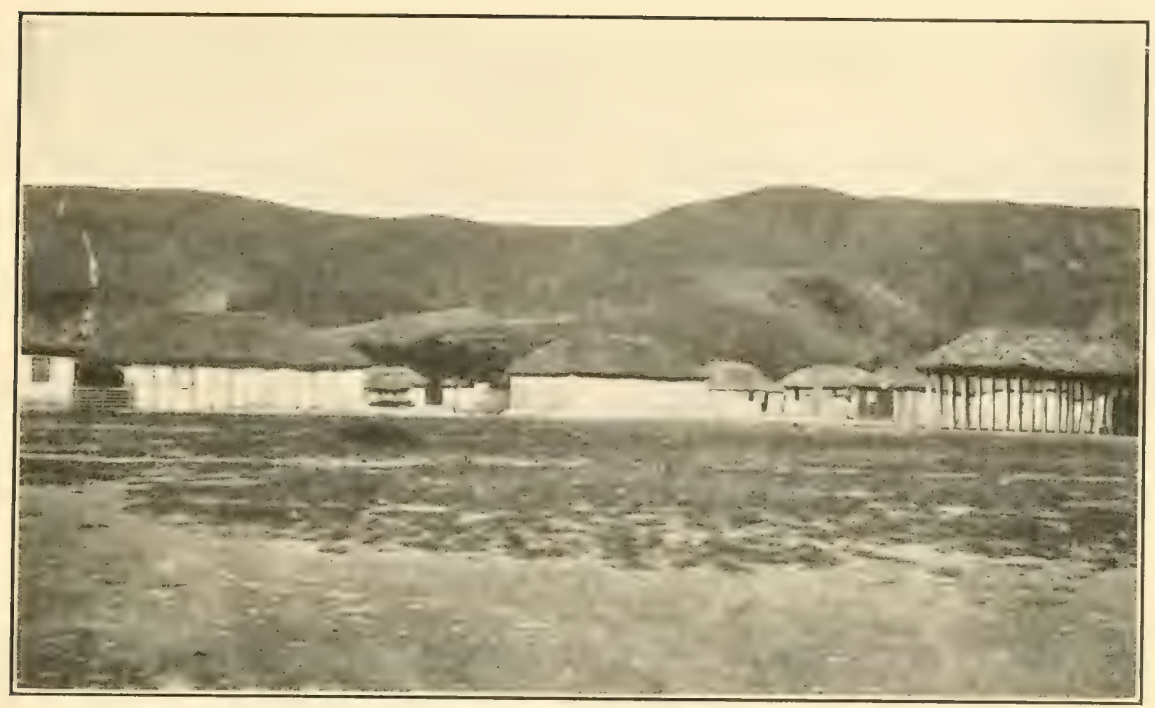

A. PART OF DUVERGÉ; SIERRA DE BAHORUCO IN BACKGROUND.

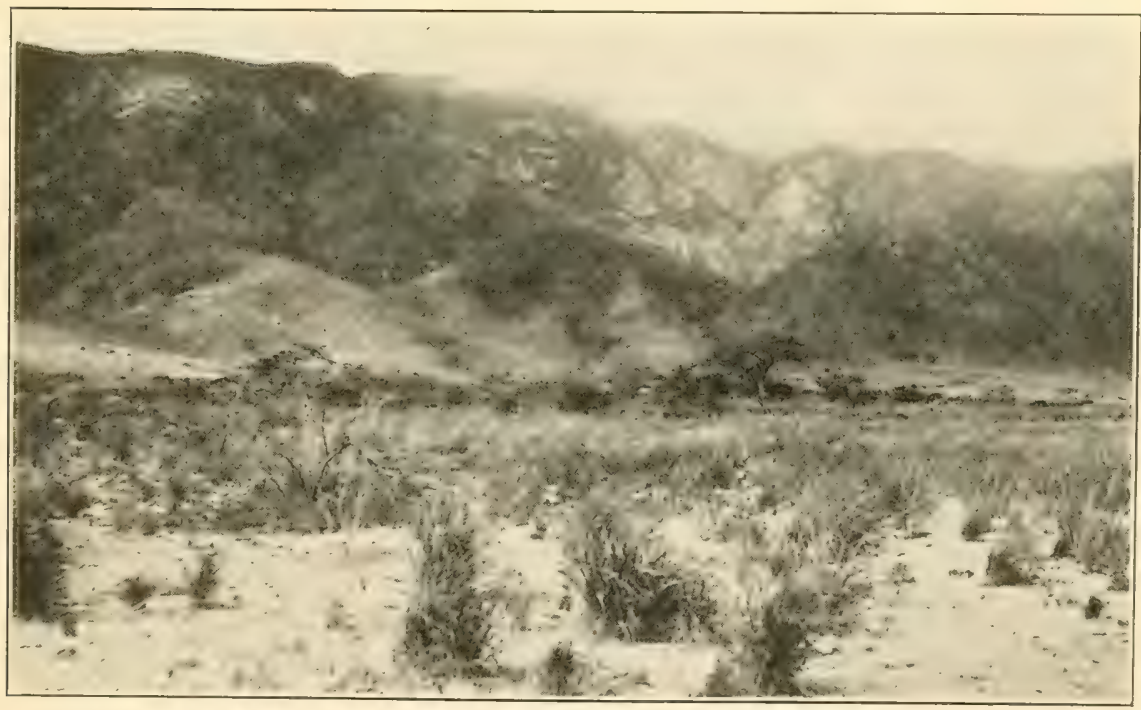

B. SIERRA DE BAHORUCO LOOFING SOUTH FROM SAN JOSÉ, WEST OF DUVERGÉ. 

indication of bedding was observed. As the investigation was not carried farther south, no data as to the probable thickness of this formation were obtained. The Foraminifera collected include Nummulites and other forms of Eocene age (stations 8626, 8627; lists of fossils on p. 106).

The following generalized section summarizes the stratigraphy of the northern part of Sierra Bahoruco. It is based on a hasty reconnaissance examination, and the thicknesses given are therefore only approximate, but the general relations are believed to be correctly shown.

Generalized section in Sierra Bahoruco south of Duvergé.

Pleistocene:

Coral limestone and limestone conglomerate, forming terrace deposits near the border of Lake Enriquillo.

Thickness in meters.

Unconformity.

Miocene (?):

Conglomerate, variegated clay, and clayey sandstone; probably some limestone

Unconformity?

Early Miocene or late Oligocene:

Rudely bedded marly limestone, with interbedded limestone conglomerate; fossiliferous, especially in the lower part, but the fossils are poorly preserved. $300-500$

Thin-bedded impure limestone; few fossils.

Brick red, and yellow tuffaceous claystone and conglomerate; no fossils observed.

Rudely bedded sandy limestone; no fossils observed $300-500$

Basal conglomerate composed of pebbles of foraminiferal limestone Unconformity.

Eocene:

Hard semicrystalline limestone with Foraminifera Not known.

BARAHONA-BAHORUCO COAST.

The village of Barahona stands on a terrace of "coast limestone" which extends from the beach inland for a few kilometers. South of Barahona, along the coast, this limestone forms a sea cliff, 15 to 20 meters high, the top of which is a narrow terrace strewn with modern shells. Back of this terrace is a higher one at an altitude of about 50 meters, consisting of coarse limestone rubble derived from the mountains in the rear. The "coast limestone" throughout this area is made up chiefly of firmly cemented limestone conglomerate containing a few corals. In the southern part of this area, beyond Rio Bahoruco, the adjacent mountains consist in part of basaltic flows and the conglomerate contains pebbles of basalt. About 5 kilometers south of Rio Bahoruco is El Derrumbado, a precipitous promontory of limestone that rises about 500 meters above the sea. This limestone probably rests in fault contact against the basalt, extending from this point northward to the vicinity of Rio Bahoruco. 
The limestone along this coast is at least in part Eocene, as indicated by Nummulites and other Foraminifera found near the sea beach on the south side of Rio Cana (station 8576 ; for list of fossils see p. 106). The only fossils found at El Derrumbarlo were a few fragments of shells and some corals, probably of Eocene age.

The basalt is evidently extrusive, for it is vesicular and its structure indicates flowage, but some of it is very compact and finely crystalline. The bed of Rio Bahoruco contains boulders of more coarsely crystalline rocks, almost of gabbroid appearance, which may have been derived from an igneous mass farther inland.

Copper stains are common in the basaltic lava, especially in its vesicular part, where thin films of chalcocite fill irregular cracks that traverse the mass and occur also as impregnations of the tufflike part. The amygdular spaces are generally filled with zeolite materials. At Bahoruco the conspicuous green malachite stain in the weathered rock has attracted the attention of local prospectors, who have dug trenches and pits over a considerable part of the hillside and have done sufficient work to show the futility of further search in this vicinity. Chalcocite occurs in insignificant amounts in the body of the rock and in films, 1 to 3 centimeters thick, that follow irregular, widely separated cracks in the rock.

Specimens from other prospect pits, farther south along the coast, near Paradís, indicate the occurrence of similar copper deposits there. The owner of the prospect near Paradís reports that his locality is the more promising of the two. One specimen found near Paradís showed a vein, about 5 centimeters thick, composed in part of chalcocite.

So far as known these are the only places in the Bahoruco Mountains where prospecting has been done for copper. On the strength of these discoveries the concession "Bahoruco" was obtained from the Dominican Government.

\section{AZUA AND VICINITY. \\ Outline of Geology.}

The town of Azua lies on a gravelly plain that slopes southeastward toward Ocoa Bay. A short distance to the north there are low hills of conglomeratic sandstone and shale, of Miocene age, beyond which lie mountainous slopes of early Tertiary limestone. In the foothills at a place known as Higuerito there is a seepage of oil that has been the chicf center of interest for the oil prospectors in the Republic. The fertile plain south of Azua consists of sand and gravel, which is possibly in part contemporancous with the Las Matas formation of the region to the west. The strata found in drilling for artesian water to a depth of about 100 meters at the Ansonia sugar plantation are said to consist of unconsolidated clay, sand, and gravel. Between the plain and the coast to the south is 
La Vigia, a ridge of hard, gray limestone about 300 meters high. No fossils were found in this limestone, but its topographic prominence and its lithology indicates that it is of early Tertiary age.

The character of the Miocene sandy beds and early Tertiary limestone is well shown along Rio Vía north of Azua, where the following notes were made by Doctor Cooke: The "old series," of Eocene or Oligocene age, is exposed near the second waterfall above Azua, about 5 kilometers from that town, where there is a massive bed of limestone conglomerate, probably not over 15 meters thick, containing pebbles of greenish rock. Superimposed on this bed is a thicker massive blue-gray limestone containing thin beds of shale. The rocks are greatly sheared and are cut by minor overthrust faults, and the entire section is repeated by a larger overthrust fault. The strike, although variable, is in general northwest, and the dip varies from vertical to northeast.

Downstream from the "old series," and apparently dipping beneath it, there is a massive conglomerate, composed chiefly of limestone pebbles, which grades southward into conglomeratic sandstone interbedded with clay-shale, the relative proportion of the clay shale increasing toward the south. About one kilometer from Azua there is a vertical bed of yellow nodular coraliferous limestone, the fossils in which are undoubtedly of Miocene age. (See list on pp. 157-158, station 8664.) These beds generally dip north or northeast at a high angle and exhibit many small faults. The sequence of strata found here suggests that the beds may be overturned.

The Azua Oil Field.

GENERAL FEATURES.

The so-called Azua oil field is about 4 kilometers northwest of the town, at a place known as Higuerito. The seepage of oil and the salt springs at this place have been known for a long time and have in recent years attracted the attention and commanded the efforts of many exploiters. Six holes have been drilled, several of which produced some oil. The land is within a concession now owned by the Santo Domingo Investment and Development Co., which is continuing the exploratory work. There is considerable difference of opinion as to the results obtained in the earlier wells.

The rock near the principal oil seep consists of conglomerate, coarse sandstone, and sandy shale, all sparingly fossiliferous. The conglomerate contains fragments of branching corals that suggest forms found to the west, in the lower strata of the Miocene deposits along Rio Yaque del Sur. The beds exposed here closely resemble the Miocene beds exposed near Quita Coraza, along Rio Yaque del Sur, and their Miocene age is shown by the fossils in the richly fossiliferous strata in the same series to the southeast, along Rio Via. The topography of the areas near the seepages is 
hilly. Bed rock lies near the surface and crops out at many places along the ravines, though at others it is covered with a mantle of gravel in which pebbles of limestone from the adjacent mountains predominate. The rocks of the slopes of these mountains, which lie about 2 kilometers to the northeast, consist of white limestone containing abundant orbitoidal Foraminifera that are probably of Eocene age. The boundary between the older limestone of the mountain slope and the sandstone and conglomerate at Higuerito may be a fault. Beds near the contact can be seen plainly along Rio Vía, where the Miocene conglomerate apparently dips under the older limestone.

HISTORY OF DEVELOPMENT.

Of the six wells said to have been drilled before the advent of the present holders of the concession all but one were put down within a few hundred meters of the principal oil seepage. More or less oil is said to have been found in each at depths ranging from 180 to about 290 meters. The deepest well is said to have reached a depth of 400 meters. The earlier wells, which gave the best promise of becoming good producers, yielded oil in quantities that are variously estimated from a dozen up to several hundred barrels a day. Most of the oil was found at depths of less than 220 meters, and drilling to greater depths almost invariably resulted in a strong flow of salt water, which was left uncontrolled and destroyed the well. One well was drilled about four kilometers north of Higuerito, in a narrow valley at the base of the mountains. A depth of 200 meters is said to have been reached. The material for the first 125 meters was recorded as "sand and gravel," beneath which was "dark, hard rock with much spar."

Drilling is now being done on the recommendation of a geologist, who has obtained data that suggest the presence of an elongated dome, which trends nearly north-south and has steeply dipping flanks. The beds to the southeast, along Rio Vía, are so greatly crumpled and faulted that a geologist should do much very careful detailed work before he makes recommendations for drilling in this region. If the next two or three holes are drilled without obtaining oil it would seem to be advisable to abandon drilling here and to look for another field to the west, where the rocks are less disturbed.

QUALITY OF OIL.

The oil from the Azua field is dark brown, very liquid, and of high gravity, the results of various tests showing a gravity of $19^{\circ}$ to $21^{\circ}$ Baumé. It is said to yield no gasoline. The following are the results of tests of a sample taken from well No. 1 at a depth of 960 feet. The tests were made by Leroy M. Law for the Interocean Oil Co. 
Tests of sample of oil from well No. 1 .

Specific gravity at $60^{\circ} \mathrm{F}$.

Gravity (Baumé).

0.9309

Pounds per gallon

$20.4^{\circ}$

Flash point, open cup.

7.752

Fire test

$185^{\circ} \mathrm{F}$

Distillation test:

\begin{tabular}{|c|c|}
\hline Initial boiling point... & $160^{\circ} \mathrm{C} .\left(320^{\circ} \mathrm{F}\right.$. \\
\hline 10 per cent distills at. & $224^{\circ}$ C. $\left(435^{\circ}\right]$ \\
\hline 20 per cent distills at... & $225^{\circ} \mathrm{C} \cdot\left(491^{\circ} \mathrm{I}\right.$ \\
\hline 30 per cent distills at... & $277^{\circ} \mathrm{C} .\left(531^{\circ} \mathrm{I}\right.$ \\
\hline 40 per cent distills at... & $296^{\circ}$ C. $\left(565^{\circ}\right.$ \\
\hline 44 per cent distills at... & $300^{\circ}$ C. $\left(572^{\circ}\right.$ \\
\hline
\end{tabular}

Moisture

Trace.

Gas also issues from the ground in the vicinity of the oil seepage but none of it appears to be inflammable. A sample taken from one of the wells was analyzed by the chief chemist of the Bessemer Gas Engine Co., Grove City, Pa., whose report states that the sample "consists of carbon dioxide and air to 94.6 per cent of the total sample." The presence of air indicates that the sample was not carefully taken. His analysis is given below.

Analysis of sample of gas from well near Azua.

$\begin{array}{lr}\text { Heavy hydrocarbons by clarioline oils._... } & 4.00 \\ \text { Heavy hydrocarbons as calculated, less } 55.5 \text { air } & 9.00 \\ \text { Carbon dioxide } & 11.60 \\ \text { Oxygen } & \\ \text { Specific gravity (air equals 1) } & 1.18\end{array}$

Reported Oil Seepages East of Azua.

The seepages of oil at Higuerito are the only ones found in the region, though there are numerous reports of others, some of which were visited and found to be merely salt springs or the carbonaceous material of fossilized plants. Mr. E. E. Dreyfus, of Santo Domingo City, who has resided for many years in the Province of Azua, reports that he has several times seen films of oil on the surface of the water near the beach along the east side of Ocoa Bay. No attempt was made to verify this report.

Another place at which oil is reported to occur is on Arroyo Salado, about one-half kilometer above its confluence with Arroyo Escondido, a branch of Rio Ocoa, about 16 kilometers northwest of Baní, in the Province of Santo Domingo. Dr. P. V. Logroño Cohen of Santo Domingo and Señor Marciel Soto of Galion state that they have collected samples of oil at this place. The place was visited by Doctor Cooke, who makes the statement that the supposed seep is near a fault contact of purplish-red limestone with shale. (See $\mathrm{Pl}$. XX, $B$; $A$ shows an exposure of similar rocks on Rio Ocoa below San José de Ocoa.) There were dark stains on the rock, 
but no trace of petroliferous material was found. The mud in the stream bed had an odor of hydrogen sulphide. At the time of the visit much rain had recently fallen, and with the rise of the creek the indications may have been obscured. The rocks in this vicinity are all early Tertiary or older and are so greatly sheared, twisted, and faulted that oil could hardly be trapped in them except in small quantities. The discovery of any petroliferous material here, however, would indicate that the "older series" may possibly contain oil elsewhere at places where the beds are not so greatly folded and faulted.

Practically all the rocks that form the hills from Ocoa Bay eastward to Rio Nizao are of Oligocene age or older (Eocene at station 8614, 5.2 kilometers cast of Baní), the principal exception being the Pliocene or more recent conglomerates that lie nearly flat and form terraces that reach altitudes of a few hundred meters. The early Tertiary or Cretaceous strata consist of gray to dark limestone, purplish to reddish slaty shales or shaly limestone, sandstone, and calcareous sandy shale, all of which are greatly distorted and broken by faulting. Rio Ocoa, in its course from San José de Ocoa to Arenoso, follows one of these faults, the uplifted side of which is preserved in El Número, a southward-trending ridge west of Rio Ocoa.

\section{SUMMARY OF ECONOMIC GEOLOGY.}

Oil and gas.-The locality at Higuerito, near Azua, has been the principal center of interest as a possible commercial oil field and is the only place where wells have been drilled for oil. The results have not been very encouraging, but drilling has been resumed in the belief that some of the earlier wells might have been valuable but were lost through the encroachment of salt water, due to mismanagement.

There are large areas in the provinces of Barahona and Azua that are of sufficient interest as possible oil fields to warrant detailed geologic investigation. The investigation should cover all the region from Azua westward to Sierra Martin Garcia and northwestward to the hills around Las Yayas, and structural studies should be made where outcrops are sufficiently numerous. All of Enriquillo Basin is worthy of careful attention. Search for oil secpages should be made east of Duvergé and also from Neiba eastward. The triangular area southeast of the limestone slopes of the Sierra de Neiba, north of Laguna Rincón, and west of Rio Yaque appears to deserve most careful attention.

San Juan Valley is so largely covered with the gravel of the Las Matas formation that the folded beds beneath it can be studied at only a few places. The exposure along Rio Yaque, near the east end of the San Juan Valley, consist almost entirely of coarse sandy materials of no promise as possible containers of oil. An examination should be made of the western part of this valley, near the Haitian border, where there are outcrops of lignite, possibly of Miocene age. 
DOMINICAN REPUBLIC

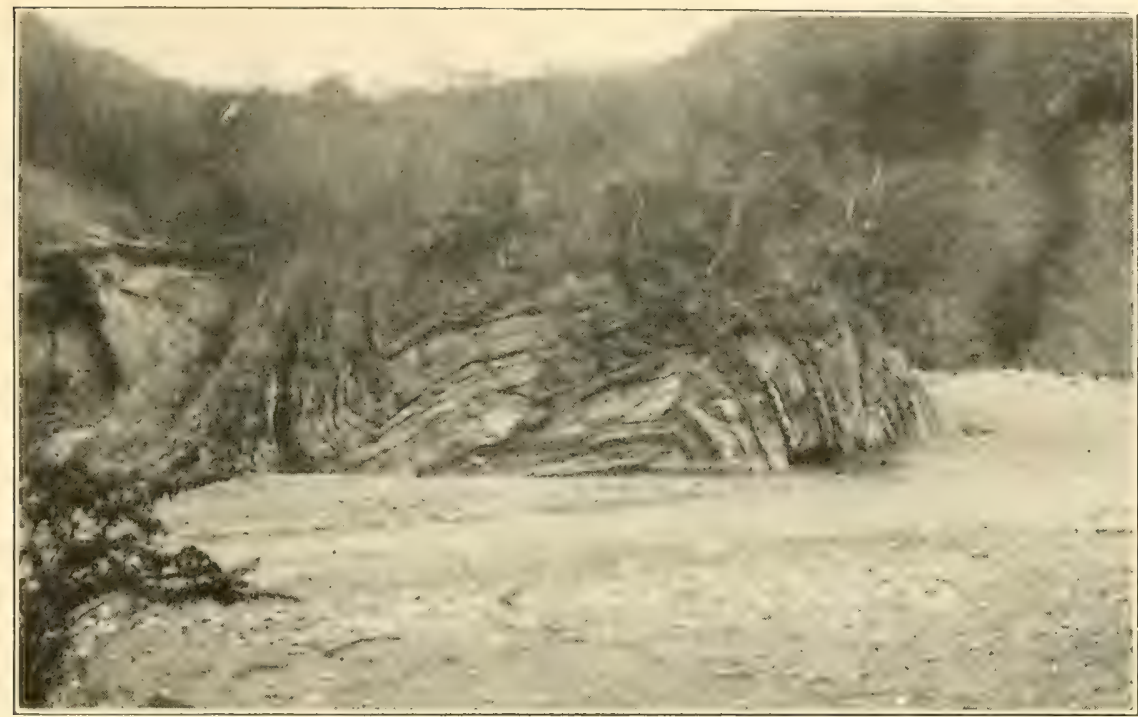

A. PLICATION IN SHALY PURPLISH-RED LIMESTONE OF EARI TY TERTIARY(?) AGE ALONG RIO OCOA A SHORT DISTANCE DOWNSTREAM FROM SAN JOSÉ DE OCOA.

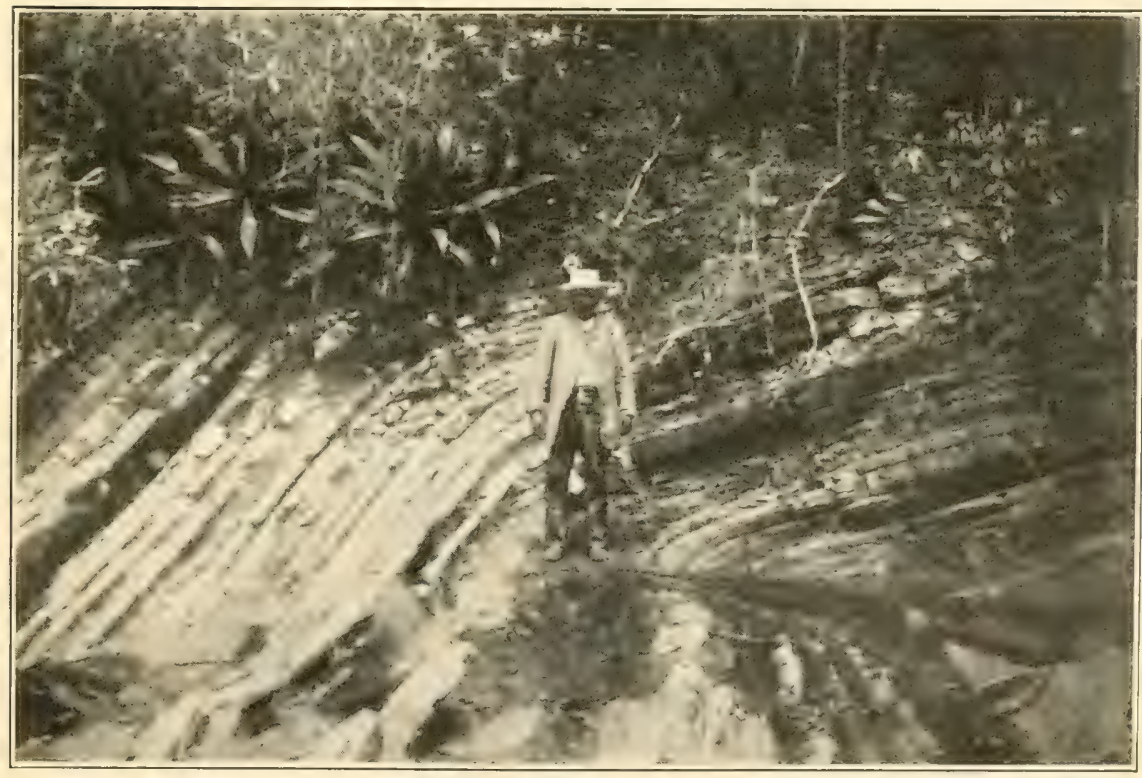

B. TILTED BEDS OF PURPLISH-RED LIMESTONE NEAR SUPPOSED OIL SEEP ON ARROYO SALADO, A TRIBUTARY OF RIO OCOA. 

Salines.-Chemical analyses of the water of Lake Enriquillo and of two salt springs showed that the waters are of no economic value. The Cerros de Sal was examined in the hope that the beds of rock salt might contain potash. The results were disappointing, as no analysis showed potash in commercial quantity. (See analyses on p.217.) The salt beds consist almost entirely of sodium chloride, with small admixture of clayey material or other salts. The deposits will probably continue to be the chief source of salt for the inhabitants of the interior, although the salt is far from pure, generally containing at least 10 per cent of impurities. If it is mined for export it must be refined, and it could probably not compete in the export market with the salt derived by evaporation in the many "salt pans" along the coast of this country and other islands of the West Indies.

Gypsum.-The Cerros de Sal contains enormous quantites of gypsum, which varies from a coarsely crystalline substance to fine-textured snowy white alabaster and can be obtained in layers of almost any thickness desired. It may be used chiefly for making plaster of Paris and possibly for statuary, so that the beds have little prospective value.

Metalliferous deposits.-Little is known concerning the metalliferous deposits in this part of the Republic, though gold, silver, nickel, copper, pyrites, and iron are mentioned in the several mining concessions now in force in the Province of Azua. Almost all the rivers that flow from areas of crystalline rocks in the Cordillera Central contain gold-bearing gravels, and some of these were mined by the Spanish in early Colonial days. Small quantities of placer gold have been obtained in the beds of several rivers from time to time.

Copper stains are plentiful in the area of volcanic rock in the Bahoruco Range south of Barahona, and they have attracted the attention of prospectors, who have done a little work near Paradis and at the mouth of Rio Bahoruco. The results do not encourage the hope of finding deposits of any value in this area. Copper sulphides and their oxidation products were noticed along the trail from Constanza to Túbano at a point about 10 kilometers northeast of Túbano.

Iron deposits in the form of limonite are reported to occur near Paradís and in the Bahoruco Range south of Duvergé, where float siderite was also noted. Reports concerning the deposit at Paradis indicate that it is probably surficial and of slight extent. It is probably derived from the decomposition of basic volcanic rock. 


\title{
CHAPTER X. ECONOMIC GEOLOGY.
}

\author{
By D. Dale Condit and Clyde P. Ross.
}

MINING CONCESSIONS IN FORCE IN JULY, 1919.

The notes of all the members of the expedition, as well as published accounts of some of the deposits, have been used in the preparation of this chapter, but the limitations of time made it impossible to study or even to visit many of the localities where mineral deposits have been reported to occur.

As will be seen by a glance at the accompanying index map (PlateXXI), the greater part of the Republic is covered by concessions granted by the government for mining minerals of diverse sorts. A list of the concessions in force in July, 1919, is given below.

Mining concessions in force in the Dominican Republic in July, 1919.

[See numbers on index map, Pl. XXI.]

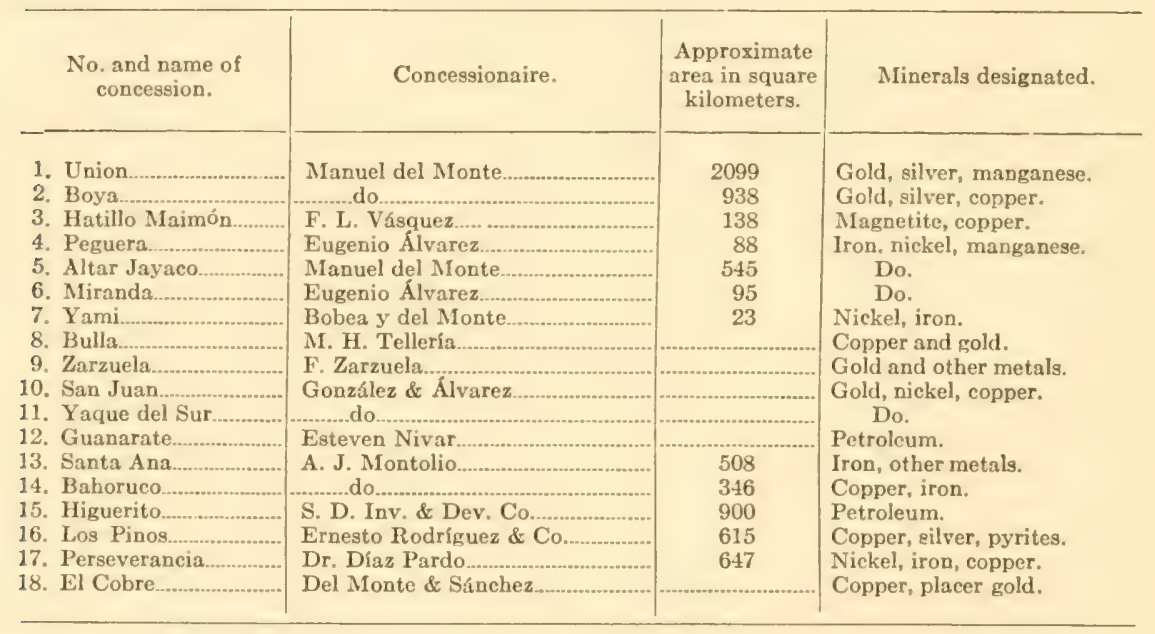

\section{MINERAL DEPOSITS NEAR HATILLO AND MAIMÓN, PROVINCE OF LA VEGA.}

By Clyde P. Ross.

Deposits of ores of copper and iron south of Cotuí, on and near Rio Yuna, have been known for many years. Much prospecting has been carried on intermittently, but the results have been discouraging. The deposits lie along the northern border of the Cordillera Central at some distance from 




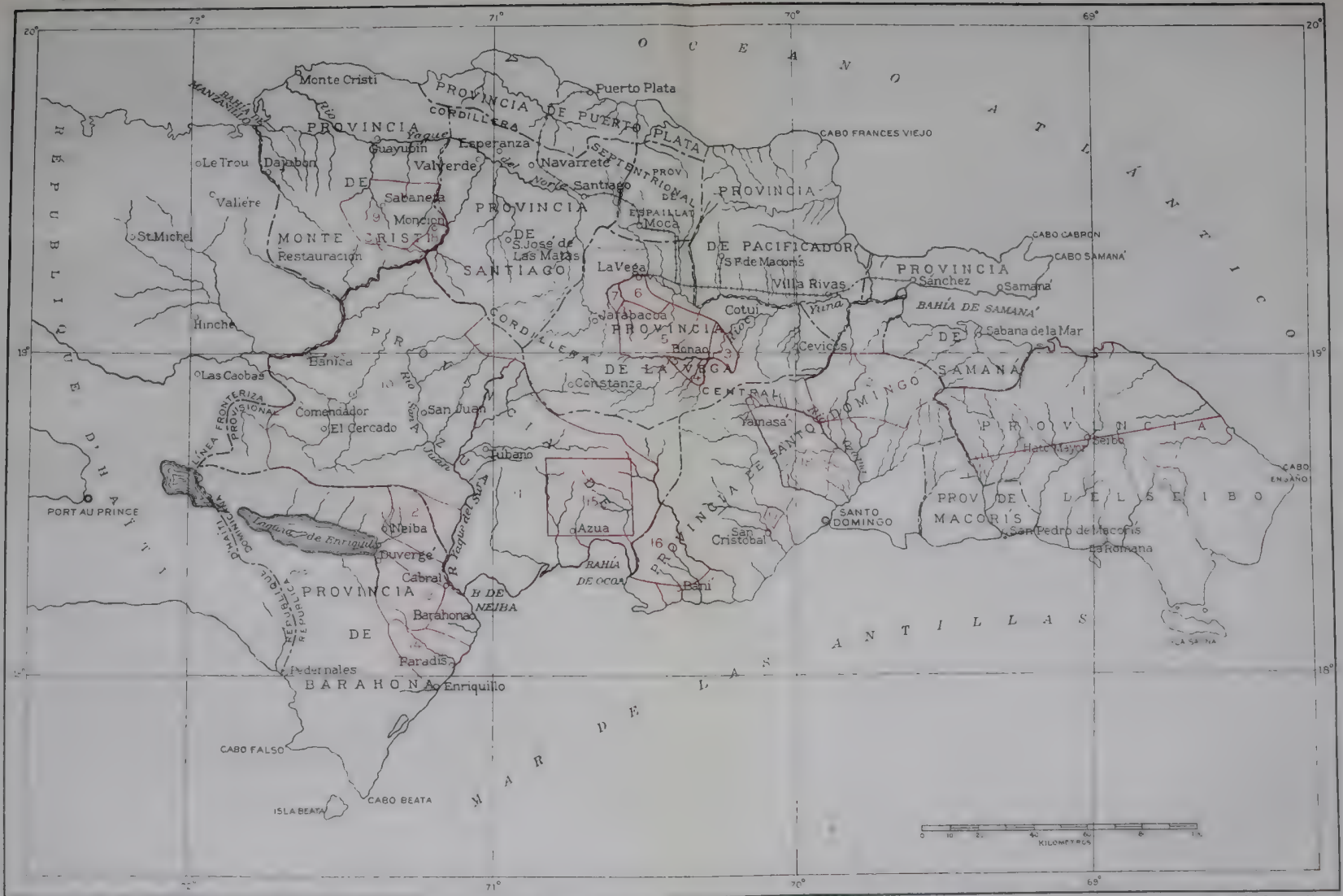

MAPA DE LA REPĹBLICA DOMINICANA QUE INDICA LAS CONCESIONES MINERAS VIGENTES,JILIO DE 1919 

the sea and from large towns, so that transportation involves difficult problems, but good wagon roads or even railroads could easily be constructed.

This report is based on observations made by Wythe Cooke and the writer in April, 1919, during a rapid reconnaissance of some of the more accessible deposits. The limitations of time prohibited a thorough examination or prospecting for other deposits.

\section{MAGNETITE DEPOSITS NEAR HATILLO.}

Prospectors have dug shallow pits in the red clayey soil of the limestone hill a little north of west of Hatillo, at the border of the savanna on which the settlement is built. The soil in these pits, most of which are near the summit of the hill, contain subangular blocks of massive magnetite, 20 to 25 centimeters wide. In the bottom of one pit is a mass of magnetite that is firmly embedded but probably is not in place. The limestone, which outcrops at many places on the hill, contains a little rusted pyrite, but no magnetite was observed at the outcrops. Similar deposits of magnetite are reported at other localities near Hatillo.

Veinlets of quartz and calcite that run parallel to the apparent bedding were observed in the limestone of a similar hill south of Hatillo, where the exposures are better. As some of the limestone is partially marmorized, it probably has been subjected to mild contact metamorphism. As stated on page 60 , this limestone is believed to be of Eocene age, but this belief is based principally on the lithology.

About 3 kilometers northwest of Hatillo, on the opposite side of Rio Yuna, H. G. Ferguson, of the United States Geological Survey, found a similar deposit of magnetite associated with limestone. He noted slate interbedded with and above the limestone and siliceous, schistose porphyry on the trail north of the magnetite deposits. Fine-grained porphyries of various types were seen during the present investigation some distance north of Hatillo but none were observed near the magnetite deposit that was examined.

The origin of the magnetite in this locality is uncertain. The boulders of magnetite are probably small masses that were originally in the limestone or at the contact of the limestone and porphyry and are now enclosed in the residual soil produced by the decomposition of the limestone. This view is strengthened by Ferguson's discovery of igneous rock near one of the known occurrences of magnetite and by our discovery of recrystallized limestone south of Hatillo. Megascopically the magnetite appears to be sufficiently pure to be a high-grade ore. Analysis of a sample collected by Ferguson gave the following results: Fe, 66.35 per cent; $\mathrm{P}, 0.75$ per cent; $\mathrm{SiO}_{2}, 2.44$ per cent. 
Brinsmade, ${ }^{1}$ in his report on this district, mentions four localities at which he found similar magnetite deposits besides the one here described. He gives six analyses, which show that the magnetite is of high quality and that the ore is a mixture of hematite and magnetite, with a larger percentage of the hematite than is evident from field examination. He thinks that the material in which the magnetite is cmbedded is decomposed porphyry.

The magnetite deposits of this district have no present commercial value, for the amount exposed in the pits is entirely too small to warrant exploitation. A magnetic survey of all areas in this district where limestone outcrops or is supposed to occur is desirable to ascertain whether there are larger lenses of magentite.

\section{COPPER DEPOSITS NEAR HATILLO.}

Copper prospecting has been carried on intermittently for many years in the vicinity of Hatillo. The known indications of copper are on Loma de la Mina, about 4 kilometers southeast of Hatillo. Many small prospect pits have been sunk on this mountain and at one place, near the summit, there are large workings consisting of shallow trenches and pits. The main dump, which is on the side of the mountain, is about 75 meters in diameter and has a maximum depth of about 25 meters. A little ore was evidently smelted by some of the prospectors. Several hundred meters south of the main workings there are some small pits, and on the surface of the ground nearby there are pieces of slag, some of which contain blebs of metallic copper.

In the pits where the ore was smelted there is a small quantity of bog iron ore mixed with lignitic material consisting of partly carbonized seeds and other vegetable matter. The bog iron ore has formed since the pits were dug. These deposits are of no commercial value, but they are of interest as showing the rapidity with which bog iron ore can be formed.

Loma de la Mina is composed principally of chloritic schist. Near its base gneissic igneous rock, probably dioritic, was observed in places. The mountain is covered with a rather thick mantle of soil and outcrops are not abundant.

The principal workings are on a shear zone in chloritic schist, which has been much crushed and sericitized. The schist is locally stained with iron and bears seattered copper stains. It contains a few small quartz stringers, but most of them are only a centimeter or two wide. Some of the stringers contain a little azurite, but most of them are barren. A few fragments of hard gossan were seen. A small amount of a mineral that is believed to be alunite and a little chalcanthite were found in the schist.

These deposits are so inaccessible and the quantity of copper they contain in so small that they are of no present commercial value.

I Brinsmade, Robert B., Iron in Santo Domingo: Mining and Scientific Press, vol. 117, pp. 356-358, Sept. 4, 1918. 


\section{THE MAIMÓN IRON DEPOSITS.}

Señor León Sánchez, of Maimón, guided us to his iron prospects on Loma Pegado, a hill about 4 kilometers southwest of Maimón. This hill is composed of serpentine, which is an alteration product of some basic igneous rock. All the hills near Maimón are apparently composed of similar rock, but none except Loma Pegado was examined. Near the top of Loma Pegado a black trap rock, hornblende diabase, which is probably part of a dike intruded into the serpentine, is exposed in a prospect pit.

There are numerous prospect trenches and pits on the flank of Loma Pegado. They expose serpentine cut by plates and banded, botryoidal, and drusy veinlets of quartz. The serpentine has weathered for a depth of more than a meter below the surface, and the upper 30 to 50 centimeters is changed to a red, very highly ferruginous residual soil.

The conditions here are similar to those in the Mayari district of Cuba, with the important difference that the deposits in the vicinity of Loma Pegado are on steep hillsides, so that the amount of residual soil of possible value as iron ore is very small, but commercial quantities of ore may be found in the vicinity of Maimón in a morefavorable topographic position.

Apparently the prospecting on Loma Pegado was originally undertaken in the hope of finding deposits of nickel. H. G. Ferguson made a hasty examination at this locality and reports that small amounts of garnierite, a silicate of nickel, occur in places in the serpentine but not in commercial quantities.

\section{la PERSEVERANCIA NICKEL DEPOSIT, PROVINCE OF SANTO DOMINGo.} By D. Dale Condit.

Sierra Prieta, a part of the property known as "La Perseverancia" concession, was visited on June 10 and July 6, 1918, by H. G. Ferguson, of the United States Geological Survey, and on June 16, 1919, by the writer, while he was in the service of the Dominican Government.

\section{HISTORY OF CONCESSIONS.}

The "Perseverancia" concession was granted to Señor Manuel Delmonte on January 13, 1915. The "denouncement" which went with this concession mentioned iron, chrome, manganese, cobalt, nickel, copper, and gold in both quartz and placers. The localities included El Cerro Pelada, El Mongote, Mirador, Leonora, Guamuna, Isabela, Matiguelo, Sierra Prieta, Higuero and Maimón, parts of Communes Villa Mella, Yamasá, and La Victoria, Santo Domingo Province. The ownership of the concession was transferred from Señor Delmonte to Doctor Rogelio Díaz Pardo of Havana, Cuba, in February, 1918. All the exploratory work since the advent of Dr. Pardo has been done at a locality known as Sierra Prieta. The accompanying map of Sierra Prieta (Pl. XXII) is a reduction, after redrafting, of the map filed in the office of the Secretario de Fomento y Comunicaciones. 


\section{GEOGRAPHY.}

Sierra Prieta is an isolated outlier of the main mountain range about 30 kilometers north of the city of Santo Domingo and about 12 kilometers northeast of Los Alcarrizos, the nearest point on the automobile road (Carretera Duarte) now being constructed from the capital city northwestward across the island. A direct trail, passable by light automobiles in dry weather, leads from Santo Domingo City northward through Villa Mella. It is an easy, natural route, which with little work could be made into a good wagon road, following as it does the nearly level upland surface of the "coast limestone," with only the valleys of Rio Isabela and Rio Yuca offering serious obstacles. Mr. Leslie, agent for the company, reports that a railroad route to the mine, extending in part up Rio Ozama, has already been surveyed. The altitude of the plain near the foothills of the mountain range is 70 to 80 meters. Sierra Prieta, the hill containing the nickel deposits, rises abruptly from this plain to an altitude of 241 meters and about 170 meters above the plain to the south. The rugged upland country of which this hill is an outlier extends northward to the Vega Real.

\section{GEOLOGY.}

The coast at Santo Domingo consists of a coral reef that has been elevated about 15 meters above sea level. Landward of this reef is a nearly level surface, which rises toward the north as a plain that extends to the mountains. This plain is made up of strata that slope gently seaward. The beds farthest from the coast are the oldest and are overlapped by successively younger rocks seaward. Coralliferous limestone, probably not all of the same age as that at the sea front, extends a few kilometers north of Santo Domingo, but beyond this limit the sections in the arroyos show chiefly gravel, sand, and fossiliferous nodules of limestone. Nearer the mountains the plain has a thin covering of limonitic conglomerate, which toward the foothills thickens and becomes increasingly ferruginous and might be of possible value as iron ore. The mountains in this vicinity consist of serpentine, which forms part of a large belt that extends northwestward across to the vicinity of La Vega. The stream pebbles are of slate and limestone and of many varieties of intrusive rock. The hill containing the nickel deposit is entirely serpentine, as is also the neighboring hill to the north, and no other rocks were found in place except a small basic dike that cuts the serpentine.

Gold has been washed by the natives from the stream gravels of the region and it is said that small quantities of platinum have been found in the placers, but probably not in quantities sufficient to encourage hopes of profitable working. A sample of black sand washed from a small brook near the camp at the east base of the hill was found on examination to contain chromite in addition to considerable magnetite. 
DOMINICAN REPUBLIC

Geological Survey

Memorrs, VoL, I, PL. XXII

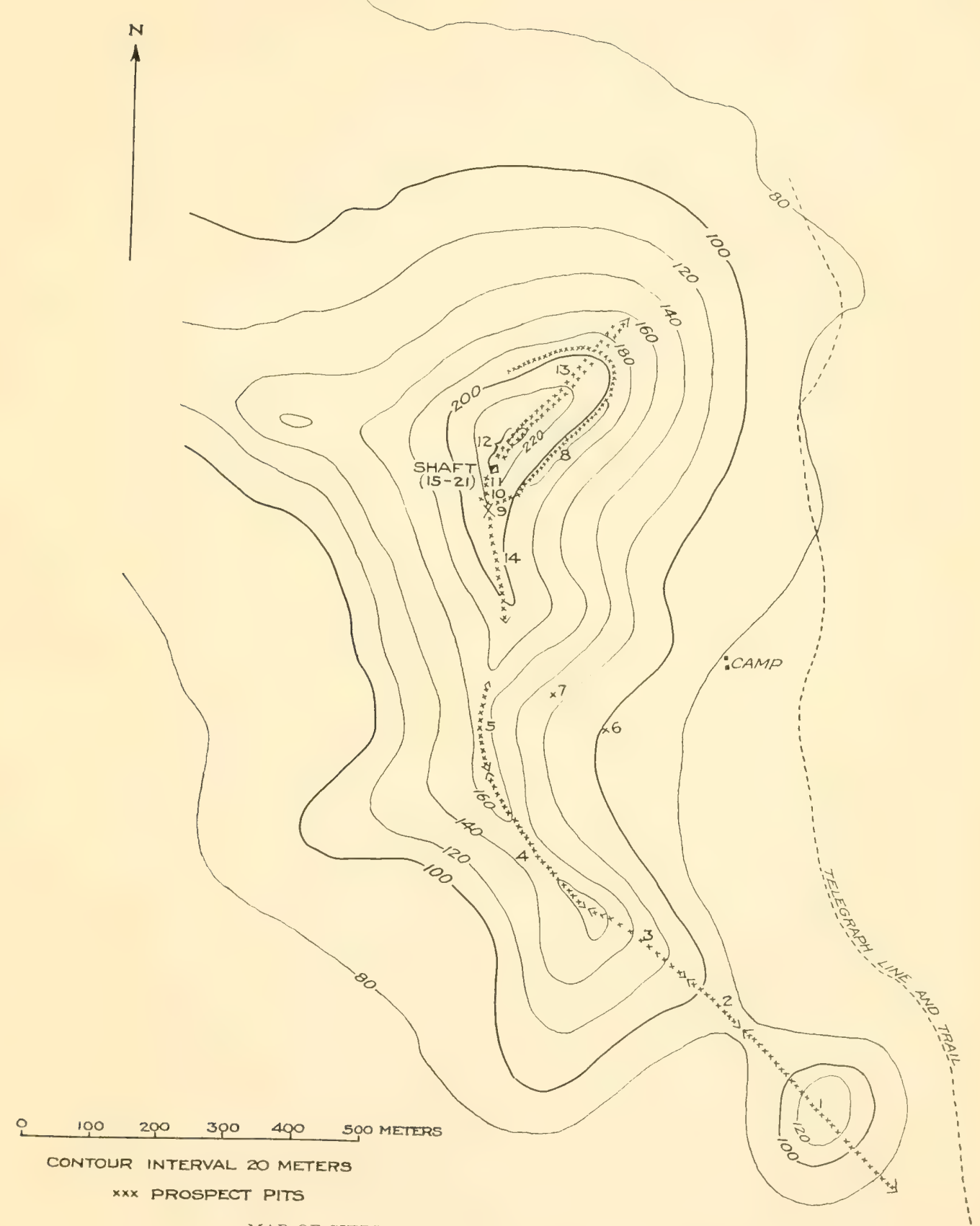

MAP OF SIERRA PRIETA AT PERSEVERANCIA MINE. 



\section{MINING OPERATIONS.}

Nickel ore is said to have been discovered at Sierra Prieta by Señor Manuel Delmonte, who obtained a concession and held it through several revolutions. The disturbed state of the country prior to American occupation prevented development. Señor Delmonte sold the concession to the syndicate of which Dr. Rogelio Diaz Pardo of Havana is the principal owner, and a small amount of shafting and trenching has been done for the syndicate under the supervision of a mining engineer named Pagliuchi. The work done includes a shelf excavation wide enough for a cart road extending around the east and north sides of the hill at about the 195 meter contour. A shaft having a depth of about 25 meters and about 15 meters of cross cuts have been dug near the highest part of the hill. The underground work has been discontinued and a tunnel is being started on the southeast side, opposite the shaft and about 50 meters below its mouth. Samples of "picked ore" sent to Havana from time to time are said to have yielded very favorable assays. The mine foreman who selected these samples assisted in the sampling in the shaft and also selected samples of "picked ore," the assays of which are given on pages 234-235.

The exploratory work done prior to 1918 consisted of digging trenches and pits at irregular intervals over the most promising part of the deposit. On the assumption that the entire hill consisted of ore, a civil engineer named Henderson was engaged to make a survey and estimate the quantity of minable ore. His report showed that $95,000,000$ tons lay above the level of the plain. The same engineer was then engaged to survey a railroad route from the mine to the harbor of Santo Domingo.

\section{MODE OF OCCURREICE OF NICKEL.}

The nickel in the outcrop occurs as the mineral garnierite (genthite), a hydrated silicate of nickel and magnesium of pale apple-green color, which is associated with a fine network of quartz veins. The mineral is probably a product of weathering, the nickel being in the form of another silicate a few meters below the surface. The mineralization appears at widely separated points over the upper part of the hill, and the weathered outcrops appear as spongy, honeycombed rock of rusty brown to greenish color, showing the garnierite stain when freshly broken. Below the surface the garnierite green becomes less and less noticeable, and at a depth of about 15 meters the vein material is almost entirely white and consists of a soft, amorphous mineral, possibly magnesite, with dark stains and a few quartz veins. The analyses of samples from a depth of over 15 meters below the surface indicate that the nickel is disseminated through the vein material and country rock, forming an "ore" of lower grade than that nearer the surface, where enrichment has more or less localized the mineral. 


\section{RESULTS OF SAMPLING.}

Samples were taken from all accessible parts of the hill (see Nos. 1-14 inclusive, on Pl. XXII), and particularly from the parts that showed best evidence of valuable mineralization, so that the mean of the samples probably shows a considerably higher tenor than the average. The following notes describe the samples taken:

\section{Prospect pits sampled by Ferguson.}

Sample 1. Grab sample from outcrops extending N. $45^{\circ} \mathrm{W}$. across small outlying hill for a distance of 360 meters. Practically unaltered serpentine at the base; cut at the summit by small quartz veinlets containing traces of garnierite. Assay result: Nickel, 0.65 per cent.

Sample 2. Grab sample from outcrops extending N. $45^{\circ} \mathrm{W}$. up main hill to 101-meter contour for a distance 120 meters. In serpentine, slightly veined. Assay result: Nickel, 0.29 per cent.

Sample 3. Grab sample from outcrops extending 190 meters to crest of ridge. Serpentine with rare quartz veinlets. Assay result: Nickel, 0.29 per cent.

Sample 4. Grab sample from outcrops extending 270 meters along crest of ridge. Same type of materials as No. 3. Assay result: Nickel, 0.41 per cent.

Sample 5. Continuation of No. 4 for a distance of 140 meters. Type of material similar. Assay result: Nickel, 0.43 per cent.

Sample 6. Open cut at base of hill near camp. Sample along sides of cut for 6 meters $\mathrm{N} .85^{\circ} \mathrm{W}$. No visible garnjerite, but slight quartz veining and weathered serpentine. Assay result: Nickel, 0.36 per cent.

Sample 7. Small open eut on trail at 124-meter contour, 6 meter face. Weathered serpentine. Assay result: Nickel, 1.13 per cent.

Sample 8. Shallow cut along 198-meter contour for distance of 195 meters. Weathered serpentine with rare quartz and garnierite. Assay result: Nickel, 1.05 per cent.

Sample 9. Open cut 50 meters long from south end of No. 8 to crest of ridge. Serpentime with many small quartz stringers and a little garnierite. Assay result: Nickel, 0.55 per cent.

Sample 10. Small open cut just below crest of ridge on east side, 18 meters long. Serpentine with quartz and garnierite. Assay result: Nickel, 1.75 per cent.

Sample 11. Open cut across top of ridge, 25 meters long. Serpentine honeycombed with small quartz veins in places, with good showing of garnierite. Assay result: Nickel, 2.09 per cent.

Sample 12. Small pits along crest of hill, in two lines, 5 meters apart and 1 meter deep, many not reaching bedrock. Samples taken from material on dumps, consisting of weathering serpentine and quartz, for a distance of 80 meters. Assay result: Nickel, 3.01 per cent.

Sample 13. Northward continuation of same line of pits, most of them, however, not reaching bedrock. Distance, 240 meters. Similar material. Assay result: Nickel, 1.24 per cent.

Sample 14. Line of similar pits southward from No. 11, most of them reaching bedrock. Distance, 220 meters. Similar material. Assay result: Nickel, 1.29 per cent.

\section{Samples from shaft on summit of hill taken by Condit.}

Samples 15 to 22 . The samples taken below the surface include Nos. 15 to 19 , selected from the ore dump, and Nos. 20 to 22, taken from the deeper part of the shaft. The material from the decpest part of the shaft consists of dark-green serpentine, veined by white, soft, amorphous material, which is regarded by the mine foreman as the 
richest ore. No trace of the garnierite green color appears in any of this material. With this soft, white vein material are chalcedonic quartz and thin films of a darker mineral. The principal veins are 2 to 4 inches thick and lie nearly vertical as seen in the mine and trend N. $20^{\circ} \mathrm{W}$. to N. $60^{\circ} \mathrm{W}$. Many fine lateral veinlets extend from the principal veins into the adjacent serpentine.

A section from north to south along the wall of the deepest workings at right angles to the principal veins is as follows:

Serpentine, $60 \mathrm{~cm}$; white vein, $8 \mathrm{~cm}$. thick; serpentine, $120 \mathrm{~cm}$., with intricate network of fine white veinlets and one vertical white vein $2.5 \mathrm{~cm}$. thick; mass of large and small white veins intimately mixed with serpentine $60 \mathrm{~cm}$; dark serpentine with black. film of mineral material on joint surface; few veinlets.

Sample 15. Taken from dump selected to represent white material from decpest workings; regarded by mine foreman as very rich. Assay result: Nickel, 0.14 per cent.

Sample 16. Similar to sample 15, but contains some dark rock, probably also mineralized. Assay result: Nickel, 0.14 per cent.

Sample 17. Selected to represent dark material, apparently mostly serpentine from deepest workings. Assay result: Nickel, 0.17 per cent.

Sample 18. Pale green and white vein rock selected from dump to represent part of shaft that lies 15 to 20 meters below the surface. Assay result: Nickel, 1.27 per cent.

Sample 19. Dark material from dump; same position in shaft as sample 18. Assay result: Nickel, 0.37 per cent.

Sample 20. Complete section across 2.5 meter face of deepest workings, including serpentine and vein material. Assay result: Nickel, 0.15 per cent.

Sample 21. Selected sample, including only light-gray part of face in deepest workings, intricately cut by veinlets. Assay result: Nickel, trace.

Sample 22. Selected sample of dark rock, mostly serpentine, excluding vein material. Assay result: Nickel, 0.19 per cent.

\section{CONCLUSIONS.}

The richest of the open pit samples taken by Ferguson come from the highest part of the hill. They are Nos. 10 to 14, which contain from 1.29 to 3.01 per cent of nickel. The shaft was sunk near the summit of the hill at a point that was apparently the most promising. Of eight samples selected to represent the material at a depth of 15 to 25 meters in this shaft one contained 1.27 per cent, and all others less than 0.4 per cent. some of these samples represent rock that was classed as very rich by the mine foreman, the same man who selected the samples of "picked ore" that gave "very good returns" as assayed in Havana.

Evidently enrichment through weathering has played an important part at Sierra Prieta. The higher results of assay of the samples from the outcrop appear to be a result of concentration through leaching and redeposition of the disseminated nickel.

In New Caledonia, where there are nickel deposits of a type somewhat similar to the one at Sierra Prieta, the ore mined generally contains 4.5 to 7 per cent of nickel and can therefore be smelted directly by fusion with limestone and gypsum. This treatment is not, however, applicable to a low grade ore, such as that at Sierra Prieta. The only practicable process would involve leaching with sulphuric acid. An ore deposit of this type 
in the United States, even if situated at a locality convenient to a supply of acid, could not be profitably worked unless it contained at least 1 per cent of nickel and included at least a million tons. In a region such as the Dominican Republic, with its transportation difficulties, the ore must be much richer in order to be profitably extracted. The evidence at hand gives but little encouragement to the hope that the nickel deposit at Sierra Prieta can be profitably mined while nickel is at its present price.

Further exploration of neighboring areas of the serpentine rock may possibly disclose a richer deposit. Nickel in disseminated form is a usual constituent of serpentine, and the deposit at Sierra Prieta is therefore not unique. The disappointing results of prospecting there need not discourage search in other parts of the Republic that are covered by extensive tracts of serpentine.

\section{SAN CRISTOBAL MINING DISTRICT, PROVINCE OF SANTO DOMINGO.}

By Clyde P. Ross.

LOCATION AND ACCESS.

The copper deposits in the old San Francisco concession, north of San Cristóbal, were examined by the writer during four days early in June, 1919. The accompanying map (Pl. XXIII), which is a reduction of a map made by the engineer of the Blanton Syndicate, shows the area occupied by the deposits. The office of the operators was at Naranja Dulce, on the west sicle of Rio Nigua, about 13 kilometers north of the town of San Cristobal. The principal workings on San Francisco Hill are directly across the river from Naranja Dulce. Carts are said to have traveled the trail from San Crist óbal to the mines to carry ore when the mines were shipping-a journey that would be possible only in the dry season, and much work would now be necessary to put the trail in shape for the use of carts even then. In the rainy season the trail is at times impassable. It would be difficult but by no means impossible to build a wagon road from some point on the Santo Domingo-San Cristóbal Carretera to Naranja Dulce and Búcaro Hill.

In addition to the openings on Búcaro and San Francisco hills a number of others are scattered over the district, but the only important ones are those recently made by Dr. Jacob Harootian near the crest of the divide between Rio Nigua and Rio Jaina, not far from the source of Arroyo Platanito, at a locality called La Rama, which has been approximately plotted on the map (Pl. XXIII). It can be reached by a rather steep inountain trail from Naranja Dulce. A trail or even a wagon road could probably be constructed from this prospect to Jaina or to some point on the carretera between Jaina and San Cristóbal, and thus shorten considerably the distance to Santo Domingo City. 

HISTORY.

Copper has been known in this district for a long time. Probably the first work on copper ore was done by Colonel Heneken, who prospected at a number of places from 1847 to 1863 but apparently shipped only a few samples. Francis Chini prospected here from 1890 to 1912, but he also appears to have found no large quantity of ore. The San Francisco mining concession, which covers the district, was granted, on April 10, 1900, to Mr. Díaz, who transferred it to Mr. E. A. Blanton, representing the Santo Domingo Exploration Co., on August 23, 1902. Captain Adams is reported to have built the houses at Naranja Dulce and to have done some prospecting, principally in the old Heneken and Chini workings, in 1900 to 1902. The Santo Domingo Exploration Co. lost the concession by forced sale, and it was bought by Mr. A. R. Justice, an associate of Mr. Blanton, on March 30, 1909. Mr. Justice transferred the concession to the San Cristóbal Mining Co., notifying the Government of the transfer on August 6, 1909. On November 17, 1910, the concession came within the terms of the mining law by virtue of a request of the company. By private agreement the Blanton Copper Mining Syndicate obtained permission from the San Cristóbal Mining Co., on August 7, 1912, to exploit that part of the claim which is known as the Búcaro. The San Cristóbal company operated on Búcaro Hill until September, 1917. The entire concession was cancelled on March 3, 1919, because of failure to do development work, and immediately after that date Dr. Jacob Harootian filed application for three concessions covering approximately the area of the old San Francisco concession, or a large part of it, and also for an exploration right in this district for 6 months. The concessions for which he has applied are (1) Dos Marías, 120 hectares, (2) Camden First, 120 hectares, (3) Camden Second, 200 hectares. He has taken up his residence at Naranja Dulce and has been actively engaged in prospecting for the last 3 months.

The above statements are based on reports on file in the office of the Departamento de Fomento supplemented by information furnished by several persons, principally Doctor Harootian and his brother-in-law Mr. J. P. McCulloch.

\section{DEVELOPMENT.}

Most of the workings were caved and entirely inacessible at the time of the examination, so that it is impossible to give any accurate statement of the development. Several shallow shafts were sunk at different places.

On Búcaro Hill there are a number of tunnels, some of which are reported to have been 100 meters or more long. Five tunnels on this hill were visited during the examination but only two could be entered, and there was no stopping in these.

The following table, compiled from records in the office at Naranja Dulce, shows that 1,061 short tons of ore were shipped in 18 different lots 
by the Blanton Copper Mining Syndicate between October 1, 1915, and July 5, 1917, inclusive. The ore, which is reported to have come principally from Búcaro Hill, was picked ore. About 10 tons were mined for each ton shipped. The average value of the ore shipped was $\$ 57.70$ per ton. The highest assay for copper in the ore shipped was 16.9 per cent; the lowest was 8.6 per cent. The highest silver assay was 2.80 ounces per ton; the lowest was 1.30 ounces per ton. The highest gold assay was 0.10 ounces per ton. None of the shipments contained valuable quantities of silver or gold.

Ore shipped from the San Francisco concession by Blanton Copper Mining Syndicate.

\begin{tabular}{|c|c|c|c|c|}
\hline \multirow{2}{*}{ Approximate date of shipment. } & \multirow{2}{*}{$\begin{array}{l}\text { Approximate } \\
\text { gross tons. }\end{array}$} & \multirow{2}{*}{$\begin{array}{l}\text { Per cent of } \\
\text { copper. }\end{array}$} & \multicolumn{2}{|c|}{ Ounces per ton of 2,000 pounds. } \\
\hline & & & Silver. & Gold. \\
\hline October 1, 1915 & \multirow{18}{*}{$\begin{array}{r}133 \\
128 \\
92 \\
43 \\
47 \\
16 \\
50 \\
39 \\
59 \\
69 \\
57 \\
45 \\
37 \\
22 \\
79 \\
40 \\
65 \\
40\end{array}$} & \multirow{18}{*}{$\begin{array}{l}8.6 \\
9.78 \\
11.03 \\
11.23 \\
13.91 \\
12.36 \\
13.94 \\
14.13 \\
16.9 \\
13.35 \\
13.35 \\
11.93 \\
11.61 \\
10.80 \\
12.69 \\
13.13 \\
11.83 \\
11.92\end{array}$} & \multirow{18}{*}{$\begin{array}{l}1.70 \\
2.20 \\
2.00 \\
1.80 \\
2.30 \\
1.90 \\
1.30 \\
2.50 \\
2.80 \\
2.10 \\
2.10 \\
1.70 \\
2.10 \\
1.30 \\
1.60 \\
1.50 \\
1.40 \\
1.60\end{array}$} & \multirow{18}{*}{ 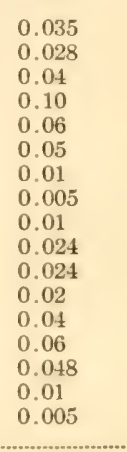 } \\
\hline November 5,1915 & & & & \\
\hline December $9,1915 \ldots$ & & & & \\
\hline January 2,1916 & & & & \\
\hline January $15,1916 \ldots$ & & & & \\
\hline January, 1916 & & & & \\
\hline February 1, 1916 & & & & \\
\hline March 2,1916 & & & & \\
\hline March 9,1916 & & & & \\
\hline March 28, 1916 & & & & \\
\hline April $10,1916 \ldots$ & & & & \\
\hline April $22,1916 \ldots$ & & & & \\
\hline June $10,1916 \ldots$ & & & & \\
\hline July $5,1916 \ldots \ldots \ldots$ & & & & \\
\hline January $6,1917 \ldots$ & & & & \\
\hline March 13,1917 & & & & \\
\hline April 13,1917 & & & & \\
\hline July, $1917 \ldots \ldots$ & & & & \\
\hline
\end{tabular}

Less than 500 tons-according to one report only 50 to 60 tons-was shipped from San Francisco Hill, but no records of the shipments are at hand, and the amounts and values are not known unless some of the above mentioned shipments were made from the San Francisco workings. Two tunnels were entered, and several caved workings on San Francisco Hill were examined. Several hundred meters of tunneling and drifting has been done here, and one small stope in the uppermost tunnel is still accessible. Much of the drifting, both here and on Búcaro IIill, was done along barren slips and appears to have been of no value in developing the property.

Doctor Harootian's La Rama prospect, near the head of Arroyo Platanito, has been just developed by four openings in the hill, the largest about 6 meters long.

GEOLOGY.

The mineralized area consists of volcanic rocks, principally tuffs and breceias. Limestone crops out along the crest of the hills on the southwest side of Rio Nigua. 
The volcanic rocks are a series of altered tuff, breccias, and lavas, cut by a few small porphyritic dikes. The tuffs and breccias appear to predominate, but the rocks are so much metamorphosed that their identification is difficult. They appear to be finely fragmental, and most of them are green to purple. The coloring is in streaks and blotches and usually is extremely variable. Some of the rocks are uniform in color, green or black, and aphanitic or nearly so. The volcanic rocks are everywhere much jointed and fractured and in places are sheeted.

The contact between the limestone that forms the upper part of the ridge on the southwest side of Rio Nigua and the volcanic rocks is probably a normal fault. The fault plane apparently strikes about $\mathrm{N} .55^{\circ} \mathrm{W}$. and dips to the northeast. The limestone is gray to cream-white, granular near the contact, and fine-grained and thin-bedded farther up hill. The beds strike approximately east and dip southward $20^{\circ}-30^{\circ}$.

In the bed of Rio Nigua there are many boulders of a coarse pink granitic rock, but this rock was not found in place. The first outcrop is reported to be about 5 kilometers upstream from Naranja Dulce.

\section{BÚCARO HILL ORE DEPOSITS.}

The volcanic rock in and near the workings on Búcaro Hill is full of small slips. Some of the slips in the tunnels that were examined strike northwestward and have copper stains along them, but no ore. The dumps of several of the caved tunnels, however, show ore, some of it of good grade. The ore is of two types - (1) malachite, with some quartz, hematite, and usually some sulphide, in chloritized volcanic rock; (2) chalcopyrite, pyrite, bornite, and specular hematite in quartz, with limonite as an alteration product of the sulphides. The quartz seen on the dump appears to have been in narrow stringers or veinlets in chloritized tuff. There are fragments of calcite veins 30 centimeters wide, but these are barren. No chalcocite was noted in the ore on any of the dumps in the district, but a specimen of high-grade massive chalcocite, reported to have come from one of the workings on Búcaro Hill, was shown to the writer by a former employee of the Blanton syndicate. At the end of a drift in the Francis Chini tunnel there is an infaulted block of black, hard slate full of small cubes of pyrite. This is the only sedimentary rock found in the volcanic series.

Mr. F. Lynwood Garrison ${ }^{1}$ considers the deposits of Búcaro Hill segregations in tuff rather than veins, but states that in the lower part of the hill, where erosion has exposed fresher rock, the deposits have the appearance of discontinuous veins.

The mineralization appears to occur along slips or shear zones and the deposits are therefore veins rather than segregations. The slips seem to be small, and the mineralization is nowhere great. It is extremely doubtful

\footnotetext{
${ }^{1}$ Garrison, F. L., Mining and Scientific Press., vol. 95, p. 308, 1907.
} 
whether any large, persistent vein exists in so shattered a volcanic rock. Although a considerable amount of copper ore occurs here and although some of it may be of high grade, the existence of enough ore to be profitably worked is doubtful.

\section{ORE DEPOSITS ON SAN FRANCISCO HILL.}

The general geology and the character of the mineralization on San Francisco Hill are very similar to that on Búcaro Hill. The accessible openings and outcrops, however, show ore as much as a meter wide along a few of the numerous slips. Sample No. 86 is a channel sample of a meter vein running $\mathrm{N} .45^{\circ} \mathrm{E}$, and dipping $40^{\circ} \mathrm{S}$, and the result of its assay is given in the table on page 241. It is possible that ore running 10 per cent or more can be readily picked from some of these veins, as is reported to have been done. Probably much richer ore than this can be found occasionally in small quantities. Garrison ${ }^{1}$ states that on the crest of this hill is the beginning of a mineralized shear zone that extends north-northeast for several miles. According to Garrison the zone is more or less regular, but the mineralization along it is uncertain and discontinuous. During the present investigation, no time was available to trace this zone through the dense vegetation of the hill.

Some of the veins on San Francisco Hill may be large enough and rich enough to be worked profitably on a small seale under favorable conditions, but it is virtually certain that the ore bodies are discontinuous and irregular.

\section{LA RAMA PROSPECT.}

The new prospect of Doctor Harootian in the Platanito district differs somewhat from those described above. The most important difference is that the ore contains more gold. Galena occurs in one of the openings here but is not found elsewhere in the district. The specular hematite found at the Búcaro and San Francisco workings was not seen here. The quartz contains a little gold in blebs visible to the eye and some chalcopyrite, pyrite, and galena. Doctor Harootian states that his assays made at Naranja Dulce indicate a value of more than 5 ounces per ton in gold and negligible amounts of silver. Assays, made by Ledoux \& Co. (see table on p. 241), of samples collected during this investigation indicate a lower content of gold. As the gold occurs in part in large blebs that are easily visible to the eye, no two small grab samples are likely to agree closely on assay. The gold in the three samples from the principal opening at La Rama varies directly with the copper. On the other hand, sample No. 85, from the dump of one of the other openings at La Rama, is very high in copper and low in gold. The sample carrying lead carries more silver than any of the others.

\footnotetext{
¿Garrison, F. L., op. cit., p. 308.
} 
Assays of samples from the San Francisco concession.

\begin{tabular}{|c|c|c|c|c|c|}
\hline \multirow{2}{*}{$\begin{array}{l}\text { Sample } \\
\text { No. }\end{array}$} & \multirow{2}{*}{ Character and source of sample. } & \multirow{2}{*}{$\begin{array}{l}\text { Per cent } \\
\text { of lead. }\end{array}$} & \multirow{2}{*}{$\begin{array}{l}\text { Per cent } \\
\text { of copper. }\end{array}$} & \multicolumn{2}{|c|}{ Ounces per ton. } \\
\hline & & & & Silver. & Gold. \\
\hline 82 & $\begin{array}{l}\text { Channel sample across face of principal opening } \\
\text { at } \mathrm{La} \text { Ruma }\end{array}$ & & 0.27 & 0.20 & 0.26 \\
\hline 83 & Picked sample at principal opening at La Rama.. & & 0.47 & 0.01 & 0.41 \\
\hline 84 & $\begin{array}{l}\text { Sample of footwall streak at principal opening } \\
\text { at La Rama }\end{array}$ & & 0.55 & 0.40 & 1.04 \\
\hline 85 & $\begin{array}{l}\text { Sample of dump of one of the La Rama open- } \\
\text { ings ("the copper showing") }\end{array}$ & & 10.62 & 1.80 & 0.04 \\
\hline 86 & $\begin{array}{l}\text { Channel sample of a vein in Francis Chini Tun- } \\
\text { nel No. 1, on San Francisco Hill. }\end{array}$ & & 1.88 & 0.40 & 0.06 \\
\hline 87 & $\begin{array}{l}\text { Picked sample of galena-bearing ore from La } \\
\text { Rama }\end{array}$ & 1.94 & 4.25 & 1.10 & 2.76 \\
\hline
\end{tabular}

The recent heavy rains had caused slides that made it impossible to see very much in any of the four small openings, which penetrated the hill 6 meters. There is a shear zone over a meter wide near the bottom of the opening and wider near the top, where it is cut off by a slip. In the shear zone there is shattered chloritized volcanic rock full of quartz stringers, with some sulphides and a few rusty streaks. The ore deposit is reported to have been about 40 centimeters wide where it was first struck and to have widened steadily as it was followed. The strike varies from about $\mathrm{N} .30^{\circ} \mathrm{E}$. at the entrance of the opening to a few degrees north of west at the face. The dip was steep to the southwest at the entrance; at the face it is nearly vertical on the hanging wall and $25^{\circ} \mathrm{N}$. E. on the foot wall.

The low assay results of the samples taken at the prospect are disappointing but are not conclusive. In a deposit of this type considerable variation in tenor is to be expected. Not enough prospecting has yet been done to enable any one to form definite opinion as to the quantity of ore likely to be found, but the showing so far made warrants further development. The country rock is the same shattered volcanic rock that is found at the Búcaro and San Francisco workings. The vein or shear zone may be discontinuous, but the small opening made shows a more definite and promising zone than any seen in the accessible workings at the other localities.

\section{CONCLUSIONS.}

Copper ore, some of it of excellent grade, occurs at numerous places in the San Francisco Concession. Many of the tunnels are now caved, so that it was impossible to determine the quantity of ore developed, but it is evidently small. In the tunnels now accessible no ore is blocked out, and there are only scanty indications of ore. The property has practically no present value as a copper mine.

The gold prospect called La Rama, in the Platanito district, has not yet reached the stage at which definite conclusions can be reached as to its 
possibilities. The results of the development so far made are sufficiently favorable to warrant further work in order to determine whether the deposit can be profitably worked.

\section{SUMMARY STATEMENT ON ECONOMIC GEOLOGY.}

In spite of the numerous concessions granted and the even more numerous rumors of "minas" which are common in almost every part of the Republic, very little actual mining is in progress. The country people call every occurrence of unusual or peculiar rock a "mina," often without themselves supposing that the "mina" has any actual or potential value. The multiplicity of rumors of mineral wealth is in part due to this practice. Many actual deposits of valuable mineral do exist. Intelligently directed exploration backed by sufficient capital may discover valuable deposits or profitably develop those already known. The mining industry of the Dominican Republic has suffered rom the operations of many irresponsible promoters. The large scale salting of gold placers, among other things, has done much to weaken the confidence of investors and has caused them to hesitate to put any money into mining enterprises. With the passing of new laws and the enforcing of old ones, the confidence of the investing public should soon be restored.

GOLD.

Large quantities of gold are supposed to have been obtained by the Spaniards from the streams of the Dominiean Republic. Ancient pits are reported to be still visible in the mountains near La Vega, near Cotur, along Rio Jaina, and elsewhere. Gold is reported to exist in the gravels of many streams in the Cordillera Central, and the native women wash out small amounts by hand from the gravel and sand in some places. Several attempts have been made to form companies to finance the working of the placer deposits by modern methods, but none have been successful, and none of these companies are now operating.

Veins carrying gold are reported to exist at several places in the Cordillera Central. None of these is now being developed except one in the Platanito district near San Cristobal, at a prospect on which development has just begun. The copper deposits in the San Cristobal district, which have long been known and intermittently worked, contain gold, but not in large amount, and there is no record of successful vein mining anywhere for gold.

SILVER.

No silver mines are now in operation in Santo Domingo nor is there any available record that any have ever been successfully worked. The veins in the San Cristobal district and the placer gold doubtless contain some silver.

\section{PLATINUM.}

Platinum is reported to have been found in the gravel of Rio Mao, on the northern slope of the Cordillera Central, southwest of Santiago. 
NICKEI.

The property known as La Perseverancia, on Sierra Prieta about 30 kilometers north of Santo Domingo City, is being prospected for nickel. This mine has been visited by H. G. Ferguson and D. D. Condit, both of the United States Geologieal Survey, whose report on it is given on pages $231-236$.

COPper.

The copper deposits of the San Cristobal district have been worked intermittently for a long time, and some ore has been shipped. An examination of these deposits and of the gold prospect in the same district was made during the present examination of the Republic and a report on them is given on pages 236-242. Copper ore is reported to occur in many other parts of the Republic, but none of it has yet been mined except in the San Cristobal district. 'The prospect on Loma de la Mina near Hatillo, south of Cotui, and the indications of copper noted on Loma Miranda, near Bánica, and near Bani are mentioned in the descriptions of those parts of the Republic.

IRON.

No iron mines are in operation in the Dominican Republic, although prospecting for iron ore has been undertaken at several places. The lateritic deposits near Maimón and the magnetite near Hatillo, both in the Cordillera Central south of Cotui, are described on pages 228-231. The known deposits in these localities are small and are of no commercial value. Deposits of limonite are reported near Paradis and in Sierra de Bahoruco, in the southwestern part of the Republic.

\section{MANGANESE AND LEAD.}

Deposits of manganese ore are mentioned in several consular reports as occurring in different parts of the Republic, but none of them are now being mined. There is a deposit in the Province of Seibo, but it was not visited. Specimens of the ore have been examined by D. F. Hewett, of the United States Geological Survey, who states that they show nodules of manganese oxides replacing red tuff and therefore resemble the ores from several districts in eastern Cuba.

Galena in very small quantities is present in some of the ore in the San Cristóbal district.

ork.

Oil has been found near Azua, in the southwestern part of the Republic, but the quantity so far obtained is small. This area is described in this report by D. D. Condit and C. P. Ross (pp. 223-225), who also consider the possibility of finding oil elsewhere in Santo Domingo. There are rumors of indications of oil in many parts of the Republic, but no such indications were found except near Azua. The oil there has an asphalt base, contains no gasoline, and is unsuitable for refining into the lighter grades of petroleum. 
COAL.

Lignite occurs at many places in the Republic. All outcrops seen during the present investigation were small lenses and irregular masses in the Tertiary sedimentary rocks. The age of the rock, where it was possible to determine it, was Miocene, but the lack of suitable fossils made the determination of the age of some of the beds impossible. None of the outcrops seen contained nearly enough lignite to be of any commercial value. Most of the lenses are only a few inches thick and in many the lignite is mixed with clay. Specimens of clean lignite ranging from material which has the appearance of charcoal to hard, dense, black pieces with conchoidal fracture and vitreous luster can be found, but all these specimens are very small. No deposit of coal is known in the Republic, although some of the lignite has been in places so much altered that specimens having the appearance of coal can be obtained from it. The mode of formation of this coal from the lignite is not definitely known.

The lignite or coal does not appear to be mined or used as fuel anywhere in the Republic. The lignitic streaks near Sánchez, Samaná Peninsula, are of no commercial value.

AMBER.

Pieces of amber have been found in stream gravels on the northwestern border of the Cordillera Central, and there are rumors that some of it was found in place. Very little has been done to work either the gravel or bedrock deposits for amber. In the vicinity of Tamboril, in the Cordillera Septentrional, there are beds of sandy shale containing seams of lignite and lumps of amber. The amber is of good quality, and the natives have for many years shipped small quantities of it from this district, but most of that shipped is obtained from the stream gravels. Exploratory work for amber has been done by an American company, ${ }^{1}$ which is reported to have found natural gas in some of the holes.

\section{COMMON SALT.}

Common salt (sodium chloride) is obtained in the Dominican Republic both by evaporation from sea water and by mining rock salt deposits. Neither industry is large. The deposits of rock salt in Cerros de Sal northwest of Barahona are described on pages 214-219. There is sufficient local demand for the salt from these deposits to satisfy the present owners. Larger and more efficient production could be made by installing modern methods, but it is doubtful whether the returns would justify the outlay of capital.

GYPSUM.

In the Cerros de Sal, associated with the salt deposits mentioned above, there are thick deposits of gypsum. Plates of almost transparent selenite are abundant, and masses of fine, snowy white alabaster occur in many

${ }_{1}$ Sample, C. C., Engineering and Mining Jour., vol. 80, pp. 250-251, 1905. 
places. Much of the gypsum is mixed with green clay or shale, but considerable pure or nearly pure gypsum can be found. Gypsum may be seen in Miocene strata at many other places, but only in the Cerros de Sal is it known to occur in quantities large enough to be of any possible commercial value.

OTHER SALTS.

Nitrate is reported to occur in the mountains on both sides of the Enriquillo Basin. A sample taken near Duvergé that was supposed to contain nitrate was examined in the chemical laboratory of the United States Geological Survey and was found to consist of impure limestone free from nitrate. Similar rock near Duvergé contains thin veinlets of common salt, which probably furnished the foundation for the supposition. The samples of this material collected were lost in transit, so that it is impossible to state whether it contains any nitrate, but even if it does the quantity is apparently insufficient to be of commercial value. Potassium occurs in small amount in the salt of Cerros de Sal and is rumored to have been found elsewhere, but so far as known nowhere in commercial quantity.

BUILDING STONE.

Rock suitable for building stone is found at many places in the Republic, though much of it is now too inaccessible to be used. The principal rock so far used for building is the so-called "coast limestone," a marly rock that is found in abundance at many places along the coast. It is soft when quarried and is easily worked, but it hardens somewhat on exposure. The old Spanish buildings, which are still well preserved, are built of this rock. Though it does not possess much architectural beauty it is accessible, is cheaply quarried, and is easily worked. Some of the harder limestones of Tertiary age in the interior are better building stone, but with the present lack of transportation facilities they are inaccessible to most of the larger towns. No marble suitable for building slone is knuwn in the Republic. Some of the granitic rocks of the basal complex would make handsome building material. In many outcrops the jointing is spaced widely enough for dimension stone of good size to be easily quarried, but all these outcrops are too far from large towns to be of value at present.

\section{ROCK FOR CONCRETE.}

Rock of excellent quality for use in concrete is abundant in many localities. Typical trap rock-that is, fine-grained basic igneous rock-is rare except at a few places in Barahona Province, but the hard, compact limestones of early Tertiary age are acceptable substitutes. This material is sufficiently tough and breaks into the angular, sharp-edged pieces which are desired in concrete construction. The outcrops of early Tertiary limestone along the northern border of the Cordillera Central, many of which have been visited and described during the present investigation, afford 
unlimited supplies of such material, awaiting only adequate transportation facilities to be utilized. Similar rock has been described in the Sierra de Monte Cristi, at the west end of the Cordillera Septentrional. Some of it occurs near Puerto Plata and doubtless in other parts of the Cordillera Septentrional. Large areas of limestone of this general type are found in the provinces of Barahona and Azua. These areas have been partly mapped on the geologic map of that region. Other sources of concrete material are to be found in the great batholithic masses of granitic and dioritic rocks in the Cordillera Central. Most of these are remote from. large towns, but almost every stream that emerges from the Cordillera carries large quantities of these rocks in the form of gravel and boulders. Where such stream gravels are found close to places where concrete is needed they can be crushed so as to produce sharp edges and successfully used. Uncrushed stream gravel is often used in concrete, but the rounded smooth pebbles do not produce so strong a concrete as angular, sharpedged rock.

\section{ROAD METAL.}

The discovery of rock suitable for road metal is one of the great problems before the engineers of the Republic, for the construction of good roads is one of the improvements most needed in the island. After a system of good roads is once established and adequately maintained many of the other desirable improvements in industry and in the condition of the people will naturally follow. The limestone and igneous rock mentioned above as suitable for concrete construction would also make excellent road metal if it could be economically quarried and transported to the places where it is needed. The schistose limestone of Samaná Peninsula and some of the metamorphosed ferromagnesian rocks and of the harder sedimentary rocks of the basal complex might well be utilized as road metal, but most of these are far from tho places where roads seem to be most urgently needed, and the soft marly limestone of the coastal plains is therefore extensively used as road metal. It is cheaply and easily obtained and has fairly good binding power, but it is too soft to make really permanent roads. Some of the rocks that would make excellent road metal are not very far from the line of roads now under construction and are quite close to places where roads will eventually have to be constructed. Perhaps some plan by which these rocks could be used might be devised. If quarries were established at suitable places and roads built from the quarries by using the good road metal obtained there many of the difficulties now encountered in road construction would be eliminated. With good material at hand the construction should proceed at a faster rate than at present. The Telford type of road, so extensively used in France, has certain advantages where labor is cheap and the rock is soft and breaks into slabs, and it might be advantageously used in some parts of the Dominican Republic. 
Tests of samples of rock and sand-clay were made by the Bureau of Public Roads, United States Department of Agriculture, with the results stated below.

A sample of crystalline limestone found in large quantity at a quarry 14 kilometers from Santo Domingo City, near Los Alcarrizos, Santo Domingo Province, tested for use in water-bound macadam road construction yielded the following results:

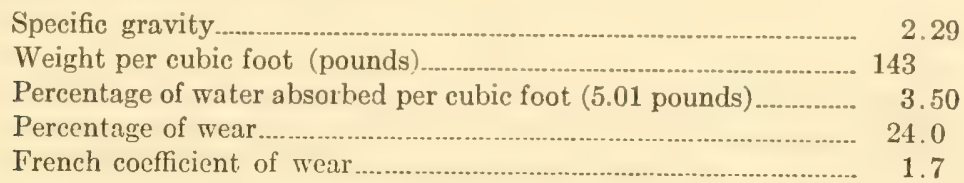

A specimen of brecciated augite andesite from road cut on Carretera Duarte, about 19 kilometers north of Los Alcarrizos, Santo Domingo Province, tested for road metal, gave the following results:

Specific gravity

Weight per cubic foot (pounds)

Pereentage of water absorbed per cubic foot..

Percentage of wear

French ccefficient of wear.

Hardness. 18.7

Toughness

Mineral analysis of specimen mentioned above.

Essential minerals:

Plagioclase (silicate of alumina, lime and soda).

Augite (silicate of lime, magnesia, iron and alumina).

Rock glass.

Accessory minerals:

Pyrite (disulphide of iron).

Secondary minerals:

Calcite (carbonate of lime).

The specimen is not suitable for quantitative microscopic analysis. It is a very dense, fine-grained, gray-black basaltic rock, composed essentially of angular fragments of vitreous basalt firmly embedded in a greenish-gray glass base.

A specimen of crystalline limestone from a large deposit of gravel in the bed of Rio del Rancho Español at the crossing of the Sánchez and Samaná road, Samaná Peninsula and Province, was tested for use in waterbound macadam road construction and concrete mixture with the following results:

Specific gravity

Weight per cubic foot, in pounds 170

Percentage of water absorbed per cubic foot (pounds).................. $\quad 0.16$

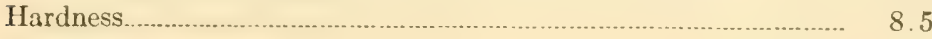

Toughness 
A specimen of tuffaceous limestone from an unlimited source on the south shore of Samaná Bay near Punta de la Boca del Infierno, Samaná Province, was tested for use in waterbound macadam road and concrete construction with the following results:

$\begin{array}{lc}\text { Specific gravity } & 3.49 \\ \text { Weight per cubic foot, in pounds } & 155 \\ \text { Percentage of water abscrbed per cubic foot } & 1.94 \\ \text { Percentage of wear } & 3.6\end{array}$

A specimen of sand-clay found in large quantity on the beach 3 kilometers east of Sánchez, Samaná Peninsula and Province, was examined for use in concrete with the results shown below. The sample consisted essentially of angular grains of quartz and kaolinized orthoclase with some ferruginous clay.

Mechanical analysis of sand. Per cent.

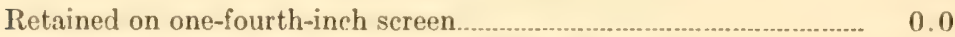

Passing one-fourth inch, retained on 10-inch mesh _................. $\quad 0.5$

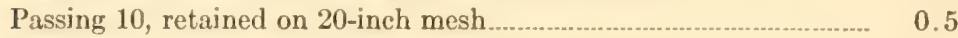

Passing 20, retained on 30-inch mesh $\quad 3.0$

Passing 30, retained on 40-inch mesh

Passing 40, retained on 50-inch mesh $\quad 17.0$

Passing 50, retained on 80-inch mesh

Passing 80, retained on 100-inch mesh

Passing 100, retained on 260-inch mesh

Passing 200

Loss by washing (silt and clay) 12.5 per cent.

100.0

The value of the sand for use in cement was compared with that of standard Ottawa sand by tests of the tensile strength of three specimens of cement-sand briquets made of each of these two sands. The briquets consisted of three parts of sand and 1 part of cement and weighed less than 10 pounds each. They were tested 28 days after manufacture, with the following results:

Tensile strength, in pounds, per square inch of sample briquets.

\begin{tabular}{l|l|c} 
Sample. & $\begin{array}{c}\text { Standard } \\
\text { Ottawa } \\
\text { sand. }\end{array}$ & $\begin{array}{c}\text { Sánchez } \\
\text { sand. }\end{array}$ \\
\hline & & \\
\hline & & \\
\hline
\end{tabular}

Ratio of strength of Sánchez sand to Ottawa sand, 65.7 per cent. 
LIME.

The impure limestone of the coastal plains is burned for making lime at many places near the towns, but nowhere in large quantities. Considerable lime is used in the plaster with which many of the houses in the larger towns are covered, and some is used also in mortar. The purer early Tertiary limestones would doubtless yield a better grade of lime, but they are now too inaccessible and too hard to quarry to be utilized.

BRICK.

The clayey alluvial soil of the flood plains of some of the rivers is suitable for the manufacture of brick. Small amounts of brick are made near San Pedro de Macorís and probably also near Santo Domingo City and elsewhere. The methods used are crude and the brick is consequently not of the best quality. Brick of better quality is reported to have been made by the Spaniards, but some of the brick then used was probably brought from Spain, so that it is not certain whether the brick found in the walls of old buildings was made from native material or imported.

GROUND WATER.

Ground water is little used in the Republic. Some of the coast towns have numerous wells, but most of them are shallow and the water in many is brackish, perhaps because of the infiltration of sea water. Some of the sugar companies near San Pedro de Macorís have put down wells a few kilometers back from the coast, and have obtained water that is only moderately saline. There are a number of wells in the rolling country north of Santo Domingo City, some of them over 50 meters deep, which are far enough inland to be unaffected by sea water. The following tables show analyses of water from typical wells, springs, and streams in this area. Although all the samples contain considerable amounts of dissolved salts. some are good enough to be entirely suitable for many purposes.

Mineral analysis and classification of spring water from Los Alcarrizos, 13 kilometers north of Santo Domingo City.

[Sample collected by C. P. Ross in April, 1919. Analyst, Addie T. Geiger.]

Silica ( $\mathrm{SiO})$

Iron $(\mathrm{Fe})$

Calcium $(\mathrm{Ca})$.

Magnesium $(\mathrm{Mg})$

Sodium and potassium $(\mathrm{Na}+\mathrm{K})$, calculated

Carbonate radicle $\left(\mathrm{CO}_{2}\right)$.

Bicarbonate radicle $\left(\mathrm{HCO}_{3}\right)$

Sulphate radicle $\left(\mathrm{SO}_{4}\right)$

Chloride radicle $(\mathrm{Cl})$

Nitrate radicle $\left(\mathrm{NO}_{3}\right)$

Tetal dissolved solids

Organic matter
Constituents.

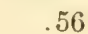

122

16

4.0

404

9.2

26

1.6

431

5.2 


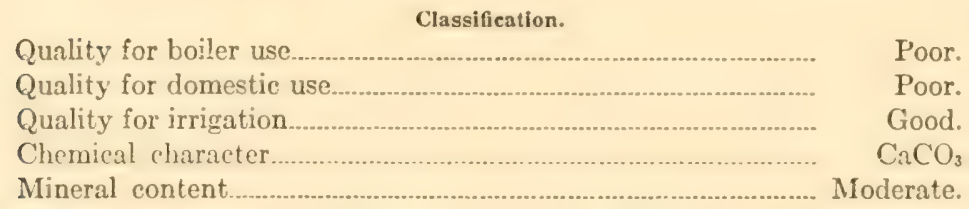

Mineral analysis and classification of surface water from Arroyo la Sulsa, 14 kilometers north of Santo Domingo City.

[Sample collected by C. P. Ross April 7, 1919. Analyst, Addie T. Geiger.]

Constituents.

Silica $\left(\mathrm{SiO}_{2}\right)$

Iron $(\mathrm{Fe})$

Calcium $(\mathrm{Ca})$.

Magnesium $(\mathrm{Mg})$

Sodium and potassium $(\mathrm{Na}+\mathrm{K})$, calculated

Carbonate radicle $\left(\mathrm{CO}_{3}\right)$

Bicarbonate radicle $\left(\mathrm{HCO}_{3}\right)$

Sulphate radicle $\left(\mathrm{SO}_{4}\right)$

Chloride radicle $(\mathrm{Cl})$.

Nitrate radicle $\left(\mathrm{NO}_{3}\right)$

Total dissolved solids

Organic matter.

Quality for boiler use

Quality for domestic use

Quality for irrigation

Chemical character

Mineral content
Parts per million.

31

.31

121

12

14

428

9.9

14

$\mathrm{Tr}$.

410

4.8

Poor.

Poor.

Good.

$\mathrm{CaCO}_{3}$

Moderate.

Mineral analysis and classification of water from dug well of Gregorio Valois, 13 kilometers north of Santo Domingo City.

Well 30 meters deep; altitude of mouth about 72 meters. Sample collected by C. P. Ross April 7, 1919. Analyst, Addie T. Geiger.]

Constituents.

Silica $\left(\mathrm{SiO}_{2}\right)$

Iron $(\mathrm{Fe})$

Calcium $(\mathrm{C} i \mathrm{i})$

Magnesium (Mg)

Sodium and potassium $(\mathrm{Na}+\mathrm{K})$, calculated

Carbonate radicle $\left(\mathrm{CO}_{3}\right)$

Bicarbonate radicle $\left(\mathrm{HCO}_{3}\right)$.

Sulphate radicle $\left(\mathrm{SO}_{4}\right)$

Chloride radicle $(\mathrm{Cl})$.

Nitrate radicle $\left(\mathrm{NO}_{3}\right)$

Total dissolved solids.

Organic matter

Classification.

Quality for boiler use

Quality for domestic use

Quality for irrigation.

Chemical character.

Mineral content.
Parts per million. 38

.31

91

28

29

.0

446

11

19

1.4

426

6.0

Poor.

Poor.

Good.

$\mathrm{CaCO}_{3}$.

Moderate. 
Mineral analysis and classification of water from dug well of Ibarra \& Gosling, 4 kilometers north of Santo Domingo City.

IWell 40 meters deep; altitude of mouth about 60 meters. Sample collected by C. P. Ross April 7, 1919. Analyst, Addie T. Geiger.]

Silica $\left(\mathrm{SiO}_{2}\right)$

Constituents.

Iron $(\mathrm{Fe})$

Parts per million.

Calcium $(\mathrm{Ca})$

Magnesium (Mg)

Sodium and potassium $(\mathrm{Na}+\mathrm{K})$, calculated.

Carbonate radicle $\left(\mathrm{CO}_{3}\right)$.

Bicarbonate radicle $\left(\mathrm{HCO}_{3}\right)$

Sulphate radicle $\left(\mathrm{SO}_{4}\right)$

Chloride radicle $(\mathrm{Cl})$

Nitrate radicle $\left(\mathrm{NO}_{3}\right)$

Total dissolved solids

Organic matter

14

.42

108

34

126

352

47

233

19

758

18

Bad.

Poor.

Fair.

$\mathrm{NaCl}$.

High.

Mineral analysis and classification of water from Bombita Spring, on bank of Rio Isabela about 3 kilometers west of north of Santo Domingo City.

[Sample collected by C. P. Ross April 7, 1919. Analyst, Addie T. Geiger.]

Silica $\left(\mathrm{SiO}_{2}\right)$

Iron $(\mathrm{Fe})$.

Calcium $(\mathrm{Ca})$

Magnesium (Mg)

Sodium and potassium $(\mathrm{Na}+\mathrm{K})$

Carbonate radicle $\left(\mathrm{CO}_{3}\right)$

Bicarbonate radicle $\left(\mathrm{HCO}_{3}\right)$

Sulphate radicle $\left(\mathrm{SO}_{4}\right)$

Chloride radicle $(\mathrm{Cl})$

Nitrate radicle $\left(\mathrm{NO}_{3}\right)$

Total dissolved solids.

Organic matter

Constituents.

Quality for boiler use

Quality for domestic use.

Quality for irrigation

Mineral content

Chemical character

\section{Classification.}

Parts per million. 20.

118

.42

308

.0

338

98

501

8. 7

1273

67

Ve. y bad.

Poor.

Poor.

High.

$\mathrm{NaCl}$. 
Mineral analysis and classification of water from dug well of Ibarra \& Gosling, 3 kilometers from Santo Domingo City, on Santa Cruz road.

[Well 56 meters deep; altitude of mouth about 36 meters. Sample collected by C. P. Ross April 7, 1919 Analyst, M. D. Foster.]

Constituents.

Silica $\left(\mathrm{SiO}_{2}\right)$

Iron $(\mathrm{Fe})$

Calcium $(\mathrm{Ca})$

Magnesium $(\mathrm{Mg})$

Sodium and potassium $(\mathrm{Na}+\mathrm{K})$

Carbonate radicle $\left(\mathrm{CO}_{3}\right)$

Bicarbonate radicle $\left(\mathrm{HCO}_{3}\right)$

Sulphate radicle $\left(\mathrm{SO}_{4}\right)$

Chloride radicle $(\mathrm{Cl})$

Nitrate radicle $\left(\mathrm{NO}_{3}\right)$

Total dissolved solids

Organic matter

Quality for boiler use

Quality for domestic use

Quality for irrigation

Chemical character

Mineral content.
Parts per million. 12

Poor

Poor.

Good.

$\mathrm{CaCO}_{3}$.

The water supplies of the Monte Cristi district are discussed by C. P. Ross on pages 177-180. Water can certainly be obtained from wells there, and in favorable situations artesian flows may be possible, but some of the water may be rather strongly mineralized.

In the parts of the Samaná Peninsula that were examined the conditions are favorable for obtaining only small quantities of water from wells. Analyses of some waters on the peninsula are appended.

Mineral analysis and classification of water from spring just below head of Arroyo Salado, Samaná Peninsula, Samaná Province.

[Sample collected by C. P. Ross June 30, 1919. Analyst, M. D. Foster.]

Silica $\left(\mathrm{SiO}_{2}\right)$

Constituents.

Iron $(\mathrm{Pe})$

Calcium $(\mathrm{Ca})$

Magnesium (Mg)

Sodium and potassium $(\mathrm{Na}+\mathrm{K})$, calculated

Carbonate radicle $\left(\mathrm{CO}_{3}\right)$

Bicarbonate radicle $\left(\mathrm{HCO}_{3}\right)$

Sulphate radicle $\left(\mathrm{SO}_{4}\right)$

Chloride radicle $(\mathrm{Cl})$

Nitrate radicle $\left(\mathrm{NO}_{3}\right)$

Organic matter.

Total dissolved solids

Quality for boiler use

Quality for domestic use

Quality for irrigation.

Chemical character.

Mineral content.
Parts per million.

13

.13

94

20

235

.0

298

40

370

14

957

Fair.

Fair.

Good.

$\mathrm{CaCO}_{3}$.

Moderate. 
Mineral analysis and classification of water from spring at head of Arroyo Santa Capuza, Samaná Peninsula, Samaná Province.

[Sample collected by C. P. Ross June 30, 1919. Analyst, M. D. Foster.]

Constituents.

Silica $\left(\mathrm{SiO}_{2}\right)$

Iron $(\mathrm{Fe})$

Calcium $(\mathrm{Ca})$

Magnesium (Mg)

Sodium and potassium $(\mathrm{Na}+\mathrm{K})$, calculated

Carbonate radicle $\left(\mathrm{CO}_{3}\right)$

Bicarbonate radicle $\left(\mathrm{HCO}_{3}\right)$

Sulphate radicle $\left(\mathrm{SO}_{4}\right)$

Chloride radicle $(\mathrm{Cl})$

Nitrate radicle $\left(\mathrm{NO}_{3}\right)$

Organic matter.

Total dissolved solids.

Qulity for boiler use

Quality for domestic use

Quality for irrigation.

Chemical character

Mineral content.
Parts per million,

13

79

9.8

6.1

0

11

3.4

265

Fair.

Fair.

Good.

$\mathrm{CaCO}_{3}$. Moderate.

Mineral analysis and classification of water from Rio del Puerto Viejo, 1800 meters upstream from Santa Bárbara de Samaná, Samaná Peninsula, Samaná Province.

[Sample collected by C. P. Ross June 25, 1919. Analyst, M. D. Foster.]

Silica $\left(\mathrm{SiO}_{2}\right)$

Constituents.

Iron $(\mathrm{Fe})$

Calcium $(\mathrm{Ca})$

Magnesium (Mg)

Sodium and potassium $(\mathrm{Na}+\mathrm{K})$, calculated

Carbonate radicle $\left(\mathrm{CO}_{3}\right)$

Bicarbonate radicle $\left(\mathrm{HCO}_{3}\right)$.

Sulphate radicle $\left(\mathrm{SO}_{4}\right)$

Chloride radicle $(\mathrm{Cl})$

Nitrate radicle $\left(\mathrm{NO}_{3}\right)$

Organic matter.

Total dissclved solids

Quality for boiler use

Quality for domestic use

Quality for irrigation

Chemical character

Mineral content
Parts per million.

27

2.4

71

6.6

11

.0

243.0

4.0

17

$\mathrm{Tr}$.

4.4

276

Poor.

Fair.

Good.

$\mathrm{CaCO}_{3}$.

Moderate. 
Mineral analysis and classification of water from Rio de los Cocos, Campo Arenoso Samaná, Samaná Peninsula, Samaná Province.

[Sample collected by C. P. Ross June 25, 1919. Analyst, M. D. Foster.]

\begin{tabular}{|c|c|}
\hline Silica $\left(\mathrm{SiO}_{2}\right) \ldots \ldots \ldots$ & $\begin{array}{c}\text { Parts per mi } \\
17\end{array}$ \\
\hline Iron $(\mathrm{Fe}) \ldots \ldots \ldots$ & 1.1 \\
\hline 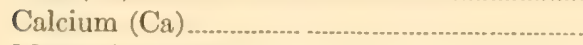 & 64 \\
\hline Magnesium (Mg) & 6.0 \\
\hline Sodium and potassium $(\mathrm{Na}+\mathrm{K})$, calculated & 8.9 \\
\hline Carbonate radicle $\left(\mathrm{CO}_{3}\right)$ & 0 \\
\hline Bicarbonate radicle $\left(\mathrm{HCO}_{3}\right)$ & 214 \\
\hline Sulphate radicle $\left(\mathrm{SO}_{4}\right) \ldots \ldots \ldots$ & 6.7 \\
\hline Chloride radicle $(\mathrm{Cl}) \ldots . . . . . . . . .$. & 15 \\
\hline Nitrate radicle $\left(\mathrm{NO}_{3}\right) \ldots . . .$. & Trace. \\
\hline Organic matter & 4.2 \\
\hline Total dissolved solids....... & 242 \\
\hline Quality for boiler use............ & Poor. \\
\hline uality for domestic use...... & Good. \\
\hline uality for irrigation............ & Good. \\
\hline hemical character & $\mathrm{CaCO}_{3}$. \\
\hline
\end{tabular}

Mineral analysis and classification of water of Rio San Juan at mouth of Arroyo Santa Maria Luisa, Samaná Peninsula, Samaná Province.

[Sample collected by C. P. Ross June 24, 1919. Analyst, M. D. Foster.]

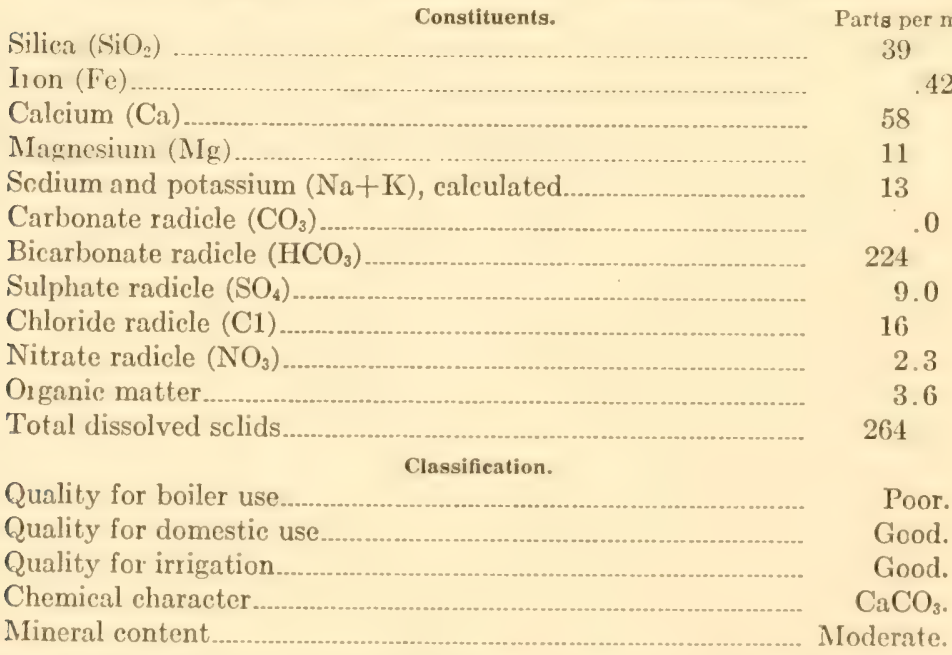

At many places in the Ciboa Valley ground water could be used to a much greater extent than it is now. In this valley very few wells are in use, but water can be obtained at moderate depths nearly everywhere in it. The outwash deposits from the mountains on both sides of the valley contain gravel beds which should be excellent reservoirs for ground water. The outwash deposits on the north slope of the Cordillera Septentrional have in places a distinct slope valleyward. Suitable locations for artesian wells might possibly be found here. In the vicinity of Azua there are artesian wells of considerable flow. 


\section{N D E X .}

Abbott, W. L., remains of extinct rodents found by.

Acknowledgments for aid

Adams, Captain, copper prospecting by

Agricultural products, Provinces of Azua and Barahona

Agua Montilla, location of.

Alberti y Bosch, N., fossils found by

Alluvial deposits, character and distribution of $175,185,202$

Alpargatal, location of..............._._.............. 195 Tertiary rocks exposed near .................... 206

Altamira, Eocene rocks and fossils found near.-

$58,59,105$

Alta Vela, geography of

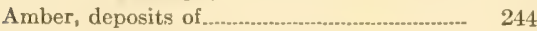

Amores, E. M., translation by _...___._........... 14

Amphibolite schist, description of................... 85

Andesites, descriptions of _.......................... 86, 87

Andesitic tuffs, descriptions of _..._........... 88

Andres Bay, geographic features near............. 48

Angostura, fossils found near....................... 163-164 indications of petroleum near............... 219

Ansonia sugar plantation, beds penetrated by drill at.

Aplite, description of

Areal geology, A zua and Barahona provinces, description of

Arenosa, Tertiary limestone near ..................... 183

Argillite, occurrence of ........................................ 83

Arroyo Blanco, Cevicos limestone in _............. 63, 64 Oligocene fossils found in

Arroyo Barranca, Oligocene rocks and fossils found in.

110

Arroyo Clavijo, conglomerate exposed in...... 54-55

Arroyo Guananitos, basal rocks exposed in.... $\quad 51$ features of.

31-32

Arroyo Guanito, Oligocene tuffs in............... 172

Arroyo Hondo, Oligocene rocks in................ 62

Arroyo Jerguen, Oligocene rocks and fossils found in.

Arroyo la Sulsa, surface water from, analysis of..

Arroya las Lavas, Mao Adentro limestone and fossils in.

ls collected in ...........101, 151-153 structure in ................................................ 78

Arroyo Lima, rocks in .................... 212

Arroyo Milac, Tabera formation near............ 61

Arroya Palma Dulce, indications of petro-

leum near.

Arroyo Quita Coraza, springs in

from, analysis of ................... 194

Arroyo Salado, oil seepage in...................... 225 rocks and fossils found in and near......... 155,

$157-162,199,212$

view of tilted beds of limestone in $(\mathrm{Pl}$ $\mathrm{XX}, B)$ water from, analysis of

Arroyo Santa Capuza, spring water from, analysis of
Arroyo Santa Cruz, Miocene or older fossils found in

Artesian water, conditions favoring occurrence of _._. 177, 178-179

Augite andesite, tests of, as road metal ___._. $\quad 247$

Azua, artesian wells near............................ 254 coralliferous limestone near......................... $\quad 223$

Eocene rocks near _..._.......................... 60-61

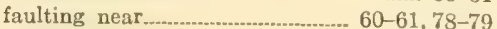
geology at and near..................... 222-223 location, surroundings, and population

of

oil field at

oil found at, quality of ........................ 224-225

oil seepage east of ................................ 225-226

rainfall at ......................................... 197

roads and trails from and to............... 196-197

salt springs near._.............................. 192

Azua Plain, features of ............................. 37-38

Azua-Bani road, fossils collected on................. 54

Azua Province, Eocene rocks and fossils found in. $60,106,199$ geography of

188

Miocene or older fossils found in........... 155-162

Oligocene fossils found in................... 63 ,

$108-109,111-112,200$

roads in ................................................. 196

springs in, analyses of water of.......... 193-194

stratigraphic section in _._................. 207

Azua and Barahona provinces, alluvial deposits in......................................... 202

areal geology of ........... 203-227

map showing (PI. XV) ........_._._..... 186

climate and vegetation in.................... 197-198

" coast limestone " in .................................. 202

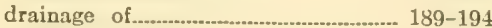

Eocene rocks in

geologic formations in, table showing...... $\quad 199$

geologic structure in ................... 203

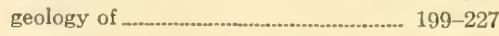

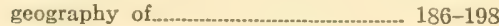

gypsum deposits in, summary con-

cerning puren 227

igneous rocks in ..................................... 202

metalliferous deposits in, summary con-

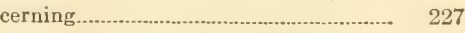

Miocene rocks and fossils found in.......... 201

oil and gas in, summary concerning...... 226

Oligocene rocks in................................ 200-201

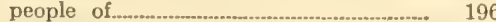

Pliocene (?) rocks in $\ldots$

population of 19t-195

pre-Tertiary formations in _.._...___._... 199

products of .............................................. 198

Quaternary sediments in _._________._. 202

roads and trails in................................. 196-197

salines in, summary concerning ............. 227

Tertiary sedimentary rocks in............... 199-201

towns and villages in

Bahoruco, copper stains noted near...-..--..... 222

Bahoruco mining concession, basis of........... 222 
Baitoa, Baitoa formation near

Miocene rocks and fossils found at and near

Oligocene rocks and fossils found at and near trail from

61,107

33-34

Baitoa formation, age of _... 57, 94 character, thickness, and distribution of 66 correlation of 100

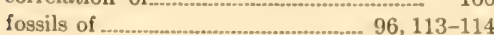
type locality of

100

Bajab6nico, Eocene rocks and fossils found

"Balketa," Miocene or older fossils from....... 155

$157-162$

Ballandra Point, references to 46,47

Bani, location of

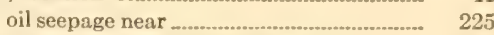

Bani Plain, location and features of $\quad 40$

Bánica, copper deposits near....................... 243 Tertiary rocks near. 199,211

Bánica-Restauración trail, view from place on (Pl. XVI, B)

Barahona, "coast limestone" near................ 202

Eocene rocks and fossils found near 60,200

geology of coast near........................ 221-222

industries of 195

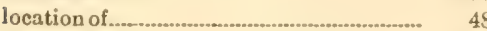

rainfall at 197

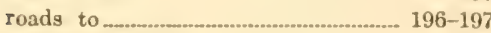

salt springs near.

spring near, analysis of water of .............. 194

Barahona-Bahoruco coast, geology of ....... 221-222

Barahona Company, aid rendered by ........... 186 irrigation project of.................... 187, 188, 195

rainfall observations made by ................ 197 stream gaging by.................................. 189

Barahona Province, elevation in, amount and dates of

Eocene rocks

geography of

187-189

lakes in.

190-199

Miocene or older fossils from............... 163-164

Pleistocene or younger fossils from . 166-168

roads in

$166-168$

springs in, analyses of waters of .......... 194

uplifted shell beds in

Barahona and Azua Provinces, alluvial deposits in. 202 map showing (Pl. XV) ................ 186 climate and vegetation in.................. 197-198

"cost limestone" in ............................. 202 drainage of

189-19.4

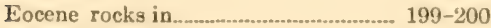
geography of _...................................... 186-198

geologic formations in, table showing..... 199 geologic structure in geology of.................... 199-227 gypsum in, summary concerning.......... 227 igneous rocks in 202 metalliferous deposits in, summary concerning

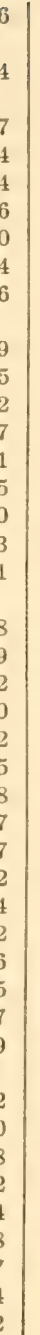

Barahona and Azua Provinces-Continued,

Miocene rocks and fossils in.............. 201

oil and gas in, summary concerning...... 226

Oligocene rocks in

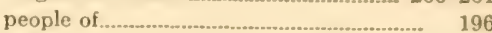

Pliocene (?) rocks in .............................. 201

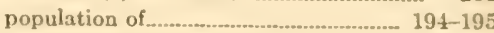

pre-Tertiary formations in

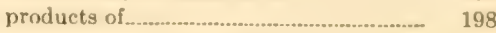

Quaternary sediments in....................... 202

roads and trails in............................ 196-197

salines in, summary concerning ............ $\quad 227$

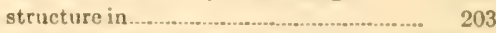

Tertiary sedimentary rocks in........... 199-201

towns and villages in ....................... 194-196

Barbacoa, Eocene rocks and fossils found

near

geology of area near............................ 214

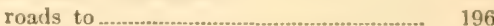

Barranca Blanca, Miocene rocks near.......... 174 structure at 176

Basal complex, description of ............. 50-53, 182-183

Basaltic rock, tests of, as road metal......... 247

Basalt tuff, description of ............................... 88

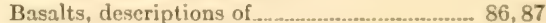

Bassler, R. S., acknowledgments to............... 89

Bastia, Olizocene rocks and fossils found near............................................. 112

Baughman, Lieut. Commander, aid rendered

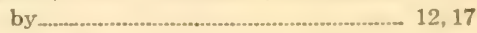

Berry, E. W., acknowledgments to................. 89 cited on age of Calvert flora................... 100 fossil plants identified by .......................... $\quad 200$

Beata Isiand, geography of........................... 48-49

Berkey, C. P., cited on depression and e!evation in West Indies. 81

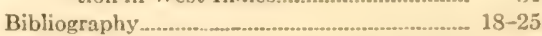

Bland and Rowell, Miocene fossils collected

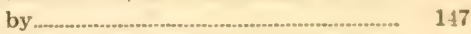

Blanton, E. A., San Francisco mining con-

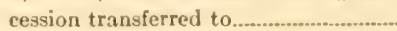

Blanton Copper Mining Syndicate, opera-

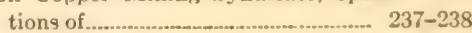
map furnished by..................................... 236

Boca Mula, fossils found near..................... 155-162 sulphur springs near............................ 192 view of valley of Rio $\mathbf{Y}$ aque del Sur near (P]. XVIII, B) ..................... 208

Bombita Spring, analysis of water of ............ 251

Bonao, basal rocks exposed near................. 51 location of $\quad 32$

Bonao trail, course and general features of $31-32,44$ rocks of basal complex along................. 50-52

Booy, Theodore de, remains of extinct rodents found by 10

Bowden, Miocene fossils found at ..................

Bowden marl, age of ..................... 97, 98-99, 100

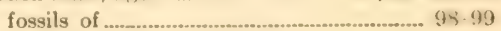

Brick, clay suitable for making..................... 219 manufacture of 219

Brinsmade, IR. B., cited on iron ore deposits near Hatillo cited on magnetite deposits near Hati!lo. 
Brown, Barnum, Jurassic shore line traced by Búcaro Hill, copper ores and copper mining 236, 237, 238, 239-240

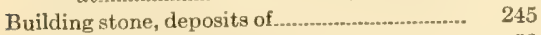

Bulla, basal rocks exposed near ....................... 52

Miocene conglomerate exposed near..... 66-67

Miocene fossils found near........... 114, 116-12t

view of exposure of conglomerate near (Pl. X).

view of gorge on Rio Mao above (Pl.

VII, $C$ ).

68

40

Bulla conglomerate, age, character, thickness, and distribution of $\ldots$

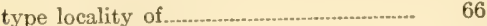
view of exposure of (Pl. X) ..................... 68

Bureau of Public Roads, tests of road-making material by. $14,247-248$

Cabeza de Toros, coral limestone at.......... 185

Cabo Falso, geography of region near._........ 47,49

Cabo Rojo, geography of region near ........... 49

Cabral, fossils found at................................... 166-168

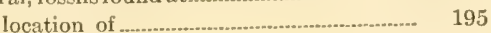

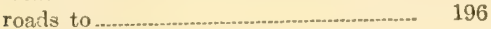

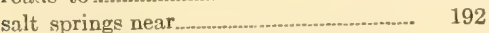

Cercado formation near, section of......- $\quad 68$

Caimito, Miocene fossils found at and near 114, 115-124, 151

Camino Real, fossils found on

Calkins, F. C., petrographic work by__._. 14,83-88

Campo El Puerto, spring at, analyses of 98 water of

Cana, section of Cercado formation near......- 68

Caño de Botiguela, Miocene rocks near__... 174-175

Cañada de Rancho Viejo, Eocene rocks and fossils found near. $60,106,200$

Cañada Diablo, geology near........................... 220

Canela, Gurabo formation near.................. 73

Canu, F., acknowledgments to..................... $\quad 89$

Cape Cabrón, topography of area near....... 46

Cape Engano, features of ............................... 47

Cape Francés Viejo, features of ....................... 46

Cape Haitien, Eocene rocks at..................... 200

Cape Rafacl, geography of area near............ $\quad 47$

Cape Samank, shore features near ................ 46

Carpintero, rocks near........................................... 211

Carrera del Potro (salt working), deposits exposed by ................................................... 216

Carretera Duarte, course of ...................... 31,32,44 road metal from, tests of .................. 247

Catalina Island, geographic features near..... 48

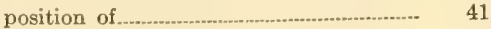

Catalinita Bay, geography of region near.... $\quad 48$

Cercado de Mao, Gurabo formation near..... 71 Gurabo formation near, view of (Pl. XIII, A)

Mao Adentro limestone near............... 73 Miocene rocks and fossils found near

$67,114,126,130-131,133-145,151-153$

Cercado formation, age of - 57,97 character, thickness, and distribution of $67-69$ correlation of

tosils of _.................. 69, 96-97, 114-130 modified fauna of (localities and lists of fossils) $97-98,126-130$
Cercado formation-Continued.

section of

71 type locality of 67 view of exposure of (Pl. XII, A )......... 72

Cerros de Jácuba, character of ................. 170-171

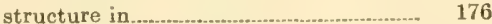

Cerro de las Chivas, rocks in

Cerros los Piñones, fossils collected in ......... 54

Cerros de la Travesia, basal rocks exposed near

Cerros de Sal, features of fossils found on $163-164$ gypsum deposits in .............................. 214 methods of mining in .......................... 218 potassium deposits in _............................... 245

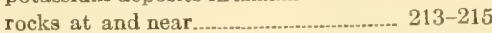

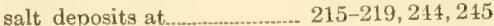
salt from, character of .........................216-218 chemical analyses of...................... 217

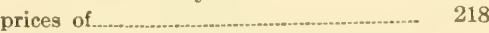

Cerros de Sal formation, age, character, and thickness of _.......... 57, 75, 199, 201, 214-215 equivalents of $\ldots 103,213,214$

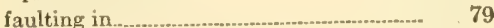

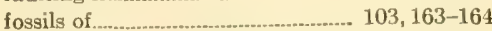

occurrence of, south of Duvergé .......... 220 stratigraphic sections of..................... 75,215

Cevicos, basal rocks exposed near.............. 51 Oligocene rocks near.............................. 63-64

Cevicos limestone, age, character, thickness, and distribution of $57,63-64$ correlation of, with Anguilla formation.. 63 fossils of structure of

Chalcocite, occurrence of ............................ 222

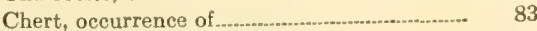

Chloritic schist, occurrence of _................... 83

Chini, Francis, copper prospecting by ......... $\quad 237$

Cibao Valley, position and general features of _29-30 previous studies of Miocene formations in 65 settlement and agriculture in..................29,30 structure in $\quad 78,203$

Clarke, F. W., cited on mineral content of

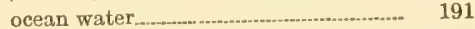

Climate and vegetation, Azua and Barahona provinces, features of _............. 197-198

Coal, deposits of

"Coast limestone" of Gabb, character, distribution, age, and equivalents of....... $\quad 77$ $199,202,213$

fossils from geologic events following the deposi-

tion of $\quad 82$

Coast line and shore features, description of.- 44-49

Coastal plain, features of.............................. 40-41

Cohen, Dr. P. V. Logroño, oil samples collected by

225

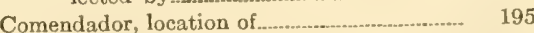

Concrete, rock for, occurrence of ...............245-246

Condit, D. D., fossils collected by ........... 105, 106 , $107,108,109,111,112,113,114,115,126,130$ $145,147,151-153,154,155,163,165,166-168$

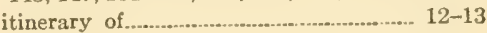


Condit, D. D.-Continued.

Miocene formations discriminated by.... $\quad 65$

nickel deposits examined by ................... 243

observations made at Sánchez by ........... 181

observations on thickness of Tabera formation made by.

Oligocene rocks noted by......

report on La Perseverancia nickel deposit by.

sample of nickel ore taken by $\quad 231$

section of Gurabo formation measured by.

specimens of rocks collected by

Condit, D. D., and Ross, C. P., Cerros de Sal formation named by

chapter on geology of provinces of Barahona and Azua by ................... 186-227 chapter on economic geology by ........ 228-254 Las Matas formation named by.............. $\quad 76$ Miocene beds deseribed by ...._.___._..... 65-66

Constanza, basal rocks exposed at.................... 52 geography and geology of region near.... 205 trail from

Constanza trail, basal rocks exposed along.... $\quad 52$ description of ...................................... 33-35 reference to

Constanza Valley, description of chapter on stratigraphic and structural geology and geologic history by... $50-82$ cited on stratigraphic significance of Orthaulax. copper and iron ores examined by ........... 229 description of geography by ............... 26-49 fossils collected by 106,110 , $111,112,113,114,115,126-129$, $130-145,151-153,155-162,165$

fossils identified by

itinerary of

12-13

observations in Province of Samaná

made by

181

oil seepage on Arroyo Salado visited

by.

225-226 work near Azua done by ..... 186

Copey, Miocene(?) deposits near..................... 174 fossils found near

154,165

Copper ores, assays of 241 deposits of, near Hatillo_....................... 230 San Cristóbal mining district, report on 236-242 summary account of

Coral reefs, Ileistocene or Recent, distribubution of 184-185

Corals common to Miocene beds in Cuba, Jamaica, and Dominican Republic (table).

Cordillera Central, amber in 244 areal geology of................................... 201-206 basal complex in ...................................... 50-53

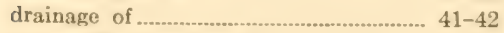
Eocene(?) limestones in......................... 58 general features of _................ 30-31, 169-170 gold in.

igneous rocks in

202-203
Cordillera Central-Continued.

iron ores in

iron and copper ores along north border

$$
\text { of }
$$

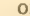$$
\text { of }
$$
228-231 platinum in $\quad 242$

Pliocene(?) gravel in

rocks for making concrete available in.. 245 streams rising in ................. $41-42$ structure in foothills of ........................... 176 trails across

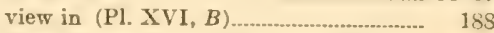

Cordillera Septentrional, Cretaceous rocks in 54

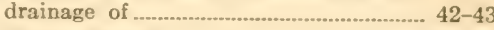
Eocene rocks in ........................................ 58-60 position and general features of............... 27-28 rock suitable for mixing concrete found

in streams rising in ............................. 42-43

view of south front of (PI. II, $A$ ) ............ $\quad 28$ view of summit of (Pl. II, C) .................. 28

Correlation, section on ........ 91-94 table showing......................................... 57 work on 1 .

Correlation table showing American and European equivalents of Tertiary formations.

Cotú, Eocone rocks near.

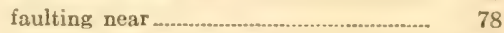
iron and copper ores near.............. 228-231,243

Cretaceous fauna, discussion of ..................... 53-55

Cretaceous system, rocks and fossils of........ 53-56

Cruz de los Caminos, Eocene fossils found

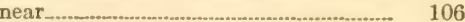

Cul de Sac district, Eocene rocks in................ $\quad 200$ volcanic erater in......................... 210

Cushman, J. A., acknowledgments to............ $\quad 89$ fossils examined by ................... 54, 59, 60, 105

Dajabon, faulting near $\quad 78$

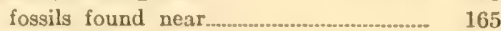

Oligocene limestone near $\quad 172$

Pliocene(?) gravel near_......................... 175

quartz diorite near. _.... 171 structure near

Dall, W. H., cited on correlation of certain

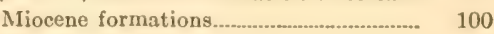
Miocene fossils described by $\quad 147$

Damajagua, Cretaceous rocks near............... 54 Eocene rocks near $\quad 58,59$ fossils found near................................. 105 structure at $\quad 78$

Darton, N. H, fossils collected by ...... $155,157-164$ Delmonte, Manuel, discovery of nickel ore by 233 mining concession granted to................. 231

Depression and elevation, evidences of ......... $\quad 82$

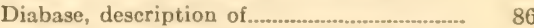

Diaz, - San Francisco concession transferred to 237

Dike rocks, description of................................. 85-86

Diorite, description of $\quad 84,85$ intrusion of, date of._................................... 80

Diorite porphyry, description of................... 86

Dixon, A. F., cited on structure from Neiba to Rio Yaque

Drainage, description of ....................................... 41-43 
Dreyfus, E. E., oil films reported by.

Duarte Highway, course of fossils found on. Duncan, P. M., cited on Miocene fauna of
the Cibao Valley

Duvergé, areal geology south of coralliferous limestone at. fossils found near. nitrate deposits near__._............................ 245 petroleum indications near.______.......... 219 population of....................................... 195 Quaternary coral reef at_.......................... 77 roads to 196,197 rock salt near rocks and fossils observed at................... 213 view of part of (Pl. XIX, A).............. 220

Dynamic metamorphism, evidences of ......... 202

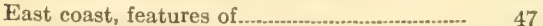

Economic geology, chapter on ..................... 228-254

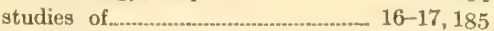
summary general statement on............ 242-254 summary of, for Azua and Barahona provinces. 226-227

El Amacey, trail from.

El Barrero, altitude of basal rocks at

El Carrizal, country near.

El Corme cave, Eocene rocks at............. 59

ack rocks and fosils at 221,222

El Gran Estero, geologic history of _................ 181 position of

El Higo Gordo, view of Sabana Llana near (PI. IV, A)

El Limón, Oligocene rocks and fossils found at and near $62-63,107$

El Madrigal, rocks of basal complex near 50,51 view of terrace flat at $(\mathrm{Pl}, \mathrm{V}, \mathrm{C}) \ldots$

El Morro de Monte Cristi, features of ............. $\quad 27$ location and altitude of _.................. 45,170 Miocene or older rocks and fossils found at ............................ 102, 153-154, 172, 173 section at ............................................... 173 strata and structure in view of $(\mathrm{Pl} . \mathrm{I1}, \mathrm{B}) \ldots$

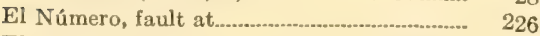

EI Paso Bajito, view of Gurabo formation near (Pl. XII, B) view of Rio Mao near (PI. XIII, $B$ )

El Paso de los Perros, Miocene fossils found near $114,116-124$

El Puerto, rocks near....................................... $\quad 211$ sulphur springs at and near................. 192

El Rucillo, height of....................................... 33

Elevation and depression, evidence of............ $\quad 82$

Elevation subsequent to deposition of the "coast limestone," evidences of.

Fnnery, Eocene rocks exposed near 58,200

Enriquillo Basin, "coast limestone" in......... 202

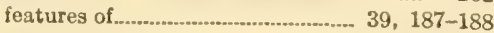
former extent of ............................... 48 geology of 213-221

nitrate deposits in

245
Enriquillo Basin-Continued. springs in 192 structure of . 213-214

Enriquillo Lake. See Lake Enriquillo.

Eocene fauna, correlation and discussion of 94-95

Eocene fossils, localities and names of.... 59, 105-106

Eocene Foraminifera, classes of .................. 94

Eocene time, events of ......................................... 80

Eocene series, character, distribution, and thickness of ........................... 58-61, 199-201 correlation of (table)................................ 57 faulting in relation of, to Oligocene _......................... 200

Epidiorite, description of _................................ 84, 85

Erickson, E. T., analyses of salt by ............. 217

Escocesa Bay, location of................................. 48

Esperanza, view in valley of Rio Yaque del Norte near (Pl. IV, B) .......................

Etang Saumatre, location and general features of. Faulting, occurrence of $\ldots . . . . . . . . . . . . . . . . . . . .77-79,203$ periods of.

erguson, H. G., aid by ................................. 14 examination of nickel deposits by ........ 231, 243 magnetite deposit near Hatillo observed by observations made at Loma Pegado by.. $\quad 231$ samples of nickel ore taken by ............... $\quad 234$ Ferrocarril Central Dominicano, route of ...... 43 Ferrocarril de Santiago y Samaná, routes of.. 43-44 Field work, summary account of ................. 12-13 Folding, occurrence of ........................... 77-79,203 Fondo Negro, salt springs at.......................................

Foraminifera, Eocene, classes of ................ 94

Forests. See Vegetation.

Fort San Felipe, location of

Fossils identified, ages and localities of.... 105-168 Cretaceous, localities........................... 53,54,55 Eocene, localities and names of ......... 105-106 Miocene, localities and names of........ 113-165 Oligocene, localities and names of...... 107-112 stations where collected, maps showing

(Pls. IX, XI)

66.70

Foster, M. D., analyses of waters by ......... 252-254

Furcy, Eocene rocks near............................. 58

Gabb, W. M., cited on identity of limestone at El Morro and in Samba Hil!s_....... 176 cited on "Iron Mountain," near

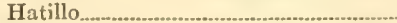
cited on limestone of Loma de los Mucrtos. cited on Miocene fauna of the Cibao Valley.

Gabbro, descriptions of

Garrison, F. L., cited on copper deposits at Búcaro Hill.

cited on copper deposits at San Fran. cisco Hill

Gas, natural, analyses of

Gas and oil, Azua and Barahona provinces, summary concerning

Geiger, A. T., analyses of waters by 
Geography, description of

Geologic correlation, results of wor

section on

table showing.......................................... 57

Geologic history, outline of ........................ 79-82

Geologic structure, general features of $176-177,203$ results of studies of .................................. 16 section on

Gold, a mount of, in copper ores, assays showing $\ldots$ recovery of, from stream gravels.......... $\quad 232$ summary statement on............................. $\quad 242$

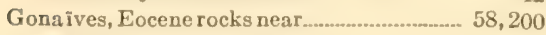

Gran Estero, geologic history of.................... 181 location of ............................................. 28, 46

Granodiorite, occurrence of .................................... 202

Granular intrusive rocks, description of....... 83-84

Gurabo, Cretaceous rocks near ................... 54 fossils collected near................................ 55

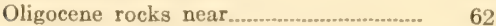
sedimentary rocks near, sequence of...... $\quad 54$ volcanic rocks exposed near................... $\quad 55$

Gurabo Adentro, Cercado formation near..... $\quad 69$ Miocene fossils found near.... 115-124, 131-145 section of Gurabo formation near........ $\quad 70$

Granite porphyry, deseription of.................. 86

Ground water, analyses of ............................. 249-253 possibility of obtaining.............. 177-178, 249

Guanarate, salt springs at........................... 192

Gurabo formation, age, character, thickness and distribution of...................... 57, 69-73 contact of Mao Adentro limestone with 74 correlation of ...................................... 100 fossils of. $69-73,98-99,130-151$ fossils from deeper-water facies of ...... 147-151 sections of. $69-70,71,72$ stratigraphic relations of thickness of

type locality of. views of (Pl. XII, B; Pl.

$\mathrm{XIII}, A)$.

Gurabo Hills, Mao Adentro limestone near.. 73-74 Miocene fossils found in.

Guayacán (lignum-vitae tree), view showing (I'l. XVII, A)

Guayajayuco, geologic structure near............ trail from.

Gypsum, deposits of ................................. 241-245 summary concerning deposits of, in Azua and Barahona provinces.

in position of

volcanic center in .................................. 210

Iarootian, Dr. Jacob, aid by ........................... 237 San Francisco mining concession sought by. openings made on copper deposits by.... work on La Rama copper prospect of....

Hatico, location of rocks near

Hatillo, copper deposits near Eoceno rocks near. faulting at
Hatillo-Continued.

iron ores near.

magnetite deposits near

rocks of basal complex near................... 50,52

view northward from (Pl, V, A )........... 34

Hatillo and Maimón, mineral deposits near 228-231 Bulla conglomerate near........................ $\quad 67$

Cercado formation near.......................... 67

Miocene fossils found near.... 114, 115, 116-124 view of Cercado formation near (Pl. XII, A).

Heneken, T. S., cited on identity of limestone capping El Morro de Monte Cristi and Samba Hills.

cited on Miocene rocks in the Cibao Valley.

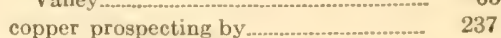

Hewett, D. F., manganese ore examined by.. 243

Highways. See Roads.

Higuerito, fossils found at and near........... 106, 155 oil field at................................ 222, 223-225 summary concerning oil and gas at........ 226

Higuero Largo, Tertiary rocks and fossils found near $\quad 106,155,157-160,199,212$

Historical geology, outline of....................... 79-82

Hoenes, Captain, aid rendered by................ 186

Hornblende andesite, deseription of............ 87

Hornblende-augite andesite, description of.. $\quad 87$

Horneblende diabase, description of .............. 86

Howe, M. A., acknowledgments to............. 90

Hubbard, Bela, cited on correlation of Tertiary formations

cited on stratigraphic limit of Orthaulax

94

Ibarra \& Gosling, wells of, analysis of water from.. 251,252

Igneous activity, evidences of.......................... 80

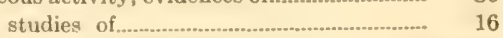

Igneous rocks, distribution of...................... 202-203

Igneous and metamorphic rocks, description of 83-88

Interocean Oil Co., tests of oil made for... 224-225

Intrusive rocks, descriptions of ......................... 84-85

"Iron Mountain" of Gabb, rocks at........... 60

Iron ores, deposits of ................................ 231, 243

Isabel de los Torres, Miocene rocks at.......... 173 Oligocene rocks near 171

Itinerary of surveying party, brief statement of

$12-13$

Jackson, R. T., acknowledgments to............ $\quad 89$

Jarabacoa, basal rocks exposed near............. 52 position of.

Joca, basal rocks exposed near position of.

Jones, W. F., cited on Focene and Oligocene rocks in Haiti.

cited on Eocene rocks at and near Port au Prince.

Juen Calvo Hill, quartz diorite at

Justice, $\Lambda$. R., San Francisco mining concession bought and sold by.

Kidwell, C. H., analyses of water by .............. 14

Kilborne, E. I., information furnished by..... 219 
Knapp, H. S., Rear Admiral, extract from letter of Director of U. S. Geological Survey to, concerning survey.

Rear Admiral, inquiry by, as to cost of survey

La Barca, Miocene or older rocks and fossils

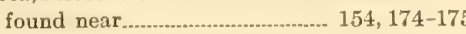
strata, structure, and fossils noted at

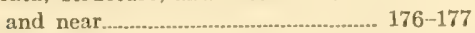

La Cerrita, contact of trap and limestone noted at...

La Cruz, basal rocks exposed near.

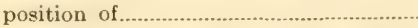
view in Cordillera Central near (Pl. $\mathrm{XVI}, B)$

La Granja, features of view of (Pl. II, $B$ ) See ulso El Morro de Monte Cristi.

La Guí, rocks near.

La Loma, trail from.

La Mata, view of Siete Picos from (Pl. VI, B).

La Partilla salt workings, description of......

La Perseverancia nickel deposit, conclusions concerning ... 235-236 geography and geology of location and history of concessions covering

mining operations on.............................. 233

mode of occurrence of nickel in.............. $\quad 233$

report on ........................................ 231-236

samples from, results of assays of........ 234-235

I a Plata, Miocene fossils found near.......... 154, 174

La Rama copper prospect, features of ............. $\quad 240$

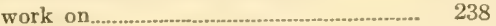

La Rama gold prospect, problematic value of ........................................................ 241-24

La Romana, geographic features near............. 48 La Subida de la Salina, Miocene or older fossils found at.

La Trinchera, limestone near Oligocene rocks and fossils collected near $63,111-112$

La Vega, basal rocks exposed near............... 51 Eocene rocks near $\ldots$

La Vega Province, Cevicos limestone in ...... 63-64 copper and iron deposits in.............. 228-231 metamorphic sedimentary rocks from. mineral deposits in, near Hatillo and

Maimón.

$228-231$

Oligocene fossils found in ...-... 107, 108, 110, 111

La Vigía, age of rocks at

Laguna de la Marias, features of..._................... 192

Lake Enriquillo, animals in and near............. 192 basin of, springs in_.................................. 195 basin of, villages in _._._._._......... 195 date of depression forming...................... 82 features of .............................. 187-188, 190-191 fossils found at _.......................... 166-168 geology of region near............................ 213-221 petroleum indications near .................... 219 Quaternary coral reef at........................... 77 roads and trails along shores of .......... 196, 197
Lake Enriquillo-Continued. springs near, features of........................... 193 structure at............................................ 213-214

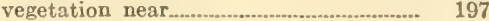
view of reef corals near (Pl. XVII, $B$ ).... 198 water of, analysis . 191 See also Enriquillo Basin.

Lake Limón, location of

Lake Rincón, features of ................................... 192

Lakes, Barahona Province, features of ........ 190-192

Laguna del Fondo, features of..................... $\quad 39$

Lamprophyre, description of _____- $\quad 86$

Lead ore, occurrence of ........................... 243

Ledoux \& Co., assays made by ................... 240, 241

Las Baitoas, view of reef corals near (Pl. XVII, B).... .................................... 198

Las Calderas Bay, reference to .................. 48

Las Canitas, altitude of ................................... 35 basal complex near _.............................. 183 geography and geology of region near....... 205

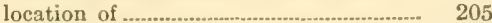
quartz vein containing copper near........ $\quad 205$ view from, description of _._. 205

Las Caobas, Miocene fossils found near.... 132-145 Oligocene rocks near............................... 63

Las Charcas, conglomerate exposed at......... $\quad 212$ Miocene fossils found near.......... 130, 133-145

Las Cuevas, Oligocene rocks and fossils found at and near........................ 109, 200

Las Guácaras, Eocene rocks at caves of .......... $\quad 59$

Las Lagunas, Oligocene rocks and fossils found near. 63,107

Las Lajas, Eocene rocks at and near............. 58 fossils found at 105

Las Lavas Creek, Oligocene fossils found on .......................................................... 111

Las Lay as Creek, Oligocene rocks on.............. 63 Las Matas de Farfán, geology of area near 210-211 Las Matas formation named from......... $\quad 76$

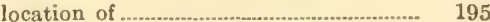
sulphur springs near ............................... 192 Tertiary sedimentary rocks near.. 199, 201, 211 view of (PI. XVI, $A$ )........................ 188 volcanic rocks near

Las Matas formation, age of......................... 57, 210 character, thickness and distribution of 76 $199,201,207,208,209-211,213,214$ equivalents of ....................................... 222 flexures in $\quad 79$

Las Minas, basal rocks at............................ 52

Las Salinas, fossils found near .................... 163-164

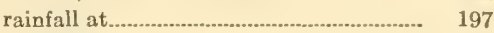
roads to 198

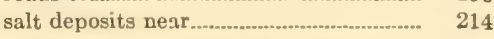
salt mines worked by inhabitants of...... 215 stratigraphic section near......-_............ 214-215

Las Yayas, rocks at and near.............. 199, 212, 213

Lavas, descriptions of ................................... 86-87 Law, L. M., tests of oil by ............................ 224-225

Lead, deposits of .................................................... 243

Lignite, deposits of ......................................... 244

Lignum-vitae tree, view showing(PI, XVII, $\boldsymbol{A}) \quad 198$

Limburgite, description of .............................. $\quad 87$

Lime, limestones suitable for making............ 249 
Limestone, occurrence of tests of, as road metal. views of beds of (PI. XX)

Limestone conglomerate, features of

Loma Chingüela (or Higüela), altitude of .... roads over

Loma Coca, view southward from $(\mathrm{Pl} . \mathrm{V}, B)$..

Loma de Joa, features of

Loma de la llina, copper c

Loma de la Vigia, location of

Loma de los Muertos, Oligocene(?) limestone

$$
\text { at }
$$

Loma de los Palos, Cevicos limestone at.... Oligocene fossils from. rocks forming.

Loma de Portezuela, Cretaceous rocks at......

Lomas de Sierra Prieta, faulting in.

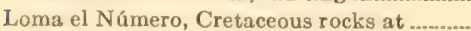
faulting near location of.

Loma Higüela (or Chingüela), altitude of .... roads over

Loma Jackson, Tertiary limestone at..................

Loma las Canitas, marble at. quart $z$ vein containing copper near...........

Loma la Cumbre, view of (PI. II, C)...........

Loma la Guia, rocks on

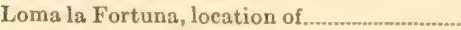

Loma la Laguna, altitude of rocks exposed near.

Loma Llanada, features of.

Loma Miranda, basal rocks composing......... $\quad 51$ copper deposits near................................. 243 trail over.

Loma Pegado, basal rocks at iron ores on

Loma Peñita, view of (PI. VI, $A$ )

Loma Tina, altitude of.

Loma Vieja, basal rocks forming.

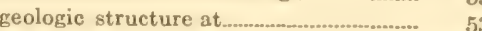

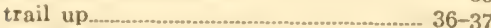

Lonsdale, W., cited on Miocene fauna of the Cibao Valley

Los Alcarrizos, limestone quarried near, tests of Miocene or older fossils found near

rocks of basal complex near.

50 spring water obtained near, analysis of 249-250

Los Bancos, Oligocene rocks and fossils found near........................................ 108, 109, 200

I.os Frailes, location of ................................... 49

Los Güiros, fossils found near......................... 156 rocks exposed near............................... 208

Los Quemados, Miocene fossils found near... 130 section of Gurabo formation at ............ 69-70

Los Rosales, coralliferous limestone near. age of ................

Macoriw, erraces near 181

topographic features near ..................... 40

Macoris Province, Miocene or older fossila from

$155,157-162$

Pleistocene or younger fossils from $166-168$
Mafic dike rocks, descriptions of................... 85, 86

Magnetite, analysis of .................................. 229

Magnetite deposits near Hatillo, description of.........

Maimón, basal rocks exposed near................ 52 iron-ore deposits near........................... 231, 243

Maimón and Hatillo, mineral deposits

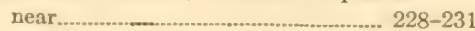

Majagual, Oligocene rocks and fossils found

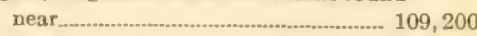

Mammals (extinct), notes on 104

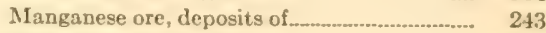

Maniel, description of.................. 33

Mansfield, W. C., acknowledgments to......... 89

Manuel Pérez salt mines, description of ...... 216

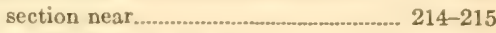

Manzanillo Bay, features of

Manzanillo Plantation, Miocene rocks at..... 173

Mao, Miocene fossils found at................... 151-153

Mao Adentro, Miocene fossils found near

$151-153$

section of Mao Adentro limestone near.. $\quad 73$

Mao Adentro limestone, age, character, thickness, and distribution of .............. 57, 73-74 contact of Gurabo formation with......... 74 equivalent of, near Monte Cristi.......... 174 fossils of ............................. 100-101, 151-153

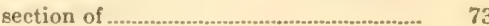

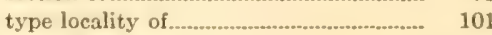

Mao clay, age of $\quad 57$

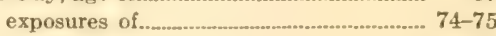
fossils of ............................................... 101, 153 reason for distinctive name for............ 75 type locality of .

Marble, occurrence of................................... 83

Matanzas, Cuba, Gurabo fossils found at..... $\quad 99$

Maury, C. J., cited on age of beds at El Morro de Monte Cristi. 102 cited on age of Quebradillas limestone.. $\quad 96$ cited on Cercado formation..................... 67 cited on correlation of Tertiary formations 94 cited on Miocene beds and fossils.......... 69, 173 cited on Miocene fauna of the Yaque Valley. cited on Oligocene fauna 96 cited on fauna of Cercado formation..... $\quad 97$ eited on fossils of Bowden marl cited on identity of limestone capping El Morro de Monte Cristi and Samba Hills cited on typical section of Gurabo formation formations discriminated by .................... 15 fossils collected by ..................... 114, 126, 130 information furnished by........................ 68 paleontologic work done by__................. $\quad 89$

McCulloch, J. P., aid by _................................... 237

Meinzer, O. E., cited on uplifted beds in the West Indies.

Metalliferous deposits, Azua and Barahona provinces, summary concerning..........

Metamorphic and igneous rocks, descriptions of 
Metamorphic sedimentary rocks, descriptions of

Miller, G. S., cited on rodents of West Indies

Mineral deposits near Hatillo and Maimón, report on.

Mineral resources, studies of 228-231

Mining concessions in force, July, 1919, list of map showing (Pl. XXI).

Miocene fauna, features of..._._. 96-103

Miocene fossils, localities and names of 65-75, 103, 113-165, 184, 201

Miocene or older fauna of Province of Monte Cristi, fossils composing...... 153-154

Miocene serjes, character, thickness and distribution of $65-75,76,172-175,183-184,201$ correlation of (table) faulting in

formations composing

Miocene time, events of.

Mona Passage, reference to.

Montagne de la Selle, altitude of

Ionte Calabaza, Oligocene rocks and fossils found at

Monte Cristi, fossils found near geology and water resources of region near.

Miocene or older fossils found near....... 154 Oligocene deposits near...................... 171-172 structure near...................................... 176-177 topographic features at and near.......... 45, 170

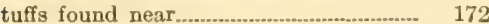

Monte Cristi and vicinity, artesian water probably available at 178-179 deposits near $171-175$ geology and water resources of.......... 169-180 ground-water conditions in................. 177-180 map of (Pl. XIV)

Miocene sedimentary rocks and fossils

found near

172-175

structure near $176-177$

topography of

169-180 water resources of $177-180$

Monte Cristi Bank, description of ............... 45

Monte Cristi Bay, features of ........................ 45

Monte Cristi Province, Cretaceous rocks in.. $\quad 54$ Miocene fossils found in $114-125,126,162,153-154$

Oligocene fossils found in 111 Pliocene or Pleistocene fossils from.... 165-166

Monte Cristi Range, general features of...- 27, 170 Miocene rocks in............................... 172-174 Oligocene rocks in _. 171-172 structure in. 176-177

Monte Cula de Maco, features of

Monte Isabel de Torres, features of................ 28 location of

Oligocene rocks and fossils found on $59,63,111$ view of (PI. III, $A$ )

Moore, J. C., cited on Miocene fauna of the Cibao Valley

Morro de Monte Cristo, view of (P!. II, $B$ ).... See also El Morro de Monte Cristi.

Moya, de, map by, reference to.
Naranja Dulce, copper mines near................. 236

Natural gas, Azua oil field, analysis of ............... 225

Navarrete, Cretaceous rocks near. $\quad 54$ Mao Adentro limestone near .................... $\quad 73$ structure near $\quad 78$

Neiba, coralliferous limestone at...................... 213 petroleum indications near. $\quad 219$ population of Quaternary coral reef at................... 77 roads to ............................................ 196, 197 rocks exposed near.

Neiba Bay, geography of region near.-.-...- 48 position of ................ 48

Neiba Mountains, altitudes of _ $\quad 188$

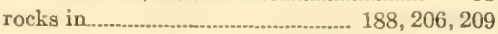

Nickel ore, assays of, results of _............. 234-235 deposits of, conclusions concerning.... 235-236 description of ............................ 231-236

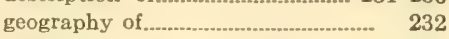
geology of - 232 history of concessions made on...... 231 location of ........................................ 243 mining operations on _.......___...... 233 mode of occurrence of nickel in....... 233 results of assays of ore from.--.. 234-235 visits to....... 243

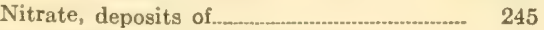

Noel, Monsignor, acknowledgments to.......... 17

Ocoa Bay, features of oil films reported on $\ldots$ rocks near. 226

Office worl, summary account of.................... 13-14

Oil, occurrence of............................. 219, 225-226, 243 tests of, results of

Oil and gas, summary concerning $\quad 226$

Oligocene deposits, features of...... 61-64, 171-172, $183-184,200-201$

relations of, to Eocene...................... 200

Oligocene fauna, correlation of ......................... 96 observations on Oligocene fossils, localities and names of....... 59 , $107-112$

Oligocene series, correlation of (table).......... 57 faulting in ..................... 79 rocks and fossils of............. 59, 61-64, 171-172, 183-184, 200-201

Oligocene time, events of............................... 80

Oligocene tuffs, occurrence of $\quad 172$

Paleontologic literature, lists showing...... 18-25, 90

Paleontologic work, objects of................. 89-90

Paleontology of Tertiary and Quaternary systems, chapter on

Palo Alto, rainfall at................................ 197 stream gage on Rio Yaque del Sur

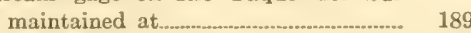

Palo Copado, fossils found near................... 156

Paradis, copper ores near.................................. 222 iron ores near ........................................ 243

Pardo, Dr. Rogelio Díaz, La Perseverancia mining concession transferred to.... 231, 233

Paso Bajito, Miocene fossils found near......... 114. $115,116-124,131,133-135$

192 Paso del Perro, Cercado formation near....... 67, 68 
Paso la Chorrera, section of Cercado formation near.

Pedernales, geographic features near roads and trails to. $68,71-72$

Peña, Oligocene rocks and fossils found near 63,107 Peñón, location of

Peridotite, description of........................... 84,85

Perseverancia mine, map of Sierra Prieta at (PI. XXII). 232

Petroleum, occurrence of............. 219, 225-226, 243

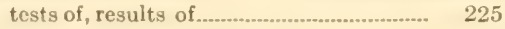

Physiography, results ot work on.................... 15

Physiographic provinces, map showing (Pl. I).

Pico del Yaque, height of

33

Piedra Blanca, Eocene rocks near................. 59-60

Plaisance, Eocene rocks at and near.......... 58, 200

Plaisance limestone, exposures of .................... 58 fossils from ... 58

Plant-bearing beds at Sánchez, character of.. 76, 184

Platanito district, gold in ............................... 242

Platinum, recovery of from stream gravels... 232 reported occurrence of .......................... 242

Pleistocene(?) beach deposits, occurrence of_ 175

Pleistocene or later deposits, fossils from..... 103-

$104,166-168$

Pleistocene or Recent terraces and coral reefs, occurrence of 1S1-185

Pleistocene time, events of

Pliocene rocks and fosils, occur

Pliocene series, character of. $103,165,175,184,201$ correlation of (table) folding in

Pliocene time, events of.

Pliocene or Miocene deposits, Province of Samaná, fossils from.............. 103, 165, 184

Pliocene or Pleistocene deposits, Province of Monte Cristi, fossils from.... 103,165

Point Espada, reference to.

Potassium, deposits of ...................................... 245

Port-au-Prince, Eocene rocks near............. 58, 200

Potrero, Miocene fossils found at and near.... 72 $130,133-145,147$

Precipitation, Azua and Barahona provinces 197

Puerto Escondido, geology near...................... 220 location of

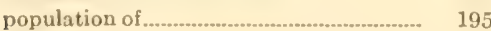

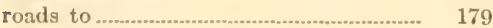

Puerto Plata, Eocene rocks near...................... $\quad 59$ geographic features near .......................... 46

Puerto Plata Bay, date of depression forming 82 features of ................................................ 45-46 Quaternary coral reef on ......................... $\quad 76$

Puerto Plata Province, Eocene rocks and fossils found in. 59,105 Oligocene rocks and fossils found in .... 63,111

Punta Avarena, geography of region near..... 48

Punta Beata, geography of region near......... 48, 49

Punta Calderas, reference to........................... 48

Punta Caña, volcanic rocks at and near.... 203, 211

Punta de la Boca del Infierno, limestone from, tests of, as road metal................ 245

Punta de los Corozos, coral limestone at....... 185
Punta de Santa, coral limestone of.

Punta de Santa Paula, Tertiary clay beds at and near.

oyster-bearing limestone near, age of .... 184

Punta Martín García, geography of region near

Punta Palengue, reographic features

Punta Salinas, geography of region near....... 48

Quartz diorite, features of ............. 84, 85, 171, 202

Quartz diorite gneiss, deseription of.............. 84

Quaternary system, deposits and fossils of..... $\quad 76$,

77,202

Quita Coraza, deposits near........................... 205 roads to .............................................. 196 stratigraphic sections near................. 66, 207

Railroads, routes of .......................................... 44

Rainfall, Azua and Barahona provinces......... 197

Rancho Español, coralliferous limestone near, age of

Rancho Viejo, Eocene rocks and fossils found near.

$106,199-200$

trail to

60

220

Rathbun, M. J., acknowledgments to............ 89

Recent alluvium, deposits of ................ 175, 185

Reef corals, view of (Pl, XVII, B)................ 199

Restauración, basal rocks exposed near.......... $\quad 52$ trail to

Results of survey, outline of........................ 15-17

Rincón, gypseous beds at............................. 213

Rincón Bay, features of................................... $\quad 46$

Rio Albano, Cercado formation on.............. 69

Miocene fossils found on..... 97, 114, 116-124

Rio Ámina, character of ................................. 42 Miocene fossils found on............. 130, 133-147

Oligocene rocks on

Rio Artibonito, character and course of....... 36, 42

Rio Bahoruco, boulders of igneous rock in.... 222 location of .............................................. $\quad 190$

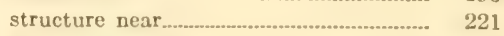

Rio Bao, Oligocene fossils found on ............... 107

Rio Bani, reference to................................ 42

Rio Boba, course of .......................................... 43

Rio Camú, location of ................................... 41

Rio Cana, Cercado formation on................... 69 character of ............... 42

Eocene rocks and fossils found near .... 106, 200

length of ........................................... 189

Miocene fossils found on..... 97, 114-125, 151

section of Cercado formation on 68

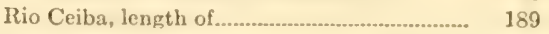

Rio Chacuey, basil rocks exposed near.......... 51

Rio Chavón, reference to................................. 42

Rio Cito, location of ..................................... 190

Rio de los Cocos, analysis of water from....... 254

Rio de las Cuevas, features of......................... 42 length of ........................................... 189

rocks and fossils found on and near ...... 109 $155,157-162,200,206,209,212$

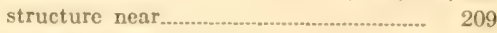

Rio de las Damas, course and features of...... 43,190

Rio de los Patos, location of ..................... 190 
Rio del Medio, basal rocks on course of gravel deposits near length of

Rio del Puerto Viejo, analysis of water from.

Rio del Rancho Español, limestone from, tests of, as road metal

Rio Guanajuma, Gurabo fo

Rio Guayajayuco, character of ____ _ 36, 32 length and course of shale and phyllite along.......................... 204-205

Rio Gurabo, basal rocks a long............................ 59 Cercado formation on ....................................... 69 Gurabo formation on ........................... 69-71 map of part of (PI. XI) ........................... $\quad 70$ Miocene rocks and fossils found on 69 $97,115-124,126-146,151$

Oligocene rocks on

Rio Iguamo, reference to.

Rio Isabel, course of

Rio Jaina, basal rocks exposed in and near.... 50-51 character of features of valley of fossils found near................................ 166,167 view of terrace flat on $(\mathrm{Pl}, \mathrm{V}, C)$.

Rio Jima, basal rocks in and near.................. 51 position of

Rio Joce, features of

Rio Juan Manuel, basal rocks exposed near.. $\quad 51$

Rio Jura, size and course of ........... 190

Rio Licey, Oligocene rocks and fossils found near.

63,107

Rio Limón, basal rocks on

Rio Macasia, headwaters of length and principal tributaries of ....... $\quad 189$

Rio Macoris, references to................................. 41,42

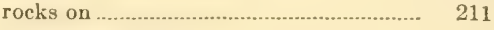
sulphur springs on ....................................... 192

Rio Maguana, length of ................................... 189

Rio Mao, basal rocks along.................. 52 Bulla conglomerate on ............................. 67 Cercado formation near............................ 67 character of Gurabo formation on ................................... 71 Miocene fossils found on $101,114-146,151-153$

Mao clay on map of part of (PI. IX) _.................... 66 platinum found on ........ 242 section of Cercado formation on ............... $\quad 68$ section of Gurabo formation on _._._. 71,72 section of Mao Adentro limestone on.... 73 view near (PI. XIII, $A$ )

view of (PI. XIII, $B$ )

view of Bulla conglomerate near (Pl. X) view of exposure of Cercado formation (Pl. XII, A) view of gorge on (PI. VII, C) views of Gurabo formation on (PI. XII, $B$; Pl. XIII, $A$ )

Rio Maguá, references to view of terraces on (PI. VII, $A$ )
Rio Massacre, features at mouth of.

Rio Mijo, length of

rocks near.

$44-45$

189

212

Rio Neita, position of ............... 36

Rio Nigua, fossils collected on

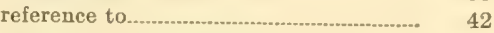

Rio Nizao, geography of region near mouth of length of 190

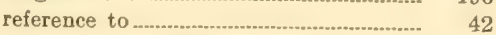

Rio Ocoa, Cretaceous rocks along........ 54

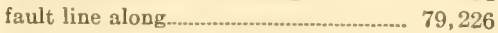
features of ........................... 190 geography of region at mouth of........... $\quad 48$ oil seepage near _.................................. 225 reference to .............................................. 42 view of plication in shaly limestone on

(Pl. XX, A ) _

Rio Ozama, reference to....................................... 41,42

Rio San Juan, area drained by ........................ 42 features of .................................................... Oligocene rocks and fossils found on...... 108 , $109,200,208-209,210-212$ water from, analysis of

Rio San Marcos, Eocene rocks near................. 59 location of . $\quad 46$

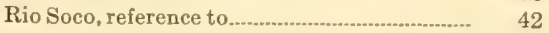
Rio Tábara, rocks and fossils found near.. 155, 157-

162,212

length of

190

Rio Vallejuelo, length of $\ldots$

Rio Via, Eocene rocks on ................................ 60-61

faulting along .......................................... 60-61

structure along

Tertiary rocks and fossils found along 155,223

Rio Yaguajal, basal rocks exposed along........ 53, 56

Rio Yaque del Norte, artesian water possibly obtainable along................. 178-179

Baitoa formation on................................ 66

course of ............................................................ 41

delta of -...... 45

features of ................................... 169-170

former course of.................................... 170

geologic structure near........................ 176-177

Mao Adentro limestone on...................... 74

Miocene rocks and fossils found on ..........65, 99, $113-114,130,133-135,137-$ $145,147,173,174,175$

Oligocene fossils found along........... 61, 107,108 recent alluvium on strata and structure along ..................... 176-177 Tabera formation on view in valley of $(\mathrm{Pl} . \mathrm{IV}, \mathrm{B}) \ldots \ldots \ldots$

Rio Yaque del Sur, delta of.............. 48

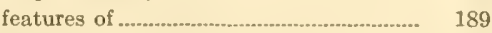
general course and tributaries of ........... 42 geography of region at mouth of _......... $\quad 48$ Miocene rocks and fossils found along.... 155162,201

Oligocene rocks and fossils found on ...... 63 $109,111-112,200$

Pliocene (?) rocks along........................... 201 rainfall observations on region east of, areal geology of ........... 212-213 
Rio Yaque del Sur-Continued.

sulphur springs on.

Tertiary rocks along

tributaries of

view of sandy shale and sandstone ex-

posed on (Pl. XVIII, $A$ )

Rio Yásica, course of 43

Rio Yuma, mouth of ...................................... 47

Rio Yuna, basal rocks exposed near.............. 51

course of ............................................... 41

delta of ................................................... 47

Eocene rocks near

iron and copper ores on and near........ 228-231

position of

Rivière Artibonite, course of _.......................... 36, 42

Road metal, rock available for.......................... 246

rock available for, tests of .................... 247-248

Roads and trails, courses and character of .... 44

196-197

Rock for concrete, deposits of.................... 245-246

Rodents, extinct, notes on.............................. 104

Rope-fiber factory near Monte Cristi, Oligocene rocks near .................................... 172

Pleistocene beach deposits near............. 175

Ross, C. P., chapter on geology and water resources of Monte Cristi and vicinity

by

$169-180$

chapter on geology of Samzná Province by. 181-185

fossils collected by 106 ,

$109,110,111,153-$ $162,165,166-168$

fossil-bearing limestone collected by....

Miocene formations discriminated by...

itinerary of

65

Oligucene (?) limestone noted by....

$12-13$

report on mineral deposits near

Hatillo and Maimón by. 228-231

report on San Cristobal mining district by

samples of water collected by $193-194,249-255$

Ross, C. P., and Condit, D. D., Cerros de Sal formation named by..

chapter on economic geology by ........ 228-254 chapter on geology of provinces of

Barahona and A zua by. $186-227$

Las Matas formation named by............. $\quad 76$

Miocene beds discriminated by $\quad 65-66$

Routes of travel..................................... 44, 196-197

Sabana Cañongo, Oligocene limestone on..... 172

Sabana de la Mar, basal complex near........... 1 S3

Tertiary limestone near......................... 64, 184

Sabana de Pérez, fossils found near............. 105

Sabana de San Tome, geology of region near.. 211

Sabana Grande, basal rocks exposed near..... 51

Sabana Llana, view of (PI. IV, A).................. 32

Sabaneta, basal rocks exposed near............. 52

fossils found near....................................... 55

Oligocene tufis near.......... 178

trail from, to San Juan........................... 35-37

volcanic rocks near................................. 55-56

St. Marc, Eocene rocks near ............................... 58
Salines, Azua and Barabona provinces, summary concerning.

Salt, deposits of 244,245

Samaná, conglomerate near............................ 184

Samaná Bay, coral limestone on..................... 185

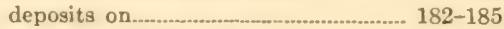

depression forming, date of.................... 82

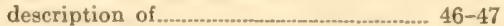

limestone from shores of, tests of, as road metal.............................................. 248

Oligocene limestone on ........................... 64

plant-bearing beds on........................ 76, 103,184

recent deposits along _........................... $\quad 185$

topography of south shore of ............... 182

Samaná Peninsula, basal rocks of _...... 53, 182-183

climate of $\quad 29$

drainage of ............................................... 43

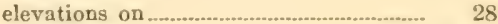

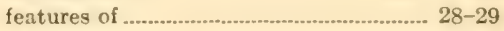

lignite streaks on ..................................... 244

limestone from, tests of, as road metal 247,248

limestone conglomerate on.................. 183

Pleistocene or Recent terraces and coral

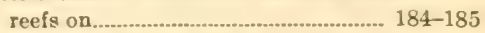

rock suitable for making concrete found

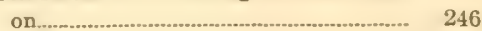

surface waters of, analyses of ............. 252-254

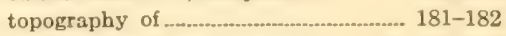

Samaná Province, basal complex in.... 53, 182-183

geology of......................................................

limestone from, test of, as road metal, 247, 248

Miocene or Pliocene rocks and fossils

found in

165,184

Oligocene fossils collected in................. 111

Pleistocene or Recent terraces and coral

reefs in.

184-185

recent deposits in $\quad 185$

Tertiary clay, sand, and conglomerate in 184

Tertiary fossils found in............... 183, 184, 185

Tertiary limestone and limestone conglomerate in

183-184

topography of ..................................... 181-182

Samba Hills, Mao Adentro limestone at........ 73

Sample, C. C., cited on explorations for amber.

244

Sánchez, fossils found near........................... 165, 184

fossil planty collected at........................ 103

lignitic streaks near ............................... 244

location of ............................................. 47

marble at $\quad 53$

plant-bearing beds at ............................ 76,184

terraces and coral reefs near.............. 18t-185

Tertiary clay beds at and near............. 184

Tertiary limestone near _..___................... 183

view of (Pl. III, C)

Sánchez, León, aid by ......................................... 231

San Cristóbal, gold prospect near................. 242

Oligocene rocks and fossils found near.. 64, 112

San Cristóbal Mining Co., San Francisco mining concession obtained by............ $\quad 237$ operations of 237

San Cristóbal mining district, conclusions

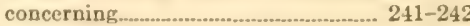
copper deposits in................................ 243 
San Cristóbal mining district-Continued. development in geology of .......................................... 238-239

history of

La Rama prospect in ..........................240-241

location of and access to......................... 236

ore deposits in .................................... 239-240

report on ............................................... 236-242

San Francisco Hill, copper deposits and mines on.................................................... 236, 240

shipments of copper ore from.

San Francisco mining concession, copperbearing rocks of

geology of

history of.

location of

map of part of (Pl. XXIII)

mineralized area of.

San José de las Matas, basal rocks exposed near.

Cercado formation near

\section{faulting near}

fossils found

Tabera formation near

San Jose de Ocoa, Cretaceous rocks near...... $\quad 54$

description of

faulting near

view of plication in shaly limestone near (PI. XX, A) location and population of .................... 195 roads and trails to $35-37,196-197$ Tertiary rocks and fossils found near..... 109

$200,211,212$ volcanic rocks near

San Juan de la Maguana, roads from............... $\quad 37$

San Juan Valley, areal geology of .................. 204

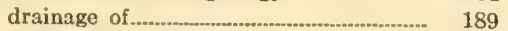
geologic features of.................................... 209-212 Las Matas formation in............................ 76, 201 location and general features of............. 37 structure in ............................................ 203 volcanic rocks in ...........................202,203, 210 width and extent of ................................ 188

San Lorenzo Bay, Oligocene limestone on ...... $\quad 64$ topography of region near...................... 47

San Pedro de Macoris, brick made near.......... $\quad 249$ fossils found at. $166-168$ geographic features near Quaternary coral reefs at............................ 76-77 raised beaches near............................. 77 remains of extinet rodents found at...... 104 uplifted shell beds near........................... 81-82 view of terraces near (PI. VII, $A$ )......... 40 well water obtained near..................... 249-252

Sand, tests of, for use in cement....................... $\quad 248$

Sand-clay available for road making, tests of 247

Santa Bárbara de Samaná, coral reef near...... $\quad 185$ geography of region near........................ 47 view of (Pl. III, $B$ )........................................ 30

Santiago, Mao Adentro limestone near........... 73-74 Miocene fossils found at and near........... 130 $133-145,151-153$
Santiago Province, Eocene fossils found in.... 59, 105 Miocene fossils found in..................... 113-153 Oligocene fossils found in.............. 107, 108, 111

Santo Domingo City, brick made near.......... 249 coastal plain near........................ 40 fossils found near._._._._._._._....... 112, 166-167 geographic features near......................... 48 nickel deposits near._............................... 243 Quaternary coral reef at.......................... $\quad 77$ well waters near, analysis of samples of.

Santo Domingo Exploration Co., San Francisco mining concession obtained and lost by....

Santo Domingo Investment and Development Co., explorations for oil by........ 223

Santo Domingo Province, copper deposits

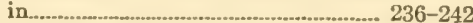

Eocene fossils found in............................. 106 Miocene or older fossils from......... 155, 157-162 nickel deposit in ............................... 231-236 oil seepages in ......................................... 225-226

Oligocene fossils collected in ..................... 112

Pleistocene or younger fossils from...... 166-167

Saona Island, features of.................................... 48

"Scotch Railroad," a name applied to the main line of the Ferrocarril de Santiago y Samaná

Seibo Plain locotion and features of

Seibo Province, manganese ores in...................

Serpentine, description of .............................. 84 Settlements, Azua and Barahona Prov-

inces _.................................................... 194-196

Shore features, description of .......................... 44-49

Sierra de Bahoruco, areal geology of............ 219-221

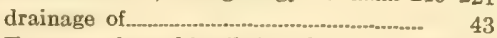

Eocene rocks and fossils found in............ 60,200

features of .................................. 39-40

generalized stratigraphic section in...... 221

iron ores in ........................................ 243

location of .............................................. 48,49

views of (Pl. XIX, $A, B$ ) ...................... $\quad 220$

villages in valleys of .................................... 195

volcanic rocks in $\ldots$

Sierra de Martín García, features of............ 38, 48, 207

Sierra de Neiba, features of ........................ 38

Oligocene rocks and fossils found in.... 63,112

streams rising in........................................ 43

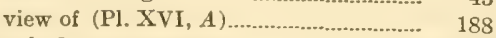

Sierra de Ocoa, features of ................................ 32-33

trails in .............................................................. 33

Sierra de los Altos, rocks on............................... 211

Sierra de los Remedios, lagoon near.................. 192

Sierra del Agua, rocks in and near....................209, 212

Sierra del Viento, Gurabo formation exposed on.

Sierra Prieta, Eocene rocks in...................... 59, 60

location and general features of............ 232

map of part of (Pl. XXII) .................... 232

Oligocene fossils found on ................................... 111

Tertiary limestone on ................................ 183

view of white limestone cliff in (PI. VII, B)

Siete Picos, view of (PI. VI, B) .................... 
Silicic dike rocks, descriptions of

Silver, occurrence of, in ores of San Cristóbal district.

85,86

Smith, Glenn S., itinerary of

241,242

Snowden, Thomas, Rear Admiral, acknowledgments to

12

action taken by, concerning survey ........ 12

Sodium chloride, deposits of..._-_.___._........ 244,245

Soto, Marciel, oil samples collected by.......... 225

South coast, features of ............................. 48-49

Southern peninsula, features of

40

Sowerby, G. B., cited on Miocene fauna of the Cibao Valley.

65

Springs, sulphur, occurrence of ...................... 192 waters of, analyses............................ 193-194

Steiger, George, chemical analyses by ........... 14

Stone for building, deposits of.......................... $\quad 245$

Stratigraphy, description of _..................... 50-77 results of work on 15

Structure, general features of........ 16,77-79, 176-

177,203

Tabera, Oligocene rocks and fossils found at.. $\quad 107$ trail from

34

Tabera formation, age of _........................ 57,94 character, distribution, thickness, and fossils of 61-63 conglomerate in, significance of .............. 80 taulting in .................................................... 78 rocks and fossils of..._...... 61-63, 107-109, 111

Tamboril, amber found near...................... 244

Terrace flats, Pleistocene or Recent, distribution of

$18 \pm-185$

Terry, D. C., acknowledgments to............. 169

Tertiary rocks, correlation of formations composing (table)

distribution, character, and thickness of

$56-76,183$

Tertiary system, rocks and fossils of $56,76,94-$ $168,183,199-201$

Tertiary and Quaternary faunas, relations of 94-104

Tertiary and Quaternary stratigraphic paleontology, chapter on....................... 89-168

Tippenhauer, L. G., clted on altitude of surface of Lake Enriquillo

Topographic divisions, brief statement of...... $\quad 26$ map showing (Pl, I) ............................. 26

Towns and villages, notes on.................. 194-196

Trails and roads, courses and character of .... 44

196-197

Transportation, routes of

43-44

Trinchera, fossils found near _............... 155, 157-162

Trou Jacob, geography of region near $\quad 49$ Oligocene fossils found near................. 109

Túbano, Miocene fossils found near..... 155, 157-162 Tertiary rocks exposed near.. 199, 206, 209, 212

Tuffaceous rocks, descriptions of $\quad 87-88$

Tuffs, descriptions of ................................... 87-88

Unconformities by erosion noted................. 80

Upham, R. D., aid rendered by......_._......... 186, 214

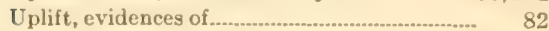

Valois, Gregorio, well of, analyses of water from.

Valverde, Mao clay near. Miocene fossils found at. 250
Vaughan, T. W., acknowledgments to............ $\quad 89$ cited on age of Gurabo formation....... $\quad 100$

cited on block faulting......................... 81

cited on corrclation of Tertiary formations. cited on need of considering ecology in the study of fossils............................ 93 cited on shore features of West Indies.... 101 Eocene rocks and fossils in Haiti noted by. $112,114,115,126-129,130-$ $145,151-153,165,166-168$

introduction by _........................................ 11

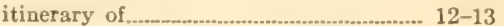

observations made at Sánchez by ........... 181

Quaternary fossils identified by............... $\quad 77$

sections of Cercado formation measured by

section of Mao Adentro limestone measured by

Vaughan, T. W., and Woodring, W. P., chapter on Tertiary and Quaternary stratigraphic paleontology by ............ 89-168

Vega Real, view of (Pl. IV, $A$ )

Vegetation, Azua and Barahona Provinces, features of 197-198

Villa Rivas, Oligocene rocks and fossils collected near.

Villages and towns, notes on........................ 194-196

Villarpando, sulphur springs near..................... 192

Volcanic activity, ages of .................................... 82

Volcanic rocks, occurrence of .......................... 202

Water, analyses of ............ 191, 193-194, 249-254

Water, ground, possibility of obtaining.... 177-178

Water power, possible sources of ..................... 190

Water resources, Monte Cristi and vicinity.... 169

Wells, J. W., cited on altitude of surface of Lake Enriquillo_................................ 190-191 cited on Laguna de las Marías................. 192

Wells near Monte Cristi, character of ........ 177-178

Woodring, W. P., aid by' _............................. 14, 89 bibliography by .................................. 18-25 cited on age of Bowden marl................. 100 monograph on the Mollusea of the Bowden marl by, reference to............... 99

Woodring, W. P., and Vaughan, T. W., chapter on Tertiary and Quaternary stratigraphic paleontology by ....................... 89-16S

Yaque group, age, character, thickness, and diatribution of rocks of .................... 57, 65-75 $199,201,207,213$

formations composing _._____........... 57,65-75 naming of - 65 north side, fossils of _................ 96-102, 154

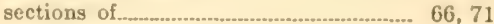
south side, fossils of............... 102-103, 155-162 view of sandy shale and sandstone of (Pl. XVIII, A ................................ 208 Yaque Valley, Miocene rocks in _..................... 201 Yaroa, Oligocene rocks found at and near_._.. 63, 107 Yaroa Creek, fossils found on .......................... 105 Yuma Bay, location of geography of region near...................... 48 





SMITHSONIAN INSTITUTION LIBRARIES

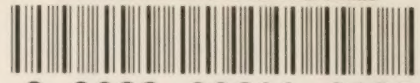
$\begin{array}{llll}3 & 9088 & 00611 & 3153\end{array}$

1) 